LA-14333

Approved for public release;

distribution is unlimited.

Radiogenic and Stable Isotope and

Hydrogeochemical Investigation of

Groundwater, Pajarito Plateau and

Surrounding Areas, New Mexico 
Los Alamos National Laboratory, an affirmative action/ equal opportunity employer, is operated by Los Alamos National Security, LLC, for the National Nuclear Security Administration of the U.S. Department of Energy under contract DE-AC52-06NA25396.

\section{INAS \\ National Nuclear Security Administration}

This report was prepared as an account of work sponsored by an agency of the U.S. Government. Neither Los Alamos National Security, LLC, the U.S. Government nor any agency thereof, nor any of their employees make any warranty, express or implied, or assume any legal liability or responsibility for the accuracy, completeness, or usefulness of any information, apparatus, product, or process disclosed, or represent that its use would not infringe privately owned rights. Reference herein to any specific commercial product, process, or service by trade name, trademark, manufacturer, or otherwise does not necessarily constitute or imply its endorsement, recommendation, or favoring by Los Alamos National Security, LLC, the U.S. Government, or any agency thereof. The views and opinions of authors expressed herein do not necessarily state or reflect those of Los Alamos National Security, LLC, the U.S. Government, or any agency thereof. Los Alamos National Laboratory strongly supports academic freedom and a researcher's right to publish; as an institution, however, the Laboratory does not endorse the viewpoint of a publication or guarantee its technical correctness. 
LA-14333

Issued: July 2007

Radiogenic and Stable Isotope and

Hydrogeochemical Investigation of

Groundwater, Pajarito Plateau and

Surrounding Areas, New Mexico

Patrick Longmire

Michael Dale

Dale Counce

Andrew Manning*

Toti Larson

Kim Granzow

Robert Gray**

Brent Newman

* U.S. Geological Survey, Denver, CO

** Daniel B. Stephens and Associates, 6020 Academy Road NE, Albuquerque, NM 87109

Los Alamos 


\section{CONTENTS}

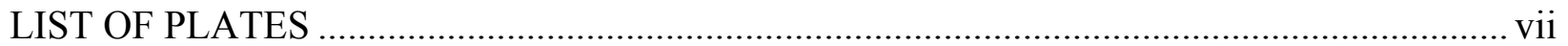

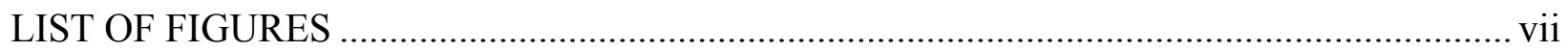

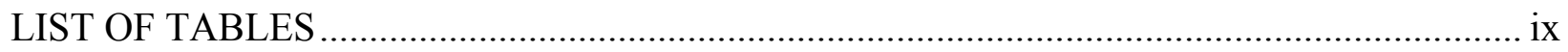

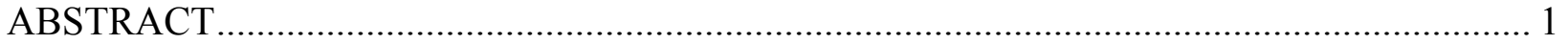

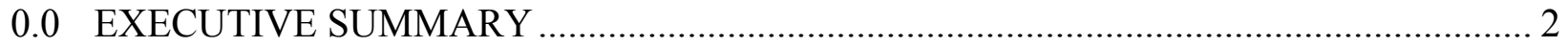

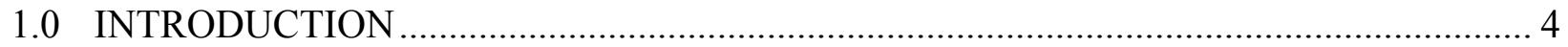

1.1 Purpose, Objectives, and Scope ..................................................................... 4

2.0 HYDROCHEMICAL APPROACH FOR THIS INVESTIGATION ................................ 6

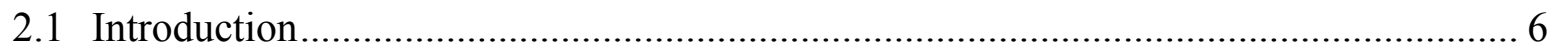

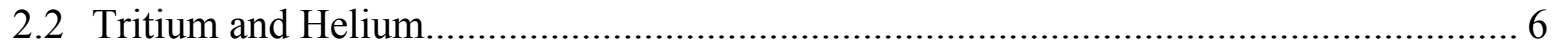

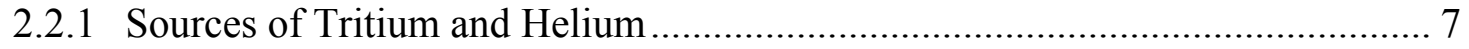

2.2.2 Tritium-Helium Dating Systematics ........................................................... 9

2.2.3 Physical Controls on Apparent Groundwater Age Determined by the ${ }^{3} \mathrm{H} /{ }^{3} \mathrm{He}$ Dating Method ...................................................................... 11

2.2.4 Protocols for Interpreting Apparent Groundwater Age Determined by the ${ }^{3} \mathrm{H} /{ }^{3} \mathrm{He}$ Dating Method and Anthropogenic Chemicals.......................... 12

2.2.4.1 Background Wells and Springs....................................................... 13

2.2.4.2 Wells, Springs, and Surface Water Containing Atmospheric Tritium Released from the Laboratory ....................... 13

2.2.4.3 Wells and Springs Containing Tritium from Laboratory Effluent ..................................................................................... 14

2.2.4.4 Wells Containing Laboratory and County of Los Alamos Effluent ............................................................................. 14

2.2.4.5 Wells Containing Laboratory Effluent, Excluding Tritium ................ 14

2.2.4.6 Previous Hydrogeologic and Environmental Geochemical Investigations Conducted at the Laboratory .................................... 15

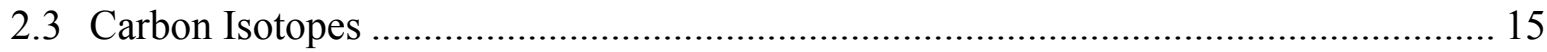

2.4 Stable Isotopes .............................................................................................. 16

2.5 Major Ion and Trace Element Geochemistry ...................................................... 16

3.0 PREVIOUS HYDROLOGIC AND HYDROCHEMICAL CONCEPTUAL MODELS .... 17

3.1 Recharge Zone Within Sierra de los Valles............................................................ 18

3.2 Recharge Along Canyon Bottoms, Pajarito Plateau ................................................ 18

3.3 Discharge of Regional Aquifer Groundwater at White Rock Canyon Springs ........... 19

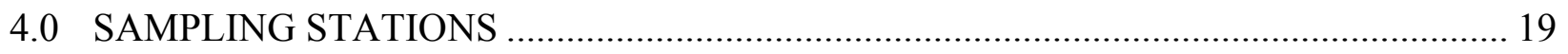

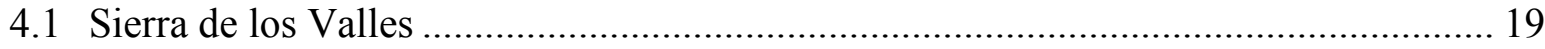

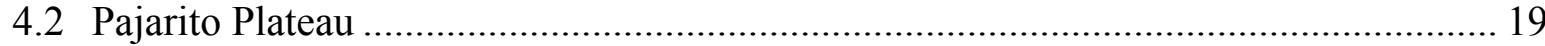

4.3 White Rock Canyon Springs........................................................................... 20 


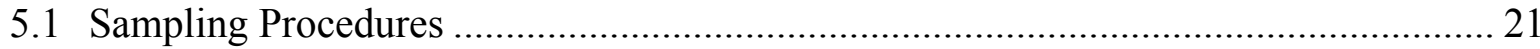

5.2 Number and Types of Samples and Analytical Methods.............................................. 22

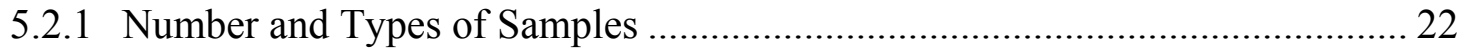

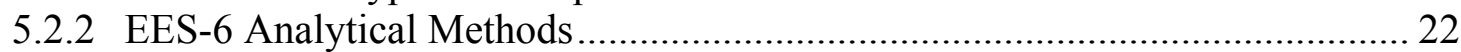

5.2.3 Carbon Isotope Analytical Methods............................................................. 23

5.2.4 Tritium and Noble Gas Analytical Methods .................................................... 23

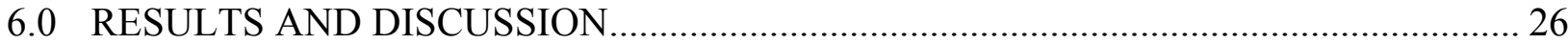

6.1 Aqueous Inorganic and Isotope Geochemistry of the Sierra de los Valles Springs .... 26

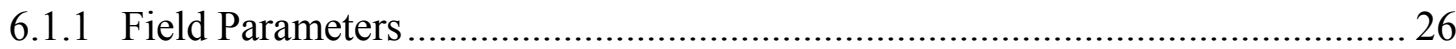

6.1.2 Inorganic Aqueous and Isotope Geochemistry of Sierra de los

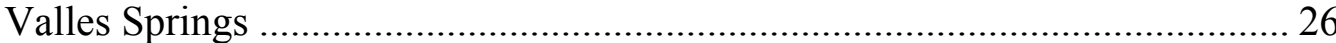

6.1.2.1 Major Ion and Trace Element Geochemistry of Sierra de los Valles Springs ................................................................................. 27

6.1.2.2 Stable Isotope Geochemistry of Sierra de los Valles Springs............. 28

6.1.2.3 Radiogenic Isotope and Noble Gas Geochemistry of Sierra de los Valles Springs........................................................................ 29

6.1.3 Summary of Sierra de los Valles Hydrochemistry .............................................. 32

6.2 Aqueous Inorganic and Isotope Chemistry of Wells and Springs, Pajarito Plateau..... 32

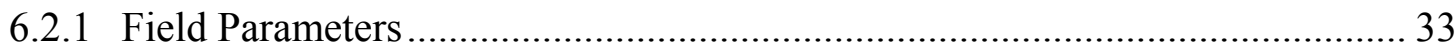

6.2.2 Major Ion and Trace Element Geochemistry for Background Wells and Springs, Pajarito Plateau............................................................................ 33

6.2.3 Stable Isotope Geochemistry of Wells and Springs, Pajarito Plateau ................ 34

6.2.4 Radiogenic Isotope and Noble Gas Geochemistry of Background

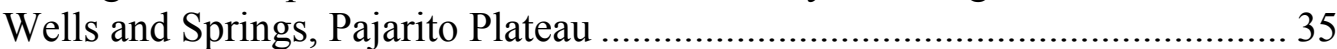

6.2.5 Major Ion and Trace Element Geochemistry from Contaminated Wells and Springs on the Pajarito Plateau.................................................................. 36

6.2.6 Radiogenic Isotope and Noble Gas Geochemistry of Contaminated

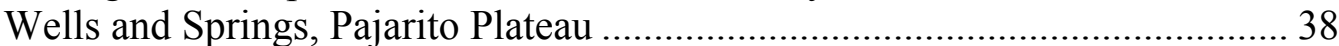

6.2.6.1 Groundwater Ages in Pueblo Canyon................................................. 39

6.2.6.1.1 Sources of Helium in Pueblo Canyon ................................. 40

6.2.6.2 Groundwater Ages in Los Alamos Canyon ......................................... 42

6.2.6.2.1 Sources of Helium in Los Alamos Canyon........................ 42

6.2.6.3 Groundwater Ages in Sandia and Mortandad Canyons ....................... 42

6.2.6.3.1 Sources of Helium in Sandia Canyon and Mortandad Canyon........................................................... 45

6.2.6.3.2 Groundwater Mixing in Mortandad Canyon...................... 46

6.2.6.4 Groundwater Ages and Chemistry for Pajarito Canyon ....................... 48

6.2.7 Summary of Pajarito Plateau Hydrochemistry .................................................... 49 
6.3 Aqueous Inorganic and Isotope Geochemistry of the White Rock Canyon

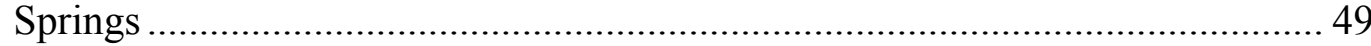

6.3.1 Field Parameters ....................................................................................... 50

6.3.2 Major and Trace Element Geochemistry of the White Rock Canyon Springs ............................................................................................... 50

6.3.3 Stable Isotope Geochemistry of the White Rock Canyon Springs.................... 52

6.3.4 Radiogenic Isotope and Noble Gas Geochemistry of the White Rock

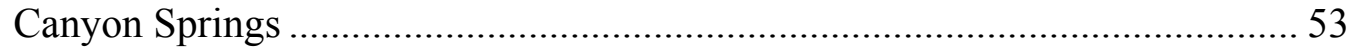

6.3.5 Hydrologic Conceptual Model for Pajarito Canyon and the 4-Series Springs, White Rock Canyon ......................................................................... 56

6.3.6 Groundwater Mixing for the 4-Series Springs ............................................... 56

6.3.7 Geochemical, Groundwater Temperature, and Isotope Relationships for the White Rock Canyon Springs ……………………………………..... 57

6.3.8 Summary of Hydrochemistry of the White Rock Canyon Springs .................... 58

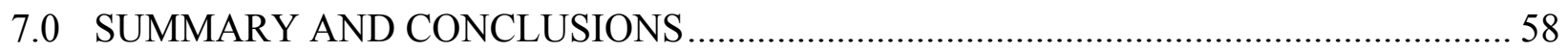

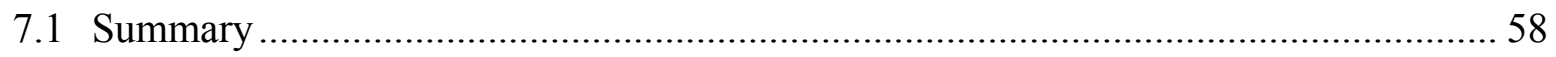

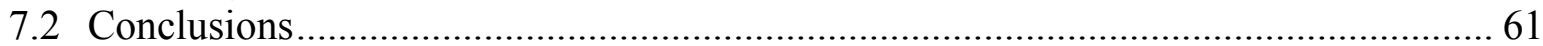

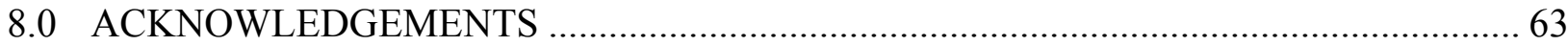

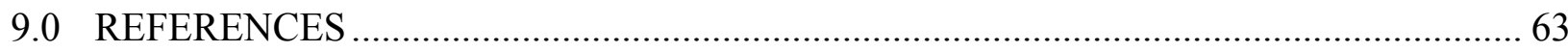

APPENDIX A: ACRONYMS AND ABBREVIATIONS ………............................................ A-1

APPENDIX B: SAMPLING PROCEDURE FOR NOBLE GASES ......................................... B-1

\section{LIST OF PLATES}

Plate 1 Tritium Concentration (TU) ....................................................................................

Plate 2 Groundwater and Surface Water Ages Based on ${ }^{3} \mathrm{H}$ and ${ }^{14} \mathrm{C}$

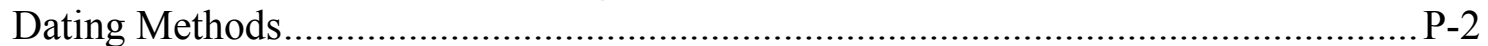

Plate 3 Initial Tritium Concentration (TU) ...................................................................

Plate 4 Mean DEL ${ }^{3} \mathrm{He}$ and $\mathrm{DEL}^{4} \mathrm{He}$ Values ..........................................................................

\section{LIST OF FIGURES}

Figure 1-1 Study area for hydrogeochemical and isotope investigation, Parajito Plateau and surrounding areas, New Mexico ……………………….......F-1

Figure 2-1 Conceptual model for tritium and helium....................................................F-2

Figure 2-2 Atmospheric tritium curve and groundwater samples collected at Los Alamos National Laboratory and surrounding area, New Mexico ....................F-3

Figure 2-3 Timeline for major liquid waste releases at Los Alamos, New Mexico ...................F-4

Figure 3-1 Generalized expected trends in groundwater age for conceptual

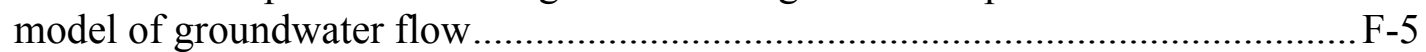

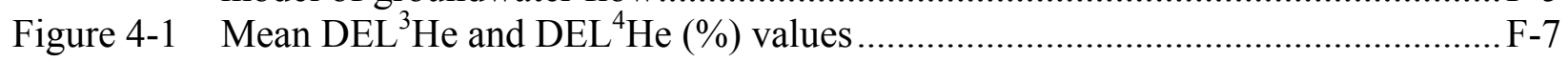


Figure 5-1 Nobel-gas-sampling apparatus...................................................................F-9

Figure 6-1 Trilinear diagram for Sierra de los Valles Springs ...........................................F-10

Figure 6-2 Distributions of average ${ }^{18} \mathrm{O}$ (permil) versus delta ${ }^{2} \mathrm{H}$ (permil) for surface water (CdV-5.6) and springs discharging within the Sierra de los Valles and Jemez Mountains (Seven Springs and Valle Caldera), New Mexico

Figure 6-3 Atmospheric tritium curve and initial tritium activities for samples collected in the Sierra de los Valles, New Mexico $\mathrm{F}-12$

Figure 6-4 Trilinear diagram for background LANL groundwater F-13

Figure 6-5 Distributions of average delta ${ }^{18} \mathrm{O}$ (permil) versus delta ${ }^{2} \mathrm{H}$ (permil) for LANL wells, TA-9 and TA-16 springs, and springs discharging within the Sierra de los Valles, New Mexico F-14

Figure 6-6 Distributions of average delta ${ }^{18} \mathrm{O}$ (permil) versus delta ${ }^{2} \mathrm{H}$ (permil) for TA-9 and TA-16 springs and surface water and springs discharging within the Sierra de los Valles, New Mexico................................F-15

Figure 6-7 Trilinear diagram for LANL wells and springs .........................................F-16

Figure 6-8 Trilinear diagram for TA-9 and TA-16 springs .........................................F-17

Figure 6-9 Atmospheric tritium curve and initial tritium activities for samples collected beneath Pajarito Plateau - perched alluvial and volcanics, and intermediate aquifers F-18

Figure 6-10 Atmospheric tritium curve and initial tritium activities for samples collected from the regional aquifer beneath Pajarito Plateau

Figure 6-11 Trilinear diagram for White Rock Canyon springs. F-20

Figure 6-12 Distributions of average delta ${ }^{18} \mathrm{O}$ (permil) versus delta ${ }^{2} \mathrm{H}$ (permil) for White Rock Canyon springs, LANL wells and springs, and surface water and springs discharging within the Sierra de los Valles, New Mexico.

Figure 6-13 Calculated recharge elevations as determined by stable isotope data for the regional aquifer water table sloping from west to east.

Figure 6-14 Distributions of average delta ${ }^{18} \mathrm{O}$ (permil) versus ${ }^{2} \mathrm{H}$ (permil) for groupings of White Rock Canyon springs, LANL regional aquifer wells and springs, and surface water and springs discharging within the Sierra de los Valles, New Mexico.

Figure 6-15 Atmospheric tritium curve and initial tritium activities for samples collected at the White Rock Canyon springs

Figure 6-16 Chloride (ppm) versus tritium (TU) for samples collected at the White Rock Canyon springs ....

Figure 6-17 Chloride (ppm) versus perchlorate (ppb) for samples collected from the White Rock Canyon springs ....

Figure 6-18 Chloride (ppm) versus temperature $\left({ }^{\circ} \mathrm{C}\right)$ for samples collected from the White Rock Canyon springs

Figure 6-19 Fraction modern ${ }^{14} \mathrm{C}$ versus tritium (TU) for samples collected from the White Rock Canyon springs 


\section{LIST OF TABLES}

Table 2-1 Background Values for Key Mobile Dissolved Chemicals Used in this Isotope-Geochemical Investigation.

Table 4-1 Location and Description of Sampling Sites

Table 5-1 Analytes, Sampling Containers, Sampling Equipment, and Analytical Laboratory and Method of Analysis

Table 6-1 Summary Results of Major Element Chemistry and Field Parameters

Table 6-2 Summary Results of Trace Elements

Table 6-3 Summary Results of Stable Isotopes................................................................. T-19

Table 6-4 Summary Results of Tritium and the Nobel Bases Helium-3, Helium-4, and Neon

Table 6-5 Summary Results of Delta ${ }^{13} \mathrm{C}$, Fraction Modern Carbon $\left({ }^{14} \mathrm{C}\right)$, and Unadjusted Groundwater Ages

Table 7-1 Summary of Age Data and Age Interpretation Using Multiple Parameters 


\title{
Radiogenic and Stable Isotope and Hydrogeochemical Investigation of Groundwater, Pajarito Plateau and Surrounding Areas, New Mexico
}

\author{
by \\ Patrick Longmire, Michael Dale, Dale Counce, Andrew Manning,
Toti Larson, Kim Granzow, Robert Gray, and Brent Newman
}

\begin{abstract}
From October 2004 through February 2006, Los Alamos National Laboratory, the New Mexico Environment Department-Department of Energy Oversight Bureau, and the United States Geological Survey conducted a hydrochemical investigation. The purpose of the investigation was to evaluate groundwater flow paths and determine groundwater ages using tritium/helium-3 and carbon-14 along with aqueous inorganic chemistry. Knowledge of groundwater age and flow paths provides a technical basis for selecting wells and springs for monitoring. Groundwater dating is also relevant to groundwater resource management, including aquifer sustainability, especially during periods of long-term drought. At Los Alamos, New Mexico, groundwater is either modern (post1943), submodern (pre-1943), or mixed (containing both pre- and post-1943 components). The regional aquifer primarily consists of submodern groundwater. Mixed-age groundwater results from initial infiltration of surface water, followed by mixing with perched alluvial and intermediate-depth groundwater and the regional aquifer. No groundwater investigation is complete without using tritium/helium-3 and carbon-14 dating methods to quantify amounts of modern, mixed, and/or submodern components present in samples. Computer models of groundwater flow and transport at Los Alamos should be calibrated to groundwater ages for perched intermediate zones and the regional aquifer determined from this investigation.

Results of this study clearly demonstrate the occurrence of multiple flow paths and groundwater ages occurring within the Sierra de los Valles, beneath the Pajarito Plateau, and at the White Rock Canyon springs. Localized groundwater recharge occurs within several canyons dissecting the Pajarito Plateau. Perched intermediate-depth groundwater and the regional aquifer beneath Pueblo Canyon, Los Alamos Canyon, Sandia Canyon, Mortandad Canyon, Pajarito Canyon, and Cañon de Valle contain a modern component. This modern component consists of tritium, nitrate, perchlorate, chromate, boron, uranium, and/or high explosive compounds. It is very unlikely that there is only one transport or travel time, ranging from 25 to 62 years, for these conservative chemicals migrating from surface water to the regional water table. Lengths of groundwater flow paths vary within deep saturated zones containing variable concentrations of tritium. The 4-series springs discharging within White Rock Canyon contain a modern component of groundwater, primarily tritium. Average groundwater ages for the regional aquifer beneath the Pajarito Plateau varied from 565 to 10,817 years, based on unadjusted carbon-14 measurements.
\end{abstract}




\section{O.0 EXECUTIVE SUMMARY}

From October 2004 through February 2006, Los Alamos National Laboratory, the New Mexico Environment Department-Department of Energy Oversight Bureau, and the United States Geological Survey conducted an investigation to evaluate groundwater flow paths and determine groundwater ages using tritium/helium-3 $\left.\left({ }^{3} \mathrm{H}\right){ }^{3} \mathrm{He}\right)$ and carbon-14 $\left({ }^{14} \mathrm{C}\right)$ isotope systematics along with groundwater chemistry.

Water samples were collected from alluvial and perched intermediate zones and the regional aquifer at Los Alamos, New Mexico, and surrounding areas. A total of 173 water samples were collected from 23 single-screen wells located on the Pajarito Plateau, two surface-water stations in upper Cañon de Valle and Pajarito Canyon, and 27 springs discharging within the Sierra de los Valles and White Rock Canyon. Samples were also collected at two remote sites to provide a chemical and isotopic comparison to the Pajarito Plateau.

Determining groundwater age and flow paths within perched intermediate zones and the regional aquifer is essential in understanding the groundwater flow system at the Laboratory. Knowledge of groundwater age and flow paths provides a technical basis for selecting wells and springs for monitoring. Models of groundwater flow, geochemistry, and contaminant transport should be calibrated to groundwater ages to provide relevant and meaningful results. Groundwater dating is also relevant to groundwater resource management, including aquifer sustainability, especially during periods of long-term drought.

Groundwater and surface water within the Sierra de los Valles provide a source of recharge to groundwater beneath the Pajarito Plateau. Infiltration of surface water within canyons dissecting the Pajarito Plateau also provides a significant source of recharge to alluvial groundwater, which, in turn, provides recharge to perched intermediate zones and ultimately to the regional aquifer. Groundwater within perched intermediate zones and the upper portion of the regional aquifer generally flows from west to east-southeast and discharges at springs within White Rock Canyon and along the banks of the Rio Grande.

With respect to ${ }^{3} \mathrm{H} /{ }^{3} \mathrm{He}$ systematics, ${ }^{3} \mathrm{H}$ is produced by natural processes occurring in the atmosphere and by anthropogenic processes including past detonation of nuclear weapons. Tritium decays to ${ }^{3} \mathrm{He}$ by emission of a beta particle $\left(\beta^{-}\right)$with a half-life of 12.32 years. In addition, the Laboratory has discharged significant amounts of ${ }^{3} \mathrm{H}$ in liquid effluent since 1943. (Greater than $2.23 \times 10^{7}$ picoCuries/liter [pCi/L] of ${ }^{3} \mathrm{H}$ in liquid effluent were released in Pueblo Canyon, Los Alamos Canyon, and Mortandad Canyon from 1943 to the present). Natural concentrations of ${ }^{3} \mathrm{H}$ are $19 \mathrm{pCi} / \mathrm{kg}$ (picoCuries/kilogram) or 6 tritium units (TU) in precipitation around Los Alamos. (One TU equals $3.222 \mathrm{pCi} / \mathrm{kg}$ of ${ }^{3} \mathrm{H}$.) Atmospheric testing of nuclear devices between 1952 and 1962 generated large amounts of atmospheric ${ }^{3} \mathrm{H}$, producing a mean concentration of approximately $6200 \mathrm{pCi} / \mathrm{kg}(2000 \mathrm{TU})$ of ${ }^{3} \mathrm{H}$ in New Mexico precipitation in 1963. As of 2006, however, concentrations of bomb-pulse ${ }^{3} \mathrm{H}$ in the atmosphere were minimal. Concentrations of natural and bomb-pulse ${ }^{3} \mathrm{H}$ are not measurable $(<0.5 \mathrm{pCi} / \mathrm{kg},<0.2 \mathrm{TU})$ within the regional aquifer. However, ${ }^{3} \mathrm{H}$ releases from the Laboratory have migrated to the regional water table beneath several canyons. Other nonadsorbing chemicals - including perchlorate $\left(\mathrm{ClO}_{4}\right)$, nitrate $\left(\mathrm{NO}_{3}\right)$, and uranium $(\mathrm{U})$ coreleased with ${ }^{3} \mathrm{H}$ - have also been measured above background concentrations in perched intermediate groundwater and the regional aquifer. During 
the past five decades, the Laboratory has also released ${ }^{3} \mathrm{H}$ to the atmosphere- ${ }^{3} \mathrm{H}$ which is detected in surface water and springs discharging within the Sierra de los Valles.

In this study, groundwater younger than 1943 is considered to be modern in age, whereas groundwater older than 1943 is submodern. The ${ }^{3} \mathrm{H} /{ }^{3} \mathrm{He}$ dating method is used to quantify apparent groundwater ages in samples younger than 1943 . The ${ }^{14} \mathrm{C}$ dating method is used to quantify groundwater ages between 500 and 40,000 years. This study showed that surface water and alluvial groundwater are entirely modern, based on the ${ }^{3} \mathrm{H} /{ }^{3} \mathrm{He}$ dating method. Average groundwater ages for the regional aquifer varied from 565 years at the western boundary of the Pajarito Plateau to 10,817 years at regional (aquifer) well R-9 in Los Alamos Canyon, based on ${ }^{14} \mathrm{C}$ measurements. Mixed-age groundwater contains both modern and submodern components, a situation resulting from initial infiltration of surface water followed by mixing with alluvial and perched intermediate groundwater and the regional aquifer. This mixing process takes place within several watersheds on the Pajarito Plateau. The regional aquifer is primarily submodern in age; however, it contains a small fraction (typically less than 10 percent by volume) of modern groundwater at some locations downgradient from Laboratory release sites.

Perched intermediate springs in the Sierra de los Valles are either modern, containing excess ${ }^{3} \mathrm{H}$ above baseline atmospheric concentrations, or mixed, containing no excess ${ }^{3} \mathrm{H}$. The ${ }^{14} \mathrm{C}$ dating method shows that two of the springs have average groundwater ages of 2662 and 2486 years. Background perched intermediate groundwater is mixed and only contains atmospheric/cosmogenic ${ }^{3} \mathrm{H}$. Perched intermediate groundwater discharging from springs within the Laboratory boundary is modern and contains excess ${ }^{3} \mathrm{H}$ above baseline atmospheric concentrations. Perched intermediate groundwater in Pueblo Canyon, Los Alamos Canyon, Mortandad Canyon, and Pajarito Canyon have mixed ages and contain excess ${ }^{3} \mathrm{H}$ and other contaminants, including $\mathrm{ClO}_{4}, \mathrm{NO}_{3}$ (as $\left.\mathrm{N}\right)$, $\mathrm{U}$, and/or chromate $\left(\mathrm{CrO}_{4}\right)$. Apparent groundwater ages ranged from 0.13 to 18.5 years, prior to 2005 , at perched intermediate springs and wells.

Regional aquifer groundwater at background wells is submodern and does not contain ${ }^{3} \mathrm{H}$. However, Laboratory-derived ${ }^{3} \mathrm{H}$ occurs in a number of other regional aquifer wells, which also contain $\mathrm{NO}_{3}$ (as $\mathrm{N}$ ), $\mathrm{ClO}_{4}, \mathrm{U}$, and/or $\mathrm{CrO}_{4}$, mostly derived from Laboratory releases. Apparent groundwater ages for 16 regional aquifer wells ranged from 17 to greater than 62 years prior to 2005. Based on groundwater ages and release histories of contaminants, it is very unlikely that there is only one transport or travel time for conservative chemicals including ${ }^{3} \mathrm{H}, \mathrm{NO}_{3}$ (as N), $\mathrm{CrO}_{4}, \mathrm{U}$, and $\mathrm{ClO}_{4}$ migrating from alluvial groundwater to the regional water table. Based on an average apparent groundwater age of 17 years, determined using the ${ }^{3} \mathrm{H} /{ }^{3} \mathrm{He}$ dating method at well R-15, it appears that in Mortandad Canyon, treated effluent initially released from Technical Area 50 (TA-50) in 1963 infiltrated and reached the regional water table within 25 years (in 1988). Mixed groundwater at R-15 contains an average of 8 percent modern water (alluvial groundwater) and 92 percent submodern water (regional aquifer) - a conclusion based on anthropogenic chloride $(\mathrm{Cl})$ measured at the well.

This study evaluated occurrences of ${ }^{3} \mathrm{He}$ and ${ }^{4} \mathrm{He}$ in groundwater, which provide information on natural and possible anthropogenic sources of He isotopes in the subsurface. Anomalous concentrations of ${ }^{3} \mathrm{He}$ and ${ }^{4} \mathrm{He}$ occur at several wells downgradient from ${ }^{3} \mathrm{H}$ and actinide release sites. Solutions used in actinide processing containing ${ }^{4} \mathrm{He}$ and other chemicals were discharged to Pueblo Canyon, Los Alamos Canyon, and Mortandad Canyon as early as 1943. These 
observations are useful in delineating sources and groundwater flow paths in conjunction with ${ }^{3} \mathrm{H}$ and other contaminants. For example, ${ }^{4} \mathrm{He}$ is produced from alpha decay ( $\alpha$ decay) of actinides, including isotopes of $\mathrm{U}$, plutonium $(\mathrm{Pu})$, and americium $(\mathrm{Am})$. Natural and/or Laboratory sources contribute to elevated concentrations of ${ }^{4} \mathrm{He}$ exceeding aqueous solubility in several groundwater samples.

The southern White Rock Canyon springs discharge submodern groundwater, whereas the White Rock Canyon springs more to the north discharge waters of mixed ages. Apparent groundwater ages for the modern component ranged from 0.46 to greater than 62 years for the springs. Several of the northern springs represent discharge zones for perched intermediate groundwater (Spring 4, Spring 4B, and Spring 4C) and contain anthropogenic $\mathrm{NO}_{3}$ (as $\left.\mathrm{N}\right), \mathrm{ClO}_{4}$, and/or ${ }^{3} \mathrm{H}$ far below regulatory limits. The ${ }^{3} \mathrm{H} /{ }^{3} \mathrm{He}$ dating method shows that apparent groundwater ages for the modern component at these three springs range from 1.32 to 21.8 years. Average groundwater ages for Spring 4, Spring 4B, and Spring 4C range from 2159 to 3531 years - a conclusion based on unadjusted ${ }^{14} \mathrm{C}$ measurements. The majority of White Rock Canyon springs - including Spring 3, Spring 3A, Spring 3C, Spring 4A, Spring 4AA, Spring 5, Spring 6, and Spring 9Adischarge from the regional aquifer. Unadjusted ${ }^{14} \mathrm{C}$ measurements show that average groundwater ages for these springs range from 1449 to 7545 years.

No groundwater investigation is complete without using ${ }^{3} \mathrm{H} /{ }^{3} \mathrm{He}$ and ${ }^{14} \mathrm{C}$ dating methods to date groundwater, quantifying amounts of modern, mixed, and/or submodern components present in samples. Results of this study clearly demonstrate the occurrence of multiple flow paths and groundwater ages for samples collected within the Sierra de los Valles, beneath the Pajarito Plateau, and at the White Rock Canyon springs.

\subsection{INTRODUCTION}

\subsection{Purpose, Objectives, and Scope}

The purpose of this investigation was to determine groundwater ages in water samples collected from alluvial and perched intermediate zones and the regional aquifer at Los Alamos, New Mexico, and surrounding areas. Groundwater becomes older as it moves along flow pathways within the three types of aquifer systems. Where flow paths of significantly different lengths converge, groundwater age becomes mixed. Beneath the Pajarito Plateau, mixed-age groundwater should occur in the regional aquifer near the water table as a result of infiltration of surface water. Surface water provides an initial source of recharge to alluvial groundwater, which, in turn, provides recharge to perched intermediate zones and finally to the regional aquifer.

The tritium-helium-3 $\left({ }^{3} \mathrm{H} /{ }^{3} \mathrm{He}\right)$ method dates groundwater younger than 62 years prior to 2005 or younger than 1943, when Los Alamos National Laboratory (LANL, the Laboratory) was established and began releasing ${ }^{3} \mathrm{H}$ to the environment (Rogers 1998, 059169). The carbon-14 $\left({ }^{14} \mathrm{C}\right)$ method can date groundwater ranging from 500 to 40,000 years old. Groundwater age determined from the ${ }^{3} \mathrm{H} /{ }^{3} \mathrm{He}$ dating method is also termed "apparent groundwater age" and does not reflect the average age determined from the ${ }^{14} \mathrm{C}$ dating method. Use of ${ }^{3} \mathrm{H},{ }^{14} \mathrm{C}$, and noble gas and inorganic geochemistry together provide information about flow paths, flow rates, recharge elevations, and mixing processes occurring within groundwater systems beneath the Pajarito 
Plateau. This information is essential in evaluating the susceptibility of perched intermediate and regional aquifer wells to contaminants.

This investigation had two objectives. The first objective was to evaluate the age of modern and/or submodern groundwater present in samples collected from alluvial and perched intermediate-depth zones and the regional aquifer. The second objective was to determine sources of modern recharge occurring since 1943 (local recharge versus Pajarito Plateau-wide recharge) containing natural and/or Laboratory-derived ${ }^{3} \mathrm{H}$ and other anthropogenic sources of chemicals.

Determining groundwater age and flow paths within alluvial and perched intermediate zones and the regional aquifer is an essential aspect of hydrologic, geochemical, and environmental investigations conducted at the Laboratory. Knowledge of groundwater ages and flow paths provides a technical basis for developing and refining hydrologic and geochemical conceptual models and selecting wells and springs for groundwater monitoring. This information is also useful for calibrating groundwater flow and transport models. Such studies are also relevant to groundwater resource management including aquifer sustainability, especially during periods of long-term drought.

The Laboratory, New Mexico Environment Department-Department of Energy Oversight Bureau (NMED-DOEOB), and the United States Geological Survey (USGS) conducted an isotope, noble gas, and geochemical investigation from October 2004 through February 2006.

Groundwater and surface-water samples were collected and analyzed for inorganic solutes, noble gases, and stable and radiogenic isotopes to evaluate groundwater flow paths and ages of samples collected from wells and springs. Figure 1-1 shows the study area for this investigation. Groundwater samples were collected from alluvial and perched intermediate zones and predominantly from the upper portion of the regional aquifer near the water table. Water samples were collected at 23 single-screen wells drilled on the Pajarito Plateau and 27 springs discharging within the Sierra de los Valles and White Rock Canyon. Additional samples were collected from two remote stations - at Seven Springs in the western portion of the Jemez Mountains, and at Arroyo Hondo, north of Taos, New Mexico - to provide an isotopic and chemical comparison to the Pajarito Plateau sites. Surface-water samples were also collected at two locations in upper Cañon de Valle and Pajarito Canyon to evaluate geochemical aspects of surface recharge to alluvial groundwater and deeper saturated zones.

Water samples were analyzed for ${ }^{3} \mathrm{H}$, noble gases including ${ }^{3} \mathrm{He}$, helium-4 $\left({ }^{4} \mathrm{He}\right)$, and neon-22 $\left({ }^{22} \mathrm{Ne}\right)$, stable isotopes of hydrogen $\left(\delta^{2} \mathrm{H}\right)$ and oxygen $\left(\delta^{18} \mathrm{O}\right)$, major ions, and trace elements. Up to six sampling rounds were conducted at springs, wells, and streams as part of this investigation. A subset of the wells and springs was sampled for $\delta^{13} \mathrm{C}$ and ${ }^{14} \mathrm{C}$ during 2005 and 2006. 


\subsection{HYDROCHEMICAL APPROACH FOR THIS INVESTIGATION}

\subsection{Introduction}

Radiogenic and stable isotopes and inorganic geochemistry are commonly used to evaluate groundwater ages and hydrological and geochemical processes occurring within aquifer systems. Inorganic and isotope geochemistry of groundwater provides important data and information for evaluating sources of recharge water, recharge elevation, mixing, oxidation and reduction, precipitation and dissolution, and adsorption and desorption processes. Inorganic geochemistry includes natural solutes and anthropogenic chemicals released from the Laboratory. Mobile or nonadsorbing inorganic contaminants released from the Laboratory include ${ }^{3} \mathrm{H}$, chloride $(\mathrm{Cl})$, perchlorate $\left(\mathrm{ClO}_{4}\right)$, boron $(\mathrm{B})$, chromate $\left(\mathrm{CrO}_{4}\right)$, molybdate $\left(\mathrm{MoO}_{4}\right)$, sulfate $\left(\mathrm{SO}_{4}\right)$, and nitrate $\left(\mathrm{NO}_{3}\right)$.

\subsection{Tritium and Helium}

The ${ }^{3} \mathrm{H} /{ }^{3} \mathrm{He}$ method is used to date modern groundwater that has been generally recharged since 1950 (Clark and Fritz 1997, 059168; Schlosser et al. 1988, 095008; Schlosser et al. 1989, 095013; Manning and Solomon 2005, 095006; Manning et al. 2005, 095004; Manning et al. 2006, 094921). The ${ }^{3} \mathrm{H} /{ }^{3} \mathrm{He}$ method actually dates groundwater because ${ }^{3} \mathrm{H}$ is part of the water molecule, whereas other dating methods including ${ }^{14} \mathrm{C}$ rely on dissolved constituents whose concentrations are controlled by physicochemical and biological processes (Clark and Fritz 1997, 059168). Weissmann et al. (2002, 095010) and Bethke and Johnson $(2002,095009)$, however, point out that groundwater can contain both modern and submodern components that produce a range of ages. Such groundwater is mixed. Groundwater ages are typically computed assuming that all water in a given sample is of the same age, and these ages are typically reported as "piston-flow" or "apparent" ages (Manning et al. 2005, 095004; Blake et al. 1995, 049931).

Investigations conducted by Ekwurzel et al. (1994, 095007), Solomon and Sudicky (1991, 095012), Solomon et al. (1993, 095014), and Schlosser et al. (1989, 095013) demonstrate that the apparent ${ }^{3} \mathrm{H} /{ }^{3} \mathrm{He}$ age is a close approximation of the actual groundwater age, provided that several conditions are met. These conditions include the following:

- the groundwater flow system is simple and homogeneous where mixing is completely due to hydrodynamic dispersion;

- groundwater samples are collected from wells with screen lengths less than one meter $(\mathrm{m})$; and

- groundwater samples are collected from the portion of an aquifer containing only modern water.

These conditions are usually not entirely met, however, and as a result, many if not most groundwater samples are of mixed age. For such samples, use of both ${ }^{3} \mathrm{H} /{ }^{3} \mathrm{He}$ and ${ }^{14} \mathrm{C}$ dating methods is useful for the following reasons: 
- the ${ }^{3} \mathrm{H} /{ }^{3} \mathrm{He}$ dating method provides a close approximation of the age of the modern fraction, regardless of the magnitude of the modern fraction;

- through calculation of initial ${ }^{3} \mathrm{H}$ values, information can be gained about the magnitudes of the modern and submodern fractions; and

- if the modern fraction is relatively small, the ${ }^{14} \mathrm{C}$ dating method can be used to approximate the age of the dominant submodern fraction.

Groundwater containing concentrations of ${ }^{3} \mathrm{H}$ above the background precipitation level strongly indicates the presence of anthropogenic ${ }^{3} \mathrm{H}$ that post dates 1950 when nuclear atmospheric testing commenced. The Laboratory began discharging ${ }^{3} \mathrm{H}$ into the environment in 1943 (Rogers 1998, 059169), and this date sets the upper bound for the apparent (modern) age of groundwater at Los Alamos. Tritium-free groundwater generally is considered to be submodern with a groundwater age often predating 1943 for the Los Alamos area.

\subsubsection{Sources of Tritium and Helium}

Tritium is produced by natural and anthropogenic processes that include past detonation of nuclear weapons resulting in atmospheric contamination. Figure 2-1 presents a conceptual model of ${ }^{3} \mathrm{H},{ }^{3} \mathrm{He}$, and ${ }^{4} \mathrm{He}$ production by both types of processes. Tritium is produced by geogenic or terrigenic processes, which include natural fission of uranium (U), thorium (Th), lithium (Li), and other radiogenic isotopes in rocks. These reactions generate low concentrations of ${ }^{3} \mathrm{H}$ in groundwater-typically less than $0.03 \mathrm{pCi} / \mathrm{kg}$ (0.01 tritium unit [TU]) (Andrews et al. 1989, 094919).

Cosmic-ray production of ${ }^{3} \mathrm{H}$ in water vapor, formed from the bombardment of nitrogen $(\mathrm{N})$ by the flux of neutrons, occurs within the upper atmosphere and is represented by the following two reactions (Clark and Fritz 1997, 059168):

$$
\begin{gathered}
{ }_{7}^{14} \mathrm{~N}+{ }_{0}^{1} \mathrm{n} \rightarrow{ }^{12} \mathrm{C}+{ }_{1}^{3} \mathrm{H} \text { and } \\
{ }_{1}^{3} \mathrm{H}+0.5{ }^{16} \mathrm{O}_{2} \rightarrow{ }_{1}^{3} \mathrm{H} 0.5{ }^{16}{ }_{8} \mathrm{O}_{2}+{ }_{1}^{1} \mathrm{H} \rightarrow{ }_{1}^{1} \mathrm{H}_{1}^{3} \mathrm{H}^{16}{ }_{8} \mathrm{O},
\end{gathered}
$$

where superscripts represent the atomic mass, and subscripts represent the atomic number of each isotope.

Precipitation contains a natural background concentration of ${ }^{3} \mathrm{H}$ that varies by latitude, position within the continent, and season of year (Shevenell and Goff 1995, 073686). The natural concentration of ${ }^{3} \mathrm{H}$ in precipitation in New Mexico prior to atmospheric nuclear testing was approximately $19 \mathrm{pCi} / \mathrm{kg}$ (6 TU) (Blake et al. 1995, 049931). Adams et al. (1995, 047192) report analytical results for ${ }^{3} \mathrm{H}$, stable isotopes, and inorganic chemistry for precipitation samples collected at 14 locations on the Pajarito Plateau and surrounding areas from 1990 to 1993. Concentrations of ${ }^{3} \mathrm{H}$ ranged from 21.07 to $454 \mathrm{pCi} / \mathrm{kg}$ (6.54 to $141 \mathrm{TU}$ ) in rain samples, with ${ }^{3} \mathrm{H}$ levels above $64 \mathrm{pCi} / \mathrm{kg}(>20 \mathrm{TU})$ indicating that the Laboratory released some ${ }^{3} \mathrm{H}$ to the atmosphere (Adams et al. 1995, 047192). Samples analyzed by Adams et al. (1995, 047192) 
showed the highest concentrations of ${ }^{3} \mathrm{H}$ in samples collected during the summer months, reflective of a localized source of precipitation around Los Alamos.

Figure 2-2 shows concentrations of ${ }^{3} \mathrm{H}$ in precipitation from 1952 through 2005 . The atmospheric ${ }^{3} \mathrm{H}$ data were compiled from Adams et al. (1995, 047192) and from stations in Albuquerque, New Mexico, and Ottawa, Canada. The data are reported as weighted means. The Ottawa data from 1952 to 1961 were modified by Shevenell and Goff $(1995,073686)$ and fitted to the Albuquerque data. Atmospheric testing of nuclear devices between 1952 and 1962 generated large amounts of atmospheric ${ }^{3} \mathrm{H}$, which is clearly shown in Figure 2-2. The peak of atmospheric ${ }^{3} \mathrm{H}$ occurred in 1963, has steadily decreased since then, and has stabilized at $19 \mathrm{pCi} / \mathrm{kg}$ (6 TU). Atmospheric nuclear testing resulted in a mean concentration of approximately $6200 \mathrm{pCi} / \mathrm{kg}$ (2000 TU) of ${ }^{3} \mathrm{H}$ in New Mexico precipitation in 1963 (Vuataz and Goff 1986, 095011). This concentration uniformly decreased to $32 \mathrm{pCi} / \mathrm{kg}(10 \mathrm{TU})$ of ${ }^{3} \mathrm{H}$ in 1992,29 years after the Nuclear Test Ban Treaty was implemented in 1963. Concentrations of bomb-pulse ${ }^{3} \mathrm{H}$ in the atmosphere were minimal in 2002 (Figure 2-2).

Groundwater recharged after 1943 contains ${ }^{3} \mathrm{H}$ and tritiogenic ${ }^{3} \mathrm{He}$ concentrations sufficient to determine the apparent groundwater age accurately, given current analytical capabilities. Laboratory discharges containing ${ }^{3} \mathrm{H}$ and other chemicals commenced during the Manhattan Project in 1943 (Rogers 1998, 059169). The time duration of discharging treated effluents containing different concentrations of ${ }^{3} \mathrm{H}$ varied between the facilities. Concentrations of ${ }^{3} \mathrm{H}$ also varied during periods of discharge at the different facilities. Summaries of the release histories of ${ }^{3} \mathrm{H}$ and other chemicals are contained in a Department of Energy (DOE) document (DOE 1987, 052975), a LANL document (LANL 1981, 006059), and Rogers (1998, 059169). The major release sites for ${ }^{3} \mathrm{H}$ include former Technical Area (TA) 1 and TA-45 outfalls that discharged to Acid Canyon and Pueblo Canyon; former TA-21 outfalls that discharged to DP Canyon, a tributary to Los Alamos Canyon; and the active TA-50 discharging to Effluent Canyon, a tributary to Mortandad Canyon. Present-day concentrations of ${ }^{3} \mathrm{H}$ in groundwater beneath the Laboratory are generally far below the U.S. Environmental Protection Agency (EPA) standard of 20,000 picoCuries per liter (pCi/L) or 6207 TU (ESP 2005, 92222).

Blake et al. (1995, 049931) sampled numerous wells and springs for ${ }^{3} \mathrm{H}$ and other constituents within and around the Laboratory, and they report groundwater ages less than 100 years using a "piston-flow" model. Blake et al. (1995, 049931) also report groundwater ages greater than 1000 years, using a "well-mixed" model, which is subject to large uncertainties based on the relatively short half-life of ${ }^{3} \mathrm{H}$ (12.32 years) (Parrington et al. 1996, 058682). The "piston-flow" and "well-mixed" models provide estimates on the minimum and maximum ages of groundwater, respectively.

Concentrations of ${ }^{3} \mathrm{He}$ and ${ }^{4} \mathrm{He}$ measured in groundwater samples collected from wells and springs result from one or more of the following processes:

- decay of ${ }^{3} \mathrm{H}$ (natural and/or anthropogenic) producing tritiogenic ${ }^{3} \mathrm{He}$;

- decay of $U$ and Th within aquifer material and groundwater producing alpha $\left[\alpha\left({ }^{4} \mathrm{He}\right)\right]$ emitters; 
- diffusion of ${ }^{3} \mathrm{He}$ and ${ }^{4} \mathrm{He}$ from the Earth's mantle and crust;

- releases of Laboratory effluent containing plutonium-238 $\left({ }^{238} \mathrm{Pu}\right)$, americium-241 $\left({ }^{241} \mathrm{Am}\right)$, and other actinides with alpha emitters; and

- neutron capture and fission of natural lithium-6 $\left({ }^{6} \mathrm{Li}\right)$, forming ${ }^{3} \mathrm{H}$ and ${ }^{4} \mathrm{He}$.

These different processes potentially provide varying amounts of natural and/or anthropogenic ${ }^{3} \mathrm{He}$ and ${ }^{4} \mathrm{He}$ to saturated zones beneath the Pajarito Plateau.

Helium- 4 is produced by $\alpha$-decay of $U$ and Th isotopes present in minerals comprising aquifer material, for example the Bandelier Tuff and Santa Fe Group sediments. Helium production from minerals containing $U$ and $T h$ varies significantly depending on the concentration of these two actinides. For example, assumed concentrations of $\mathrm{U}$ and $\mathrm{Th}$ within basalt and silica-rich sediments within the Santa Fe Group beneath the Pajarito Plateau are 1 and 4 ppm and 4 and $16 \mathrm{ppm}$, respectively (Vaniman June 2006, 095110). Production of ${ }^{4} \mathrm{He}$ from decay of $\mathrm{U}$ and $\mathrm{Th}$ is estimated using the following equation cited in Clark and Fritz (1997, 059168):

$$
\left[{ }^{4} \mathrm{He}\right]=(\rho)\left(\theta^{-1}\right)(\mathrm{t})\left(1.19 \times 10^{-13}[\mathrm{U}]+2.88 \times 10^{-14}[\mathrm{Th}]\right),
$$

where

$\left[{ }^{4} \mathrm{He}\right]={ }^{4} \mathrm{He}$ concentration in $\mathrm{cm}^{3}$ at standard temperature and pressure (STP)/g water $\left(\mathrm{H}_{2} \mathrm{O}\right)$;

$\theta=$ effective or fractional porosity (volume of void space/volume of rock);

$\rho=$ bulk density $\left(\mathrm{g} / \mathrm{cm}^{3}\right)$;

$\mathrm{t}=$ time (age) of groundwater (years);

$[\mathrm{U}]=$ uranium concentration in rock ppm or $\mathrm{mg} / \mathrm{kg}$; and

$[\mathrm{Th}]=$ thorium concentration in rock in ppm or $\mathrm{mg} / \mathrm{kg}$.

Neutron capture with ${ }^{6} \mathrm{Li}$ usually produces very low concentrations $(<0.03 \mathrm{pCi} / \mathrm{kg},<0.01 \mathrm{TU})$ of both ${ }^{3} \mathrm{H}$ and ${ }^{4} \mathrm{He}$ in groundwater (Clark and Fritz 1997, 059168). Lithium at high enough concentrations (weight percent) produces both ${ }^{3} \mathrm{H}$ and ${ }^{4} \mathrm{He}$ through neutron capture with ${ }^{6} \mathrm{Li}$ by the following reaction:

$$
{ }_{3}^{6} \mathrm{Li}+{ }_{0}^{1} \mathrm{n} \rightarrow{ }_{2}^{4} \mathrm{He}+{ }_{1}^{3} \mathrm{H} .
$$

The molar production of ${ }^{4} \mathrm{He}$ and ${ }^{3} \mathrm{H}$ is 1 to 1 for this reaction.

\subsubsection{Tritium-Helium Dating Systematics}

Dating of modern groundwater using ${ }^{3} \mathrm{H}$ is based on the assumption that the initial ${ }^{3} \mathrm{H}$ present in a given groundwater is established and that the remaining ${ }^{3} \mathrm{H}$ measured in a given sample only 
results from decay that is represented by the following expression (Clark and Fritz 1997, 059168):

$$
{ }^{3} \mathrm{H}_{\mathrm{t}}={ }^{3} \mathrm{H}_{0}\left(\mathrm{e}^{-\lambda \mathrm{t}}\right)
$$

where

$$
\begin{aligned}
& \left.{ }^{3} \mathrm{H}_{0}=\text { initial tritium activity or concentration (TU or } \mathrm{pCi} / \mathrm{kg}\right) ; \\
& \begin{array}{l}
{ }^{3} \mathrm{H}_{\mathrm{t}}= \\
\quad \text { residual tritium activity or concentration }(\mathrm{TU} \text { or } \mathrm{pCi} / \mathrm{kg}) \text { remaining after decay at time }
\end{array} \\
& \lambda=\text { decay constant }\left(\ln 2 / \mathrm{t}_{1 / 2}\right) .
\end{aligned}
$$

The half-life of ${ }^{3} \mathrm{H}$ decay is 12.32 years (Parrington et al. 1996, 058682), and $\lambda=0.0563$. Tritium decays to ${ }^{3} \mathrm{He}$ with the emission of a beta particle ( $\beta^{-}$particle) according to the following reaction (Clark and Fritz 1997, 059168):

$$
{ }^{3} \mathrm{H} \rightarrow{ }^{3} \mathrm{He}+\beta^{-} .
$$

The amount of ${ }^{3} \mathrm{He}$ that is produced from the decay of ${ }^{3} \mathrm{H}$ over time is represented by the following equation:

$$
{ }^{3} \mathrm{He}_{\mathrm{t}}={ }^{3} \mathrm{H}_{\mathrm{t}}-{ }^{3} \mathrm{H}_{\mathrm{t}} \mathrm{e}^{-\lambda \mathrm{t}}
$$

where

$$
\begin{aligned}
& { }^{3} \mathrm{He}_{\mathrm{t}}=\text { helium- } 3 \text { concentration at time } \mathrm{t} ; \\
& { }^{3} \mathrm{H}_{\mathrm{t}}=\text { tritium concentration at time } \mathrm{t} \text {; } \\
& \lambda=\text { decay constant }\left(\ln 2 / \mathrm{t}_{1 / 2}\right) \text {; and } \\
& \mathrm{t}=\text { time. }
\end{aligned}
$$

${ }^{3} \mathrm{He}_{\mathrm{t}}$ is in units of TU, and there is one ${ }^{3} \mathrm{He}$ atom per $10^{18} \mathrm{H}$ atoms, which is equivalent to 3.222 $\mathrm{pCi} / \mathrm{kg} \mathrm{H}_{2} \mathrm{O}$ (Clark and Fritz 1997, 059168).

Concentrations of ${ }^{3} \mathrm{He}_{\mathrm{t}}$ and ${ }^{3} \mathrm{H}_{\mathrm{t}}$ are measured during analysis, and the groundwater age for a given sample is obtained by rearranging equation 2-5 and solving (as follows) for time $t$ (years):

$$
\begin{gathered}
\mathrm{t}=1 / \lambda \ln \left(1+{ }^{3} \mathrm{He}_{\mathrm{t}} /{ }^{3} \mathrm{H}_{\mathrm{t}}\right), \text { therefore, } \\
\mathrm{t}=17.77 \ln \left(1+{ }^{3} \mathrm{He}_{\mathrm{t}} /{ }^{3} \mathrm{H}_{\mathrm{t}}\right) .
\end{gathered}
$$

The initial concentrations of ${ }^{3} \mathrm{H}$ calculated for samples analyzed as part of this investigation were determined by the following expression: 


$$
{ }^{3} \mathrm{H}_{\mathrm{o}}={ }^{3} \mathrm{H}_{\mathrm{t}} / \mathrm{e}^{-\lambda \mathrm{t}}
$$

where

$$
\begin{aligned}
& { }^{3} \mathrm{H}_{\mathrm{o}}=\text { initial concentration of }{ }^{3} \mathrm{H} \text { in } \mathrm{pCi} / \mathrm{kg} \text { or TU; } \\
& { }^{3} \mathrm{H}_{\mathrm{t}}=\text { present day concentration of }{ }^{3} \mathrm{H} \text { in } \mathrm{pCi} / \mathrm{kg} \text { or } \mathrm{TU} ; \\
& -\lambda=\text { decay constant }\left(\ln 2 / \text { half-life of }{ }^{3} \mathrm{H}, 12.32 \text { years }\right) \text {; and } \\
& \mathrm{t}=\text { time or age in years. }
\end{aligned}
$$

\subsubsection{Physical Controls on Apparent Groundwater Age Determined by the ${ }^{3} \mathrm{H} /{ }^{3} \mathrm{He}$ Dating Method}

The magnitude of a given apparent groundwater age, as determined by the ${ }^{3} \mathrm{H} /{ }^{3} \mathrm{He}$ dating method, is directly influenced by saturated and unsaturated flow conditions. The ${ }^{3} \mathrm{H} /{ }^{3} \mathrm{He}$ dating method quantifies the time lapse since ${ }^{3} \mathrm{H}$ encountered fully saturated media. Calculated initial ${ }^{3} \mathrm{H}$ values represent ${ }^{3} \mathrm{H}$ activity at the point when the tritiated water entered the saturated zone and began accumulating ${ }^{3} \mathrm{He}$ (Figure 2-1).

Precipitation contributes a source of ${ }^{3} \mathrm{H}$ from cosmogenic and Laboratory atmospheric releases and residual bomb pulse. Laboratory-derived ${ }^{3} \mathrm{H}$ is present in treated effluent discharged to stream channels, providing an additional source of recharge to alluvial groundwater. Tritium decay occurs within alluvial groundwater, and ${ }^{3} \mathrm{He}$ starts to accumulate under saturated flow conditions. Apparent ${ }^{3} \mathrm{H} /{ }^{3} \mathrm{He}$ groundwater ages in samples collected from a given alluvial aquifer are typically less than a few years - in response to relatively fast groundwater flow velocities within permeable, alluvial sediments (Purtymun 1974, 005476; and Purtymun et al. 1977, 011846). Variations in recharge from local precipitation versus that of groundwater sources such as springs located upstream may also affect the apparent groundwater ages. For example, during time of drought, the alluvial aquifer groundwater may be biased as old because recharge is dominated by springs with ages exceeding the seasonal atmospheric signals. Likewise, during a large snowmelt-runoff period, the alluvial groundwater will reflect a very young apparent age derived from the seasonal snowfall.

Alluvial groundwater provides a source of recharge to perched intermediate zones. Unsaturated flow conditions occur between shallow alluvial aquifers and perched intermediate-depth aquifers, and between perched intermediate zones and the regional water table. Loss of tritiogenic ${ }^{3} \mathrm{He}$ should occur through gas exchange with vadose-zone air under unsaturated flow conditions. Samples collected from perched intermediate zones and the regional aquifer, therefore, should have apparent ${ }^{3} \mathrm{H} /{ }^{3} \mathrm{He}$ ages considerably less than the time elapsed since infiltration. When groundwater recharges a perched intermediate zone, ${ }^{3} \mathrm{He}$ starts to reaccumulate under saturated flow conditions, and the ${ }^{3} \mathrm{H} /{ }^{3} \mathrm{He}$ "clock" is reset. Samples collected from perched intermediate wells located within a recharge zone can have young apparent ${ }^{3} \mathrm{H} /{ }^{3} \mathrm{He}$ ages of several years because of the reaccumulation of ${ }^{3} \mathrm{He}$. Apparent ${ }^{3} \mathrm{H} /{ }^{3} \mathrm{He}$ ages will increase along flow paths within perched intermediate zones under saturated flow conditions. The same processes take place within the unsaturated zone overlying the regional water table and within the regional aquifer. 


\subsubsection{Protocols for Interpreting Apparent Groundwater Age Determined by the ${ }^{3} \mathrm{H} /{ }^{3} \mathrm{He}$ Dating Method and Anthropogenic Chemicals}

This subsection presents a technical basis for establishing protocols for interpreting ${ }^{3} \mathrm{H}$ and other anthropogenic chemicals detected above background in groundwater beneath the Pajarito Plateau. Figure 2-3 shows release timelines for different types of liquid effluent containing ${ }^{3} \mathrm{H}$, $\mathrm{NO}_{3}$ (as N), $\mathrm{B}, \mathrm{CrO}_{4}, \mathrm{ClO}_{4}, \mathrm{MoO}_{4}, \mathrm{U}, \mathrm{Pu}, \mathrm{Am}$, fission products, and other contaminants that were released to several watersheds from 1943 to 2005 . These contaminants fall into five general categories shown in Figure 2-3. Tritium and chromium (Cr) are the only contaminants detected in perched intermediate groundwater (Mortandad Canyon Observation Bandelier Tuff well [MCOBT]-4.4) and the regional aquifer (R-28), respectively, that currently exceed state and/or federal drinking water standards (LANL 2006, 091987; LANL 2006, 094161).

1. Untreated Laboratory industrial effluents were discharged into Acid Canyon and Pueblo Canyon from 1943 to the early 1950s. These releases contained high concentrations of ${ }^{3} \mathrm{H}$ and other radionuclides, $\mathrm{NO}_{3}($ as $\mathrm{N}), \mathrm{SO}_{4}, \mathrm{ClO}_{4}$, and other chemicals.

2. Power-steam plant blowdown water has been discharged to Los Alamos Canyon, Sandia Canyon, and Effluent Canyon, and to Cañon de Valle since the early 1950s. The regional aquifer water used at the power-steam plant is assumed to be ${ }^{3} \mathrm{H}$-free. The blowdown water has high concentrations of $\mathrm{Cl}, \mathrm{CrO}_{4}, \mathrm{MoO}_{4}$, phosphate $\left(\mathrm{PO}_{4}\right), \mathrm{SO}_{4}$, zinc $(\mathrm{Zn})$ and other chemicals. Isotopically, these discharge waters are enriched in ${ }^{18} \mathrm{O}$ and ${ }^{2} \mathrm{H}$ compared to local groundwater because of evaporation occurring within the cooling towers.

3. Residual high-explosive (HE) wastes were discharged by the Laboratory to Cañon de Valle and Water Canyon from the early 1950s to the mid 1990s. These releases are assumed to be ${ }^{3} \mathrm{H}$-free with high concentrations of HE, metals, and other mobile solutes.

4. Treated industrial effluents have been discharged by the Laboratory to Bayo Canyon, Pueblo Canyon, Los Alamos Canyon, Ten Site Canyon, and Mortandad Canyon since the early 1950s. These releases contained high concentrations of ${ }^{3} \mathrm{H}$ and other radionuclides, $\mathrm{NO}_{3}\left(\right.$ as N)$, \mathrm{SO}_{4}, \mathrm{ClO}_{4}$, and other chemicals.

5. Treated sanitary effluents were discharged by the Laboratory and/or the County of Los Alamos to Pueblo Canyon, Los Alamos Canyon, Sandia Canyon, Ten Site Canyon, and Pajarito Canyon, and to Cañada del Buey. Regional aquifer water in most of these releases is assumed to be ${ }^{3} \mathrm{H}$-free with $\mathrm{NO}_{3}($ as $\mathrm{N}), \mathrm{B}, \mathrm{Cl}$, total organic carbon, and other solutes.

Volumes and concentrations of contaminants varied during discharge histories for major industrial (DOE 1987, 052975) and municipal outfalls. The Laboratory discharged effluents containing ${ }^{3} \mathrm{H}$ and other chemicals to Pueblo Canyon, Los Alamos Canyon, Sandia Canyon, and Mortandad Canyon and Cañon de Valle as early as 1943 (Rogers 1998, 059169). Tritium, $\mathrm{SO}_{4}$, $\mathrm{NO}_{3}\left(\right.$ as N)$, \mathrm{CrO}_{4}, \mathrm{ClO}_{4}, \mathrm{~B}, \mathrm{MoO}_{4}, \mathrm{Cl}$, fluoride $(\mathrm{F})$, and $\mathrm{U}$ are present in the liquid effluents, and these mobile contaminants are detected in groundwater downgradient from the various outfalls. Usually, several of the mobile contaminants are present at contaminated regional aquifer wells 
because they were released during similar periods of time. Some of the contaminants including barium $(\mathrm{Ba})$, cesium-137 $\left({ }^{137} \mathrm{Cs}\right)$, strontium-90 $\left({ }^{90} \mathrm{Sr}\right),{ }^{238,239,240} \mathrm{Pu}$, and ${ }^{241} \mathrm{Am}$ are less mobile and adsorb onto solids (Langmuir 1997, 056037). The adsorbing contaminants are concentrated within alluvial groundwater and upper portions of the unsaturated zone, and their detection in deep aquifers is sporadic (LANL 2006, 094161).

It is reasonable to assume that wells and springs outside the Laboratory property containing contaminants associated with treated sewage effluent and not from industrial effluent are derived from other sources. This assumption applies to wells within the Española basin, north of the Los Alamos Canyon-Rio Grande confluence and east of the Rio Grande.

\subsubsection{Background Wells and Springs}

This subsection presents a summary of natural or anthropogenic ${ }^{3} \mathrm{H}$ and other chemicals detected at springs, wells, and surface water sampled as part of this investigation. Section 6 provides detailed discussions on analytical results for samples collected from the Sierra de los Valles, Pajarito Plateau, White Rock Canyon, and surrounding areas (Jemez Mountains and Arroyo Hondo). Table 2-1 provides background concentrations of $\mathrm{Cl}, \mathrm{F}, \mathrm{NO}_{3}+\mathrm{NO}_{2}$ (as $\left.\mathrm{N}\right), \mathrm{NO}_{3}$ (as N), $\mathrm{ClO}_{4}, \mathrm{SO}_{4}$, and $\mathrm{U}$ within perched intermediate groundwater and the regional aquifer (LANL 2007, 094856). These analytes are mobile in groundwater, and they are used to detect contamination within saturated zones. They also travel the greatest distance along groundwater flow paths and do not adsorb onto aquifer material to a significant extent.

Remote sampling stations including Seven Springs and Arroyo Hondo contain cosmogenic ${ }^{3} \mathrm{H}$, and they are not impacted by Laboratory discharges. Concentrations of ${ }^{3} \mathrm{H}, \mathrm{NO}_{3}($ as $\mathrm{N}), \mathrm{Cl}, \mathrm{SO}_{4}$, $\mathrm{ClO}_{4}$, and other chemicals are lower at these two off-site sampling stations (Section 6) in comparison to contaminated wells and springs sampled during this investigation. Springs discharging in the Sierra de los Valles, including Barbara Spring, Campsite Springs, Alamo(AL)-10.6 Spring, and Water Canyon Gallery (WCG) Spring, contain cosmogenic ${ }^{3} \mathrm{H}$. These springs provide a source of recharge to groundwater beneath the western portion of the Pajarito Plateau. Los Alamos Observation Intermediate well LAOI(A)-1.1 in upper Los Alamos

Canyon contains ${ }^{3} \mathrm{H}$ at concentrations less than baseline precipitation. This well does not contain Laboratory-derived contaminants even though it is downgradient from TA-2, which released ${ }^{3} \mathrm{H}$ directly to alluvial groundwater, probably from 1956 through 1992 (Rogers 1998, 059169). Regional aquifer wells R-1, R-2, R-6, and R-18 contain natural ${ }^{3} \mathrm{H}$ at concentrations less than $0.5 \mathrm{pCi} / \mathrm{kg}(0.2 \mathrm{TU})$ and are free of Laboratory-derived contaminants. Springs discharging in White Rock Canyon, including Spring 6 and Spring 9A, do not contain ${ }^{3} \mathrm{H}$ or any other Laboratory-derived contaminants.

\subsubsection{Wells, Springs, and Surface Water Containing Atmospheric Tritium Released from the Laboratory}

In several cases, ${ }^{3} \mathrm{H}$ is the only contaminant detected in groundwater and surface water at concentrations exceeding baseline precipitation. This situation occurs at several sampling stations within the Sierra de los Valles, including Cañon de Valle (CdV)-5.0 Spring, PC Spring, and Young Spring, Pajarito Ski Well \#2, and surface water stations PA-10.6 and CdV-5.6. 
Tritium at these upgradient sampling sites is most likely derived from a combination of a cosmogenic source and Laboratory atmospheric releases.

\subsubsection{Wells and Springs Containing Tritium from Laboratory Effluent}

Groundwater contamination occurs downgradient of industrial outfalls at the Laboratory.

The co-occurrence of ${ }^{3} \mathrm{H}, \mathrm{CrO}_{4}, \mathrm{U}, \mathrm{NO}_{3}$ (as N), and/or $\mathrm{ClO}_{4}$ in groundwater provides sufficient evidence that these contaminants were derived from the Laboratory. Los Alamos Canyon, Sandia Canyon, and Mortandad Canyon received industrial effluent discharges containing ${ }^{3} \mathrm{H}, \mathrm{NO}_{3}($ as $\mathrm{N}), \mathrm{U}, \mathrm{CrO}_{4}, \mathrm{MoO}_{4}$, and/or $\mathrm{ClO}_{4}$ that are mobile in groundwater. Perched intermediate springs including Martin Spring, Starmer Spring, Burning Ground Spring, Homestead Spring, Bulldog Spring, and TA-18 contain anthropogenic ${ }^{3} \mathrm{H}$ concentrations in excess of baseline precipitation. Regional aquifer wells including test well (TW)-2, TW-3, TW-8, R-9, R-11, R-15, R-28, and perched intermediate wells MCOBT-4.4, Mortandad Canyon Observation Intermediate depth (MCOI)-6, and R-6i, contain ${ }^{3} \mathrm{H}$ and other chemicals released from the Laboratory. Several springs discharging in White Rock Canyon, including Spring 3, Spring 3A, Spring 3C, Spring 4, Spring 4A, Spring 4AA, and Spring 4B, contain ${ }^{3} \mathrm{H}$ concentrations ranging between 0.45 and $41.69 \mathrm{pCi} / \mathrm{kg}(0.14$ and $12.94 \mathrm{TU})$. Because ${ }^{3} \mathrm{H}$ is not detected at all of the White Rock Canyon springs, some of the springs containing ${ }^{3} \mathrm{H}$ suggest a Laboratory source. Nitrate, $\mathrm{ClO}_{4}$, and other chemicals present at several springs above background provide additional evidence for contamination from mixed sources.

\subsubsection{Wells Containing Laboratory and County of Los Alamos Effluent}

Pueblo Canyon has received effluent discharged by both the Laboratory $\left({ }^{3} \mathrm{H}, \mathrm{NO}_{3}, \mathrm{U}, \mathrm{Pu}, \mathrm{Am}\right.$, and $\mathrm{ClO}_{4}$ ) and the County of Los Alamos (primarily $\mathrm{NO}_{3}$ from the Bayo Sewage Treatment Plant and predecessor treatment plants) resulting in commingled plumes within perched intermediate zones and the regional aquifer. Regional aquifer wells R-4, TW-1, and inactive supply well Otowi(O)-1 and perched intermediate wells TW-1A and Pueblo Observation Intermediate (depth) (POI)-4 contain effluent derived from both the Laboratory and the County of Los Alamos. The County of Los Alamos also operates a sewage treatment plant in White Rock that releases treated effluent to lower Cañada del Buey. Nitrate, $\mathrm{Cl}, \mathrm{SO}_{4}, \mathrm{~B}$, and other chemicals are detected above background at the downgradient Spring 2B. Contamination at Spring 2B is most likely derived from the White Rock sewage treatment plant. Tritium is also present above cosmogenic background at Spring 2B, and its origin is unknown. Regional aquifer groundwater free of ${ }^{3} \mathrm{H}$ is processed or treated at the sewage treatment plants operated by the Laboratory and the County of Los Alamos. These treated waters are assumed to be ${ }^{3} \mathrm{H}$ free because the water was originally derived from the regional aquifer, which is assumed to be free of ${ }^{3} \mathrm{H}$.

\subsubsection{Wells Containing Laboratory Effluent, Excluding Tritium}

Nitrate and other contaminants detected in regional aquifer groundwater, without ${ }^{3} \mathrm{H}$ present, provide evidence for mixed-age components. Pajarito Canyon has received sewage effluent discharged by the Laboratory (TA-18) (DOE 1987, 052975). Regional aquifer well R-23 contains concentrations of $\mathrm{NO}_{3}$ (as $\left.\mathrm{N}\right)$ that exceed LANL background (Table 2-1); however, the well does not contain detectable ${ }^{3} \mathrm{H}$. This well is downgradient of the inactive sewage lagoons east of the TA-18 facilities within the Laboratory. Regional aquifer well R-13 in Mortandad 
Canyon also contains $\mathrm{NO}_{3}$ (as $\mathrm{N}$ ) concentrations slightly exceeding LANL background (Table 2-1), and this well is generally free of ${ }^{3} \mathrm{H}$. Spring 5, discharging in White Rock Canyon, contains $\mathrm{NO}_{3}$ (as $\left.\mathrm{N}\right)$; however, concentrations of ${ }^{3} \mathrm{H}$ are less than detection.

\subsubsection{Previous Hydrogeologic and Environmental Geochemical Investigations Conducted at the Laboratory}

Knowledge of the hydrogeologic setting of the Pajarito Plateau, groundwater geochemistry, and sources and types of contaminants released from the Laboratory is required for the reader to understand occurrence and source of contaminants found in deep groundwater. This knowledge is essential for evaluating groundwater age, mixing, and flow paths. A thorough discussion on the hydrogeology of the Pajarito Plateau is presented in the Hydrologic Synthesis Report (LANL 2005, 092028). Work plans and investigation reports for Mortandad Canyon (LANL 1997, 056835; LANL 2006, 094161) and Los Alamos Canyon (LANL 1997, 055622) are examples of documents that provide detailed discussions on previous releases from the Laboratory and the nature and extent of groundwater contamination. The Laboratory has addressed groundwater background in detail for the Pajarito Plateau (LANL 2005, 090580; LANL 2007, 094856). Detailed discussions on groundwater and surface-water monitoring are presented in the annual Laboratory Surveillance reports. Groundwater geochemistry is discussed in detail by Longmire (2002, 072713; 2002, 072800; 2002, 073282; 2002, 072614; 2002, 073676; 2005, 088510) and Longmire and Goff (2002, 075905).

\subsection{Carbon Isotopes}

Carbon isotopes including ${ }^{14} \mathrm{C}$ and $\delta^{13} \mathrm{C}$ were analyzed in groundwater samples to determine average ages and to evaluate geochemical processes such as $\mathrm{CaCO}_{3}$ (calcite) dissolution that influence average groundwater ages determined through the use of the ${ }^{14} \mathrm{C}$ dating method. Carbon-14 decays to nitrogen-14 $\left({ }^{14} \mathrm{~N}\right)$, and this decay involves the emission of a $\beta^{-}$particle (Parrington et al. 1996, 058682). Carbon-14 has a half-life of 5730 years (Clark and Fritz 1997, 059168). Groundwater ages determined by the ${ }^{14} \mathrm{C}$ dating method, however, are not affected by vadose-zone gas exchange, and they record the time since infiltration. Carbon-14 ages should generally increase subhorizontally along flow paths at depth, from recharge to discharge zones within the regional aquifer. This conclusion assumes that the majority of groundwater at the regional water table is older than 63 years or is submodern.

The $\delta^{13} \mathrm{C}$ ratios in groundwater samples collected during this investigation are influenced by several factors including concentration of dissolved inorganic carbon (DIC) mainly in the form of bicarbonate $\left(\mathrm{HCO}_{3}\right), \mathrm{pH}$ (negative log base 10 of the hydrogen-ion activity, a measure of acidbase range), equilibrium with $\mathrm{CaCO}_{3}$, and open and closed systems with respect to carbon dioxide $\left[\mathrm{CO}_{2}(\mathrm{~g})\right]$ (Clark and Fritz 1997, 059168). Open systems are characteristic of water table conditions in which there is an infinite reservoir of $\mathrm{CO}_{2}(\mathrm{~g})$ allowing exchange between groundwater and the overlying unsaturated zone. Closed systems are characteristic of conditions below the water table in which there is a finite reservoir of $\mathrm{CO}_{2}(\mathrm{~g}) . \delta^{13} \mathrm{C}$ ratios of DIC vary depending on open and closed systems and the source of carbon. Between $\mathrm{pH}$ values of 7 and 8 , the $\delta^{13} \mathrm{C}$ ratio of DIC in equilibrium with marine $\mathrm{CaCO}_{3}$, characterized by a $\delta^{13} \mathrm{C}$ ratio of 0 permil under open conditions $\left[\mathrm{CO}_{2}(\mathrm{~g})=10^{-2.5} \mathrm{bar}\right]$, is calculated to be -15.5 permil with $\mathrm{C}$ derived from $\mathrm{C}_{3}$ plants (Clark and Fritz 1997, 059168). Examples of $\mathrm{C}_{3}$ plants include ponderosa 
pine, piñon, juniper, and certain species of grass, which occur on the Pajarito Plateau and within the Sierra de los Valles and Jemez Mountains. Concentration of $\mathrm{HCO}_{3}^{-}$exceeds $61 \mathrm{ppm}\left(10^{-3}\right.$ moles $/ \mathrm{kg} \mathrm{H}_{2} \mathrm{O}$ ) under these conditions. An open system with respect to $\mathrm{CO}_{2}(\mathrm{~g})$ is consistent with flow paths at the regional water table rather than flow paths occurring deep below the regional water table characteristic of a closed system. A closed system with respect to $\mathrm{CO}_{2}(\mathrm{~g})$ under the same conditions with respect to $\mathrm{CO}_{2}(\mathrm{~g})$ and $\mathrm{C}_{3}$ plants would produce $\delta^{13} \mathrm{C}$ ratios of -12.1 permil at a $\mathrm{pH}$ of 9.8 in equilibrium with marine $\mathrm{CaCO}_{3}$. Carbon derived from $\mathrm{C}_{4}$ plants - including blue grama grass - produce $\delta^{13} \mathrm{C}$ ratios that are much heavier (-1.5 permil) in groundwater in equilibrium with $\mathrm{CaCO}_{3}$ under open conditions with respect to $\mathrm{CO}_{2}(\mathrm{~g})$ at $10^{-2.5}$ bar between $\mathrm{pH}$ values of 7 and 8 (Clark and Fritz 1997, 059168).

Fresh-water or nonmarine $\mathrm{CaCO}_{3}$ occurring in different volcanic and sedimentary aquifer material around Los Alamos is characterized by $\delta^{13} \mathrm{C}$ ratios varying from -7.5 to +2.5 permil. This type of $\mathrm{CaCO}_{3}$ is also predicted to cause a shift to heavier $\delta^{13} \mathrm{C}$ ratios for DIC under both open and closed systems with respect to $\mathrm{CO}_{2}(\mathrm{~g})$.

\subsection{Stable Isotopes}

Groundwater samples collected as part of this investigation were analyzed for $\delta^{2} \mathrm{H}$ and $\delta^{18} \mathrm{O}$. $\delta^{2} \mathrm{H}$ and $\delta^{18} \mathrm{O}$ are useful in evaluating groundwater mixing and seasonal isotopic shifts in precipitation, and for determining recharge elevation — assuming that precipitation and infiltration occur at the same elevation. This assumption is mostly valid for springs discharging within the Sierra de los Valles, but it may not be entirely applicable for groundwater beneath the Pajarito Plateau because recharge could take place at lower elevations in comparison to precipitation. Mixing of recharge water with groundwater within perched intermediate zones and the upper portion of the regional aquifer influences $\delta^{2} \mathrm{H}$ and $\delta^{18} \mathrm{O}$ values in the groundwater samples.

\subsection{Major Ion and Trace Element Geochemistry}

Groundwater and surface water samples collected during this investigation were analyzed for major ions including calcium $(\mathrm{Ca})$, sodium $(\mathrm{Na})$, potassium $(\mathrm{K})$, magnesium $(\mathrm{Mg}), \mathrm{Cl}, \mathrm{SO}_{4}$, and total carbonate alkalinity. The major ions provide information on the type of groundwater$\mathrm{Ca}-\mathrm{Na}-\mathrm{HCO}_{3}$, for example - and can be compared with other groundwaters to evaluate mixing and geochemical reactions including cation exchange. The samples were also analyzed for trace elements including $\mathrm{B}, \mathrm{Cr}, \mathrm{Li}, \mathrm{Sr}$, and $\mathrm{U}$. These different trace elements are discussed in this report because:

- they are naturally occurring;

- their concentrations generally are unique to each of the three aquifer types beneath the Pajarito Plateau (LANL 2005, 090580; LANL 2007, 094856);

- they can increase in concentration along groundwater flow paths within the perched intermediate zones and/or regional aquifer; and

- they are generally found in treated effluent released from the Laboratory. 
Lithium is dominantly stable as free or noncomplexed $\mathrm{Li}^{+}$in aqueous solution. Lithium is partly attenuated along groundwater flow paths through cation exchange reactions (Langmuir 1997, 056037). Lithium is associated with hydrothermal fluids found in the Jemez Mountains.

Boron hydrolyzes, forming the species $\mathrm{B}(\mathrm{OH})_{3}{ }^{0}$ that is stable at $\mathrm{pH}$ values less than 10.22 at $25^{\circ} \mathrm{C}$ (Brookins 1988, 049928). This species is mobile in groundwater because of its neutral charge. Boron is concentrated in detergents and is commonly associated with treated sewage effluent discharged by the Laboratory and the town of Los Alamos.

Chromium is stable as $\mathrm{Cr}(\mathrm{III})$ and $\mathrm{Cr}(\mathrm{VI})$ in aqueous solution (Rai and Zachara 1986, 091684). Chromium(III) is less mobile than $\mathrm{Cr}(\mathrm{VI})$ in groundwater because of adsorption and coprecipitation reactions with iron (Rai and Zachara 1986, 091684). Under oxidizing conditions and above $\mathrm{pH} 6.5, \mathrm{Cr}(\mathrm{VI})$ is dominantly stable as $\mathrm{CrO}_{4}{ }^{2-}$ and is more mobile than $\mathrm{Cr}(\mathrm{III})$ species. Chromate adsorption onto ferric (oxy)hydroxide decreases under alkaline $\mathrm{pH}$ conditions (Rai and Zachara 1986, 091684). Background concentrations of detectable $\mathrm{Cr}(\mathrm{VI})$ measured in groundwater samples from selected wells on the Pajarito Plateau ranged from 0.001 to $0.006 \mathrm{ppm}$ (1 to $6 \mu \mathrm{g} / \mathrm{L}$ or ppb) (LANL 2006, 091987). Background concentrations of total dissolved $\mathrm{Cr}$ range from 0.00039 to $0.00731 \mathrm{ppm}(0.39$ to $7.31 \mathrm{ppb})$ within the regional aquifer (LANL 2007, 094856).

Strontium is dominantly stable as $\mathrm{Sr}^{2+}$ in groundwater beneath the Laboratory. Strontium carbonate may precipitate from solution, provided that sufficient concentrations of total carbonate alkalinity are available. Such conditions are typical of the regional aquifer (Santa $\mathrm{Fe}$ Group sediments). Strontium substitutes for $\mathrm{Ca}^{2+}$, since these metals have similar ionic charge and ionic radii. Strontium tends to concentrate in $\mathrm{CaCO}_{3}$ (calcite), occurring as fracture fill within soils and Cerros del Rio volcanic rocks and as coatings within the Santa Fe Group sediments and basalt. The geochemistry of stable or nonradiogenic Sr is identical to that of ${ }^{90} \mathrm{Sr}^{2+}$ in terms of speciation, mineral equilibrium, and adsorption reactions.

Uranium is dominantly stable in the $+\mathrm{IV}$ and $+\mathrm{VI}$ oxidation states in aqueous solution. In most groundwater beneath the Laboratory, $\mathrm{U}(\mathrm{VI})$ species including $\mathrm{UO}_{2} \mathrm{CO}_{3}{ }^{0}, \mathrm{UO}_{2}\left(\mathrm{CO}_{3}\right)_{2}{ }^{2-}$, and $\mathrm{UO}_{2}\left(\mathrm{CO}_{3}\right)_{3}{ }^{4}$ dominate under oxidizing conditions in the presence of dissolved oxygen (DO), $\mathrm{NO}_{3}$, and $\mathrm{SO}_{4}$. Uranium(VI)-carbonate species tend not to adsorb onto solids and are mobile under alkaline $\mathrm{pH}$ conditions typical of local groundwater (Langmuir 1997, 056037).

Barium is a trace element of interest at the Laboratory because of its use as $\mathrm{Ba}\left(\mathrm{NO}_{3}\right)_{2}$ in the preparation of $\mathrm{HE}$ compounds at TA-16. Use of $\mathrm{Ba}$ as a contaminant indicator during this investigation is restricted because $\mathrm{Ba}-\mathrm{a}$ trace constituent of some sample filters - was leached from sample filters used prior to sample preservation. Concentrations of Ba were higher in some filtered samples than in nonfiltered samples. No other analytes showed this concentration relationship between filtered and nonfiltered samples.

\subsection{PREVIOUS HYDROLOGIC AND HYDROCHEMICAL CONCEPTUAL MODELS}

This section provides a discussion on hydrological and geochemical processes that influence recharge, discharge, and groundwater age. Figure 3-1 shows generalized expected trends in groundwater age for a conceptual model for groundwater flow within the Sierra de los Valles and 
beneath the Pajarito Plateau with discharge occurring at the White Rock Canyon springs. This conceptual model is based in part on previous hydrologic conceptual models presented in LANL (2005, 092028), Birdsell et al. (2005, 092048), Keating et al. (2005, 090039), Robinson et al. (2005, 091682), and Kwicklis et al. (2005, 090069).

\subsection{Recharge Zone Within Sierra de los Valles}

Groundwater recharge within the Sierra de los Valles may occur through subsurface inflow and focused transmission along drainages within the mountain block and front (Figure 3-1). This groundwater may either discharge to mountain streams and springs or infiltrate to perched intermediate zones and the regional aquifer beneath the Sierra de los Valles. Mountain stream water infiltrates and recharges perched intermediate zones and the regional aquifer as it flows across the Pajarito fault at the Sierra de los Valles/Pajarito Plateau transition, providing a source of recharge to perched intermediate zones (Dale et al. 2005, 095002) and possibly to the regional aquifer.

\subsection{Recharge Along Canyon Bottoms, Pajarito Plateau}

Recharge also occurs along stream channels on the Pajarito Plateau by infiltration of surface water. This "canyon recharge" flows directly to alluvial groundwater with additional infiltration to perched intermediate zones and the regional aquifer (Figure 3-1). Groundwater flow paths may consist of a combination of vertical and subhorizontal ("step-wise" or "stair-step") vectors of variable lengths depending upon position of recharge and hydrologic properties of the aquifer material (Figure 3-1). Vector lengths of groundwater flow are controlled by porous or fractured media, hydraulic gradients, saturated and unsaturated flow conditions, geologic structure, and contrasting permeability within and between hydrostratigraphic units. Based on the presence of contaminants [for example, $\mathrm{ClO}_{4}, \mathrm{CrO}_{4}, \mathrm{NO}_{3}$ (as N), ${ }^{3} \mathrm{H}$, and $\mathrm{U}$ ] within the regional aquifer, it appears that groundwater ages for "step-wise" flow vectors are shorter than 50 years within the vadose zone. Vertical or "fast paths" can also occur such that ponded or perennial surface water provides a source of recharge and the underlying hydrostratigraphic units are characterized by high matrix permeability and/or fracture flow conditions.

Alluvial groundwater consists of modern water derived from precipitation, Laboratory releases, and/or springs. Submodern water (regional aquifer groundwater) is also present in alluvial groundwater, derived from natural sources (for example, artesian conditions within lower Los Alamos Canyon) and treated effluent and processing water released from the Laboratory. Laboratory-derived effluents can have ${ }^{3} \mathrm{H}$ concentrations that exceed those found in precipitation. Laboratory-derived ${ }^{3} \mathrm{H}$ in groundwater occurs in Pueblo Canyon, Los Alamos Canyon, DP Canyon, Sandia Canyon, Mortandad Canyon, and Pajarito Canyon, and in Cañon de Valle. Occurrences of ${ }^{3} \mathrm{H}, \mathrm{NO}_{3}$ (as N), $\mathrm{ClO}_{4}, \mathrm{CrO}_{4}, \mathrm{U}$, and other Laboratory-derived chemicals detected in deep monitoring wells also confirm recharge from surface water. Localized recharge from the alluvial aquifers to deeper saturated zones may also occur through borehole leakage at several deep nongrouted test wells installed in the late 1940s and early 1950s. 


\subsection{Discharge of Regional Aquifer Groundwater at White Rock Canyon Springs}

Groundwater within perched intermediate zones and the upper portion of the regional aquifer generally flows from west to east-southeast, and some of this flow discharges at springs within White Rock Canyon (Figure 3-1). Groundwater deeper within the regional aquifer is also artificially discharged at supply wells. Deeper regional aquifer groundwater within the Rio Grande rift is hypothesized to flow to the south. Additional discharge zones for deeper saturated zones within the regional aquifer probably occur along the banks of the Rio Grande. Groundwater ages for the White Rock Canyon springs are believed to vary, indicating that mixing takes place and that flow paths are of different lengths (Figure 3-1).

\subsection{SAMPLING STATIONS}

Samples were collected from contaminated and contaminant-free, single-screen wells and springs to evaluate modern, mixed, or submodern groundwater within recharge and discharge zones and along groundwater flow paths. Surface water within the Sierra de los Valles was also sampled at two locations. Water samples were collected from 52 stations in and around the Laboratory from October 2004 through February 2006. Water samples were collected during periods of recharge from snowmelt occurring in the spring and during periods of groundwater baseflow occurring in the summer months. Figure 4-1 shows the locations of sampling stations within the Laboratory boundary and surrounding areas, including Seven Springs and Arroyo Hondo. Table 4-1 provides a list of the names of sampling stations, northing and easting coordinates, elevation, date of sampling, and hydrogeologic unit.

\subsection{Sierra de los Valles}

Springs sampled within the Sierra de los Valles include Barbara Spring, AL-10.6 Spring, WCG Spring, PC Spring, CdV-5.0 Spring, Campsite Springs, and Young Spring (Figure 4-1). Distribution of these springs provided an adequate evaluation of groundwater ages and aqueous chemistry within the Sierra de los Valles. Groundwater discharging from the springs occurs yearround, but flow rates at the springs are dependent on the amount of snow pack present in the Sierra de los Valles. Pajarito Ski Well \#2 was also sampled as part of this investigation to determine a groundwater age for the Tschicoma Formation within the Sierra de los Valles.

\subsection{Pajarito Plateau}

Groundwater samples were collected from wells representing background and site conditions (contaminated) for alluvial and perched intermediate zones and the regional aquifer. Los Alamos Observation well LAO-B is located in upper Los Alamos Canyon near the western boundary of the Laboratory (Figure 4-1) and provides local background water chemistry for the alluvium. Other wells providing background chemistry include LAOI(A)-1.1, completed in the Guaje Pumice Bed of the Bandelier Tuff in upper Los Alamos Canyon; R-1 in Mortandad Canyon, completed in the pumice-rich unit underlying the Puye Formation; R-2 in upper Pueblo Canyon, completed in the Older Fanglomerate; and R-18 on the mesa top north of Cañon de Valle, completed within the Tschicoma Formation (Figure 4-1). These wells contain low concentrations of $\mathrm{ClO}_{4}(<0.0002 \mathrm{ppm})$ and $\mathrm{NO}_{3}($ as $\mathrm{N})(<0.5 \mathrm{ppm})$, and concentrations of ${ }^{3} \mathrm{H}$ generally are less than $1.5 \mathrm{pCi} / \mathrm{kg}(0.5 \mathrm{TU})$. Samples were also collected from wells containing Laboratory-derived 
contaminants to determine groundwater ages and estimates of travel times of mobile chemicals from surface water to perched intermediate zones and the regional aquifer.

Water samples were also collected from several springs discharging from the Bandelier Tuff including Bulldog Spring, Burning Ground Spring, Homestead Spring, Martin Spring, and Starmer Spring (Figure 4-1). These springs are located in TA-9 and TA-16 and are commonly fed by surface water discharging from springs within the Sierra de los Valles (Dale et al. 2005, 095002). Laboratory-derived contaminants - including ${ }^{3} \mathrm{H}$; chlorinated aliphatic hydrocarbons (CAHs) (for example, tetrachloroethylene or $\mathrm{PCE}$ ), $\mathrm{ClO}_{4}$; and $\mathrm{HE}$ compounds (for example, 2,4,6-trinitrotoluene [TNT]; and 1,3,5-trinitro-1,3,5-triazine [RDX]) — have been detected at Bulldog Spring, Burning Ground Spring, and Martin Spring. Monitoring data show, however, that Homestead Spring and Starmer Spring are free of Laboratory-derived contaminants (ESP 2005, 092222).

Perched intermediate groundwater occurs within the Bandelier Tuff, Puye Formation, and Cerros del Rio volcanic rocks. Wells completed within perched intermediate zones containing Laboratory-derived contaminants sampled as part of this investigation included POI-4 and TW-1A in Pueblo Canyon; MCOI-6 and MCOBT-4.4 in Mortandad Canyon; R-23i in Pajarito Canyon; and R-6i on the mesa bounded to the north by DP Canyon and the south by Los Alamos Canyon. Wells TW-1A, POI-4, MCOBT-4.4, R-23i, and MCOI-6 are completed within the Cerros del Rio volcanic rocks (LANL 2005, 092028). Perched intermediate well R-6i is completed within the Puye Formation (LANL 2005, 092028). TA-18 Spring discharges from the Bandelier Tuff in Pajarito Canyon.

Wells completed within the upper portion of the regional aquifer and containing Laboratoryderived contaminants - sampled as part of this investigation — included R-4, TW-1, TW-2, and O-1 (a supply well) in Pueblo Canyon; TW-3 and R-9 in Los Alamos Canyon; R-11 in Sandia Canyon; TW-8, R-13, R-15, and R-28 in Mortandad Canyon; and R-23 in Pajarito Canyon. Wells R-2, TW-2, and R-4 are completed within the Older Fanglomerate; O-1 is completed within the Santa Fe Group sands and basalts; and TW-1 is completed within the Puye Formation (LANL 2005, 092028). Regional aquifer wells R-6 and TW-3 are completed within the Older Fanglomerate, and R-9 is completed within a Miocene basalt (LANL 2005, 092028). Regional aquifer wells R-1, R-11, R-13, R-15, R-28, and TW-8 are completed within the pumiceous-rich unit underlying the Puye Formation (LANL 2005, 092028). Well R-23 in Pajarito Canyon is completed with Santa Fe Group sands.

\subsection{White Rock Canyon Springs}

Groundwater samples were collected from several White Rock Canyon springs discharging from both phreato-magmatic deposits (formed by magma or molten rock reacting with water) within sections of the Cerros del Rio volcanic rocks, and sediments within the Santa Fe Group. Sampled springs included Spring 2B, Spring 3, Spring 3A, Spring 3C, Spring 4, Spring 4A, Spring 4AA, Spring 4B, Spring 4C, Spring 5, Spring 6, and Spring 9A (Figure 4-1). These springs discharge from either perched intermediate zones or the regional aquifer. Several springs, including the 3and 4-series, are overlain by slump block material derived from Cerros del Rio volcanic rocks. 


\subsection{SAMPLING PROCEDURES AND ANALYTICAL METHODS}

This section describes sampling procedures and analytical methods for ${ }^{3} \mathrm{H},{ }^{14} \mathrm{C}$, major ions, trace elements, and dissolved noble gases. Sampling for ${ }^{3} \mathrm{H}, \delta^{18} \mathrm{O}, \delta^{2} \mathrm{H}$, major ions, trace elements, and field parameters followed applicable Laboratory Water Quality and Hydrology Group (WQH) standard operating procedures (SOPs) - with the exception that additional guidance for ${ }^{3} \mathrm{H}$ sampling is provided below. Sampling for dissolved noble gases required specialized equipment and procedures not previously covered by available WQH SOPs. Analytical methods consisted of mass spectrometry (MS) for noble gases, He ingrowth for ${ }^{3} \mathrm{H}$, isotope ratio mass spectrometry (IR-MS) for stable isotopes, and accelerator mass spectrometry (AMS) or ${ }^{14} \mathrm{C}$. Other analytical methods included inductively coupled (argon) plasma-mass spectrometry (ICP-MS) for the trace elements, inductively coupled (argon) plasma-optical emission spectroscopy (ICP-OES) for the major cations, alkalinity titration, and ion chromatography (IC) for the anions.

\subsection{Sampling Procedures}

Samples were collected at springs, wells, and streams to determine ${ }^{3} \mathrm{H}$ concentrations, which were calculated from ${ }^{3} \mathrm{He}$ ingrowth. Nonfiltered samples were collected in 1-L polyethylene bottles that were purged at the University of Miami Noble Gas Laboratory to remove all He from the samples. Concentrations of ${ }^{4} \mathrm{He},{ }^{3} \mathrm{He}$, and ${ }^{22} \mathrm{Ne}$ were determined by analyzing water contained within sealed copper tubes. Analysis of ${ }^{22} \mathrm{Ne}$ provided data on the presence or absence of air bubbles in the samples. Sampling of groundwater for $\delta^{13} \mathrm{C}$ and ${ }^{14} \mathrm{C}$ analyses followed procedures established by Rogerson (1996, 095003).

Appendix B provides details of the sampling procedure for noble gases. Figure 5-1 shows a configuration of the sampling apparatus and the various components.

Each sample analyzed for dissolved noble gases was collected in a 3/8-inch-diameter copper tube clamped shut at both ends with stainless steel pinch clamps. The copper tube and clamps were assembled inside an aluminum channel during the sample collection. The University of MiamiNoble Gas Isotope Laboratory provided the copper tubes, aluminum channels, and clamps. This laboratory also provided clear Tygon tubing with an inner diameter slightly less than 3/8-inch, which was slipped over the ends of the copper collection tubes. Additional Tygon tubing was acquired so that sufficient lengths were available to sample at varying distances from springs and wells. Sampling at wells required a variety of hardware to connect the well discharge port fittings to the inflow tubing. Inflow, bypass, and backflow valves were installed upstream and downstream of the copper sample collection tube during sampling round 4 at most of the stations. A portable peristaltic pump was required for spring and surface water sampling. Vise-Grip clamps were used to pinch the Tygon tubing shut on either end of the copper sample collection tube prior to clamping the collection tube shut.

Samples were collected and analyzed for $\delta^{13} \mathrm{C}$ and ${ }^{14} \mathrm{C}$ in samples collected at springs and single-screen wells. These analyses were performed on the DIC fraction in the form of total carbonate alkalinity. Samples for $\delta^{13} \mathrm{C}$ and ${ }^{14} \mathrm{C}$ analyses were collected in 1-L amber glass bottles with a silicon-teflon septum in the caps. The bottles were rinsed and purged several times with a hose connected from a single-screen well or spring. The hose was inserted to the bottom of the bottle to avoid splashing but allow overflow. Purging several volumes allowed all gases 
remaining in the bottle to be removed. The samples were filtered using 0.45 -micrometer $(\mu \mathrm{m})$ membranes, chilled, and stored in the dark prior to ${ }^{14} \mathrm{C}$ analysis.

Field parameters including $\mathrm{pH}$, temperature, specific conductance, and dissolved oxygen were measured during sampling. Groundwater samples were filtered through $0.45-\mu \mathrm{m}$ membranes prior to analyses for trace elements and major ions. Samples were acidified with analytical grade nitric acid to a $\mathrm{pH}$ of 2.0 or less for metal and major cation analyses.

\subsection{Number and Types of Samples and Analytical Methods}

This section describes the number of samples, sample types (including quality assurance samples), analytical methods, analytes, and analytical laboratories performing chemical, stable isotope, and radiochemical analyses.

\subsubsection{Number and Types of Samples}

A total of 173 water samples were collected and analyzed for different constituents during this investigation. Table 5-1 provides information on analytes, sample containers, sampling equipment, and analytical laboratory and method.

A total of 134 groundwater samples were collected and analyzed for ${ }^{3} \mathrm{H}$ and noble gases $\left({ }^{3} \mathrm{He}\right.$, ${ }^{4} \mathrm{He}$, and ${ }^{22} \mathrm{Ne}$ ) by the University of Miami, Miami, Florida. Of these, 18 were intralaboratory, blind field duplicates, and four were interlaboratory (USGS, Denver, Colorado) blind field duplicates. The majority of the ${ }^{3} \mathrm{H}$ and noble gases samples were collected during the spring snowmelt and summer season in 2005. Fifty-two samples were collected and analyzed for ${ }^{14} \mathrm{C}$ (radiocarbon) and $\delta^{13} \mathrm{C}$, including seven blind field duplicates. These samples were collected from selected springs and wells from June 2005 through February 2006. Surface water and alluvial groundwater were not sampled for $\delta^{13} \mathrm{C}$ and ${ }^{14} \mathrm{C}$ as part of this investigation. The Laboratory's Earth and Environmental Sciences Division (Group EES-6) analyzed 149 water samples for major ions, trace elements, $\delta^{2} \mathrm{H}$, and $\delta^{18} \mathrm{O}$. WQH analyzed the remaining 24 samples using the contractor General Engineering Laboratories (GEL). Of the 173 samples, 18 were interlaboratory duplicates, and six were intralaboratory duplicates with GEL.

\subsubsection{EES-6 Analytical Methods}

Groundwater samples were analyzed by EES-6 using techniques specified in the EPA SW-846 manual. Total carbonate alkalinity was measured at EES-6 using standard titration techniques. Samples collected for stable isotope analyses were not filtered. Ion chromatography was the analytical method for bromide $(\mathrm{Br}), \mathrm{Cl}, \mathrm{F}, \mathrm{NO}_{3}($ as $\mathrm{N})$, nitrite $\left(\mathrm{NO}_{2}\right)$, oxalate $\left(\mathrm{C}_{2} \mathrm{O}_{4}\right), \mathrm{ClO}_{4}, \mathrm{PO}_{4}$, and $\mathrm{SO}_{4}$. The instrument detection limits (IDLs) for $\mathrm{ClO}_{4}$ analyses were $0.0005,0.001$, and $0.002 \mathrm{ppm}$, depending on matrix interference from other anions. EES-6 used ICP-OES for analyses of $\mathrm{Ca}$, iron ( $\mathrm{Fe}), \mathrm{Mg}, \mathrm{K}$, silica $\left(\mathrm{SiO}_{2}\right.$, calculated from silicon), and $\mathrm{Na}$. Aluminum (Al), antimony ( $\mathrm{Sb})$, arsenic (As), Ba, beryllium (Be), B, cadmium (Cd), cesium (Cs), Cr, cobalt (Co), copper $(\mathrm{Cu}), \mathrm{Fe}$, lead $(\mathrm{Pb}), \mathrm{Li}$, manganese $(\mathrm{Mn})$, mercury $(\mathrm{Hg})$, nickel $(\mathrm{Ni})$, rubidium $(\mathrm{Rb})$, selenium (Se), silver (Ag), thallium (Tl), Th, tin ( $\mathrm{Sn})$, vanadium $(\mathrm{V}), \mathrm{U}$, and $\mathrm{Zn}$ were analyzed by ICP-MS. The precision limits (analytical error) for major ions and trace elements were generally less than $\pm 10 \%$ using ICP-OES and ICP-MS. EES-6 used IR-MS to analyze the water 
samples for $\delta^{18} \mathrm{O}$ and $\delta^{2} \mathrm{H}$. Analytical uncertainties of $\delta^{18} \mathrm{O}$ and $\delta^{2} \mathrm{H}$ were typically less than \pm 0.2 and \pm 0.4 permil (\%o), respectively.

\subsubsection{Carbon Isotope Analytical Methods}

At the University of Arizona, carbon isotopes $\left(\delta^{13} \mathrm{C}\right)$ and ${ }^{14} \mathrm{C}$ were measured using IR-MS and AMS, respectively. The AMS analytical method differs from decay-counting methods in that the amount of ${ }^{14} \mathrm{C}$ in the sample is measured directly, which makes the AMS method 1000 to 10,000 times more sensitive than decay counting. Dissolved inorganic carbon, mainly as $\mathrm{HCO}_{3}$, was extracted from solution using phosphoric acid $\left(\mathrm{H}_{3} \mathrm{PO}_{4}\right)$ under vacuum, and the purified $\mathrm{CO}_{2}$ gas was sealed in a glass breakseal for conversion to black (elemental) carbon at the University of Arizona. The $\mathrm{C}$ was mounted on Fe-filaments in the source of a mass spectrometer and was ionized and accelerated through a magnetic field to separate the three $\mathrm{C}$ isotopes, including ${ }^{12} \mathrm{C}$, ${ }^{13} \mathrm{C}$, and ${ }^{14} \mathrm{C}$. The radiocarbon age of a given groundwater sample is determined by measuring the ratio ${ }^{14} \mathrm{C} /{ }^{13} \mathrm{C}$ and comparing that ratio to a similar one measured with known standards. The measured ratios of standards and samples are corrected to values corresponding to $\delta^{13} \mathrm{C}=-25$ permil (belemnite from the Pee Dee Formation) using ${ }^{13} \mathrm{C} /{ }^{12} \mathrm{C}$ ratios measured by IR-MS. The fraction of modern $\mathrm{C}$ of the sample is determined from ${ }^{14} \mathrm{C} /{ }^{13} \mathrm{C}$ and $\delta^{13} \mathrm{C}$ values of both the sample and standard. The fraction of modern $\mathrm{C}$ is the amount of ${ }^{14} \mathrm{C}$ remaining in a given sample.

\subsubsection{Tritium and Noble Gas Analytical Methods}

Helium isotopes $\left({ }^{3} \mathrm{He}\right.$ and $\left.{ }^{4} \mathrm{He}\right)$ and ${ }^{22} \mathrm{Ne}$ were measured using MS at the University of Miami. Helium was purged from each sample prior to noble gas analysis. After a period of time based on previously measured or estimated ${ }^{3} \mathrm{H}$ concentration for each sample, every sample was analyzed for ${ }^{3} \mathrm{He}$. The concentration of ${ }^{3} \mathrm{H}$ was calculated from the production of ${ }^{3} \mathrm{He}$ in each sample. Laboratory procedures for $\mathrm{He}$ and $\mathrm{Ne}$ measurements consisted of gas extraction under vacuum, separation of the He-Ne fraction, splitting of $\mathrm{He}-\mathrm{Ne}$ fraction (when required), sealing of $\mathrm{He}-\mathrm{Ne}$ fraction in Corning-1742 glass ampoules, purification and sealing of argon (Ar) fraction, and measurements in a statically operated magnetic-sector gas mass spectrometer, with either a $25-\mathrm{cm}$ or $15-\mathrm{cm}$ radius. Absolute concentrations of Ne were measured routinely in a quadrupole mass spectrometer, or in a 15-cm radius, magnetic sector mass spectrometer with isotope dilution (as required for higher precision). The precision of $\mathrm{He}$ and $\mathrm{Ne}$ measurements varies between 0.25 and 2 percent depending on the technique. The precision of total $\mathrm{He}$ and ${ }^{3} \mathrm{He} /{ }^{4} \mathrm{He}$ measurements was 0.5 percent. Measurements were calibrated with an atmospheric He aliquot, and accuracy was monitored by running National Institute of Standards and Testing standards with the unknowns.

Concentration of ${ }^{3} \mathrm{H}$ is reported in $\mathrm{TU}$ and converted to units of $\mathrm{pCi} / \mathrm{kg}$ with $1 \sigma$ analytical uncertainty. The apparent groundwater age (in years) with $1 \sigma$ analytical uncertainty is also provided. (See Table 6-4.) The ${ }^{3} \mathrm{H}$ concentration in each sample was calculated by He ingrowth, which has an uncertainty of \pm 1.5 percent or $0.048 \mathrm{pCi} / \mathrm{kg}(0.015 \mathrm{TU})$, which ever is greater. To calculate the concentration of ${ }^{3} \mathrm{H}$ present in a given sample, He was initially purged from each water sample and was allowed to reaccumulate. The amount of time required to determine ${ }^{3} \mathrm{H}$ concentration by He ingrowth varied with each sample and was dependent on the concentration of the parent isotope $\left({ }^{3} \mathrm{H}\right)$. Samples with low concentrations of ${ }^{3} \mathrm{H}$ required long periods of time 
to allow sufficient ingrowth of ${ }^{3} \mathrm{He}$. For example, a $0.70 \mathrm{~kg}$ water sample containing $32.2 \mathrm{pCi} / \mathrm{kg}$ (10.0 TU) of ${ }^{3} \mathrm{H}$ was analyzed after a month's storage. The minimum detectable activity of tritium was $0.048 \mathrm{pCi} / \mathrm{kg}(0.015 \mathrm{TU})$ measured using this method.

Measured ${ }^{3} \mathrm{He}$ in groundwater samples needs to be corrected for atmospheric ${ }^{3} \mathrm{He}$ that was dissolved at the time of groundwater recharge. Atmospheric $\mathrm{He}$ is dominantly ${ }^{4} \mathrm{He}(5.24 \mathrm{ppmv})$ and the ratio of ${ }^{3} \mathrm{He} /{ }^{4} \mathrm{He}$ is $1.38 \times 10^{-6}$ (cited in Clark and Fritz 1997, 059168). The solubility of $\mathrm{He}$ is temperature-dependent, and at $10^{\circ} \mathrm{C}$, its solubility is $4.75 \times 10^{-8} \mathrm{~cm}^{3} \mathrm{STP} / \mathrm{cm}^{3}$ or g $\mathrm{H}_{2} \mathrm{O}$ (Clark and Fritz 1997, 059168). Neon was also analyzed to check for excess atmospheric air potentially introduced during sampling. The solubility of $\mathrm{Ne}$ is temperature-dependent, and at $10^{\circ} \mathrm{C}$, its solubility is $20.7 \times 10^{-8} \mathrm{~cm}^{3} \mathrm{STP} / \mathrm{g} \mathrm{H}_{2} \mathrm{O}$ (Clark and Fritz 1997, 059168). Water samples with Ne concentrations exceeding $25.0 \times 10^{-8} \mathrm{~cm}^{3} \mathrm{STP} / \mathrm{g} \mathrm{H}_{2} \mathrm{O}$ indicate atmospheric air may have been introduced during sampling and are suspect. Samples collected as part of this investigation with excess dissolved $\mathrm{Ne}$ gas greater than $34.0 \times 10^{-8} \mathrm{~cm}^{3} \mathrm{STP} / \mathrm{g} \mathrm{H} \mathrm{H}_{2} \mathrm{O}$ were not included in any interpretation due to air bubbles. Eight water samples collected during this investigation contained excess air with Ne concentrations greater than $34.0 \times 10^{-8} \mathrm{~cm}^{3} \mathrm{STP} / \mathrm{g} \mathrm{H}_{2} \mathrm{O}$.

The parameter $\mathrm{R}(3 / 4)$ in $\mathrm{Ra}\left(\right.$ air) is the ratio of ${ }^{3} \mathrm{He} /{ }^{4} \mathrm{He}$ in a given sample normalized to ${ }^{3} \mathrm{He} /{ }^{4} \mathrm{He}$ in air. (See Table 6-4.) The atmosphere has a total He concentration of 5.24 ppmV (Clark and Fritz 1997, 059168). Water in equilibrium with the atmosphere has an $\mathrm{R}(3 / 4)$ in $\mathrm{Ra}$ approximately equal to 1 and a total He concentration of $4.75 \times 10^{-8} \mathrm{~cm}^{3} \mathrm{STP} / \mathrm{g} \mathrm{H}_{2} \mathrm{O}$ at $10^{\circ} \mathrm{C}$ (Clark and Fritz 1997, 059168). When surface water recharges and becomes groundwater, isolated from the atmosphere in the saturated zone, the $\mathrm{R} / \mathrm{Ra}$ value increases with time as tritiogenic ${ }^{3} \mathrm{He}$ is produced from ${ }^{3} \mathrm{H}$ decay. Fluids from the Earth's crust have $\mathrm{R}(3 / 4)$ in $\mathrm{Ra}$ values ranging from 0.007 to 0.022 ; total He concentrations ranging from $10^{-7}$ to $10^{-4} \mathrm{~cm}^{3} \mathrm{STP} / \mathrm{g}$ $\mathrm{H}_{2} \mathrm{O}$; and ${ }^{3} \mathrm{He} /{ }^{4} \mathrm{He}$ ratios ranging from $1.0 \times 10^{-8}$ to less than $1.0 \times 10^{-10}$ (Clark and Fritz 1997, 059168). Mantle-derived He has R(3/4) in Ra values ranging from 7 to 21; total He concentrations up to $2.7 \times 10^{-5} \mathrm{~cm}^{3} \mathrm{STP} / \mathrm{g} \mathrm{H}_{2} \mathrm{O}$; and ${ }^{3} \mathrm{He} /{ }^{4} \mathrm{He}$ ratios ranging from $1.0 \times 10^{-5}$ to $3.0 \times 10^{-5}$ (Clark and Fritz 1997, 059168). Henceforth, crust- and mantle-sourced He will be referred to together as "terrigenic" $\mathrm{He}$ - that is, nontritiogenic He produced in the subsurface. Groundwater containing Laboratory-derived ${ }^{3} \mathrm{H}$ can have values of $\mathrm{R}(3 / 4)$ in $\mathrm{Ra}$ of unity or greater, depending on the amount of tritiogenic ${ }^{3} \mathrm{He}$ present. Occurrence of other Laboratoryderived contaminants including $\mathrm{NO}_{3}, \mathrm{CrO}_{4}, \mathrm{ClO}_{4}, \mathrm{U}, \mathrm{SO}_{4}, \mathrm{~B}$, and/or $\mathrm{Cl}$ at a given well or spring should be considered in determining the presence of natural and/or anthropogenic source(s) of ${ }^{3} \mathrm{He}$. Tritiogenic ${ }^{3} \mathrm{He}$ produced from decay of Laboratory-derived ${ }^{3} \mathrm{H}$ occurs at several wells installed in Pueblo Canyon, Los Alamos Canyon, and Mortandad Canyon.

The apparent age of a given water sample, based on the ${ }^{3} \mathrm{H} /{ }^{3} \mathrm{He}$ dating method, was calculated by the University of Miami using the following expression:

$$
\text { Age }=17.93\left(\ln \left[1+\left[\mathrm{DEL}^{3} \mathrm{He}\right]\left[{ }^{4} \mathrm{He}_{\text {soluble }}\right] /\left[{ }^{3} \mathrm{H}\right][18.25]\right]\right)
$$


where

$\mathrm{DEL}^{3} \mathrm{He}$ is tritiogenic ${ }^{3} \mathrm{He}$ excess, in percent, above solubility;

${ }^{4} \mathrm{He}_{\text {soluble }}$ is the solubility of ${ }^{4} \mathrm{He}$ in units of $10^{-8} \mathrm{~cm}^{3} \mathrm{STP} / \mathrm{g} \mathrm{H}_{2} \mathrm{O}$; and

${ }^{3} \mathrm{H}$ is tritium concentration in TU.

${ }^{4} \mathrm{He}_{\text {solubility }}$ equals ${ }^{3} \mathrm{He}_{\text {solubility }} \times 1.36$, and $10^{-14} \mathrm{~cm}^{3} \mathrm{STP} / \mathrm{g} \mathrm{H}_{2} \mathrm{O}$ of ${ }^{3} \mathrm{He}$ equals $4.02 \mathrm{TU}$ or $12.95 \mathrm{pCi} / \mathrm{kg}$. Apparent ages for samples were calculated by the University of Miami using $\mathrm{T}_{1 / 2}$ for ${ }^{3} \mathrm{H}$ equal to 12.43 years.

Using Equations 2-5 and 5-1, the oldest apparent age based on the ${ }^{3} \mathrm{H} /{ }^{3} \mathrm{He}$ dating method calculated for groundwater is 113.7 years. This maximum apparent age is based on both a measured ${ }^{3} \mathrm{H}$ concentration of $0.03 \mathrm{pCi} / \mathrm{kg}(0.01 \mathrm{TU})$ and an initial ${ }^{3} \mathrm{H}$ concentration of $19 \mathrm{pCi} / \mathrm{kg}$ (6 TU) representative of preatmospheric detonation of nuclear weapons. The MDL for ${ }^{3} \mathrm{H}$ determined by He-ingrowth is $0.03 \mathrm{pCi} / \mathrm{kg}(0.01 \mathrm{TU})$.

Some of the groundwater samples containing Laboratory-derived ${ }^{3} \mathrm{H}$ and other contaminants contained excess ${ }^{3} \mathrm{He}$ and ${ }^{4} \mathrm{He}$. This excess ${ }^{3} \mathrm{He}$ and ${ }^{4} \mathrm{He}$, reported as $\mathrm{DEL}{ }^{3} \mathrm{He}$ and $\mathrm{DEL}{ }^{4} \mathrm{He}$, resulted in ages greater than 62 years. For these particular samples collected in Pueblo Canyon and Los Alamos Canyon, a maximum age is set at 62 years and is not further quantifiable to determine a specific age. The first discharge of ${ }^{3} \mathrm{H}$ at the Laboratory occurred at former TA-1 and TA-45 in 1943 (Rogers 1998, 059169). Discharge of ${ }^{3} \mathrm{H}$ from TA-50 into Mortandad Canyon commenced in 1963 (LANL 1997, 056835), 42 years prior to this investigation. Some groundwater samples collected in Mortandad Canyon have ages exceeding 42 years because of anomalous $\mathrm{DEL}^{3} \mathrm{He}$ and $\mathrm{DEL}^{4} \mathrm{He}$ values. For these particular samples containing Laboratoryderived ${ }^{3} \mathrm{H}$, a maximum age is set at between 42 and 62 years and is not further quantifiable to determine a specific age.

Excess ${ }^{4} \mathrm{He}$ can accumulate in deep groundwater at Los Alamos because of recent volcanism within the Jemez Mountains and subsurface production from decay of $U$ and Th within the crust. Another source of excess ${ }^{4} \mathrm{He}$ is from $\alpha$ decay of actinides processed at the Laboratory including isotopes of $\mathrm{U}, \mathrm{Pu}$, and Am. Excess He above equilibrium solubility results in errors (positive bias) in apparent groundwater age calculations based on the ${ }^{3} \mathrm{H} /{ }^{3} \mathrm{He}$ dating method. Protocols described in Section 5.2 were used to minimize and evaluate the presence of excess air in groundwater and surface water samples dated by the ${ }^{3} \mathrm{H} /{ }^{3} \mathrm{He}$ method. Initial concentrations of ${ }^{3} \mathrm{H}$ (Sections 6.1, 6.2, and 6.3) were calculated for those samples with DEL ${ }^{4} \mathrm{He}$ less than 100 percent that had apparent ages less than 62 years. These samples had an analytical error of \pm 5 years with an error range of 10 years. The University of Miami (home of the analytical laboratory performing ${ }^{3} \mathrm{H}$ and noble gas analyses) reports that $\mathrm{DEL}^{4} \mathrm{He}$ is the corrected ${ }^{4} \mathrm{He}$ excess, in percent, above solubility. Samples with $\mathrm{DEL}^{4} \mathrm{He}$ greater than 100 percent were not included in initial ${ }^{3} \mathrm{H}$ calculations because of the large uncertainty in age. 


\subsection{RESULTS AND DISCUSSION}

This section presents analytical results for major ions, trace elements, ${ }^{3} \mathrm{H}$, noble gases, ${ }^{14} \mathrm{C}, \delta^{13} \mathrm{C}$, $\delta^{2} \mathrm{H}$, and $\delta^{18} \mathrm{O}$ for groundwater and surface water samples collected during this investigation. Information and data are presented first for water samples collected within the Sierra del los Valles (Section 6.1), next for samples collected on the Pajarito Plateau including background and contaminated wells and springs (Section 6.2), and finally, for samples collected at several of the White Rock Canyon springs (Section 6.3).

Table 6-1 presents analytical results for $\mathrm{SiO}_{2}$, major and minor ions including $\mathrm{HCO}_{3}, \mathrm{Br}, \mathrm{Ca}, \mathrm{Cl}$, F, $\mathrm{Mg}, \mathrm{NO}_{3}$ (as N), $\mathrm{NO}_{2}$ (as N), $\mathrm{ClO}_{4}, \mathrm{~K}, \mathrm{Na}, \mathrm{SO}_{4}$, total dissolved solids (TDS), and field parameters. Analytical results for trace elements are provided in Table 6-2. Table 6-3 provides results for $\delta^{2} \mathrm{H}$ and $\delta^{18} \mathrm{O}$ and recharge elevations calculated from $\delta^{2} \mathrm{H}$ and $\delta^{18} \mathrm{O}$ relationships presented by Vuataz and Goff $(1986,073687)$. Table 6-4 provides analytical results of ${ }^{3} \mathrm{H}$, noble gases, groundwater age based on the ${ }^{3} \mathrm{H} /{ }^{3} \mathrm{He}$ dating method, and initial ${ }^{3} \mathrm{H}$ concentrations. Table 6-5 presents analytical results for ${ }^{14} \mathrm{C}, \delta^{13} \mathrm{C}$, fraction of modern $\mathrm{C}$, and unadjusted ${ }^{14} \mathrm{C}$ age for groundwater. Plate 1 shows ${ }^{3} \mathrm{H}$ concentrations at wells, springs, and surface water locations. Plate 2 shows apparent and average groundwater ages based on ${ }^{3} \mathrm{H} /{ }^{3} \mathrm{He}$ and ${ }^{14} \mathrm{C}$ dating methods, respectively, for the water samples. Plate 3 shows calculated initial ${ }^{3} \mathrm{H}$ values for the water samples. Plate 4 shows analytical results for $\mathrm{DEL}^{3} \mathrm{He}$ and $\mathrm{DEL}{ }^{4} \mathrm{He}$ values in samples collected during this investigation.

\subsection{Aqueous Inorganic and Isotope Geochemistry of the Sierra de los Valles Springs}

\subsubsection{Field Parameters}

Field $\mathrm{pH}$ ranged from 6.75 to 7.86 (reported in standard units). The lowest and highest values were measured at WCG Spring (Table 6-1). Field pH is controlled by the partial pressure of $\mathrm{CO}_{2}$ gas, alkalinity, and, possibly, by dissolved organic carbon (DOC) consisting of soluble organic acids (humic and fulvic acids) present within vegetated recharge zones. Temperature measurements recorded during sampling ranged from $5.5^{\circ} \mathrm{C}$ at $\mathrm{PC}$ Spring to $15.5^{\circ} \mathrm{C}$ at Barbara Spring. Cooler values were associated with samples collected at higher elevations (Table 6-1). Groundwater discharging at the springs is aerobic. Dissolved oxygen concentrations ranged from 4.41 to $9.92 \mathrm{mg} / \mathrm{L}$. Springs discharging within the Sierra de los Valles showing little or no response to flow derived from snowmelt tend to illustrate less variability in field-parameter measurements.

\subsubsection{Inorganic Aqueous and Isotope Geochemistry of Sierra de los Valles Springs}

Figure 6-1 presents a trilinear or Piper diagram for filtered samples collected from springs and surface water within the Sierra de los Valles. Groundwater and surface water consists of a mixed $\mathrm{Ca}-\mathrm{Na}-\mathrm{Mg}-\mathrm{HCO}_{3}-\mathrm{SO}_{4}$ composition. Calcium, $\mathrm{Na}$, and $\mathrm{HCO}_{3}$ are the dominant solutes that are most likely stable as free or uncomplexed species - a conclusion based on their low concentrations. Groundwater discharging at springs characterized by longer flow paths and ages, including Barbara Spring and Campsite Springs, tends to show less variation in major ion chemistry than do springs with shorter flow paths and ages, which are characteristic of WCG Spring and CdV-5.0 Spring (Table 6-1). Barbara Spring and Campsite Springs, discharging from 
the Tschicoma Formation, are more enriched in $\mathrm{Na}$ and $\mathrm{HCO}_{3}$ in comparison to samples collected from the other springs (Figure 6-1). CdV-5.0 Spring, discharging from the Bandelier Tuff/Tschicoma Formation, however, is more enriched in $\mathrm{SO}_{4}$ in comparison to the other springs. This anion is readily leached from soils and aquifer material during recharge.

\subsubsection{Major Ion and Trace Element Geochemistry of Sierra de los Valles Springs}

Concentrations of major ions vary seasonally between periods of recharge from snowmelt, occurring in the spring months, and groundwater baseflow, dominating in the late fall and early winter. For example, concentrations of $\mathrm{Ca}$ and $\mathrm{SO}_{4}$ decreased from 11.1 to $7.38 \mathrm{ppm}$ or $\mathrm{mg} / \mathrm{L}$ and 18.3 to $3.0 \mathrm{ppm}$ for WCG Spring samples collected on March 4 and July 7, 2005, respectively (Table 6-1). Dissolved concentrations of $\mathrm{SiO}_{2}$, stable as $\mathrm{Si}(\mathrm{OH})_{4}{ }^{0}$, ranged from $25.0 \mathrm{ppm}$ for surface water collected at CdV-5.6 to $79.2 \mathrm{ppm}$ at WCG Spring. Calculations using the computer program MINTEQA2 (Allison et al. 1991, 049930) and analytical results for WCG Spring (sampled on September 23, 2005) and CdV-5.6 (sampled on April 18, 2005) showed that the concentration of dissolved $\mathrm{SiO}_{2}$ is controlled by cristobalite. Groundwater is predicted to be in close equilibrium with this solid silica phase, which is present within the Bandelier Tuff (Broxton et al. 1995, 005121). Concentrations of calculated TDS ranged from 66.5 to $176 \mathrm{ppm}$ (determined from the summation of all analytes). Total dissolved solids generally decreased between sampling events, suggesting that concentrations of solutes were higher during periods of recharge when soil zones were flushed, and decreased during groundwater baseflow at the springs. This relationship between TDS and seasonality suggests that solutes are leached from soils and/or aquifer material during recharge. Analytical charge balances for filtered samples ranged from -6.15 percent at Campsite Springs to +1.90 percent at PC Spring (Table 6-1).

Concentrations of $\mathrm{NO}_{3}(\mathrm{~N})$ ranged from 0.11 to $1.78 \mathrm{ppm}$ in samples collected within the Sierra de los Valles. These values are significantly less than the EPA standard of $10 \mathrm{ppm}$ or $\mathrm{mg} / \mathrm{L}$.

Concentrations of $\mathrm{Cl}$ and $\mathrm{SO}_{4}$ ranged from 0.69 to $11.4 \mathrm{ppm}$ and 1.07 to $30.92 \mathrm{ppm}$, respectively, and are less than the EPA secondary standards of $250 \mathrm{ppm}$ or $\mathrm{mg} / \mathrm{L}$.

Concentrations of $\mathrm{ClO}_{4}$ were less than analytical detection $(0.0005$ and $0.001 \mathrm{ppm})$ using the IC method. One water sample collected from PC Spring was analyzed for $\mathrm{ClO}_{4}$ using the liquid chromatography-mass spectrometry/mass spectrometry (LC-MS/MS) method at GEL. The result was $0.00031 \mathrm{ppm}(0.31 \mathrm{ppb})$.

Detectable concentrations of dissolved Li ranged from 0.001 to $0.040 \mathrm{ppm}$ in water samples collected within the Sierra de los Valles (Table 6-2). The highest concentration of Li was measured at Barbara Spring.

Boron concentrations ranged from 0.0023 to $0.0089 \mathrm{ppm}$. The highest value was measured at WCG Spring.

Detectable concentrations of total dissolved $\mathrm{Cr}$ ranged from 0.001 to $0.0024 \mathrm{ppm}$ in samples collected at the Sierra de los Valles sites (Table 6-2). The highest concentration of total dissolved $\mathrm{Cr}$ was measured at Campsite Springs. Speciation was not performed on these samples to distinguish $\mathrm{Cr}$ (III) from $\mathrm{Cr}(\mathrm{VI})$; however, because total dissolved $\mathrm{Cr}$ was detected, it is likely that $\mathrm{Cr}(\mathrm{VI})$ dominates in the samples. This conclusion is consistent with analytical results for 
numerous samples provided in LANL (2006, 091987). The Campsite Springs are characterized by groundwater flow path(s) within the Tschicoma Formation, which contains pyroxene, feldspars, silica, minerals, manganese oxide, and volcanic glass. This trace element becomes soluble during oxidation under alkaline $\mathrm{pH}$ conditions, and, hence, small concentrations of total dissolved $\mathrm{Cr}$ (0.001 to $0.006 \mathrm{ppm})$ are measured in groundwater. Springs having groundwater flow paths within the Bandelier Tuff-including WCG Spring, Barbara Spring, CdV-5.0 Spring, and PC Spring - have concentrations of total dissolved Cr less than the IDL of $0.001 \mathrm{ppm}$ (Table 6-2) using ICP-MS. Young Spring, discharging from the Tschicoma Formation, contained 0.001 and 0.0015 ppm Cr.

Detectable concentrations of dissolved Sr ranged from 0.019 to $0.140 \mathrm{ppm}$. The highest concentration was measured at CdV-5.0 Spring (Table 6-2). This spring also had the highest concentrations of $\mathrm{Ca}$, ranging from 8.2 to $15.6 \mathrm{ppm}$.

Detectable concentrations of dissolved U ranged from 0.0003 to $0.0005 \mathrm{ppm}$. The highest value was measured at Campsite Springs (Table 6-2). Concentrations of dissolved U above analytical detection were measured in water samples collected from Campsite Springs, Barbara Spring, Young Spring, and Pajarito Ski Well \#2.

Most other trace elements provided in Table 6-2 did not show significant variation in concentration, a conclusion that is consistent with groundwater originating within the recharge zone of the Sierra de los Valles. The exceptions are Al, Fe, Rb, and Zn, and their detection could be related to the presence of colloids consisting of clay minerals, volcanic glass, and ferric (oxy)hydroxide.

\subsubsection{Stable Isotope Geochemistry of Sierra de los Valles Springs}

Analyses of $\delta^{18} \mathrm{O}$ and $\delta^{2} \mathrm{H}$ were performed on groundwater samples collected within the Sierra de los Valles (Table 6-3). The average isotopic results for each sampling station are shown in Figure 6-2. In this figure, the Jemez Mountains meteoric line (upper) and the world meteoric water line (lower) are denoted by JMML and WMWL, respectively. Results of stable isotope analyses for water samples collected from the springs show that they were derived from a meteoric source, and evaporation along groundwater flow paths, defined by a deviation of $\delta^{2} \mathrm{H} / \delta^{18} \mathrm{O}$ less than 8 , is not observed. The groundwater samples plot close to both the JMML and WMWL (Figure 6-2). Seasonal variations in $\delta^{18} \mathrm{O}$ and $\delta^{2} \mathrm{H}$ ranging within 1 to 3 and 9 to 50 permil difference, respectively, were observed at Pajarito Mountain. These variations result from varying degrees of isotopic fractionation occurring in precipitation either originating from the Gulf of Mexico in summer months or the Pacific Ocean in winter months (Adams et al. 1995, 047192). Winter storms become progressively lighter in $\delta^{18} \mathrm{O}$ and $\delta^{2} \mathrm{H}$ as they reach the Los Alamos area because of isotopic fractionation or removal of ${ }^{18} \mathrm{O}$ and ${ }^{2} \mathrm{H}$. In contrast, local summer storms are heavier in $\delta^{18} \mathrm{O}$ and $\delta^{2} \mathrm{H}$ with less depletion of ${ }^{18} \mathrm{O}$ and ${ }^{2} \mathrm{H}$ (Adams et al. 1995, 047192). Precipitation of meteoric water at higher elevations, for example, within the Sierra de los Valles and Valles Caldera, is characterized by cooler temperatures relative to other waters found at lower elevations on the Pajarito Plateau. Long-term temperature differences (paleotemperatures) and seasonal variations in temperature also influence $\delta^{18} \mathrm{O}$ and $\delta^{2} \mathrm{H}$ values because of enrichment or depletion of ${ }^{18} \mathrm{O}$ and ${ }^{2} \mathrm{H}$ (Clark and Fritz 1997, 059168). 
Samples collected from Seven Springs are the most depleted $\mathrm{in}^{18} \mathrm{O}$ and ${ }^{2} \mathrm{H}$ in comparison to the other springs because their source of recharge probably occurs at a higher elevation (Table 6-3). Springs discharging within the Valles Caldera (ring fracture zone) have relatively light $\delta^{18} \mathrm{O}$ and $\delta^{2} \mathrm{H}$ ratios compared to waters plotted on Figure 6-2. This observation suggests that they are not commonly connected or related to most of the springs discharging into the Sierra de los Valles, to groundwater beneath the Pajarito Plateau (Section 6.2), and to groundwater discharging at the White Rock Canyon springs (Section 6.3). It is possible, however, that shallow groundwater within the Valles Caldera is mixing with heavier groundwater within the Sierra de los Valles and producing heavier $\delta^{18} \mathrm{O}$ and $\delta^{2} \mathrm{H}$ values at some of the springs. Groundwater discharging at Campsite Springs and Barbara Spring could have originated west of the Sierra de los Valles. This hypothesis is based on a component of submodern water present at these two springs, which is discussed below. PC Spring discharges near the top of the Pajarito Canyon watershed, which is slightly more depleted in ${ }^{18} \mathrm{O}$ and ${ }^{2} \mathrm{H}$ in comparison to other springs that receive recharge at slightly lower elevations. Alamo-10.6 Spring, Barbara Spring, Campsite Springs, WCG, Young Spring, and CdV-5.0 Spring plot close to each other, suggesting a similar source and elevation of recharge.

Stable-isotope ratios for surface water stations PA-10.6 and CdV-5.6 were very similar to the upgradient springs (PC Spring and CdV-5.0 Spring) that supply perennial flow at these stations. Stable isotope ratios for these stations fall on the local meteoric water line.

\subsubsection{Radiogenic Isotope and Noble Gas Geochemistry of Sierra de los Valles Springs}

Groundwater and surface water samples were collected within the Sierra de los Valles and analyzed for ${ }^{3} \mathrm{H}$ and ${ }^{3} \mathrm{He}$ to determine apparent groundwater ages. These results are provided in Table 6-4 and shown on Plates 1 and 2. Concentrations of total $\mathrm{He}$ and $\mathrm{Ne}$ are reported in units of $10^{-8} \mathrm{~cm}^{3} \mathrm{STP} / \mathrm{g} \mathrm{H}_{2} \mathrm{O}$ (Table 6-4). Concentrations of ${ }^{3} \mathrm{H}$ in groundwater within the Sierra de los Valles ranged from $1.26 \mathrm{pCi} / \mathrm{kg}(0.39 \mathrm{TU})$ at Barbara Spring to $69.53 \mathrm{pCi} / \mathrm{kg}(21.58 \mathrm{TU})$ at PC Spring (Table 6-4, Plate 1). Corresponding apparent ${ }^{3} \mathrm{H} /{ }^{3} \mathrm{He}$ ages for Barbara Spring and PC Spring ranged from 2.41 to 31.05 years and from 0.38 to 1.25 years, respectively (Table 6-4, Plate 2). The total He concentrations in water samples generally ranged from $5 \times 10^{-8}$ to $10 \times 10^{-8} \mathrm{~cm}^{3} \mathrm{STP} / \mathrm{g} \mathrm{H}_{2} \mathrm{O}$, indicating only minor concentrations of terrigenic He.

Measured atmospheric ${ }^{3} \mathrm{H}$ and calculated initial ${ }^{3} \mathrm{H}$ concentration for groundwater samples collected within the Sierra de los Valles are shown in Figure 6-3. The initial ${ }^{3} \mathrm{H}$ concentration in each groundwater sample with $\mathrm{DEL}^{4} \mathrm{He}$ less than 100 percent was determined from the groundwater age derived from ${ }^{3} \mathrm{He}$ ingrowth. Higher concentrations of ${ }^{3} \mathrm{H}$ in precipitation were measured (four-year period) at the Pajarito Mountain station (Adams et al. 1995, 047192) relative to those at the Albuquerque, New Mexico, station (Figure 6-3). This increase is reflective of local variations in atmospheric ${ }^{3} \mathrm{H}$ concentrations and of Laboratory releases.

A sample with an initial ${ }^{3} \mathrm{H}$ concentration greater than $19 \mathrm{pCi} / \mathrm{kg}$ (6 TU) and plotting on the atmospheric ${ }^{3} \mathrm{H}$ curve has ${ }^{3} \mathrm{H}$ derived from both a natural source (cosmogenic) and residual atmospheric testing of nuclear weapons. This type of sample consists entirely of a modern component, postdating 1943. A sample with an initial ${ }^{3} \mathrm{H}$ concentration plotting below the atmospheric ${ }^{3} \mathrm{H}$ curve contains ${ }^{3} \mathrm{H}$ that has been diluted by mixing with submodern groundwater. The source(s) of ${ }^{3} \mathrm{H}$ for this type of sample could be natural, anthropogenic, or a combination of 
both. Site-specific knowledge of hydrogeologic conditions and location (upgradient or downgradient) relative to a given contaminant source are required to determine the source(s) of ${ }^{3} \mathrm{H}$ measured in the sample. Regional aquifer wells containing ${ }^{3} \mathrm{H}$ and plotting below the atmospheric ${ }^{3} \mathrm{H}$ curve are considered to have anthropogenic ${ }^{3} \mathrm{H}$. This radionuclide is not ubiquitously detected in the regional aquifer. A sample with an initial ${ }^{3} \mathrm{H}$ concentration plotting above the atmospheric ${ }^{3} \mathrm{H}$ curve contains excess ${ }^{3} \mathrm{H}$ derived from Laboratory releases. A component of baseline atmospheric ${ }^{3} \mathrm{H}$ is also present in this type of sample. This type of sample probably consists entirely of a modern component, although under specific conditions, the sample could contain a mixed age with a majority of modern water present. Anomalously high concentrations of ${ }^{3} \mathrm{H}$ are required to fulfill this condition.

Analytical results for initial ${ }^{3} \mathrm{H}$ concentrations for WCG Spring (one sample), Young Spring (one ample), CdV-5.0 Spring, PC Spring, and Pajarito Ski Well \#2 typically plot above the atmospheric ${ }^{3} \mathrm{H}$ curve, suggesting that excess ${ }^{3} \mathrm{H}$ is most likely anthropogenic in origin and is derived from Laboratory releases (Figure 6-3). Initial ${ }^{3} \mathrm{H}$ concentrations for WCG Spring (for one sample), AL-10.6 Spring, Campsite Springs, and Barbara Spring fall below the atmospheric ${ }^{3} \mathrm{H}$ curve, an indication that these samples are mixed. Dilution of ${ }^{3} \mathrm{H}$ takes place in mixed groundwater; the maximum dilution occurs in deeper portions of the saturated zone that is submodern.

Total concentrations of corrected He ranged from 4.82 to $11.99 \times 10^{-8} \mathrm{~cm}^{3} \mathrm{STP} / \mathrm{g} \mathrm{H}_{2} \mathrm{O}$ in air-free samples collected within the Sierra de los Valles (Table 6-4), suggesting that the source of He is from surface water (Clark and Fritz 1997, 059168). This hypothesis is consistent with surface water providing recharge to groundwater within the Sierra de Los Valles. Most groundwater primarily consists of a modern component contributing to groundwater ages typically less than 10 years. Anomalous high $\mathrm{DEL}^{4} \mathrm{He}$ and $\mathrm{DEL}^{3} \mathrm{He}$ values (Table 6-4, Plate 4) can result from compromised samples (gas bubbles) that produce artificially old apparent groundwater ages. Defective samples containing air were collected from CdV-5.0 Spring and WCG Spring, and analytical results for the samples were not included in any interpretation. Air-free samples had $\mathrm{DEL}^{4} \mathrm{He}$ and $\mathrm{DEL}^{3} \mathrm{He}$ values ranging from 0.06 to 150.51 percent and from 0.33 to 154.41 percent, respectively (Table 6-4). Values of $\mathrm{R}(3 / 4)$ in Ra ranged from 0.82 to 1.04 in air-free samples, also suggesting that He is derived from surface water (Clark and Fritz 1997, 059168).

Groundwater ages vary seasonally for the springs, reflecting seasonal changes in flow paths leading to the springs. In general, apparent ${ }^{3} \mathrm{H} /{ }^{3} \mathrm{He}$ ages and/or the magnitude of the submodern fraction for mixed samples (based on initial ${ }^{3} \mathrm{H}$ values) are greater during summer and fall. The younger apparent ${ }^{3} \mathrm{H} /{ }^{3} \mathrm{He}$ ages and smaller submodern fractions present during spring months probably result from spring snowmelt recharge and the seasonal reactivation of short, fast flow paths leading to the springs. The springs, therefore, appear to have a perennial baseflow component characterized by longer flow paths and an ephemeral high-flow component with short flow paths, much like streams.

An example of short flow paths includes groundwater discharging at PC Spring. Concentrations of ${ }^{3} \mathrm{H}$ were $40.11 \mathrm{pCi} / \mathrm{kg}(12.45 \mathrm{TU})$ in a sample collected on March 30, 2005, and $69.53 \mathrm{pCi} / \mathrm{kg}$ $(21.58 \mathrm{TU})$ in another sample collected on July 12, 2005 (Table 6-4, Plate 1). The groundwater 
ages for PC Spring ranged from 0.38 to 1.25 years, a finding that suggests that groundwater flow paths from the recharge zone to PC Spring are short throughout a given year.

Barbara Spring provides an example of variation in apparent ${ }^{3} \mathrm{H} /{ }^{3} \mathrm{He}$ age taking place during groundwater baseflow and recharge from snow melt. Concentrations of ${ }^{3} \mathrm{H}$ were 1.26 and $1.87 \mathrm{Ci} / \mathrm{kg}(0.39$ and $0.58 \mathrm{TU})$ for samples collected on March 29 and July 13, 2005, respectively (Table 6-4, Plate 1). Apparent groundwater ${ }^{3} \mathrm{H} /{ }^{3} \mathrm{He}$ ages for Barbara Spring are 2.41 and 31.05 years. The numerically larger age might be the result of less mixed groundwater containing a smaller component of recent recharge and a larger amount of submodern groundwater that has an unadjusted ${ }^{14} \mathrm{C}$ age of 2486 years (Table 6-5, Plate 2 ).

Concentrations of ${ }^{3} \mathrm{H}$ ranged from 14.11 to $29.42 \mathrm{pCi} / \mathrm{kg}$ (4.38 to $9.13 \mathrm{TU}$ ) at Seven Springs (Table 6-4, Plate 1) in the western portion of the Jemez Mountains, a finding that provides a local baseline for cosmogenic ${ }^{3} \mathrm{H}$ present in groundwater. This finding suggests that ${ }^{3} \mathrm{H}(40.44$ and $69.53 \mathrm{pCi} / \mathrm{kg}$ or 12.45 and $21.58 \mathrm{TU})$ at PC Spring contains a fraction of ${ }^{3} \mathrm{H}$ originating from atmospheric releases from the Laboratory. This source of excess ${ }^{3} \mathrm{H}$ is consistent with analytical results provided by Adams et al. (1995, 047192).

Surface water sampled at CdV-5.6 within Cañon de Valle and PA-10.6 within Pajarito Canyon contained 50.33 to $68.76 \mathrm{pCi} / \mathrm{kg}$ (15.63 to $21.34 \mathrm{TU}$ ) of ${ }^{3} \mathrm{H}$ (Table 6-4, Plate 1 ). Higher concentrations were associated with PA-10.6. These two surface waters also contain ${ }^{3} \mathrm{H}$ mostly derived from Laboratory releases to the atmosphere because concentrations of ${ }^{3} \mathrm{H}$ exceed both concentrations at the Sierra de los Valles springs and cosmogenic levels (19 pCi/kg, $6 \mathrm{TU})$. Values of $\mathrm{R}(3 / 4)$ in Ra ranged from 0.82 to 1.04 for Ne concentrations less than $34 \times 10^{-8} \mathrm{~cm}^{3}$ $\mathrm{STP} / \mathrm{g} \mathrm{H}_{2} \mathrm{O}$ (Table 6.4), suggesting a surface or atmospheric source of ${ }^{3} \mathrm{H}$. Surface water at PA-10.6 and CdV-5.6 is dominated by modern water because flow is primarily supported by springs containing modern-age water. Present-day and initial ${ }^{3} \mathrm{H}$ activities for these two surfacewater stations plot well above the atmospheric ${ }^{3} \mathrm{H}$ input curve (Table 6-4, Plate 1, and Figure 3 ).

Attempting to correlate noble-gas ages at PA-10.6 and CdV-5.6 to downgradient discharge points may not be valid because gain or loss of ${ }^{3} \mathrm{He}$ during surface flow and recharge within the vadose zone may occur. Nevertheless, ages for PA-10.6 and the downgradient springsHomestead, Starmer, and Bulldog-agree with each other. (See Section 6.2.6.) Hydrochemical and seepage measurements by Dale et al. $(2005,095002)$ before and after the Cerro Grande fire indicate that surface water flow from PA-10.6 enters the Pajarito fault zone within several hundred feet downstream of PA-10.6 and discharges at springs (e.g., Homestead Spring) located about $1.6 \mathrm{~km}$ (one mile) downgradient. Subsurface inflow of water at CdV-5.6 may supply recharge to downgradient springs, including Burning Ground Spring.

Concentrations of ${ }^{3} \mathrm{H}$ ranged from 19.69 to $20.98 \mathrm{pCi} / \mathrm{kg}$ (6.11 to $6.51 \mathrm{TU}$ ) at Arroyo Hondo-0.2 Spring (Table 6-4, Plate 1) north of Taos, New Mexico, which provides a regional baseline for cosmogenic ${ }^{3} \mathrm{H}$ present in groundwater. This range in ${ }^{3} \mathrm{H}$ concentration is lower than ${ }^{3} \mathrm{H}$ concentrations measured at Pajarito Ski Well \#2, WCG Spring, Young Spring, CdV-5.0 Spring, and PC Spring within the Sierra de los Valles. The two off-site samples providing the most useful groundwater ages, in terms of least amount of atmospheric air present during sampling, were collected on February 5 and April 8, 2005 (Table 6-4). Apparent ${ }^{3} \mathrm{H} /{ }^{3} \mathrm{He}$ ages for the two samples were 21.26 and 25.26 years (Table 6-4, Plate 2). Values of R(3/4) in Ra were 1.28 and 
1.31 for the samples; and total He concentrations were $6.26 \times 10^{-8}$ and $6.34 \times 10^{-8} \mathrm{~cm}^{3} \mathrm{STP} / \mathrm{g}$ $\mathrm{H}_{2} \mathrm{O}$ (Table 6.4). The unadjusted ${ }^{14} \mathrm{C}$ age for Arroyo Hondo-0.2 Spring is 912 years (Plate 2) with a non-normalized fraction of modern $\mathrm{C}$ of 0.8867 (Table 6-5).

Groundwater discharging at Barbara Spring and Campsite Springs is mixed (Figure 6-3). Although no ${ }^{14} \mathrm{C}$ data are available for AL-10.6 Spring, we suspect that groundwater at this spring is also mixed because it plots below the atmospheric ${ }^{3} \mathrm{H}$ input curve. Unadjusted ${ }^{14} \mathrm{C}$ ages for Barbara Spring and Campsite Springs are 2486 and 2662 years, respectively (Table 6-5, Plate 2). Unadjusted ${ }^{14} \mathrm{C}$ ages for the remaining springs discharging in the Sierra de los Valles are all negative, except for AL-10.6 and Young Spring for which there are no ${ }^{14} \mathrm{C}$ isotope data, an observation indicating that the remaining springs probably discharge little water greater than 500-1000 years old (Table 6-5, Plate 2). Samples collected from PC Spring, WCG Spring, CdV-5.0 Spring, and Seven Springs, and Pajarito Ski Well \# 2 are modern, with apparent ${ }^{3} \mathrm{H} /{ }^{3} \mathrm{He}$ ages ranging from 0.38 to 27.54 years (Table 6-4, Plate 1).

\subsubsection{Summary of Sierra de los Valles Hydrochemistry}

Infiltration of snowmelt provides the main source of recharge to the Sierra de los Valles springs, discharging from perched intermediate zones. Groundwater discharging from springs and surface water within the Sierra de los Valles provides recharge to the Pajarito Plateau.

Groundwater discharging at the Sierra de los Valles springs consists of a $\mathrm{Ca}-\mathrm{Na}-\mathrm{Mg}-\mathrm{HCO}_{3}-\mathrm{SO}_{4}$ composition with calculated TDS ranging from 66.5 to $176 \mathrm{ppm}$. Concentrations of trace elements in the samples were less than $0.010 \mathrm{ppm}$, which is consistent with generally short groundwater ages and varying reaction half times for water-rock interactions including precipitation/dissolution and adsorption/desorption reactions. Groundwater discharging at the springs is mostly modern, and the ${ }^{3} \mathrm{H} /{ }^{3} \mathrm{He}$ dating method indicated that it postdates 1985 .

Unadjusted ${ }^{14} \mathrm{C}$ measurements show that groundwater discharging from Campsite Springs and Barbara Spring has average ages of 2662 and 2486 years, respectively. These two springs represent a mixture of modern and submodern groundwater. Analytical results for $\delta^{2} \mathrm{H}$ and $\delta^{18} \mathrm{O}$ suggest that the majority of groundwater discharging at the springs originated as precipitation within the Sierra de los Valles. On the basis of the springs' average ages - determined through the ${ }^{14} \mathrm{C}$ dating method - it appears that groundwater discharging at Campsite Springs and Barbara Spring may have originated west of the Sierra de los Valles, somewhere within the Jemez Mountains. These submodern ages suggest much longer flow paths and/or much lower inflow rates, and potential recharge from the Valles Caldera and/or Sierra de Los Valles.

\subsection{Aqueous Inorganic and Isotope Chemistry of Wells and Springs, Pajarito Plateau}

This section presents analytical results for samples collected on the Pajarito Plateau and discussions on field parameters, major and trace element chemistry, stable isotope chemistry, ${ }^{3} \mathrm{H}$, ${ }^{14} \mathrm{C}$, and noble gas geochemistry. Groundwater samples were collected from both background and contaminated springs and wells. All of the contaminated springs and wells contain a modern component consisting of Laboratory-derived chemicals. A few stations contain a mixture of Laboratory and Los Alamos County treated effluent (R-4, O-1, and Spring 2B). 


\subsubsection{Field Parameters}

The Pajarito Plateau samples had field $\mathrm{pH}$ values ranging from 6.25 at TA-18 Spring to 8.64 at O-1 (Table 6-1). An anomalous pH of 9.62 was recorded at LAOI(A)-1.1 on March 4, 2005. Temperature measurements recorded during sampling ranged from $5.0^{\circ} \mathrm{C}$ at LAO-B to $27.2^{\circ} \mathrm{C}$ at O-1. Warmer values were associated with samples collected from the regional aquifer (Table 6-1). Groundwater varied from anaerobic to aerobic with reasonable DO concentrations ranging from $0.06 \mathrm{mg} / \mathrm{L}$ at TW-3 to $8.91 \mathrm{mg} / \mathrm{L}$ at Starmer Spring. Concentrations of DO greater than $9 \mathrm{mg} / \mathrm{L}$ are suspect and were not used in any part of geochemical interpretation.

\subsubsection{Major Ion and Trace Element Geochemistry for Background Wells and Springs, Pajarito Plateau}

Background samples were collected at wells both upgradient (LAO-B) from release sites and at facility wells (R-1, R-2, and R-18) not impacted by Laboratory discharges containing ${ }^{3} \mathrm{H}, \mathrm{ClO}_{4}$, and other chemicals. Figure 6-4 presents a trilinear diagram for filtered samples collected from background stations within the Laboratory.

Background water samples consist of a mixed $\mathrm{Ca}-\mathrm{Na}-\mathrm{HCO}_{3}$ composition. Alluvial groundwater at LAO-B contained more $\mathrm{Cl}, \mathrm{Na}$, and $\mathrm{SO}_{4}$ and less $\mathrm{HCO}_{3}$ in comparison to samples collected at LAOI(A)-1.1, R-1, R-2, and R-18. This finding was expected because of the varying seasonal chemistry of recharge (surface) water and the short groundwater age associated with the alluvial system. Groundwater samples collected at R-2 and LAOI(A)1.1 are characterized by a $\mathrm{Na}-\mathrm{Ca}-\mathrm{HCO}_{3}$ composition (Figure 6-4).

In aquifers beneath the Pajarito Plateau, dissolved concentrations of $\mathrm{SiO}_{2}$ vary based on the amount and reactivity of volcanic glass and types of crystalline forms of $\mathrm{SiO}_{2}$. Dissolved concentrations of $\mathrm{SiO}_{2}$ ranged from $27.5 \mathrm{ppm}$ at LAO-B to $87.4 \mathrm{ppm}$ at R-2. Factors that contribute to dissolved $\mathrm{SiO}_{2}$ concentrations observed at LAO-B include sources of groundwater, aquifer material, and groundwater residence time, coupled with reaction kinetics of silica dissolution. The alluvium at LAO-B consists of a mixture of Bandelier Tuff and Tschicoma Formation derived from the Sierra del los Valles. The Tschicoma Formation has much smaller amounts of soluble volcanic glass in comparison to the Bandelier Tuff and pumiceous-rich units of the Puye Formation. Groundwater flow rates within the alluvium are approximately several hundred feet per day (Purtymun 1974, 005476; and Purtymun et al. 1977, 011846), which can exceed the reaction half time $\left(\mathrm{t}_{1 / 2}\right)$ for silica glass dissolution. Dissolved concentrations of $\mathrm{SiO}_{2}$ increase within other sections of the alluvium in Los Alamos Canyon containing higher proportions of Bandelier Tuff. Concentrations of calculated TDS ranged from 144 to 208 ppm for the background wells. Concentrations of TDS increase from alluvial groundwater to perched intermediate groundwater at LAOI(A)-1.1 to the regional aquifer at R-1, R-2, and R-18. Silica

and $\mathrm{HCO}_{3}$ are the dominant solutes contributing to TDS increases with aquifer depth (Table 6-1). Analytical charge balance for filtered samples ranged from -11.30 percent in a sample collected at $\mathrm{R}-18$ to +6.40 percent in a sample collected at LAO-B (Table 6-1). 
Detectable concentrations of dissolved Li ranged from 0.0036 to $0.024 \mathrm{ppm}$ in groundwater samples collected from the background wells (Table 6-2). The highest concentration of Li was measured at R-2.

Dissolved concentrations of B ranged from 0.0086 to $0.022 \mathrm{ppm}$. The highest value was measured at LAO-B (Table 6-2).

Detectable concentrations of total dissolved $\mathrm{Cr}$ ranged from 0.0016 to $0.005 \mathrm{ppm}$. The highest concentration was measured at R-1 (Table 6-2). Concentrations of total dissolved $\mathrm{Cr}$ were less than analytical detection (0.001 ppm) using ICP-MS at LAO-B and LAOI(A)-1.1 (Table 6-2).

Detectable concentrations of dissolved $\mathrm{Sr}$ ranged from $0.051 \mathrm{ppm}$ at R-1 to $0.12 \mathrm{ppm}$ at LAO-B. Concentrations of Sr measured at LAO-B may have been influenced by the Cerro Grande fire, in which this trace element is associated with $\mathrm{Ca}$ in ash and sediments mobilized by the fire. Increasing concentrations of $\mathrm{Ca}$ and other solutes were measured in surface water and alluvial groundwater after the Cerro Grande fire (Bitner et al. 2001, 094920; and Gallaher and Koch 2004, 088747).

Detectable background concentrations of dissolved $\mathrm{U}$ at the wells ranged from 0.0005 to 0.0007 $\mathrm{ppm}$. The highest value was measured at R-1. Most other trace elements provided in Table 6-2 do not show significant variation in concentration at the background wells. Aluminum and $\mathrm{Zn}$, however, are exceptions, and they could be associated with colloids consisting of clay minerals and ferric (oxy)hydroxide.

\subsubsection{Stable Isotope Geochemistry of Wells and Springs, Pajarito Plateau}

This section presents analytical results (Table 6-3) for stable isotopes $\left(\delta^{18} \mathrm{O}\right.$ and $\left.\delta^{2} \mathrm{H}\right)$ for the Pajarito Plateau, including contaminated and noncontaminated samples. Average isotopic results for all wells are shown in Figure 6-5. Results of stable isotope analyses for all Pajarito Plateau wells indicate a meteoric source. Groundwater samples plot close to both the JMML and WMWL. Wells LAO-B, LAOI(A)-1.1, R-1, and R-2 are enriched in ${ }^{18} \mathrm{O}$ and ${ }^{2} \mathrm{H}$ in comparison to the Sierra de los Valles springs (average $\delta^{18} \mathrm{O}$ and $\delta^{2} \mathrm{H}$ ratios). Seasonal variations in $\delta^{18} \mathrm{O}$ and $\delta^{2} \mathrm{H}$ are observed at LAO-B, whereas other perched intermediate groundwaters and the regional aquifer wells showed smaller variations in $\delta^{18} \mathrm{O}$ and $\delta^{2} \mathrm{H}$ (Table 6-3). Both groundwater mixing and long ages associated with deep aquifers lead to more uniform $\delta^{18} \mathrm{O}$ and $\delta^{2} \mathrm{H}$ ratios such that seasonal variations become attenuated. Well LAO-B is most depleted in $^{18} \mathrm{O}$ and ${ }^{2} \mathrm{H}$ in comparison to the other background wells sampled. Its source of recharge occurs at a higher elevation within the Sierra de los Valles (Figure 6-5, Table 6-3). Wells completed within the regional aquifer have heavier $\delta^{18} \mathrm{O}$ and $\delta^{2} \mathrm{H}$ values in comparison to LAO-B, and regional aquifer groundwater tends to become progressively heavier from west to east across the Pajarito Plateau (Table 6-3 and Figure 4-1). This isotopic gradient within the regional aquifer may be attributed to either climate change and/or changes in canyon-bottom recharge with respect to recharge elevation. Additional work is needed to delineate the isotopic distributions and gradients within each aquifer type.

Bulldog Spring, Burning Ground Spring, Starmer Spring, Martin Spring, and Homestead Spring have $\delta^{18} \mathrm{O}$ and $\delta^{2} \mathrm{H}$ values slightly lighter than the average $\delta^{18} \mathrm{O}$ and $\delta^{2} \mathrm{H}$ values for springs 
discharging within the Sierra de los Valles (Figure 6-6). Martin Spring plots to the right of the JMML and WMWL, indicating that evaporation has taken place leading to greater enrichment of ${ }^{18} \mathrm{O}$ relative to ${ }^{2} \mathrm{H}$. This isotope signature could be in response to former waste ponds at TA-16 and/or cooling tower (evaporative) outfall releases.

\subsubsection{Radiogenic Isotope and Noble Gas Geochemistry of Background Wells and Springs, Pajarito Plateau}

Anthropogenic and/or cosmogenic ${ }^{3} \mathrm{H}$ are not ubiquitously detected within the regional aquifer beneath the Laboratory. Concentrations of ${ }^{3} \mathrm{H}$ are typically less than $0.59 \mathrm{pCi} / \mathrm{kg}(0.18 \mathrm{TU})$ in many regional aquifer samples collected in 2005 (ESP 2005, 092222), a finding that suggests that regional aquifer groundwater commonly is submodern. This finding also holds true for numerous other samples collected from the regional aquifer prior to 2005. Previous sampling of regional aquifer wells R-20, R-23, and R-32 within Pajarito Canyon typically contained concentrations of ${ }^{3} \mathrm{H}$ less than analytical detection $(0.30 \mathrm{pCi} / \mathrm{kg}, 0.09 \mathrm{TU})$ (ESP 2005, 092222). The same is true for R-21, located in Cañada del Buey, north of Pajarito Canyon. Regional aquifer wells sampled as part of this investigation that did not contain ${ }^{3} \mathrm{H}$ include R-1, R-2, R-18, and R-23. This fact suggests that cosmogenic and/or bomb-pulse ${ }^{3} \mathrm{H}$ is not ubiquitously present within the upper portion of the regional aquifer beneath the Laboratory. Tritium is typically detected at various concentrations within the regional aquifer downgradient from ${ }^{3} \mathrm{H}$-release sites within Pueblo Canyon (R-4 and O-1), Los Alamos Canyon (TW-3 and R-9), Sandia Canyon (R-11 and R-12), Mortandad Canyon (TW-8, R-15, and R-28), and Cañon de Valle (R-25) (ESP 2005, 092222).

Concentrations of ${ }^{3} \mathrm{H}$ ranged from $0.06 \mathrm{pCi} / \mathrm{kg}(0.02 \mathrm{TU})$ at regional aquifer well R-1 to $64.41 \mathrm{pCi} / \mathrm{kg}(19.99 \mathrm{TU})$ at alluvial well LAO-B (Table 6-4, Plate 1). The corresponding apparent groundwater ages are greater than 62 (prior to 2005) and 3.84 years, respectively (Table 6-4, Plate 2), for samples collected at LAO-B and R-1. Groundwater samples collected from R-1 are submodern. Well R-18 contains submodern groundwater with a concentration of ${ }^{3} \mathrm{H}$ less than $0.06 \mathrm{pCi} / \mathrm{kg}(0.02 \mathrm{TU})$ (Table 6-4, Plate 1). Initial ${ }^{3} \mathrm{H}$ concentrations for LAOI(A)-1.1 fall below the atmospheric ${ }^{3} \mathrm{H}$ curve, indicating that these samples are mixed (Figure 6-9). Absence of Laboratory-derived contaminants at LAOI(A)-1.1 suggests that the ${ }^{3} \mathrm{H}$ is cosmogenic in origin. Concentrations of ${ }^{3} \mathrm{H}$ were $5.70 \mathrm{pCi} / \mathrm{kg}(1.77 \mathrm{TU})$, with associated apparent ages of 13.98 and 18.52 years, in two samples collected from the well (Table 6-5, Plate 2). The apparent ${ }^{3} \mathrm{H} /{ }^{3} \mathrm{He}$ age of 3.84 years for LAO-B suggests that an older component of groundwater baseflow is present in the alluvial aquifer for the sample collected on May 10, 2005. It appears, however, based on the negative apparent groundwater age (Table 6-4), that this component is not present for the sample collected on August 17, 2005.

Anomalous DEL ${ }^{3} \mathrm{He}$ and $\mathrm{DEL}^{4} \mathrm{He}$ values of 3760 and 2688 percent, respectively, with a $\mathrm{Ne}$ concentration of $22.61 \times 10^{-8} \mathrm{~cm}^{3} \mathrm{STP} / \mathrm{g} \mathrm{H}_{2} \mathrm{O}$ (Table 6-4) were measured in an air-free sample from R-1. It is possible that diffusion of ${ }^{3} \mathrm{He}$ from the mantle resulted in this anomalous $\mathrm{DEL}^{3} \mathrm{He}$ value. The anomalous $\mathrm{DEL}^{4} \mathrm{He}$ value for R-1 may be terrigenic, resulting from decay of $\mathrm{U}$ and Th in the crust. Samples collected from some other wells within the Española Basin have both high terrigenic He and $\mathrm{R}(3 / 4)$ in Ra values indicating a significant mantle component (Manning et al. 2006, 094921). An alternative hypothesis for explaining the anomalous $\mathrm{DEL}^{3} \mathrm{He}$ and DEL ${ }^{4} \mathrm{He}$ values for R-1 is that a fraction of excess dissolved ${ }^{3} \mathrm{He}$ and ${ }^{4} \mathrm{He}$ released from TA-50 
migrates under unsaturated flow conditions downward and ahead of the tritiated recharge waters to the regional water table. Core samples collected from the unsaturated zone within the Bandelier Tuff at R-1 contain ${ }^{3} \mathrm{H}$ concentrations greater than $100,000 \mathrm{pCi} / \mathrm{L}$ (LANL 2006, 094161). Release of TA-50 treated effluent containing ${ }^{4} \mathrm{He}$ from the processing of actinides (Am and $\mathrm{Pu}$ isotopes) since 1963 may contribute to the anomalous $\mathrm{DEL}^{4} \mathrm{He}$ values measured at $\mathrm{R}-1$. The regional aquifer at R-1, however, is not contaminated, suggesting that ${ }^{3} \mathrm{He}$ migrated much faster than ${ }^{3} \mathrm{H}$ through the overlying vadose zone.

The parameter $\mathrm{R}(3 / 4)$ in Ra for R-1 samples ranged from 1.24 to 1.37 (Table 6-4), indicating some enrichment of $\mathrm{He}$ in the groundwater samples relative to air. Values of $\mathrm{R}(3 / 4)$ in $\mathrm{Ra}$ measured at R-2 and R-18 were 1.01 and 1.30, respectively. Mixing of groundwater from different sources (magmatic and regional aquifer) containing different concentrations of He potentially decreases initial $\mathrm{R}(3 / 4)$ in Ra values originally associated with mantle-derived He. The parameter $\mathrm{R}(3 / 4)$ in $\mathrm{Ra}$ for the mixed groundwater approaches unity through this process. Samples collected from ${ }^{3} \mathrm{H}$-contaminated wells — including R-4, R-9, R-15, R-28, O-1, MCOI-6, and MCOBT-4.4 - have R(3/4) in Ra values ranging from 1.03 to 1.99 (Table 6-4). These abnormal Ra values may also be attributed to excess He moving under unsaturated flow conditions from alluvial groundwater downward, and/or the presence of excess He in the capillary fringe as noted above. The presence of other Laboratory-derived contaminants including $\mathrm{NO}_{3}$ (as $\left.\mathrm{N}\right), \mathrm{ClO}_{4}, \mathrm{CrO}_{4}, \mathrm{SO}_{4}$, and/or $\mathrm{U}$ should also be considered in evaluating sources of ${ }^{4} \mathrm{He}$ in some of the groundwater samples.

For the background wells, the oldest average groundwater age of 4193 years was measured at $\mathrm{R}-2$. It was based on an unadjusted ${ }^{14} \mathrm{C}$ measurement with a non-normalized fraction of modern C equal to 0.5894 (Table 6-5, Plate 2). A sample collected from R-1 had an average groundwater age of 3534 years, which was based on an unadjusted ${ }^{14} \mathrm{C}$ with a non-normalized fraction of modern $\mathrm{C}$ of 0.6398 (Table 6-5, Plate 2). Unadjusted ${ }^{14} \mathrm{C}$ ages at $\mathrm{R}-18$ were 536 and 604 years with non-normalized fractions of modern $\mathrm{C}$ of 0.9292 and 0.9214 , respectively (Table 6-5, Plate 2). These two submodern samples have the youngest unadjusted ${ }^{14} \mathrm{C}$ ages of all of the regional aquifer samples analyzed during this investigation (Table 6-5). Well R-18 is located near the Sierra de los Valles, and its young ${ }^{14} \mathrm{C}$ age is consistent with recharge to the regional aquifer largely occurring at the western edge of the Pajarito Plateau or in the Sierra de los Valles. Unadjusted ${ }^{14} \mathrm{C}$ ages for LAOI(A)-1.1 are not known because samples have not been collected and analyzed for $\delta^{13} \mathrm{C}$ and ${ }^{14} \mathrm{C}$.

\subsubsection{Major Ion and Trace Element Geochemistry from Contaminated Wells and Springs on the Pajarito Plateau}

The analytical charge balance for filtered samples ranged from -6.83 percent in a sample collected at TW-1A to +4.90 percent in a sample collected at R-11 (Table 6-1). Figure 6-7 shows a trilinear diagram for filtered samples containing Laboratory-derived contaminants, consisting of a mixed Ca-Na-Mg- $\mathrm{HCO}_{3}-\mathrm{Cl}-\mathrm{SO}_{4}$ composition. Samples collected from O-1, TW-1A, and TW-2 contained more $\mathrm{Na}$ than $\mathrm{Ca}$ in comparison to the other wells plotted on Figure 6-7. Well MCOBT-4.4 and TA-18 Spring show higher concentrations of $\mathrm{SO}_{4}$ in comparison to samples collected from other wells. One source of anthropogenic $\mathrm{SO}_{4}$ is neutralized and dissociated sulfuric acid $\left(\mathrm{H}_{2} \mathrm{SO}_{4}\right)$ discharged to Mortandad Canyon, Sandia Canyon, and Los Alamos Canyon. 
It is interesting to note that $\mathrm{TW}-1 \mathrm{~A}$ and $\mathrm{TW}-2$ had $\mathrm{SO}_{4}$ concentrations less than $0.6 \mathrm{ppm}$ (Table 6-1), which may suggest the presence of $\mathrm{SO}_{4}$-reducing bacteria within the wells. Test wells and water supply wells are constructed of carbon steel. Some of the casing has oxidized to ferric (oxy)hydroxide, manganese oxide, and other metal oxides over the past 40 years. Bacteria present in the wells catalyze oxidation-reduction reactions involving many anions, metals, and transition metals including $\mathrm{SO}_{4}, \mathrm{Cr}, \mathrm{Fe}, \mathrm{Mn}$, molybdenum (Mo), and $\mathrm{U}$. Sulfate reduction, however, is not observed at TW-1, TW-3, and TW-8. It is also possible that organic reductants present in sewage effluent from inactive and active treatment plants in Pueblo Canyon (LANL 1981, 006059) have reacted with groundwater at TW-1A and TW-2 causing $\mathrm{SO}_{4}$ reduction.

Figure 6-8 is a trilinear diagram for filtered samples collected from the TA-9 and TA-16 springs. The spring samples consist of a mixed $\mathrm{Ca}-\mathrm{Na}-\mathrm{HCO}_{3}-\mathrm{Cl}-\mathrm{SO}_{4}$ composition. Calcium, $\mathrm{Na}$, $\mathrm{K}$, and $\mathrm{Mg}$ show less variability in concentrations in comparison to $\mathrm{HCO}_{3}, \mathrm{Cl}$, and $\mathrm{SO}_{4}$. The milliequivalents of major cations at the TA-9 and TA-16 springs are very similar to those of the Sierra de los Valles springs. There are, however, higher concentrations of the major ions in samples collected from the TA-9 and TA-16 springs (Table 6-1). Higher concentrations of Na and $\mathrm{Cl}$ observed at the TA-9 and TA-16 springs could result from dissolution and infiltration of road salt.

The discussion that follows focuses on TDS and several trace elements unique to contaminant sources at the Laboratory. Concentrations of TDS consisting of natural solutes and contaminants observed at perched intermediate and regional aquifer wells are influenced by several factors. These include contaminant source chemistry, duration and volume of effluent discharge, point versus nonpoint source, hydrologic and geochemical properties of the vadose zone and regional aquifer, porous and fracture flow conditions, and position and construction of a monitoring well installed downgradient from the source(s).

Higher concentrations of solutes and TDS occur at wells and springs containing Laboratoryderived contaminants in comparison to background (Tables 6-1 and 6-2). For example, Ba, B, Cl, $\mathrm{ClO}_{4}, \mathrm{Mo}, \mathrm{Na}, \mathrm{NO}_{3}$ (as N), actinides, fission products, ${ }^{3} \mathrm{H}, \mathrm{CrO}_{4}, \mathrm{HE}$ compounds, and CAHs from Laboratory discharges are found in groundwater beneath the Pajarito Plateau. Concentrations of calculated TDS ranged from $93 \mathrm{ppm}$ at regional aquifer well TW-2 to $481 \mathrm{ppm}$ at perched intermediate well POI-4. Well POI-4 is located downgradient from the Bayo Sewage Treatment Plant operated by the County of Los Alamos and contains both Laboratory- and domesticderived contaminants. Alkalinity, $\mathrm{Ca}, \mathrm{Na}$, and $\mathrm{Cl}$ are the main solutes contributing to TDS at POI-4 (Table 6-1).

Dissolved As concentrations above analytical detection ranged from 0.0001 to $0.0041 \mathrm{ppm}$. The lowest and highest values were measured at TW-1A and TW-2, respectively (Table 6-2). Natural As has been detected in former supply wells (LA well field in lower Los Alamos Canyon) completed in the Santa Fe Group.

Detectable concentrations of dissolved Li ranged from 0.0045 to $0.049 \mathrm{ppm}$ in the groundwater samples. The highest concentration occurred at MCOI-6 (Table 6-2).

Boron concentrations ranged from 0.010 to $0.87 \mathrm{ppm}$. The lowest and highest values were measured at Starmer Spring and Martin Spring, respectively. Boron is a constituent of detergents 
and is associated with treated sewage discharges to Pueblo Canyon, Los Alamos Canyon, Sandia Canyon, and Pajarito Canyon. Boron is also used in the preparation of HE compounds at TA-16.

Detectable concentrations of total dissolved $\mathrm{Cr}$ ranged from 0.001 to $0.370 \mathrm{ppm}$ in the Pajarito Plateau samples (Table 6-2). The highest concentration of total dissolved $\mathrm{Cr}$ was measured at $\mathrm{R}-28$ in Mortandad Canyon. The dominant source of $\mathrm{Cr}(\mathrm{VI})\left(\right.$ as $\left.\mathrm{CrO}_{4}{ }^{2-}\right)$ is from the dissociation of $\mathrm{K}_{2} \mathrm{Cr}_{2} \mathrm{O}_{7}$ (potassium dichromate) used as a scale inhibitor in the cooling towers at TA-03 steam plant from 1956 through 1972 (LANL 2006, 091987).

Dissolved Mo concentrations above analytical detection ranged from 0.0011 to $0.048 \mathrm{ppm}$. The lowest values were measured at TA-18 Spring and TW-1, and the highest value was at R-2 (Table 6-2). Sodium molybdate $\left(\mathrm{Na}_{2} \mathrm{MoO}_{4}\right)$ was used in cooling towers at TA-03 and TA-53 from 1993 to 2001 as a scale inhibitor (LANL 2006, 091987). In the 1990s, blowdown from TA-53 cooling towers was discharged to Los Alamos Canyon, where concentrations of Mo have exceeded $1 \mathrm{ppm}$ within alluvial groundwater.

Nitrate(as $\mathrm{N})$ concentrations ranged from 0.05 to $4.36 \mathrm{ppm}$. The lowest and highest values were measured at TA-18 Spring and R-28, respectively (Table 6-1). The main sources of $\mathrm{NO}_{3}$ at the Laboratory are from neutralized nitric acid $\left(\mathrm{HNO}_{3}\right)$ and from nutrients present in treated sewage effluent.

Use of the IC method showed that dissolved $\mathrm{ClO}_{4}$ concentrations above detection ranged from 0.001 to $0.210 \mathrm{ppm}$. The lowest and highest values were measured at TW-1 and MCOBT-4.4, respectively (Table 6-1). The main source of $\mathrm{ClO}_{4}$ is perchloric acid $\left(\mathrm{HClO}_{4}\right)$ used as an oxidizing acid in actinide research at the Laboratory.

Detectable concentrations of dissolved Sr ranged from $0.028 \mathrm{ppm}$ at TW-2 to $0.28 \mathrm{ppm}$ at TW-1.

Detectable concentrations of dissolved U ranged from 0.0003 to $0.0031 \mathrm{ppm}$. The highest value was measured at TW-1 (Table 6-2). Uranium concentrations at TW-1 exceed LANL background (Table 2-1) within the regional aquifer, and this actinide is most likely derived from past Laboratory releases to Pueblo Canyon. The median background concentration of dissolved $U$ is $0.45 \mu \mathrm{g} / \mathrm{L}$ in the regional aquifer (LANL 2007, 094856).

Several other trace elements provided in Table 6-2, including $\mathrm{Mn}, \mathrm{Ni}, \mathrm{Pb}, \mathrm{V}$, and $\mathrm{Zn}$, showed concentration variations attributed to natural processes and possibly to Laboratory discharges.

\subsubsection{Radiogenic Isotope and Noble Gas Geochemistry of Contaminated Wells and Springs, Pajarito Plateau}

A general discussion on analytical results for ${ }^{3} \mathrm{H}$, noble gases, and groundwater ages for water samples collected from contaminated wells and the TA-9 and TA-16 springs is presented below. The subsection will first focus on Laboratory-wide ranges of ${ }^{3} \mathrm{H}$ concentrations and groundwater ages. Canyon-specific discussions will follow.

Measured atmospheric ${ }^{3} \mathrm{H}$ and calculated initial ${ }^{3} \mathrm{H}$ concentrations in alluvial and perched intermediate groundwater are shown in Figure 6-9. The initial ${ }^{3} \mathrm{H}$ concentration in each groundwater sample with $\mathrm{DEL}^{4} \mathrm{He}$ less than 100 percent was determined from the groundwater 
age derived from ${ }^{3} \mathrm{He}$ ingrowth (Equation 5-1). Initial ${ }^{3} \mathrm{H}$ concentrations for LAO-B, R-6i, MCOI-6, MCOBT-4.4, TW-1A, Homestead Spring, Starmer Spring, Bulldog Spring, Burning Ground Spring, TA-18 Spring, and Martin Spring plot above the atmospheric ${ }^{3} \mathrm{H}$ input curve. This finding suggests that excess ${ }^{3} \mathrm{H}$ is most likely anthropogenic in origin, mainly derived from Laboratory releases to the atmosphere, surface water, and/or groundwater. Well POI-4 plots just above the atmospheric ${ }^{3} \mathrm{H}$ input curve. It contains a small amount of cosmogenic ${ }^{3} \mathrm{H}$ mixed with a very large amount of Laboratory-derived ${ }^{3} \mathrm{H}$ (Figure 6-9).

Measured atmospheric ${ }^{3} \mathrm{H}$ and initial ${ }^{3} \mathrm{H}$ concentrations calculated from groundwater samples collected at regional aquifer wells on the Pajarito Plateau are shown in Figure 6-10. The initial ${ }^{3} \mathrm{H}$ concentration in each groundwater sample with $\mathrm{DEL}{ }^{4} \mathrm{He}$ less than 100 percent was determined from the groundwater age derived from ${ }^{3} \mathrm{He}$ ingrowth. Initial ${ }^{3} \mathrm{H}$ concentrations for TW-1 and R-15 plot above the atmospheric ${ }^{3} \mathrm{H}$ input curve showing that excess ${ }^{3} \mathrm{H}$ is most likely anthropogenic in origin and is derived from the Laboratory releases within Pueblo and Mortandad canyons, respectively. Test Well-1 and R-15 are mixed, and the concentration of initial ${ }^{3} \mathrm{H}$ becomes diluted as recharge water mixes with regional aquifer groundwater. Wells R-13 and TW-2 plot below the atmospheric ${ }^{3} \mathrm{H}$ input curve (Figure 6-10); TW-2 possibly contains ${ }^{3} \mathrm{H}$ derived from residual atmospheric detonation and/or Laboratory discharges. Another possible explanation is that the residual ${ }^{3} \mathrm{H}$ at TW-2 is from a contaminant plume and that the well is located on the tail end. Concentrations of ${ }^{3} \mathrm{H}$ are higher within the regional aquifer at R-4 and O-1 downgradient of TW-2 (Table 6-4). Groundwater at O-1 is mixed; ${ }^{3} \mathrm{H}$ concentrations range from 28.77 to $41.47 \mathrm{pCi} / \mathrm{kg}$ (8.93 to $12.87 \mathrm{TU}$ ) (Table 6-5, Plate 1). This well is discussed in more detail below. Figure 6-10 provides additional comments regarding other regional aquifer wells sampled as part of this investigation.

Anomalous $\mathrm{DEL}^{3} \mathrm{He}$ and $\mathrm{DEL}{ }^{4} \mathrm{He}$ were measured in air-free groundwater samples collected from perched intermediate zones at R-6i, MCOI-6, and MCOBT-4.4. These wells contain Laboratory-derived ${ }^{3} \mathrm{H}$ ranging from 3683 to $21,007 \mathrm{pCi} / \mathrm{kg}$ (1143 to $\left.6520 \mathrm{TU}\right)$ (Table 6-4). $\mathrm{DEL}^{3} \mathrm{He}$ values for these three wells ranged from 182 to 2277 percent. Values of DEL ${ }^{4} \mathrm{He}$ ranged from 20.96 to 60.75 percent for the samples. The parameter R(3/4) in Ra for R-6i, MCOI-6, and MCOBT-4.4 ranged from 1.79 to 14.53 , a finding consistent with tritiogenic ${ }^{3} \mathrm{He}$ produced from Laboratory-derived ${ }^{3} \mathrm{H}$.

Anomalous $\mathrm{DEL}^{3} \mathrm{He}$ and $\mathrm{DEL}^{4} \mathrm{He}$ values measured in air-free groundwater samples collected from the regional aquifer at R-4, R-9, R-28, TW-3, and O-1 ranged from 1546 to 12,987 percent and from 459 to 9320 percent, respectively. These $\mathrm{DEL}^{3} \mathrm{He}$ and $\mathrm{DEL}{ }^{4} \mathrm{He}$ values for the wells support the occurrence of tritiogenic and possibly terrigenic ${ }^{3} \mathrm{He}$ discussed below. The parameter $\mathrm{R}(3 / 4)$ in $\mathrm{Ra}$ for these samples ranged from 1.50 to 2.40 , a finding that is consistent with tritiogenic ${ }^{3} \mathrm{He}$ produced from Laboratory-derived ${ }^{3} \mathrm{H}$. These wells also contain coreleased contaminants including $\mathrm{NO}_{3}$ (as $\left.\mathrm{N}\right), \mathrm{ClO}_{4},{ }^{3} \mathrm{H}$, and/or $\mathrm{CrO}_{4}$, which represent mixed groundwater.

\subsubsection{Groundwater Ages in Pueblo Canyon}

Tritium was released from the former TA-1 and TA-45 outfalls into Acid Canyon and Pueblo Canyon from 1943 to 1964 (LANL 1981, 006059; Rogers 1998, 059169). Approximately 58.5 curies $(\mathrm{Ci})$ of ${ }^{3} \mathrm{H}$ in $1.65 \times 10^{6}$ gallons of effluent $\left(9.35 \times 10^{5} \mathrm{pCi} / \mathrm{L}\right)$ was released to Acid Canyon and Pueblo Canyon at these two former TAs. 
Apparent ages for TW-1, TW-1A, TW-2, R-4, O-1, and POI-4 are provided in Table 6-4 and are shown on Plate 2. Samples collected from these wells have estimated and apparent ages listed from oldest to youngest: $\mathrm{O}-1$, less than 62 years (not quantifiable because of excess ${ }^{3} \mathrm{He}$ and ${ }^{4} \mathrm{He}$ ); R-4, 31 years; TW-2, 17.2 years; TW-1A, 11.31 years; POI-4, 5.13 years; and TW-1, 3.99 years (Table 6-4, Plate 2). The apparent groundwater age calculated for TW-1 most likely results from improper well construction allowing water to migrate down the well annulus to the screened interval. The apparent age for TW-1 is younger than that of TW-1A, completed at a shallower depth within the Cerros del Rio volcanic rocks - a finding inconsistent with groundwater movement with depth. These wells also contain concentrations of $\mathrm{ClO}_{4}, \mathrm{NO}_{3}($ as $\mathrm{N})$, ${ }^{3} \mathrm{H}$, and/or U that exceed background (Table 2-1) (LANL 2007, 094856), indicating mixed groundwater beneath Pueblo Canyon.

Using Equation 2-9 showed that the initial ${ }^{3} \mathrm{H}$ concentration was $67 \mathrm{pCi} / \mathrm{kg}(21 \mathrm{TU})$ for TW-1A (Table 6-4, Plate 3). This calculated value represents the concentration of ${ }^{3} \mathrm{H}$ entering the perched intermediate zone upgradient of TW-1A during 1994. This calculation shows that concentrations of ${ }^{3} \mathrm{H}$ in groundwater were much higher during the past several decades. The majority of ${ }^{3} \mathrm{H}$ released from TA-1 and TA-45 since 1943 has decayed to ${ }^{3} \mathrm{He}$. The effluent has infiltrated, mixed with groundwater, and continues to migrate along groundwater flow paths within perched intermediate zones and the regional aquifer beneath Pueblo Canyon.

Unadjusted ${ }^{14} \mathrm{C}$ measurements on samples collected from R-2, R-4, and O-1 show that they have average ages of 3951 and 4193 years, 7609 years, and 9827 years, respectively, (Table 6-5). Average groundwater ages for samples collected from these three wells increase along flow paths within the regional aquifer in Pueblo Canyon. Groundwater samples collected from R-2, R-4, and O-1 have fractions of modern C (non-normalized) of 0.5894 and $0.6074,0.3852$, and 0.2923 , respectively (Table 6-5). The $\delta^{13} \mathrm{C}$ ratios in samples collected from R-2, R-4, and O-1 were $-14.9,-11.8$, and -9.5 permil, respectively. The heavier isotope ratio for a groundwater sample collected at $\mathrm{O}-1$ indicates possible dilution of ${ }^{14} \mathrm{C}$ by $\mathrm{HCO}_{3}$ produced by dissolution of $\mathrm{CaCO}_{3}$ within the aquifer matrix or by $\mathrm{C}_{4}$ plants. Calcite dissolution produces an artificially old groundwater age that, when corrected, will yield a younger and more accurate age (Clark and Fritz 1997, 059168). Groundwater sampled at TW-1 is entirely modern with a fraction of modern $\mathrm{C}$ equal to 1.9346 (Table 6-5), a finding which could result from improper well design. Another explanation for the very young age measured at TW-1 is accumulation of ${ }^{14} \mathrm{C}$ in a component of treated sewage effluent present in groundwater. This process, however, has not significantly affected the $\delta^{13} \mathrm{C}$, which has a value of -12.7 permil (Table 6-5).

\subsection{Sources of Helium in Pueblo Canyon}

The DEL ${ }^{4} \mathrm{He}$ and $\mathrm{DEL}^{3} \mathrm{He}$ values in air-free groundwater samples collected from R-2, R-4, TW-1, TW-1A, TW-2, POI-4, and O-1 ranged from 0.802 to 40,603 percent and from 10.76 to 69,297 percent, respectively (Table 6-4, Plate 4). The highest $\mathrm{DEL}^{4} \mathrm{He}$ and $\mathrm{DEL}^{3} \mathrm{He}$ values for Pueblo Canyon were measured at O-1. Values of R(3/4) in Ra provided in Table 6-4 also support enrichment of He in water relative to $\mathrm{He}$ in air for samples collected from O-1 and other wells with anomalous $\mathrm{DEL}^{4} \mathrm{He}$ and $\mathrm{DEL}^{3} \mathrm{He}$. Reliable values (air-free) of $\mathrm{R}(3 / 4)$ in Ra ranged from 1.00 at TW-2 to 1.99 at R-4, suggesting that the source of He was surface water. Concentrations of corrected He in the samples ranged from 4.68 to $1818 \times 10^{-8} \mathrm{~cm}^{3} \mathrm{STP} / \mathrm{g} \mathrm{H}_{2} \mathrm{O}$ (Table 6-4), and excess $\mathrm{He}$ is derived from ${ }^{3} \mathrm{H}$ decay. 
A series of calculations was performed for O-1, using Equation 2-3 to evaluate ${ }^{4} \mathrm{He}$ produced from $U$ and $T h$ decay based on modern and submodern groundwater ages determined by means of the ${ }^{14} \mathrm{C}$ dating method. Potential sources of dissolved $\mathrm{U}$ concentrations at $\mathrm{O}-1$, ranging from 0.0017 to $0.0019 \mathrm{ppm}$, (Table 6-2), can also be evaluated using Equation 2-3. For this calculation, we assume a bulk density $(\rho)$ of $2.2 \mathrm{~g} / \mathrm{cm}^{3}$ for the Santa Fe Group sands and an effective porosity $(\theta)$ of 0.20 . Time $(t)$ is equal to 62 years, the upper bound for the apparent age. [U] and [Th] are assumed to be equal to $4 \mathrm{ppm}$ and $16 \mathrm{ppm}$, respectively, for the Santa Fe Group sands (Vaniman 2006, 095110). The calculated amount of ${ }^{4} \mathrm{He}$ generated from $\mathrm{U}$ and Th within the Santa Fe Group sands is $6.57 \times 10^{-10} \mathrm{~cm}^{3} \mathrm{STP} / \mathrm{g} \mathrm{H} \mathrm{H}_{2} \mathrm{O}$. This value is less than He solubility in water $\left(4.55 \times 10^{-8} \mathrm{~cm}^{3} \mathrm{STP} / \mathrm{g} \mathrm{H}_{2} \mathrm{O}\right.$ at $25^{\circ} \mathrm{C}$, the estimated recharge temperature) by a factor of 69. It is also very much smaller than the average corrected $\mathrm{He}$ of $1.30 \times 10^{-5} \mathrm{~cm}^{3} \mathrm{STP} / \mathrm{g} \mathrm{H}_{2} \mathrm{O}$ measured in samples, with concentrations of Ne less than $25 \times 10^{-8} \mathrm{~cm}^{3} \mathrm{STP} / \mathrm{g} \mathrm{H}_{2} \mathrm{O}$. Since 1943 , in situ production of ${ }^{4} \mathrm{He}$ from decay of natural $\mathrm{U}$ and $\mathrm{Th}$ within the rock matrix is unlikely at $\mathrm{O}-1$, based on this calculation.

Concentrations of dissolved Li ranged from 0.020 to $0.023 \mathrm{ppm}$ at O-1 (Table 6-2); they probably are not sufficient naturally to produce the observed ${ }^{3} \mathrm{H}$ and ${ }^{4} \mathrm{He}$ concentrations in groundwater. Another natural source of ${ }^{3} \mathrm{H}$ production is granite pegmatites, which contain several weight percent $\mathrm{Li}$ in the form of lithium silicates. These minerals include spodumene $\left[\mathrm{LiAlSi}_{2} \mathrm{O}_{6}\right]$ and lepidolite $\left.\left[\mathrm{K}(\mathrm{Li}, \mathrm{Al})_{3}(\mathrm{Si}, \mathrm{Al})_{4}\right)_{10}(\mathrm{~F}, \mathrm{OH})_{2}\right]$ with theoretical weight percents of $\mathrm{Li}_{2} \mathrm{O}$ equal to 8.03 and 4.09, respectively. Both these minerals are capable of producing ${ }^{3} \mathrm{H}$ and ${ }^{4} \mathrm{He}$. Pegmatites are unique rocks that are not known to occur in the Los Alamos area. Based on these considerations, production of ${ }^{3} \mathrm{H}$ and ${ }^{4} \mathrm{He}$ from $\mathrm{Li}$ is not a plausible process for explaining the observed $\mathrm{DEL}^{3} \mathrm{He}$ and $\mathrm{DEL}^{4} \mathrm{He}$ values in groundwater samples collected at $\mathrm{O}-1$.

Diffusion of ${ }^{4} \mathrm{He}$ from the Earth's crust and mantle is a viable possibility at O-1. Hydrothermal alteration of the Puye Formation, the pumiceous unit above the Miocene basalt, and/or the Santa Fe Group is observed in core and cutting samples taken at R-5, R-9, R-12, and O-1 (Vaniman 2006, 095111). Observed chemical and mineralogical alteration indicates that magmatic fluids have reacted with the aquifer matrix to form kaolinite and smectite (Vaniman 2006, 095111). These hydrothermal-magmatic fluids may have contained anomalous concentrations of $\mathrm{He}$ isotopes. Structural features such as deep faults within the basement rocks may control He diffusion beneath specific portions the Pajarito Plateau, especially near the Jemez Mountains. Anomalous DEL ${ }^{4} \mathrm{He}$ values were also measured in samples collected from the Española Basin. These anomalous values are attributed to crust and mantle-derived ${ }^{4} \mathrm{He}$ (Manning et al 2006, 094921).

Using the same values for parameters defined in Equation 2-3 with t equal to 9827 years for the average age at $\mathrm{O}-1$, the amount of ${ }^{4} \mathrm{He}$ generated from regional aquifer material is $1.04 \times 10^{-7} \mathrm{~cm}^{3}$ $\mathrm{STP} / \mathrm{g} \mathrm{H}_{2} \mathrm{O}$. This value is less than the average corrected $\mathrm{He}\left(1.30 \times 10^{-5} \mathrm{~cm}^{3} \mathrm{STP} / \mathrm{g} \mathrm{H}_{2} \mathrm{O}\right)$ measured in air-free samples collected from $\mathrm{O}-1$. In situ production of ${ }^{4} \mathrm{He}$ from decay of natural $\mathrm{U}$ and Th within rock matrix during the past 9830 years is very unlikely at $\mathrm{O}-1$, given the site geochemical conditions.

Solving Equation 2-3 for $t$ and using the same input values that were used in the above calculations with an average ${ }^{4} \mathrm{He}$ equal to $1.48 \times 10^{-5} \mathrm{~cm}^{3} \mathrm{STP} / \mathrm{g} \mathrm{H}_{2} \mathrm{O}$ (air-free samples), the 
calculated average groundwater age for O-1 is $1,535,588$ years. This calculated age is much older than that determined by the ${ }^{14} \mathrm{C}$ dating method (Table 6-5) and is not consistent with site hydrogeologic conditions. Results of this calculation suggest that the dissolved ${ }^{4} \mathrm{He}$ in groundwater samples collected at O-1 are most likely derived from a combination of sources. These sources include crust and mantle-derived ${ }^{4} \mathrm{He}$ and unknown amounts of dissolved $\mathrm{U}$ and $\alpha$ particles produced from processing of ${ }^{234} \mathrm{U},{ }^{235} \mathrm{U},{ }^{238} \mathrm{U},{ }^{238} \mathrm{Pu},{ }^{239,240} \mathrm{Pu}$, and ${ }^{241} \mathrm{Am}$ at former TA-1 and TA-45 upgradient from $\mathrm{O}-1$.

\subsubsection{Groundwater Ages in Los Alamos Canyon}

Approximately $181 \mathrm{Ci}^{3}{ }^{3} \mathrm{H}$ in $7.21 \times 10^{7}$ gallons of TA-21 effluent $\left(9.35 \times 10^{5} \mathrm{pCi} / \mathrm{L}\right)$ discharged into DP Canyon and Los Alamos Canyon from 1952 to 1985 (LANL 1981, 006059; Rogers 1998, 059169). At TA-2, a maximum of $70 \mathrm{Ci}$ of ${ }^{3} \mathrm{H}$ in $9.96 \times 10^{5}$ gallons of reactor cooling water $\left(2.01 \times 10^{7} \mathrm{pCi} / \mathrm{L}\right)$ was directly released to alluvial groundwater in upper Los Alamos Canyon, possibly from 1956 through 1992.

Concentrations of ${ }^{3} \mathrm{H}$ at R-9 and TW-3 ranged from 9.44 to $12.47 \mathrm{pCi} / \mathrm{kg}(2.93$ to $3.87 \mathrm{TU})$ and from 3.90 to $14.94 \mathrm{pCi} / \mathrm{kg}(1.21$ to $4.64 \mathrm{TU})$, respectively (Table 6-4, Plate 1). The concentration of ${ }^{3} \mathrm{H}$ at R-6i was $3683 \mathrm{pCi} / \mathrm{kg}$ (1143 TU) (Table 6-4, Plate 1). The apparent groundwater age was 4.49 years at R-6i (Table 6-4, Plate 2). This finding suggests that rapid infiltration from DP Canyon and/or Los Alamos Canyon to the perched intermediate zone took place. Using Equation 2-9 showed that the initial ${ }^{3} \mathrm{H}$ concentration for the sample collected from R-6i was $4740 \mathrm{pCi} / \mathrm{kg}$ (1471 TU).

Unadjusted ${ }^{14} \mathrm{C}$ measurements showed that average groundwater ages for samples collected from R-6, TW-3, and R-9 are 6283, 6704, and 10,817 years, respectively (Table 6-5, Plate 2). Average groundwater ages increase along flow paths within the regional aquifer beneath Los Alamos Canyon. Groundwater samples collected from R-6, TW-3, and R-9 have fractions of modern C (non-normalized) of $0.4544,0.4312$, and 0.2584 , respectively (Table 6-5). The $\delta^{13} \mathrm{C}$ values in samples collected from R-6, TW-3, and R-9 were $-12.3,-10.1$, and -9.0 permil, respectively. The heavier isotope ratio measured at R-9 indicates possible dilution of modern ${ }^{14} \mathrm{C}_{\text {by }} \mathrm{HCO}_{3}$ produced from the dissolution of $\mathrm{CaCO}_{3}$ within the aquifer matrix of the Miocene basalt. The presence of treated sewage effluent released from TA-21 and/or Pueblo Canyon is another potential source of organic carbon resulting in enrichment of ${ }^{13} \mathrm{C}$ in regional aquifer groundwater at the well.

\subsection{Sources of Helium in Los Alamos Canyon}

Decay of ${ }^{3} \mathrm{H}$ released from TA-2 and TA-21 provides a source of ${ }^{3} \mathrm{He}$ contributing to elevated DEL $^{3} \mathrm{He}$ values observed at downgradient wells R-9, TW-3, and R-6i (Table 6-4, Plate 4). The highest DEL ${ }^{4} \mathrm{He}$ and $\mathrm{DEL}^{3} \mathrm{He}$ values were measured in groundwater samples collected at TW-3. DEL ${ }^{3} \mathrm{He}$ values for R-9 and TW-3 ranged from 1635 to 2225 percent and 1546 to 4749 percent, respectively (Table 6-4, Plate 4). A DEL ${ }^{3} \mathrm{He}$ value for R-6i was 1292 percent (Table 6-4) because of excess ${ }^{3} \mathrm{H}$. Values of $\mathrm{R}(3 / 4)$ in Ra ranged from 1.0 to 11.31 for the sampled wells in Los Alamos Canyon, suggesting mixed sources of He that include surface water for background well LAOI(A)-1.1, and ${ }^{3} \mathrm{H}$-contaminated groundwater at R-6i (Table 6-4). The R(3/4) in Ra value for R-6i shows the accumulation of tritiogenic ${ }^{3} \mathrm{He}$ in the sample (Table 6-4). 
Tritium was directly released to alluvial groundwater from the Omega West Reactor (OWR) at TA-2 in upper Los Alamos Canyon (Rogers 1998, 059169). The OWR started operations in 1956, and a leak in the reactor cooling system below grade was discovered in 1993 (Rogers 1998, 059169). The OWR was placed on standby shortly afterward, and the leakage of reactor cooling water stopped. Neutron activation of $\mathrm{H}_{2} \mathrm{O}$ produced ${ }^{2} \mathrm{H}$ and ${ }^{3} \mathrm{H}$ (deuterium and tritium) in the cooling water at the OWR. The estimated total ${ }^{3} \mathrm{H}$ reported by Rogers $(1998,059169)$ assumes that the leak started in 1956 and occurred at a rate of 70 gallons per day, with a cooling water ${ }^{3} \mathrm{H}$ activity of $2.0 \times 10^{7} \mathrm{pCi} / \mathrm{L}$.

Helium-4 was produced at the OWR through neutron $\left({ }_{0}^{1} \mathrm{n}\right)$ capture by boron-10 $\left({ }^{10} \mathrm{~B}\right)$ present in control rods represented by the following reaction:

$$
{ }_{5}^{10} \mathrm{~B}+{ }_{0}^{1} \mathrm{n} \rightarrow{ }_{3}^{7} \mathrm{Li}+{ }_{2}^{4} \mathrm{He} \text {. }
$$

Based on the OWR decommissioning report's value of $610,000 \mathrm{MW}$-hours of operation over its 36 -year life, a total of about $1.8 \times 10^{26}$ neutrons were produced within the OWR. About $41 \%$ of the neutrons produced simply sustained the fission chain reaction while the remainder were absorbed in other materials in and surrounding the core (Richmond 2006, 095886). Boron was used in the control rods to capture or regulate neutrons generated from fission of $U$ isotopes in the fuel rods at TA-2. The concentration of B in the control rods at the OWR ranged between 0.1 and 1 weight percent (1000 and 10,000 ppm or $\mathrm{mg} / \mathrm{kg}$ ), and ${ }^{10} \mathrm{~B}$ constituted 6 to 7 percent (60 to $700 \mathrm{ppm}$ ) of the total B (Richmond 2006, 095886). Boron-10 has a large thermal cross section of 941 barns (Parrington et al. 1996, 058682). The thermal neutron absorption cross section measures the probability of interaction of a neutron with matter (nucleus of an atom). About 12\% to $15 \%$ of all the neutrons produced in the reactor would have participated in reaction 6-1. Swelling of the control rods would be expected to cause the release of small quantities of ${ }^{4} \mathrm{He}$ to reactor cooling water. A more detailed analysis is required to determine the amount of ${ }^{4} \mathrm{He}$ present in the reactor cooling water that was released to alluvial groundwater. Based on the neutron flux in the reactor and the time duration (a maximum of 36 years) of the leak at the OWR, it appears that the amount of ${ }^{4} \mathrm{He}$ released could have been substantial (about 1-100 ppb in the 1 million gallons leaked from the OWR). Helium- 4 and ${ }^{3} \mathrm{H}$ were directly released to alluvial groundwater through a leak in the cooling water system. Alluvial groundwater provides a source of recharge to perched intermediate groundwater and the regional aquifer within upper Los Alamos Canyon. Anomalous DEL ${ }^{4} \mathrm{He}$ values were measured in groundwater samples collected from TW-3 and R-9 downgradient from TA-2. It is hypothesized that downgradient TW-3 contains ${ }^{3} \mathrm{H}$ released from TA-2, and that R-9 contains ${ }^{3} \mathrm{H}$ released from TA-21 with lower $\mathrm{DEL}^{4} \mathrm{He}$ values.

\subsubsection{Groundwater Ages in Sandia Canyon and Mortandad Canyon}

The discussions of isotope geochemistry of Sandia Canyon and Mortandad Canyon are combined below. These two canyons are adjacent, and mixing of regional aquifer groundwater may occur beneath the two canyons. A total of eight wells completed within perched intermediate zones and the regional aquifer in Sandia and Mortandad canyons were sampled for ${ }^{3} \mathrm{H},{ }^{14} \mathrm{C}, \delta^{13} \mathrm{C}$, noble gases, and other constituents. The sample locations included regional aquifer wells $\mathrm{R}-1, \mathrm{R}-11$, R-13, R-15, R-28, and TW-8; and perched-intermediate wells MCOI-6 and MCOBT-4.4. 
A total of $823 \mathrm{Ci}$ of ${ }^{3} \mathrm{H}$ in $3.77 \times 10^{8}$ gallons of effluent $\left(5.76 \times 10^{5} \mathrm{pCi} / \mathrm{L}\right)$ were released from the Radioactive Liquid Waste Treatment Facility (RLWTF) at TA-50 from 1963 through 2005 (Rogers 1998, 059169; LANL 2006, 094161). This tritiated surface water flows down canyon and provides recharge to alluvial and perched intermediate groundwater and, ultimately, to the regional aquifer. The primary location of recharge reaching perched intermediate zones occurs below the confluence of Ten Site and Mortandad canyons (LANL 2006, 094161). Concentrations of ${ }^{3} \mathrm{H}$ ranged from less than detection to $185 \mathrm{pCi} / \mathrm{kg}(57.6 \mathrm{TU})$ in regional aquifer samples (Table 6-4). Wells MCOBT-4.4, MCOI-6, R-15, and R-28 east of the confluence contain concentrations of ${ }^{3} \mathrm{H}$ above the cosmogenic threshold of $19 \mathrm{pCi} / \mathrm{kg}(6 \mathrm{TU})$, whereas ${ }^{3} \mathrm{H}$ is less than detection at the upgradient well R-1 (Table 6-4).

Well R-11 in Sandia Canyon contained 2.58 and $7.99 \mathrm{pCi} / \mathrm{kg}(0.80$ and $2.48 \mathrm{TU})$ of ${ }^{3} \mathrm{H}$ (Table 6-4, Plate 1). Concentrations of ${ }^{3} \mathrm{H}$ ranged from 0.03 to $0.45 \mathrm{pCi} / \mathrm{kg}(0.01$ to $0.14 \mathrm{TU})$ at R-13 in Mortandad Canyon, suggesting that a small fraction of modern water occurs at this well (Table 6-4, Plate 1). Well R-15 contained concentrations of ${ }^{3} \mathrm{H}$ ranging from 22.26 to 31.80 $\mathrm{pCi} / \mathrm{kg}$ (6.91 to $9.87 \mathrm{TU}$ ) (LANL 2006, 094161), which have increased during the past several years. This finding suggests that the well is positioned within a migrating ${ }^{3} \mathrm{H}$ plume. At R-28, concentrations of ${ }^{3} \mathrm{H}$ were 164 and $185 \mathrm{pCi} / \mathrm{kg}$ (50.78 and $57.57 \mathrm{TU}$ ) (Table 6-4, Plate 1). These are the highest concentrations of ${ }^{3} \mathrm{H}$ measured within the regional aquifer beneath the Laboratory. Samples collected from TW-8 had ${ }^{3} \mathrm{H}$ concentrations of 9.31 and $34.38 \mathrm{pCi} / \mathrm{kg}(2.89$ and $10.67 \mathrm{TU})$.

Based on the initial discharge of ${ }^{3} \mathrm{H}$ from the RLWTF in 1963 (LANL 1997, 056835), we have established the upper limit for estimated apparent age for groundwater containing Laboratory-derived ${ }^{3} \mathrm{H}$ as 42 years (prior to 2005) in Mortandad Canyon. The R-28 samples contained excess tritiogenic ${ }^{3} \mathrm{He}$ producing anomalous $\mathrm{DEL}^{3} \mathrm{He}$ values with apparent ages exceeding 42 years. Apparent groundwater ages for R-13 were also greater than 42 years (submodern) without anomalous $\mathrm{DEL}^{3} \mathrm{He}$ values (Table 6-4, Plate 2). The apparent groundwater ages for samples collected from R-11 are biased high because of excess air present in the samples with Ne concentrations greater than $34 \times 10^{-8} \mathrm{~cm}^{3} \mathrm{STP} / \mathrm{g} \mathrm{H}_{2} \mathrm{O}$ (Table 6-4). Apparent groundwater ages for R-15 ranged from 14.90 to 17.21 years (Table 6-4, Plate 2). These results suggest that ${ }^{3} \mathrm{H}$ had reached the regional aquifer upgradient of R-15 after 1988. The amount of time required for ${ }^{3} \mathrm{H}$ to migrate through the vadose zone and reach the regional water table is estimated at 25 years at R-15 because the initial releases of ${ }^{3} \mathrm{H}$ from TA-50 occurred in 1963. Two samples collected from TW-8 had apparent groundwater ages of 32.75 and 51.48 years (Table 6-4). Occurrence of ${ }^{3} \mathrm{H}, \mathrm{NO}_{3}$ (as N), $\mathrm{CrO}_{4}, \mathrm{SO}_{4}$, and/or $\mathrm{ClO}_{4}$ confirms that the regional aquifer groundwater is mixed at TW-8, R-11, R-15, and R-28.

Concentrations of ${ }^{3} \mathrm{H}$ measured at MCOBT-4.4 and MCOI-6 were 21,007 and 12,650 pCi $/ \mathrm{kg}$ (6520 and 3926 TU), respectively. Apparent groundwater ages for MCOBT-4.4 and MCOI-6 were 0.13 and 2.50 years, respectively (Table 6-4, Plate 2). These ages are biased low because of loss of tritigenic ${ }^{3} \mathrm{He}$ within the overlying unsaturated zone above the perched aquifer. The low groundwater ages suggest that these two wells are located within a recharge area for the perched intermediate zone within the Puye Formation and Cerros del Rio volcanic rocks.

For R-15, the initial ${ }^{3} \mathrm{H}$ concentrations in regional aquifer groundwater were 58.67, 54.07, 73.53, and $73.91 \mathrm{pCi} / \mathrm{kg}(18.21,16.78,22.82$, and $22.94 \mathrm{TU}$ ) (Table 6-4, Plate 3), using Equation 2.9. 
The initial ${ }^{3} \mathrm{H}$ concentrations were 21,156 and $14,557 \mathrm{pCi} / \mathrm{kg}(6566$ and $4518 \mathrm{TU})$ calculated for groundwater samples collected from MCOBT-4.4 and MCOI-6, respectively (Table 6-4, Plate 3). These calculated values represent initial ${ }^{3} \mathrm{H}$ concentrations present during recharge when ${ }^{3} \mathrm{He}$ begins to reaccumulate under saturated flow conditions. Laboratory-derived contaminants including $\mathrm{ClO}_{4}, \mathrm{NO}_{3}$ (as $\mathrm{N}$ ), and $\mathrm{CrO}_{4}$, are also present at MCOBT-4.4, MCOI-6, and R-15 (Tables 6-1 and 6-2) (LANL 2006, 094161).

The upper saturated portion of the regional aquifer beneath Sandia Canyon and Mortandad Canyon is mainly submodern in age. Average ${ }^{14} \mathrm{C}$ groundwater ages for R-1 and R-11 were 3534 and 6164 years, respectively (Table 6-5, Plate 2). These two samples had fractions of modern C (non-normalized) of 0.6398 and 0.4509 , respectively (Table 6-5). Average groundwater ages for R-13 were 3584 and 3655 years (Table 6-5, Plate 2) with fractions of modern C (nonnormalized) of 0.6359 and 0.6303 , respectively. Well R-15 had an average age of 3335 years (Table 6-5, Plate 2) with a fraction of modern C (non-normalized) of 0.6559 (Table 6-5). Average groundwater ages for two samples collected from R-28 are 5493 and 5720 years (Table 6-5, Plate 2) with fractions of modern C (non-normalized) of 0.5014 and 0.4847 , respectively. The $\delta^{13} \mathrm{C}$ values for samples collected at R-1, R-11, and R-13 were $-14.9,-10.7$, and -14.1 and -14.4 permil, respectively (Table 6-5). A sample collected at $\mathrm{R}-15$ had a $\delta^{13} \mathrm{C}$ value of -13.4 permil, and the two samples collected at $\mathrm{R}-28$ had $\delta^{13} \mathrm{C}$ ratios of -11.4 and -11.8 permil (Table 6-5).

\subsection{Sources of Helium in Sandia and Mortandad Canyons}

Several wells completed within perched intermediate zones and the regional aquifer beneath Mortandad Canyon and Sandia Canyon contain concentrations of ${ }^{3} \mathrm{H}$ above cosmogenic levels (19 pCi $/ \mathrm{kg}, 6 \mathrm{TU}$ ) (Table 6-4, Plate 1). The DEL ${ }^{4} \mathrm{He}$ and $\mathrm{DEL}^{3} \mathrm{He}$ values for R-11, R-13, R-15, R-28, TW-8, MCOBT-4.4, and MCOI-6 ranged from 26 to 23,137 percent and from 39 to 37,133 percent, respectively (Table 6-4, Plate 4). Values of $\mathrm{R}(3 / 4)$ in Ra provided in Table 6-4 also support enrichment of $\mathrm{He}$ in water relative to air for the samples, ranging from 1.36 to 14.53. One groundwater sample collected from MCOI-6 had an R(3/4) in Ra value of 14.5, which is unique compared to the other samples. This value does not reflect terrigenic He but rather tritiogenic ${ }^{3} \mathrm{He}$ produced from decay of ${ }^{3} \mathrm{H}$ released from TA-50.

Two calculations are presented to quantify the amount of residual ${ }^{4} \mathrm{He}$ generated from $\alpha$-decay of ${ }^{238} \mathrm{Pu}$ and ${ }^{241} \mathrm{Am}$, two prominent actinides discharged from TA-50 to surface water in Mortandad Canyon. The RLWTF has also discharged other actinides including ${ }^{239,240} \mathrm{Pu},{ }^{238} \mathrm{U},{ }^{235} \mathrm{U}$, and ${ }^{234} \mathrm{U},{ }^{3} \mathrm{H}$, fission products (mainly ${ }^{90} \mathrm{Sr}$ and ${ }^{137} \mathrm{Cs}$ ), $\mathrm{NO}_{3}$ (as $\mathrm{N}$ ), $\mathrm{ClO}_{4}$, and other chemicals into Mortandad Canyon since 1963 (LANL 1997, 056835). Activities of ${ }^{238} \mathrm{Pu}$ and ${ }^{241} \mathrm{Am}$ entering the RLWTF are much higher than those discharged because more than 99.9 percent of the actinides are removed from the waste stream during precipitation processes. The influent activity of the actinides indicates that excess ${ }^{4} \mathrm{He}$ is likely to be present in the TA-50 discharge water.

Actinides decay at different rates, generating $\alpha$ particles $\left({ }^{4} \mathrm{He}\right.$ nuclei) associated with the production of daughter radionuclides. From 1972 to $1995,0.09732 \mathrm{Ci}$ of residual ${ }^{238} \mathrm{Pu}$ was discharged from TA-50 (LANL 1997, 056835). Amounts of ${ }^{238} \mathrm{Pu}$ discharged annually from 1963 through 1972 are not available to allow for quantitative evaluation of the production of additional ${ }^{4} \mathrm{He}$ during this time period. The total volume of effluent discharged to surface water 
from 1972 to 1995 was $221,683,377$ gallons $(840,180,000 \mathrm{~L})$, resulting in an average residual

${ }^{238} \mathrm{Pu}$ concentration of $116 \mathrm{pCi} / \mathrm{L}$. Plutonium-238 decays to ${ }^{234} \mathrm{U}$ with a half-life of 87.7 years (Parrington et al. 1996, 058682). In the 33 years since 1972, 23 percent of ${ }^{238} \mathrm{Pu}$ discharged to Mortandad Canyon has decayed to ${ }^{234} \mathrm{U}$, producing $1.14 \times 10^{-11} \mathrm{ppm}$ of ${ }^{4} \mathrm{He}$. Very small amounts of ${ }^{4} \mathrm{He}$ were produced from decay of residual ${ }^{238} \mathrm{Pu}$ discharged from the RLWTF to surface water in Mortandad Canyon. Helium-4 concentrations entering the RLWTF, however, could be much higher than those associated with the residual actinides discharged.

Another example is provided for release of residual ${ }^{241} \mathrm{Am}$ from the TA-50 outfall. Approximately $0.15 \mathrm{Ci}$ of residual ${ }^{241} \mathrm{Am}$ was discharged from TA-50 from 1973 through 1995 (LANL 1997, 056835). The amounts of ${ }^{241} \mathrm{Am}$ discharged annually from 1963 through 1972 are not available to allow for quantitative evaluation of ${ }^{4} \mathrm{He}$ production during this time period. The total volume of effluent discharged from 1973 through 1995 was 206,625,330 gallons $(783,110,000 \mathrm{~L})$, which results in an average residual ${ }^{241} \mathrm{Am}$ concentration of $187 \mathrm{pCi} / \mathrm{L}$. Decay of ${ }^{241} \mathrm{Am}$ to neptunium-237 $\left.{ }^{237} \mathrm{~Np}\right)$ releases one $\alpha$ particle with a half-life of 432.7 years (Parrington et al. 1996, 058682). During the 32 years since 1973, 5 percent of ${ }^{241} \mathrm{Am}$ discharged to Mortandad Canyon has decayed to ${ }^{237} \mathrm{~Np}$ producing $4.54 \times 10^{-11} \mathrm{ppm}$ of ${ }^{4} \mathrm{He}$. In summary, very small amounts of ${ }^{4} \mathrm{He}$ were produced from decay of residual ${ }^{238} \mathrm{Pu}$ and ${ }^{241} \mathrm{Am}$ discharged from the RLWTF to surface water in Mortandad Canyon.

\subsection{Groundwater Mixing in Mortandad Canyon}

Mixing calculations were performed to estimate volume percentages of alluvial and regional aquifer groundwater within Mortandad Canyon. Alluvial groundwater in Mortandad Canyon provided the dominant source of ${ }^{3} \mathrm{H}, \mathrm{NO}_{3}($ as N $), \mathrm{ClO}_{4}, \mathrm{Cl}$, and other contaminants to deeper saturated zones. Mixing calculations were also performed using average groundwater ages for the alluvium and regional aquifer. Calculations for volumetric binary mixing were performed for $\mathrm{R}-15$ using $\mathrm{Cl}$ as a conservative (nonadsorbing) tracer by rearranging the following equation and solving for $\mathrm{X}$, the volumetric fraction of water in the regional aquifer:

$$
\mathrm{Cl}_{\text {sample }}=(\mathrm{X})\left(\mathrm{Cl}_{\text {regional aquifer }}\right)+(1-\mathrm{X})\left(\mathrm{Cl}_{\text {alluvial groundwater }}\right) \text {. }
$$

The mean background concentration of $\mathrm{Cl}$ in the regional aquifer in Mortandad Canyon is $2.0 \mathrm{ppm}$ at $\mathrm{R}-1$ (Table 6-1). This is the lowest concentration of $\mathrm{Cl}$ measured at regional aquifer wells drilled within the canyon. This mean background concentration of $\mathrm{Cl}$ compares well with mean concentrations of $\mathrm{Cl}(2.1 \mathrm{ppm})$ at noncontaminated Spring 6 and Spring 9A, discharging within White Rock Canyon (Table 6-1). Alluvial groundwater has a mean $\mathrm{Cl}$ concentration of $32 \mathrm{ppm}$ with a range of 6 to $88 \mathrm{ppm}$. This statistical distribution is shown in analytical results of samples collected from MCO-4B and MCO-5 from 1964 through 2005. (LANL Water Quality Database Reports can be viewed on a public webpage, http://wqdbworld.lanl.gov/.) The mean concentration of $\mathrm{Cl}$ was $4.3 \mathrm{ppm}$ at R-15 from 1999 through 2005. The mixed groundwater at R-15 consists of an average of 8 percent alluvial groundwater and 92 percent regional aquifer groundwater. Results of this calculation show that groundwater at R-15 is mixed and consists primarily of submodern water. This finding is consistent with the average ages calculated from unadjusted ${ }^{14} \mathrm{C}$ measurements. The average concentration of $\mathrm{Cl}$ is $26 \mathrm{ppm}$ at R-28 (Table 6-1). Results of volumetric mixing calculations using $\mathrm{Cl}$ and Equation 6-2 show that averages of 20 percent of alluvial groundwater (modern) and 80 percent (submodern) regional aquifer 
groundwater occur at R-28. R-28 is the most contaminated regional aquifer well at the Laboratory.

Additional calculations were performed for R-15-using groundwater ages for the alluvium and regional aquifer - by rearranging the following equation and solving for $\mathrm{X}$, the volumetric fraction of water in the regional aquifer:

$$
\operatorname{age}_{\mathrm{R}-15 \text { sample }}=(\mathrm{X})\left(\text { age }_{\mathrm{R}-1 \text { regional aquifer }}\right)+(1-\mathrm{X})\left(\text { age }_{\text {alluvial groundwater }}\right) .
$$

The average groundwater age for $\mathrm{R}-1$ is 3532 years (Table 6-5). Unadjusted ${ }^{14} \mathrm{C}$ measurement and the lack of detection of ${ }^{3} \mathrm{H}$ at the well indicate that the groundwater here is entirely submodern. The groundwater age for the alluvium is estimated at one year - a finding based on movement of ${ }^{3} \mathrm{H}$ and other mobile solutes through the alluvial aquifer (Purtymun 1974, 005476; Purtymun et al. 1977, 011846). Equation 6-3, however, does not consider the groundwater travel time from R-1 to R-15, which is independent of the mixing ratio between contaminated alluvial groundwater and noncontaminated regional aquifer groundwater. Based on the age calculation, we determined that mixed groundwater at R-15 consists of an average of 6 percent alluvial groundwater and 94 percent regional aquifer groundwater. This result agrees very well with the mixing calculation using $\mathrm{Cl}$. The average groundwater age for $\mathrm{R}-15$ is younger than those calculated for R-1 and R-13. This result suggests that R-15 contains a larger component of modern recharge. This observation is also supported by the presence of ${ }^{3} \mathrm{H}, \mathrm{NO}_{3}($ as $\mathrm{N}), \mathrm{CrO}_{4}$, and $\mathrm{ClO}_{4}$ at $\mathrm{R}-15$.

The magnitude of a given mixed groundwater age for the regional aquifer is controlled by the volume of modern water recharging and mixing with native, submodern groundwater within the upper portion of the regional aquifer. Average groundwater ages for R-1, R-15, R-28, and R-13 do not vary systematically along flow paths within the regional aquifer in Mortandad Canyon. This fact implies that there are multiple sources of recharge reaching the regional water table east of R-1. Groundwater ages for R-1 (3532 years) and R-13 (3619 years) are very similar; however, R-1 is approximately $2.9 \mathrm{~km}$ (1.8 miles) upgradient (northwest) from R-13 (Figure 4-1). One explanation is that the recharge of modern groundwater in Mortandad Canyon partly or completely offsets the decay of ${ }^{14} \mathrm{C}$ associated with the groundwater travel time from $\mathrm{R}-1$ to R-13.

The presence of $\mathrm{NO}_{3}$ (as $\left.\mathrm{N}\right), \mathrm{CrO}_{4}, \mathrm{ClO}_{4}$, and ${ }^{3} \mathrm{H}$ at $\mathrm{R}-28$ suggests that recharge water originated from both Mortandad Canyon and Sandia Canyon (LANL 2006, 094161). Concentrations of $\mathrm{NO}_{3}$ (as $\mathrm{N}$ ), derived from neutralized $\mathrm{HNO}_{3}$, and ${ }^{3} \mathrm{H}$ released from TA-50 into Mortandad Canyon greatly exceeded concentrations of $\mathrm{NO}_{3}$ (treated sewage effluent) and ${ }^{3} \mathrm{H}$ released within Sandia Canyon. The dominant source of $\mathrm{CrO}_{4}$, however, was from the cooling towers at the TA-03 steam plant that used $\mathrm{K}_{2} \mathrm{Cr}_{2} \mathrm{O}_{7}$ from 1956 to 1972 (LANL 2006, 091987). Chromium usage at the TA-03 plant averaged $79.1 \mathrm{~kg} /$ day (35.9 pounds/day) from 1956 to 1972 (DOE 1987, 052975). This amount was discharged into upper Sandia Canyon with blowdown water volumes ranging from 484,480 to $1,090,080 \mathrm{~L} /$ day (128,000 to 288,000 gallons/day) (DOE 1987, 052975). Hexavalent $\mathrm{Cr}$ concentrations of up to $34 \mathrm{ppm}$ or $\mathrm{mg} / \mathrm{L}$ were reported in the steam plant discharge, and $\mathrm{CrO}_{4}$ concentrations of 10 to $15 \mathrm{ppm}$ were measured downstream (DOE 1987, 052975). Concentrations of $\mathrm{CrO}_{4}$ in both the cooling tower discharge and groundwater recharging the regional aquifer were higher than those measured at $\mathrm{R}-28$. Dilution of $\mathrm{CrO}_{4}$ and 
other contaminants is significant, as they enter the regional aquifer upgradient of R-28.

Groundwater at R-28 is mixed, which also supports dilution of contaminants as they enter the regional water table. Based on the variety of contaminants observed at the well, we conclude that it is very likely that there are at least two groundwater plumes at R-28, one from Sandia Canyon and the other from Mortandad Canyon.

Based on an unadjusted ${ }^{14} \mathrm{C}$ measurement with a non-normalized fraction of modern $\mathrm{C}$ of 0.4612 (Table 6-5, Plate 2), we determined that R-11 had an average groundwater age of 6164 years. The $\delta^{13} \mathrm{C}$ ratio was -10.7 permil, indicating that some dilution of modern ${ }^{14} \mathrm{C}$ by $\mathrm{HCO}_{3}$ produced from dissolution of $\mathrm{CaCO}_{3}$ within the aquifer matrix is taking place. Unadjusted ${ }^{14} \mathrm{C}$ measurements with non-normalized fractions of modern $\mathrm{C}$ of 0.5014 and 0.4874 , respectively (Table 6-5, Plate 2), indicated that Well R-28 had average groundwater ages of 5493 and 5720 years. The $\delta^{13} \mathrm{C}$ ratios for the two R-28 samples were -11.8 and -11.4 permil, respectively (Table 6-5). The younger average age for R-28 indicates a higher proportion of modern water, containing contaminants, in comparison to the situation in $\mathrm{R}-11$, which is less contaminated with respect to ${ }^{3} \mathrm{H}, \mathrm{NO}_{3}\left(\right.$ as $\mathrm{N}$ ), and $\mathrm{CrO}_{4}$ (Tables 6-1, 6-2, and 6-4). This viewpoint assumes that the average groundwater ages for R-11 and R-28 were the same prior to Laboratory discharges within Sandia Canyon and Mortandad Canyon.

\subsubsection{Groundwater Ages and Chemistry for Pajarito Canyon}

Well R-23 located in Pajarito Canyon was sampled for ${ }^{14} \mathrm{C}, \delta^{13} \mathrm{C}$, and other constituents during July and August 2005 (Table 6-5). The concentration of ${ }^{3} \mathrm{H}$ was less than analytical detection $(0.06 \mathrm{pCi} / \mathrm{kg}, 0.02 \mathrm{TU})$ in a sample collected on August 15, 2005. Unadjusted ${ }^{14} \mathrm{C}$ measurements (Table 6-5, Plate 2) showed that groundwater from R-23 is submodern with average ages of 3693 and 4444 years. These two groundwater samples had fractions of modern $\mathrm{C}$ (non-normalized) of 0.6273 and 0.5712 , respectively (Table 6-5). The $\delta^{13} \mathrm{C}$ ratios at $\mathrm{R}-23$ were -10.6 and -10.4 permil, indicating that some dilution of modern ${ }^{14} \mathrm{C}$ by $\mathrm{HCO}_{3}$ produced from dissolution of $\mathrm{CaCO}_{3}$ within the aquifer matrix is taking place.

Dissolved concentrations of $\mathrm{NO}_{3}($ as $\mathrm{N})$ were 1.02 and $1.36 \mathrm{ppm}$ in samples collected from $\mathrm{R}-23$ on July 14, 2005, and August 15, 2006, respectively (Table 6-1). Concentrations of $\mathrm{NO}_{3}$ (as N) at this well are elevated above background LANL median $(0.33 \mathrm{mg} / \mathrm{L})$ concentration for the regional aquifer (Table 2-1) (LANL 2007, 094856). This finding suggests that a component of modern water is present in the regional aquifer, even though the concentration of ${ }^{3} \mathrm{H}$ is below analytical detection.

Perched intermediate well R-23i is completed within the Cerros del Rio volcanic rocks. A groundwater sample collected from the well on October 31,2005 , contained $60.70 \mathrm{pCi} / \mathrm{kg}$ of ${ }^{3} \mathrm{H}$ (18.84 TU) (Table 6-4). The presence of ${ }^{3} \mathrm{H}$ at R-23i suggests that a modern component of water is present in perched intermediate groundwater. The dissolved concentration of $\mathrm{NO}_{3}$ (as $\mathrm{N}$ ) was $0.77 \mathrm{mg} / \mathrm{L}$ in a sample collected on October 3, 2006 (Table 6-1). This level exceeds background LANL median concentrations $(0.34 \mathrm{mg} / \mathrm{L})$ within perched intermediate groundwater (Table 2-1) (LANL 2007, 094856). 


\subsubsection{Summary of Pajarito Plateau Hydrochemistry}

Groundwater recharge on the Pajarito Plateau provides a component of modern water to perched intermediate zones and the regional aquifer. Alluvial and perched intermediate groundwater and the regional aquifer beneath Pueblo Canyon, Los Alamos Canyon, Sandia Canyon, Mortandad Canyon, and Pajarito Canyon, and in Cañon de Valle contain Laboratory-derived contaminants. These contaminants include, primarily, ${ }^{3} \mathrm{H}, \mathrm{NO}_{3}$ (as N), $\mathrm{CrO}_{4}, \mathrm{HE}$ compounds, $\mathrm{ClO}_{4}$, and/or U. Concentrations of contaminants are generally below EPA drinking water standards within perched intermediate zones and the regional aquifer. Exceptions include ${ }^{3} \mathrm{H}$ at MCOBT-4.4 (ESP 2005, 092222) and total dissolved Cr at R-28 (LANL 2006, 091987). Reliable apparent groundwater ages ranged from 0.13 to 18.52 years prior to 2005 for perched intermediate zones. Reliable apparent groundwater ages ranged from 17 to 31 years prior to 2005 for the regional aquifer. Based on unadjusted ${ }^{14} \mathrm{C}$ measurements, it appears that regional aquifer groundwater beneath the Pajarito Plateau is primarily submodern with average groundwater ages varying from 536 to 10,817 years. Results of volumetric mixing calculations using $\mathrm{Cl}$ show that an average of 8 percent of alluvial groundwater (modern) contains 92 percent (submodern) regional aquifer groundwater at R-15 in Mortandad Canyon. Results of volumetric mixing calculations using $\mathrm{Cl}$ show that an average of 20 percent of alluvial groundwater (modern) primarily consists of 80 percent (submodern) regional aquifer groundwater at R-28.

Anomalous $\mathrm{DEL}^{3} \mathrm{He}$ measurements in several groundwater samples collected from perched intermediate zones and the regional aquifer support the occurrences of anthropogenic ${ }^{3} \mathrm{H}$. The parameter R(3/4) in Ra for most of the samples collected at wells and springs on the Pajarito Plateau had values slightly exceeding unity, suggesting that He was concentrated in the sample relative to air. Sources of ${ }^{3} \mathrm{He}$ include surface water and contaminated groundwater containing anthropogenic ${ }^{3} \mathrm{H}$ derived from Laboratory releases.

Anomalous DEL ${ }^{4} \mathrm{He}$ values were measured in samples collected from R-1, R-4, R-9, R-28, TW-3, and O-1, resulting from a combination of natural and anthropogenic sources. A component of terrigenic ${ }^{4} \mathrm{He}$ derived from recent volcanism in the Jemez Mountains and localized hydrothermal alteration within the Puye Formation, pumiceous units, and the Santa Fe Group may contribute to the total He at R-1 and R-2. Anomalous DEL ${ }^{4} \mathrm{He}$ values were also measured in samples collected from the Española Basin. They are attributed to crust and mantlederived ${ }^{4} \mathrm{He}$ (Manning et al. 2006, 094921). The release of reactor-produced ${ }^{4} \mathrm{He}$ from the OWR directly to alluvial groundwater is most likely the source of anomalous DEL ${ }^{4} \mathrm{He}$ values measured at TW-3. Residual releases of actinides including ${ }^{238} \mathrm{Pu},{ }^{239,240} \mathrm{Pu}$, and ${ }^{241} \mathrm{Am}$ from TA-1 and TA-45, TA-21, and TA-50 into Acid Canyon, Pueblo Canyon, Los Alamos Canyon, and Mortandad Canyon contribute a very small fraction of ${ }^{4} \mathrm{He}$ through $\alpha$-decay. Higher concentrations of actinides and ${ }^{4} \mathrm{He}$ are probably present in the TA-50 influent water prior to precipitation, which removes more than 99 percent of the actinides from the waste stream. This excess ${ }^{4} \mathrm{He}$ could be present in the TA-50 effluent discharged to Mortandad Canyon since 1963.

\subsection{Aqueous Inorganic and Isotope Geochemistry of the White Rock Canyon Springs}

This section presents analytical results for samples collected at the White Rock Canyon springs, followed by discussions on field parameters, major and trace element chemistry, stable isotope chemistry, ${ }^{3} \mathrm{H},{ }^{14} \mathrm{C}$, and noble gas geochemistry. The White Rock Canyon springs represent 
discharge zones for perched intermediate groundwater and the upper portion of the regional aquifer at the water table. Groundwater discharge varies between the springs, ranging from a seep at Spring 2B to consistent large volumes at Spring 4A. Seasonal variation in flow rate is observed at Spring 9B, discharging from the Cerros del Rio volcanic rocks. This spring was not sampled as part of this investigation; however, it is an important background spring discharging from the regional aquifer (Cerros del Rio volcanic rocks) above the west bank of the Rio Grande.

\subsubsection{Field Parameters}

Field $\mathrm{pH}$ measurements taken at the White Rock Canyon springs ranged from 6.43 at Spring 6 to 8.13 at Spring 5 (Table 6-1).

Temperature measurements recorded at the springs ranged from $14.2^{\circ} \mathrm{C}$ at Spring $2 \mathrm{~B}$ to $21.4^{\circ} \mathrm{C}$ at Spring 3. Temperatures greater than $18^{\circ} \mathrm{C}$ are associated with springs consisting entirely of the regional aquifer groundwater (Table 6-1). Spring 3A, Spring 4A, Spring 5, Spring 6, and Spring 9A did not show significant seasonal variation in temperature. Spring samples with temperatures below $18^{\circ} \mathrm{C}$ most likely represent a mixture of waters derived from surface water, alluvial groundwater, and/or perched intermediate zones. This category includes Spring 2B, Spring 3C, Spring 4, Spring 4B, and Spring 4C (Table 6-1). The temperature of groundwater measured at Spring $3 \mathrm{C}$, for example, was $15.4^{\circ} \mathrm{C}$ (Table 6-1), indicating the presence of cooler perched intermediate groundwater and/or Rio Grande water.

Groundwater is oxygenated, with DO concentrations ranging from $1.1 \mathrm{mg} / \mathrm{L}$ at Spring $2 \mathrm{~B}$ to $10.8 \mathrm{mg} / \mathrm{L}$ at Spring 5 (Table 6-1). Most of the DO concentrations ranged between 6 and $8 \mathrm{mg} / \mathrm{L}$ (Table 6-1). Concentrations of DO were generally consistent at the springs, excluding the measurements taken at Spring 2B.

\subsubsection{Major and Trace Element Geochemistry of the White Rock Canyon Springs}

Concentrations of $\mathrm{Cl}, \mathrm{ClO}_{4}, \mathrm{SO}_{4}$, and $\mathrm{NO}_{3}$ (as $\left.\mathrm{N}\right)$ for Spring 6 and Spring 9A are within LANL background for the regional aquifer (Table 2-1) (LANL 2007, 094856). These two springs represent background water chemistry for the White Rock Canyon springs sampled as part of this investigation. Concentrations of the above solutes, TDS, and other species are lower at Spring 6 and Spring 9A in comparison to Spring 2B, Spring 3, Spring 3A, Spring 3C, Spring 4, Spring 4A, Spring 4AA, Spring 4B, Spring 4C, and Spring 5. Spring 6 and Spring 9A consist entirely of submodern water. Figure 6-11 shows a trilinear diagram for the White Rock Canyon springs. Spring 6 and Spring 9A consist of a Ca-Na- $\mathrm{HCO}_{3}$ composition. Spring 2B, Spring 3, Spring 3A, Spring 3C, Spring 4, Spring 4A, Spring 4AA, Spring 4B, Spring 4C, and Spring 5 also consist of a Ca-Na- $\mathrm{HCO}_{3}$ composition but with higher concentrations of $\mathrm{Cl}, \mathrm{NO}_{3}($ as $\mathrm{N}$ ), and $\mathrm{SO}_{4}$ than Spring 6 and Spring 9A (Table 6-1). Analytical charge balances for filtered samples ranged from -6.32 percent at Spring 5 to +5.10 percent at Spring 6 (Table 6-1).

Dissolved concentrations of $\mathrm{SiO}_{2}$ ranged from $34.80 \mathrm{ppm}$ at Spring $2 \mathrm{~B}$ to $76.19 \mathrm{ppm}$ at Spring 9A (Table 6-1). Variation in silica concentration is controlled by the abundance and reactivity of $\mathrm{SiO}_{2}$ glass found within the volcanic and sedimentary lithologies comprising a portion of the regional aquifer material. Concentrations of calculated TDS ranged from $171 \mathrm{ppm}$ at Spring 9A to $476 \mathrm{ppm}$ at Spring 2B. Several of the White Rock Canyon springs were sampled 
during September 2005, and concentrations of TDS were measured by gravimetric methods at a contract analytical laboratory rather than by calculation at EES-6. Concentrations of measured TDS were less than the calculated TDS for these samples, because concentrations of total carbonate alkalinity reported by the analytical contract laboratory are less than those measured by EES-6. Delay in analysis of total carbonate alkalinity, measured by titration at the contract laboratory, may have resulted in loss of $\mathrm{CO}_{2}$ gas and/or precipitation of $\mathrm{CaCO}_{3}$, which decrease concentrations of both $\mathrm{HCO}_{3}$ and $\mathrm{Ca}$. Silica and $\mathrm{HCO}_{3}$ are the dominant solutes contributing to TDS in samples collected from the White Rock Canyon springs (Table 6-1).

Concentrations of $\mathrm{NO}_{3}$ (as N) ranged from $0.22 \mathrm{ppm}$ at Spring 9A to $4.23 \mathrm{ppm}$ at Spring 2B (Table 6-1). Spring 2B most likely consists of a mixture of waters including groundwater and treated effluent derived from the nearby White Rock Sewage Treatment Plant. This spring contains the highest concentrations of major ions and other solutes (Table 6-1). At Spring 3, Spring 3A, Spring 3C, Spring 4A, Spring 4AA, and Spring 5, concentrations of $\mathrm{NO}_{3}($ as N) exceeded the median of LANL background $(0.33 \mathrm{ppm}$ or $\mathrm{mg} / \mathrm{L})($ Table $2-1)$ for the regional aquifer (LANL 2007, 094856). Concentrations of $\mathrm{NO}_{3}$ (as N) ranged from 0.76 to $1.40 \mathrm{ppm}$ at the three springs discharging from perched intermediate zones-Spring 4, Spring 4B, and Spring 4C (Table 6-1). At Spring 4A and Spring 4AA, concentrations of $\mathrm{NO}_{3}($ as $\mathrm{N})$ ranged from 0.84 to $1.21 \mathrm{ppm}$.

Dissolved concentrations of $\mathrm{ClO}_{4}$ measured above analytical detection using the LC-MS/MS method ranged from $0.00027 \mathrm{ppm}(0.27 \mathrm{ppb}$ or $\mu \mathrm{g} / \mathrm{L})$ at Spring $9 \mathrm{~A}$ to $0.00062 \mathrm{ppm}(0.62 \mathrm{ppb}$ or $\mu \mathrm{g} / \mathrm{L}$ ) at Spring 4. (Table 6-1). Concentrations of LANL background $\mathrm{ClO}_{4}$ for the regional aquifer ranged from 0.00009 to $0.00044 \mathrm{ppm}(0.09$ to $0.44 \mu \mathrm{g} / \mathrm{L})$ with a median value of $0.00031 \mathrm{ppm}(0.31 \mu \mathrm{g} / \mathrm{L})$ (Table 2-1) (LANL 2007, 094856). Concentrations of $\mathrm{ClO}_{4}$ and $\mathrm{NO}_{3}$ (as N) measured in samples collected at Spring 4, Spring 4A, Spring 4B, Spring 4C, and Spring 4AA (Table 6-1) are elevated above LANL background (Table 2-1). This finding suggests that a component of modern water is present at these springs.

Concentrations of $\mathrm{ClO}_{4}$, analyzed by LC-MS/MS, ranged from 0.00051 to $0.00062 \mathrm{ppm}$ (0.51 to $0.62 \mathrm{ppb}$ or $\mu \mathrm{g} / \mathrm{L}$ ) at Spring 4, Spring 4A, and Spring 4AA (Table 6-1). Concentrations of $\mathrm{ClO}_{4}$ and $\mathrm{NO}_{3}($ as $\mathrm{N})$ at the 4-series springs suggest that they were derived from anthropogenic sources, which are most likely located within the Pajarito Canyon watershed. Potential contaminant sources include former sewage lagoons east of the buildings and structures within TA-18, a former sewage treatment plant/lagoon in Pajarito Acres subdivision immediately west of the east-facing rim of White Rock Canyon, and TA-9 within the upper Pajarito Canyon watershed, where $\mathrm{ClO}_{4}$ is used.

Dissolved As concentrations above analytical detection ranged from $0.0008 \mathrm{ppm}$ at Spring 6 to $0.0026 \mathrm{ppm}$ at Spring 2B (Table 6-2). Arsenic is stable in the + III and $+\mathrm{V}$ oxidation states in the forms of arsenite $\left(\mathrm{AsO}_{3}{ }^{3-}\right)$ and arsenate $\left(\mathrm{AsO}_{4}{ }^{3-}\right)$, respectively. The mobility of $\mathrm{As}(\mathrm{III})$ and $\mathrm{As}(\mathrm{V})$ species in groundwater increases with increasing $\mathrm{pH}$ (Langmuir 1997, 056037). Arsenic adsorption onto ferric (oxy)hydroxide decreases as the number of negatively-charged surface sites increases with increasing $\mathrm{pH}$ (Langmuir 1997, 056037). Sulfate competes with As(III, V) species for adsorption sites on ferric (oxy)hydroxide. Concentrations of $\mathrm{SO}_{4}$ were 25.68 and 30.55 ppm at Spring 2B, amounts much higher than those measured at other White Rock Canyon 
springs (Table 6.1). Sulfate competition for adsorption sites may explain the higher concentrations of As at Spring 2B, Spring 3, Spring 3A, and Spring 3C.

Detectable concentrations of dissolved Li ranged from 0.019 to $0.044 \mathrm{ppm}$ in groundwater samples collected from the White Rock Canyon springs (Table 6-2). The lowest and highest concentrations of dissolved Li were measured at Spring 4B and Spring 2B, respectively.

Dissolved B concentrations ranged from 0.012 to $0.17 \mathrm{ppm}$. The lowest and highest values were measured at Spring 9A and Spring 2B, respectively. Boron is associated with treated sewage discharges released from the White Rock Sewage Treatment Plant.

Detectable concentrations of total dissolved $\mathrm{Cr}$ ranged from 0.0016 to $0.0057 \mathrm{ppm}$. The highest concentrations were at Spring 5 (Table 6-2).

Molybdenum concentrations above analytical detection were consistent in most samples, ranging from 0.0011 to $0.0013 \mathrm{ppm}$ (Table 6-2).

Detectable concentrations of dissolved Sr ranged from $0.046 \mathrm{ppm}$ at Spring 9A to $0.46 \mathrm{ppm}$ at Spring 2B.

Detectable concentrations of dissolved $U$ ranged from 0.0003 to $0.016 \mathrm{ppm}$. The highest value was measured at Spring 2B (Table 6-2). Because of the elevated alkalinity associated with the treated sewage effluent discharged from the White Rock facility, we hypothesize that natural U measured at Spring 2B is leached from the Santa Fe Group sediments. Uranium(VI) forms strong anionic complexes with $\mathrm{HCO}_{3}$ and $\mathrm{CO}_{3}$ under alkaline $\mathrm{pH}$ conditions. These complexes are mobile in groundwater (Langmuir 1997, 056037). Several other trace elements provided in Table 6-2-including F, Ni, V, and $\mathrm{Zn}$ - showed variations in concentration that are attributed to natural processes.

\subsubsection{Stable Isotope Geochemistry of the White Rock Canyon Springs}

Analytical results for $\delta^{18} \mathrm{O}$ and $\delta^{2} \mathrm{H}$ for the White Rock Canyon springs are provided in Table 6-3 and shown on Figure 6-12. Results of stable isotope analyses indicate a meteoric source. The groundwater samples plot close to both the JMML and WMWL (Figure 6-12). Seasonal variations in $\delta^{18} \mathrm{O}$ and $\delta^{2} \mathrm{H}$ generally are not observed at the regional aquifer springs. Spring 2B is enriched in ${ }^{18} \mathrm{O}$ and ${ }^{2} \mathrm{H}$ in comparison to the other White Rock Canyon springs. The $\delta^{18} \mathrm{O}$ and $\delta^{2} \mathrm{H}$ values in samples collected from Spring 9A are lighter in comparison to stable isotope results for the 3- and 4-series springs (Table 6-3, Figure 6-12). The source of recharge water for Spring 9A may occur at a higher elevation (average $7706 \mathrm{ft}$ ) and/or from surface waters infiltrating at lower elevations from their headwaters - as found in Frijoles Canyon (Table 6-3). The calculated recharge elevations for Spring 9A and the other springs assume that precipitation followed by recharge occurs at the same elevation.

Figure 6-13 shows a generalized west to east cross section with the water table elevation for the regional aquifer, topographic (land surface) elevation, and estimated recharge elevation calculated from $\delta^{18} \mathrm{O}$ ratios based on the following equation (Vuatez and Goff 1986, 073687): 


$$
\text { Elevation }(\mathrm{ft})=\left(-314 \delta^{18} \mathrm{O}-1161\right)(3.28)
$$

An average discharge elevation and $\delta^{18} \mathrm{O}$ ratio were used to represent the White Rock Canyon springs shown in Figure 6-13. Recharge elevations calculated from $\delta^{18} \mathrm{O}$ ratios decrease to the east. Recharge elevations for the White Rock Canyon springs ranged from 2138 to $2427 \mathrm{~m}$ (7013 to $7962 \mathrm{ft}$ ) calculated from $\delta^{2} \mathrm{H}$ ratios, and from 1970 to $2462 \mathrm{~m}$ (6463 to $8077 \mathrm{ft}$ ) calculated from $\delta^{18} \mathrm{O}$ ratios. Recharge elevations calculated from $\delta^{18} \mathrm{O}$ are considered to be more accurate because there is a smaller analytical error associated with the measurement compared to $\delta^{2} \mathrm{H}$ analysis. The average recharge elevation for the White Rock Canyon springs, based on $\delta^{18} \mathrm{O}$, occurs in the west-central portion of the Laboratory at approximately $2195 \mathrm{~m}(7200 \mathrm{ft})$ (Figure 6-13). Results of calculations for recharge elevation for the White Rock Canyon springs are consistent with the Pajarito Plateau providing a source of infiltration occurring along wet canyon bottoms (Kwicklis et al. 2005, 090069; Birdsell et al. 2005, 092048; Robinson et al. 2005, 091682). Contaminated alluvial groundwater provides an important "line source of recharge" to perched intermediate zones and the regional aquifer beneath the Pajarito Plateau. The presence of Laboratory-derived contaminants within alluvial and perched intermediate groundwater and the regional aquifer beneath several canyons supports the occurrence of a hydraulic connection between the aquifer systems.

Figure 6-14 shows average $\delta^{18} \mathrm{O}$ and $\delta^{2} \mathrm{H}$ ratios for springs discharging within the Sierra de los Valles, springs and wells on the Pajarito Plateau, and the White Rock Canyon springs. The White Rock Canyon springs and regional aquifer wells are enriched in both ${ }^{18} \mathrm{O}$ and ${ }^{2} \mathrm{H}$ in comparison to TA-9, TA-16, and Sierra de los Valles springs. All of these springs are very similar in $\delta^{18} \mathrm{O}$ and $\delta^{2} \mathrm{H}$ ratios, suggesting that they have a common source of water. The same relationship for $\delta^{18} \mathrm{O}$ and $\delta^{2} \mathrm{H}$ ratios is observed for regional aquifer wells on the Pajarito Plateau and the White Rock Canyon springs. The $\delta^{18} \mathrm{O}$ and $\delta^{2} \mathrm{H}$ ratios shown on Figure 6-14 suggest that regional aquifer groundwaters beneath the Laboratory and the White Rock Canyon springs are hydraulically connected, and regional aquifer groundwater constitutes the dominant source of discharge from most of the springs. The presence of $\mathrm{NO}_{3}($ as $\mathrm{N}),{ }^{3} \mathrm{H}$, and $\mathrm{ClO}_{4}$ in perched intermediate zones and the regional aquifer beneath the Laboratory and the 4-series springs supports this hydraulic connection.

\subsubsection{Radiogenic Isotope and Noble Gas Geochemistry of the White Rock Canyon Springs}

Measured atmospheric and calculated initial ${ }^{3} \mathrm{H}$ concentrations for the White Rock Canyon springs are shown in Figure 6-15. The initial ${ }^{3} \mathrm{H}$ concentration in each groundwater sample with $\mathrm{DEL}^{3} \mathrm{He}$ less than 100 percent was determined from the groundwater age derived from ${ }^{3} \mathrm{He}$ ingrowth. Analytical results for initial ${ }^{3} \mathrm{H}$ concentrations for Spring 4B plot above the atmospheric ${ }^{3} \mathrm{H}$ input curve, suggesting that excess ${ }^{3} \mathrm{H}$ is anthropogenic in origin and is derived from the Laboratory releases (Figure 6-15). Spring 4 and Spring 4A plot just above the atmospheric ${ }^{3} \mathrm{H}$ input curve and probably contain ${ }^{3} \mathrm{H}$ derived from a cosmogenic source, residual atmospheric detonation, and Laboratory discharges (Figure 6-15). Initial ${ }^{3} \mathrm{H}$ concentrations for Spring 2B, Spring 3, Spring 4AA, and Spring 4C fall below the atmospheric ${ }^{3} \mathrm{H}$ curve, indicating that these samples are mixed. Spring 4, Spring 4A, Spring 4AA, Spring 4B, and Spring 4C probably contain various amounts of a submodern component because the volume of recharge 
varies for the different aquifer systems from which the springs discharge. Spring 5, Spring 6, and Spring 9A are not plotted on Figure B-4 because they are entirely submodern.

Background concentrations of ${ }^{3} \mathrm{H}$ ranged from $0.06 \mathrm{pCi} / \mathrm{kg}(0.02 \mathrm{TU})$ at Spring $9 \mathrm{~A}$ to $0.74 \mathrm{pCi} / \mathrm{kg}(0.23 \mathrm{TU})$ at Spring 6 (Table 6-4, Plate 1). Detectable ${ }^{3} \mathrm{H}$ measured at Spring 6 during July 2005 could be the result of infiltration or flooding of Rio Grande water during periods of high flow. Tritium present in Rio Grande water becomes diluted during mixing with groundwater discharging at Spring 6. Apparent groundwater ages for samples collected at Spring 6, based on the ${ }^{3} \mathrm{H} /{ }^{3} \mathrm{He}$ dating method, ranged from 29.3 to greater than 62 years. Groundwater ages for Spring 9A are greater than 62 years (Table 6-4, Plate 2). Values of $\mathrm{DEL}^{3} \mathrm{He}$ and $\mathrm{DEL}{ }^{4} \mathrm{He}$ measured in groundwater samples collected from Spring 6 and Spring 9A ranged from 3.85 to 55.79 percent and from 6.04 to 70.43 percent, respectively (Table 6-4, Plate 4). These values indicate some enrichment of ${ }^{3} \mathrm{He}$ and ${ }^{4} \mathrm{He}$ in the samples, but not to the extent measured for R-1, R-2, R-4, R-9, R-28, TW-3, and O-1.

On the basis of unadjusted ${ }^{14} \mathrm{C}$ measurements with non-normalized fractions of modern $\mathrm{C}$ of 0.6599 and 0.6591 , respectively (Table 6-5, Plate 2), we determined average groundwater ages to be 3286 and 3296 years at Spring 6. At Spring 9A, the average groundwater ages were 2133 and 1525 years - analytical results based on unadjusted ${ }^{14} \mathrm{C}$ measurements. The non-normalized fractions of modern carbon were 0.7617 and 0.8216 , respectively (Table 6-5, Plate 2). Spring 9A is much younger than the other White Rock Canyon springs sampled as part of this investigation (Table 6-5). Groundwater flow paths to Spring 9A are shorter than those for other regional aquifer springs discharging within White Rock Canyon. An alternative hypothesis for explaining average groundwater ages at Spring 9A suggests that recharge from Frijoles Canyon mixes with older groundwater.

Spring 2B contained a ${ }^{3} \mathrm{H}$ concentration of $10.99 \mathrm{pCi} / \mathrm{kg}$ (3.41 TU) (Table 6-4, Plate 1$)$, and the apparent groundwater age was 17.48 years (Table 6-4). Because Spring 2B probably consists of a mixture of waters previously discussed, the apparent age reflects different flow paths containing modern and submodern groundwater. The concentration of ${ }^{3} \mathrm{H}$ observed at Spring $2 \mathrm{~B}$ could be primarily derived from a combination of cosmogenic and unidentified anthropogenic sources.

Average concentrations of ${ }^{3} \mathrm{H}$ at Spring 3 and Spring $3 \mathrm{~A}$ were 1.24 and $4.75 \mathrm{pCi} / \mathrm{kg}(0.38$ and 1.47 TU) respectively (Table 6-4, Plate 1). Apparent groundwater ages for Spring 3 and Spring $3 \mathrm{~A}$ - calculated using the ${ }^{3} \mathrm{H} /{ }^{3} \mathrm{He}$ dating method - ranged from 46.51 years to less than 62 years (not quantifiable because of excess ${ }^{3} \mathrm{He}$ and ${ }^{4} \mathrm{He}$ ), respectively (Table 6-4, Plate 1). Spring 3C contained $5.19 \mathrm{pCi} / \mathrm{kg}$ of ${ }^{3} \mathrm{H}$ (1.61 TU) (Table 6-4, Plate 1). It has an apparent groundwater age of 0.46 year. This young age suggests that there are short flow paths for the modern component at the spring. Water samples collected from Spring 3C were not analyzed for ${ }^{14} \mathrm{C}$; however, it is very likely that the majority of groundwater discharging at the spring is submodern. Using Equation 2-9, the initial ${ }^{3} \mathrm{H}$ concentrations for Spring 3 and Spring $3 \mathrm{~A}$ (one sample) were 29.51 and $51.55 \mathrm{pCi} / \mathrm{kg}(9.16$ and $16.0 \mathrm{TU})$ and $49.55 \mathrm{pCi} / \mathrm{kg}(15.38 \mathrm{TU})$, respectively (Table 6-4). Apparent groundwater ages for Spring 3 were 47.45 years for one sample and a nonquantifiable age of less than 62 years for two samples (Table 6-4, Plate 2). The estimated apparent age for Spring 3A is also nonquantifiable with an age less than 62 years (Table 6-4, Plate 2). Concentrations of ${ }^{3} \mathrm{H}$ measured at Spring 5 were less than analytical 
detection $0.03 \mathrm{pCi} / \mathrm{kg}(0.01 \mathrm{TU})$, and apparent groundwater ages for Spring 5 exceed 62 years (Table 6-4, Plate 2).

Spring 3 is mixed. It shows average groundwater ages of 5923 and 6465 years, based on unadjusted ${ }^{14} \mathrm{C}$ measurements with fractions of modern ${ }^{14} \mathrm{C}$ (non-normalized) of 0.4752 and 0.4442 , respectively (Table 6-5, Plate 2). Spring $3 \mathrm{~A}$ is also mixed, with average ages of 7203 and 7545 years, based on unadjusted ${ }^{14} \mathrm{C}$ measurements with fractions of modern ${ }^{14} \mathrm{C}$ (nonnormalized) of 0.4052 and 0.3883 , respectively (Table 6-5, Plate 2). The $\delta^{13} \mathrm{C}$ ratios for Spring 3 and Spring $3 \mathrm{~A}$ were -11.8 and -13.1 , and -13.2 and -12.3 permil, respectively (Table 6-5). The light $\delta^{13} \mathrm{C}$ ratios indicate that ${ }^{14} \mathrm{C}$ is not being diluted by $\mathrm{HCO}_{3}{ }^{-}$provided by $\mathrm{CaCO}_{3}$ dissolution within the aquifer matrix. The other White Rock Canyon springs have similar $\delta^{13} \mathrm{C}$ ratios.

The highest concentrations of ${ }^{3} \mathrm{H}$ at the White Rock Canyon springs were measured at the 4-series springs discharging in the lower reaches of the Pajarito watershed. Concentrations of ${ }^{3} \mathrm{H}$ at the 4-series springs ranged from $0.45 \mathrm{pCi} / \mathrm{kg}(0.14 \mathrm{TU})$ at $\mathrm{Spring} 4 \mathrm{~A}$ to $41.69 \mathrm{pCi} / \mathrm{kg}$ (12.94 TU) at Spring 4B (Table 6-4, Plate 1). Concentrations of ${ }^{3} \mathrm{H}$ are lower at regional aquifer Spring 4A and Spring 4AA in comparison to perched intermediate Spring 4, Spring 4B, and Spring 4C (Table 4-4). Concentrations of ${ }^{3} \mathrm{H}$ at Spring 4B exceed those derived from a cosmogenic source (19 pCi/kg, $6 \mathrm{TU})$, suggesting that the ${ }^{3} \mathrm{H}$ is anthropogenic in origin. Apparent groundwater ages for Spring 4A and Spring 4B were 46.40 and 1.32 years, respectively (Table 6-4, Plate 1). Concentrations of ${ }^{3} \mathrm{H}$ ranged from 1.80 to $2.22 \mathrm{pCi} / \mathrm{kg}(0.56$ to $0.69 \mathrm{TU})$ at Spring 4AA (Table 6-4, Plate 1), with apparent groundwater ages ranging from 17.63 to 40.34 years. This situation suggests that the flow paths for the modern component in the regional saturated zone from which Spring 4AA discharges are relatively long in comparison to the perched intermediate flow paths for Spring 4, Spring 4B, and Spring 4C (Table 6-4, Plate 1). Based on the springs' apparent groundwater ages, ranging from 46.4 to less than 62 years (Table 6-4), it appears that recharge to the regional aquifer from which Spring 4A discharges is located farther to the west beneath the Pajarito Plateau. The low apparent groundwater ages for Spring 4B and Spring 4C suggest that these two springs discharge in close proximity to the respective recharge zone(s) for their modern components.

A recharge temperature of $9.2^{\circ} \mathrm{C}$ - based on noble-gas concentrations for Spring $4 \mathrm{C}$ - suggests that groundwater discharging at the spring is perched intermediate with a source near the Pajarito fault or a mountain front zone of the Sierra de los Valles (Manning et al. 2006, 094921). Concentrations of ${ }^{3} \mathrm{H}$, major ions, and trace elements and groundwater temperatures are similar between Spring 4, Spring 4B, and Spring 4C and the lowermost perched intermediate zone encountered at R-23i (Tables 6.1 through 6.4). These three springs are hypothesized to represent discharge zones for perched intermediate groundwater encountered at upgradient intermediate well R-23i.

Average groundwater ages for Spring 5 were 4029, 4051, and 5043 years (Plate 2), based on unadjusted ${ }^{14} \mathrm{C}$ measurements with non-normalized fractions of modern $\mathrm{C}$ of $0.6016,0.5999$, and 0.5302 , respectively (Table 6-5). Concentrations of $\mathrm{NO}_{3}($ as $\mathrm{N})$, however, ranged from 0.38 to $0.76 \mathrm{ppm}$ and averaged $0.62 \mathrm{ppm}$ in samples collected at Spring 5 (Table 6-1). This situation suggests that there is a small, modern component at Spring 5. 


\subsubsection{Hydrologic Conceptual Model for Pajarito Canyon and the 4-Series Springs, White Rock Canyon}

A simple hydrologic conceptual model for Pajarito Canyon includes groundwater flow within alluvial and perched intermediate zones and the regional aquifer. Surface water and alluvial groundwater provide recharge to perched intermediate zones within the Cerros del Rio volcanic rocks and Puye Formation and the regional aquifer at different locations within the Pajarito watershed. Mixed groundwater is present in perched intermediate zones $\left({ }^{3} \mathrm{H}\right.$ at R-23i) and the regional aquifer [increasing concentrations of $\mathrm{NO}_{3}($ as $\mathrm{N})$ at $\mathrm{R}-23$ ] with volumetric mixing ratios varying along groundwater flow paths because of different amounts of recharge. Downgradient wells R-20, R-21, R-23, and R-32 contain ${ }^{3} \mathrm{H}$ at concentrations typically less than $1 \mathrm{pCi} / \mathrm{kg}$ (0.3 TU) (ESP 2005, 092222; LANL Water Quality Data Base), suggesting that no significant releases of ${ }^{3} \mathrm{H}$ from TA-18 have taken place. This finding also implies that residual ${ }^{3} \mathrm{H}$ from past nuclear atmospheric detonations is not detectable in the regional aquifer.

Groundwater ages for the regional aquifer vary in response to permeability of aquifer material, hydraulic gradients, fracture and porous media flow, and the distance between the recharge and discharge zones. Perched intermediate groundwater within the Cerros del Rio volcanic rocks beneath Pajarito Canyon is hypothesized to discharge at Spring 4, Spring 4B, and Spring 4C. This hypothesis is based on cooler temperatures, shorter average groundwater ages, and concentrations of $\mathrm{NO}_{3}\left(\right.$ as $\mathrm{N}$ ) and/or $\mathrm{ClO}_{4}$ above median LANL background (Table 2-1) at the three springs (Table 6-1). Regional aquifer groundwater beneath Pajarito Canyon discharges at Spring 4A and Spring 4AA - a finding based on warmer temperatures and longer average groundwater ages. Concentrations of dissolved $\mathrm{NO}_{3}($ as $\mathrm{N})$ also exceed median LANL background (Table 2-1) at these two springs (Table 6-1). This conceptual model does not place emphasis on transverse groundwater flow from the northwest to southeast such that discharges from the White Rock Sewage Treatment Plant do not impact the 4-series springs. Chemical data (major anions and trace elements) for Spring 2B and the 4-series springs do not support a hydraulic connection between lower Cañada del Buey and lower Pajarito Canyon.

\subsubsection{Groundwater Mixing for the 4-Series Springs}

Calculations of volumetric binary mixing were performed (Equation 6-2) for the regional aquifer Spring 4A using $\mathrm{Cl}$ as a conservative (nonadsorbing) tracer. The mean background concentration of $\mathrm{Cl}$ is $2.1 \mathrm{ppm}$ for the White Rock Canyon springs (Spring 6 and Spring 9A) (Table 6-1). The mean concentration of $\mathrm{Cl}$ is $37 \mathrm{ppm}$, with a range of 6 to $452 \mathrm{ppm}$ in alluvial groundwater within Pajarito Canyon. This mean value was calculated from 17 years of monitoring data for alluvial groundwater in the canyon (LANL Water Quality Data Base). At Spring 4A, the mean concentration of $\mathrm{Cl}$ is $5.3 \mathrm{ppm}$ (Table 6-1). Spring 4A contains an average 9 percent alluvial groundwater and 91 percent regional aquifer groundwater (a conclusion based on the mixing calculation). This mixing calculation shows that the Spring 4A is primarily submodern with a small component of modern water present.

Additional calculations for mixing were performed for Spring 4A using Equation 6-3 and groundwater ages for the alluvium in Pajarito Canyon and the regional aquifer discharging at Spring 3 and Spring 3A. The mean of the average groundwater ages (unadjusted) for Spring 3 and Spring 3A is 6867 years (calculated from data presented in Table 6-5) - a finding based on 
the ${ }^{14} \mathrm{C}$ dating method. These two springs, however, contain a small amount of modern water [represented by $\mathrm{NO}_{3}($ as $\mathrm{N})$ ] (Table 6-1), even though they have the oldest average groundwater ages of the springs sampled as part of this investigation. The groundwater age for the Pajarito Canyon alluvium is estimated at one year, based on groundwater movement within Mortandad Canyon (Purtymun 1974, 005476; and Purtymun et al. 1977, 011846). Spring 4A contains an average 6 percent alluvial groundwater and 94 percent regional aquifer groundwater. Results of this mixing calculation, based on groundwater ages, agree within 3 percent with the mixing calculation using $\mathrm{Cl}$ for Spring 4A.

\subsubsection{Geochemical, Groundwater Temperature, and Isotope Relationships for the White Rock Canyon Springs}

Figure 6-16 shows concentrations of $\mathrm{Cl}$ versus ${ }^{3} \mathrm{H}$ for the White Rock Canyon springs. Springs that are less mixed tend to contain lower concentrations of ${ }^{3} \mathrm{H}, \mathrm{Cl}$, and other chemicals. The highest concentrations of $\mathrm{Cl}$ and ${ }^{3} \mathrm{H}$ were measured at Spring $4 \mathrm{~B}$ and Spring $2 \mathrm{~B}$, respectively, whereas concentrations of these two analytes were the lowest at background Spring 6 and Spring 9A (Figure 6-16). Figure 6-17 shows $\mathrm{Cl}$ versus $\mathrm{ClO}_{4}$ concentrations (analyzed by the LC-MS/MS method) for the White Rock Canyon springs. Mixed groundwater at the springs has higher concentrations of both $\mathrm{Cl}$ and $\mathrm{ClO}_{4}$. Spring 4B contains smaller concentrations of $\mathrm{ClO}_{4}$ and the highest concentration of $\mathrm{Cl}$ in comparison to the other White Rock Canyon springs (Figure 6-17).

Figure 6-18 shows $\mathrm{Cl}$ concentration versus temperature for the White Rock Canyon springs. Spring 6 and Spring 9A have groundwater temperatures exceeding $20^{\circ} \mathrm{C}$ with concentrations of $\mathrm{Cl}$ of approximately $2 \mathrm{ppm}$ (Table 6-1). Temperatures recorded at Spring 4, Spring 4B, and Spring 4C ranged from 15.5 to $17.5^{\circ} \mathrm{C}$ (Table 6-1) (Figure 6-18). Temperatures recorded at Spring 4A and Spring 4AA ranged from 18.3 to $21.1^{\circ} \mathrm{C}$ (Table 6-1)(Figure 6-18).

Figure 6-19 shows the fraction of modern ${ }^{14} \mathrm{C}$ versus ${ }^{3} \mathrm{H}$ concentration in samples collected at the White Rock Canyon springs. Increasing fractions of modern ${ }^{14} \mathrm{C}$ correlate within increasing concentrations of ${ }^{3} \mathrm{H}$ at the springs (Figure 6-19).

Higher concentrations of ${ }^{3} \mathrm{H}$ occur at the 3- and 4-series springs in comparison to background Spring 6 and Spring 9A. The average groundwater age for Spring 4A is 6592 years (Table 6-5, Plate 2). These samples had a non-normalized fraction of modern $C$ equal to 0.4372 . The $\delta^{13} \mathrm{C}$ values for the 4-series springs ranged from -12.6 to -11.4 permil (Table 6-5), indicating the absence of groundwater interactions with $\mathrm{CaCO}_{3}$ within the aquifer matrix. Spring $4 \mathrm{~A}$ has the smallest detectable concentrations of ${ }^{3} \mathrm{H}$ of the 4-series springs, suggesting that its groundwater is primarily submodern. The average groundwater age (unadjusted ${ }^{14} \mathrm{C}$ ) for Spring $4 \mathrm{~B}$ is 2159 years (Table 6-5. Plate 2). The non-normalized fraction of modern $\mathrm{C}$ was 0.7593 (Table 6-5). This spring contains the highest concentrations of ${ }^{3} \mathrm{H}$ and is mixed to a greater extent in comparison to the other 4-series springs. Spring $4 \mathrm{C}$ has an average age of 3531 years (unadjusted ${ }^{14} \mathrm{C}$ ) (Table 6-5, Plate 2). For this sample, the non-normalized fraction of modern $\mathrm{C}$ was 0.6401 (Table 6-5). Average groundwater ages for Spring 4AA are 4920 and 5376 years (unadjusted ${ }^{14} \mathrm{C}$ ) (Table 6-5, Plate 2). Non-normalized fractions of modern $\mathrm{C}$ were 0.5384 and 0.5087 , respectively (Table 6-5). 


\subsubsection{Summary of Hydrochemistry of the White Rock Canyon Springs}

The White Rock Canyon springs represent discharge zones for perched intermediate zones (Spring 4, Spring 4B, and Spring 4C) and the regional aquifer (Spring 3, Spring 3A, Spring 3C, Spring 4A, Spring 4AA, Spring 5, Spring 6, and Spring 9A). Several of the White Rock Canyon springs are characterized by mixed ages and contain anthropogenic $\mathrm{ClO}_{4}, \mathrm{NO}_{3}$ (as $\mathrm{N}$ ), $\mathrm{Cl}$, and/or ${ }^{3} \mathrm{H}$. Concentrations of ${ }^{3} \mathrm{H}$ ranged from 0.45 to $41.69 \mathrm{pCi} / \mathrm{kg}(0.14$ to $12.95 \mathrm{TU})$ at the 3 - and 4-series springs.

Apparent groundwater ages ranged from 0.46 to greater than 62 years for the White Rock Canyon springs. Apparent groundwater ages exceeding 40 years have been measured in samples collected from Spring 3, Spring 3A, Spring 4A, Spring 5, Spring 6, and Spring 9A. Apparent groundwater ages less than 10 years occur at Spring 3C, Spring 4B, and Spring 4C. Mixed groundwater at Spring 2B, Spring 4, Spring 4B, and Spring 4C generally contains anthropogenic tracers $\left[\mathrm{ClO}_{4}, \mathrm{NO}_{3}\left(\right.\right.$ as N),${ }^{3} \mathrm{H}$, and/or $\left.\mathrm{Cl}\right]$ in comparison to submodern groundwater present at other White Rock Canyon springs.

$\mathrm{DEL}^{3} \mathrm{He}$ and $\mathrm{DEL}{ }^{4} \mathrm{He}$ measured in air-free groundwater samples collected from the White Rock Canyon springs ranged from 0.166 to 117.35 percent and from 0.030 to 115.701 percent, respectively. The $\mathrm{DEL}^{3} \mathrm{He}$ and $\mathrm{DEL}^{4} \mathrm{He}$ values are much lower in the White Rock Canyon spring samples than those measured for R-1, R-4, R-9, R-28, TW-3, and O-1.

Results of mixing calculations for regional aquifer Spring 4A suggest that this spring contains an average of 9 percent alluvial groundwater from Pajarito Canyon and 91 percent regional aquifer groundwater. The results of mixing calculations using groundwater ages for Spring 4A and alluvial groundwater suggest that Spring 4A consists of an average of 6 percent alluvial groundwater and 94 percent regional aquifer groundwater.

Average groundwater ages ranged from 1525 to 7545 years for the White Rock Canyon springs. The 4-series springs show the greatest variation in average groundwater ages, ranging from 2159 to 6592 years, with the younger perched intermediate groundwater (Spring 4, Spring 4B, and Spring 4C) containing concentrations of ${ }^{3} \mathrm{H}, \mathrm{NO}_{3}$, and/or $\mathrm{ClO}_{4}$ exceeding LANL background. Average groundwater ages for Spring 3 and Spring 3A exceed those for Spring 4, Spring 4A, Spring 4AA, Spring 4B, Spring 4C, Spring 5, Spring 6, and Spring 9A. Spring 5, Spring 6 and Spring 9A are submodern with average groundwater ages ranging from 4029 to 5043, from 3286 to 3296 , and from 1449 to 2133 years, respectively. Regional groundwater flow paths for Spring 6 and Spring 9A are shorter or faster than those for the other White Rock Canyon springs discharging from the regional aquifer.

\subsection{SUMMARY AND CONCLUSIONS}

\subsection{Summary}

The Laboratory, NMED-DOEOB, and the USGS conducted an isotope and geochemical investigation from October 2004 through February 2006 to evaluate groundwater flow paths and ages of samples collected from different saturated zones. Water samples were collected at 23 single-screen wells located on the Pajarito Plateau and 27 springs discharging within the Sierra 
de los Valles and White Rock Canyon. Additional samples were collected from two remote stations at Seven Springs in the western portion of the Jemez Mountains and at Arroyo Hondo, north of Taos, New Mexico. The remote stations provided an isotopic and chemical comparison to the Pajarito Plateau sites. Surface-water samples were also collected at two locations in upper Cañon de Valle and Pajarito Canyon to evaluate geochemical aspects of surface recharge to alluvial groundwater.

Groundwater age and flow paths within perched intermediate zones and the regional aquifer are essential for understanding the groundwater flow system at the Laboratory. Knowledge of groundwater age and flow paths provides a technical basis for hydrologic and geochemical conceptual models and the selection of wells and springs for groundwater monitoring. This information is also useful for calibrating groundwater flow and transport models. Groundwater dating studies are relevant to groundwater resource management and aquifer sustainability, especially during periods of long-term drought.

Groundwater samples were analyzed for ${ }^{3} \mathrm{H},{ }^{14} \mathrm{C}$, noble gases $\left({ }^{3} \mathrm{He},{ }^{4} \mathrm{He}\right.$, and $\left.{ }^{22} \mathrm{Ne}\right)$, stable isotopes $\left(\delta^{13} \mathrm{C}, \delta^{2} \mathrm{H}\right.$, and $\left.\delta^{18} \mathrm{O}\right)$, and inorganic chemistry to evaluate groundwater ages and aqueous chemistry of natural solutes and contaminants. Analytical methods consisted of MS for noble gases, He ingrowth for ${ }^{3} \mathrm{H}$, IR-MS for stable isotopes, and AMS for ${ }^{14} \mathrm{C}$. Other analytical methods included ICP-MS for the trace elements, ICP-OES for the major cations, alkalinity titration, and IC for the anions.

Table 7-1 provides a summary of information and data for samples collected and analyzed as part of this investigation. Table 7-1 includes measured ${ }^{3} \mathrm{H}$ and calculated initial ${ }^{3} \mathrm{H}$ concentrations, ${ }^{3} \mathrm{H}$ concentrations in samples relative to the atmospheric ${ }^{3} \mathrm{H}$ input curve, average groundwater age based on the ${ }^{14} \mathrm{C}$ dating method, presence or absence of contaminants, and groundwater age category. Surface water in the Sierra de los Valles (CdV-5.6 and PA-10.6) plots above the atmospheric ${ }^{3} \mathrm{H}$ input curve, containing excess ${ }^{3} \mathrm{H}$ derived from precipitation. Alluvial groundwater at background well LAO-B is modern and contains atmospheric ${ }^{3} \mathrm{H}$; however, the well does not contain other Laboratory-derived contaminants (Table 7-1). Perched intermediate springs in the Sierra de los Valles are either modern (WCG Spring, Young Spring, Pajarito Ski Well \# 2, PC Spring, and CdV-5.0 Spring) and plot above the atmospheric ${ }^{3} \mathrm{H}$ input curve, or they are mixed and plot below the curve (Barbara Spring and Campsite Springs) (Table 7-1). Perched intermediate groundwater discharging from the TA-9 and TA-16 springs is modern. Groundwater samples from these springs plots above the atmospheric ${ }^{3} \mathrm{H}$ input curve (Table 7-1). Bulldog Spring, Burning Ground Spring, and Martin Spring are contaminated, and Homestead Spring and Starmer Spring represent background. The TA-18 Spring, discharging from the Bandelier Tuff, is modern and contains anthropogenic ${ }^{3} \mathrm{H}$. Perched intermediate groundwater in Pueblo Canyon (TW-1A and POI-4), Los Alamos Canyon (R-6i), Mortandad Canyon (MCOI-6 and MCOBT-4.4), and Pajarito Canyon (R-23i) is mixed and contains contaminants (Table 7-1). Samples collected from these saturated zones generally plot above the atmospheric ${ }^{3} \mathrm{H}$ input curve, an indication that they are dominantly modern. Mixed groundwater at LAOI(A)-1.1 is not contaminated, and ${ }^{3} \mathrm{H}$ measured for the well is most likely derived from an atmospheric/cosmogenic source.

Concentrations of initial ${ }^{3} \mathrm{H}$ at regional aquifer wells and springs either plot near or below the atmospheric ${ }^{3} \mathrm{H}$ input curve (Table 7-1). Test Well-1, however, plots above the input curve, and 
the measured ${ }^{3} \mathrm{H}$ for the well is anthropogenic with other contaminants present. Regional aquifer wells R-1, R-2, R-6, and R-18 are submodern and do not contain ${ }^{3} \mathrm{H}$ or any other Laboratoryderived contaminants (Table 7.1). Laboratory-derived ${ }^{3} \mathrm{H}$ occurs in mixed groundwater at wells R-4, R-9, R-11, R-15, R-28, TW-1, TW-3, TW-8, and O-1. These wells also contain $\mathrm{NO}_{3}$ (as N), $\mathrm{ClO}_{4}$, and/or $\mathrm{CrO}_{4}$, mostly derived from Laboratory releases. Occurrences of anthropogenic $\mathrm{NO}_{3}$ (as $\mathrm{N}$ ) at $\mathrm{R}-4, \mathrm{TW}-1$, and $\mathrm{O}-1$ are derived from treated sewage effluent discharged from former and active treatment plants in Pueblo Canyon operated by the County of Los Alamos. Concentrations of ${ }^{3} \mathrm{H}(<7 \mathrm{pCi} / \mathrm{kg},<3 \mathrm{TU})$ at TW-2 in Pueblo Canyon may consist of residual bomb pulse ${ }^{3} \mathrm{H}$ in the absence of the above contaminants. Well R-23 in Pajarito Canyon does not contain ${ }^{3} \mathrm{H}$, however, concentrations of $\mathrm{NO}_{3}($ as $\mathrm{N})$ exceed LANL background, and groundwater at the well is most likely mixed. Seepage from upgradient TA-18 sewage lagoons probably provides the source of increasing concentrations of $\mathrm{NO}_{3}$ (as $\mathrm{N}$ ) observed at $\mathrm{R}-23$. Concentrations of ${ }^{3} \mathrm{H}$ are at or slightly above analytical detection $(0.01 \mathrm{TU})$ at $\mathrm{R}-13$; however, this groundwater, possibly, is mixed, containing $\mathrm{NO}_{3}$ (as $\mathrm{N}$ ) concentrations slightly exceeding LANL background. The White Rock Canyon springs are either submodern (Spring 5, Spring 6, and Spring 9A) or mixed (Spring 3, Spring 3A, Spring 3C, Spring 4, Spring 4A, Spring 4AA, Spring 4B, and Spring 4C). These springs mostly plot at or below the atmospheric ${ }^{3} \mathrm{H}$ input curve (Figure 6-15). Spring 4B plots above the input curve, and the ${ }^{3} \mathrm{H}$ at the spring is clearly anthropogenic in origin (Table 7-1).

The ${ }^{3} \mathrm{H} /{ }^{3} \mathrm{He}$ dating method shows that the Sierra de los Valles springs are mostly modern. The ${ }^{14} \mathrm{C}$ dating method shows that Campsite Springs and Barbara Spring are mixed and have average groundwater ages of 2662 and 2486 years, respectively. The ${ }^{3} \mathrm{H} /{ }^{3} \mathrm{He}$ dating method showed that apparent groundwater ages ranged from 0.13 to 18.5 years, prior to 2005 , for TW-1A, POI-4, LAOI(A)-1.1, R-6i, MCOBT-4.4, and MCOI-6. Concentrations of ${ }^{3} \mathrm{H}$ above $19 \mathrm{pCi} / \mathrm{kg}$ (6 TU), the current cosmogenic level in the atmosphere, were measured in samples collected from POI-4, R-6i, TW-1A, MCOI-6, and MCOI-4.4. Apparent groundwater ages for R-1, R-2, R-4, R-6, R-9, R-11, R-13, R-15, R-18, R-23, R-28, TW-1, TW-2, TW-3, TW-8, and O-1 ranged from 17 to greater than 62 years prior to 2005. Groundwater samples collected from R-1, R-2, and R-18 are entirely submodern. Concentrations of ${ }^{3} \mathrm{H}$ above $3 \mathrm{pCi} / \mathrm{kg}(1 \mathrm{TU})$ in the regional aquifer occur at R-4, R-9, R-11, R-15, R-28, TW-1, TW-2, TW-3, TW-8, and O-1. The upper portion of the regional aquifer at these locations is mixed. Unadjusted ${ }^{14} \mathrm{C}$ measurements show that groundwater ages vary from 3335 to 10,817 years. Average groundwater ages generally increase along flow paths within the regional aquifer within Pueblo Canyon and Los Alamos Canyon. Average groundwater ages vary along flow paths near the regional water table within Mortandad Canyon with recharge of modern water containing ${ }^{3} \mathrm{H}$, $\mathrm{NO}_{3}\left(\right.$ as N), $\mathrm{ClO}_{4}$, and/or $\mathrm{CrO}_{4}$.

Results of mixing calculations using $\mathrm{Cl}$ show that an average of 8 percent of alluvial groundwater (modern) mixes with 92 percent of the regional aquifer (submodern) near the regional water table at R-15 in Mortandad Canyon. Apparent groundwater ages range from 15 to 17 years at R-15. The initial release of ${ }^{3} \mathrm{H}$ from the RLWTF at TA-50 occurred in 1963 . The travel time of nonadsorbing contaminants migrating through the vadose zone to the regional water table in Mortandad Canyon is approximately 25 years.

This study evaluated occurrences of dissolved ${ }^{3} \mathrm{He}$ and ${ }^{4} \mathrm{He}$ in groundwater, which provide information on natural and possible anthropogenic sources of He isotopes in the subsurface. 
Anomalous concentrations of ${ }^{3} \mathrm{He}$ and ${ }^{4} \mathrm{He}$ occur at several wells downgradient from ${ }^{3} \mathrm{H}$ and actinide release sites. Solutions used in actinide processing, containing ${ }^{4} \mathrm{He}$ and other chemicals, were discharged to Pueblo Canyon, Los Alamos Canyon, and Mortandad Canyon as early as 1943. Occurrences of ${ }^{3} \mathrm{He}$ and ${ }^{4} \mathrm{He}$ in groundwater are useful in delineating sources and groundwater flow paths in conjunction with ${ }^{3} \mathrm{H}$ and other contaminants. Helium-4 is produced from $\alpha$-decay of actinides, including isotopes of $\mathrm{U}, \mathrm{Pu}$, and $\mathrm{Am}$. Natural and/or Laboratory sources contribute to elevated concentrations of dissolved ${ }^{4} \mathrm{He}$ measured in several of the groundwater samples.

The southern White Rock Canyon springs discharge submodern groundwater, whereas the White Rock Canyon springs more to the north discharge waters of mixed ages. Several of the northern springs represent discharge zones for perched intermediate groundwater (Spring 4, Spring 4B, and Spring 4C) and contain anthropogenic $\mathrm{NO}_{3}\left(\right.$ as N), $\mathrm{ClO}_{4}$, and/or ${ }^{3} \mathrm{H}$ with concentrations far below regulatory limits. Apparent groundwater ages for the modern component ranged from 0.46 to less than 62 years for the springs. The ${ }^{3} \mathrm{H} /{ }^{3} \mathrm{He}$ dating method showed that apparent groundwater ages for the modern component at these three springs ranged from 1.32 to 21.8 years. Unadjusted ${ }^{14} \mathrm{C}$ measurements showed that average groundwater ages for Spring 4 , Spring 4B, and Spring 4C ranged from 2159 to 3531 years. The majority of White Rock Canyon springs discharge from the regional aquifer, including Spring 3, Spring 3A, Spring 4A, Spring 4AA, Spring 5, Spring 6, and Spring 9A. Unadjusted ${ }^{14} \mathrm{C}$ measurements show that average groundwater ages for these springs range from 1449 to 7545 years.

Results of volumetric mixing calculations for Spring 4A in lower Pajarito Canyon using Cl suggest that alluvial and regional aquifer groundwater are present at an average of 9 and 91 percent, respectively. Results of calculations using groundwater ages suggest that Spring 4A consists of an average of 6 percent alluvial groundwater and 94 percent regional aquifer groundwater.

\subsection{Conclusions}

- No groundwater investigation is complete without using ${ }^{3} \mathrm{H} /{ }^{3} \mathrm{He}$ and ${ }^{14} \mathrm{C}$ dating methods in dating groundwater to quantify amounts of modern, mixed, and/or submodern components present in samples.

- Results of this study clearly demonstrate the occurrence of multiple flow paths and groundwater ages occurring in samples collected within the Sierra de los Valles, beneath the Pajarito Plateau, and at the White Rock Canyon springs. It is very unlikely that there is only one transport or travel time for conservative chemicals including ${ }^{3} \mathrm{H}, \mathrm{NO}_{3}$ (as $\mathrm{N}$ ), and $\mathrm{ClO}_{4}$ migrating from alluvial groundwater to perched intermediate zones and the regional aquifer.

- Computer models of groundwater flow and transport should be calibrated to groundwater ages $\left({ }^{3} \mathrm{H} /{ }^{3} \mathrm{He}\right.$ and ${ }^{14} \mathrm{C}$ dating methods) for perched intermediate zones and the regional aquifer determined from this investigation.

- The ${ }^{3} \mathrm{H} /{ }^{3} \mathrm{He}$ dating method used in this study showed that alluvial groundwater is entirely modern. Perched intermediate-depth groundwater within the Sierra de los Valles and 
beneath the Pajarito Plateau is mixed. The regional aquifer is either submodern or mixed. Submodern groundwater most commonly is not contaminated with treated effluent. Increasing concentrations of $\mathrm{NO}_{3}$ (as $\left.\mathrm{N}\right)$ at $\mathrm{R}-23$ in Pajarito Canyon, however, provide an exception. This well does not contain ${ }^{3} \mathrm{H}$.

- Mixed-age groundwater results from initial infiltration of surface water followed by mixing with perched intermediate groundwater and the regional aquifer. Within several canyons on the Pajarito Plateau, this recharge water typically contains ${ }^{3} \mathrm{H}, \mathrm{NO}_{3}$ (as $\left.\mathrm{N}\right)$, $\mathrm{ClO}_{4}, \mathrm{U}, \mathrm{B}, \mathrm{CrO}_{4}$, and/or $\mathrm{HE}$ compounds. Groundwater at the regional water table is mixed at several locations downgradient of Laboratory discharges within Pueblo Canyon, Los Alamos Canyon, Sandia Canyon, and Mortandad Canyon, and in Cañon de Valle. Concentrations of ${ }^{3} \mathrm{H}, \mathrm{NO}_{3}$ (asN), $\mathrm{B}, \mathrm{ClO}_{4}, \mathrm{U}$, and/or $\mathrm{CrO}_{4}$ exceeding background at regional aquifer wells also confirm the occurrence of mixed groundwater.

- Bomb-pulse ${ }^{3} \mathrm{H}$ is not detectable $(<0.6 \mathrm{pCi} / \mathrm{kg},<0.2 \mathrm{TU})$ within the regional aquifer at the wells in Pajarito Canyon and Cañada de Buey and other areas around the Laboratory. This finding strongly supports the concept that measurable ${ }^{3} \mathrm{H}$ above 1 or $2 \mathrm{pCi} / \mathrm{kg}(0.3$ or $0.6 \mathrm{TU}$ ) in the regional aquifer is Laboratory-derived.

- Apparent groundwater ages less than several years for the White Rock Canyon springs (regional aquifer) strongly suggest that ${ }^{3} \mathrm{H}$ and other mobile solutes migrated greater distances within the vadose zone and only short distances within the upper portion of the regional aquifer prior to discharge. In other words, it is very unlikely that ${ }^{3} \mathrm{H}$ migrated directly to the regional aquifer beneath the Laboratory and migrated several miles prior to discharging at the White Rock Canyon springs. Travel times for this scenario require long periods of time greatly exceeding 62 years prior to 2005 .

- Spring 4, Spring 4B, and Spring 4C represent perched intermediate discharge zones for the Cerros del Rio volcanic rocks within the Pajarito watershed. These springs are mixed; however, they are dominated by submodern water.

- Recharge from the Valles Caldera, on the whole, is not likely to be based on separation of groups of $\delta^{2} \mathrm{H}$ and $\delta^{18} \mathrm{O}$ ratios for the Sierra de los Valles springs. These springs largely consist of modern water. Springs discharging mixed water, including Barbara Spring and Campsite Springs, however, may have recharge sources west of the Sierra de los Valles. Groundwater travel times for mixed water should exceed those for modern water within the Sierra de los Valles.

- The $\delta^{2} \mathrm{H}$ and $\delta^{18} \mathrm{O}$ ratios suggest that the majority of modern groundwater discharging at the Sierra de los Valles springs originated as local precipitation that provides recharge to the western portion of the Pajarito Plateau.

- The similarity in $\delta^{2} \mathrm{H}$ and $\delta^{18} \mathrm{O}$ ratios and the presence of ${ }^{3} \mathrm{H}, \mathrm{NO}_{3}($ as $\mathrm{N})$, and/or $\mathrm{ClO}_{4}$ support the hypothesis that perched intermediate groundwater beneath the Pajarito Plateau is hydraulically connected to some of the White Rock Canyon springs. 


\subsection{ACKNOWLEDGEMENTS}

Logistical and coordination efforts by Mike Alexander, Jeff Walterscheid, and Alethea Banar were critical to the success of this project.

We extend a very special thank-you to Mat Johansen of the Los Alamos Area Office, DOE, for his efforts and for appreciating the significance of this investigation.

Special thanks also go to Marcey Hess, Dave Englert, Jim Jordon, Alethea Banar, Max Maes, Melissa Sandoval, Adrian Martinez, Rick Velasquez, Shannon Allen, Bill Bartels, Steve Yanicak, Jeff Walterscheid, David Gallegos, and Erik Galloway for their hard work and cooperation in collecting groundwater samples.

Many thanks are due to our reviewers_-David Vaniman, Elizabeth Keating, Ed Kwicklis, Jeff Heikoop, and Ardyth Simmons.

We appreciated the database assistance from Brian Spall.

\subsection{REFERENCES}

Adams, A.I., F. Goff, and D. Counce, February 1995. "Chemical and Isotopic Variations of Precipitation in the Los Alamos Region, New Mexico," Los Alamos National Laboratory report LA-12895-MS, Los Alamos, New Mexico. (Adams et al. 1995, 047192)

Allison, J.D., D.S. Brown, and K.J. Novo-Gradac, March 1991. "MINTEQA2/PRODEFA2, A Geochemical Assessment Model for Environmental Systems: Version 3.0 User's Manual." EPA/600/3-91/021, Office of Research and Development, Athens, Georgia. (Allison et al. 1991, 049930)

Andrews, J.N., S.N. Davis, J. Fabryka-Martin, J.Ch. Fontes, B.E. Lehmann, H.H. Loosli, J.L. Moser, B. Smith, and M. Wolf, 1989. "The In-Situ Production of Radioisotopes in Rock Matrices with Particular Reference to the Stripa Granite," Geochim. Cosmochim. Acta, Vol. 53. pp.1803-1815. (Andrews et al. 1989, 094919)

Bethke, C.M., and T.M. Johnson, 2002. "Paradox of Groundwater Age," Geology, Vol. 30, pp. 107-110. (Bethke and Johnson 2002, 095009)

Birdsell, K.H., B.D. Newman, D.E. Broxton, and B.A. Robinson, 2005. "Conceptual Models of Vadose Zone Flow and Transport beneath the Pajarito Plateau, Los Alamos, New Mexico," Vadose Zone Journal, Vol. 4, pp. 620-636. (Birdsell et al. 2005, 092048)

Bitner, K., B. Gallaher, and K. Mullen, May 2001. "Review of Wildfire Effects on Chemical Water Quality," Los Alamos National Laboratory report LA-13826-MS, Los Alamos, New Mexico. (Bitner et al. 2001, 094920) 
Blake, W.D., F. Goff, A.I. Adams, and D. Counce, May 1995. "Environmental Geochemistry for Surface and Subsurface Waters in the Pajarito Plateau and Outlying Areas, New Mexico," Los Alamos National Laboratory report LA-12912-MS, Los Alamos, New Mexico. (Blake et al. 1995, 049931)

Brookins, D.G., February 1988. Eh-pH Diagrams for Geochemistry, Springer-Verlag, New York, New York. (Brookins 1988, 049928)

Broxton, D.E., G. Heiken, S.J. Chipera, and F.M. Byers, Jr., June 1995. "Stratigraphy, Petrography, and Mineralogy of Bandelier Tuff and Cerro Toledo Deposits," in D.E. Broxton and P.G. Eller, eds., "Earth Science Investigations for Environmental Restoration-Los Alamos National Laboratory Technical Area 21," Los Alamos National Laboratory report LA-12934-MS, pp. 33-64. (Broxton et al. 1995, 005121)

Clark, I.D., and P. Fritz, 1997. Environmental Isotopes in Hydrogeology, Lewis Publishers, New York, New York. (Clark and Fritz 1997, 059168)

Dale, M.D., F. Goff, K. Granzow, P. Longmire, and D. Counce, April 2005. "Assessing Groundwater Recharge through the Pajarito Fault Zone, Upper Pajarito Canyon, Los Alamos, New Mexico," New Mexico Geological Society, 2005 Spring Meeting, Socorro, New Mexico, Proceedings Volume, p. 13. (Dale et al. 2005, 095002)

Dethier, D. P., 1997. "Geology of White Rock Quadrangle, Los Alamos and Santa Fe Counties, New Mexico," Map 73, New Mexico Bureau of Mines and Mineral Resources. (Dethier 1997, 049843)

DOE (U.S. Department of Energy), October 1987. "Phase 1: Installation Assessment, Los Alamos National Laboratory," Volumes 1 and 2, Comprehensive Environmental Assessment and Response Program, Albuquerque Operation Office, Albuquerque, New Mexico. (DOE 1987, 052975)

Ekwurzel, B., P. Schlosser, W.M. Smethie, L.N. Plummer, E. Busenberg, R.L. Michel, R. Weppernig, and M. Stute, 1994. "Dating of Shallow Groundwater: Comparison of the Transient Tracers ${ }^{3} \mathrm{H} /{ }^{3} \mathrm{He}$, Chlorofluorocarbons, and ${ }^{85} \mathrm{Kr}$," Water Resources Research, Vol. 30, pp. 1693-1708. (Ekwurzel et al. 1994, 095007)

ESP (Environmental Surveillance Program), September 2005. "Environmental Surveillance at Los Alamos during 2004," Los Alamos National Laboratory report LA-14239-ENV, Los Alamos, New Mexico. (ESP 2005, 092222)

Gallaher, B., and R. Koch, September 2004. "Cerro Grande Fire Impacts to Water Quality and Stream Flow near Los Alamos National Laboratory: Results of Four Years of Monitoring," Los Alamos National Laboratory report LA-14177, Los Alamos, New Mexico. (Gallaher and Koch 2004, 088747)

Keating, E.H., B.A. Robinson, and V.V. Vesselinov, 2005. "Development and Application of Numerical Models to Estimate Fluxes through the Regional Aquifer beneath the Pajarito Plateau," Vadose Zone Journal, Vol. 4, pp. 653-671. (Keating et al. 2005, 090039) 
Kwicklis, E., M. Witowski, K. Birdsell, B. Newman, and D. Walther, 2005. "Development of an Infiltration Map for the Los Alamos Area, New Mexico," Vadose Zone Journal, Vol. 4, pp. 672-693. (Kwicklis et al. 2005, 090069)

Langmuir, D., 1997. Aqueous Environmental Geochemistry, Prentice-Hall, Inc., Upper Saddle River, New Jersey. (Langmuir 1997, 056037)

LANL (Los Alamos National Laboratory), May 1981. "Formerly Utilized MED/AEC Sites Remedial Action Program, Radiological Survey of the Site of a Former Radioactive Liquid Waste Treatment Plant (TA-45) and the Effluent Receiving Areas of Acid, Pueblo, and Los Alamos Canyons, Los Alamos, New Mexico," Los Alamos National Laboratory report LA-8890-ENV, Los Alamos, New Mexico. (LANL 1981, 006059)

LANL (Los Alamos National Laboratory), April 1997. "Core Document for Canyons Investigations," Los Alamos National Laboratory document LA-UR-96-2083, Los Alamos, New Mexico. (LANL 1997, 055622)

LANL (Los Alamos National Laboratory), September 1997. "Work Plan for Mortandad Canyon," Los Alamos National Laboratory document LA-UR-97-3291, Los Alamos, New Mexico. (LANL 1997, 056835)

LANL (Los Alamos National Laboratory), June 2005. “Groundwater Background Investigation Report,” Los Alamos National Laboratory document LA-UR-05-2295, Los Alamos, New Mexico. (LANL 2005, 090580)

LANL (Los Alamos National Laboratory), December 2005. “Los Alamos National Laboratory's Hydrogeologic Studies of the Pajarito Plateau: A Synthesis of Hydrogeologic Work Plan Activities (1998-2004)," K.A. Collins, A.M. Simmons, B.A. Robinson, and C.L. Nylander, eds., Los Alamos National Laboratory report LA-14263-MS, Los Alamos, New Mexico. (LANL 2005, 092028)

LANL (Los Alamos National Laboratory), March 2006. "Interim Measures Work Plan for Chromium Contamination in Groundwater," Los Alamos National Laboratory document LA-UR-06-1961, Los Alamos, New Mexico. (LANL 2006, 091987)

LANL (Los Alamos National Laboratory), October 2006. "Mortandad Canyon Investigation Report," Los Alamos National Laboratory document LA-UR-06-6752, Los Alamos, New Mexico. (LANL 2006, 094161)

LANL (Los Alamos National Laboratory), February 2007. “Groundwater Background Investigation Report, Revision 2," Los Alamos National Laboratory report LA-UR-07-0755, Los Alamos, New Mexico. (LANL 2007, 094856)

Longmire, P., March 2002. “Characterization Well R-15 Geochemistry Report,” Los Alamos National Laboratory report LA-13896-MS, Los Alamos, New Mexico. (Longmire 2002, 072614) 
Longmire, P., April 2002. "Characterization Wells R-9 and R-9i Geochemistry Report," Los Alamos National Laboratory report LA-13927-MS, Los Alamos, New Mexico. (Longmire 2002, 072713)

Longmire, P., June 2002. “Characterization Well R-12 Geochemistry Report,” Los Alamos National Laboratory report LA-13952-MS, Los Alamos, New Mexico. (Longmire 2002, 072800)

Longmire, P., June 2002. "Characterization Well R-19 Geochemistry Report,” Los Alamos National Laboratory report LA-13964-MS, Los Alamos, New Mexico. (Longmire 2002, 073282)

Longmire, P., September 2002. "Characterization Well R-22 Geochemistry Report,” Los Alamos National Laboratory report LA-13986-MS, Los Alamos, New Mexico. (Longmire 2002, 073676)

Longmire, P., May 2005. “Characterization Well R-25 Geochemistry Report,” Los Alamos National Laboratory report LA-14198-MS, Los Alamos, New Mexico. (Longmire 2005, 088510)

Longmire, P., and F. Goff, December 2002. "Characterization Well R-7 Geochemistry Report," Los Alamos National Laboratory report LA-14004-MS, Los Alamos, New Mexico. (Longmire and Goff 2002, 075905)

Manning, A.H., and D.K. Solomon, 2005. "An Integrated Environmental Tracer Approach to Characterizing Groundwater Circulation in a Mountain Block," Water Resources Research, Vol. 41. (Manning and Solomon 2005, 095006)

Manning, A.H., D.K. Solomon, and S.A. Thiros, May-June 2005. “3 $\mathrm{H} /{ }^{3} \mathrm{He}$ Age Data in Assessing the Susceptibility of Wells to Contamination," Ground Water, Vol. 43, pp. 353-367. (Manning et al. 2005, 095004)

Manning, A.H., E. Keating, and J.S. Caine, March 2006. "Insights into Recharge to the Española Basin Provided by Noble Gas, Groundwater Age, and Temperature Data," presented at Española Basin Technical Advisory Group Meeting, March 7 and 8, 2006, Santa Fe, New Mexico.

(Manning et al. 2006, 094921)

Parrington, J.R., H.D. Knox, S.1. Breneman, E.M. Baum, and F. Feiner, 1996. "Nuclides and Isotopes-Chart of the Nuclides, Fifteenth Edition," General Electric Co. and KAPL, Inc. (Parrington et al. 1996, 058682)

Plummer, L. N., L. M. Bexfield, Scott K. Anderholm, W. E. Sanford, and E. Busenberg 2004. "Geochemical Characterization of Ground-Water Flow in the Santa Fe Group Aquifer System, Middle Rio Grande Basin, New Mexico," U.S. Geological Survey Water Resources Investigations Report 03-4131, Reston Virginia (Plummer et al. 2004, 096573)

Purtymun, W.D., 1974. "Dispersion and Movement of Tritium in a Shallow Alluvial Aquifer in Mortandad Canyon at the Los Alamos Scientific Laboratory," Los Alamos National Laboratory report LA-5716-MS, Los Alamos, New Mexico. (Purtymun 1974, 005476) 
Purtymun, W.D., J.R. Buchholz, and T.E. Hakonson, 1977. "Chemical Quality of Effluents and Their Influence on Water Quality in a Shallow Aquifer," Journal of Environmental Quality, Vol. 6, pp. 29-32. (Purtymun et al. 1977, 011846)

Purtymun, W. D., January 1995. "Geologic and Hydrologic Records of Observation Wells, Test Holes, Test Wells, Supply Wells, Springs, and Surface Water Stations in the Los Alamos Area," Los Alamos National Laboratory report LA-12883-MS, Los Alamos, New Mexico. (Purtymun 1995, 045344)

Rai, D., and J.M. Zachara, May 1986. "Geochemical Behavior of Chromium Species,” Electric Power Research Institute interim report, Battelle, Pacific Northwest National Laboratory, Richland, Washington. (Rai and Zachara 1986, 091684)

Richmond, S., July 14, 2006. Personal Communication between Scott Richmond and Patrick Longmire Regarding Helium-4 Generation at the Decommissioned Omega West Reactor, Los Alamos National Laboratory, Los Alamos, New Mexico. (Richmond 2006, 095886)

Robinson, B.A., D.E. Broxton, and D.T. Vaniman, 2005. "Observations and Modeling of Deep Perched Water Beneath the Pajarito Plateau," Vadose Zone Journal, Vol. 4, pp. 637-652. (Robinson et al. 2005, 091682)

Rogers, D.B., July 1998. "Impact of Tritium Disposal on Surface Water and Groundwater at Los Alamos National Laboratory through 1997," Los Alamos National Laboratory report LA-13465-SR, Los Alamos, New Mexico. (Rogers 1998, 059169)

Rogerson, P.F., April 5, 1996. "Collection, Processing, and Analysis of Carbon Isotope Samples," United States Geological Survey, NWQL Technical Memorandum 96-05, p. 7. (Rogerson 1996, 095003)

Schlosser, P., M. Stute, H. Dorr, C. Sonntag, and K.O. Munnich, 1988. "Tritium/ ${ }^{3}$ He Dating of Shallow Groundwater," Earth and Planetary Sciences Letters, Vol. 89, pp. 353-362. (Schlosser et al. 1988, 095008)

Schlosser, P., M. Stute, C. Sonntag, and K.O. Munnich, 1989. “Tritiogenic ${ }^{3} \mathrm{He}$ in Shallow Groundwater," Earth and Planetary Sciences Letters, Vol. 94, pp. 245-256. (Schlosser et al. 1989, 095013)

Shevenell, L., and F. Goff, 1995. "The Use of Tritium in Groundwater to Determine Fluid Mean Residence Times of Valles Caldera Hydrothermal Fluids, New Mexico," Journal of Volcanology and Geothermal Research, Vol. 67, pp. 187-205. (Shevenell and Goff 1995, 073686)

Smith, R.L., R. A. Bailey, and C. S. Ross 1970. "Geologic Map of Jemez Mountains, New Mexico," U.S. Geological Survey Miscellaneous Investigations Series, Map 1-571, Washington, D.C. (Smith et al. 1970, 009752)

Solomon, D.K., S.L. Schiff, R.J. Poreda, and W.B. Clarke, September 1993. "A Validation of the ${ }^{3} \mathrm{H} /{ }^{3} \mathrm{He}$ Method for Determining Groundwater Recharge," Water Resources Research, Vol. 29, No. 9, pp. 2951-2962. (Solomon et al. 1993, 095014) 
Solomon, D.K. and E.A. Sudicky, September 1991. "Tritium and Helium 3 Isotope Ratios for Direct Estimation of Spatial Variations in Groundwater Recharge," Water Resources Research, Vol. 27, No. 9, pp. 2309-2319. (Solomon and Sudicky 1991, 095012)

Vaniman, D., June 2006. Personal Communication between David Vaniman and Patrick Longmire Regarding Uranium and Thorium Concentrations in Basalt and Silica-Rich Sediments within the Santa Fe Group beneath the Pajarito Plateau, Los Alamos, New Mexico. (Vaniman 2006, 095110)

Vaniman, D., June 2006. Personal Communication between David Vaniman and Patrick Longmire Regarding Hydrothermal Alteration in Santa Fe Group Sediment and Basalt around Los Alamos, New Mexico. (Vaniman 2006, 095111)

Vuataz, F.D., and F. Goff, February 10, 1986. "Isotope Geochemistry of Thermal Waters in the Valles Caldera, Jemez Mountains, Northern New Mexico," Journal of Geophysical Research, Vol. 91(B2), pp. 1835-1853. (Vuataz and Goff 1986, 095011)

Weissmann, G.S., Y. Zhang, E.M. La Bolle, and G.E. Fogg, 2002. "Dispersion of Groundwater Age in an Alluvial Aquifer System," Water Resources Research, Vol. 38, pp. 16-1-16-13. (Weissmann et al. 2002, 095010)

\section{Recommended Supplemental Reading}

LANL (Los Alamos National Laboratory), May 1991. "TA-21 Operable Unit RFI Work Plan for Environmental Restoration, Volume 1," Los Alamos National Laboratory document LA-UR-91-962, Los Alamos, New Mexico. (LANL 1991, 007528)

LANL (Los Alamos National Laboratory), May 1991. "TA-21 Operable Unit RFI Work Plan for Environmental Restoration, Volume 2," Los Alamos National Laboratory document LA-UR-91-962, Los Alamos, New Mexico. (LANL 1991, 007529)

LANL (Los Alamos National Laboratory), May 1991. "TA-21 Operable Unit RFI Work Plan for Environmental Restoration, Volume 3," Los Alamos National Laboratory document LA-UR-91-962, Los Alamos, New Mexico. (LANL 1991, 007680)

LANL (Los Alamos National Laboratory), November 2006. "Interim Measures Report for Chromium Contamination in Groundwater," Los Alamos National Laboratory document LA-UR-06-8372, Los Alamos, New Mexico. (LANL 2006, 094431) 


\title{
APPENDIX A: ACRONYMS AND ABBREVIATIONS
}

\author{
Acronyms and Initialisms Used in This Document \\ AMS \\ $\mathrm{CdV}$ \\ CAHs \\ DIC \\ DO \\ DOE \\ DOEOB \\ EES-6 \\ EPA \\ GEL \\ $\mathrm{HE}$ \\ IC \\ ICP-MS \\ ICP-OES \\ IDL \\ IR-MS \\ JMML \\ LAO \\ LAOI \\ LANL \\ LC-MS/MS \\ MCOBT \\ MCOI \\ MS \\ NMED \\ $\mathrm{O}$ \\ OWR \\ POI \\ $\mathrm{R}$ \\ RLWTF \\ SOP \\ accelerator mass spectrometry \\ Cañon de Valle \\ chlorinated aliphatic hydrocarbons \\ dissolved inorganic carbon \\ dissolved oxygen \\ (United States) Department of Energy \\ Department of Energy Oversight Bureau \\ Earth and Environmental Sciences (Group) \\ (United States) Environmental Protection Agency \\ General Engineering Laboratory \\ high explosive \\ ion chromatography \\ inductively coupled (argon) plasma-mass spectrometry \\ inductively coupled (argon) plasma-optical emission spectroscopy \\ instrument detection limit \\ isotope ratio mass spectrometry \\ Jemez Mountains meteoric line \\ Los Alamos Observation (well) \\ Los Alamos Observation Intermediate (well) \\ Los Alamos National Laboratory (the Laboratory) \\ liquid chromatography-mass spectrometry/mass spectrometry (method) \\ Mortandad Canyon Observation Bandelier Tuff (well) \\ Mortandad Canyon Observation Intermediate (depth) (well) \\ mass spectrometry \\ New Mexico Environment Department \\ Otowi (a supply-well designation) \\ Omega West Reactor \\ Pueblo Observation Intermediate (depth) (well) \\ Regional (aquifer) (well) \\ Radioactive Liquid Waste Treatment Facility \\ standard operating procedure
}


STP

TA

TDS

TU

TW

USGS

VOC

WCG

WQH

WMWL standard temperature and pressure

technical area

total dissolved solids

tritium unit

test well

United States Geological Survey

volatile organic compound

Water Canyon Gallery

Water Quality and Hydrology (Group)

world meteoric water line

\section{Symbols for Elements Mentioned in This Document}

$\begin{array}{ll}\mathrm{Ag} & \text { silver } \\ \mathrm{Al} & \text { aluminum } \\ \mathrm{Am} & \text { americium } \\ \mathrm{Ar} & \text { argon } \\ \mathrm{As} & \text { arsenic } \\ \mathrm{B} & \text { boron } \\ \mathrm{Ba} & \text { barium } \\ \mathrm{Be} & \text { beryllium } \\ \mathrm{Br} & \text { bromine } \\ \mathrm{C} & \text { carbon } \\ \mathrm{Ca} & \text { calcium } \\ \mathrm{Cd} & \text { cadmium } \\ \mathrm{Cl} & \text { chlorine } \\ \mathrm{Co} & \text { cobalt } \\ \mathrm{Cr} & \text { chromium } \\ \mathrm{Cs} & \text { cesium } \\ \mathrm{Cu} & \text { copper } \\ \mathrm{F} & \text { fluorine } \\ \mathrm{Fe} & \text { iron } \\ \mathrm{Hg} & \text { mercury } \\ \mathrm{He} & \text { helium } \\ \mathrm{K} & \text { potassium } \\ & \end{array}$




$\begin{array}{ll}\mathrm{Kr} & \text { krypton } \\ \mathrm{Li} & \text { lithium } \\ \mathrm{Mg} & \text { magnesium } \\ \mathrm{Mn} & \text { manganese } \\ \mathrm{Mo} & \text { molybdenum } \\ \mathrm{N} & \text { nitrogen } \\ \mathrm{Na} & \text { sodium } \\ \mathrm{Ne} & \text { neon } \\ \mathrm{Ni} & \text { nickel } \\ \mathrm{Np} & \text { neptunium } \\ \mathrm{Pb} & \text { lead } \\ \mathrm{Pu} & \text { plutonium } \\ \mathrm{Rb} & \text { rubidium } \\ \mathrm{Se} & \text { selenium } \\ \mathrm{Sb} & \text { antimony } \\ \mathrm{Sn} & \text { tin } \\ \mathrm{Sr} & \text { strontium } \\ \mathrm{Th} & \text { thorium } \\ \mathrm{Tl} & \text { thallium } \\ \mathrm{U} & \text { uranium } \\ \mathrm{V} & \text { vanadium } \\ \mathrm{Zn} & \text { zinc } \\ \mathrm{Na} & \\ \mathrm{Na} & \end{array}$

\section{Other Relevant Chemical Descriptors and Units}

$\begin{array}{ll}\alpha & \text { alpha } \\ \beta & \text { beta } \\ \delta^{13} \mathrm{C} & \text { stable isotope of carbon } \\ \delta^{18} \mathrm{O} & \text { stable isotope of oxygen } \\ \delta^{2} \mathrm{H} & \text { stable isotope of hydrogen } \\ \mu \mathrm{m} & \text { micrometer } \\ 1 \sigma & \text { a measurement of analytical uncertainty } \\ { }^{241} \mathrm{Am} & \text { americium-241 } \\ { }^{39} \mathrm{Ar} & \text { argon-39 (radiogenic isotope) } \\ \mathrm{AsO}_{3}{ }^{3-} & \text { arsenite }\end{array}$




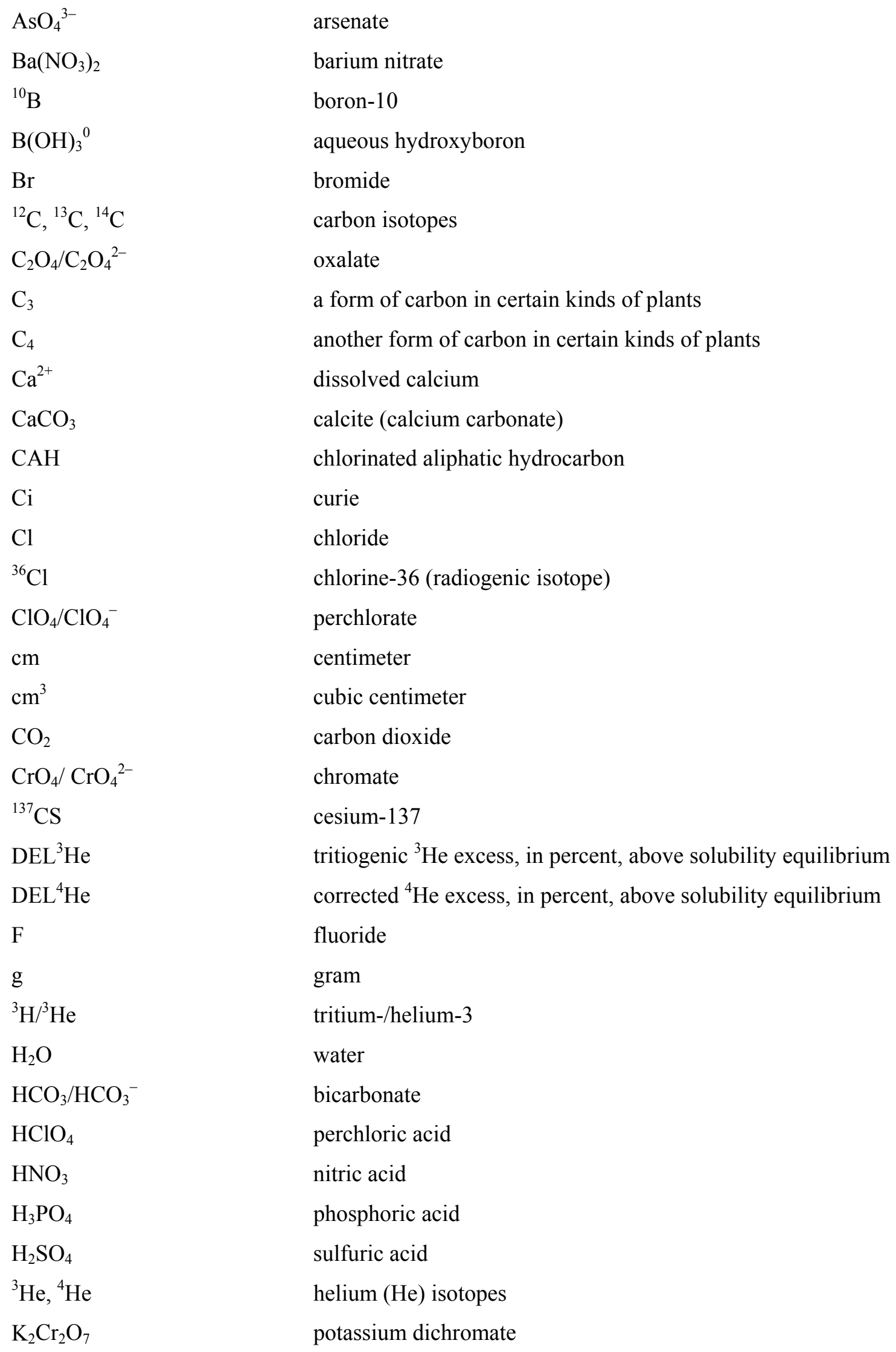




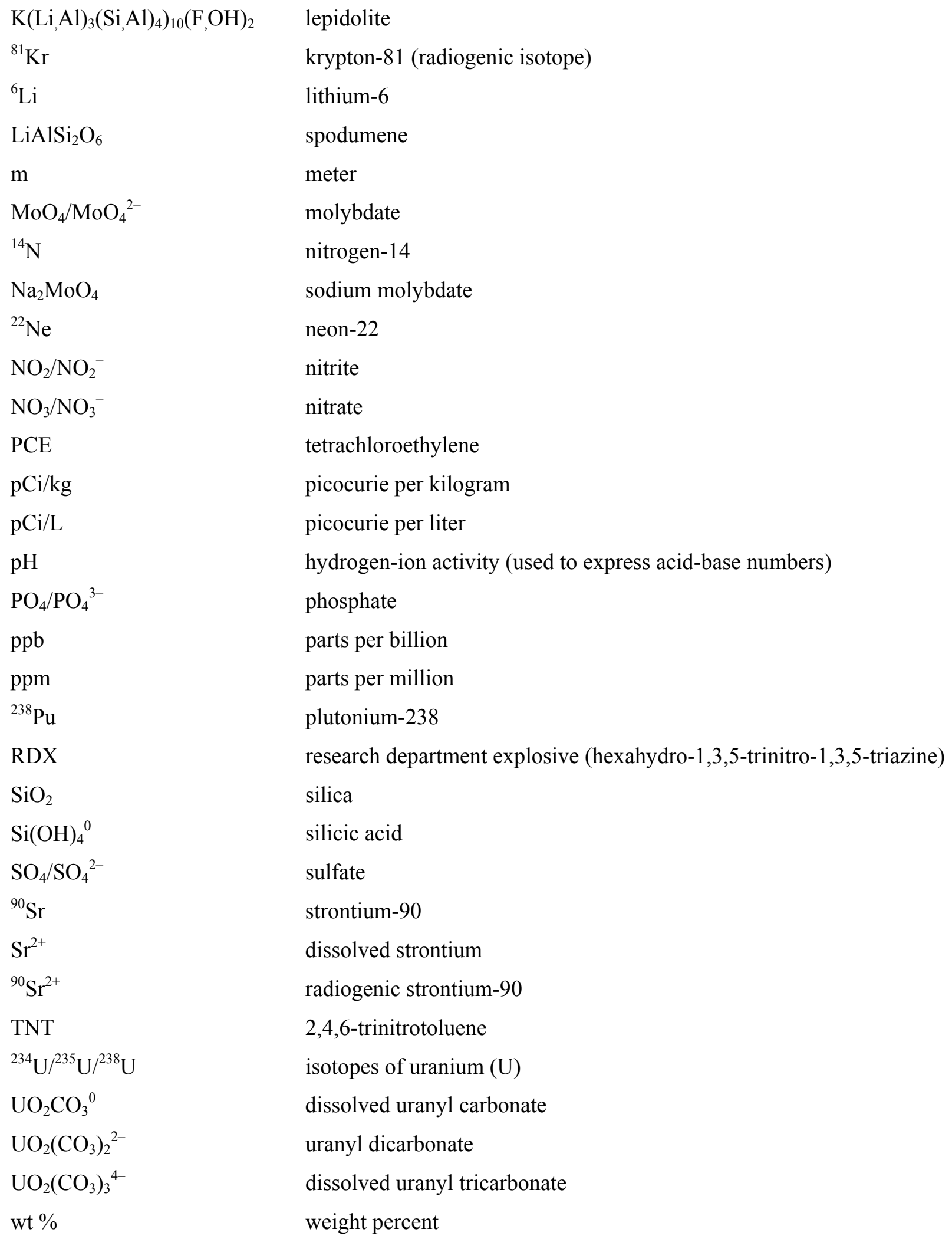




\section{APPENDIX B: SAMPLING PROCEDURE FOR NOBLE GASES}

Sampling groundwater at wells and springs for noble gases during this investigation required a specialized procedure developed by the University of Miami and USGS (Manning et al. 2005, 095004). Those taking samples adhered to the following steps when collecting the noble-gas samples:

1. A sample identification label was attached to the copper collection tube prior to sample collection.

2. Clamps were placed in the notches of the aluminum channel to secure the copper collection tube into the clamps such that the copper tube was centrally positioned in the clamps.

3. Clamp nuts were partly tightened - just enough to hold the copper tube securely in position. The clamp nuts were adjusted so that both halves of each clamp were parallel to each other.

4. Long and short Tygon tubes were attached to the copper tube. The connection was made by forcing the Tygon tubing over the ends of the copper tube and overlapping the ends of the tube by 1/4-inch or more to create an air-tight seal. The free end of the long Tygon tube was attached to the pump outlet, or it was submerged in the spring or surface water source. The collection tube assembly was secured in a vertical position such that inflow would be into the bottom and outflow would be from the top. For spring and surface water sampling, a peristaltic pump was connected to the outflow tubing so that the water was pumped upward through the collection tube.

5. Starting in a bubble-free, continuous, and slow-flow mode (approximately 1 to $1.5 \mathrm{~L} / \mathrm{min}$ ), water was allowed to run through the sampling system for at least 1 minute to flush the sample tube.

6. The copper tube was lightly tapped with a wrench along the full length, up and down, while the tube was flushed to dislodge any bubbles that might form.

7. When no gas bubbles were visible in the upper Tygon tube during sampling at springs, surface water, and LAO-B, flow was stopped, and Vise-Grip (or similar) clamps were used to squeeze the Tygon tubing shut a short distance upstream and downstream of the collection tube. Shutoff valves were used at intermediate and regional aquifer wells.

8. Starting with the bottom clamp first, one side of the clamp nut was tightened half-way; then the opposite nut was tightened 3/4 of the way; then the first one was tightened all the way; and finally, the opposite nut was tightened all the way. The top clamp was tightened in the same fashion. It was properly tight when a sudden resistance to tightening was met. There was some variance between clamps as to their appearance when they were sufficiently tightened. The proper tightness was obtained when the squeezing edges had a gap of about $1 \mathrm{~mm}$ around the copper tube. 
9. The ends of the copper tube were capped with plastic caps - without shaking the water out of the ends of the collection tube.

10. The clamped collection tube was removed from the aluminum channel by squeezing the spring-loaded handles beneath the channel to relieve the pressure on the clamps, then pulling the collection tube/clamp assembly up out of the channel. The clamps remained affixed to the copper tube during shipment to the laboratory.

11. The sample-identification label—including date, time, and location — was completed immediately after sample collection.

12. The collection tube/clamp assemblies were stored with suitable protection and padding (e.g., bubble wrap or similar padding) to prevent damage during transport.

Purging of the well bore was generally not required prior to collection of the dissolved-gas sample because the dissolved gas in the well bore was in equilibrium with the formation water unless a clogged screen inhibited efficient transmission of formation water into the well. 


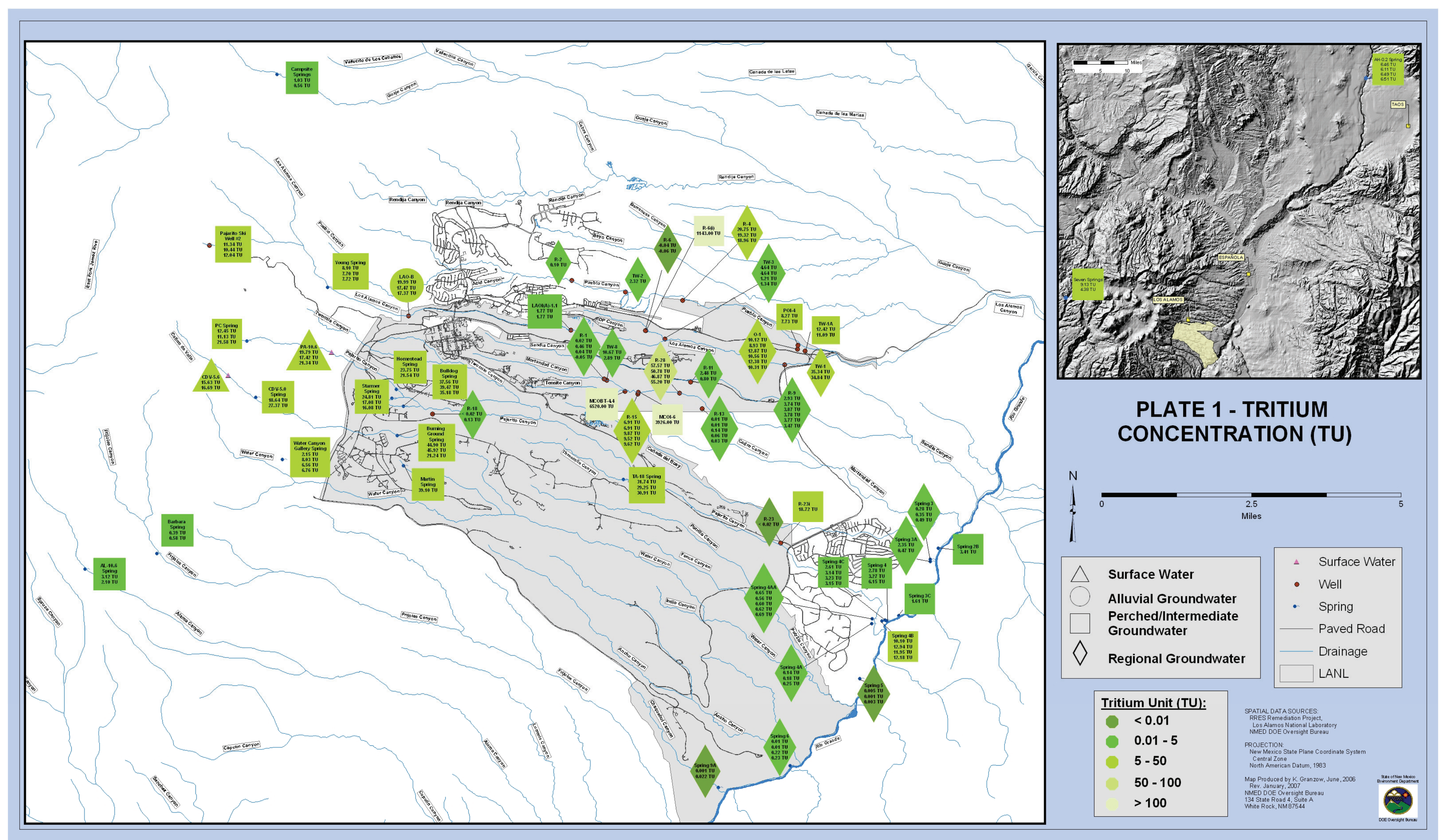




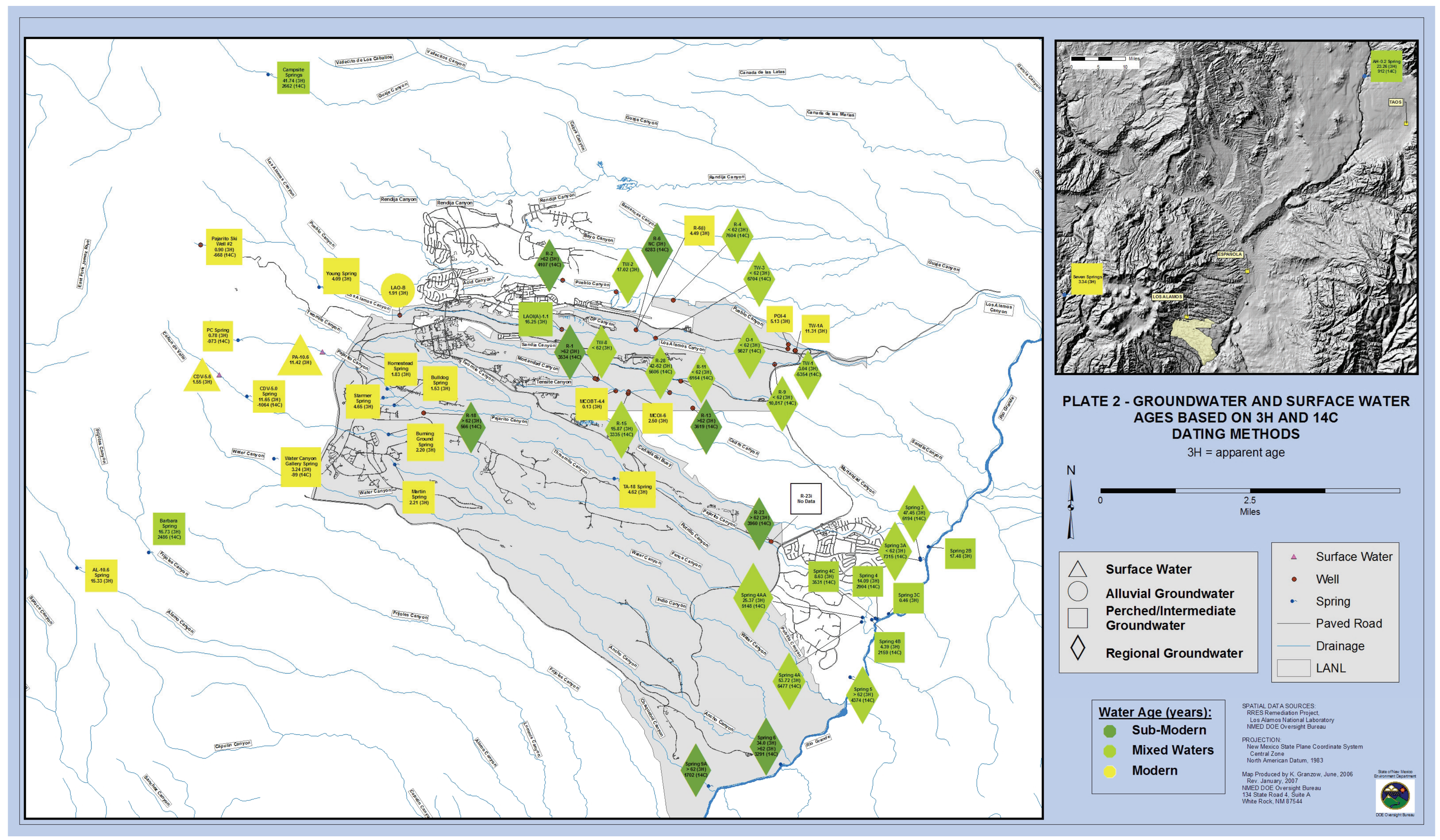




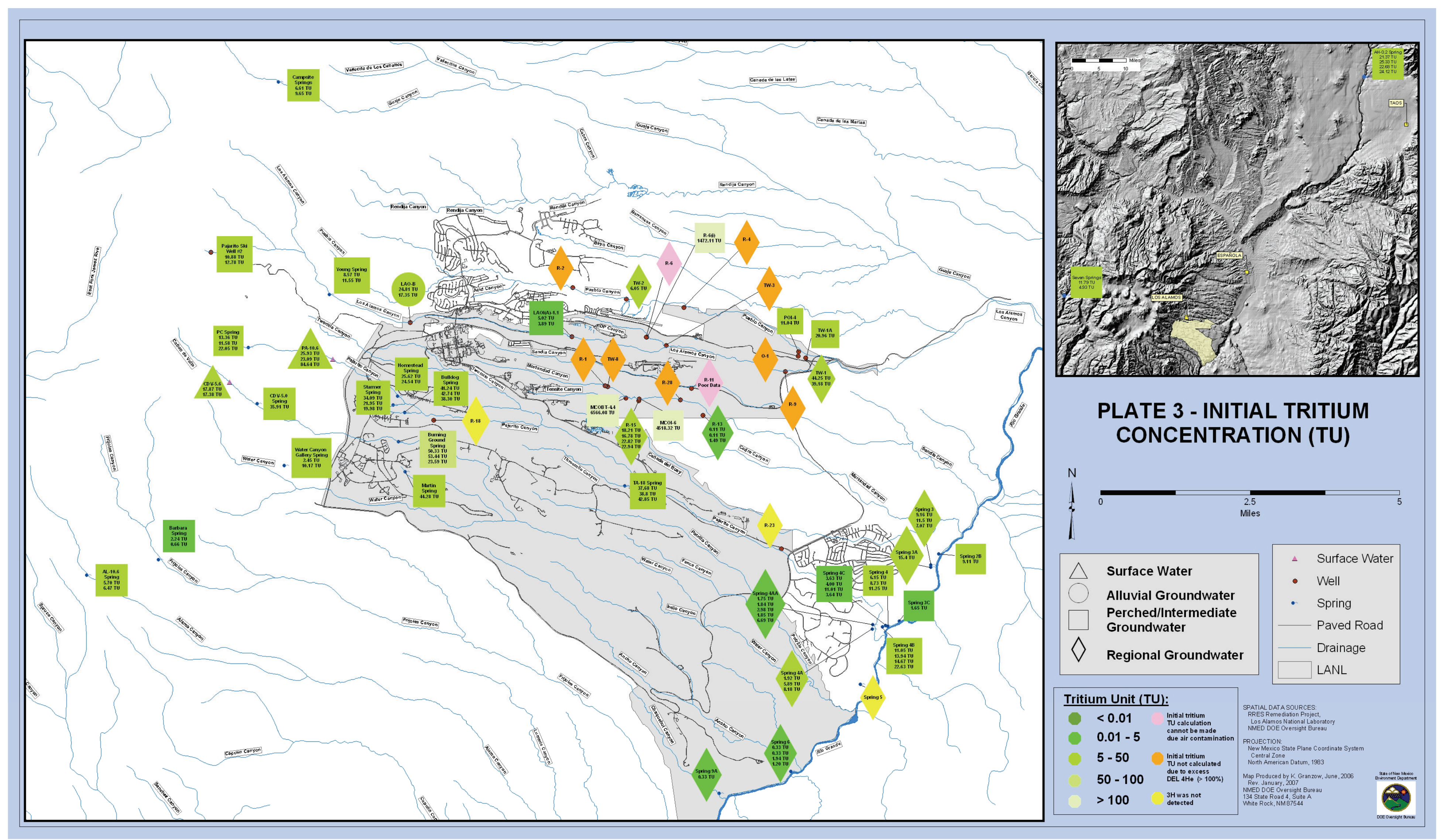




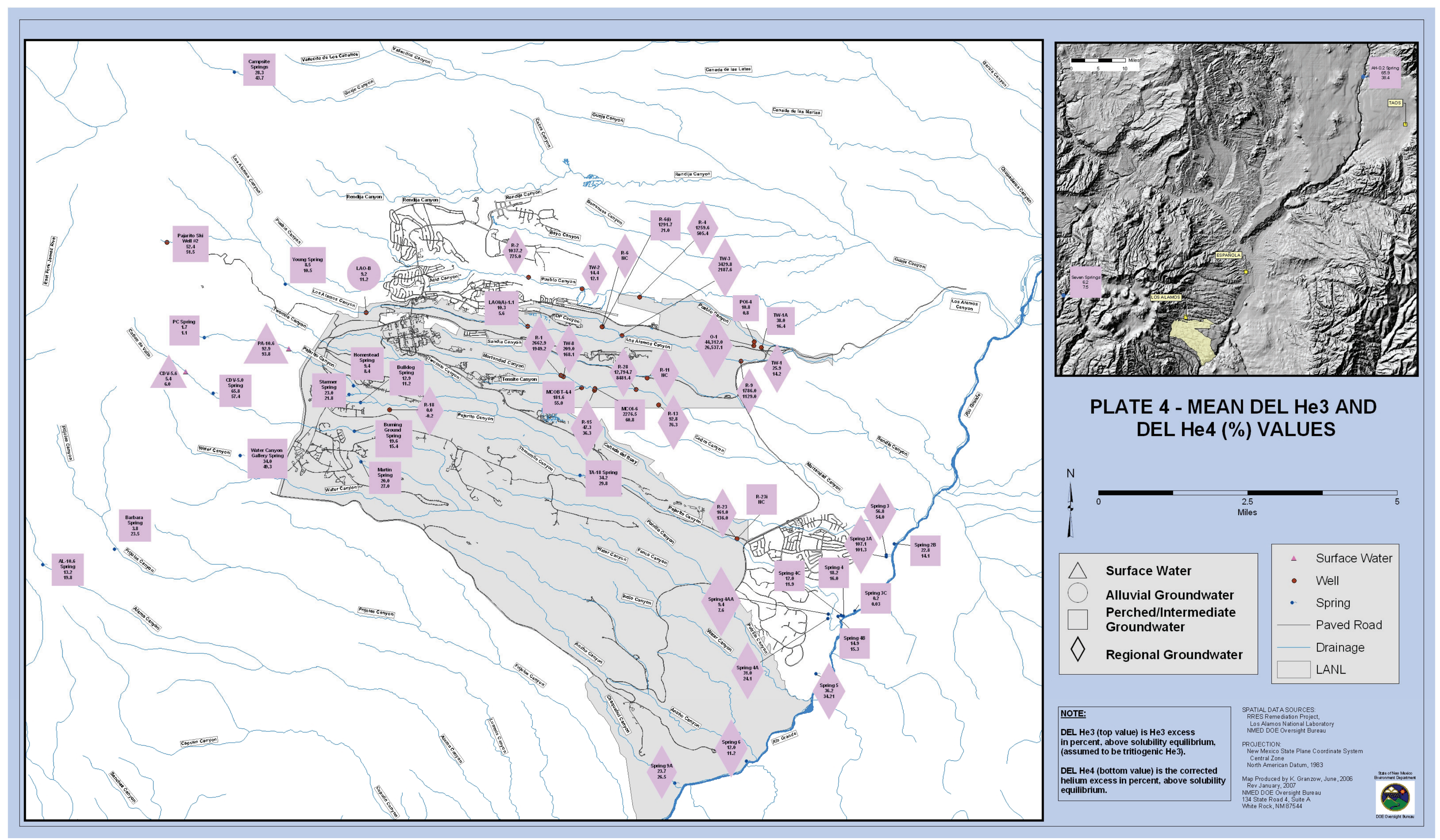




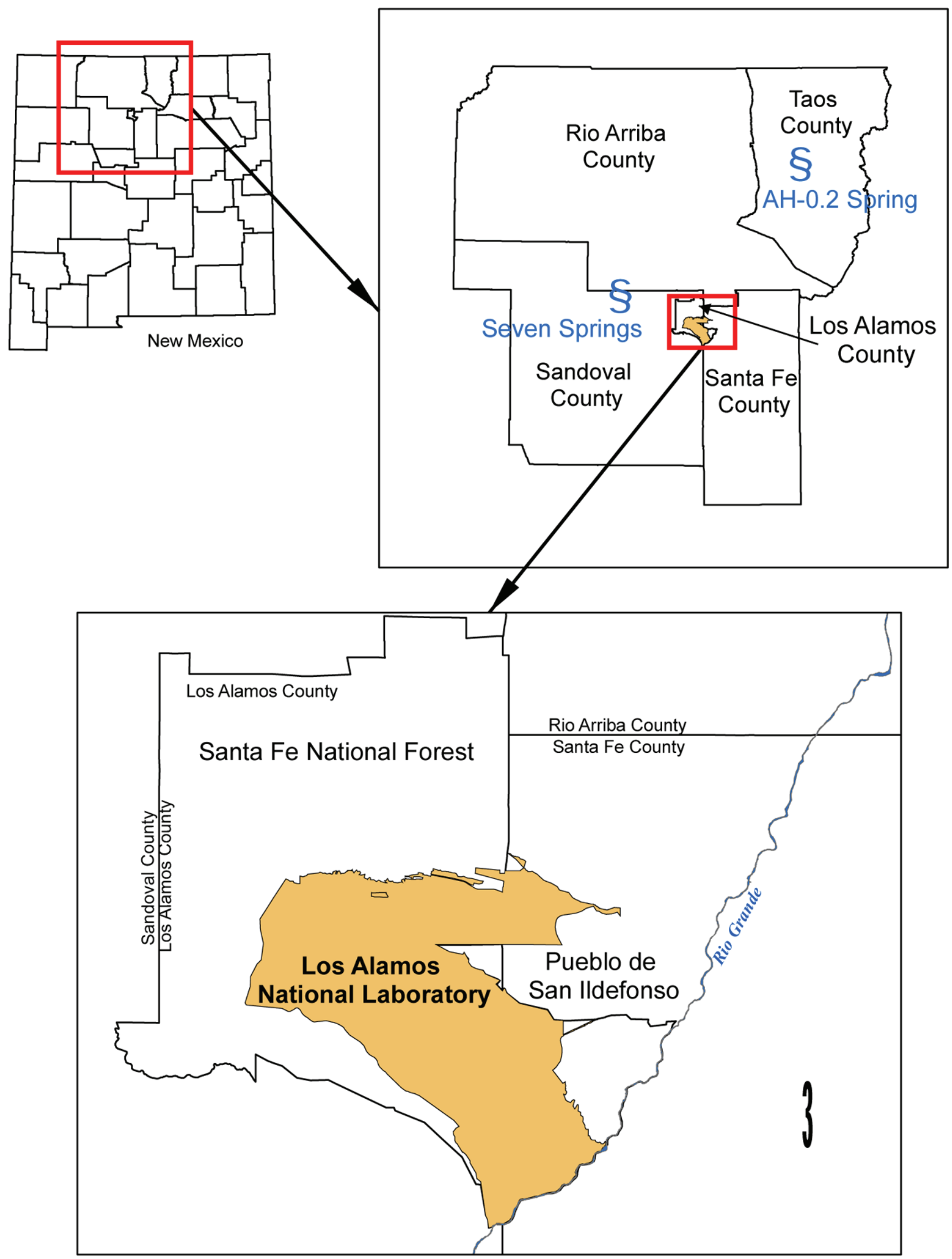

Figure 1-1 Study area for hydrogeochemical and isotope investigation, Pajarito Plateau and surrounding areas, New Mexico 


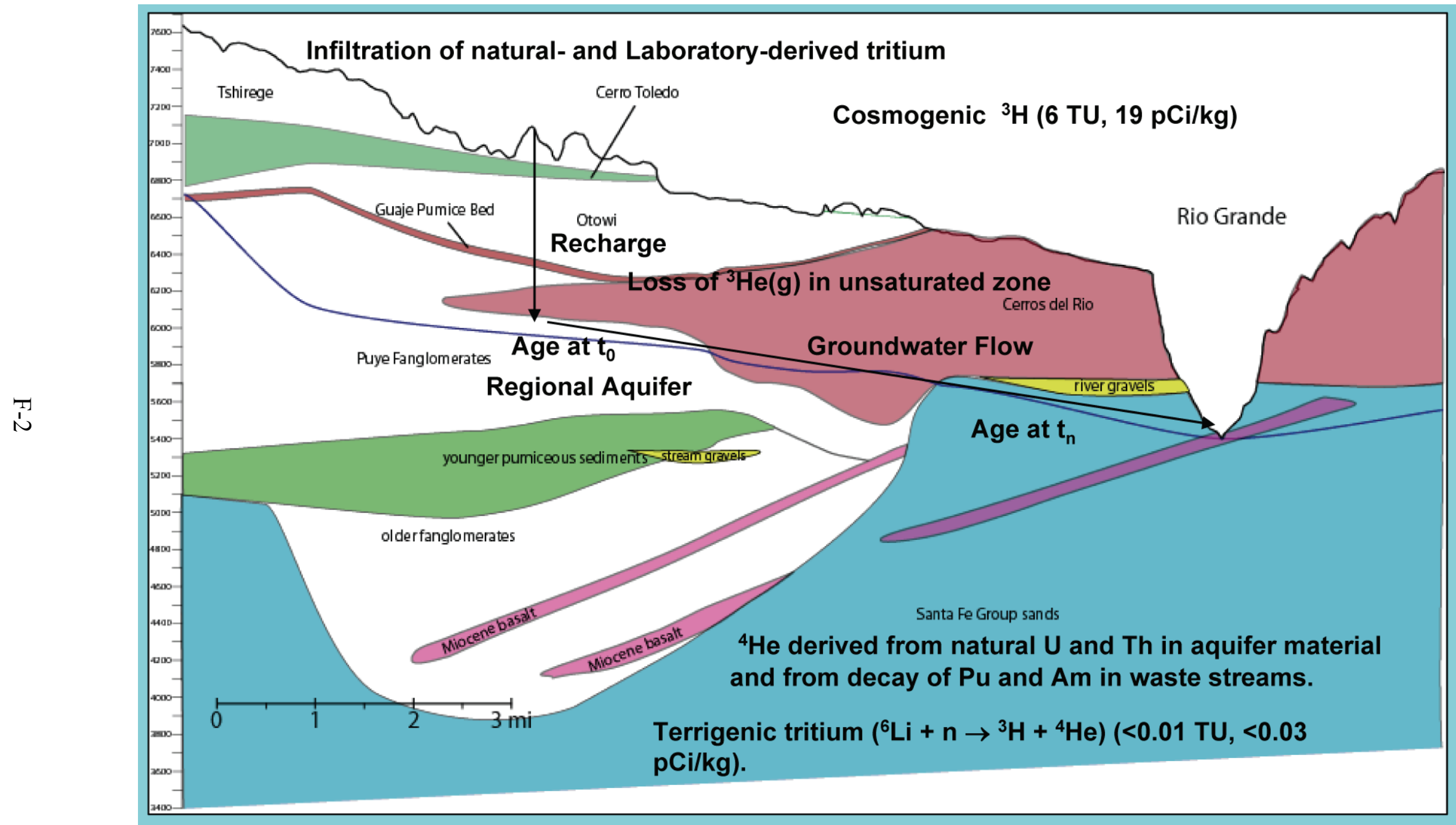

Figure 2-1 Conceptual model for tritium and helium 


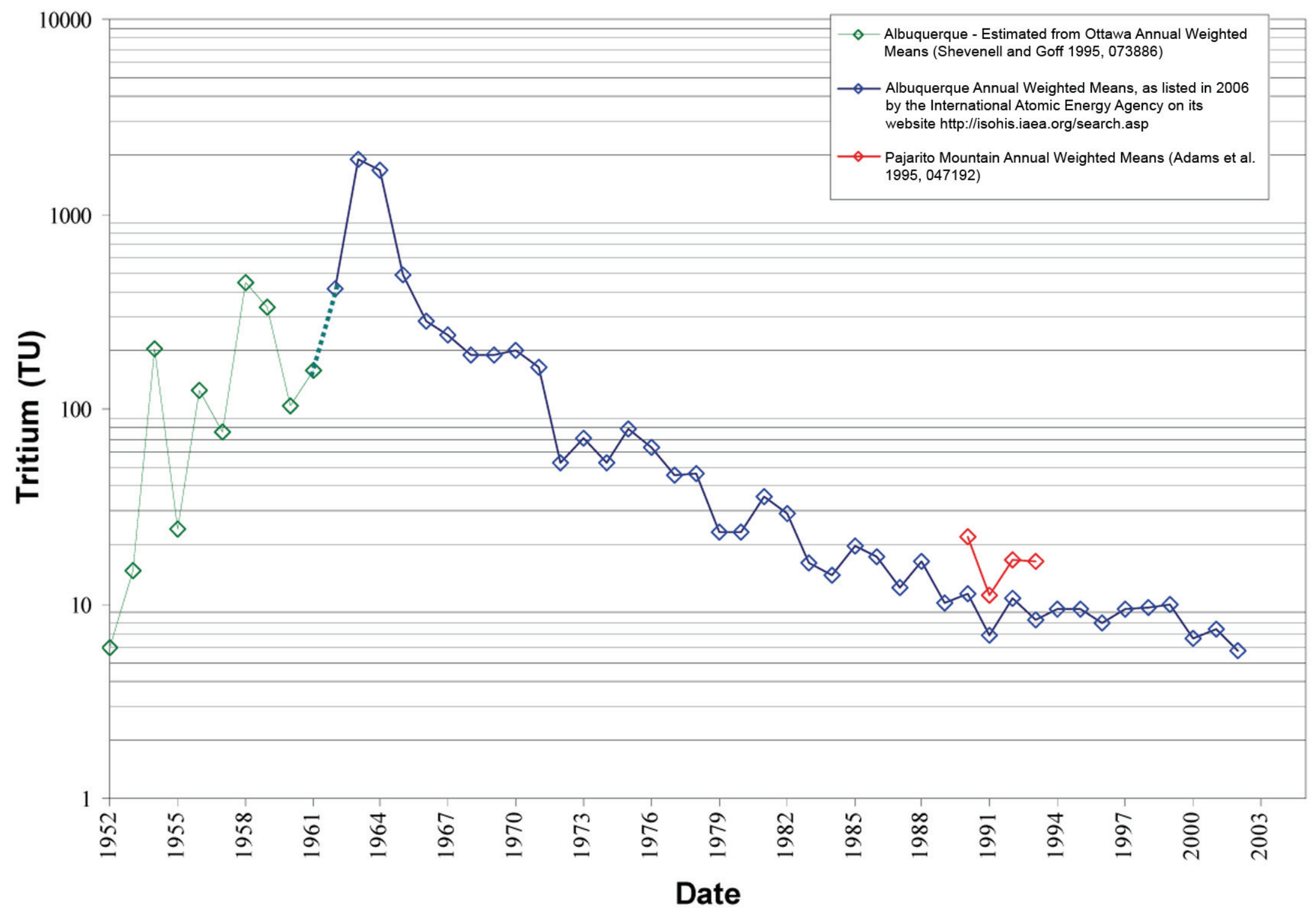

Figure 2-2 Atmospheric tritium curve and groundwater samples collected at Los Alamos National Laboratory and surrounding area, New Mexico 


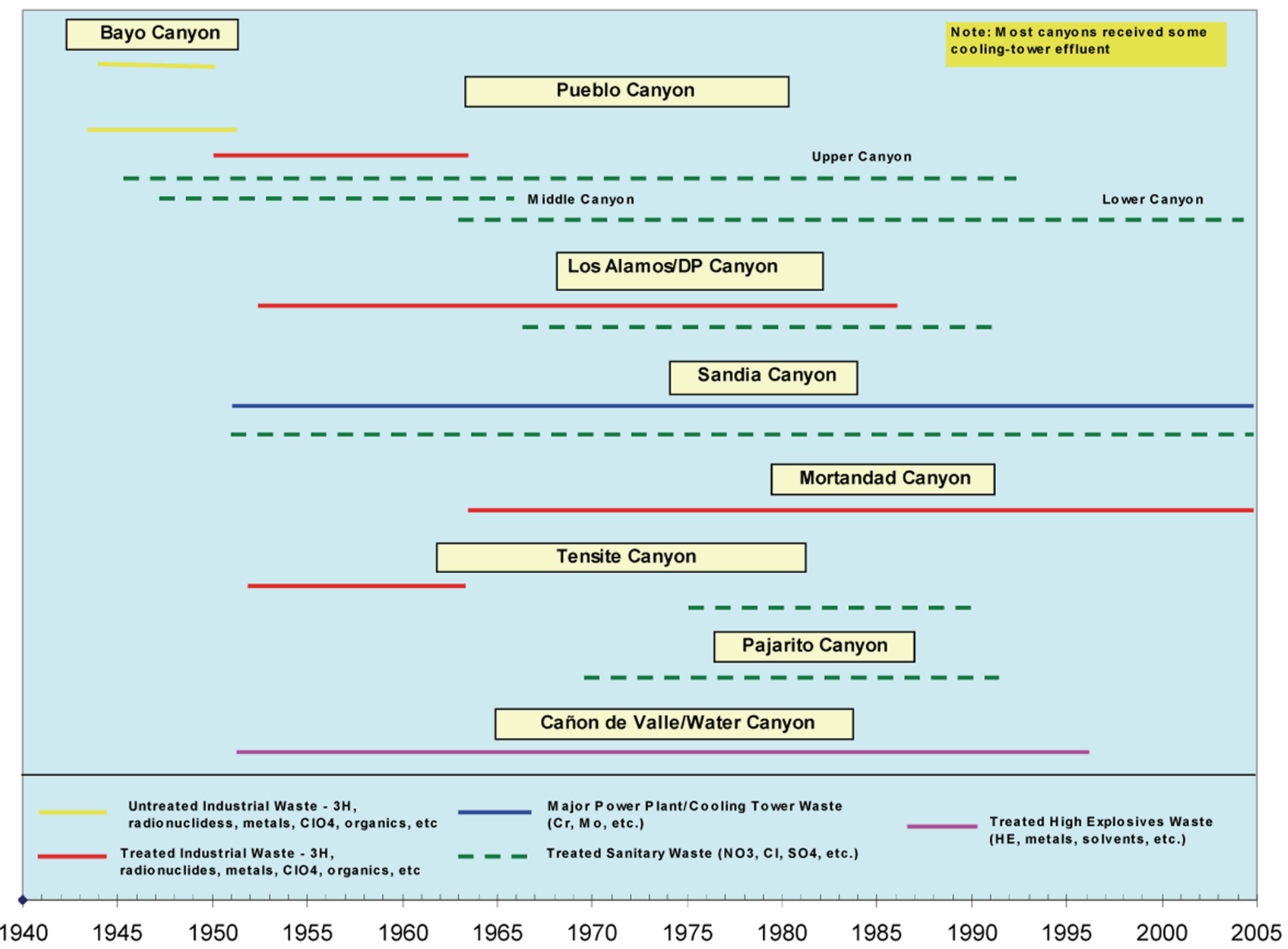

Figure 2-3 Timeline for major liquid waste releases at Los Alamos, New Mexico 


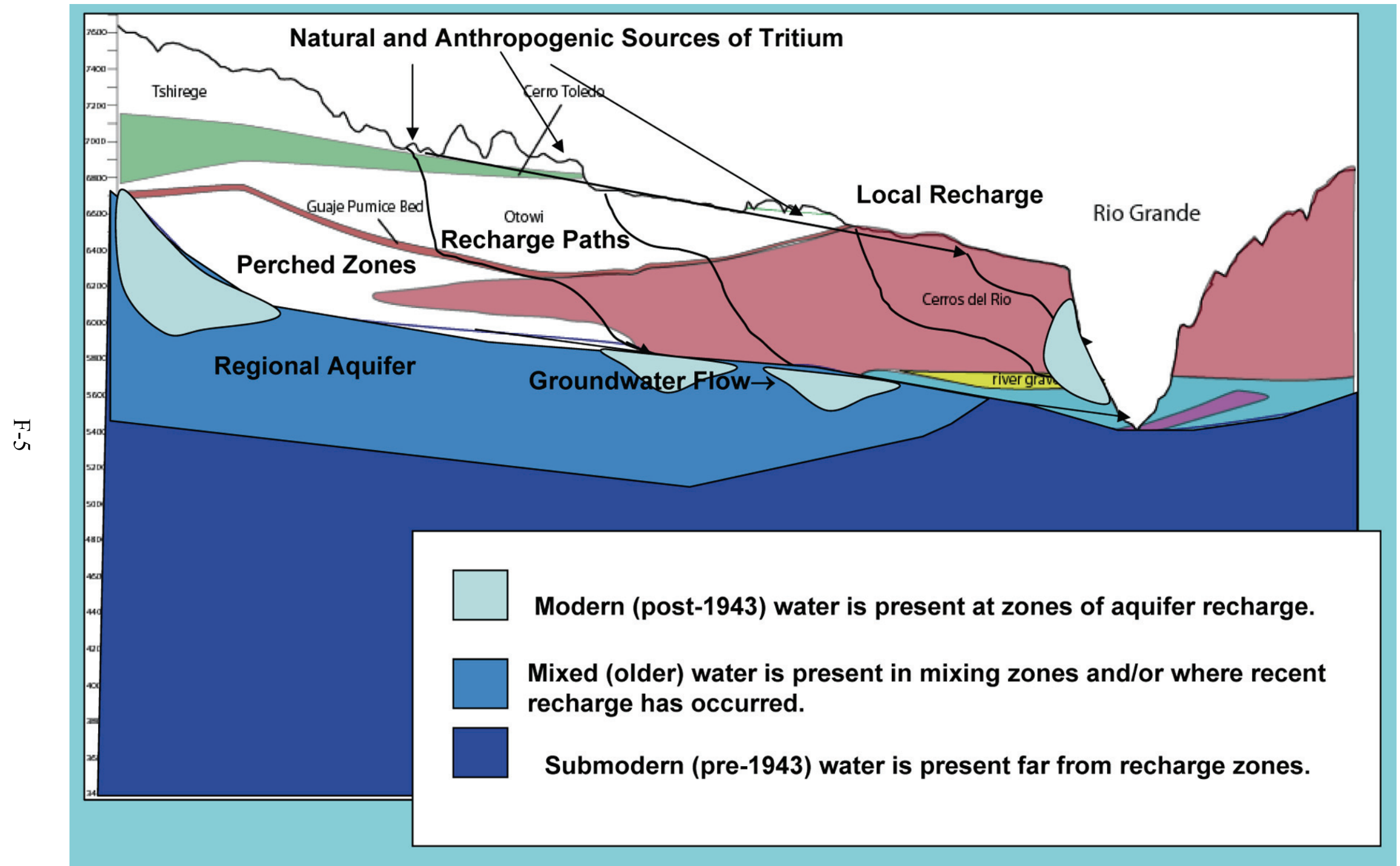

Figure 3-1 Generalized expected trends in groundwater age for conceptual model of groundwater flow 
F-6 


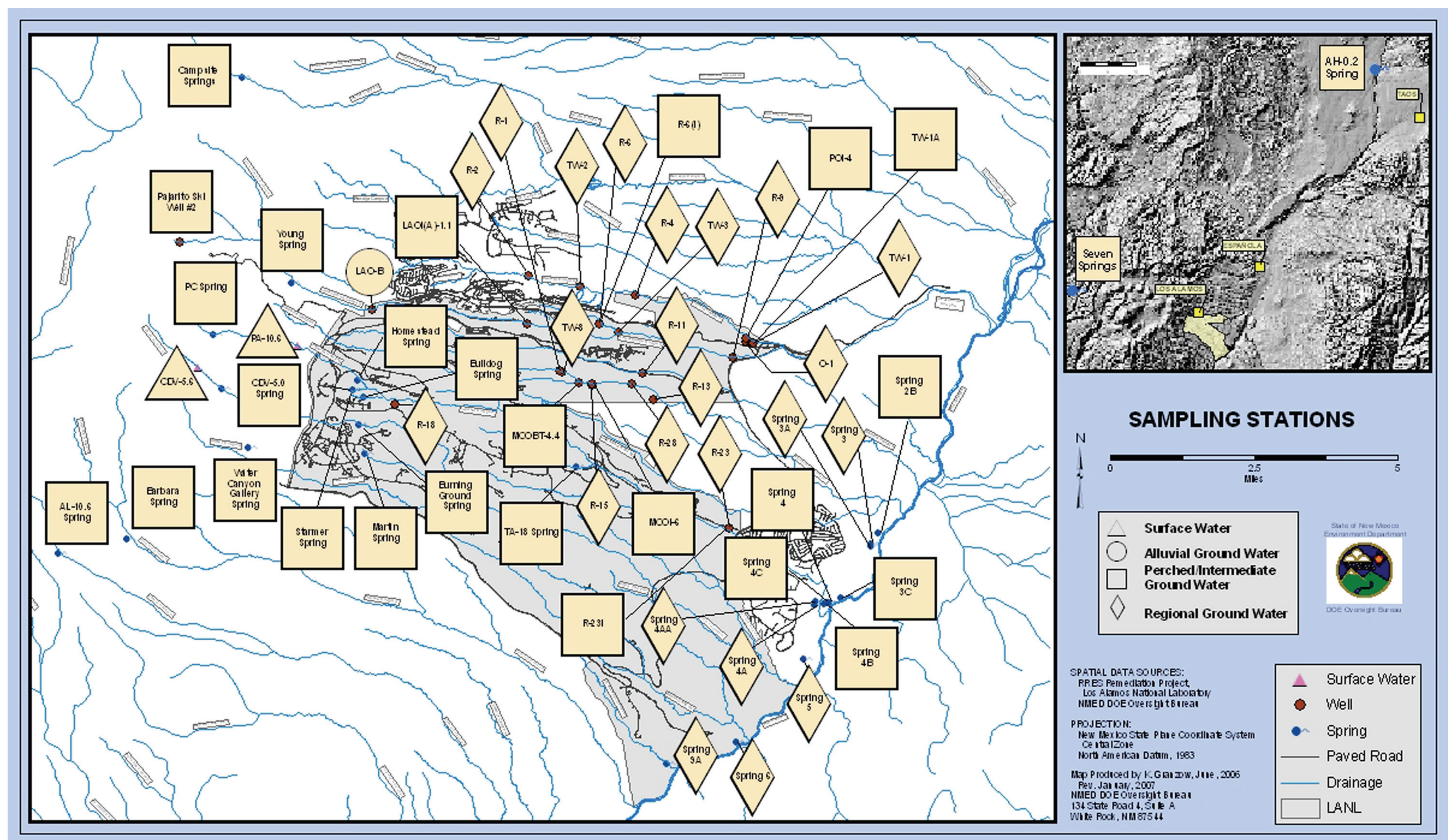

Fig 4-1 Mean DEL ${ }^{3} \mathrm{He}$ and $\mathrm{DEL}^{4} \mathrm{He}(\%)$ values 



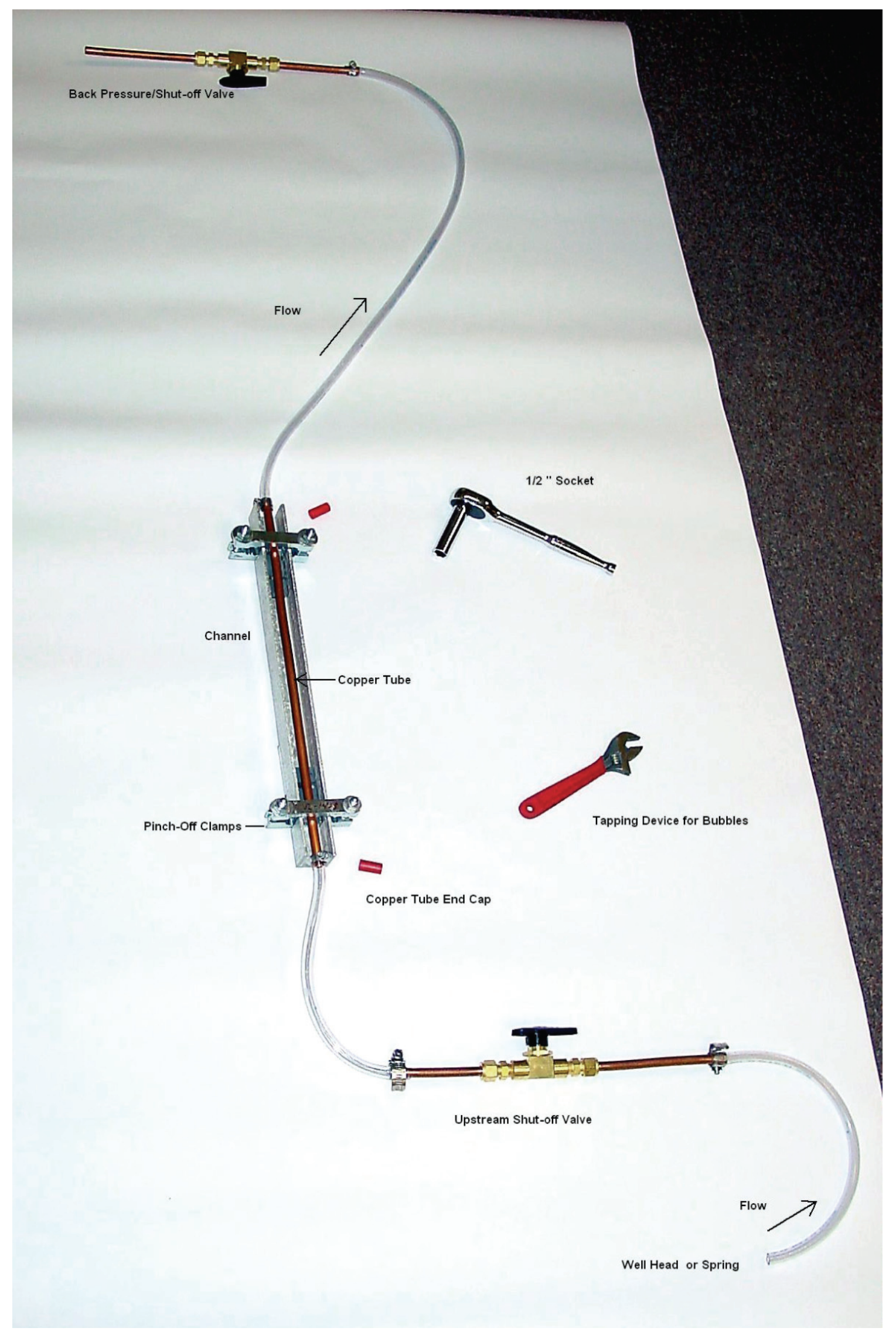

Figure 5-1 Noble-gas-sampling apparatus 


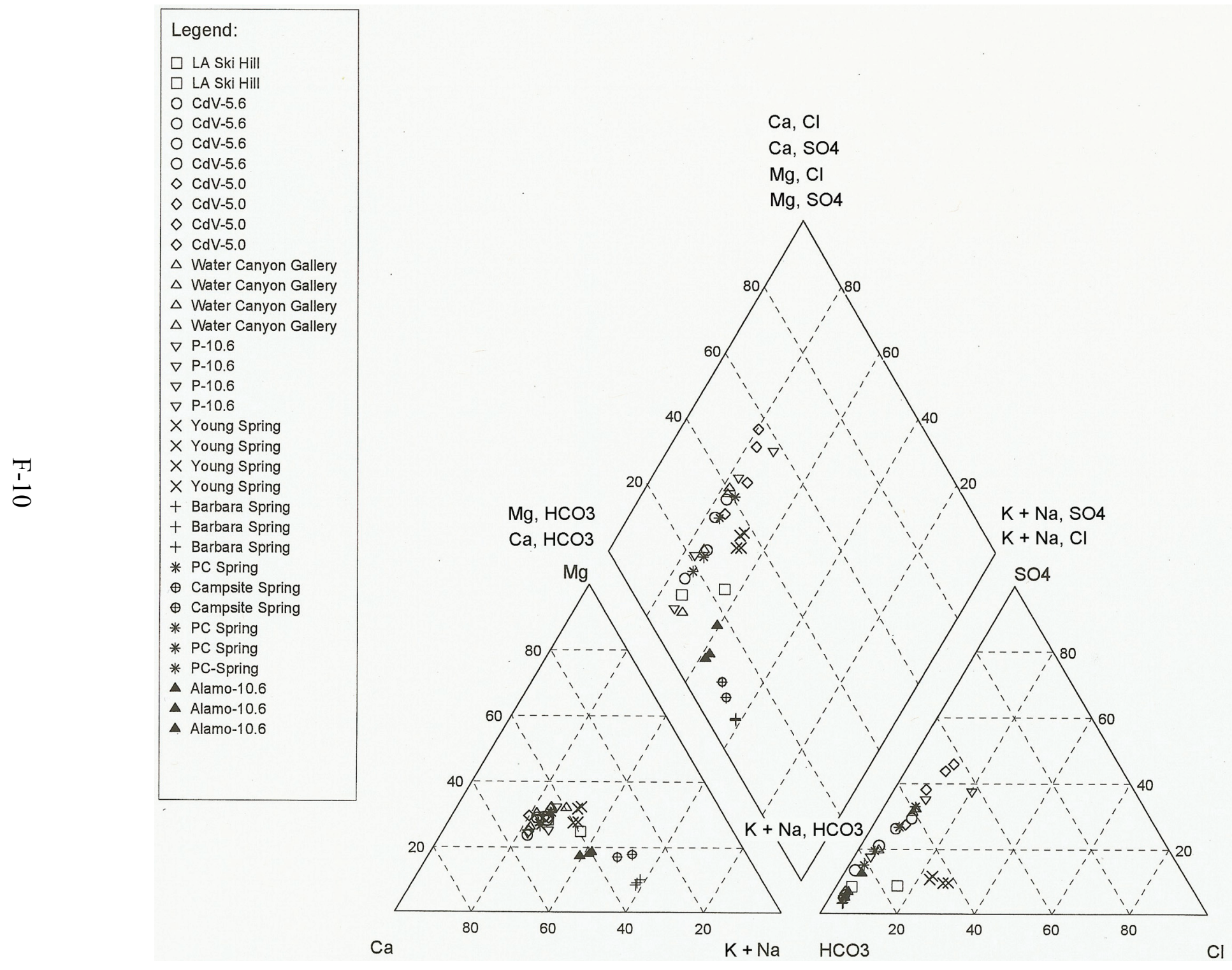

Figure 6-1 Trilinear diagram for Sierra de los Valles Springs 


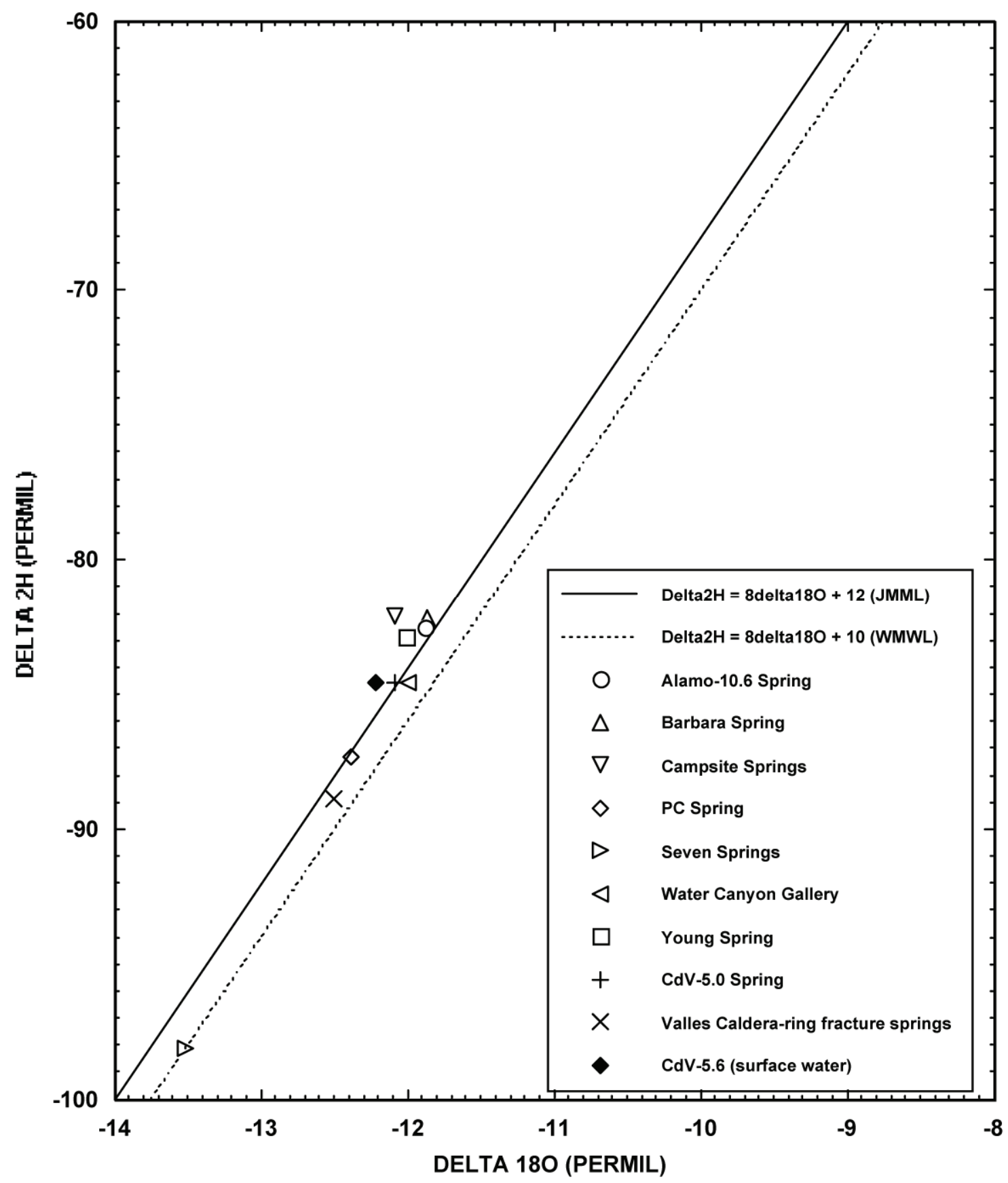

Figure 6-2 Distributions of average delta ${ }^{18} \mathrm{O}$ (shown in above graph as 180) (permil) versus delta ${ }^{2} \mathrm{H}$ (shown as $2 \mathrm{H}$ above) (permil) for surface water (CdV-5.6) and springs discharging within the Sierra de los Valles and Jemez Mountains (Seven Springs and Valles Caldera), New Mexico 


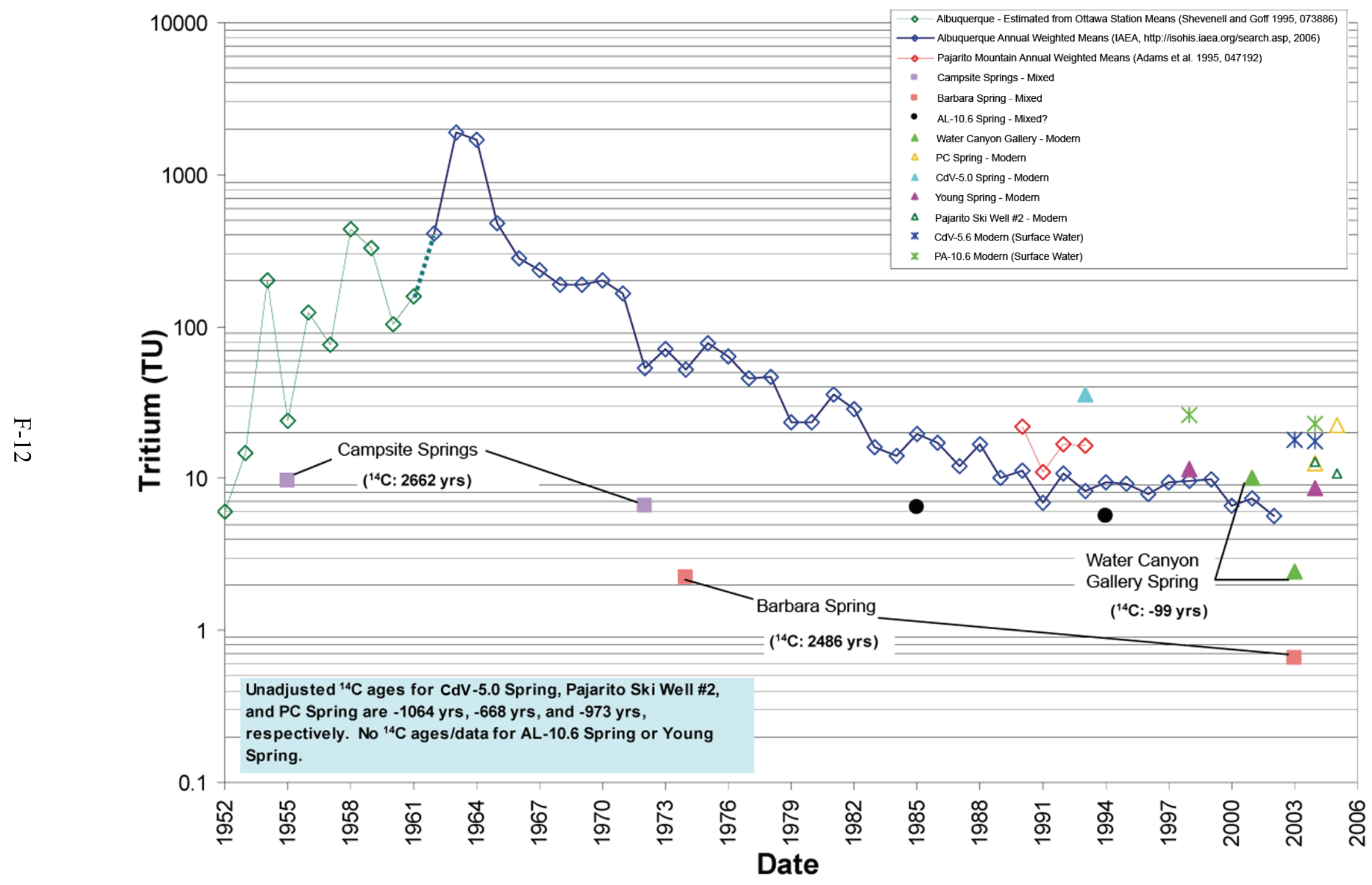

Figure 6-3 Atmospheric tritium curve and initial tritium activities for samples collected in the Sierra de los Valles, New Mexico 


Legend:
O LAO-B
O LAO-B
O LAO-B
$\square$ LAOI(A)-1.1
$+R-1$
$+R-1$
$\triangle R-2$
$\triangle R-2$
$\triangle R-2$
$\diamond R-18$
$\diamond R-18$

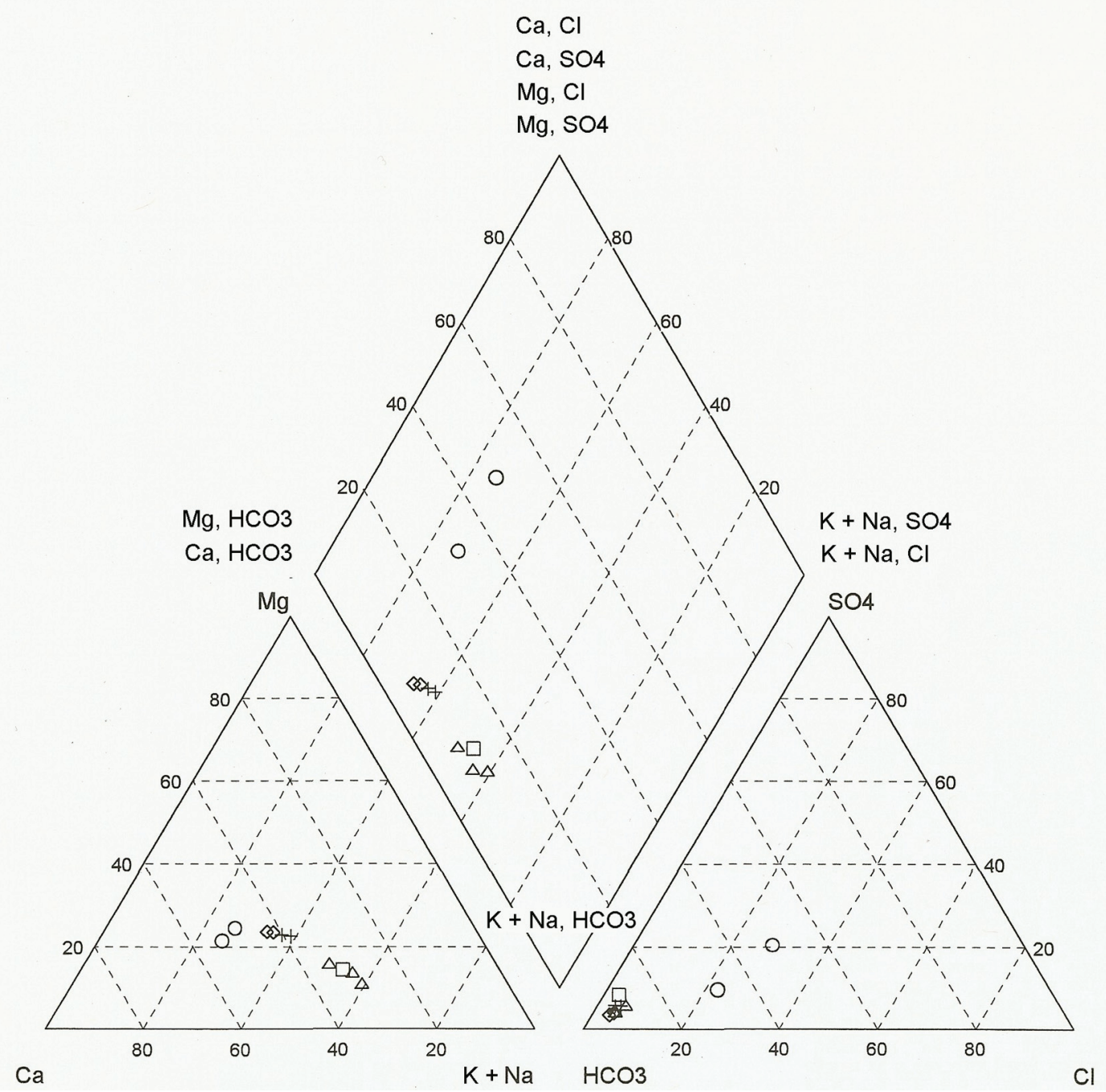

Figure 6-4 Trilinear diagram for background LANL groundwater 


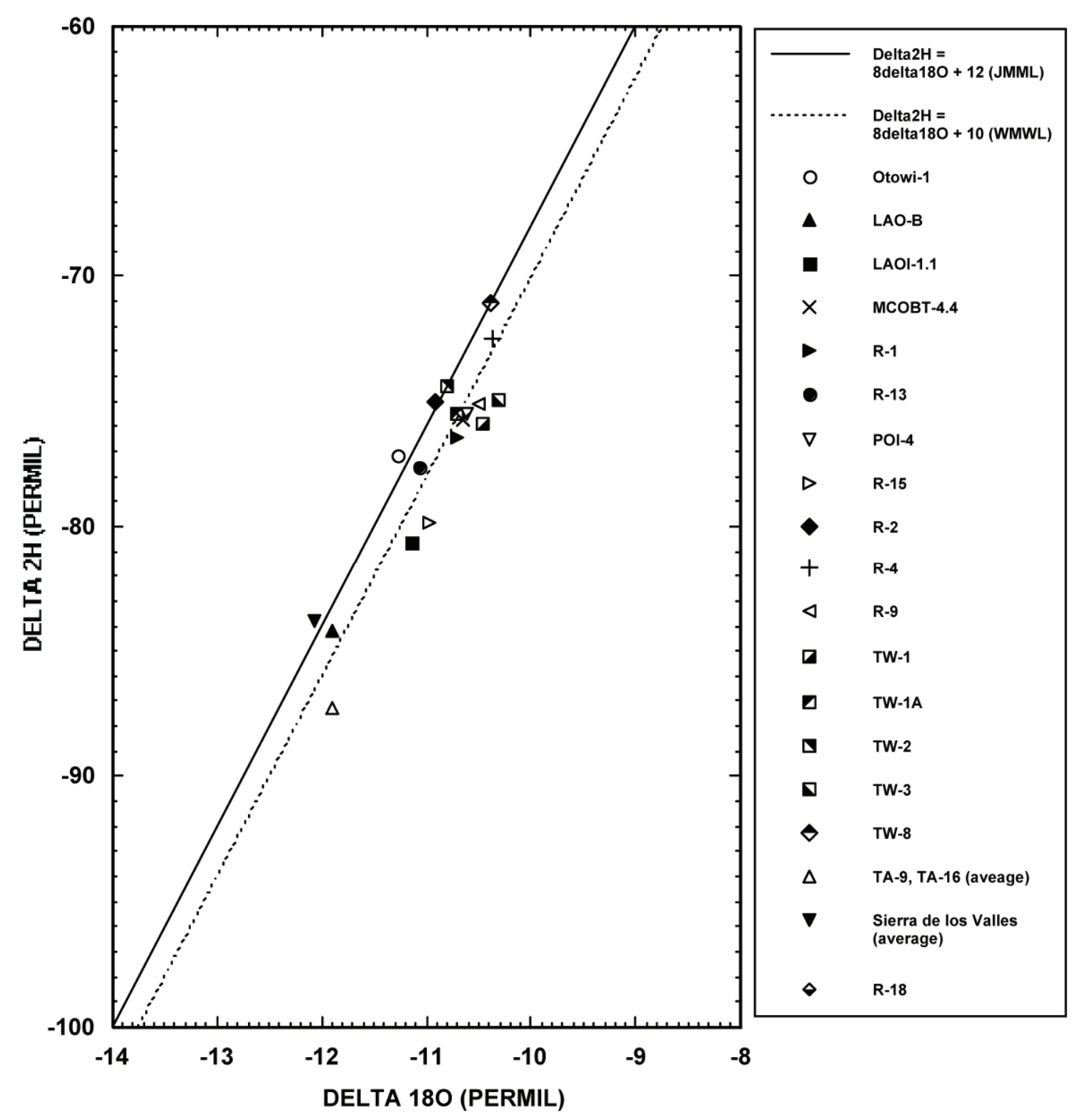

Figure 6-5 Distributions of average delta ${ }^{18} \mathrm{O}$ (shown in above graph as 180) (permil) versus delta ${ }^{2} \mathrm{H}$ (shown as $2 \mathrm{H}$ above) (permil) for LANL wells, TA-9 and TA-16 springs, and springs discharging within the Sierra de los Valles, New Mexico 


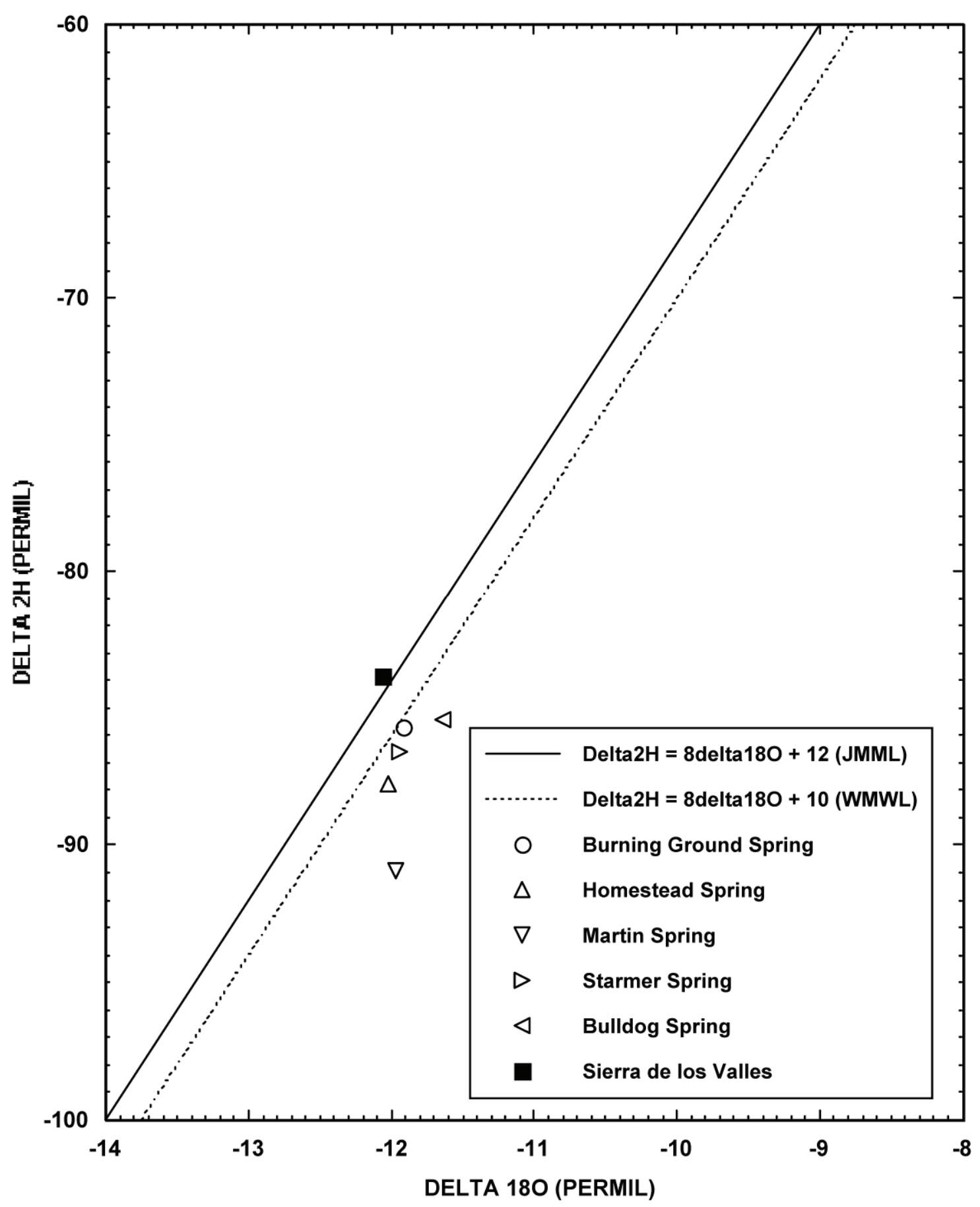

Figure 6-6 Distributions of average delta ${ }^{18} \mathrm{O}$ (shown in above graph as 180) (permil) versus delta ${ }^{2} \mathrm{H}$ (shown as $2 \mathrm{H}$ above) (permil) for TA-9 and TA-16 springs and surface water and springs discharging within the Sierra de los Valles, New Mexico 

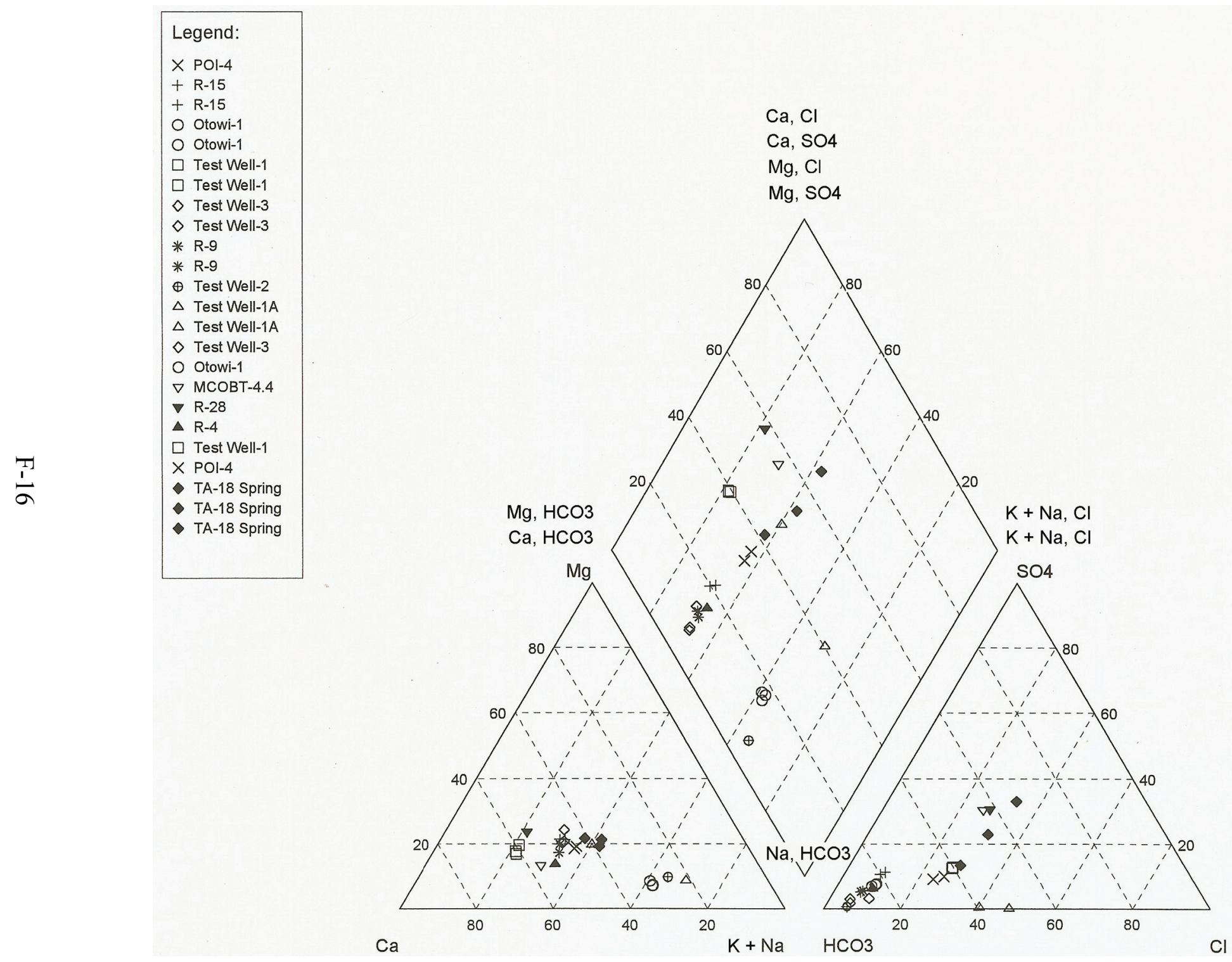

Figure 6-7 Trilinear diagram for LANL wells and springs 


\begin{tabular}{|l|}
\hline Legend: \\
$\square$ Bulldog Spring \\
$\square$ Bulldog Spring \\
$\square$ Bulldog Spring \\
$\bigcirc$ Burning Ground Spring \\
$\bigcirc$ Burning Ground Spring \\
$\bigcirc$ Burning Ground Spring \\
$\diamond$ Homestead Spring \\
$\diamond$ Homestead Spring \\
$\diamond$ Homestead Spring \\
$\times$ Martin Spring \\
$\times$ Martin Spring \\
$\nabla$ Starmer Spring \\
$\nabla$ Starmer Spring \\
$\nabla$ Starmer Spring \\
\hline
\end{tabular}

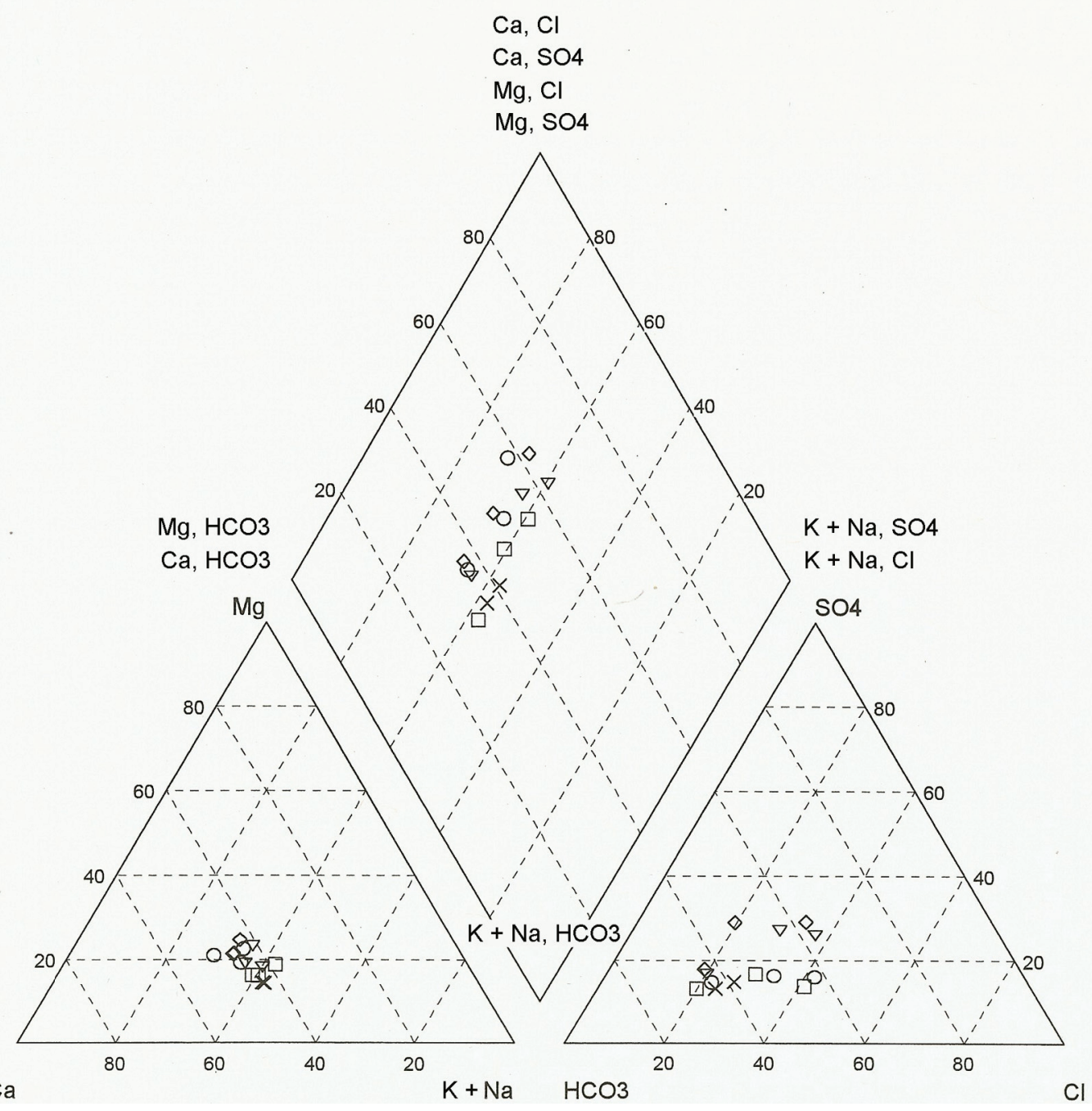

Figure 6-8 Trilinear diagram for TA-9 and TA-16 springs 


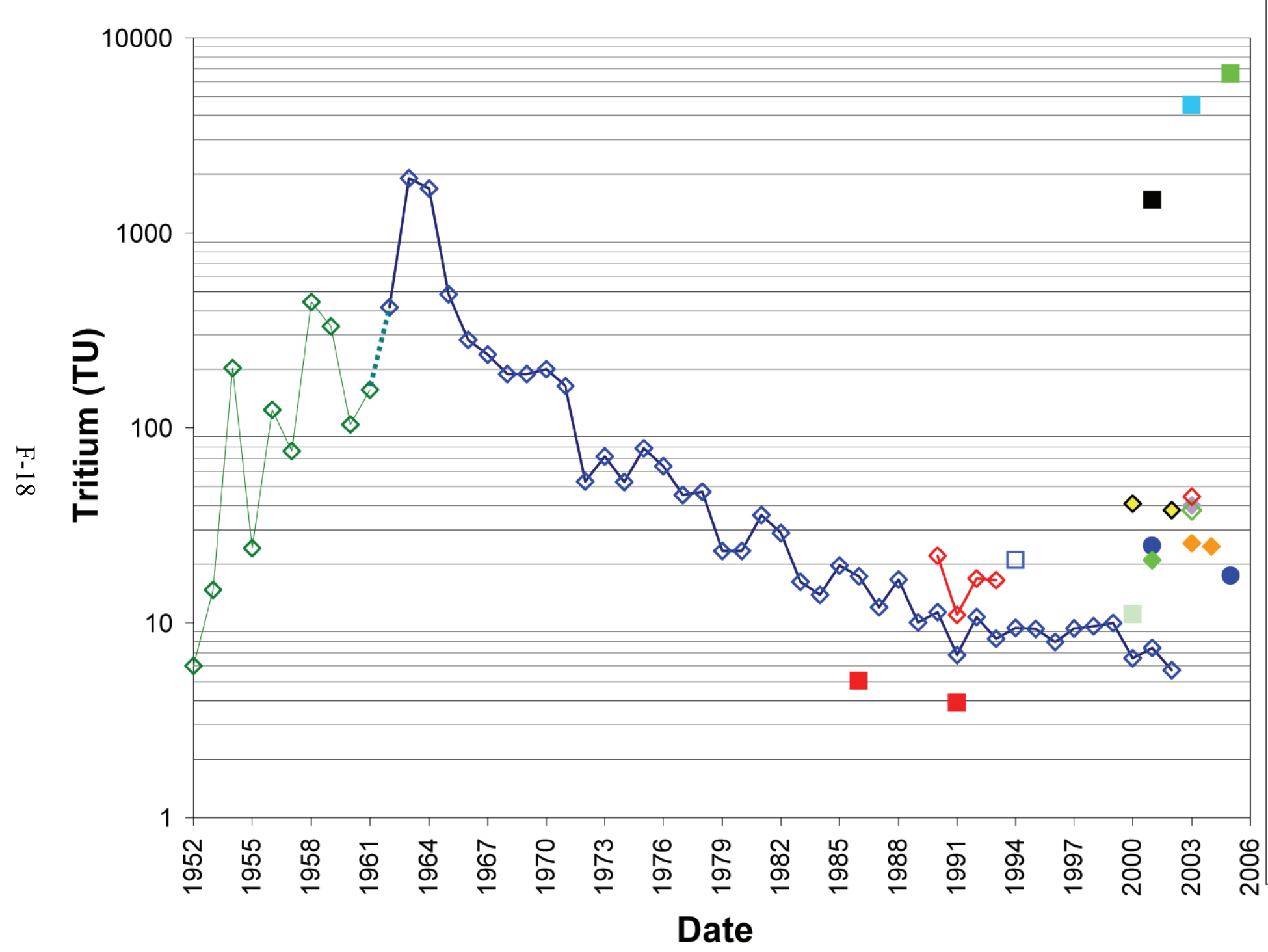

- Albuquerque - Estimate from Ottawa Station Means (Shevenell and Goff 1995, 073886)

$\multimap$ Albuquerque Annual Weighted Means (IAEA, http://isohis jaea. org/search.asp, 2006)

$\multimap$ Pajarito Mountain Annual Weighted Means (Adams et al. 1995, 047192)

- LAO-B - Modern (Alluvial)

- Homestead Spring - Modern (Perched Volcanics)

- Starmer Spring - Modern (Perched Volcanics)

Bulldog Spring - Modern (Perched Volcanics)

- Burning Ground Spring - Modern (Perched Volcanics)

ه Martin Spring - Modern (Perched Volcanics)

ه TA-18 Spring - Modern (Perched Volcanics)

ㅁ. POI-4 - Mixed? (Intermediate)

- R-6i - Mixed? (Intermediate)

- LAOI(A)-1.1 - Mixed? (Intermediate)

ㅁ TW-1A - Mixed? (Intermediate)

MCOI-6 - Mixed? (Intermediate)

MCOBT-4 4 - Mixed? (Intermediate)

Figure 6-9 Atmospheric tritium curve and initial tritium activities for samples collected beneath the Pajarito Plateau - perched alluvial and volcanics, and intermediate aquifers 


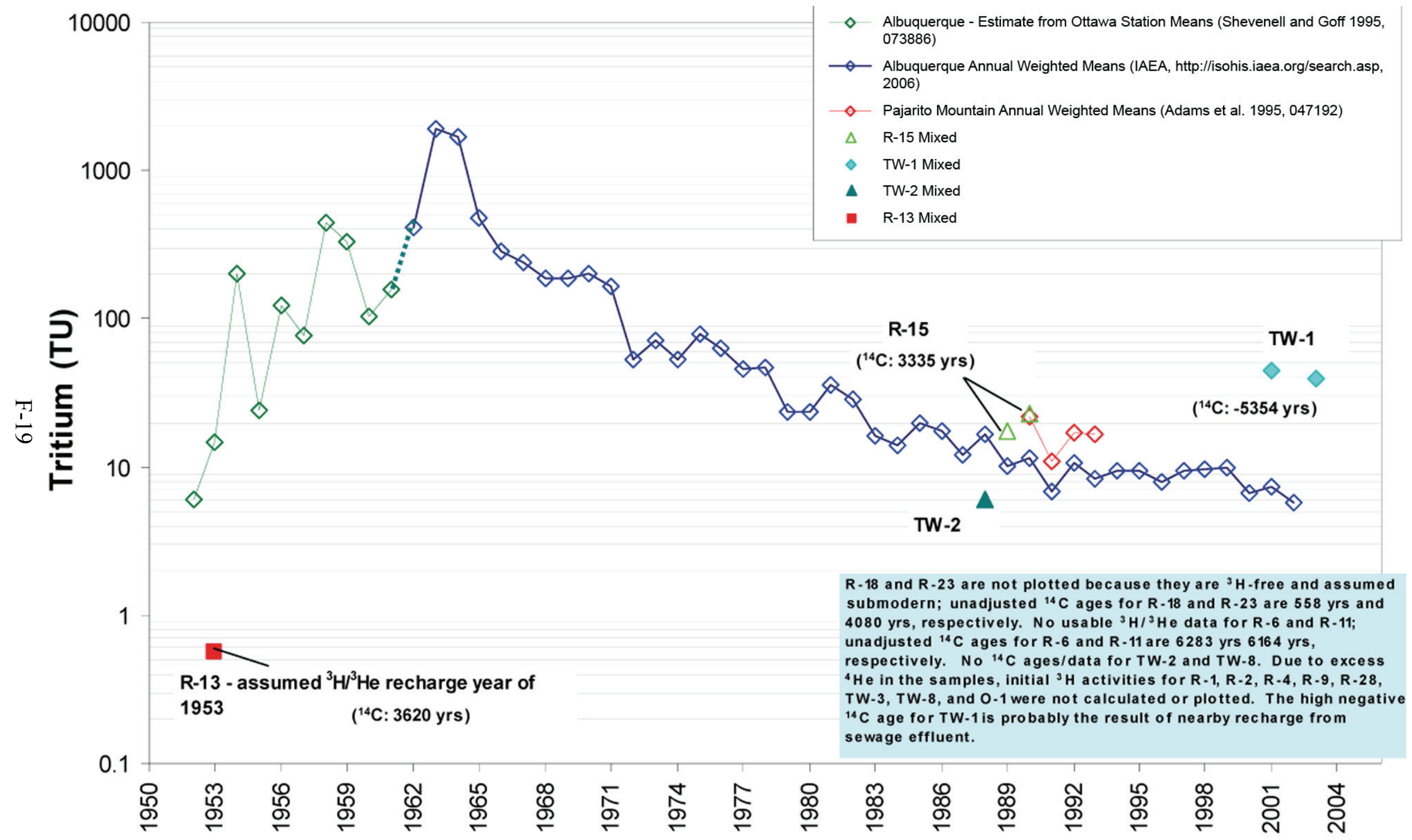

Figure 6-10 Atmospheric tritium curve and initial tritium activities for samples collected from the regional aquifer beneath the Pajarito Plateau 


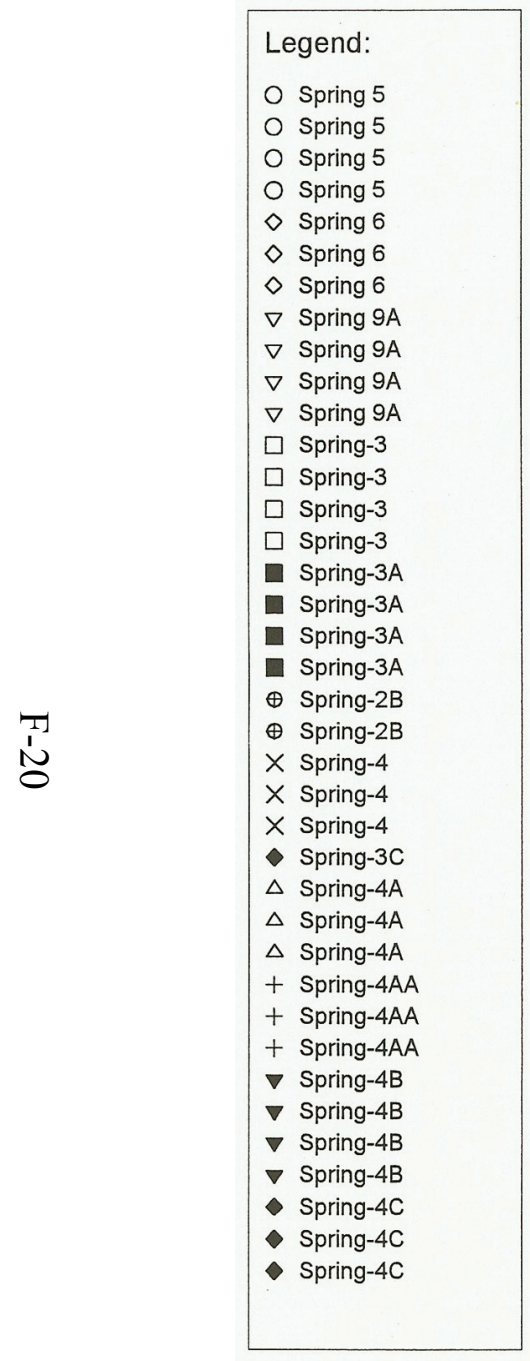

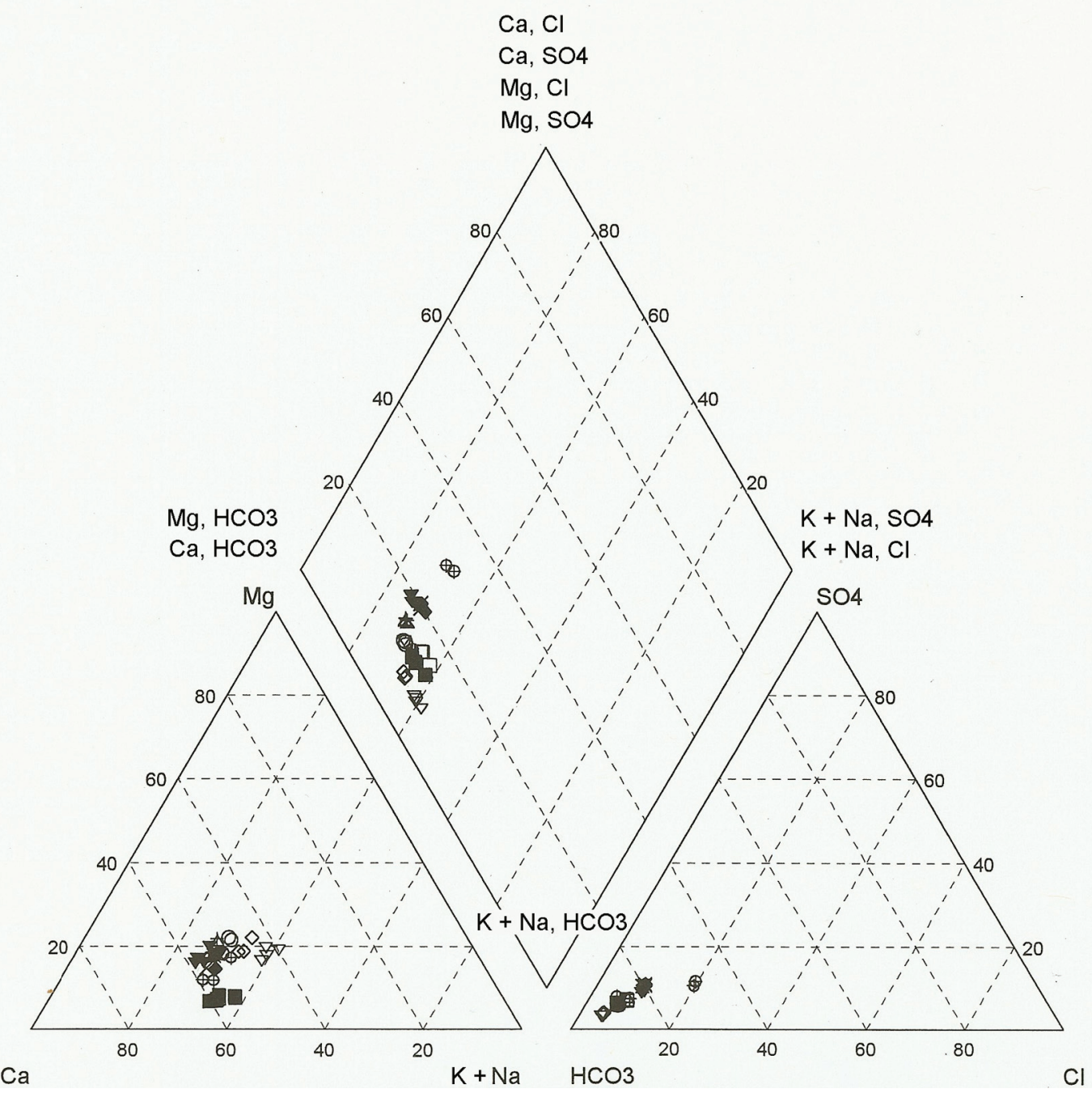

Figure 6-11 Trilinear diagram for White Rock Canyon springs 


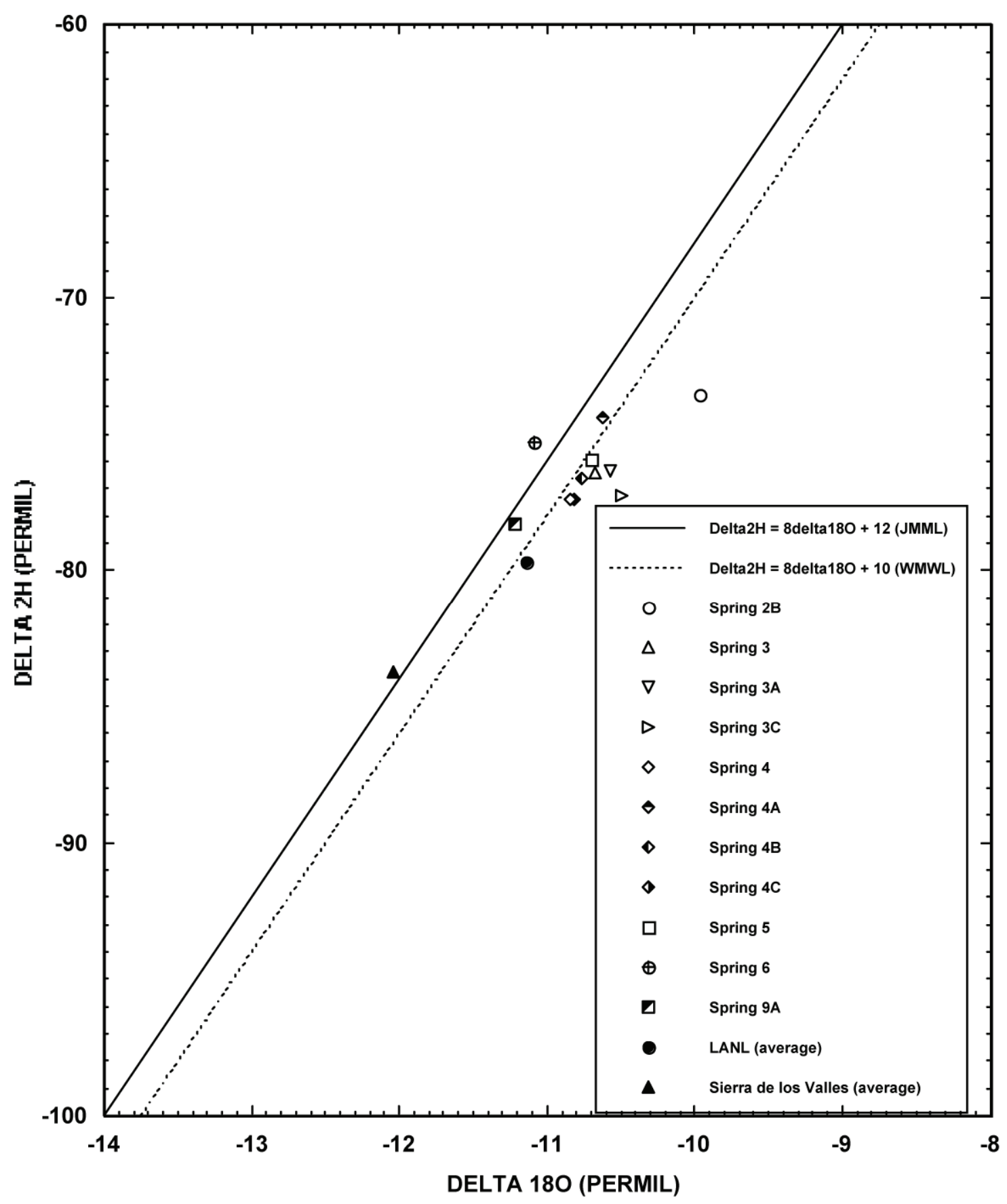

Figure 6-12 Distributions of average delta ${ }^{18} \mathrm{O}$ (shown in above graph as 180) (permil) versus delta ${ }^{2} \mathrm{H}$ (shown as $2 \mathrm{H}$ above) (permil) for White Rock Canyon springs, LANL wells and springs, and surface water and springs discharging within the Sierra de los Valles, New Mexico 


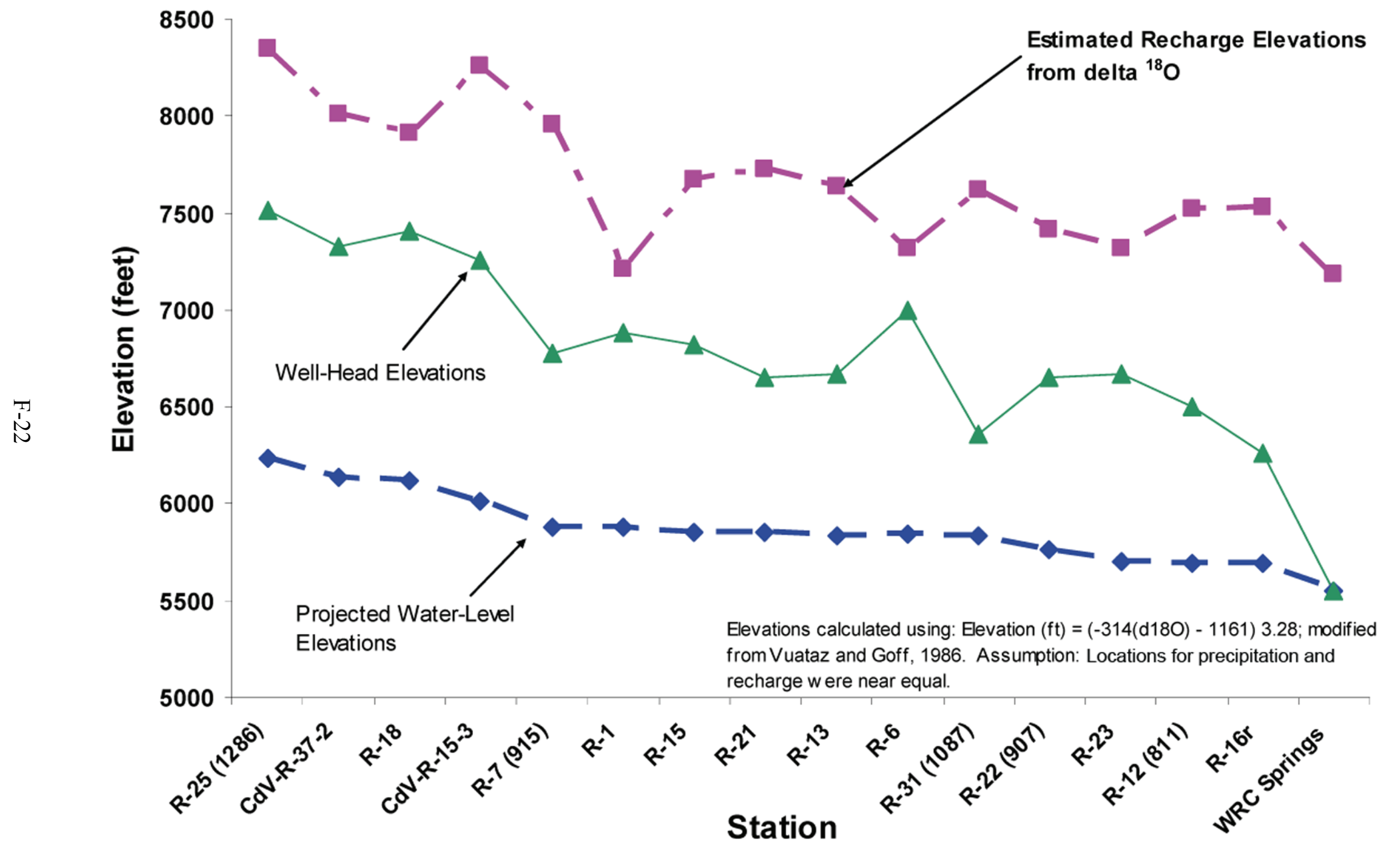

Figure 6-13 Calculated recharge elevations as determined by stable isotope data for the regional aquifer water table sloping from west to east 


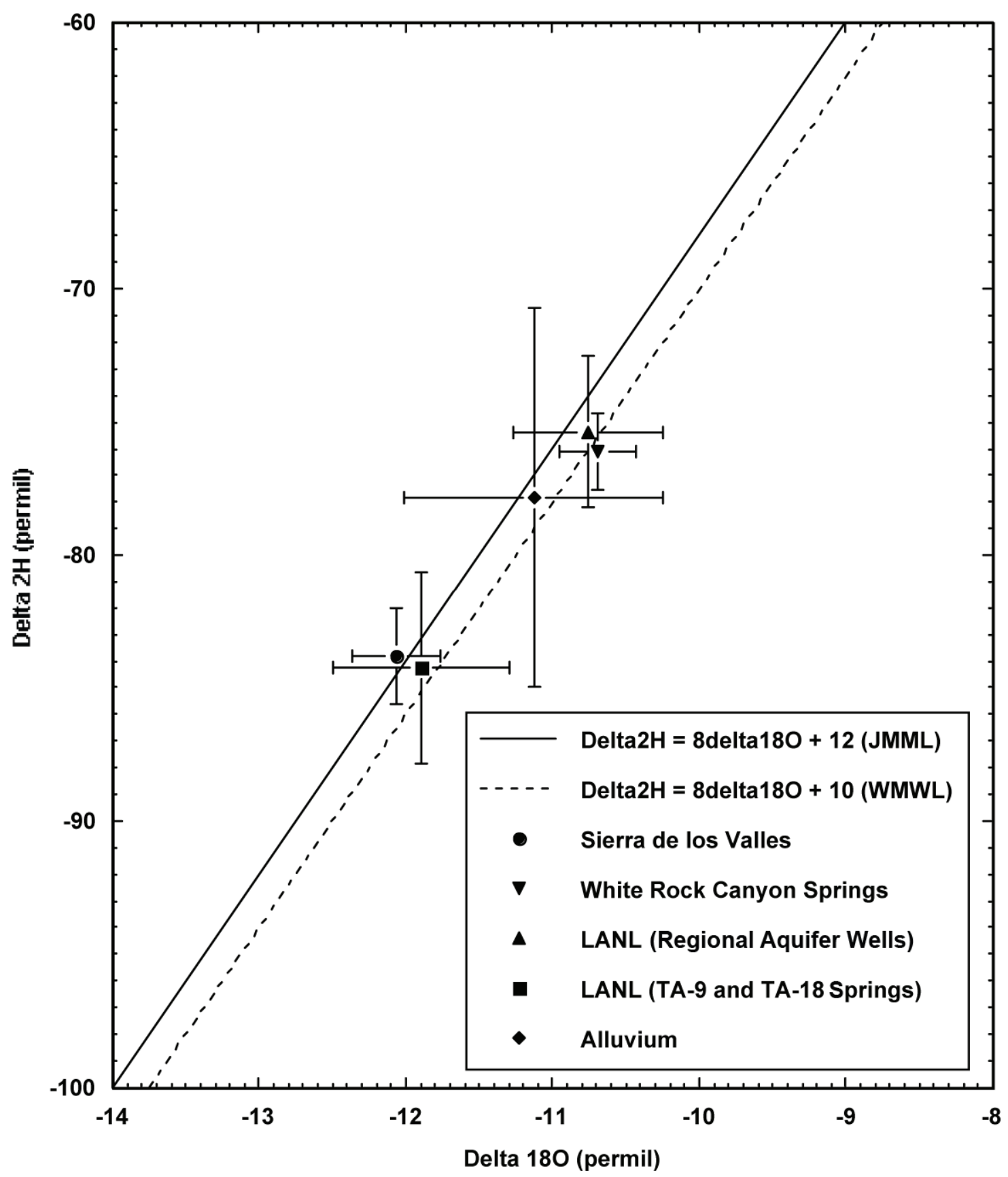

Figure 6-14 Distributions of average delta ${ }^{18} \mathrm{O}$ (shown in above graph as 180) (permil) versus delta ${ }^{2} \mathrm{H}$ (shown as $2 \mathrm{H}$ above) (permil) for groupings of White Rock Canyon springs, LANL regional aquifer wells and springs, and surface water and springs discharging within the Sierra de los Valles, New Mexico. One standard deviation for delta ${ }^{18} \mathrm{O}$ and delta ${ }^{2} \mathrm{H}$ of samples is shown as error bars. 


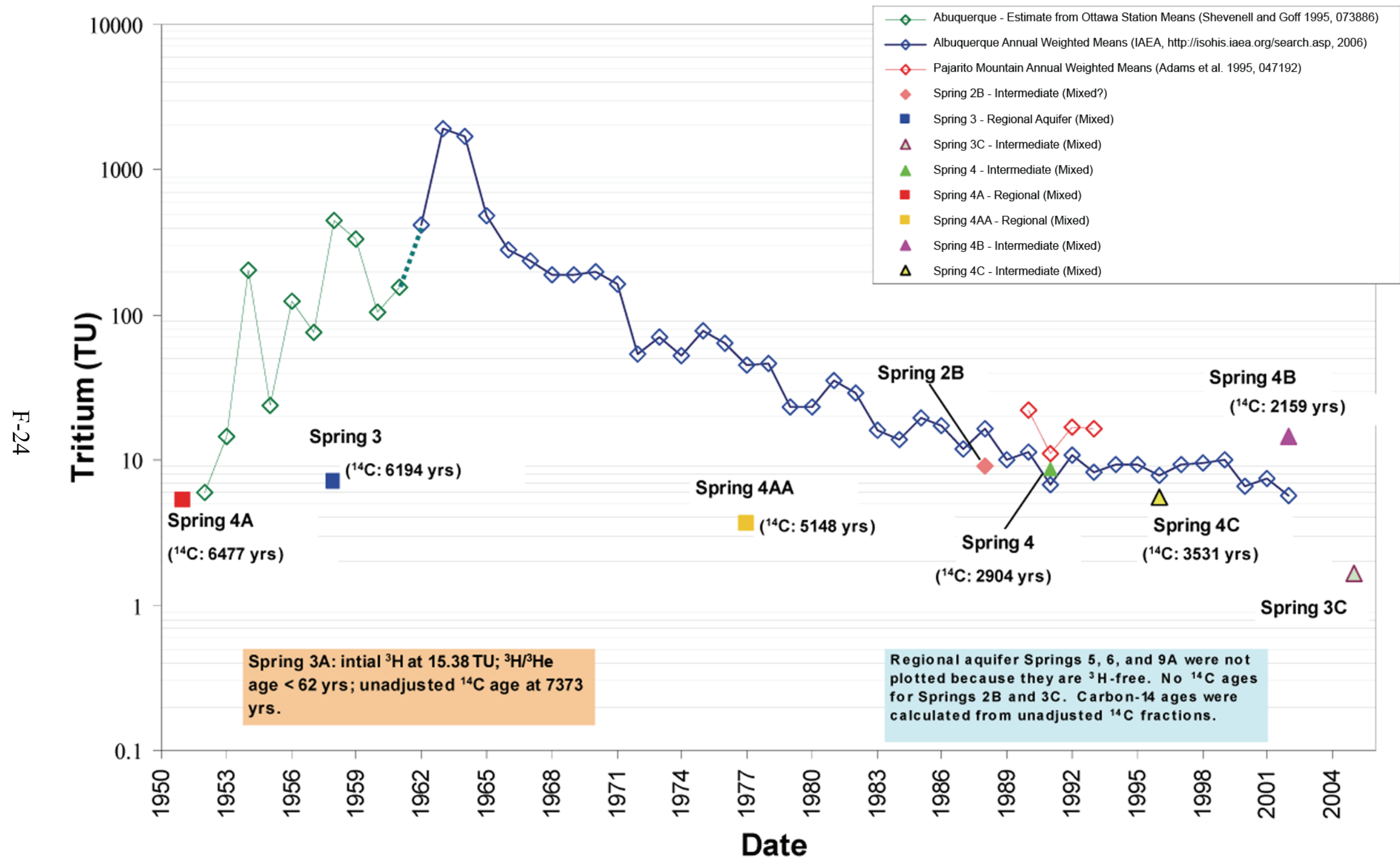

Figure 6-15 Atmospheric tritium curve and initial tritium activities for samples collected at the White Rock Canyon springs 


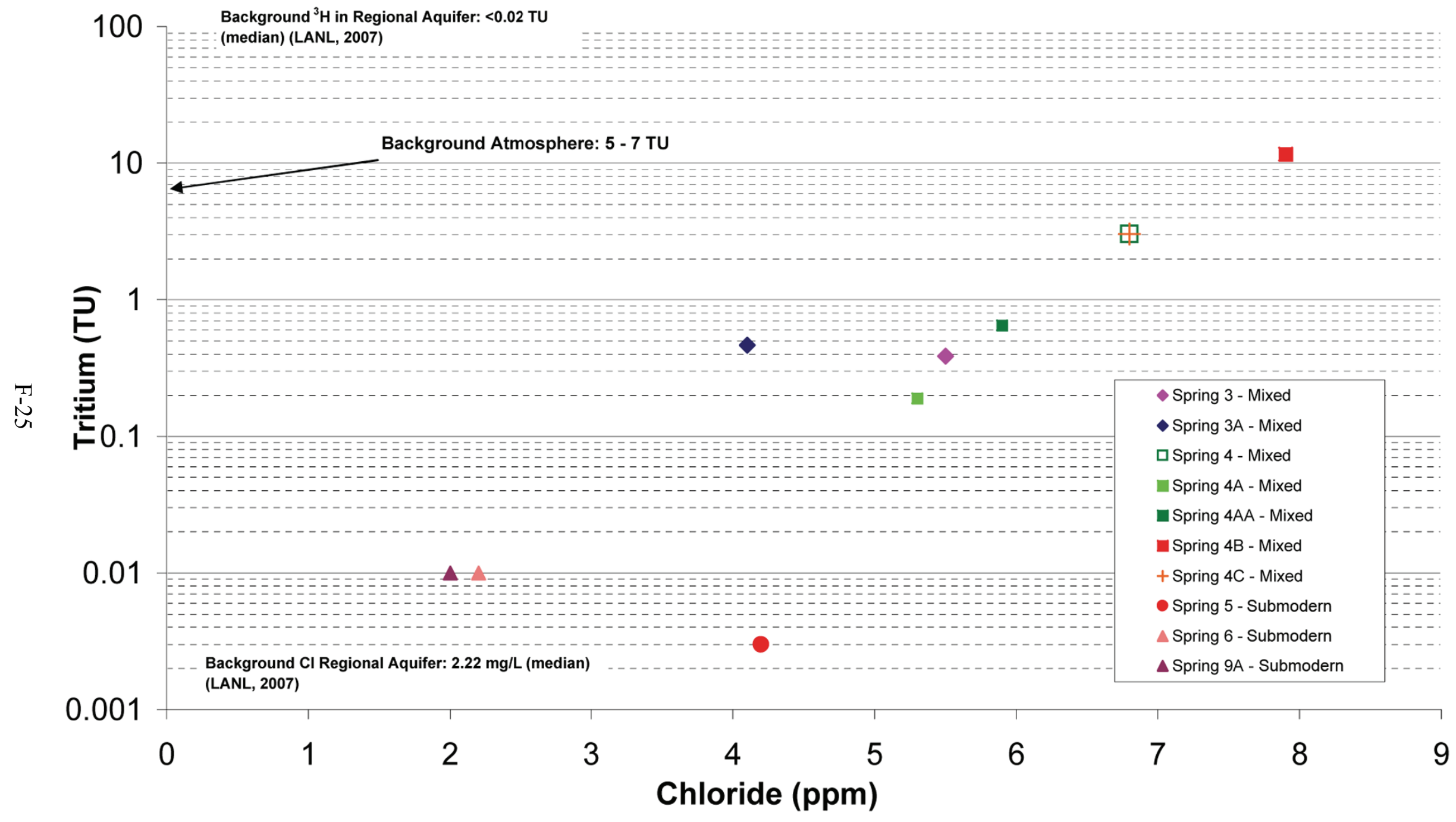

Figure 6-16 Chloride (ppm) versus tritium (TU) for samples collected at the White Rock Canyon springs. (Regional aquifer information is taken from "Groundwater Backaround Investiqation Report, Revision 2" [LANL 2007, 094856l. Atmosphere information is taken from this report.) 


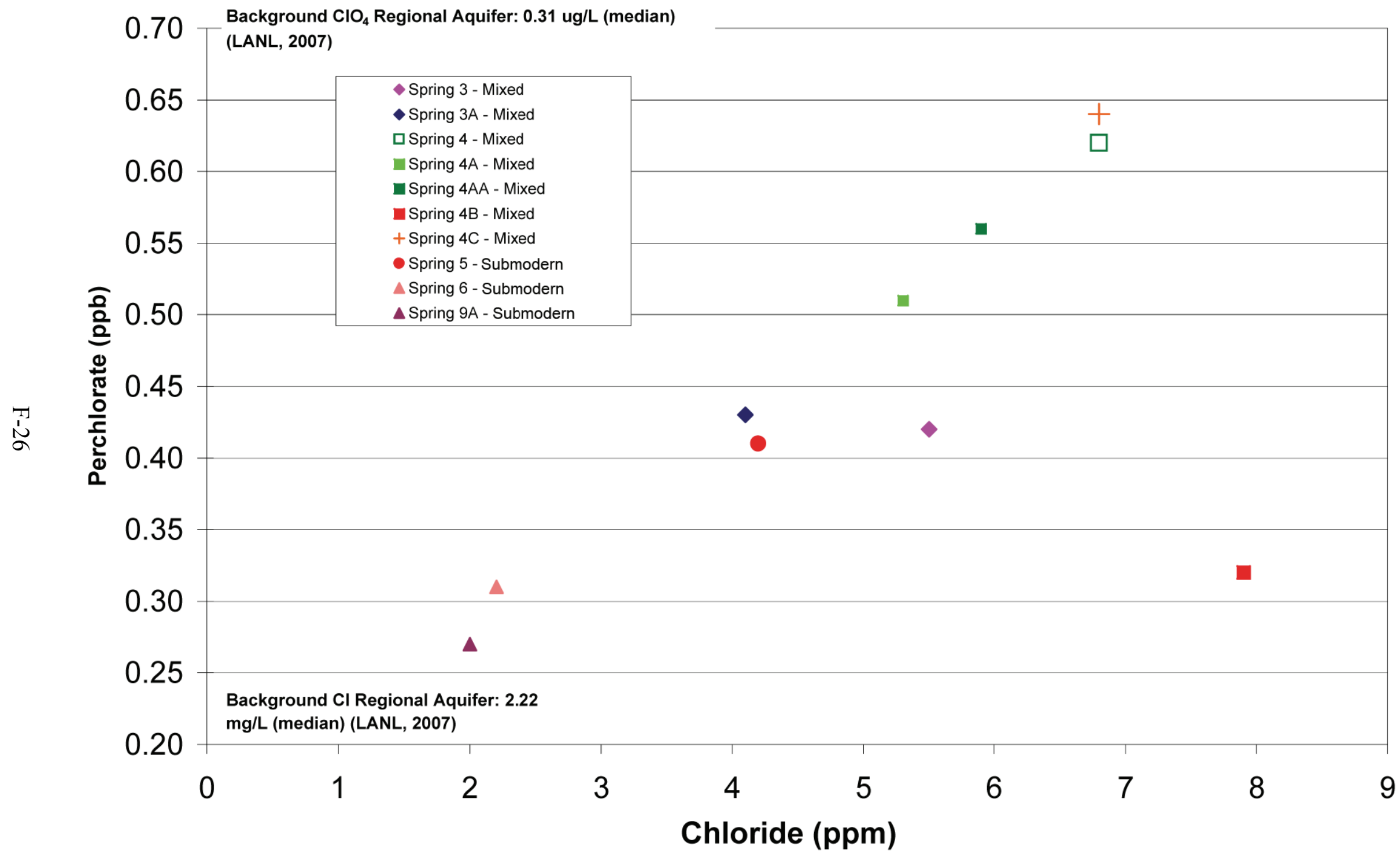

Figure 6-17 Chloride (ppm) versus perchlorate (ppb) for samples collected from the White Rock Canyon springs. (Regional aquifer information is taken from "Groundwater Backaround Investiqation Report. Revision 2" [LANL 2007, 094856].) 


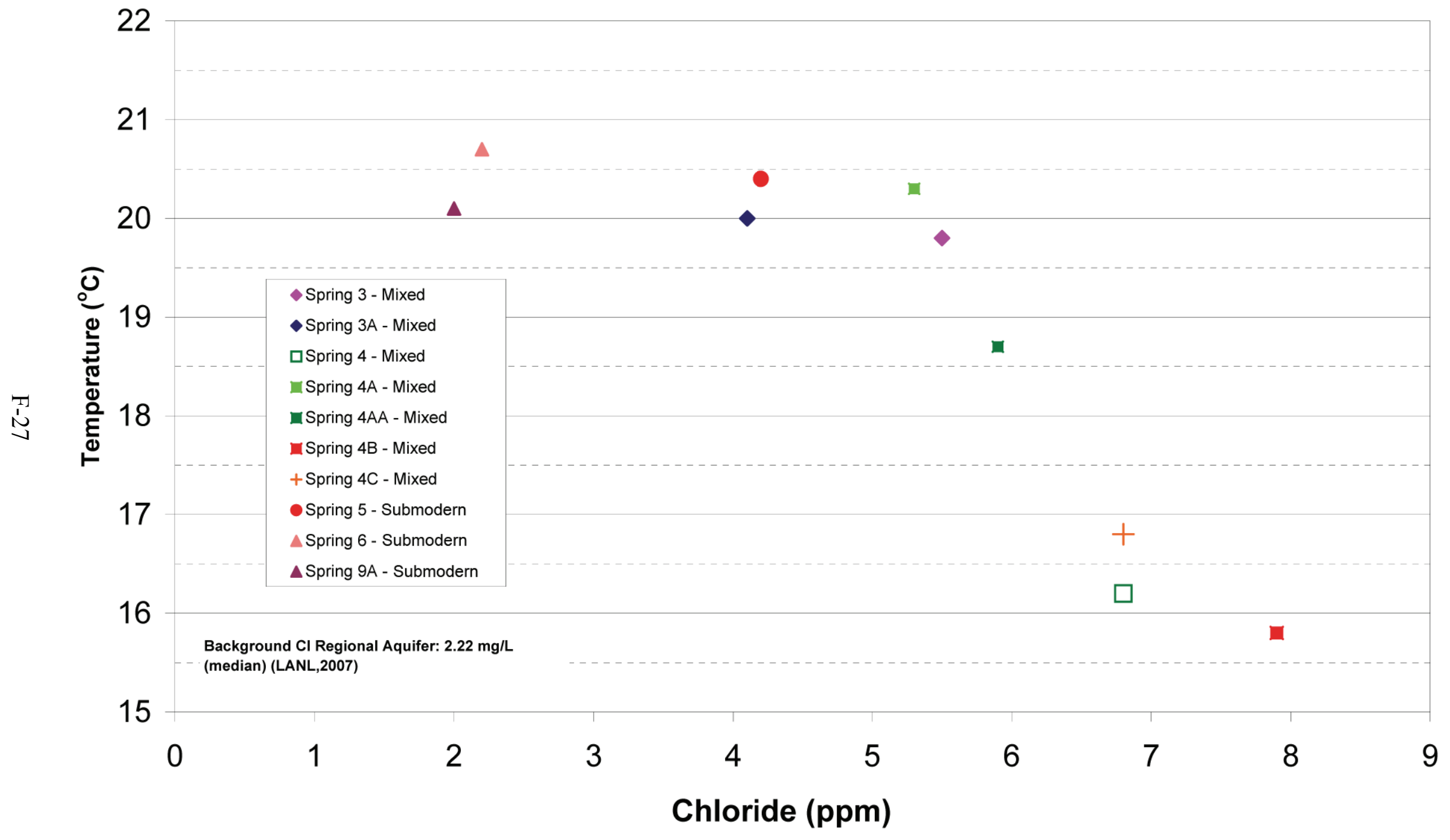

Figure 6-18 Chloride (ppm) versus temperature $\left({ }^{\circ} \mathrm{C}\right)$ for samples collected from the White Rock Canyon springs. (Regional aquifer information is taken from "Groundwater Background Investigation Report, Revision 2" [LANL 2007, 094856].) 


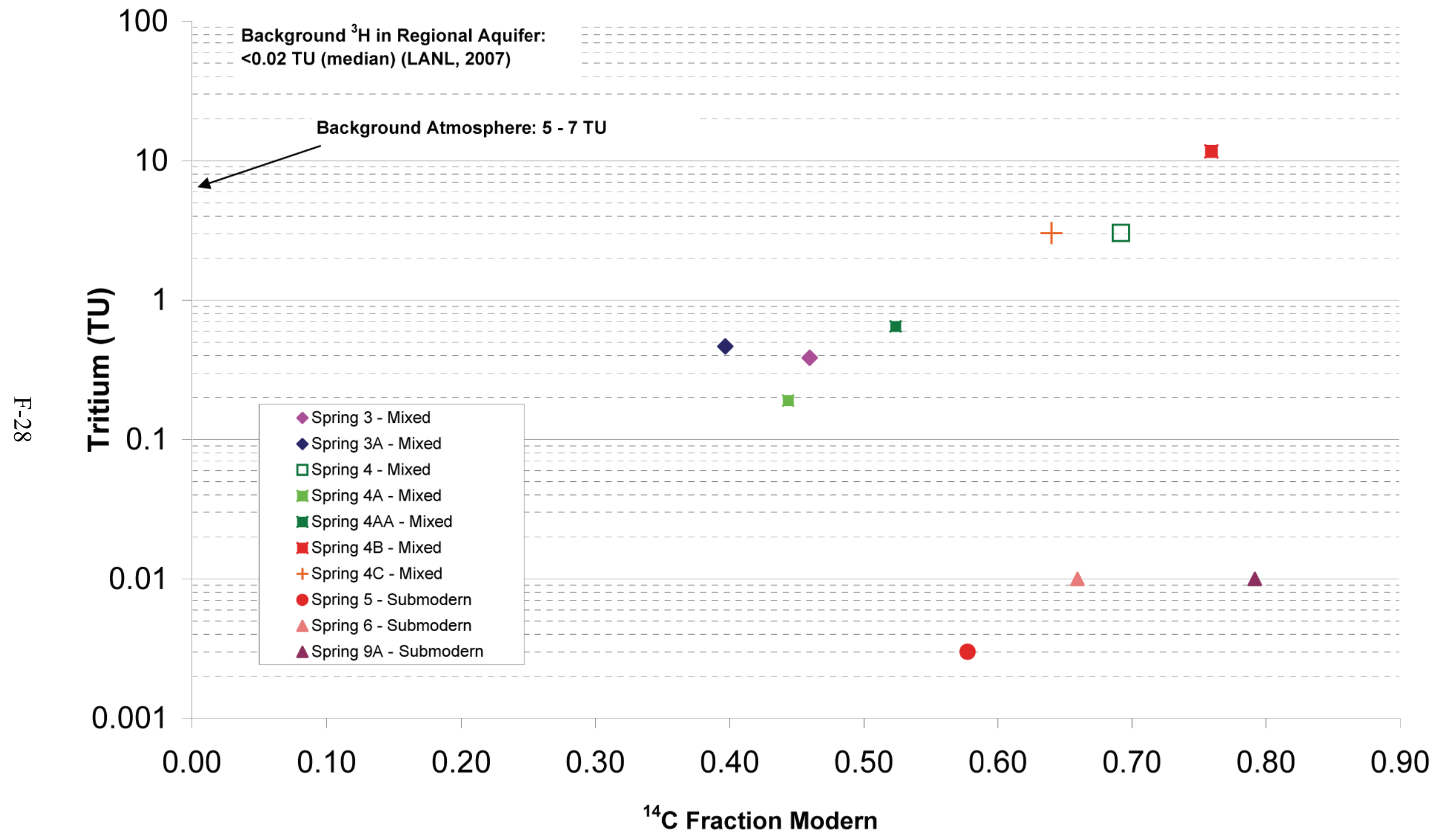

Figure 6-19 Fraction modern ${ }^{14} \mathrm{C}$ versus tritium (TU) for samples collected from the White Rock Canyon springs. (Regional aquifer information is taken from "Groundwater Background Investigation Report, Revision 2" [LANL 2007, 094856]. Atmosphere information is taken from this report.) 


\section{Table 2-1}

Background Values for Key Mobile Dissolved Chemicals Used in this Isotope-Geochemical Investigation

\begin{tabular}{|c|c|c|c|c|c|c|c|c|c|c|c|}
\hline \multirow{2}{*}{ Analyte } & \multirow{2}{*}{ Units } & \multicolumn{5}{|c|}{ Regional Aquifer } & \multicolumn{5}{|c|}{ Intermediate Perched Aquifers } \\
\hline & & Count & Non-Detects & Minimum $^{a}$ & Median & Maximum & Count & Non-Detects & Minimum $^{a}$ & Median & Maximum \\
\hline Chloride & $\mathrm{mg} / \mathrm{L}$ & 121 & 0 & 1.20 & 2.22 & 7.56 & 22 & 0 & 0.98 & 1.37 & 6.43 \\
\hline Fluoride & $\mathrm{mg} / \mathrm{L}$ & 158 & 15 & 0.07 & 0.32 & 0.63 & 22 & 0 & 0.04 & 0.12 & 0.20 \\
\hline $\begin{array}{l}\text { Nitrate plus nitrite } \\
(\text { as N) }\end{array}$ & $\mathrm{mg} / \mathrm{L}$ & 156 & 14 & 0.01 & 0.33 & 1.05 & na & na & na & na & na \\
\hline Nitrate (as N) & $\mathrm{mg} / \mathrm{L}$ & na & na & na & na & na & 20 & 0 & 0.18 & 0.34 & 1.78 \\
\hline Perchlorate & $\mu \mathrm{g} / \mathrm{L}$ & 74 & 1 & 0.09 & 0.31 & 0.44 & 1 & 0 & 0.18 & 0.18 & 0.18 \\
\hline Sulfate & $\mathrm{mg} / \mathrm{L}$ & 121 & 2 & 0.80 & 2.90 & 8.63 & 22 & 0 & 1.07 & 4.08 & 34.80 \\
\hline Uranium & $\mu \mathrm{g} / \mathrm{L}$ & 78 & 3 & 0.06 & 0.45 & 2.5 & 21 & 9 & 0.10 & 0.30 & 0.60 \\
\hline \multicolumn{12}{|c|}{$\begin{array}{l}\text { Source of values: Groundwater Background Investigation Report, Rev. } 2 \text { (LANL 2007, 094856), Tables } 4.2-2 \text { and 4.2-3. } \\
\text { Note that "na" means "not applicable." } \\
\text { a Minimum is set at one-half the method detection limit if the analyte was not detected in one of the samples. } \\
\text { Mean concentrations of chloride, fluoride, nitrate (as N), sulfate, and uranium are } 2.07 \mathrm{mg} / \mathrm{L}, 0.11 \mathrm{mg} / \mathrm{L}, 0.49 \mathrm{mg} / \mathrm{L}, 8.30 \mathrm{mg} / \mathrm{L} \text {, and } 0.28 \mu \mathrm{g} / \mathrm{L} \text {, respectively, within perched intermediate aquifers ( } \mathrm{LANL} \\
2007,094856 \text { ). The upper tolerance limits (UTLs)-at the } 95 \text { confidence interval and } 95 \text { percentile-for dissolved chloride, fluoride, sulfate, and uranium are } 8.37 \mathrm{mg} / \mathrm{L}, 0.23 \mathrm{mg} / \mathrm{L}, 40.03 \mathrm{mg} / \mathrm{L} \text {, and } \\
0.72 \mu \mathrm{g} / \mathrm{L} \text {, respectively, within perched intermediate aquifers (LANL } 2007,094856 \text { ). }\end{array}$} \\
\hline \multicolumn{12}{|c|}{$\begin{array}{l}\text { Mean concentrations of chloride, fluoride, nitrate plus nitrite (as N), perchlorate, sulfate, and uranium are } 2.36 \mathrm{mg} / \mathrm{L}, 0.32 \mathrm{mg} / \mathrm{L}, 0.36 \mathrm{mg} / \mathrm{L}, 0.32 \mu \mathrm{g} / \mathrm{L}, 3.28 \mathrm{mg} / \mathrm{L} \text {, and } 0.60 \mu \mathrm{g} / \mathrm{L} \text {, respectively, within } \\
\text { the regional aquifer (LANL } 2007,094856 \text { ). The UTLs—at } 95 \text { confidence interval and } 95 \text { percentile-for dissolved chloride, fluoride, nitrate + nitrite (as N), perchlorate, sulfate, and uranium are } 3.75 \\
\mathrm{mg} / \mathrm{L}, 0.53 \mathrm{mg} / \mathrm{L}, 0.75 \mathrm{mg} / \mathrm{L}, 0.44 \mu \mathrm{g} / \mathrm{L}, 6.22 \mathrm{mg} / \mathrm{L} \text {, and } 1.52 \mu \mathrm{g} / \mathrm{L} \text {, respectively, within the regional aquifer (LANL 2007, 094856). }\end{array}$} \\
\hline
\end{tabular}


Table 4.1

Location and Description of Sampling Sites

\begin{tabular}{|c|c|c|c|c|c|c|c|}
\hline \multirow[t]{2}{*}{ Station ID } & \multirow[t]{2}{*}{$\begin{array}{c}\text { Dates } \\
\text { Sampled }\end{array}$} & \multirow[t]{2}{*}{$\begin{array}{l}\text { Aquifer } \\
\text { Type }\end{array}$} & \multirow[t]{2}{*}{$\begin{array}{c}\text { Hydrostratigraphic } \\
\text { Unit (s) }\end{array}$} & \multicolumn{2}{|c|}{$\begin{array}{c}\text { Discharge or } \\
\text { Water-Level } \\
\text { Elevation }\end{array}$} & \multirow[t]{2}{*}{ X-Coordinate } & \multirow[t]{2}{*}{ Y-Coordinate } \\
\hline & & & & (m) & (ft) & & \\
\hline \multicolumn{8}{|l|}{ Sierra de los Valles } \\
\hline \multicolumn{8}{|l|}{ Perched Volcanics } \\
\hline AL-10.6 Spring & $\begin{array}{l}5 / 12 / 2005,6 / 15 / 2005 \\
7 / 13 / 2005\end{array}$ & Intermediate & Qbt? & 2558 & 8393 & 1586782.126 & 1752840.12 \\
\hline Barbara Spring & $\begin{array}{l}3 / 29 / 2005,5 / 12 / 2005 \\
6 / 15 / 2005,7 / 13 / 2005\end{array}$ & Intermediate & $\begin{array}{l}\text { Qbt/Tt } \\
\text { (near contact) }\end{array}$ & 2357 & 7734 & 1593101.22 & 1754219.24 \\
\hline Campsite Springs & $\begin{array}{l}\text { 5/17/2005, 6/8/2005, } \\
7 / 14 / 2005\end{array}$ & Intermediate & $\mathrm{Tt}^{\mathrm{a}}$ & 2622 & 8602 & 1603673.95 & 1796416.85 \\
\hline CdV-5.0 Spring & $\begin{array}{l}\text { 3/3/2005, 4/18/2005, } \\
5 / 27 / 2005,7 / 11 / 2005 \\
12 / 23 / 2005\end{array}$ & Intermediate & $\mathrm{Tt}^{\mathrm{a}}$ & 2562 & 8407 & 1601806.342 & 1767986.45 \\
\hline PC Spring & $\begin{array}{l}3 / 30 / 2005,5 / 3 / 2005 \\
6 / 10 / 2005,6 / 21 / 2005 \\
6 / 29 / 2005,7 / 12 / 2005\end{array}$ & Intermediate & $\begin{array}{l}\mathrm{Qal}^{\mathrm{b}} / \mathrm{Tt} \\
\text { (near contact) }^{\mathrm{a}}\end{array}$ & 2679 & 8790 & 1601022.14 & 1772943.43 \\
\hline Water Canyon Gallery Spring & $\begin{array}{l}3 / 4 / 2005,4 / 18 / 2005 \\
5 / 27 / 2005,7 / 11 / 2005 \\
9 / 23 / 2005\end{array}$ & Intermediate & $\mathrm{Qbt}^{\mathrm{a}}$ & 2423 & 7948 & 1604172.61 & 1762507.18 \\
\hline Young Spring & $\begin{array}{l}3 / 23 / 2005,5 / 5 / 2005 \\
6 / 16 / 2005,7 / 12 / 2005\end{array}$ & Intermediate & $\mathrm{Tt}^{\mathrm{a}}$ & 2357 & 7732 & 1608157.39 & 1777653.32 \\
\hline Pajarito Ski Well \#2 & $\begin{array}{l}3 / 2 / 2005,8 / 31 / 2005 \\
1 / 12 / 2006\end{array}$ & Intermediate & $\mathrm{Tt}^{\mathrm{c}}$ & $\sim 2745$ & $\sim 9274$ & 1597573.748 & 1781378.697 \\
\hline \multicolumn{8}{|l|}{ Pajarito Plateau } \\
\hline \multicolumn{8}{|l|}{ Perched Alluvial } \\
\hline LAO-B & $\begin{array}{l}3 / 3 / 2005,5 / 10 / 2005 \\
8 / 17 / 2005\end{array}$ & $\begin{array}{l}\text { Perched } \\
\text { Alluvial }\end{array}$ & Qal & 2232 & 7323 & 1615148.84 & 1775170.43 \\
\hline \multicolumn{8}{|l|}{ Perched Volcanics at Surface } \\
\hline Homestead Spring & $\begin{array}{l}3 / 31 / 2005,5 / 9 / 2005 \\
6 / 20 / 2005,7 / 18 / 2005\end{array}$ & Intermediate & $\mathrm{Qbt}^{\mathrm{a}}$ & 2268 & 7440 & 1614176.32 & 1768659.27 \\
\hline Starmer Spring & $\begin{array}{l}3 / 31 / 2005,5 / 9 / 2005 \\
6 / 21 / 2005,7 / 18 / 2005\end{array}$ & Intermediate & $\mathrm{Qbt}^{\mathrm{a}}$ & 2270 & 7447 & 1613806.09 & 1767878.8 \\
\hline
\end{tabular}


Table 4.1

Location and Description of Sampling Sites (Cont.)

\begin{tabular}{|c|c|c|c|c|c|c|c|}
\hline \multirow[t]{2}{*}{ Station ID } & \multirow[t]{2}{*}{$\begin{array}{c}\text { Dates } \\
\text { Sampled }\end{array}$} & \multirow[t]{2}{*}{$\begin{array}{l}\text { Aquifer } \\
\text { Type }\end{array}$} & \multirow{2}{*}{$\begin{array}{l}\text { Hydrostratigraphic } \\
\text { Unit (s) }\end{array}$} & \multicolumn{2}{|c|}{$\begin{array}{c}\text { Discharge or } \\
\text { Water-Level } \\
\text { Elevation }\end{array}$} & \multirow[t]{2}{*}{ X-Coordinate } & \multirow[t]{2}{*}{ Y-Coordinate } \\
\hline & & & & $(\mathrm{m})$ & (ft) & & \\
\hline Bulldog Spring & $\begin{array}{l}3 / 31 / 2005,5 / 9 / 2005 \\
6 / 22 / 2005,7 / 18 / 2005\end{array}$ & Intermediate & $\mathrm{Qbt}^{\mathrm{a}}$ & 2254 & 7395 & 1614808.72 & 1767195.69 \\
\hline Burning Ground Spring & $\begin{array}{l}4: 1 / 2005,5 / 13 / 2005, \\
7: 19 / 2005\end{array}$ & Intermediate & $\mathrm{Qbt}^{\mathrm{a}}$ & 2261 & 7417 & 1614267.99 & 1764632.99 \\
\hline Martin Spring & $4 / 6 / 2005,5 / 9 / 2005$ & Intermediate & $\mathrm{Qbt}^{\mathrm{a}}$ & 2269 & 7443 & 1614836.99 & 1761965 \\
\hline TA-18 Spring & $\begin{array}{l}3: 18 / 2005,5 / 9 / 2005 \\
6: 22 / 2005,8 / 1 / 2005 \\
\end{array}$ & Intermediate & $\mathrm{Qbt}^{\mathrm{a}}$ & 2061 & 6761 & 1634208.51 & 1760732.94 \\
\hline \multicolumn{8}{|c|}{ Intermediate at Depth Volcanics and Sediments } \\
\hline LAOI(A)-1.1 & 3/4/2005, 3/7/2005 & Intermediate & Qbog & 2083 & 6835 & 1629427.38 & 1773924.51 \\
\hline MCOBT-4.4 & $3,29 / 2005$ & Intermediate & $\mathrm{Tp}$ & 2084 & 6836 & 1634189.8 & 1768514.7 \\
\hline MCOI-6 & 9:1/2005 & Intermediate & $\mathrm{Tb}$ & 2076 & 6811 & 1635345.65 & 1768428.06 \\
\hline POI-4 & $3 / 8 / 2005,8 / 3 / 2005$ & Intermediate & $\mathrm{Tp}$ & 1942 & 6372 & 1649431.424 & 1772587.85 \\
\hline $\mathrm{R}-6 \mathrm{i}$ & $8 / 24 / 2005$ & Intermediate & $\mathrm{Tp}$ & 2133 & 6997 & 1635992.34 & 1773889.89 \\
\hline $\mathrm{R}-23 \mathrm{i}$ & $12 / 11 / 2005,10 / 31 / 05$ & Intermediate & $\mathrm{Tb}$ & 2003 & 6573 & 1647898.02 & 1755148.04 \\
\hline TW-1A & $3: 24 / 2005,8 / 18 / 2005$ & Intermediate & $\mathrm{Tp}$ & 1941 & 6369 & 1650056.88 & 1772065.82 \\
\hline \multicolumn{8}{|l|}{ Regional Aquifer Wells } \\
\hline $\mathrm{R}-1$ & $5 / 19 / 2005,9 / 12 / 2005$ & Regional & $\mathrm{Tp}$ & 2097 & 6881 & 1632355.1 & 1769598.8 \\
\hline $\mathrm{R}-2$ & $\begin{array}{l}4,26 / 2005,8 / 9 / 2005, \\
2 / 27 / 2006\end{array}$ & Regional & $\mathrm{Tf}$ & 2063 & 6770 & 1629519.57 & 1778281.56 \\
\hline $\mathrm{R}-4$ & $4 / 27 / 2005,8 / 8 / 2005$ & Regional & Tf & 2005 & 6577 & 1639287.977 & 1776530.284 \\
\hline $\mathrm{R}-6$ & $8,23 / 2005$ & Regional & $\mathrm{Tf}$ & 2132 & 6996 & 1636011.02 & 1773884.07 \\
\hline R-9 & $\begin{array}{l}\text { 3:19/2005, 4/6/2005, } \\
8: 16 / 2005\end{array}$ & Regional & Tsf & 1946 & 6383 & 1648236.5 & 1770847.1 \\
\hline $\mathrm{R}-11$ & $5: 17 / 2005,8 / 3 / 2005$ & Regional & $\mathrm{Tp}$ & 2034 & 6674 & 1639959.61 & 1769353.57 \\
\hline $\mathrm{R}-13$ & $\begin{array}{l}3: 10 / 2005,9 / 1 / 2005 \\
2 / 2 / 2006\end{array}$ & Regional & $\mathrm{Tp}$ & 2034 & 6673 & 1640991.7 & 1766994.2 \\
\hline $\mathrm{R}-15$ & $3 / 9 / 2005,8 / 31 / 2005$ & Regional & $\mathrm{Tp}$ & 2079 & 6820 & 1635308.6 & 1768272.5 \\
\hline $\mathrm{R}-18$ & $8,25 / 2005,12 / 1 / 2005$ & Regional & $\mathrm{Tp}$ & 2257 & 7405 & 1617254.37 & 1766545.47 \\
\hline
\end{tabular}


Table 4.1

Location and Description of Sampling Sites (Cont.)

\begin{tabular}{|c|c|c|c|c|c|c|c|}
\hline \multirow[t]{2}{*}{ Station ID } & \multirow[t]{2}{*}{$\begin{array}{c}\text { Dates } \\
\text { Sampled }\end{array}$} & \multirow[t]{2}{*}{$\begin{array}{l}\text { Aquifer } \\
\text { Type }\end{array}$} & \multirow[t]{2}{*}{$\begin{array}{l}\text { Hydrostratigraphic } \\
\text { Unit (s) }\end{array}$} & \multicolumn{2}{|c|}{$\begin{array}{l}\text { Discharge or } \\
\text { Water-Level } \\
\text { Elevation }\end{array}$} & \multirow[t]{2}{*}{ X-Coordinate } & \multirow[t]{2}{*}{ Y-Coordinate } \\
\hline & & & & (m) & (ft) & & \\
\hline $\mathrm{R}-23$ & 7/14/2005, 8/15/2005 & Regional & Tsf & 1990 & 6528 & 1647914 & 1755165 \\
\hline $\mathrm{R}-28$ & $\begin{array}{l}5 / 20 / 2005,9 / 1 / 2005 \\
1 / 26 / 2006\end{array}$ & Regional & $\mathrm{Tp}$ & 2051 & 6729 & 1638988.73 & 1768358.57 \\
\hline TW-1 & $\begin{array}{l}\text { 3/23/2005, 5/4/2005, } \\
8 / 17 / 2005\end{array}$ & Regional & $\mathrm{Tp}$ & 1941 & 6369 & 1650042 & 1772077 \\
\hline TW-2 & $3 / 22 / 2005$ & Regional & $\mathrm{Tp}$ & 2026 & 6648 & 1634231.16 & 1777267.92 \\
\hline TW-3 & $\begin{array}{l}3 / 21 / 2005,4 / 6 / 2005 \\
8 / 11 / 2005\end{array}$ & Regional & $\mathrm{Tp}$ & 2010 & 6595 & 1637727.49 & 1773138.09 \\
\hline TW-8 & $3 / 28 / 2005,10 / 3 / 2005$ & Regional & $\mathrm{Tp}$ & 2096 & 6875 & 1632573.95 & 1769504.85 \\
\hline \multicolumn{8}{|c|}{ Regional Aquifer Production Well } \\
\hline $\mathrm{O}-1$ & $\begin{array}{l}3 / 23 / 2005,5 / 18 / 2005 \\
8 / 17 / 2005\end{array}$ & Regional & $\mathrm{Tp} / \mathrm{Tsf}$ & 1950 & 6396 & 1649396.26 & 1772232.07 \\
\hline \multicolumn{8}{|c|}{ White Rock Canyon Springs } \\
\hline Spring 2B & $3 / 9 / 2005,7 / 21 / 2005$ & Intermediate & Qls over Tsfud? & 1656 & 5433 & 1661936.293 & 1754700.032 \\
\hline Spring 3 & $\begin{array}{l}\text { 3/9/2005, 4/20/2005, } \\
5 / 16 / 2005,7 / 21 / 2005 \\
9 / 26 / 2005\end{array}$ & Regional & Q1s over Tsfud? & 1687 & 5535 & 1661216.24 & 1753718.34 \\
\hline Spring 3A & $\begin{array}{l}\text { 3/9/2005, 4/15/2005, } \\
\text { 4/20/2005, 5/16/2005, } \\
7 / 21 / 2005,9 / 26 / 2005\end{array}$ & Regional & Qls over Tsfud? & 1680 & 5512 & 1661229.5 & 1753534.16 \\
\hline Spring 3C & $3 / 11 / 2005$ & Intermediate & Qls over Tsfu ${ }^{\mathrm{d}} ?$ & 1653 & 5422 & 1658441.84 & 1748762.52 \\
\hline Spring 4 & $\begin{array}{l}\text { 2/21/2005, 3/11/2005, } \\
\text { 4/22/2005, 7/27/2005, } \\
9 / 26 / 2005\end{array}$ & Intermediate & Qls over Tsfu' ${ }^{\mathrm{d}}$ ? & 1654 & 5427 & 1657414.67 & 1748291.71 \\
\hline Spring 4A & $\begin{array}{l}\text { 2/22/2005, 3/22/2005, } \\
4 / 26 / 2005,5 / 16 / 2005 \\
7 / 28 / 2005,9 / 27 / 2005\end{array}$ & Regional & Qls over Tsfu ${ }^{\mathrm{d}}$ ? & 1712 & 5617 & 1656064.01 & 1748068.89 \\
\hline Spring 4AA & $\begin{array}{l}\text { 3/22/2005, 4/26/2005, } \\
5 / 16 / 2005,7 / 26 / 2005 \\
9 / 27 / 2005\end{array}$ & Regional & Qls over Tsfu ${ }^{\mathrm{d}}$ ? & 1717 & 5634 & 1656115.51 & 1748461.51 \\
\hline
\end{tabular}


Table 4.1

Location and Description of Sampling Sites (Cont.)

\begin{tabular}{|c|c|c|c|c|c|c|c|}
\hline \multirow[t]{2}{*}{ Station ID } & \multirow[t]{2}{*}{$\begin{array}{c}\text { Dates } \\
\text { Sampled }\end{array}$} & \multirow[t]{2}{*}{$\begin{array}{l}\text { Aquifer } \\
\text { Type }\end{array}$} & \multirow[t]{2}{*}{$\begin{array}{l}\text { Hydrostratigraphic } \\
\text { Unit (s) }\end{array}$} & \multicolumn{2}{|c|}{$\begin{array}{l}\text { Discharge or } \\
\text { Water-Level } \\
\text { Elevation }\end{array}$} & \multirow[t]{2}{*}{ X-Coordinate } & \multirow[t]{2}{*}{ Y-Coordinate } \\
\hline & & & & (m) & (ft) & & \\
\hline Spring 4B & $\begin{array}{l}\text { 3/22/2005, 4/22/2005, } \\
5 / 20 / 2005,7 / 27 / 2005\end{array}$ & Intermediate & Qls over Tsfu ${ }^{\mathrm{d}}$ ? & 1678 & 5506 & 1656962.59 & 1748270.68 \\
\hline Spring $4 \mathrm{C}$ & $\begin{array}{l}\text { 2/21/2005, 3/11/2005, } \\
4 / 22 / 2005,5 / 20 / 2005 \\
7 / 27 / 2005\end{array}$ & Intermediate & Qls over Tsfu ${ }^{\mathrm{d}}$ ? & 1665 & 5464 & 1657251.15 & 1748374.13 \\
\hline Spring 5 & $\begin{array}{l}\text { 2/21/2005, 3/24/2005, } \\
\text { 4/26/2005, } 6 / 2 / 2005, \\
7 / 26 / 2005,9 / 27 / 2005 \\
\end{array}$ & Regional & Qls over Tsfu ${ }^{\mathrm{d}}$ ? & 1693 & 5554 & 1655026.92 & 1743190.17 \\
\hline Spring 6 & $\begin{array}{l}\text { 3/2/2005, 3/24/2005 } \\
4 / 29 / 2005,7 / 25 / 2005 \\
9 / 27 / 2005\end{array}$ & Regional & $\mathrm{Tcb}_{1}^{\mathrm{d}}$ & 1640 & 5381 & 1648882 & 1735517 \\
\hline Spring 9A & $\begin{array}{l}\text { 3/8/2005, 4/29/2005, } \\
5 / 18 / 2005,7 / 20 / 2005 \\
9 / 28 / 2005\end{array}$ & Regional & $\mathrm{Tcm}^{\mathrm{d}}$ & 1696 & 5563 & 1642542.55 & 1733606.12 \\
\hline \multicolumn{8}{|c|}{ Perennial Surface Water } \\
\hline CdV-5.6 & $\begin{array}{l}3 / 3 / 2005,4 / 18 / 2005 \\
5 / 27 / 2005,7 / 11 / 2005\end{array}$ & NA & NA & 2615 & 8580 & 1599267.268 & 1769915.374 \\
\hline PA-10.6 & $\begin{array}{l}\text { 2/14/2005, 3/8/2005 } \\
5 / 3 / 2005,6 / 10 / 2005 \\
7 / 12 / 2005\end{array}$ & NA & $\mathrm{NA}$ & 2409 & 7904 & 1608365.42 & 1771944.92 \\
\hline \multicolumn{8}{|l|}{ Offsite Reference } \\
\hline \multicolumn{8}{|c|}{ Perched Volcanics South Valles Caldera } \\
\hline Seven Springs & $\begin{array}{l}\text { 3/10/2005, 5/9/2005, } \\
6 / 23 / 2005,7 / 15 / 2005\end{array}$ & Intermediate & $\mathrm{Qbt}^{\mathrm{e}}$ & 2484 & 8151 & 1505881.17 & 1798835.43 \\
\hline \multicolumn{8}{|c|}{ Perched Basalts - Taos Eastside Rio Grande } \\
\hline AH-0.2 Spring & $\begin{array}{l}2 / 15 / 2005,4 / 8 / 2005 \\
5 / 13 / 2005,6 / 24 / 2005 \\
7 / 22 / 2005\end{array}$ & Intermediate & $\begin{array}{l}\text { Servilleta Formation, } \\
\text { basalt (Pliocene) }{ }^{\mathrm{f}}\end{array}$ & 1994 & 6543 & 1800286.454 & 2014059.595 \\
\hline
\end{tabular}


Table 4.1

Location and Description of Sampling Sites (Cont.)

\begin{tabular}{|c|c|c|c|c|c|c|c|c|}
\hline \multirow{2}{*}{\multicolumn{2}{|c|}{ Station ID }} & \multirow[t]{2}{*}{$\begin{array}{c}\text { Dates } \\
\text { Sampled }\end{array}$} & \multirow[t]{2}{*}{$\begin{array}{l}\text { Aquifer } \\
\text { Type }\end{array}$} & \multirow[t]{2}{*}{$\begin{array}{c}\text { Hydrostratigraphic } \\
\text { Unit (s) }\end{array}$} & \multicolumn{2}{|c|}{$\begin{array}{l}\text { Discharge or } \\
\text { Water-Level } \\
\text { Elevation }\end{array}$} & \multirow[t]{2}{*}{ X-Coordinate } & \multirow[t]{2}{*}{ Y-Coordinate } \\
\hline & & & & & (m) & (ft) & & \\
\hline \multicolumn{9}{|c|}{$\begin{array}{l}\text { Note: The symbol ? denotes uncertainty in assigning a stratigraphic unit to a particular spring. } \\
\text { a Smith, R.L., R. A. Bailey, and C. S. Ross 1970. "Geologic Map of Jemez Mountains, New Mexico," U.S. Geological Survey Miscellaneous Investigations Series, Map 1-571, Washington, D.C. } \\
\text { (Smith et al. 1970, 009752) }\end{array}$} \\
\hline \multicolumn{9}{|c|}{ ' NMED DOE OB. } \\
\hline \multicolumn{9}{|c|}{$\begin{array}{l}\text { ' Purtymun, W. D., January 1995. "Geologic and Hydrologic Records of Observation Wells, Test Holes, Test Wells, Supply Wells, Springs, and Surface Water Stations in the Los Alamos Area," } \\
\text { Los Alamos National Laboratory report LA-12883-MS, Los Alamos, New Mexico. (Purtymun 1995, 045344) }\end{array}$} \\
\hline \multicolumn{9}{|c|}{$\begin{array}{l}\text { d Dethier, D. P., 1997. "Geology of White Rock Quadrangle, Los Alamos and Santa Fe Counties, New Mexico," Map 73, New Mexico Bureau of Mines and Mineral Resources. (Dethier 1997, 049843). } \\
\text { e Blake et al. 1995, 049931. }\end{array}$} \\
\hline \multicolumn{9}{|c|}{ f Kelson and Bauer, 2006 (preliminary). } \\
\hline NA & \multicolumn{8}{|c|}{ Not available. $\quad$} \\
\hline Qal & \multicolumn{8}{|c|}{ Alluvium; stream deposits. } \\
\hline Qls & \multicolumn{8}{|l|}{ Landslide deposit. } \\
\hline Qbt & \multicolumn{8}{|l|}{ Bandelier Tuff. } \\
\hline Qbog & \multicolumn{8}{|c|}{ Bandelier Tuff, Otowi member, Guaje Pumice Bed. } \\
\hline $\mathrm{Tb}$ & \multicolumn{8}{|c|}{ Cerros del Rio Basalts. } \\
\hline $\mathrm{Tt}$ & \multicolumn{8}{|c|}{ Tschicoma Formation. } \\
\hline $\mathrm{Tcm}$ & \multicolumn{8}{|c|}{ Phreatomagmatic deposit. } \\
\hline $\mathrm{Teb}_{\mathrm{i}}$ & \multicolumn{8}{|c|}{ Basalt flows. } \\
\hline $\mathrm{Tp}$ & \multicolumn{8}{|c|}{ Puye Formation fanglomerate. } \\
\hline $\mathrm{Tf}$ & \multicolumn{8}{|c|}{ Unassigned Formation Fanglomerates. } \\
\hline Tsfu & \multicolumn{8}{|c|}{ Santa Fe Group, undivided. } \\
\hline Tsf & Santa Fe Formati & t et al., 1970, & & & & & & \\
\hline
\end{tabular}


Table 5-1

Analytes, Sampling Containers, Sampling Equipment, and Analytical Laboratory and Method of Analysis

\begin{tabular}{|c|c|c|c|}
\hline Analytes & Containers & Sampling Equipment and Notes & Laboratory/Method \\
\hline${ }^{3} \mathrm{He},{ }^{4} \mathrm{He},{ }^{22} \mathrm{Ne}$ & $\begin{array}{l}\text { 3/8-inch copper tube } \\
\text { (clamped) }\end{array}$ & $\begin{array}{l}\text { Copper tubes and clamps supplied by } \\
\text { University of Miami }\end{array}$ & $\begin{array}{l}\text { University of Miami Noble Gas } \\
\text { Isotope Laboratory/MS }\end{array}$ \\
\hline${ }^{3} \mathrm{H}$ & 1-liter Nalgene bottle & $\begin{array}{l}\text { 1-inch head space; wrapped in parafilm } \\
\text { and enclosed in ziplock bag }\end{array}$ & $\begin{array}{l}\text { University of Miami Noble Gas } \\
\text { Isotope Laboratory/ingrowth from } \\
{ }^{3} \mathrm{He}\end{array}$ \\
\hline$\delta^{18} \mathrm{O}, \delta^{2} \mathrm{H}$ & $40 \mathrm{~mL}$ glass septum bottle & No head space, nonfiltered, nonacidified & EES-6 Laboratory/IR-MS \\
\hline$\delta^{13} \mathrm{C},{ }^{14} \mathrm{C}$ & $\begin{array}{l}\text { 1-liter amber glass bottle } \\
\text { with silicon septum in cap }\end{array}$ & $\begin{array}{l}\text { Rinse and purge several times with hose } \\
\text { placed near bottom of bottle }\end{array}$ & $\begin{array}{l}\text { University of Arizona/IR-MS and } \\
\text { AMS }\end{array}$ \\
\hline Major ions & $125 \mathrm{~mL}$ plastic bottle & Filtered, nonacidified & $\begin{array}{l}\text { EES-6 Laboratory and GEL/ICP- } \\
\text { OES, alkalinity titration }\end{array}$ \\
\hline Trace elements & $125 \mathrm{~mL}$ plastic bottle & Filtered, acidified $\left(\mathrm{HNO}_{3}\right)$ & EES-6 Laboratory and GEL/ICP-MS \\
\hline $\begin{array}{l}\mathrm{pH}, \text { specific } \\
\text { conductivity, } \\
\text { dissolved oxygen, } \\
\text { temperature, } \\
\text { turbidity }\end{array}$ & None & $\begin{array}{l}\text { Field parameters measured by sampling } \\
\text { team }\end{array}$ & None/portable meters \\
\hline \multicolumn{4}{|c|}{$\begin{array}{l}\text { AMS means accelerator mass spectrometry. } \\
\text { GEL means General Engineering Laboratories. } \\
\text { IR-MS means isotope ratio-mass spectrometry. } \\
\text { ICP-OES means inductively coupled (argon) plasma-optical emission spectroscopy. } \\
\text { ICP-MS means inductively coupled (argon) plasma-mass spectrometry. } \\
\text { MS means mass spectrometry. }\end{array}$} \\
\hline
\end{tabular}


Table 6.1

Summary Results of Major Element Chemistry and Field Parameters

\begin{tabular}{|c|c|c|c|c|c|c|c|c|c|c|c|c|c|c|c|c|c|c|c|c|c|}
\hline \multirow[b]{2}{*}{ Station ID } & \multirow[b]{2}{*}{$\begin{array}{c}\text { Date } \\
\text { Sampled }\end{array}$} & \multirow{2}{*}{$\begin{array}{c}\text { Total } \\
\text { Alkalinity (lab) } \\
\text { (ppm) }\end{array}$} & \multirow[b]{2}{*}{$\mid \begin{array}{l}\mathrm{HCO}_{3} \\
(\mathrm{ppm})\end{array}$} & \multirow[b]{2}{*}{$\begin{array}{c}\mathrm{CO}_{3} \\
(\mathbf{p p m})\end{array}$} & \multirow[b]{2}{*}{$\begin{array}{c}\mathrm{SO}_{4} \\
(\mathbf{p p m})\end{array}$} & \multirow[b]{2}{*}{$\begin{array}{c}\mathrm{Cl} \\
(\mathrm{ppm})\end{array}$} & \multirow[b]{2}{*}{$\begin{array}{c}\mathbf{F} \\
(\mathbf{p p m})\end{array}$} & \multirow[b]{2}{*}{$\begin{array}{c}\mathrm{Br} \\
(\mathrm{ppm})\end{array}$} & \multirow[b]{2}{*}{$\begin{array}{c}\mathrm{NO}_{3} \text { as } \mathrm{N} \\
(\mathbf{p p m})\end{array}$} & \multirow[b]{2}{*}{$\begin{array}{l}\mathrm{ClO}_{4} \\
(\mathrm{ppb})\end{array}$} & \multirow[b]{2}{*}{$\begin{array}{c}\mathrm{Ca} \\
(\mathbf{p p m})\end{array}$} & \multirow[b]{2}{*}{$\begin{array}{c}\mathrm{Mg} \\
(\mathbf{p p m})\end{array}$} & \multirow[b]{2}{*}{$\begin{array}{c}\mathrm{Na} \\
(\mathrm{ppm})\end{array}$} & \multirow[b]{2}{*}{$\begin{array}{c}\mathbf{K} \\
(\mathbf{p p m})\end{array}$} & \multirow[b]{2}{*}{$\begin{array}{c}\mathrm{SiO}_{2}(\mathrm{cal}) \\
(\mathrm{ppm})\end{array}$} & \multirow[b]{2}{*}{$\begin{array}{c}\text { Lab TDS } \\
(\mathbf{p p m})\end{array}$} & \multirow[b]{2}{*}{$\begin{array}{c}\text { Charge } \\
\text { Balance } \\
(\%)\end{array}$} & \multicolumn{4}{|c|}{ Field Properties } \\
\hline & & & & & & & & & & & & & & & & & & $\begin{array}{l}\text { Temp } \\
\left.{ }^{\circ} \mathrm{C}\right)\end{array}$ & \begin{tabular}{|c|}
$\mathbf{p H}$ \\
(S.U.)
\end{tabular} & $\begin{array}{c}\text { Dissolved } \\
\text { Oxygen } \\
(\mathrm{mg} / \mathrm{L}) \\
\end{array}$ & $\begin{array}{c}\text { Specific } \\
\text { Conductance } \\
\text { (uS/cm) }\end{array}$ \\
\hline \multicolumn{22}{|l|}{ Sierra de los Valles } \\
\hline \multicolumn{22}{|l|}{ Perched Volcanics } \\
\hline AL-10.6 Spring & $\begin{array}{l}5 / 112 / 2005 \\
6 / 11 / 2005 \\
7 / 13 / 2005\end{array}$ & $\begin{array}{l}31.23 \\
34.26 \\
34.59\end{array}$ & $\begin{array}{l}38.1 \\
41.8 \\
42.2\end{array}$ & $\begin{array}{l}0 \\
0 \\
0\end{array}$ & $\begin{array}{l}4.45 \\
2.45 \\
1.76\end{array}$ & $\begin{array}{l}1.22 \\
1.07 \\
1.09\end{array}$ & $\begin{array}{l}0.07 \\
0.07 \\
0.06\end{array}$ & $\begin{array}{l}0.02 \\
0.02 \\
0.01\end{array}$ & $\begin{array}{l}0.26 \\
0.24 \\
0.22\end{array}$ & $\begin{array}{l}{[0.5], \mathrm{U}} \\
{[0.5] \mathrm{U}} \\
{[0.5, \mathrm{U}}\end{array}$ & $\begin{array}{l}5.96 \\
5.69 \\
5.94\end{array}$ & $\begin{array}{l}1.44 \\
1.60 \\
1.58\end{array}$ & $\begin{array}{l}6.19 \\
6.85 \\
6.92\end{array}$ & $\begin{array}{l}1.66 \\
1.95 \\
1.83\end{array}$ & $\begin{array}{l}54.12 \\
58.48 \\
57.56\end{array}$ & $\begin{array}{l}115 \\
122 \\
120\end{array}$ & $\begin{array}{l}-3.12 \\
-2.34 \\
-0.21\end{array}$ & $\begin{array}{l}7.8 \\
8.4 \\
8.7\end{array}$ & $\begin{array}{l}7.28 \\
6.76 \\
6.94\end{array}$ & $\begin{array}{l}7.1 \\
6.1 \\
6.0\end{array}$ & $\begin{array}{l}80 \\
78 \\
74\end{array}$ \\
\hline Barbara Spring & $\begin{array}{l}3 / 29 / 2005 \\
5 / 12 / 2005 \\
6 / 15 / 2005 \\
7 / 13 / 2005\end{array}$ & $\begin{array}{l}35.74 \\
34.84 \\
35.16 \\
34.59 \\
\end{array}$ & $\begin{array}{l}43.6 \\
42.5 \\
42.9 \\
42.2 \\
\end{array}$ & $\begin{array}{l}0 \\
0 \\
0 \\
0 \\
\end{array}$ & $\begin{array}{l}1.22 \\
1.14 \\
1.15 \\
1.07\end{array}$ & $\begin{array}{l}1.21 \\
1.15 \\
1.15 \\
1.11\end{array}$ & $\begin{array}{l}0.12 \\
0.12 \\
0.12 \\
0.12 \\
\end{array}$ & $\begin{array}{l}0.01 \\
0.02 \\
0.02 \\
0.01 \\
\end{array}$ & $\begin{array}{l}0.27 \\
0.28 \\
0.25 \\
0.28 \\
\end{array}$ & $\begin{array}{l}{[0.5], \mathrm{U}} \\
{[0.5], \mathrm{U}} \\
{[0.5], \mathrm{U}} \\
{[0.5], \mathrm{U}}\end{array}$ & $\begin{array}{l}4.86 \\
4.60 \\
4.64 \\
4.81 \\
\end{array}$ & $\begin{array}{l}0.74 \\
0.77 \\
0.90 \\
0.91 \\
\end{array}$ & $\begin{array}{r}9.75 \\
9.43 \\
9.97 \\
10.06 \\
\end{array}$ & $\begin{array}{l}0.19 \\
0.21 \\
0.29 \\
0.32 \\
\end{array}$ & $\begin{array}{l}73.15 \\
71.97 \\
74.70 \\
74.02 \\
\end{array}$ & $\begin{array}{l}136 \\
133 \\
137 \\
136\end{array}$ & $\begin{array}{l}-4.21 \\
-4.45 \\
-2.20 \\
-0.54 \\
\end{array}$ & $\begin{array}{l}13.8 \\
15.2 \\
15.4 \\
15.5\end{array}$ & $\begin{array}{l}7.76 \\
7.39 \\
7.06 \\
7.22 \\
\end{array}$ & $\begin{array}{l}9.9 \\
7.0 \\
6.2 \\
5.0\end{array}$ & $\begin{array}{l}73 \\
73 \\
75 \\
73 \\
\end{array}$ \\
\hline Campsite Springs & $\begin{array}{l}5 / 17 / 2005 \\
6 / 8 / 2005 \\
7 / 14 / 2005\end{array}$ & $\begin{array}{l}38.52 \\
38.65 \\
38.77\end{array}$ & $\begin{array}{l}47.0 \\
47.2 \\
47.3\end{array}$ & $\begin{array}{l}0 \\
0 \\
0\end{array}$ & $\begin{array}{l}2.46 \\
1.93 \\
1.54\end{array}$ & $\begin{array}{l}1.12 \\
1.08 \\
1.05\end{array}$ & $\begin{array}{l}0.13 \\
0.14 \\
0.14\end{array}$ & $\begin{array}{l}0.02 \\
0.02 \\
0.01\end{array}$ & $\begin{array}{l}0.33 \\
0.35 \\
0.34\end{array}$ & $\begin{array}{l}{[0.5], \mathrm{U}} \\
{[0.5], \mathrm{U}} \\
{[0.5], \mathrm{U}}\end{array}$ & $\begin{array}{l}5.35 \\
4.39 \\
4.90\end{array}$ & $\begin{array}{l}1.63 \\
1.60 \\
1.74\end{array}$ & \begin{tabular}{|l|}
8.95 \\
8.97 \\
9.60
\end{tabular} & $\begin{array}{l}1.21 \\
1.27 \\
1.45\end{array}$ & $\begin{array}{l}56.09 \\
53.76 \\
57.04\end{array}$ & $\begin{array}{l}126 \\
122 \\
126\end{array}$ & $\begin{array}{l}-3.57 \\
-6.15 \\
-1.39\end{array}$ & $\begin{array}{l}14.4 \\
14.9 \\
15.0\end{array}$ & $\begin{array}{l}7.86 \\
7.73 \\
7.85\end{array}$ & $\begin{array}{l}6.7 \\
6.5 \\
4.9\end{array}$ & $\begin{array}{r}75 \\
\mathrm{NA} \\
83\end{array}$ \\
\hline CdV-5.0 Spring & $\begin{array}{l}3 / 3 / 2005 \\
4 / 18 / 2005 \\
5 / 27 / 2005 \\
7 / 11 / 2005 \\
12 / 23 / 2005 \\
\end{array}$ & $\begin{array}{l}33.77 \\
33.77 \\
25.66 \\
34.67 \\
36.72 \\
\end{array}$ & $\begin{array}{l}41.2 \\
41.2 \\
31.3 \\
42.3 \\
44.8 \\
\end{array}$ & $\begin{array}{l}0 \\
0 \\
0 \\
0 \\
0 \\
\end{array}$ & $\begin{array}{l}34.82 \\
30.92 \\
17.54 \\
14.19 \\
13.51 \\
\end{array}$ & $\begin{array}{l}6.43 \\
5.38 \\
2.79 \\
3.20 \\
3.13 \\
\end{array}$ & $\begin{array}{l}0.07 \\
0.09 \\
0.06 \\
0.05 \\
0.07 \\
\end{array}$ & $\begin{array}{l}0.02 \\
0.03 \\
0.02 \\
0.02 \\
0.02 \\
\end{array}$ & $\begin{array}{l}1.31 \\
1.78 \\
0.90 \\
0.76 \\
0.81 \\
\end{array}$ & $\begin{array}{l}{[1.0], \mathrm{U}} \\
{[1.0], \mathrm{U}} \\
{[2.0], \mathrm{U}} \\
{[1.0], \mathrm{U}} \\
{[0.5], \mathrm{U}}\end{array}$ & $\begin{array}{r}16.47 \\
15.64 \\
8.20 \\
9.86 \\
9.69 \\
\end{array}$ & $\begin{array}{l}5.86 \\
4.45 \\
3.14 \\
3.79 \\
3.70 \\
\end{array}$ & $\begin{array}{l}7.49 \\
7.52 \\
5.20 \\
5.93 \\
5.58 \\
\end{array}$ & $\begin{array}{l}3.54 \\
2.62 \\
2.41 \\
3.62 \\
2.80 \\
\end{array}$ & $\begin{array}{l}52.39 \\
51.74 \\
40.72 \\
42.69 \\
46.08 \\
\end{array}$ & $\begin{array}{l}176 \\
168 \\
116 \\
129 \\
134 \\
\end{array}$ & $\begin{array}{r}0.90 \\
-1.94 \\
-3.55 \\
0.79 \\
-2.80 \\
\end{array}$ & $\begin{array}{l}8.7 \\
9.0 \\
8.6 \\
8.9 \\
6.6 \\
\end{array}$ & $\begin{array}{l}7.86 \\
7.02 \\
7.35 \\
6.97 \\
7.78 \\
\end{array}$ & $\begin{array}{c}8.1 \\
\text { NA } \\
\text { NA } \\
6.1 \\
9.0 \\
\end{array}$ & $\begin{array}{l}173 \\
177 \\
115 \\
120 \\
113 \\
\end{array}$ \\
\hline (Interlaboratory Field Duplicate) & $\begin{array}{l}3 / 30 / 2005 \\
5 / 3 / 2005 \\
6 / 10 / 2005 \\
6 / 21 / 2005 \\
6 / 21 / 2005 \\
6 / 29 / 2005 \\
7 / 12 / 2005 \\
\end{array}$ & $\begin{array}{l}25.82 \\
20.00 \\
25.25 \\
26.10 \\
28.60 \\
26.70 \\
28.20 \\
\end{array}$ & $\begin{array}{l}31.5 \\
24.4 \\
30.8 \\
31.9 \\
34.9 \\
32.6 \\
34.4 \\
\end{array}$ & $\begin{array}{c}0 \\
0 \\
0 \\
0 \\
{[1.45], \mathrm{U}} \\
0 \\
0 \\
\end{array}$ & $\begin{array}{r}10.00 \\
10.71 \\
6.14 \\
\text { NA } \\
5.78 \\
4.73 \\
4.98 \\
\end{array}$ & $\begin{array}{l}1.97 \\
1.97 \\
1.06 \\
\text { NA } \\
1.02 \\
0.87 \\
0.97 \\
\end{array}$ & $\begin{array}{l}0.05 \\
0.06 \\
0.05 \\
\text { NA } \\
0.07 \\
0.03 \\
0.05 \\
\end{array}$ & $\begin{array}{c}{[0.01], \mathrm{U}} \\
0.02 \\
0.01 \\
\mathrm{NA} \\
{[0.04], \mathrm{U}} \\
0.01 \\
{[0.01], \mathrm{U}} \\
\end{array}$ & $\begin{array}{l}0.55 \\
0.32 \\
0.26 \\
\text { NA } \\
\text { NA } \\
0.21 \\
0.21 \\
\end{array}$ & $\begin{array}{c}{[0.5], \mathrm{U}} \\
{[0.5], \mathrm{U}} \\
{[0.5], \mathrm{U}} \\
\mathrm{NA} \\
0.311 \\
{[0.5], \mathrm{U}} \\
{[0.5], \mathrm{U}} \\
\end{array}$ & $\begin{array}{l}7.03 \\
6.05 \\
5.13 \\
5.77 \\
6.18 \\
5.84 \\
6.09 \\
\end{array}$ & $\begin{array}{l}2.39 \\
1.99 \\
2.15 \\
2.40 \\
2.50 \\
2.47 \\
2.55 \\
\end{array}$ & $\begin{array}{l}3.88 \\
3.45 \\
3.39 \\
3.78 \\
3.84 \\
3.72 \\
3.91 \\
\end{array}$ & $\begin{array}{l}1.85 \\
1.29 \\
1.50 \\
1.74 \\
1.87 \\
1.73 \\
1.73 \\
\end{array}$ & $\begin{array}{l}39.03 \\
33.55 \\
32.10 \\
35.50 \\
36.20 \\
36.50 \\
34.59 \\
\end{array}$ & $\begin{array}{r}101 \\
85 \\
84 \\
\text { NA } \\
77 \\
90 \\
90 \\
\end{array}$ & $\begin{array}{r}-4.18 \\
-4.22 \\
-4.99 \\
-2.10 \\
-3.00 \\
1.90 \\
1.10 \\
\end{array}$ & $\begin{array}{l}5.5 \\
5.7 \\
6.3 \\
6.9 \\
6.9 \\
6.4 \\
6.6 \\
\end{array}$ & $\begin{array}{l}7.61 \\
7.23 \\
6.94 \\
7.20 \\
7.20 \\
6.58 \\
6.91 \\
\end{array}$ & $\begin{array}{c}8.9 \\
8.5 \\
\text { NA } \\
9.1 \\
9.1 \\
9.3 \\
7.6 \\
\end{array}$ & $\begin{array}{l}83 \\
78 \\
72 \\
69 \\
69 \\
64 \\
70 \\
\end{array}$ \\
\hline (Blind Intralaboratory Field Duplicate) & $\begin{array}{l}3 / 4 / 2005 \\
4 / 18 / 2005 \\
5 / 27 / 2005 \\
7 / 11 / 2005 \\
7 / 1 / 12005 \\
9 / 23 / 2005 \\
\end{array}$ & $\begin{array}{l}34.92 \\
35.66 \\
38.39 \\
40.74 \\
40.66 \\
41.90 \\
\end{array}$ & $\begin{array}{l}42.6 \\
43.5 \\
46.8 \\
49.7 \\
49.6 \\
51.1 \\
\end{array}$ & $\begin{array}{l}0 \\
0 \\
0 \\
0 \\
0 \\
0 \\
\end{array}$ & $\begin{array}{r}18.35 \\
17.63 \\
9.58 \\
2.96 \\
2.98 \\
1.78 \\
\end{array}$ & $\begin{array}{l}3.60 \\
3.49 \\
1.96 \\
0.99 \\
0.96 \\
0.88 \\
\end{array}$ & $\begin{array}{l}0.05 \\
0.05 \\
0.04 \\
0.04 \\
0.04 \\
0.04\end{array}$ & $\begin{array}{c}{[0.01], \mathrm{U}} \\
0.02 \\
0.02 \\
0.01 \\
0.01 \\
0.01 \\
\end{array}$ & $\begin{array}{l}0.35 \\
0.45 \\
0.54 \\
0.26 \\
0.36 \\
0.35\end{array}$ & $\begin{array}{l}{[1.0], \mathrm{U}} \\
{[1.0, \mathrm{U}} \\
{[0.5], \mathrm{U}} \\
{[0.5], \mathrm{U}} \\
{[0.5], \mathrm{U}} \\
{[0.5], \mathrm{U}}\end{array}$ & \begin{tabular}{|r}
11.07 \\
11.24 \\
8.04 \\
7.08 \\
7.22 \\
7.38 \\
\end{tabular} & $\begin{array}{l}4.25 \\
3.43 \\
3.61 \\
3.47 \\
3.52 \\
3.43 \\
\end{array}$ & $\begin{array}{l}5.70 \\
5.44 \\
5.17 \\
5.82 \\
5.82 \\
5.73 \\
\end{array}$ & $\begin{array}{l}2.89 \\
1.96 \\
1.82 \\
1.65 \\
1.68 \\
1.73 \\
\end{array}$ & $\begin{array}{l}39.48 \\
38.25 \\
34.96 \\
41.03 \\
41.71 \\
79.20 \\
\end{array}$ & $\begin{array}{l}131 \\
127 \\
115 \\
114 \\
115 \\
119 \\
\end{array}$ & $\begin{array}{r}0.47 \\
-3.48 \\
-4.58 \\
0.58 \\
0.87 \\
0.90 \\
\end{array}$ & $\begin{array}{r}9.9 \\
10.7 \\
11.3 \\
12.1 \\
12.1 \\
11.4 \\
\end{array}$ & $\begin{array}{l}7.95 \\
6.75 \\
7.21 \\
7.15 \\
7.15 \\
\text { NA }\end{array}$ & $\begin{array}{c}4.4 \\
\text { NA } \\
\text { NA } \\
8.1 \\
8.1 \\
7.3 \\
\end{array}$ & $\begin{array}{r}122 \\
125 \\
128 \\
90 \\
90 \\
\text { NA } \\
\end{array}$ \\
\hline Young Spring & $\begin{array}{l}3 / 23 / 2005 \\
5 / 5 / 2005 \\
6 / 16 / 2005 \\
7 / 12 / 2005\end{array}$ & $\begin{array}{l}36.15 \\
35.41 \\
35.25 \\
36.56 \\
\end{array}$ & $\begin{array}{l}44.1 \\
43.2 \\
43.0 \\
44.6 \\
\end{array}$ & $\begin{array}{l}0 \\
0 \\
0 \\
0 \\
\end{array}$ & $\begin{array}{l}5.51 \\
6.05 \\
5.22 \\
4.74 \\
\end{array}$ & $\begin{array}{r}8.92 \\
8.94 \\
11.41 \\
11.04 \\
\end{array}$ & $\begin{array}{l}0.04 \\
0.05 \\
0.04 \\
0.03 \\
\end{array}$ & $\begin{array}{c}{[0.01], \mathrm{U}} \\
0.02 \\
0.01 \\
0.01\end{array}$ & $\begin{array}{l}0.36 \\
0.69 \\
0.57 \\
0.54 \\
\end{array}$ & $\begin{array}{l}{[0.5], \mathrm{U}} \\
{[0.5], \mathrm{U}} \\
{[0.5], \mathrm{U}} \\
{[0.5], \mathrm{U}}\end{array}$ & $\begin{array}{l}7.99 \\
7.61 \\
7.81 \\
8.30 \\
\end{array}$ & $\begin{array}{l}3.32 \\
3.29 \\
4.30 \\
4.33 \\
\end{array}$ & $\begin{array}{l}7.41 \\
7.56 \\
8.10 \\
8.14 \\
\end{array}$ & $\begin{array}{l}1.97 \\
1.89 \\
2.35 \\
2.31 \\
\end{array}$ & $\begin{array}{l}50.48 \\
50.03 \\
51.11 \\
49.99 \\
\end{array}$ & $\begin{array}{l}132 \\
132 \\
136 \\
136 \\
\end{array}$ & $\begin{array}{r}-3.28 \\
-5.04 \\
-0.82 \\
0.16 \\
\end{array}$ & $\begin{array}{l}12.8 \\
12.8 \\
13.0 \\
15.0 \\
\end{array}$ & $\begin{array}{l}7.34 \\
7.61 \\
7.20 \\
7.34 \\
\end{array}$ & $\begin{array}{c}8.0 \\
7.4 \\
\mathrm{NA} \\
4.5 \\
\end{array}$ & $\begin{array}{l}116 \\
119 \\
126 \\
125 \\
\end{array}$ \\
\hline Pajarito Ski Well \#2 & $\begin{array}{l}3 / 2 / 2005 \\
8 / 31 / 2005 \\
1 / 12 / 2006 \\
\end{array}$ & $\begin{array}{l}37.13 \\
37.38 \\
37.00 \\
\end{array}$ & $\begin{array}{l}45.3 \\
45.6 \\
45.1 \\
\end{array}$ & $\begin{array}{l}0 \\
0 \\
0 \\
\end{array}$ & $\begin{array}{l}3.36 \\
4.08 \\
4.22 \\
\end{array}$ & $\begin{array}{l}1.26 \\
5.53 \\
1.44 \\
\end{array}$ & $\begin{array}{l}0.03 \\
0.03 \\
0.03 \\
\end{array}$ & $\begin{array}{c}{[0.01], \mathrm{U}} \\
{[0.01], \mathrm{U}} \\
0.01 \\
\end{array}$ & $\begin{array}{l}0.45 \\
0.40 \\
0.53 \\
\end{array}$ & $\begin{array}{l}{[0.5], \mathrm{U}} \\
{[0.5], \mathrm{U}} \\
{[0.5], \mathrm{U}} \\
\end{array}$ & $\begin{array}{l}7.52 \\
7.10 \\
6.94 \\
\end{array}$ & $\begin{array}{l}2.81 \\
2.71 \\
2.63 \\
\end{array}$ & $\begin{array}{l}4.79 \\
7.37 \\
4.80 \\
\end{array}$ & $\begin{array}{l}2.18 \\
2.15 \\
2.18 \\
\end{array}$ & $\begin{array}{l}43.77 \\
41.45 \\
42.30 \\
\end{array}$ & $\begin{array}{l}113 \\
119 \\
112 \\
\end{array}$ & $\begin{array}{l}-0.47 \\
-2.48 \\
-4.60 \\
\end{array}$ & $\begin{array}{r}6.3 \\
16.2 \\
7.6 \\
\end{array}$ & $\begin{array}{l}8.85 \\
7.12 \\
7.07 \\
\end{array}$ & $\begin{array}{l}8.1 \\
5.4 \\
9.6 \\
\end{array}$ & $\begin{array}{l}91 \\
99 \\
86 \\
\end{array}$ \\
\hline \multicolumn{22}{|l|}{ Pajarito Plateau } \\
\hline \multicolumn{22}{|l|}{ Perched Alluvial } \\
\hline (Interlaboratory Field Duplicate) & $\begin{array}{l}3 / 3 / 2005 \\
5 / 10 / 2005 \\
5 / 10 / 2005 \\
8 / 17 / 2005\end{array}$ & $\begin{array}{l}50.70 \\
41.23 \\
38.60 \\
67.87\end{array}$ & $\begin{array}{l}61.9 \\
50.3 \\
47.1 \\
82.8\end{array}$ & $\begin{array}{c}0 \\
0 \\
{[1.45], \mathrm{U}} \\
0\end{array}$ & $\begin{array}{r}15.13 \\
15.77 \\
14.20 \\
9.22\end{array}$ & $\begin{array}{l}14.86 \\
16.20 \\
14.70 \\
16.04\end{array}$ & $\begin{array}{c}0.09 \\
0.15 \\
{[0.03], \mathrm{U}} \\
0.08\end{array}$ & $\begin{array}{c}{[0.01], \mathrm{U}} \\
{[0.01], \mathrm{U}} \\
{[0.041], \mathrm{U}} \\
0.02\end{array}$ & $\begin{array}{l}0.45 \\
0.57 \\
0.45 \\
0.10\end{array}$ & $\begin{array}{c}{[2.0], \mathrm{U}} \\
{[1.0], \mathrm{U}} \\
0.390 \\
\mathrm{NA}\end{array}$ & $\begin{array}{l}17.57 \\
15.39 \\
16.50 \\
18.24\end{array}$ & $\begin{array}{l}5.22 \\
3.75 \\
5.02 \\
5.50\end{array}$ & \begin{tabular}{|r|}
8.65 \\
8.41 \\
9.29 \\
11.27
\end{tabular} & $\begin{array}{l}3.02 \\
2.33 \\
3.17 \\
3.96\end{array}$ & $\begin{array}{l}27.52 \\
29.15 \\
31.10 \\
35.86\end{array}$ & $\begin{array}{l}156 \\
144 \\
115 \\
184\end{array}$ & $\begin{array}{r}-0.66 \\
-4.93 \\
6.40 \\
-1.45\end{array}$ & $\begin{array}{r}5.0 \\
6.8 \\
6.8 \\
11.5\end{array}$ & $\begin{array}{l}7.48 \\
7.20 \\
7.20 \\
6.82\end{array}$ & $\begin{array}{r}5.1 \\
5.7 \\
5.7 \\
13.1\end{array}$ & $\begin{array}{l}104 \\
180 \\
180 \\
211\end{array}$ \\
\hline
\end{tabular}


Table 6.1

Summary Results of Major Element Chemistry and Field Parameters (Cont.)

\begin{tabular}{|c|c|c|c|c|c|c|c|c|c|c|c|c|c|c|c|c|c|c|c|c|c|}
\hline \multirow[b]{2}{*}{ Station ID } & \multirow[b]{2}{*}{$\begin{array}{c}\text { Date } \\
\text { Sampled }\end{array}$} & \multirow[b]{2}{*}{$\begin{array}{c}\text { Total } \\
\text { Alkalinity (lab) } \\
\text { (ppm) }\end{array}$} & \multirow[b]{2}{*}{$\begin{array}{l}\mathrm{HCO}_{3} \\
\text { (ppm) }\end{array}$} & \multirow[b]{2}{*}{$\underset{(\mathbf{p p m})}{\mathrm{CO}_{3}}$} & \multirow[b]{2}{*}{$\underset{(\mathbf{p p m})}{\mathrm{SO}_{4}}$} & \multirow[b]{2}{*}{$\begin{array}{c}\mathrm{Cl} \\
(\mathbf{p p m})\end{array}$} & \multirow[b]{2}{*}{$\begin{array}{c}\mathbf{F} \\
(\mathbf{p p m})\end{array}$} & \multirow[b]{2}{*}{$\begin{array}{c}\mathbf{B r} \\
(\mathbf{p p m})\end{array}$} & \multirow[b]{2}{*}{$\begin{array}{c}\mathrm{NO}_{3} \text { as } \mathrm{N} \\
(\mathrm{ppm})\end{array}$} & \multirow[b]{2}{*}{$\begin{array}{l}\mathrm{ClO}_{4} \\
(\mathbf{p p b})\end{array}$} & \multirow[b]{2}{*}{$\begin{array}{c}\mathrm{Ca} \\
(\mathbf{p p m})\end{array}$} & \multirow[b]{2}{*}{$\begin{array}{c}\mathbf{M g} \\
(\mathbf{p p m})\end{array}$} & \multirow[b]{2}{*}{\begin{tabular}{|c|c}
$\mathrm{Na}$ \\
$(\mathbf{p p m})$
\end{tabular}} & \multirow[b]{2}{*}{$\begin{array}{c}\mathbf{K} \\
(\mathbf{p p m})\end{array}$} & \multirow[b]{2}{*}{$\begin{array}{c}\mathrm{SiO}_{2}(\mathrm{cal}) \\
(\mathrm{ppm})\end{array}$} & & & & & ield Propert & \\
\hline & & & & & & & & & & & & & & & & $\begin{array}{c}\text { Lab TDS } \\
\text { (ppm) }\end{array}$ & $\begin{array}{c}\text { Calarge } \\
\text { Balance } \\
(\%)\end{array}$ & $\begin{array}{c}\text { Temp } \\
\left({ }^{\circ} \mathrm{C}\right)\end{array}$ & $\begin{array}{c}\mathbf{p H} \\
\text { (S.U.). }\end{array}$ & $\begin{array}{c}\text { Dissolved } \\
\text { Oxygen } \\
(\mathbf{m g / L})\end{array}$ & $\begin{array}{c}\text { Specific } \\
\text { Conductance } \\
\text { (uS/cm) }\end{array}$ \\
\hline Perched Volcanics at Surface & & & & & & & & & & & & & & & & & & & & & \\
\hline Homestead Spring & $3 / 31 / 2005$ & 24.84 & 30.3 & 0 & 18.57 & 15.93 & 0.06 & {$[0.01], \mathrm{U}$} & 0.39 & {$[2.0], \mathrm{U}$} & 11.98 & 3.44 & 9.93 & 2.31 & 37.77 & 135 & -0.49 & 8.6 & 6.59 & 6.7 & 149 \\
\hline & & & & 0 & & 8.14 & 0.06 & 0.02 & 0.36 & {$[1.0], \mathrm{U}$} & 9.47 & 2.67 & 7.76 & 1.79 & 29.31 & 114 & -5.47 & 9.6 & 7.32 & 3.3 & 124 \\
\hline & & 32.00 & 39.1 & 0 & $\mathrm{NA}$ & $\mathrm{NA}$ & NA & NA & NA & $\mathrm{N}$ & 7.56 & 2.71 & 7.2 & 2.10 & 33 & NA & 1.7 & 10.8 & & 7.1 & 100 \\
\hline (Interlaboratory Field Duplicate) & & 31.70 & 38.7 & [1.45], U & 8.20 & 3.72 & 0.09 & {$[0.04$} & 0.21 & 0.2 & 7.97 & 2.82 & 7.47 & 2.35 & 34. & 89 & 4.4 & 10.8 & & 7.1 & 100 \\
\hline & $7 / 18 / 2005$ & & & & & 7.86 & 0.06 & 0.01 & 0.39 & {$[2.0], \mathrm{U}$} & 9.83 & 3.44 & 8.57 & 2.45 & 34.60 & 124 & 0.69 & 13.7 & 6.40 & 4.4 & 131 \\
\hline Starmer Spring & $3 / 31 / 2005$ & 28.69 & 35.0 & 0 & 19.75 & 20.43 & 0.09 & 0.02 & 0.33 & {$[2.0], \mathrm{U}$} & 12.68 & 3.45 & 14.10 & 2.44 & 41.46 & 154 & -0.83 & 9.2 & 6.74 & 6.7 & 175 \\
\hline & $5 / 9 / 2005$ & & 36.9 & 0 & 17.54 & 13.76 & 0.09 & 0.03 & 0.54 & {$[1.0], \mathrm{U}$} & 11.15 & 2.95 & 10.42 & 1.91 & 30.40 & 128 & -3.73 & 9.6 & 6.99 & 8.9 & 153 \\
\hline & $6 / 21 / 2005$ & 34.40 & $\begin{array}{l}42.0 \\
43.9\end{array}$ & $\begin{array}{c}0 \\
457 \mathrm{U}\end{array}$ & $\begin{array}{l}\mathrm{NA} \\
782\end{array}$ & $\begin{array}{l}\text { NA } \\
357\end{array}$ & $\mathrm{NA}$ & NA & NA & $\begin{array}{c}\mathrm{NA} \\
0301\end{array}$ & 7.66 & 2.66 & 7.58 & 2.02 & 33.60 & $\mathrm{NA}$ & 0.70 & 12.1 & 6.55 & 7.3 & 104 \\
\hline (Interlaboratory Field Duplicate) & $\begin{array}{l}6 / 21 / 12005 \\
7 / 1 / 2005\end{array}$ & $\begin{array}{l}36.00 \\
38.61\end{array}$ & $\begin{array}{l}43.9 \\
47.1\end{array}$ & {$\left[\begin{array}{l}{[1.45], \mathrm{U}} \\
0\end{array}\right.$} & $\begin{array}{l}7.82 \\
9.96\end{array}$ & $\begin{array}{l}3.57 \\
8.66\end{array}$ & {$\left[\begin{array}{l}{[0.03], \mathrm{U}} \\
0.07\end{array}\right.$} & {$[0.04], \mathrm{U}$} & $\begin{array}{l}0.23 \\
0.51\end{array}$ & $\begin{array}{l}0.301 \\
{[1.01, \mathrm{U}}\end{array}$ & 8.41 & 2.87 & 8.19 & 2.36 & 36.20 & 93 & 3.50 & 12.1 & 6.55 & 7.3 & 104 \\
\hline (Blind Intralaboratory Field Duplicate) & $7 / 18 / 2005$ & 36.39 & 44.4 & 0 & 9.97 & 8.66 & 0.07 & 0.02 & 0.51 & {$[1.0], \mathrm{U}$} & $\begin{array}{l}7.00 \\
9.91\end{array}$ & 3.40 & 9.04 & 2.34 & 34.75 & 125 & 0.26 & $\begin{array}{l}.0 .0 \\
8.8\end{array}$ & $\begin{array}{l}6.39 \\
6.39\end{array}$ & $\begin{array}{l}0.3 \\
6.3\end{array}$ & 127 \\
\hline Bulldog Spring & $3 / 31 / 2005$ & 52.21 & 63.7 & 0 & 15.19 & 33.69 & 0.24 & 0.02 & 0.51 & {$[1.0], \mathrm{U}$} & 19.84 & 4.48 & 21.18 & 2.77 & 47.51 & 214 & -0.78 & 9.8 & 7.41 & 7.8 & 246 \\
\hline (Blind Intralaboratory Field Duplicate) & $3 / 31 / 2005$ & & 63.9 & 0 & 15.20 & 33.70 & 0.24 & 0.02 & 0.61 & {$[1.0], \mathrm{U}$} & 20.27 & 4.49 & 20.86 & 2.74 & 46.83 & 214 & -0.84 & 9.8 & 7.41 & 7.8 & 246 \\
\hline & $5 / 9 / 2005$ & & 68.8 & 0 & 16.92 & 22.44 & 0.25 & 0.05 & 0.95 & {$[1.0], \mathrm{U}$} & 17.50 & 3.87 & 17.72 & 2.26 & 35.75 & 190 & -4.15 & 10.2 & 7.13 & 11.3 & 204 \\
\hline & 6/22/2005 & 58. & 71.6 & 0 & $\mathrm{NA}$ & NA & NA & NA & $\mathrm{NA}$ & $\mathrm{NA}$ & 14.42 & 4.03 & 17.13 & 2.74 & 40.60 & NA & 0.70 & 10.8 & 7.50 & 5.9 & 194 \\
\hline (Interlaboratory Field Duplicate) & 6/22/2005 & & 74.9 & [1.45], U & 12.00 & 13.00 & 0.12 & {$[0.04], \mathrm{U}$} & NA & 0.614 & 15.20 & 4.17 & 17.40 & 2.79 & 40.60 & 143 & 0.90 & 10.8 & 7.5 & 5.9 & 194 \\
\hline & $7 / 18 / 2005$ & 61.80 & 75.4 & 0 & 11.60 & 12.95 & 0.26 & 0.05 & 0.76 & {$[1.0], \mathrm{U}$} & 13.90 & 4.10 & 17.50 & 2.43 & 41.61 & 183 & -1.52 & 9.7 & 7.12 & 5.8 & 190 \\
\hline $\begin{array}{l}\text { Burning Ground Spring } \\
\text { (llind Intrathorntry Field Dunlicrte }\end{array}$ & 4/1/2005 & $\begin{array}{r}48.85 \\
4885\end{array}$ & 59.6 & 0 & $\begin{array}{l}20.04 \\
109\end{array}$ & $\begin{array}{l}23.36 \\
23.37\end{array}$ & 0.15 & 0.02 & $\begin{array}{l}0.80 \\
083\end{array}$ & {$[1.0], U$} & $\begin{array}{l}18.48 \\
1842\end{array}$ & $\begin{array}{l}4.76 \\
4.65\end{array}$ & $\begin{array}{l}16.65 \\
11.14\end{array}$ & 2.82 & $\begin{array}{l}50.68 \\
4701\end{array}$ & $\begin{array}{l}204 \\
109\end{array}$ & $\begin{array}{l}-0.82 \\
-159\end{array}$ & $\begin{array}{l}9.8 \\
98\end{array}$ & 6.91 & 6.6 & $\begin{array}{l}99 \\
99\end{array}$ \\
\hline & 4/1/2005 & 48. 3. & 59.6 & 0 & 19.9 & 23 & 0.1 & 0.03 & 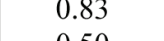 & {$[1,0]$} & 18.42 & 4.65 & 16.14 & 2.71 & 47.6 & 19 & -1.59 & 9.8 & & 6.6 & 99 \\
\hline & $\begin{array}{l}5 / 13 / 2005 \\
7 / 19 / 2005\end{array}$ & $\begin{array}{l}46.31 \\
51.15\end{array}$ & $\begin{array}{l}56.5 \\
62.4\end{array}$ & $\begin{array}{l}0 \\
0\end{array}$ & $\begin{array}{l}23.41 \\
11.33\end{array}$ & $\begin{array}{l}32.76 \\
12.68\end{array}$ & $\begin{array}{l}0.13 \\
0.14\end{array}$ & $\begin{array}{l}0.04 \\
0.04\end{array}$ & $\begin{array}{l}0.50 \\
0.77\end{array}$ & $\begin{array}{l}{[1.0], \mathrm{U}} \\
{[1.01 \mathrm{U}}\end{array}$ & $\begin{array}{l}21.85 \\
13.91\end{array}$ & $\begin{array}{l}5.59 \\
4.42\end{array}$ & $\begin{array}{l}14.69 \\
12.67\end{array}$ & $\begin{array}{l}2.62 \\
2.71\end{array}$ & $\begin{array}{l}34.69 \\
38.88\end{array}$ & $\begin{array}{l}195 \\
163\end{array}$ & $\begin{array}{r}-2.65 \\
4.00\end{array}$ & $\begin{array}{l}9.8 \\
9.8\end{array}$ & $\begin{array}{l}7.10 \\
6.79\end{array}$ & $\begin{array}{l}6.1 \\
8.4\end{array}$ & $\begin{array}{l}256 \\
171\end{array}$ \\
\hline Martin Spring & $4 / 6 / 2005$ & 61.80 & 75.4 & 0 & 14.89 & 19.78 & 0.38 & 0.03 & 0.68 & {$[1.0], \mathrm{U}$} & 18.15 & 3.65 & 20.54 & 2.47 & 37.22 & 197 & -1.14 & 10.8 & 7.24 & 6.2 & 220 \\
\hline & 5/9/2005 & 70.00 & 85.4 & 0 & 13.93 & 18.53 & 0.43 & 0.08 & 1.16 & {$[1.0], \mathrm{U}$} & 18.88 & 3.81 & 20.98 & 2.16 & 36.05 & 207 & -2.67 & 14.0 & 7.07 & 7.0 & 232 \\
\hline TA-18 Spring & $3 / 18 / 2005$ & 24.75 & 30.2 & 0 & 23.43 & 17.47 & 0.09 & 0.02 & 0.05 & {$[1.0], U$} & 11.45 & 3.44 & 14.38 & 3.65 & 63.98 & 180 & -0.59 & 48.0 & 6.62 & 4.0 & 157 \\
\hline & $5 / 9 / 2005$ & & 44.4 & 0 & 17.42 & 21.51 & 0.11 & 0.05 & {$[0.002], \mathrm{U}$} & {$[1.0], \mathrm{U}$} & 12.14 & 3.09 & 14.85 & 2.59 & 28.7 & 145 & -3.82 & 9.5 & 7.15 & 1.5 & 195 \\
\hline & $6 / 22 / 2005$ & 51.60 & 62.9 & 0 & $\mathrm{NA}$ & NA & NA & NA & $\mathrm{NA}$ & $\mathrm{NA}$ & 14.10 & 4.56 & 17.00 & 3.56 & 30. & $\mathrm{~N} t$ & 1.60 & 14.4 & 6.57 & 1.3 & 217 \\
\hline (Interlaboratory Field Duplicate) & 6/22/2005 & 54.00 & 65.9 & [1.45], U & 13.00 & 19.40 & {$[0.03], \mathrm{U}$} & {$[0.04], \mathrm{U}$} & {$[0.017], \mathrm{U}$} & {$[0.05], \mathrm{U}$} & 15.00 & 4.64 & 17.90 & 3.89 & 30. & 140 & 2.80 & 14.4 & 6. & 1.3 & 217 \\
\hline & $8 / 1 / 2005$ & & 74.3 & 0 & 13.4 & 21.47 & 0.12 & 0.07 & 0.00 & $\mathrm{NA}$ & 16.03 & 5.10 & 16.70 & 3.73 & 31.5 & 18 & & 12.6 & & 4.0 & 226 \\
\hline (Blind Intralaboratory Field Duplicate) & $8 / 1 / 2005$ & 57.79 & 70.5 & 0 & 16.38 & 21.59 & 0.12 & 0.08 & 0.00 & NA & 15.68 & 5.10 & 17.01 & 3.78 & 31.10 & 182 & -1.58 & 12.6 & 6.25 & 4.0 & 226 \\
\hline Intermediate at Depth, Volcanics and Sedime & & & & & & & & & & & & & & & & & & & & & \\
\hline LAOI(A)-1.1 & $3 / 4 / 2005$ & 51.23 & 62.5 & 0 & 4.58 & 1.29 & 0.10 & 0.01 & 0.47 & {$[0.5], \mathrm{U}$} & 5.78 & 1.57 & 11.13 & 10.01 & 67.69 & 167 & -1.52 & 9.5 & 9.62 & 15.3 & 148 \\
\hline & $3 / 7 / 2005$ & NA & NA & NA & NA & NA & NA & NA & NA & $\mathrm{NA}$ & NA & NA & $\mathrm{NA}$ & NA & NA & NA & $\mathrm{NA}$ & 9.5 & 8.27 & 7.4 & 129 \\
\hline MCOBT-4.4 & $3 / 29 / 2005$ & 40.74 & 49.7 & 0 & 27.34 & 17.31 & 0.35 & 0.13 & 20.20 & 210 & 38.04 & 5.43 & 23.22 & 0.62 & 70.60 & 323 & 0.65 & 15.7 & 7.49 & 6.3 & 376 \\
\hline MCOI-6 & 9/1/2005 & 66.10 & 80.6 & [1.45], U & 37.60 & 22.90 & 0.55 & 0.30 & 16.40 & 246 & 48.10 & 9.65 & 21.60 & 0.74 & 70.90 & 343 & 2.59 & 19.7 & 7.38 & 5.0 & 418 \\
\hline POI-4 & $\begin{array}{l}/ 8 / 2005 \\
8 / 3 / 2005\end{array}$ & $\begin{array}{l}181.15 \\
159.84\end{array}$ & \begin{tabular}{|l|}
221.0 \\
195.0
\end{tabular} & $\begin{array}{l}0 \\
0\end{array}$ & $\begin{array}{l}23.47 \\
23.71\end{array}$ & $\begin{array}{l}45.63 \\
46.48\end{array}$ & $\begin{array}{l}0.29 \\
0.28\end{array}$ & $\begin{array}{l}0.05 \\
0.10\end{array}$ & $\begin{array}{l}4.54 \\
4.25\end{array}$ & $\begin{array}{c}{[5.0], \mathrm{U}} \\
\mathrm{NA}\end{array}$ & \begin{tabular}{|l|}
48.72 \\
46.43
\end{tabular} & \begin{tabular}{|l|}
11.98 \\
12.10 \\
\end{tabular} & \begin{tabular}{|l|l|}
44.53 \\
43.65
\end{tabular} & $\begin{array}{l}8.45 \\
8.39\end{array}$ & $\begin{array}{l}52.81 \\
55.53\end{array}$ & $\begin{array}{l}481 \\
454\end{array}$ & $\begin{array}{r}-1.91 \\
0.46\end{array}$ & $\begin{array}{l}12.7 \\
14.1\end{array}$ & $\begin{array}{l}7.40 \\
7.00\end{array}$ & $\begin{array}{l}6.5 \\
7.3\end{array}$ & $\begin{array}{l}555 \\
186\end{array}$ \\
\hline R-6i & $8 / 24 / 2005$ & 77.87 & 95.0 & 0 & 14.10 & 19.22 & 0.54 & 0.07 & 4.51 & 5.0 & 26.78 & 4.81 & 19.34 & 0.63 & 70.80 & 272 & -2.77 & 17.5 & 7.26 & 6.1 & 270 \\
\hline R-23i (bottom screen) & $12 / 11 / 2005$ & 78.90 & 96.2 & 0 & 12.4 & 10.4 & 0.25 & 0.08 & 0.82 & {$[0.5], \mathrm{U}$} & 19.20 & 5.74 & 13.30 & 2.75 & 45.60 & 159 & -1.42 & 17.7 & 8.22 & $\mathrm{NA}$ & 227 \\
\hline TW-1A & 3/24/2005 & 106.56 & 130.0 & 0 & 0.53 & 50.88 & 0.62 & 0.11 & 0.19 & {$[2.0], \mathrm{U}$} & 12.65 & 3.11 & 47.77 & 5.39 & 3.01 & 266 & -3.51 & 11.2 & 7.59 & 16.8 & 457 \\
\hline & $8 / 18 / 2005$ & 122.13 & 149.0 & 0 & {$[0.01], \mathrm{U}$} & 79.97 & 0.28 & 0.18 & 0.00 & $\mathrm{NA}$ & 31.80 & 9.49 & 36.38 & 5.42 & 3.08 & 317 & -6.83 & 13.0 & 7.87 & 0.9 & 445 \\
\hline Regional Aquifer Wells & & & & & & & & & & & & & & & & & & & & & \\
\hline & $5 / 19 / 2005$ & 68.70 & 83.8 & 0 & 3.70 & 1.89 & 0.15 & 0.17 & 0.31 & {$[0.5], \mathrm{U}$} & 10.59 & 3.34 & 11.40 & 1.37 & 70.85 & 189 & -6.94 & 22.4 & 7.63 & 4.5 & 158 \\
\hline (Interlaboratory Field Duplicate) & & & 75.9 & [1.45], U & 3.65 & 1.84 & 0.26 & & 0.25 & $0.314 \mathrm{NF}$ & 12.20 & 4.22 & 12.90 & 1.79 & 75.90 & 189 & -6.94 & 22.4 & 7.63 & 4.5 & 158 \\
\hline & $9 / 12 / 2005$ & 66.15 & 80.7 & & 3.22 & 2.11 & 0.14 & 0.11 & 0.33 & {$[0.5], \mathrm{U}$} & 10.98 & 3.92 & 12.77 & 1.74 & 74.95 & 189 & -3.51 & 21.7 & 7.78 & 4.4 & 143 \\
\hline
\end{tabular}


Table 6.1

Summary Results of Major Element Chemistry and Field Parameters (Cont.)

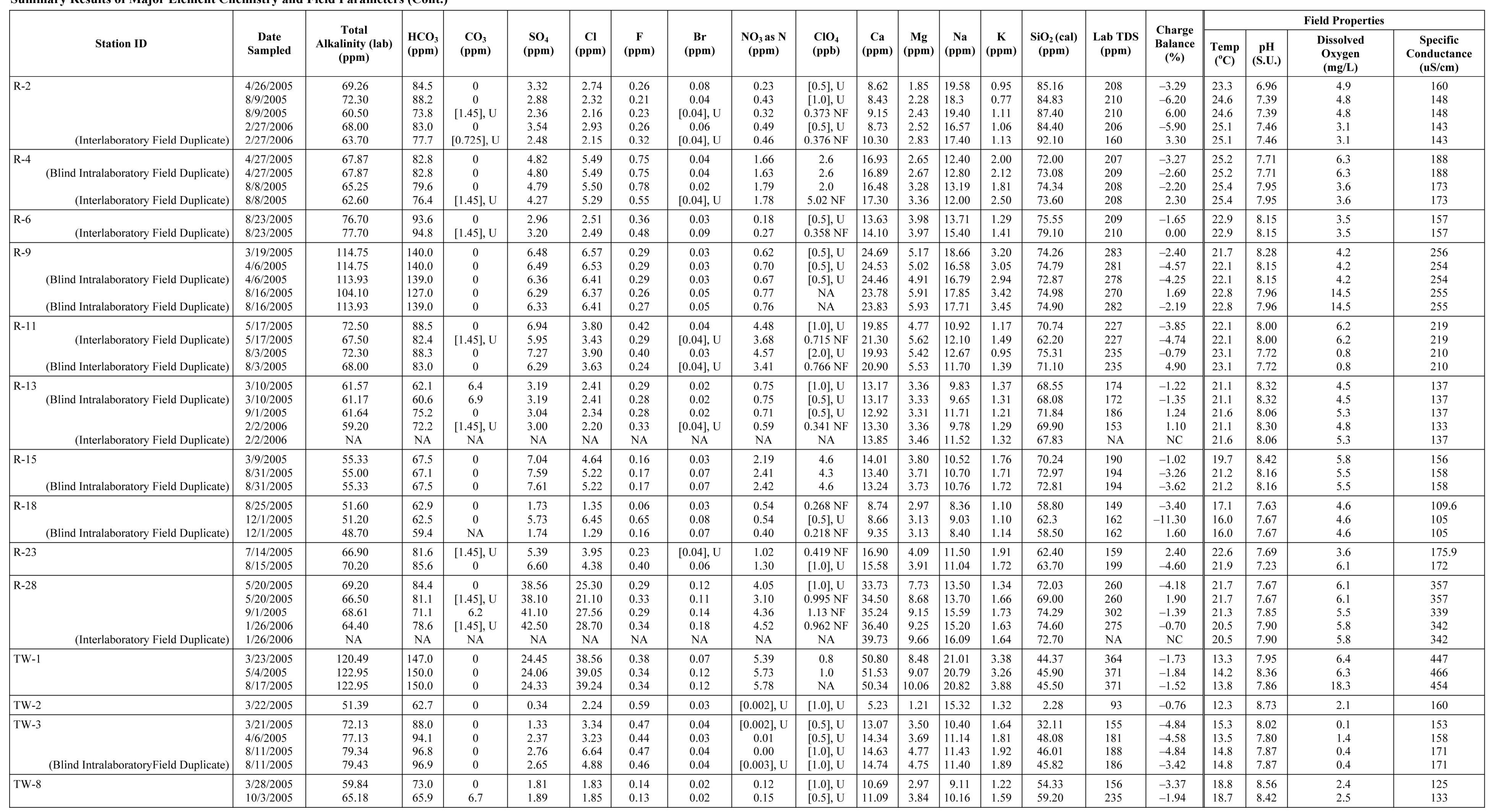


Table 6.1

Summary Results of Major Element Chemistry and Field Parameters (Cont.)

\begin{tabular}{|c|c|c|c|c|c|c|c|c|c|c|c|c|c|c|c|c|c|c|c|c|c|}
\hline \multirow[b]{2}{*}{ Station ID } & \multirow[b]{2}{*}{$\begin{array}{c}\text { Date } \\
\text { Sampled }\end{array}$} & \multirow{2}{*}{$\begin{array}{c}\text { Total } \\
\text { Alkalinity (lab) } \\
\quad \text { (ppm) }\end{array}$} & \multirow[b]{2}{*}{$\begin{array}{l}\mathrm{HCO}_{3} \\
\text { (ppm) }\end{array}$} & \multirow[b]{2}{*}{$\begin{array}{c}\mathrm{CO}_{3} \\
(\mathrm{ppm})\end{array}$} & \multirow[b]{2}{*}{$\begin{array}{c}\mathrm{SO}_{4} \\
(\mathbf{p p m})\end{array}$} & \multirow[b]{2}{*}{$\underset{(\mathbf{p p m})}{\mathrm{Cl}}$} & \multirow[b]{2}{*}{$\begin{array}{c}\mathbf{F} \\
(\mathbf{p p m})\end{array}$} & \multirow[b]{2}{*}{$\begin{array}{c}\mathrm{Br} \\
(\mathbf{p p m})\end{array}$} & \multirow[b]{2}{*}{$\begin{array}{c}\mathrm{NO}_{3} \text { as } \mathrm{N} \\
(\mathrm{ppm})\end{array}$} & \multirow[b]{2}{*}{$\begin{array}{l}\mathrm{ClO}_{4} \\
(\mathrm{ppb})\end{array}$} & \multirow[b]{2}{*}{$\begin{array}{c}\mathrm{Ca} \\
(\mathrm{ppm})\end{array}$} & \multirow[b]{2}{*}{$\begin{array}{c}\mathbf{M g} \\
(\mathbf{p p m})\end{array}$} & & & & & & & & Field Propert & \\
\hline & & & & & & & & & & & & & \begin{tabular}{|c|}
$\mathrm{Na}$ \\
$(\mathrm{ppm})$
\end{tabular} & $\begin{array}{c}\mathrm{K} \\
(\mathbf{p p m})\end{array}$ & $\begin{array}{c}\mathrm{SiO}_{2}(\mathrm{cal}) \\
(\mathrm{ppm})\end{array}$ & $\begin{array}{c}\text { Lab TDS } \\
\text { (ppm) }\end{array}$ & $\begin{array}{c}\text { Charge } \\
\text { Balance } \\
(\%)\end{array}$ & $\begin{array}{c}\text { Temp } \\
\left({ }^{\circ} \mathrm{C}\right)\end{array}$ & $\begin{array}{c}\mathrm{pH} \\
\text { (S.U.) }\end{array}$ & $\begin{array}{c}\text { Dissolved } \\
\text { Oxygen } \\
(\mathbf{m g} / \mathbf{L})\end{array}$ & $\begin{array}{c}\text { Specific } \\
\text { Conductance } \\
\text { (uS } / \mathrm{cm})\end{array}$ \\
\hline Regional Aquifer Production Well & & & & & & & & & & & & & & & & & & & & & \\
\hline $0-1$ & $3 / 23 / 2005$ & 101.19 & 108.0 & 7.6 & 7.91 & 7.58 & 0.38 & 0.03 & 1.45 & 1.1 & 14.81 & 2.05 & 34.27 & 2.66 & 59.62 & 252 & -1.15 & 24.3 & 8.57 & 5.4 & 232 \\
\hline (Blind Intralaboratory Field Duplicate) & 3/23/2005 & 101.52 & 108.0 & 7.8 & 7.91 & 7.58 & 0.37 & 0.03 & 1.42 & 1.1 & 16.42 & 2.02 & 33.24 & 2.35 & 57.29 & 250 & -0.72 & 24.3 & 8.57 & 5.4 & 232 \\
\hline & $5 / 18 / 2005$ & 103.98 & 111.0 & 7.8 & 7.16 & 6.98 & 0.34 & 0.05 & 1.33 & 1.1 & 14.54 & 2.06 & 33.72 & 2.37 & 56.47 & 249 & -2.29 & 27.2 & 8.50 & NA & 250 \\
\hline & $8 / 17 / 2005$ & 103.00 & 110.0 & 7.7 & 7.72 & 7.55 & 0.33 & 0.05 & 1.46 & 2.25 & 14.76 & 2.46 & 33.59 & 2.78 & 57.82 & 251 & -1.61 & 26.0 & 8.64 & 3.9 & 102 \\
\hline (Blind Intralaboratory Field Duplicate) & $8 / 17 / 2005$ & 103.34 & 109.0 & 8.4 & 7.74 & 7.58 & 0.33 & 0.05 & 1.46 & 2.25 & 14.36 & 2.44 & 33.03 & 2.69 & 56.38 & 249 & -2.78 & 26.0 & 8.64 & 3.9 & 102 \\
\hline White Rock Canyon Springs & & & & & & & & & & & & & & & & & & & & & \\
\hline Spring 2B & 3/9/2005 & 177.05 & 216.0 & 0 & 25.68 & 35.65 & 0.39 & 0.03 & 3.74 & {$[2.0], \mathrm{U}$} & 59.80 & 7.35 & 34.04 & 3.86 & 34.80 & 435 & -1.78 & 14.2 & 8.03 & 10.1 & 496 \\
\hline & $7 / 21 / 2005$ & 189.34 & 231.0 & 0 & 30.55 & 38.09 & 0.41 & 0.05 & 4.23 & {$[2.0], \mathrm{U}$} & 62.26 & 7.83 & 39.58 & 4.40 & 42.12 & 476 & -1.96 & 21.0 & 7.56 & 1.1 & 542 \\
\hline Spring 3 & 3/9/2005 & 85.25 & 104.0 & 0 & 6.79 & 5.54 & 0.43 & 0.02 & 1.35 & {$[1.0], \mathrm{U}$} & 22.96 & 1.98 & 15.76 & 2.90 & 47.37 & 214 & -1.09 & 18.7 & 7.78 & 5.5 & 199 \\
\hline (Blind Intralaboratory Field Duplicate) & 3/9/2005 & 85.25 & 104.0 & 0 & 6.81 & 5.55 & 0.44 & 0.02 & 1.35 & {$[1.0], \mathrm{U}$} & 22.62 & 1.95 & 15.73 & 2.89 & 47.07 & 213 & -1.64 & 18.7 & 7.78 & 5.5 & 199 \\
\hline & $4 / 20 / 2005$ & 85.25 & 104.0 & 0 & 6.58 & 5.64 & 0.44 & 0.04 & 1.30 & {$[0.5], \mathrm{U}$} & 22.57 & 1.60 & 15.21 & 2.35 & 49.14 & 214 & -3.15 & 19.2 & 6.77 & 5.0 & 208 \\
\hline & $5 / 16 / 2005$ & 86.89 & 106.0 & 0 & 6.88 & 5.83 & 0.45 & 0.05 & 1.32 & {$[0.5], \mathrm{U}$} & 22.79 & 1.76 & 15.74 & 2.42 & 48.12 & 216 & -3.04 & 21.4 & NA & NA & 213 \\
\hline & $\begin{array}{l}7 / 21 / 2005 \\
9 / 26 / 2005\end{array}$ & $\begin{array}{l}82.79 \\
76.20\end{array}$ & $\begin{array}{r}101.0 \\
93.0\end{array}$ & $\begin{array}{c}0 \\
05] \mathrm{U}\end{array}$ & $\begin{array}{l}6.65 \\
6.14\end{array}$ & $\begin{array}{r}5.38 \\
5.03\end{array}$ & $\begin{array}{l}0.44 \\
0.45\end{array}$ & $\begin{array}{l}0.04 \\
0.07\end{array}$ & $\begin{array}{l}1.31 \\
1.22\end{array}$ & {$\left[\begin{array}{ll}1.00], \mathrm{U} \\
0.42\end{array}\right.$} & $\left|\begin{array}{l}21.35 \\
22.40\end{array}\right|$ & $\begin{array}{l}1.89 \\
1.93\end{array}$ & $\begin{array}{l}17.13 \\
17.10\end{array}$ & $\begin{array}{l}2.74 \\
2.84\end{array}$ & $\begin{array}{l}48.68 \\
55110\end{array}$ & 211 & $\begin{array}{l}-0.49 \\
470\end{array}$ & 19.4 & 7.68 & 4.7 & $\begin{array}{l}203 \\
174\end{array}$ \\
\hline Spring 3A & $3 / 9 / 2005$ & 81.39 & 99.3 & 0 & 5.42 & 4.16 & 0.40 & 0.02 & 1.02 & {$[1.01, \mathrm{U}$} & 21.18 & 1.77 & 14.64 & 2.90 & 48.36 & 203 & -0.81 & 19.9 & 7.80 & 5.6 & 183 \\
\hline & $4 / 15 / 2005$ & 79.75 & 97.3 & 0 & 5.28 & 4.06 & 0.41 & 0.02 & 1.02 & {$[0.5], \mathrm{U}$} & 21.15 & 1.43 & 12.97 & 2.17 & 48.66 & 198 & -3.13 & 20.1 & 7.72 & 6.2 & 183 \\
\hline & $4 / 20 / 2005$ & 80.98 & 98.8 & 0 & 5.20 & 4.21 & 0.41 & 0.04 & $\begin{array}{l}1.02 \\
1.00\end{array}$ & {$[0.5], \mathrm{U}$} & 20.50 & $\begin{array}{l}1.38 \\
1.38\end{array}$ & 12.97 & 2.19 & 48. & 199 & -4.74 & 20.1 & 7.00 & $\begin{array}{l}0.2 \\
6.6\end{array}$ & 191 \\
\hline & $5 / 16 / 2005$ & 81.15 & 99.0 & 0 & 5.44 & $\begin{array}{l}4.16 \\
4.16\end{array}$ & 0.42 & 0.04 & $\begin{array}{l}1.05 \\
1.05\end{array}$ & {$[0.5], \mathrm{U}$} & 20.83 & $\begin{array}{l}1.55 \\
1.55\end{array}$ & 14.06 & 2.36 & $\begin{array}{l}40.459 \\
48.59\end{array}$ & 201 & -2.78 & 20.0 & $\mathrm{NA}$ & $\mathrm{NA}$ & 190 \\
\hline & $7 / 21 / 2005$ & 80.25 & 97.9 & 0 & 5.62 & 4.27 & 0.43 & 0.04 & 1.04 & {$[1.0], \mathrm{U}$} & 20.18 & 1.70 & 16.21 & 2.74 & 48.78 & 203 & -0.26 & 19.5 & 7.61 & 3.5 & 189 \\
\hline & 9/26/2005 & 73.20 & 89.3 & {$[1.45], \mathrm{U}$} & 5.13 & 3.95 & 0.42 & {$[0.04], \mathrm{U}$} & 0.95 & 0.43 & 20.20 & 1.69 & 15.50 & 2.71 & 49.50 & 158 & 3.20 & 20.2 & 7.56 & 6.0 & 187 \\
\hline Spring 3C & $3 / 11 / 2005$ & 85.25 & \begin{tabular}{|l|}
104.0 \\
\end{tabular} & 0 & 7.52 & 3.75 & 0.43 & 0.03 & 0.99 & {$[1.0], \mathrm{U}$} & 19.47 & 4.03 & 14.28 & 2.61 & 43.19 & 204 & -1.63 & 15.4 & 7.97 & 7.7 & 186 \\
\hline Spring 4 & 2/21/2005 & 80.20 & 97.9 & 0 & 10.20 & 6.74 & 0.48 & 0.05 & 1.07 & {$[0.5], \mathrm{U}$} & 22.40 & 3.52 & 13.00 & 2.04 & 53.30 & 215 & -2.10 & 15.6 & 6.70 & 7.4 & 213 \\
\hline & 3/11/2005 & 80.74 & 98.5 & 0 & 10.57 & 6.97 & 0.47 & 0.05 & 1.31 & {$[1.0], \mathrm{U}$} & 21.72 & 4.31 & 13.21 & 2.57 & 50.90 & 215 & -1.56 & 15.5 & 7.12 & 8.5 & 203 \\
\hline & $4 / 22 / 2005$ & 80.82 & 98.6 & 0 & 10.22 & 7.00 & 0.46 & 0.08 & 1.30 & {$[0.5], \mathrm{U}$} & 22.08 & 3.48 & 12.70 & 2.05 & 53.03 & 216 & -3.52 & 15.7 & 7.40 & 7.4 & 213 \\
\hline & $7 / 27 / 2005$ & 80.82 & 98.6 & 0 & 10.11 & 6.65 & 0.48 & 0.05 & 1.21 & {$[1.0], \mathrm{U}$} & 21.18 & 4.45 & 13.37 & 2.47 & 54.09 & 217 & -1.27 & 16.8 & 7.06 & 8.9 & 211 \\
\hline & $9 / 26 / 2005$ & 75.20 & 91.7 & {$[1.45], \mathrm{U}$} & 9.69 & 6.53 & 0.48 & 0.08 & 1.22 & 0.62 & 21.80 & 4.29 & 13.70 & 2.44 & 53.50 & 175 & 2.30 & 17.5 & 7.03 & 8.5 & 211 \\
\hline Spring 4A & 2/22/2005 & 81.40 & 99.3 & 0 & 6.61 & 5.31 & 0.49 & 0.04 & 0.96 & {$[0.5], \mathrm{U}$} & 20.70 & 3.86 & 12.20 & 1.84 & 68.50 & 223 & -2.10 & 20.3 & 7.13 & 6.4 & 200 \\
\hline & & 81.15 & 99.0 & & 6.67 & 5.41 & 0.48 & & 0.85 & {$[0.5], \mathrm{U}$} & 20.07 & 3.87 & 12.02 & 1.85 & 67.16 & 221 & -2.72 & 20.3 & 7.76 & 6.4 & 192 \\
\hline & $4 / 26 / 2005$ & 81.80 & 99.8 & 0 & 6.58 & 5.52 & 0.52 & 0.06 & 1.16 & {$[0.5], \mathrm{U}$} & 21.84 & 4.06 & 12.37 & $\begin{array}{l}1.80 \\
1.80\end{array}$ & 68.22 & 226 & -0.66 & 20.0 & 7.87 & 7.1 & 200 \\
\hline & $5 / 16 / 2005$ & 82.79 & 101.0 & 0 & 6.87 & 5.56 & 0.50 & 0.07 & 1.16 & {$[0.5], \mathrm{U}$} & 20.79 & 4.12 & 11.57 & 1.76 & 66.01 & 224 & -3.50 & 20.4 & 6.47 & $\mathrm{NA}$ & 199 \\
\hline & 7/28/2005 & 81.31 & 99.2 & 0 & 6.60 & 5.30 & 0.49 & 0.04 & 1.05 & {$[2.0], \mathrm{U}$} & 19.57 & 4.83 & 12.15 & 2.07 & 67.88 & 223 & -2.90 & 19.6 & 7.52 & 7.3 & 199 \\
\hline & 9/27/2005 & 70.20 & 85.6 & {$[1.45], \mathrm{U}$} & 5.62 & 4.61 & 0.47 & {$[0.04], \mathrm{U}$} & 0.92 & 0.51 & 18.90 & 4.32 & 12.50 & 2.01 & 68.60 & 180 & 4.20 & 21.1 & 7.89 & 7.7 & 184 \\
\hline Spring 4AA & $3 / 22 / 2005$ & 83.61 & 102.0 & 0 & 7.14 & 5.79 & 0.48 & 0.04 & 1.16 & {$[0.5], \mathrm{U}$} & 20.68 & 4.31 & 12.32 & 1.92 & 66.58 & 227 & -2.90 & 18.7 & 7.79 & 6.3 & 198 \\
\hline (Blind Intralaboratory Field Duplicate) & $3 / 22 / 2005$ & 83.6 & 102.0 & 0 & 7.12 & 5.78 & 0.48 & & 1.17 & & 20.14 & 4.24 & 12.27 & 1.91 & 65.6 & 225 & -3.77 & 18.7 & 7.79 & 6.3 & 198 \\
\hline & $4 / 26 / 2005$ & 84.10 & 102 & 0 & 7.07 & 5.98 & 0.52 & 0.06 & 1.21 & {$[0.5$} & 22.01 & 4.46 & 12.69 & 1.87 & 67. & 23 & -1.01 & 18.6 & 7.67 & 6.4 & 206 \\
\hline & $5 / 16 / 2005$ & 83. & 102. & 0 & 7.33 & 6.01 & 0.50 & 77 & 1.17 & {$[0.5]$} & 20.24 & 4.49 & 11.83 & 1.76 & 64. & $22>22>2$ & -3.6 & 18.7 & 7. & $\mathrm{NA}$ & 205 \\
\hline & $7 / 26 / 2005$ & 85.25 & 104.0 & & 7.23 & 5.91 & 0.51 & 0.04 & 0.84 & {$[1.0], \mathrm{U}$} & 20.10 & 5.21 & 12.28 & 1.83 & 68.91 & & -2.21 & 18.3 & 7.20 & 6.9 & 209 \\
\hline & 9/27/2005 & 76.20 & 93.0 & {$[1.45], \mathrm{U}$} & 7.05 & 5.85 & 0.52 & 0.06 & 0.92 & 0.56 & $\mathrm{NA}$ & $\mathrm{NA}$ & $\mathrm{NA}$ & NA & NA & 189 & $\mathrm{NC}$ & 19.1 & 7.21 & 6.3 & 201 \\
\hline Spring 4B & 3/22/2005 & 90.98 & 111.0 & & & & & & & & & & & 2.26 & 52.10 & 230 & & & 7.64 & 6.5 & 223 \\
\hline & $4 / 22 / 2005$ & 90.98 & 111.0 & 0 & 10.48 & 8.13 & 0.44 & 0.07 & 1.00 & {$[0.5], \mathrm{U}$} & 24.76 & 4.22 & 12.36 & 2.05 & 51.89 & 230 & -4.05 & 15.7 & 7.52 & 6.5 & 231 \\
\hline & $5 / 20 / 2005$ & 90.98 & 111.0 & 0 & 10.34 & 8.11 & 0.45 & 0.08 & 1.02 & {$[0.5], \mathrm{U}$} & 24.22 & 4.46 & 12.30 & 1.99 & 50.14 & 228 & -4.30 & 15.7 & 7.29 & NA & 230 \\
\hline & $7 / 27 / 2005$ & 90.98 & $\begin{array}{l}111.0 \\
111.0\end{array}$ & 0 & 9.87 & $\begin{array}{l}0.11 \\
7.69\end{array}$ & 0.46 & 0.05 & 0.87 & {$[2.0], \mathrm{U}$} & 24.26 & 5.40 & 13.87 & 2.49 & 54.37 & 234 & -3.00 & 16.1 & 6.98 & 7.5 & 228 \\
\hline (Blind Intralaboratory Field Duplicate) & $7 / 27 / 2005$ & 90.16 & 110.0 & 0 & 9.85 & 7.68 & 0.45 & 0.05 & 0.86 & {$[2.0], \mathrm{U}$} & 23.31 & 5.38 & 13.16 & 2.39 & 53.75 & 230 & -1.45 & 16.1 & 6.98 & 7.5 & 228 \\
\hline 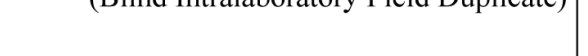 & 9/26/2005 & 90.20 & 110.0 & {$[1.45], \mathrm{U}$} & 8.65 & 7.90 & 0.47 & 0.06 & 0.24 & 0.32 & NA & $\mathrm{NA}$ & NA & $\mathrm{NA}$ & NA & 186 & $\mathrm{NC}$ & 16.6 & 7.82 & 6.6 & 234 \\
\hline Spring $4 \mathrm{C}$ & & 79.10 & 96.5 & 0 & 10.20 & 6.66 & 0.49 & 0.05 & 1.25 & {$[0.5], \mathrm{U}$} & 21.80 & 3.51 & 12.80 & 2.03 & 53.00 & 213 & -2.80 & 16.9 & 7.16 & 7.7 & 208 \\
\hline & 3/11/2005 & 79.43 & 96.9 & 0 & 10.53 & 6.94 & 0.47 & & 1.40 & {$[1.0], \mathrm{U}$} & 21.17 & 4.29 & 13.05 & 2.58 & 50. & 213 & -1.95 & 17.0 & 7.65 & 8.6 & 201 \\
\hline & $4 / 22 / 2005$ & 79.75 & 97.3 & 0 & 10.15 & 7.00 & 0.47 & 0.08 & 1.37 & {$[0.5]$} & 21.94 & 3.52 & 13.85 & 2.09 & 53.6 & 216 & -1.5 & 17.1 & 7.80 & 7.6 & 211 \\
\hline & $5 / 20 / 2005$ & 79.75 & 97.3 & 0 & 10.52 & 6.99 & 0.48 & 0.09 & 1.37 & {$[0.5], \mathrm{U}$} & 21.39 & 3.80 & 12.64 & 2.11 & 51.70 & 213 & -3.56 & 16.6 & 7.65 & NA & 204 \\
\hline & $7 / 27 / 2005$ & 79.51 & 97.0 & 0 & 10.10 & 6.63 & 0.48 & 0.06 & 1.29 & {$[1.0], \mathrm{U}$} & 20.87 & 4.48 & 13.21 & 2.53 & 54.02 & 215 & -1.23 & 16.3 & 7.18 & 9.5 & 210 \\
\hline
\end{tabular}


Table 6.1

Summary Results of Major Element Chemistry and Field Parameters (Cont.)

\begin{tabular}{|c|c|c|c|c|c|c|c|c|c|c|c|c|c|c|c|c|c|c|c|c|c|}
\hline \multirow[b]{2}{*}{ Station ID } & \multirow[b]{2}{*}{$\begin{array}{l}\text { Date } \\
\text { Sampled }\end{array}$} & \multirow[b]{2}{*}{$\begin{array}{c}\text { Total } \\
\text { Alkalinity (lab) } \\
\text { (ppm) }\end{array}$} & \multirow[b]{2}{*}{$\begin{array}{l}\mathrm{HCO}_{3} \\
(\mathrm{ppm})\end{array}$} & \multirow[b]{2}{*}{$\begin{array}{c}\mathrm{CO}_{3} \\
(\mathrm{ppm})\end{array}$} & \multirow[b]{2}{*}{$\begin{array}{c}\mathrm{SO}_{4} \\
(\mathbf{p p m})\end{array}$} & \multirow[b]{2}{*}{$\begin{array}{c}\mathrm{Cl} \\
(\mathbf{p p m})\end{array}$} & \multirow[b]{2}{*}{$\begin{array}{c}\mathbf{F} \\
(\mathrm{ppm})\end{array}$} & \multirow[b]{2}{*}{$\begin{array}{c}\mathrm{Br} \\
(\mathbf{p p m})\end{array}$} & \multirow[b]{2}{*}{$\begin{array}{c}\mathrm{NO}_{3} \text { as N } \\
(\text { ppm) }\end{array}$} & \multirow[b]{2}{*}{$\begin{array}{l}\mathrm{ClO}_{4} \\
(\mathbf{p p b})\end{array}$} & \multirow[b]{2}{*}{$\begin{array}{c}\mathrm{Ca} \\
(\mathbf{p p m})\end{array}$} & \multirow[b]{2}{*}{$\underset{(\mathbf{p p m})}{\mathbf{M g}}$} & \multirow[b]{2}{*}{$\begin{array}{c}\mathrm{Na} \\
(\mathbf{p p m})\end{array}$} & \multirow[b]{2}{*}{\begin{tabular}{c|c}
$\mathbf{K}$ \\
$(\mathbf{p p m})$
\end{tabular}} & \multirow[b]{2}{*}{$\begin{array}{c}\mathrm{SiO}_{2} \text { (cal) } \\
(\mathbf{p p m})\end{array}$} & \multirow[b]{2}{*}{$\begin{array}{c}\text { Lab TDS } \\
(\text { ppm })\end{array}$} & \multirow[b]{2}{*}{$\begin{array}{c}\text { Charge } \\
\text { Balance } \\
(\%)\end{array}$} & \multicolumn{4}{|c|}{ Field Properties } \\
\hline & & & & & & & & & & & & & & & & & & $\begin{array}{c}\text { Temp } \\
\left.{ }^{\circ} \mathrm{C}\right)\end{array}$ & $\begin{array}{c}\mathrm{pH} \\
\text { (S.U.) }\end{array}$ & $\begin{array}{c}\text { Dissolved } \\
\text { Oxygen } \\
(\mathbf{m g} / \mathbf{L})\end{array}$ & $\begin{array}{c}\text { Specific } \\
\text { Conductance } \\
\text { (uS/cm) }\end{array}$ \\
\hline Spring 5 & $\begin{array}{l}2 / 21 / 2005 \\
3 / 24 / 2005 \\
4 / 26 / 2005 \\
6 / 2 / 2005 \\
7 / 26 / 2005 \\
9 / 27 / 2005 \\
\end{array}$ & $\begin{array}{l}77.40 \\
77.30 \\
78.28 \\
78.31 \\
77.62 \\
71.20 \\
\end{array}$ & $\begin{array}{l}94.4 \\
94.3 \\
95.5 \\
95.5 \\
94.7 \\
86.9 \\
\end{array}$ & $\begin{array}{c}0 \\
0 \\
0 \\
0 \\
0 \\
{[1.45], \mathrm{U}} \\
\end{array}$ & $\begin{array}{l}5.02 \\
4.99 \\
5.02 \\
5.00 \\
4.97 \\
4.92 \\
\end{array}$ & $\begin{array}{l}4.22 \\
4.31 \\
4.43 \\
4.17 \\
4.16 \\
4.06 \\
\end{array}$ & $\begin{array}{l}0.39 \\
0.39 \\
0.44 \\
0.39 \\
0.39 \\
0.42 \\
\end{array}$ & $\begin{array}{c}0.03 \\
0.03 \\
0.05 \\
0.05 \\
0.03 \\
{[0.04], \mathrm{U}} \\
\end{array}$ & $\begin{array}{l}0.54 \\
0.38 \\
0.75 \\
0.76 \\
0.69 \\
0.63 \\
\end{array}$ & $\begin{array}{c}{[0.5], \mathrm{U}} \\
{[0.5, \mathrm{U}} \\
{[0.5], \mathbf{U}} \\
{[0.5], \mathrm{U}} \\
{[1.0], \mathrm{U}} \\
0.41 \\
\end{array}$ & $\begin{array}{l}18.90 \\
17.89 \\
18.64 \\
15.43 \\
17.34 \\
17.40 \\
\end{array}$ & \begin{tabular}{l|}
3.76 \\
3.83 \\
4.01 \\
4.15 \\
4.77 \\
4.49 \\
\end{tabular} & 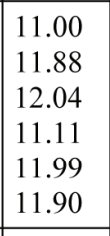 & $\begin{array}{l}1.47 \\
1.67 \\
1.60 \\
1.68 \\
1.85 \\
1.83 \\
\end{array}$ & $\begin{array}{l}67.90 \\
66.26 \\
67.29 \\
61.83 \\
68.12 \\
64.30 \\
\end{array}$ & $\begin{array}{l}210 \\
208 \\
213 \\
203 \\
212 \\
196 \\
\end{array}$ & $\begin{array}{l}-1.70 \\
-1.39 \\
-1.17 \\
-6.32 \\
-0.35 \\
2.70 \\
\end{array}$ & $\begin{array}{l}20.5 \\
20.8 \\
20.7 \\
20.9 \\
20.4 \\
19.3 \\
\end{array}$ & $\begin{array}{l}6.95 \\
7.52 \\
7.87 \\
7.57 \\
7.58 \\
8.13 \\
\end{array}$ & $\begin{array}{r}6.2 \\
6.1 \\
6.1 \\
5.1 \\
6.5 \\
10.8 \\
\end{array}$ & $\begin{array}{l}182 \\
173 \\
182 \\
181 \\
180 \\
175 \\
\end{array}$ \\
\hline (Blind Intralaboratory Field Duplicate) & $\begin{array}{l}3 / 2 / 2005 \\
3 / 24 / 2005 \\
4 / 29 / 2005 \\
7 / 25 / 2005 \\
7 / 25 / 2005 \\
9 / 27 / 2005\end{array}$ & $\begin{array}{l}60.20 \\
60.49 \\
60.98 \\
62.21 \\
64.02 \\
55.10\end{array}$ & $\begin{array}{l}73.4 \\
73.8 \\
74.4 \\
75.9 \\
78.1 \\
67.2\end{array}$ & $\begin{array}{c}0 \\
0 \\
0 \\
0 \\
0 \\
{[1.45], \mathrm{U}}\end{array}$ & $\begin{array}{l}2.47 \\
2.53 \\
2.47 \\
2.49 \\
2.51 \\
2.56\end{array}$ & $\begin{array}{l}2.20 \\
2.23 \\
2.29 \\
2.14 \\
2.16 \\
2.14\end{array}$ & $\begin{array}{l}0.33 \\
0.32 \\
0.31 \\
0.30 \\
0.30 \\
0.34\end{array}$ & $\begin{array}{c}0.02 \\
0.02 \\
0.03 \\
0.03 \\
0.02 \\
{[0.04], \mathrm{U}}\end{array}$ & $\begin{array}{l}0.21 \\
0.39 \\
0.43 \\
0.42 \\
0.42 \\
0.34\end{array}$ & $\begin{array}{l}{[1.0], \mathrm{U}} \\
{[0.5], \mathrm{U}} \\
{[0.5, \mathrm{U}} \\
\text { NA } \\
\text { NA } \\
0.31\end{array}$ & $\begin{array}{l}11.20 \\
11.88 \\
11.96 \\
11.37 \\
12.02 \\
11.80\end{array}$ & \begin{tabular}{l|}
2.78 \\
2.79 \\
2.90 \\
3.48 \\
3.44 \\
3.55
\end{tabular} & \begin{tabular}{|r|}
10.40 \\
9.37 \\
9.98 \\
10.20 \\
10.16 \\
10.70
\end{tabular} & $\begin{array}{l}1.62 \\
1.53 \\
1.54 \\
2.01 \\
1.94 \\
1.88\end{array}$ & $\begin{array}{l}74.10 \\
70.58 \\
72.78 \\
72.01 \\
72.03 \\
73.80\end{array}$ & $\begin{array}{l}180 \\
177 \\
181 \\
182 \\
185 \\
141\end{array}$ & $\begin{array}{r}-2.60 \\
-3.72 \\
-2.66 \\
-1.86 \\
-2.22 \\
5.10\end{array}$ & $\begin{array}{l}20.9 \\
20.5 \\
21.0 \\
20.0 \\
20.0 \\
21.0\end{array}$ & $\begin{array}{l}7.12 \\
6.43 \\
7.74 \\
7.51 \\
7.51 \\
7.41\end{array}$ & $\begin{array}{l}6.5 \\
7.1 \\
6.8 \\
7.0 \\
7.0 \\
7.5\end{array}$ & $\begin{array}{l}133 \\
129 \\
134 \\
135 \\
135 \\
131\end{array}$ \\
\hline Spring 9A & $\begin{array}{l}3 / 8 / 2005 \\
4 / 29 / 2005 \\
5 / 18 / 2005 \\
7 / 20 / 2005 \\
9 / 28 / 2005 \\
\end{array}$ & $\begin{array}{l}56.97 \\
56.58 \\
57.70 \\
56.89 \\
51.10 \\
\end{array}$ & $\begin{array}{l}69.5 \\
69.0 \\
70.4 \\
69.4 \\
62.3 \\
\end{array}$ & $\begin{array}{c}0 \\
0 \\
0 \\
0 \\
{[1.45], \mathrm{U}} \\
\end{array}$ & $\begin{array}{l}2.13 \\
2.04 \\
2.08 \\
2.09 \\
2.09 \\
\end{array}$ & $\begin{array}{l}2.05 \\
2.08 \\
1.95 \\
2.00 \\
1.95 \\
\end{array}$ & $\begin{array}{l}0.44 \\
0.48 \\
0.46 \\
0.46 \\
0.46 \\
\end{array}$ & $\begin{array}{l}0.01 \\
0.02 \\
0.03 \\
0.02 \\
0.05 \\
\end{array}$ & $\begin{array}{l}0.37 \\
0.39 \\
0.31 \\
0.22 \\
0.30 \\
\end{array}$ & $\begin{array}{c}{[1.0], \mathrm{U}} \\
{[0.5, \mathrm{U}} \\
{[0.5], \mathrm{U}} \\
{[0.5], \mathrm{U}} \\
0.27 \\
\end{array}$ & $\begin{array}{r}10.24 \\
10.75 \\
10.10 \\
9.89 \\
10.20 \\
\end{array}$ & \begin{tabular}{l|}
2.94 \\
2.49 \\
2.59 \\
2.93 \\
2.91 \\
\end{tabular} & \begin{tabular}{|l|}
10.61 \\
10.79 \\
10.61 \\
11.71 \\
11.10 \\
\end{tabular} & $\begin{array}{l}1.48 \\
1.18 \\
1.10 \\
1.38 \\
1.37 \\
\end{array}$ & $\begin{array}{l}69.66 \\
72.54 \\
71.00 \\
76.19 \\
72.50 \\
\end{array}$ & $\begin{array}{l}171 \\
173 \\
172 \\
177 \\
147 \\
\end{array}$ & $\begin{array}{r}-1.44 \\
-1.63 \\
-3.54 \\
0.19 \\
4.10 \\
\end{array}$ & $\begin{array}{l}20.1 \\
19.3 \\
20.5 \\
20.6 \\
20.0 \\
\end{array}$ & $\begin{array}{l}7.74 \\
7.47 \\
7.85 \\
7.79 \\
7.02 \\
\end{array}$ & $\begin{array}{c}5.7 \\
6.2 \\
\mathrm{NA} \\
7.1 \\
4.1 \\
\end{array}$ & $\begin{array}{l}122 \\
125 \\
124 \\
123 \\
122 \\
\end{array}$ \\
\hline \multicolumn{22}{|l|}{ Perennial Surface Water } \\
\hline CdV-5.6 & $\begin{array}{l}\text { 3/3/2005 } \\
4 / 11 / 2005 \\
5 / 27 / 2005 \\
7 / 11 / 2005 \\
\end{array}$ & $\begin{array}{l}25.40 \\
16.30 \\
24.30 \\
34.30 \\
\end{array}$ & $\begin{array}{l}31.0 \\
19.9 \\
29.6 \\
41.8 \\
\end{array}$ & $\begin{array}{l}0 \\
0 \\
0 \\
0 \\
\end{array}$ & $\begin{array}{l}9.52 \\
7.46 \\
6.57 \\
5.19 \\
\end{array}$ & $\begin{array}{l}1.73 \\
1.70 \\
1.11 \\
0.69 \\
\end{array}$ & $\begin{array}{l}0.04 \\
0.03 \\
0.04 \\
0.03 \\
\end{array}$ & $\begin{array}{c}{[0.011], \mathrm{U}} \\
0.01 \\
{[0.01], \mathrm{U}} \\
{[0.01], \mathrm{U}}\end{array}$ & $\begin{array}{l}0.63 \\
0.31 \\
0.11 \\
0.05 \\
\end{array}$ & $\begin{array}{l}{[1.0], \mathbf{U}} \\
{[1.0], \mathbf{U}} \\
{[2.0], \mathbf{U}} \\
{[0.5], \mathbf{U}}\end{array}$ & $\begin{array}{l}7.52 \\
5.30 \\
5.43 \\
7.50 \\
\end{array}$ & $\begin{array}{l}2.72 \\
1.41 \\
2.00 \\
2.82 \\
\end{array}$ & $\begin{array}{l}3.95 \\
2.54 \\
3.38 \\
4.36 \\
\end{array}$ & $\begin{array}{l}1.53 \\
0.93 \\
1.18 \\
1.47 \\
\end{array}$ & $\begin{array}{l}32.00 \\
25.00 \\
26.80 \\
34.60 \\
\end{array}$ & $\begin{array}{l}93 \\
66 \\
77 \\
99 \\
\end{array}$ & $\begin{array}{r}0.43 \\
-4.08 \\
-4.00 \\
0.95 \\
\end{array}$ & $\begin{array}{r}0.6 \\
4.9 \\
7.7 \\
11.6 \\
\end{array}$ & $\begin{array}{l}8.44 \\
6.81 \\
7.71 \\
7.61 \\
\end{array}$ & $\begin{array}{l}10.5 \\
\text { NA } \\
\text { NA } \\
5.2 \\
\end{array}$ & $\begin{array}{l}79 \\
61 \\
70 \\
81 \\
\end{array}$ \\
\hline PA-10.6 & $\begin{array}{l}2 / 14 / 2005 \\
3 / 8 / 2005 \\
5 / 3 / 2005 \\
6 / 10 / 2005 \\
7 / 12 / 2005\end{array}$ & $\begin{array}{l}21.60 \\
26.00 \\
25.20 \\
33.10 \\
36.90 \\
\end{array}$ & $\begin{array}{l}26.4 \\
31.7 \\
30.7 \\
40.4 \\
45.0\end{array}$ & $\begin{array}{l}0 \\
0 \\
0 \\
0 \\
0\end{array}$ & $\begin{array}{r}22.50 \\
22.20 \\
15.40 \\
7.11 \\
4.99 \\
\end{array}$ & $\begin{array}{r}10.60 \\
8.87 \\
3.12 \\
1.28 \\
1.28 \\
\end{array}$ & $\begin{array}{l}0.05 \\
0.06 \\
0.05 \\
0.05 \\
0.05\end{array}$ & $\begin{array}{c}0.01], \mathrm{U} \\
{[0.01], \mathrm{U}} \\
0.01 \\
{[0.01], \mathrm{U}} \\
{[0.01], \mathrm{U}}\end{array}$ & $\begin{array}{l}0.31 \\
0.46 \\
0.43 \\
0.22 \\
0.08\end{array}$ & $\begin{array}{l}{[2.0], \mathbf{U}} \\
{[1.0], \mathrm{U}} \\
{[1.0 ., \mathrm{U}} \\
{[0.5], \mathrm{U}} \\
{[0.5], \mathrm{U}}\end{array}$ & $\begin{array}{r}13.10 \\
12.00 \\
9.12 \\
7.03 \\
7.03 \\
\end{array}$ & $\begin{array}{l}3.17 \\
3.86 \\
2.52 \\
2.58 \\
2.77 \\
\end{array}$ & $\begin{array}{l}7.65 \\
7.84 \\
4.36 \\
3.82 \\
4.16 \\
\end{array}$ & $\begin{array}{l}2.13 \\
2.60 \\
1.71 \\
1.93 \\
2.34\end{array}$ & $\begin{array}{l}37.00 \\
35.20 \\
34.60 \\
34.00 \\
37.80 \\
\end{array}$ & $\begin{array}{l}126 \\
128 \\
104 \\
100 \\
107\end{array}$ & $\begin{array}{r}.10 \\
1.87 \\
-2.86 \\
-5.36 \\
-0.85 \\
\end{array}$ & $\begin{array}{r}4.2 \\
5.0 \\
5.5 \\
10.3 \\
17.5 \\
\end{array}$ & $\begin{array}{l}7.21 \\
8.02 \\
7.91 \\
7.74 \\
7.87\end{array}$ & $\begin{array}{c}9.0 \\
10.3 \\
10.2 \\
\text { NA } \\
6.3\end{array}$ & $\begin{array}{r}146 \\
135 \\
105 \\
89 \\
88 \\
\end{array}$ \\
\hline \multicolumn{22}{|l|}{ Offsite Reference } \\
\hline \multicolumn{22}{|l|}{ Perched Volcanics, South Valles Caldera } \\
\hline $\begin{array}{l}\text { Seven Springs } \\
\text { (Blind Intralaboratory Field Duplicate) }\end{array}$ & $\begin{array}{l}3 / 10 / 2005 \\
3 / 10 / 2005 \\
5 / 9 / 2005 \\
6 / 23 / 2005 \\
7 / 15 / 2005 \\
\end{array}$ & $\begin{array}{l}43.85 \\
43.93 \\
42.95 \\
45.08 \\
46.39 \\
\end{array}$ & $\begin{array}{l}53.5 \\
53.6 \\
52.4 \\
55.0 \\
56.6 \\
\end{array}$ & $\begin{array}{l}0 \\
0 \\
0 \\
0 \\
0 \\
\end{array}$ & $\begin{array}{l}4.04 \\
4.03 \\
4.22 \\
4.28 \\
4.12 \\
\end{array}$ & $\begin{array}{l}1.88 \\
1.88 \\
1.52 \\
1.45 \\
1.47 \\
\end{array}$ & $\begin{array}{l}0.20 \\
0.20 \\
0.20 \\
0.17 \\
0.17 \\
\end{array}$ & $\begin{array}{l}0.01 \\
0.02 \\
0.02 \\
0.02 \\
0.02 \\
\end{array}$ & $\begin{array}{l}0.25 \\
0.25 \\
0.22 \\
0.18 \\
0.22 \\
\end{array}$ & $\begin{array}{l}{[0.5], \mathrm{U}} \\
{[0.5, \mathrm{U}} \\
{[0.5], \mathrm{U}} \\
{[0.5, \mathrm{U}} \\
{[0.5], \mathrm{U}}\end{array}$ & $\begin{array}{l}11.23 \\
11.18 \\
10.90 \\
11.49 \\
11.95 \\
\end{array}$ & $\begin{array}{l}1.50 \\
1.48 \\
1.25 \\
1.51 \\
1.56 \\
\end{array}$ & $\begin{array}{l}6.97 \\
6.84 \\
5.84 \\
6.16 \\
6.24 \\
\end{array}$ & $\begin{array}{l}1.90 \\
1.87 \\
1.47 \\
1.82 \\
1.83 \\
\end{array}$ & $\begin{array}{l}32.42 \\
32.07 \\
29.18 \\
30.26 \\
29.00 \\
\end{array}$ & $\begin{array}{l}116 \\
115 \\
108 \\
113 \\
114 \\
\end{array}$ & $\begin{array}{l}-0.58 \\
-1.07 \\
-3.98 \\
-1.96 \\
-1.70 \\
\end{array}$ & $\begin{array}{l}10.7 \\
10.7 \\
11.8 \\
12.2 \\
11.1 \\
\end{array}$ & $\begin{array}{l}7.30 \\
7.30 \\
7.37 \\
6.73 \\
7.30 \\
\end{array}$ & $\begin{array}{c}7.4 \\
7.4 \\
7.6 \\
\text { NA } \\
5.4 \\
\end{array}$ & $\begin{array}{l}100 \\
100 \\
103 \\
107 \\
108 \\
\end{array}$ \\
\hline \multicolumn{22}{|l|}{ Perched Basalts - Taos, Eastside Rio Grande } \\
\hline AH-0.2 Spring & $\begin{array}{l}2 / 15 / 2005 \\
4 / 8 / 2005 \\
5 / 13 / 2005 \\
6 / 24 / 2005 \\
7 / 22 / 2005\end{array}$ & $\begin{array}{l}111.00 \\
111.48 \\
112.30 \\
111.48 \\
112.30\end{array}$ & $\begin{array}{l}136.0 \\
136.0 \\
137.0 \\
136.0 \\
137.0\end{array}$ & $\begin{array}{l}0 \\
0 \\
0 \\
0 \\
0\end{array}$ & $\begin{array}{l}30.30 \\
29.85 \\
30.29 \\
29.26 \\
29.58\end{array}$ & $\begin{array}{l}3.39 \\
3.35 \\
3.30 \\
3.12 \\
3.32\end{array}$ & $\begin{array}{l}0.22 \\
0.22 \\
0.21 \\
0.20 \\
0.22\end{array}$ & $\begin{array}{l}0.03 \\
0.03 \\
0.04 \\
0.04 \\
0.03\end{array}$ & $\begin{array}{l}0.64 \\
0.67 \\
0.70 \\
0.65 \\
0.67\end{array}$ & $\begin{array}{l}{[1.0], \mathrm{U}} \\
{[1.0], \mathrm{U}} \\
{[1.0 ., \mathrm{U}} \\
{[0.5], \mathrm{U}} \\
{[2.0, \mathrm{U}}\end{array}$ & \begin{tabular}{|l}
33.90 \\
32.78 \\
32.99 \\
31.71 \\
32.03
\end{tabular} & $\begin{array}{l}6.68 \\
6.49 \\
7.09 \\
8.01 \\
8.63\end{array}$ & \begin{tabular}{|l}
11.90 \\
10.96 \\
12.05 \\
12.26 \\
11.75
\end{tabular} & $\begin{array}{l}2.46 \\
2.49 \\
2.64 \\
3.09 \\
3.12\end{array}$ & $\begin{array}{l}27.30 \\
26.60 \\
26.61 \\
27.81 \\
27.99\end{array}$ & $\begin{array}{l}256 \\
252 \\
256 \\
255 \\
257\end{array}$ & $\begin{array}{l}-3.30 \\
-5.11 \\
-3.49 \\
-2.13 \\
-1.85\end{array}$ & $\begin{array}{l}14.0 \\
14.0 \\
13.8 \\
14.3 \\
13.8\end{array}$ & $\begin{array}{l}7.44 \\
8.03 \\
8.02 \\
7.92 \\
8.00\end{array}$ & $\begin{array}{l}7.3 \\
5.4 \\
7.7 \\
6.6 \\
3.5\end{array}$ & $\begin{array}{l}290 \\
290 \\
291 \\
288 \\
286\end{array}$ \\
\hline $\begin{array}{l}\text { Notes: } \\
\text { The column header "Total Alkalinity" is in units of } \\
\text { NA - Not analyzed. } \\
\text { NF - Nonfiltered. } \\
\text { NC - Not calculated. } \\
\text { U - Not detected. }\end{array}$ & & & & & & & & & & & & & & & & & & & & & \\
\hline
\end{tabular}



Table 6.2

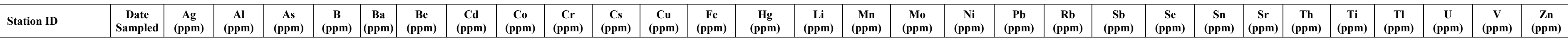
Sierra de los Valles

\begin{tabular}{|c|c|c|c|c|c|c|c|c|c|c|c|c|c|c|c|c|c|c|c|c|c|c|c|c|c|c|c|c|c|c|}
\hline \\
\hline $\mathrm{L}-10.6$ Spring & 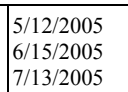 & {$\left[\begin{array}{l}{[0.001], \mathrm{U}} \\
{[[0.001], \mathrm{U}} \\
{[[0.0101], \mathrm{U}}\end{array}\right.$} & $\begin{array}{l}0.104 \\
0.0082 \\
0.00050\end{array}$ & $\begin{array}{l}0.0003 \\
0.00004 \\
0.0003\end{array}$ & $\left|\begin{array}{l}0.0077 \\
0.0057 \\
0.0555\end{array}\right|$ & $\mid \begin{array}{l}0.00009 \\
0.0039 \\
0.039\end{array}$ & 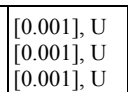 & 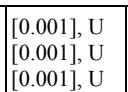 & 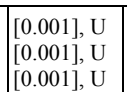 & 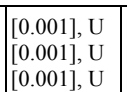 & 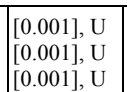 & 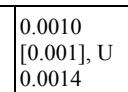 & $\begin{array}{l}0.0 .06 \\
{[0.0 .11], U} \\
{[0.01], U}\end{array}$ & 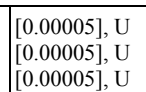 & $\mid \begin{array}{l}0.013 \\
0.015 \\
0.016\end{array}$ & 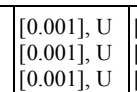 & 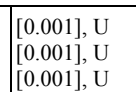 & 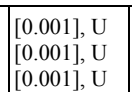 & 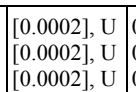 & $\begin{array}{l}0.0064 \\
0.0006 \\
0.0062\end{array}$ & 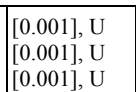 & 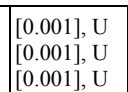 & 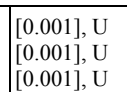 & $\mid \begin{array}{l}0.031 \\
0.029 \\
0.292\end{array}$ & 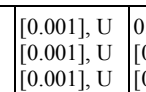 & 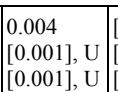 & 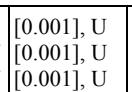 & 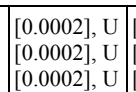 & 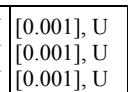 & $\begin{array}{l}{\left[\begin{array}{l}{[0.0101, \mathrm{U}} \\
0.004 \\
0.003\end{array}\right.} \\
0.00\end{array}$ \\
\hline Sarbara Spring & $\begin{array}{l}3 / 29212005 \\
51 / 212005 \\
6 \\
61 / 152005 \\
71 / 212005\end{array}$ & $\begin{array}{l}{[0.001], \mathrm{U}} \\
{[[0.0101], \mathrm{U}} \\
{[0.001], \mathrm{U}} \\
{[0.001], \mathrm{U}}\end{array}$ & $\mid \begin{array}{l}0.015 \\
0.011 \\
0.005 \\
0.0060\end{array}$ & \begin{tabular}{|l|l|}
0.0005 \\
0.0006 \\
0.0007 \\
0.0005
\end{tabular} & \begin{tabular}{|l}
0.0075 \\
0.0066 \\
0.0063 \\
0.0060
\end{tabular} & $\mid$\begin{tabular}{|l|l}
0.0014 \\
0.0014 \\
0.0013 \\
0.0016
\end{tabular} & $\begin{array}{l}{[0.001], \mathrm{U}} \\
{\left[\begin{array}{l}[0.0001] 1], \mathrm{U} \\
{[0.0001], \mathrm{U}} \\
{[0.001], \mathrm{U}}\end{array}\right.}\end{array}$ & $\begin{array}{l}{[0.001], \mathrm{U}} \\
{[[0.001], \mathrm{U}} \\
{[0.001], \mathrm{U}} \\
{[0.001], \mathrm{U}}\end{array}$ & $\mid \begin{array}{l}{[0.001], \mathrm{U}} \\
{\left[\begin{array}{l}[0.0001] 1], \mathrm{U} \\
{[0.001], \mathrm{U}} \\
{[0.001], \mathrm{U}}\end{array}\right.}\end{array}$ & 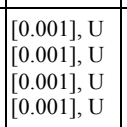 & 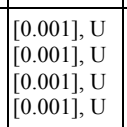 & 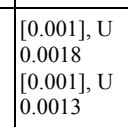 & {$\left[\begin{array}{l}0.02 \\
{[0.01], \mathrm{U}} \\
{[0.01], \mathrm{U}} \\
{[0.01], \mathrm{U}}\end{array}\right.$} & 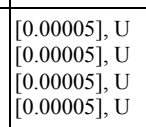 & $\begin{array}{l}0.040 \\
0.036 \\
0.037 \\
0.039\end{array}$ & 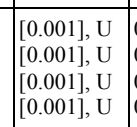 & \begin{tabular}{|l}
0.0016 \\
0.0013 \\
0.0023 \\
0.0014 \\
0.014
\end{tabular} & $\left.\begin{array}{|l|}[0.001]], \mathrm{U} \\
{[[0.001], \mathrm{U}} \\
{[0.001], \mathrm{U}} \\
{[0.001], \mathrm{U}}\end{array}\right]$ & 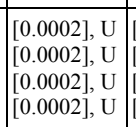 & 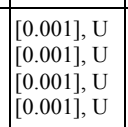 & {$\left[\begin{array}{l}{[0.001], \mathrm{U}} \\
{[[0.0101], \mathrm{U}} \\
{[0.001], \mathrm{U}} \\
{[0.001], \mathrm{U}}\end{array}\right.$} & 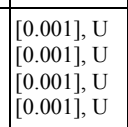 & 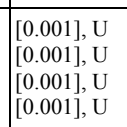 & $\begin{array}{l}0.022 \\
0.0220 \\
0.021 \\
0.021\end{array}$ & 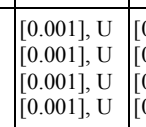 & $\mid$ & 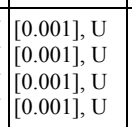 & $\left.\begin{array}{l}0.0003 \\
0.0003 \\
0.0003 \\
{[0.0002], \mathrm{U}}\end{array}\right]$ & \begin{tabular}{|l|}
0.002 \\
0.002 \\
0.002 \\
0.001
\end{tabular} & 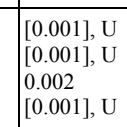 \\
\hline ampsite Springs & $\begin{array}{l}5 / 1772005 \\
6 / 822005 \\
7 / 142005\end{array}$ & $\begin{array}{l}{[0.001], U} \\
{[0.001], U} \\
{[0.011, U} \\
\end{array}$ & $\begin{array}{l}0.036 \\
0.011 \\
0.0021\end{array}$ & \begin{tabular}{|l|}
0.0005 \\
0.0006 \\
0.0005
\end{tabular} & \begin{tabular}{|l|l}
0.0088 \\
0.0079 \\
0.0078
\end{tabular} & \begin{tabular}{|l|l|}
0.00222 \\
0.0019 \\
0.0021
\end{tabular} & $\begin{array}{l}{[0.001], \mathrm{U}} \\
{\left[\begin{array}{l}0.00001] 1], \mathrm{U} \\
{[0.001], \mathrm{U}}\end{array}\right.}\end{array}$ & {$\left[\begin{array}{l}{[0.001], \mathrm{U}} \\
{[0.001], \mathrm{U}} \\
{[0.001], \mathrm{U}}\end{array}\right.$} & $\mid \begin{array}{l}{[0.001], \mathrm{U}} \\
{\left[\begin{array}{l}0.00001] \\
{[0.001], \mathrm{U}}\end{array}\right.}\end{array}$ & \begin{tabular}{|l|}
0.00222 \\
0.0024 \\
0.0024
\end{tabular} & $\mid \begin{array}{l}{[0.001], \mathrm{U}} \\
{\left[\begin{array}{l}0.00001] \\
{[0.001], \mathrm{U}}\end{array}\right.}\end{array}$ & \begin{tabular}{|l}
0.0035 \\
0.0029 \\
{$[0.001], \mathrm{U}$}
\end{tabular} & $\left\{\begin{array}{l}0.02 \\
{[0.01], \mathrm{U}} \\
{[0.01], \mathrm{U}}\end{array}\right.$ & 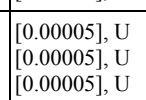 & $\begin{array}{l}0.026 \\
0.023 \\
0.027\end{array}$ & 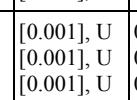 & $\mid \begin{array}{l}0.0011 \\
0.0011 \\
0.0011\end{array}$ & 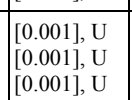 & $\begin{array}{l}{\left[\begin{array}{l}0.0002], \mathrm{U} \\
{[0.0002],} \\
{[0.0002], \mathrm{U}}\end{array}\right.} \\
{[0.002}\end{array}$ & \begin{tabular}{|l|}
0.00051 \\
0.0042 \\
0.0044
\end{tabular} & {$\left[\begin{array}{l}{[0.001], U} \\
{[0.001], U} \\
{[0.001], U}\end{array}\right.$} & 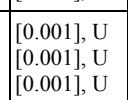 & 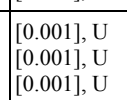 & $\begin{array}{l}0.020 \\
0.019 \\
0.19 \\
0.19\end{array}$ & 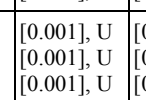 & $\mid\left[\begin{array}{l}{[0.001], \mathrm{U}} \\
{[[0.001], \mathrm{U}} \\
{[0.001], \mathrm{U}}\end{array}\right]$ & {$\left[\begin{array}{l}{[0.001], \mathrm{U}} \\
{[0.001], \mathrm{U}} \\
{[0.001], \mathrm{U}}\end{array}\right]$} & \begin{tabular}{|l|}
0.0005 \\
0.0004 \\
0.0004
\end{tabular} & \begin{tabular}{|l}
0.003 \\
0.003 \\
0.003
\end{tabular} & $\begin{array}{l}{\left[\begin{array}{l}0.001], \mathrm{U} \\
0.005 \\
{[0.001], \mathrm{U}}\end{array}\right.} \\
{[0.001]}\end{array}$ \\
\hline dV-5.0 Spring & 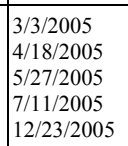 & 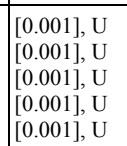 & \begin{tabular}{|l|l}
0.82 \\
0.075 \\
0.085 \\
0.021 \\
0.28
\end{tabular} & \begin{tabular}{|l|}
0.0005 \\
0.0005 \\
0.0004 \\
0.0004 \\
0.0004
\end{tabular} & \begin{tabular}{|l|l}
0.0079 \\
0.0006 \\
0.006 \\
0.0060 \\
0.0079 \\
0.012
\end{tabular} & \begin{tabular}{|l|l}
0.058 \\
0.054 \\
0.034 \\
0.030 \\
0.035 \\
0.030
\end{tabular} & 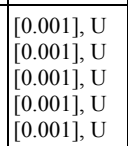 & \begin{tabular}{|l|}
{$[0.001], \mathrm{U}$} \\
{$[[0.001]], \mathrm{U}$} \\
{$[[0.001], \mathrm{U}$} \\
{$[0.001], \mathrm{U}$} \\
{$[0.001], \mathrm{U}$}
\end{tabular} & 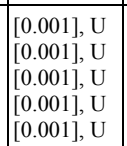 & 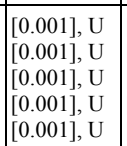 & 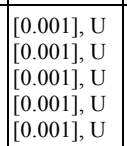 & \begin{tabular}{|l}
0.0021 \\
0.0033 \\
0.0038 \\
0.0014 \\
0.0015
\end{tabular} & \begin{tabular}{|l|l}
.48 \\
0.04 \\
0.003 \\
{$[0.03], U$} \\
0.014
\end{tabular} & 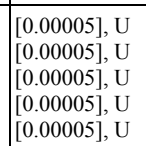 & \begin{tabular}{|l|}
0.004 \\
0.0033 \\
0.00023 \\
0.0023 \\
0.0027
\end{tabular} & 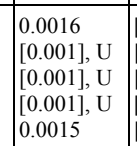 & {$\left[\begin{array}{l}{[0.0011], \mathrm{U}} \\
{[0.001], \mathrm{U}} \\
{[0[0.01], \mathrm{U}} \\
{[[0.001], \mathrm{U}} \\
{[0.001], \mathrm{U}}\end{array}\right.$} & 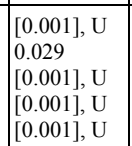 & \begin{tabular}{|l}
0.0003 \\
{$[0.0002], \mathrm{U}$} \\
{$[0.00022], \mathrm{U}$} \\
{$[0.0002], \mathrm{U}$} \\
0.0014
\end{tabular} & \begin{tabular}{|l}
0.0082 \\
0.0063 \\
0.0054 \\
0.0074 \\
0.0062
\end{tabular} & \begin{tabular}{|l|}
{$[[0.001], U$} \\
{$[[0.01], U$} \\
{$[[0.0101], U$} \\
{$[[0.0101], U$} \\
{$[0.001], U$} \\
\end{tabular} & 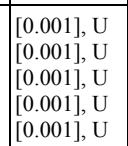 & 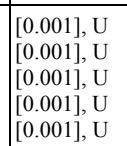 & $\begin{array}{l}0.14 \\
0.12 \\
0.087 \\
0.089 \\
0.081\end{array}$ & 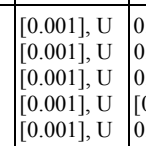 & $\mid$\begin{tabular}{|l|}
0.009 \\
0.002 \\
0.003 \\
$0.0031], \mathrm{U}$ \\
0.0009
\end{tabular} & 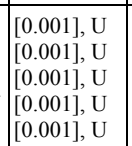 & {$\left[\begin{array}{l}{[0.00022], \mathrm{U}} \\
{[0.00022, \mathrm{U}} \\
{[0.00022, \mathrm{U}} \\
{[0.0022], \mathrm{U}} \\
{[0.00022], \mathrm{U}}\end{array}\right.$} & \begin{tabular}{|l}
0.004 \\
0.004 \\
0.003 \\
0.003 \\
0.003
\end{tabular} & \begin{tabular}{|l|}
{$[0.001], \mathrm{U}$} \\
0.019 \\
0.002 \\
0.002 \\
$0.00101, \mathrm{U}$ \\
0.002
\end{tabular} \\
\hline C Spring & 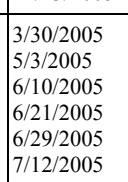 & {$\left[\begin{array}{l}{[0.001], \mathrm{U}} \\
{[[0.001], \mathrm{U}} \\
{[[0.001], \mathrm{U}} \\
{[[0.0002], \mathrm{U}} \\
{[0.001], \mathrm{U}} \\
{[0.001], \mathrm{U}}\end{array}\right.$} & $\mid \begin{array}{l}0.57 \\
0.048 \\
0.043 \\
0.029 \\
0.02285 \\
0.013\end{array}$ & 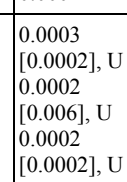 & $\mid \begin{array}{l}0.0034 \\
0.0066 \\
0.0031 \\
0.0033 \\
0.0033 \\
0.005\end{array}$ & $\mid$\begin{tabular}{l|l}
0.025 \\
0.02004 \\
0.014 \\
0.017 \\
0.019 \\
0.019
\end{tabular} & 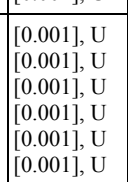 & {$\left[\begin{array}{l}{[0.001], \mathrm{U}} \\
{[0.001], \mathrm{U}} \\
{[0.001], \mathrm{U}} \\
{[[0.0001], \mathrm{U}} \\
{[[0.001], \mathrm{U}} \\
{[0.001], \mathrm{U}}\end{array}\right.$} & 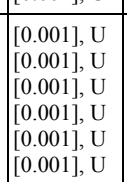 & {$\left[\begin{array}{l}{[0.001], \mathrm{U}} \\
{[0.001], \mathrm{U}} \\
{[0.001], \mathrm{U}} \\
{[[0.001], \mathrm{U}} \\
{[[0.001], \mathrm{U}} \\
{[0.001], \mathrm{U}}\end{array}\right]$} & 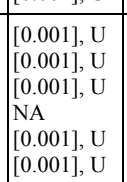 & 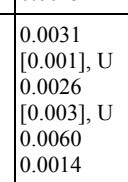 & $\mid \begin{array}{l}0.24 \\
0.03 \\
0.01 \\
0.01 \\
0.01 \\
00.01], \mathrm{U}\end{array}$ & {$\left[\begin{array}{l}{[0.00005], \mathrm{U}} \\
{[0.00005], \mathrm{U}} \\
{[0.000005], \mathrm{U}} \\
{[0.0 .0005], \mathrm{U}} \\
{[0.00005], \mathrm{U}} \\
{[0.00005], \mathrm{U}}\end{array}\right.$} & $\begin{array}{l}0.0021 \\
0.0012 \\
0.0012 \\
0.0014 \\
0.0002 \\
0.0014\end{array}$ & 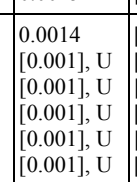 & $\mid \begin{array}{l}{[[0.0001], \mathrm{U}} \\
{[0[0.01], \mathrm{U}} \\
{[[0.001], \mathrm{U}} \\
{[0[002], \mathrm{U}} \\
{[0.001], \mathrm{U}} \\
{[0.001], \mathrm{U}}\end{array}$ & 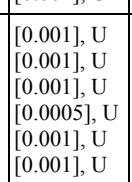 & $\mid \begin{array}{l}0.0003 \\
{[0.0002], \mathrm{U}} \\
{[0.0002], \mathrm{U}} \\
{[0.00002], \mathrm{U}} \\
{[0.0002], \mathrm{U}} \\
{[0.0002], \mathrm{U}}\end{array}$ & $\begin{array}{l}0.0049 \\
0.0034 \\
0.0035 \\
0.0036 \\
0.0036 \\
0.0036\end{array}$ & 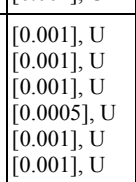 & 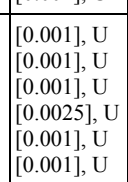 & 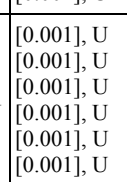 & $\begin{array}{l}0.064 \\
0.052 \\
0.054 \\
0.054 \\
0.056 \\
0.058\end{array}$ & 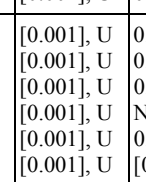 & $\mid \begin{array}{l}0.017 \\
0.002 \\
0.001 \\
0.01 \\
0.0057 \\
0.0001], \mathrm{U}\end{array}$ & 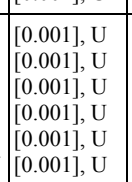 & $\left|\begin{array}{l}{[0.0002], \mathrm{U}} \\
{[0.00022, \mathrm{U}} \\
{[0.0002], \mathrm{U}} \\
{[0.00022], \mathrm{U}} \\
{[0.0002], \mathrm{U}} \\
{[0.0002], \mathrm{U}}\end{array}\right|$ & $\mid \begin{array}{l}0.003 \\
0.002 \\
0.002 \\
0.0022 \\
0.002 \\
0.002\end{array}$ & $\begin{array}{l}{[0.001], \mathrm{U}} \\
0.002 \\
{[0.001], \mathrm{U}} \\
{[0.0202], \mathrm{U}} \\
{[0.0021, \mathrm{U}} \\
0.0003\end{array}$ \\
\hline ater Canyon Gallery Spring & 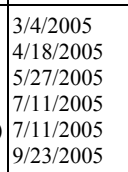 & 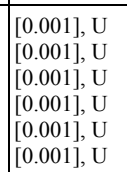 & $\begin{array}{l}0.32 \\
0.113 \\
0.025 \\
0.0034 \\
0.0065 \\
0.040\end{array}$ & $\mid \begin{array}{l}0.0003 \\
0.0003 \\
0.0003 \\
0.0003 \\
0.0003 \\
0.0003\end{array}$ & $\begin{array}{l}0.0081 \\
0.00084 \\
0.0089 \\
0.0006 \\
0.0052 \\
0.052 \\
0.011\end{array}$ & $\begin{array}{l}0.032 \\
0.028 \\
0.018 \\
0.016 \\
0.017 \\
0.01 \\
0.015\end{array}$ & 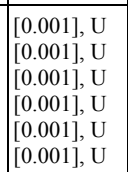 & 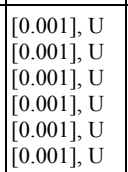 & 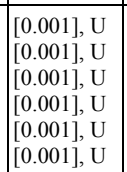 & {$\left[\begin{array}{l}{[0.001], \mathrm{U}} \\
{[[0.001], \mathrm{U}} \\
{[[0.001], \mathrm{U}} \\
{[[0.001], \mathrm{U}} \\
{[[0.001], \mathrm{U}} \\
{[0.0101], \mathrm{U}}\end{array}\right]$} & 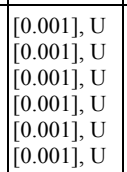 & 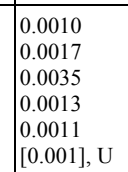 & $\begin{array}{l}0.42 \\
0.051 \\
0.0 .01], U \\
{[0.011], U} \\
{[0.01], U} \\
0.020 .\end{array}$ & 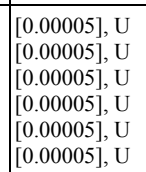 & $\begin{array}{l}0.007 \\
0.0066 \\
0.0066 \\
0.00078 \\
0.0078 \\
0.0074\end{array}$ & 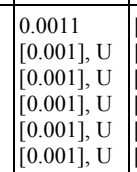 & 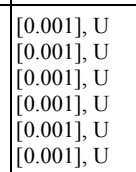 & 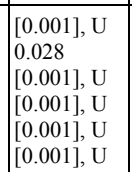 & 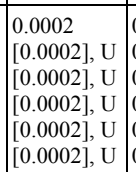 & $\begin{array}{l}0.0037 \\
0.00034 \\
0.00323 \\
0.00034 \\
0.0034 \\
0.0335\end{array}$ & 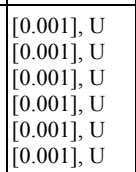 & 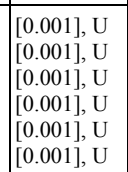 & 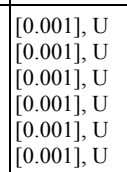 & $\begin{array}{l}0.084 \\
0.078 \\
0.077 \\
0.075 \\
0.055 \\
0.052 \\
0.052\end{array}$ & 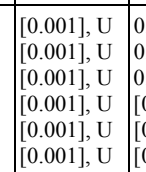 & 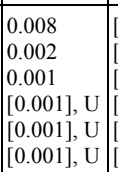 & 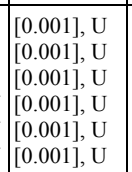 & 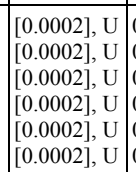 & $\begin{array}{l}0.003 \\
0.002 \\
0.003 \\
0.003 \\
0.003 \\
0.0040\end{array}$ & 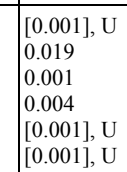 \\
\hline Young Spring & $\begin{array}{l}3123232005 \\
5 / 52005 \\
61 / 162005 \\
7 \\
71 / 2212005\end{array}$ & 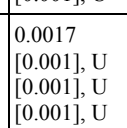 & $\begin{array}{l}0.017 \\
0.036 \\
0.011 \\
0.0006\end{array}$ & $\mid \begin{array}{l}0.0003 \\
0.0003 \\
0.0004 \\
0.0003\end{array}$ & $\mid \begin{array}{l}0.0069 \\
0.0009 \\
0.0057 \\
0.0057\end{array}$ & $\mid$\begin{tabular}{l|l}
0.016 \\
0.0054 \\
0.011 \\
0.012
\end{tabular} & 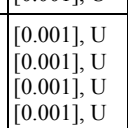 & 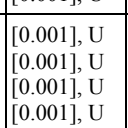 & 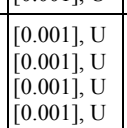 & $\begin{array}{l}0.0015 \\
0.0011 \\
0.0014 \\
0.001010\end{array}$ & 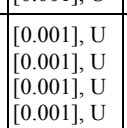 & 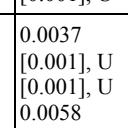 & $\mid \begin{array}{l}{[0.01], \mathrm{U}} \\
0.02, \mathrm{U} \\
{[0.011], \mathrm{U}} \\
{[0.010 .1], \mathrm{U}}\end{array}$ & 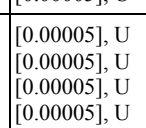 & $\begin{array}{l}0.013 \\
0.013 \\
0.014 \\
0.014\end{array}$ & $\mid$ & 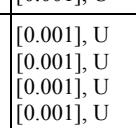 & 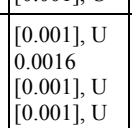 & 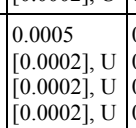 & $\begin{array}{l}0.0075 \\
0.0068 \\
0.0073 \\
0.0073\end{array}$ & 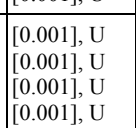 & 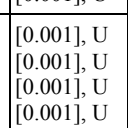 & 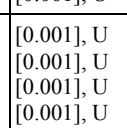 & $\mid \begin{array}{l}0.046 \\
0.044 \\
0.045 \\
0.047 \\
0.047\end{array}$ & 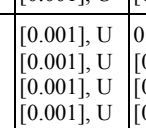 & 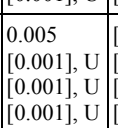 & 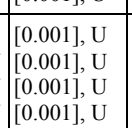 & & & \\
\hline ajarito Ski Well \#2 & $\begin{array}{l}3 / 212005 \\
8 / 31 / 2005 \\
1 / 122006\end{array}$ & 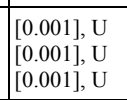 & $\begin{array}{l}0.0091 \\
0.0043 \\
0.0073\end{array}$ & \begin{tabular}{|l}
{$\left[\begin{array}{l}{[0.0002], \mathrm{U}} \\
0.0003 \\
0.0003\end{array}\right.$} \\
0.003
\end{tabular} & $\begin{array}{l}0.0035 \\
0.0039 \\
0.027\end{array}$ & $\mid$\begin{tabular}{|l|l|}
0.013 \\
0.015 \\
0.011
\end{tabular} & $\begin{array}{l}{[0.001], \mathrm{U}} \\
{\left[\begin{array}{l}0.00001] 1], \mathrm{U} \\
{[0.001], \mathrm{U}}\end{array}\right.}\end{array}$ & $\begin{array}{l}{[0.001], \mathrm{U}} \\
{[0.001], \mathrm{U}} \\
{[0.001], \mathrm{U}}\end{array}$ & \begin{tabular}{|l|}
{$[0.001], \mathrm{U}$} \\
{$\left[\begin{array}{l}0.00001] 1], \mathrm{U} \\
{[0.001], \mathrm{U}}\end{array}\right.$}
\end{tabular} & $\begin{array}{l}{[0.001], \mathrm{U}} \\
{[0.001], \mathrm{U}} \\
{[0.001], \mathrm{U}}\end{array}$ & \begin{tabular}{|l|}
{$[0.001], \mathrm{U}$} \\
{$\left[\begin{array}{l}0.00001] 1], \mathrm{U} \\
{[0.001], \mathrm{U}}\end{array}\right.$}
\end{tabular} & \begin{tabular}{|l}
0.0051 \\
0.0124 \\
{$[0.001], \mathrm{U}$}
\end{tabular} & 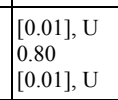 & 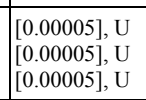 & $\begin{array}{l}0.007 \\
0.0073 \\
0.0067\end{array}$ & $\mid \begin{array}{l}{[0.0011, \mathrm{U}} \\
0.0029 \\
{[0.021], \mathrm{U}}\end{array}$ & {$\left[\begin{array}{l}{[0.001], \mathrm{U}} \\
{[[0.001], \mathrm{U}} \\
{[0.001], \mathrm{U}}\end{array}\right.$} & $\mid \begin{array}{l}{[0.001], \mathrm{U}} \\
{\left[\begin{array}{l}{[.0001], \mathrm{U}} \\
{[0.001], \mathrm{U}}\end{array}\right.}\end{array}$ & \begin{tabular}{|l|}
0.0008 \\
0.020 \\
0.0013
\end{tabular} & $\begin{array}{l}0.0051 \\
0.0050 \\
0.0046\end{array}$ & $\begin{array}{l}{[0.001], U} \\
{[0.0101], U} \\
{[0.001], U} \\
\end{array}$ & 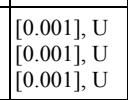 & 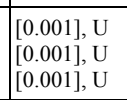 & $\begin{array}{l}0.061 \\
0.058 \\
0.055\end{array}$ & 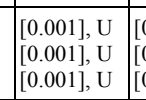 & $\mid$\begin{tabular}{|c|}
$[0.001]], \mathrm{U}$ \\
{$[[0.001], \mathrm{U}$} \\
{$[0.002], \mathrm{U}$}
\end{tabular} & {$\left[\begin{array}{l}{[0.001], \mathrm{U}} \\
{\left[\begin{array}{l}0.0001], \mathrm{U} \\
{[0.01], \mathrm{U}}\end{array}\right.}\end{array}\right.$} & $\mid \begin{array}{l}{[0.0002], 1,1} \\
{[0.00022], 1}\end{array}$ & {$\left[\begin{array}{l}{[0.001], \mathrm{U}} \\
{\left[\begin{array}{l}0.0001] 1], \mathrm{U} \\
{[0.001], \mathrm{U}}\end{array}\right.}\end{array}\right.$} & $\begin{array}{l}0.072 \\
0.47 \\
0.002\end{array}$ \\
\hline \multicolumn{31}{|l|}{ Pajarito Plateau } \\
\hline \multicolumn{31}{|l|}{ Perched Volcanics at Surface } \\
\hline Tomestead Spring & $\begin{array}{l}3 / 31 / 2005 \\
59 / 2005 \\
6202005 \\
7 / 1820005\end{array}$ & $\begin{array}{l}{[0.001], \mathrm{U}} \\
{[[0.0101], \mathrm{U}} \\
{[0.02001], \mathrm{U}}\end{array}$ & $\begin{array}{l}1.37 \\
0.068 \\
0.059 \\
0.16\end{array}$ & {$\left[\begin{array}{l}0.0007 \\
0.0002 \\
{\left[\begin{array}{ll}0.00606 \\
0.0004\end{array}\right.}\end{array}\right.$} & $\mid \begin{array}{l}0.0095 \\
0.014 \\
0.0094 \\
0.0092\end{array}$ & 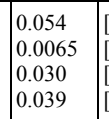 & 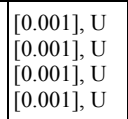 & {$\left[\begin{array}{l}{[0.001], \mathrm{U}} \\
{[[0.001]], \mathrm{U}} \\
{[0.0011], \mathrm{U}} \\
{[0.001], \mathrm{U}}\end{array}\right]$} & 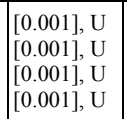 & $\left.\mid \begin{array}{l}{[0.001], \mathrm{U}} \\
{[[0.001]], \mathrm{U}} \\
{[0.001], \mathrm{U}} \\
{[0.001], \mathrm{U}}\end{array}\right]$ & 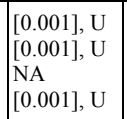 & $\mid \begin{array}{l}0.0070 \\
0.00019 \\
{\left[\begin{array}{l}0.0 .1931, \mathrm{U} \\
0.0015\end{array}\right.}\end{array}$ & $\mid \begin{array}{l}0.93 \\
0.05 \\
0.04 \\
0.14\end{array}$ & 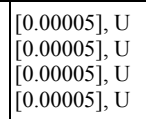 & $\mid \begin{array}{l}0.0034 \\
0.0019 \\
0.0017 \\
0.0020\end{array}$ & 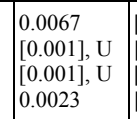 & 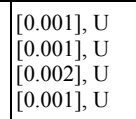 & $\mid \begin{array}{l}0.0021 \\
0.0006 \\
0.0007 \\
{[0.001], U}\end{array}$ & $\mid \begin{array}{l}0.0012 \\
{[0.00022], \mathrm{U}} \\
{[0.00002], \mathrm{U}} \\
0.0002\end{array}$ & $\left|\begin{array}{l}0.0051 \\
0.0022 \\
0.0021 \\
0.0024\end{array}\right|$ & 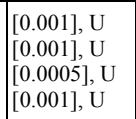 & 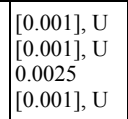 & 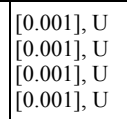 & $\begin{array}{l}0.089 \\
0.069 \\
0.060 \\
0.076\end{array}$ & 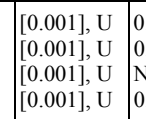 & & {$\left[\begin{array}{l}[0.001]], U \\
{[[0.001], U} \\
{[[0.001], U} \\
{[0.001], U}\end{array}\right.$} & & & {$\left[\begin{array}{l}{[0.001], \mathrm{U}} \\
0.0012 \\
{[0.002], \mathrm{U}} \\
0.0022\end{array}\right.$} \\
\hline Starmer Spring & 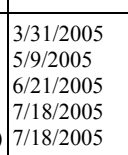 & $\begin{array}{l}{[0.0001], \mathrm{U}} \\
{[[0.001], \mathrm{U}} \\
{[[0.0201], \mathrm{U}} \\
{[0.001], \mathrm{U}} \\
{[0.011, \mathrm{U}}\end{array}$ & $\begin{array}{l}1.84 \\
\begin{array}{l}1.045 \\
0.045 \\
0.056 \\
0.17 \\
0.10\end{array}\end{array}$ & 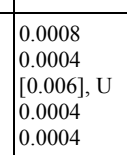 & $\begin{array}{l}0.013 \\
0.024 \\
0.0210 \\
0.010 \\
0.010\end{array}$ & \begin{tabular}{|l|l|}
0.058 \\
0.010 \\
0.0101 \\
0.039 \\
0.039
\end{tabular} & 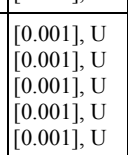 & 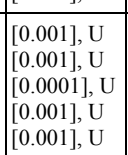 & $\begin{array}{l}{\left[\begin{array}{l}{[0.001], \mathrm{U}} \\
{[0.001], \mathrm{U}} \\
0.0013 \\
{[[0.001], \mathrm{U}} \\
{[0.001], \mathrm{U}}\end{array}\right.} \\
\end{array}$ & 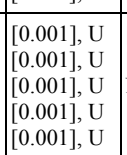 & 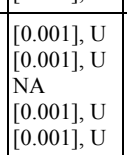 & $\mid \begin{array}{l}0.0041 \\
0.00011 \\
\text { lo. } 0.031, \mathrm{U} \\
0.0020 \\
0.0016\end{array}$ & $\begin{array}{l}1.12 \\
0.04 \\
0.03 \\
0.03 \\
0.13\end{array}$ & {$\left[\begin{array}{l}[0.00005]], \mathrm{U} \\
{[0.00005], \mathrm{U}} \\
{[0.0000505], \mathrm{U}} \\
{[0.00005], \mathrm{U}} \\
{[0.000005], \mathrm{U}}\end{array}\right.$} & $\begin{array}{l}0.0043 \\
0.0025 \\
0.00020 \\
0.0022 \\
0.0021\end{array}$ & $\left|\begin{array}{l}0.0060 \\
{[0.001], U} \\
{[0.001], U} \\
0.0021 \\
0.021\end{array}\right|$ & $\begin{array}{l}{[0.001], \mathrm{U}} \\
{[[0.001], \mathrm{U}} \\
{[[0.020] \mathrm{U}} \\
{[[0.001], \mathrm{U}} \\
{[0.001], \mathrm{U}}\end{array}$ & $\begin{array}{l}0.0019 \\
0.00049 \\
0.00076 \\
{\left[\begin{array}{l}0.0011, \mathrm{U} \\
{[0.001], \mathrm{U}}\end{array}\right.}\end{array}$ & $\begin{array}{l}0.0010 \\
{[0.0002], \mathrm{U}} \\
{[0.00002], \mathrm{U}} \\
0.00003] \\
{[0.0022], \mathrm{U}}\end{array}$ & $\begin{array}{l}0.0050 \\
0.0021 \\
0.001919 \\
0.0022 \\
0.0022\end{array}$ & 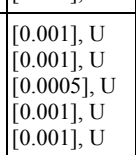 & 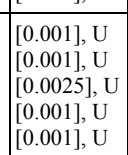 & 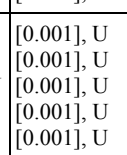 & $\begin{array}{l}0.089 \\
0.078 \\
0.0099 \\
0.074 \\
0.075\end{array}$ & 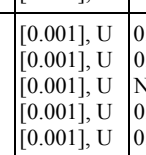 & \begin{tabular}{|l}
0.041 \\
0.003 \\
0.00 \\
0.007 \\
0.005
\end{tabular} & \begin{tabular}{|l}
{$[0.001], \mathrm{U}$} \\
{$[[0.001], \mathrm{U}$} \\
{$[[0.001], \mathrm{U}$} \\
{$[0.001], \mathrm{U}$} \\
{$[0.001], \mathrm{U}$}
\end{tabular} & 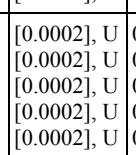 & $\mid \begin{array}{l}0.004 \\
0.002 \\
0.0012 \\
0.002 \\
0.002\end{array}$ & \begin{tabular}{|l|}
{$\left[\begin{array}{l}{[0.001], \mathrm{U}} \\
0.007 \\
0.0034 \\
0.0004 \\
0.002\end{array}\right.$} \\
0.002
\end{tabular} \\
\hline $\begin{array}{l}\text { Bulldog Spring } \\
\text { (Binin Intrabor }\end{array}$ & 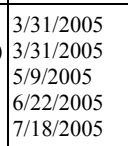 & $\begin{array}{l}{[0.001], \mathrm{U}} \\
{[[0.001], \mathrm{U}} \\
{[[0.0101], \mathrm{U}} \\
{[0.0201], \mathrm{U}} \\
{[0.001, \mathrm{U}}\end{array}$ & $\begin{array}{l}1.79 \\
1.73 \\
0.020 \\
0.0225 \\
0.020\end{array}$ & 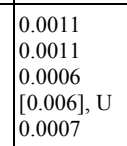 & $\begin{array}{l}\mid \begin{array}{l}0.016 \\
0.017 \\
0.057 \\
0.025 \\
0.0216\end{array} \\
0.016\end{array}$ & \begin{tabular}{|l}
0.078 \\
0.077 \\
0.073 \\
0.013 \\
0.045 \\
0.054
\end{tabular} & 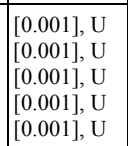 & $\mid \begin{array}{l}{[0.001], \mathrm{U}} \\
{[[0.001]], \mathrm{U}} \\
{[[0.001], \mathrm{U}} \\
{[0.0001], \mathrm{U}} \\
{[0.001], \mathrm{U}}\end{array}$ & 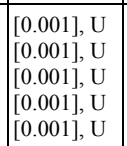 & 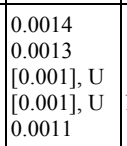 & 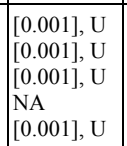 & 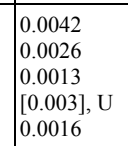 & \begin{tabular}{|l|l}
.06 \\
0.98 \\
0.02 \\
0.02 \\
0.01 \\
{$[0.01], \mathrm{U}$}
\end{tabular} & 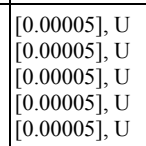 & $\mid \begin{array}{l}0.0064 \\
0.0066 \\
0.0048 \\
0.00051 \\
0.0047\end{array}$ & $\begin{array}{l}0.0094 \\
0.0092 \\
{[0.001], \mathrm{U}} \\
{[[0.001], \mathrm{U}} \\
{[0.001], \mathrm{U}}\end{array}$ & {$\left[\begin{array}{l}{[0.0011], \mathrm{U}} \\
{[0.001], \mathrm{U}} \\
{[0.001], \mathrm{U}} \\
{[[0.020), \mathrm{U}} \\
{[0.001], \mathrm{U}}\end{array}\right.$} & 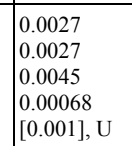 & $\begin{array}{l}0.0014 \\
0.0011 \\
{[0.0002], \mathrm{U}} \\
{[0.00022, \mathrm{U}} \\
{[0.0002], \mathrm{U}}\end{array}$ & \begin{tabular}{|l|l}
0.0051 \\
0.0051 \\
0.0021 \\
0.00221 \\
0.00220
\end{tabular} & 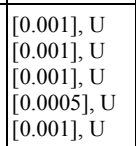 & 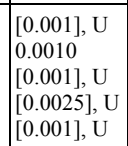 & 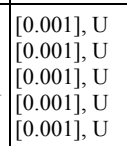 & $\begin{array}{l}0.11 \\
0.11 \\
0.10 \\
0.090 \\
0.087\end{array}$ & 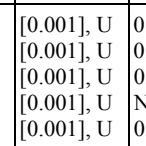 & $\begin{array}{l}0.055 \\
0.051 \\
0.001 \\
\text { NA } \\
0.001\end{array}$ & 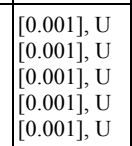 & \begin{tabular}{ll|l}
0.03 \\
$0.021, \mathrm{U}$ \\
$0.022], \mathrm{U}$
\end{tabular} & $\begin{array}{l}0.005 \\
0.005 \\
0.002 \\
0.0025 \\
0.003\end{array}$ & \begin{tabular}{|l}
0.003 \\
0.002 \\
0.006 \\
0.00021 \\
0.00221
\end{tabular} \\
\hline $\begin{array}{l}\text { Burning Ground Spring } \\
\text { (Blind Intralaboratory Field D }\end{array}$ & $\begin{array}{l}4 / 1 / 2005 \\
4 / 1 / 2005 \\
5 / 1212005 \\
7 / 19 / 2005\end{array}$ & 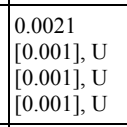 & $\begin{array}{l}1.199 \\
1.54 \\
0.010 \\
0.020 \\
0.020\end{array}$ & \begin{tabular}{|l}
0.0008 \\
0.0008 \\
0.0003 \\
0.0004
\end{tabular} & $\begin{array}{l}0.042 \\
0.042 \\
0.052 \\
0.019 \\
0.019\end{array}$ & $\begin{array}{l}0.42 \\
0.41 \\
0.045 \\
0.27\end{array}$ & 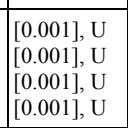 & {$\left[\begin{array}{l}{[0.001], \mathrm{U}} \\
{[[0.001], \mathrm{U}} \\
{[0.001], \mathrm{U}} \\
{[0.001], \mathrm{U}}\end{array}\right]$} & 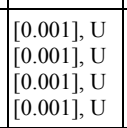 & \begin{tabular}{|l|}
0.00011 \\
0.0013 \\
0.0015 \\
{$[0.0011, \mathrm{U}$}
\end{tabular} \mid & 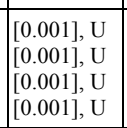 & 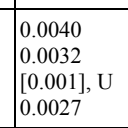 & $\begin{array}{l}1.19 \\
0.03 \\
0.01 \\
0.01\end{array}$ & 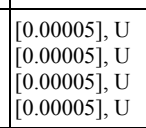 & $\begin{array}{l}0.0072 \\
0.0072 \\
0.0045 \\
0.0048\end{array}$ & $\left|\begin{array}{l}0.0073 \\
0.012 \\
0.012 \\
{[0.0001], U}\end{array}\right|$ & 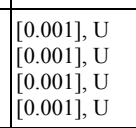 & $\mid \begin{array}{l}0.0037 \\
0.0037 \\
{\left[\begin{array}{ll}0.00111, \mathrm{U} \\
0.0021\end{array}\right.}\end{array}$ & 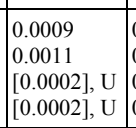 & $\begin{array}{l}0.0062 \\
0.0064 \\
0.0034 \\
0.0031\end{array}$ & {$\left[\begin{array}{l}{[0.0011], U} \\
{[0.0101], U} \\
{[0.011], U} \\
{[0.011], U}\end{array}\right.$} & 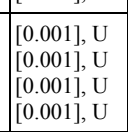 & 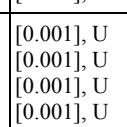 & $\left(\begin{array}{l}0.12 \\
0.12 \\
0.14 \\
0.094\end{array}\right.$ & 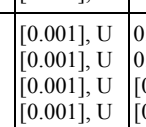 & $\left.\mid \begin{array}{l}0.039 \\
0.005 \\
{[0.001], \mathrm{U}}\end{array}\right]$ & 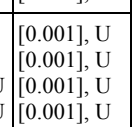 & $\left.\mid \begin{array}{l}0.0003 \\
0.0003 \\
{[0.00021, \mathrm{U}} \\
{[10.000021, \mathrm{U}}\end{array}\right]$ & $\mid \begin{array}{l}0.004 \\
0.005 \\
0.002 \\
0.002\end{array}$ & 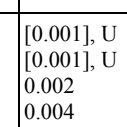 \\
\hline artin Spring & \begin{tabular}{|l|}
$4 / 6 / 2005$ \\
$5 / 9 / 2005$
\end{tabular} & $\begin{array}{l}{[0.0011], U} \\
{[0.001], U}\end{array}$ & \begin{tabular}{|l|}
0.098 \\
0.039
\end{tabular} & \begin{tabular}{|l|}
0.0011 \\
0.0009
\end{tabular} & \begin{tabular}{|l|}
0.87 \\
0.84
\end{tabular} & \begin{tabular}{|l|}
0.099 \\
0.83
\end{tabular} & $\begin{array}{l}{[0.001], U} \\
{[0.001], U} \\
\end{array}$ & \begin{tabular}{|l|l}
0.0012 \\
{$[0.001], \mathrm{U}$}
\end{tabular} & \begin{tabular}{|l|}
{$[0.001], \mathrm{U}$} \\
{$[0.001], \mathrm{U}$}
\end{tabular} & $\begin{array}{l}{[0.001], \mathrm{U}} \\
{[0.001], \mathrm{U}}\end{array}$ & \begin{tabular}{|l|}
{$[0.001], \mathrm{U}$} \\
{$[0.001], \mathrm{U}$}
\end{tabular} & $\begin{array}{l}0.0039 \\
0.0036\end{array}$ & $\begin{array}{l}0.05 \\
0.03\end{array}$ & \begin{tabular}{|l}
{$[0.00005], \mathrm{U}$} \\
{$[0.000055], \mathrm{U}$}
\end{tabular} & {$\left[\begin{array}{l}0.006 \\
0.0056\end{array}\right.$} & \begin{tabular}{|l|}
0.00047 \\
{$[0.001], \mathrm{U}$}
\end{tabular} & $\begin{array}{l}0.0024 \\
0.0024\end{array}$ & \begin{tabular}{|l|}
0.0040 \\
0.0048
\end{tabular} & $\mid$\begin{tabular}{|l|}
0.0002 \\
{$[0.0002], \mathrm{U}$}
\end{tabular} & \begin{tabular}{|l|}
0.00222 \\
0.021
\end{tabular} & {$\left[\begin{array}{ll}{[0.001], U} \\
{[0.011, U}\end{array}\right.$} & {$\left[\begin{array}{ll}{[0.0011], \mathrm{U}} \\
{[0.001], \mathrm{U}}\end{array}\right]$} & {$\left[\begin{array}{ll}{[0.001] 1, \mathrm{U}} \\
{[0.001], \mathrm{U}}\end{array}\right]$} & {$\left[\begin{array}{l}0.092 \\
0.992\end{array}\right.$} & 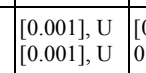 & $\mid$ & {$\left[\begin{array}{ll}{[0.011], \mathrm{U}} \\
{[0.0001], \mathrm{U}}\end{array}\right]$} & $\begin{array}{l}{\left[\begin{array}{l}0.00022], \mathrm{U} \\
{[0.0002], \mathrm{U}}\end{array}\right.} \\
\end{array}$ & $\begin{array}{l}0.003 \\
0.003\end{array}$ & \begin{tabular}{|l|}
0.010 \\
0.008
\end{tabular} \\
\hline TA-18 Spring & 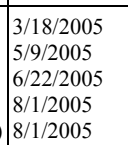 & $\begin{array}{l}{[0.001], \mathrm{U}} \\
{[[.001], \mathrm{U}} \\
{[[0.0202], \mathrm{U}} \\
{[[0.010), \mathrm{U}} \\
{[0.001], \mathrm{U}}\end{array}$ & $\begin{array}{l}6.67 \\
0.017 \\
0.016 \\
0.0058 \\
0.0046\end{array}$ & \begin{tabular}{|l}
0.0008 \\
0.0005 \\
$0.0065, \mathrm{U}$ \\
0.00006 \\
0.00006
\end{tabular} & $\begin{array}{l}0.025 \\
0.022 \\
0.022 \\
0.022 \\
0.022\end{array}$ & $\begin{array}{l}0.096 \\
0.019 \\
0.090 \\
0.090 \\
0.12 \\
0.11\end{array}$ & {$\left[\begin{array}{l}{[0.001], \mathrm{U}} \\
{[[0.001], \mathrm{U}} \\
{[[0.001], \mathrm{U}} \\
{[0.001], \mathrm{U}} \\
{[0.001], \mathrm{U}}\end{array}\right.$} & $\mid \begin{array}{l}{[0.001], \mathrm{U}} \\
{[0.001], \mathrm{U}} \\
{[[0.0001], \mathrm{U}} \\
{[0.001], \mathrm{U}} \\
{[0.001], \mathrm{U}}\end{array}$ & $\mid \begin{array}{l}{\left[\begin{array}{l}0.001], \mathrm{U} \\
0.0011, \\
0.0011 \\
0.0013 \\
0.0023\end{array}\right.} \\
0.002\end{array}$ & $\mid$\begin{tabular}{|c|}
0.0052 \\
{$[0.001], \mathrm{U}$} \\
{$[[0.001], \mathrm{U}$} \\
{$[[0.001]], \mathrm{U}$} \\
{$[0.001], \mathrm{U}$}
\end{tabular} & 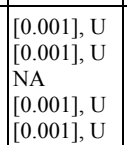 & $\mid \begin{array}{l}0.0031 \\
0.00014 \\
{\left[\begin{array}{l}0.00131, \mathrm{U} \\
0.0013 \\
0.0013\end{array}\right.}\end{array}$ & $\mid \begin{array}{l}4.76 \\
0.26 \\
0.70 \\
0.26 \\
0.17\end{array}$ & 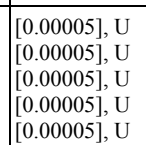 & $\begin{array}{l}0.010 \\
0.0030 \\
0.0034 \\
0.003 \\
0.0032\end{array}$ & \begin{tabular}{|l|}
0.049 \\
0.13 \\
0.15 \\
0.16 \\
0.13
\end{tabular} & {$\left[\begin{array}{l}{[0.001], \mathrm{U}} \\
{[0.001], \mathrm{U}} \\
{[0.002], \mathrm{U}} \\
0.0014 \\
0.0011\end{array}\right.$} & $\begin{array}{l}0.0039 \\
0.0033 \\
0.0016 \\
0.00032 \\
0.0064\end{array}$ & 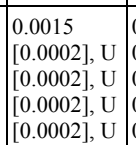 & $\mid \begin{array}{l}0.011 \\
0.0011 \\
0.0014 \\
0.0015 \\
0.0015\end{array}$ & 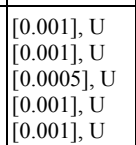 & 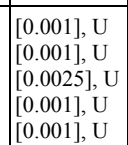 & 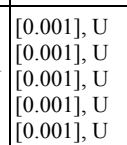 & $\begin{array}{l}0.068 \\
0.076 \\
0.096 \\
0.11 \\
0.11\end{array}$ & 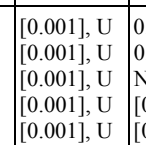 & 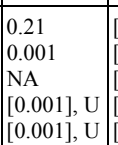 & 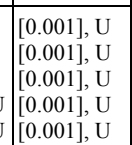 & {$\left[\begin{array}{l}0.0004 \\
{[[0.0002], \mathrm{U}} \\
{[[0.00022], \mathrm{U}} \\
{[[0.00202], \mathrm{U}} \\
{[0.00022], \mathrm{U}}\end{array}\right.$} & 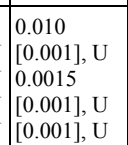 & $\begin{array}{l}0.019 \\
0.008 \\
0.0035 \\
0.014 \\
0.024\end{array}$ \\
\hline
\end{tabular}


Table 6.2

Summary Results of Trace Elements (Cont.)

Station ID

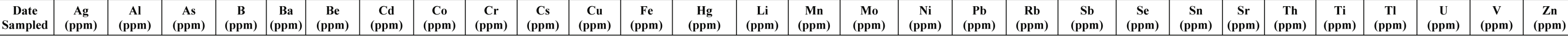
Intermetiate at Depth, Volcanics and Sedim

\begin{tabular}{|c|c|c|c|c|c|c|c|c|c|c|c|c|c|c|c|c|c|c|c|c|c|c|c|c|c|c|c|c|c|c|}
\hline & 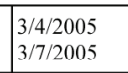 & toll], U & $\mid \begin{array}{l}0.070 \\
\text { NA }\end{array}$ & {$\left[\begin{array}{l}0.0004 \\
\mathrm{NA}\end{array}\right.$} & $\begin{array}{l}0.0886 \\
\text { NA }\end{array}$ & $\begin{array}{l}0.0093 \\
\mathrm{NA}\end{array}$ & $\begin{array}{l}{[0.0001], \mathrm{U}} \\
\mathrm{NA}\end{array}$ & {$\left[\begin{array}{ll}0.001] \\
\mathrm{NA}\end{array}\right.$} & 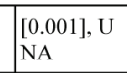 & {$\left[\begin{array}{ll}{[0.001], \mathrm{U}} \\
\mathrm{NA}\end{array}\right.$} & $\mid \begin{array}{l}0.0016 \\
\mathrm{NA}\end{array}$ & $\begin{array}{l}0.013 \\
\text { NA }\end{array}$ & $\mid \begin{array}{l}0.11 \\
\mathrm{NA}\end{array}$ & {$\left[\begin{array}{l}{[0.00005], \mathrm{U}} \\
\mathrm{NA}\end{array}\right.$} & {$\left[\begin{array}{l}0.012 \\
\mathrm{~N} A\end{array}\right.$} & {$\left[\begin{array}{l}0.001] \\
\mathrm{NA}\end{array}\right.$} & $\left.\right|_{\mathrm{NA}} ^{0.0224}$ & {$\left[\begin{array}{l}{[0.001], \mathrm{U}} \\
\mathrm{NA}\end{array}\right.$} & $\begin{array}{l}0.0002 \\
\text { NA }\end{array}$ & $\mid \begin{array}{ll}0.048 \\
N \wedge\end{array}$ & {$\left[\begin{array}{ll}{[0.0011], \mathrm{U}} \\
\mathrm{NA}\end{array}\right.$} & [0.001], U & $\begin{array}{l}{[0.0001, \mathrm{U}} \\
\mathrm{NA}\end{array}$ & {$\left[\begin{array}{l}0.057 \\
\mathrm{NA}\end{array}\right.$} & $\left.\begin{array}{l}{[0.001], \mathrm{U}} \\
\mathrm{NA}\end{array}\right]$ & $\mid 0.002$ & $\begin{array}{l}{[0.001], \mathrm{U}} \\
\mathrm{NA}\end{array}$ & $\begin{array}{l}\text { lo.0005 } \\
\text { NA }\end{array}$ & {$\left[\begin{array}{l}{[0.001], \mathrm{U}} \\
\mathrm{NA}\end{array}\right.$} & $\begin{array}{l}0.003 \\
\mathrm{NA}\end{array}$ \\
\hline $3 \mathrm{~T}-4$ & 29:2005 & $011, \mathrm{U}$ & 0.0081 & 0.0004 & 25 & 15 & {$[0.0011, \mathrm{U}$} & {$[0.001], \mathrm{U}$} & {$[0.001], \mathrm{U}$} & 0.015 & {$[0.001], \mathrm{U}$} & 0028 & $.011, \mathrm{U}$ & $00005], \mathrm{U}$ & 0.039 & 0.0016 & {$[0.001], \mathrm{U}$} & 0.0034 & {$[0.0002], \mathrm{U}$} & $\mathrm{J} 0.0022$ & $0.0011, \mathrm{U}$ & {$[0.0011, \mathrm{U}]$} & {$[0.001], \mathrm{U}$} & 0.17 & {$[0.001], \mathrm{U} / \mathrm{G}, \mathrm{C}$} & 0.001 & $0.0011, \mathrm{U}$ & {$[0.0002], \mathrm{U}$} & $\mathrm{U} 0.001$ & 0.009 \\
\hline II-6 & 9//1/2005 & {$[0.0022], \mathrm{U}$} & {$[0.0068], \mathrm{U}$} & {$[0.006], \mathrm{U}$} & 0.0325 & 0.0331 & $0.0011, \mathrm{U}$ & $.0011, \mathrm{U}$ & {$[0.001], \mathrm{U}$} & 0.0572 & $\mathrm{NA}$ & 10.0066 & $0.018 \mathrm{l}, \mathrm{U}, \mathrm{C}_{0}$ & [0.00005], U & $\mathrm{NA}$ & 0.0116 & 0.0025 & 0.0055 & {$[0.0005]$,} & $\sqrt{\mathrm{NA}}$ & $\begin{array}{l}0.0005], \mathrm{U} \\
\end{array}$ & {$[0.0025 \mathrm{]}, \mathrm{U}$} & {$[0.0025]$, } & 0.218 & & $\mathrm{NA}$ & [0.00004] & 0.0005 & 0.0014 & 0.0515 \\
\hline & $\begin{array}{l}338 / 2005 \\
8 / 3 / 2005\end{array}$ & $\begin{array}{l}{[0.001], \mathrm{U}} \\
{[0.001] \mathrm{U}}\end{array}$ & $\begin{array}{l}{[0.002], U} \\
{[10.002], U}\end{array}$ & $\begin{array}{l}0.0037 \\
0.00034\end{array}$ & $\begin{array}{l}0.21 \\
0.22\end{array}$ & 0 & $\begin{array}{l}{[0.001], U} \\
{[[0.001] \mid \mathrm{U}}\end{array}$ & $\begin{array}{l}{\left[\begin{array}{ll}{[0.011, \mathrm{U}} \\
{[0.0011] \mathrm{U}}\end{array}\right.} \\
\end{array}$ & $\begin{array}{l}0.0019 \\
0.0017\end{array}$ & $\begin{array}{l}0.00024 \\
{[10.011, \mathrm{U}}\end{array}$ & $\begin{array}{l}{\left[\begin{array}{ll}{[0.001], \mathrm{U}} \\
{[0.001] \mathrm{U}}\end{array}\right.} \\
\end{array}$ & $\begin{array}{l}0.037 \\
0.0032\end{array}$ & $\frac{[0.01], \mathrm{U}}{[0.01], \mathrm{U}}$ & $\begin{array}{l}{[0.0005], U} \\
0.000055], U\end{array}$ & $\begin{array}{l}0.009 \\
0.0082\end{array}$ & $\begin{array}{l}{[0.001, \mathrm{U}} \\
0.0 .011) \mathrm{U}\end{array}$ & $\begin{array}{l}0.0021 \\
0.0002\end{array}$ & $\begin{array}{l}0.0091 \\
0.0089 \\
\end{array}$ & 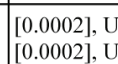 & $\mid \begin{array}{ll}0.022 \\
0.21\end{array}$ & {$\left[\begin{array}{ll}{[0.0011], U} \\
{[0.001], U}\end{array}\right.$} & $\mid \begin{array}{ll}{[0.0011], \mathrm{U}} \\
{[0.001] \cdot \mathrm{U}}\end{array}$ & $\begin{array}{l}{[0.0011], \mathrm{U}} \\
{[[0.001], \mathrm{U}}\end{array}$ & 0.25 & . & 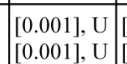 & {$\left[\begin{array}{lll}{[0.0011] \mathrm{U}} \\
{[0.001] \mathrm{U}}\end{array}\right.$} & $\begin{array}{l}0.0026 \\
0.0027\end{array}$ & $\begin{array}{l}0.005 \\
0.004\end{array}$ & $\begin{array}{l}0.004 \\
0.006\end{array}$ \\
\hline & $8 / 242005$ & {$[0.001], \mathrm{U}$} & 0.0041 & 0.0009 & 0.021 & 0.30 & {$[0.0011, \mathrm{U}$} & $001], \mathrm{U}$ & {$[0.001], \mathrm{U}$} & 0.0022 & {$[0.001], \mathrm{U}$} & 0.0015 & {$[0.01], \mathrm{U}$} & {$[0.00005], \mathrm{U}$} & 0.041 & 0.011 & 0.0013 & {$[0.001], \mathrm{U}$} & {$[0.0002], \mathrm{U}$} & 0.0021 & {$[0.001], \mathrm{U}$} & {$[0.001], \mathrm{U}$} & {$[0.001], \mathrm{U}$} & 0.12 & $0.0011, \mathrm{U}$ & $|[0.001], \mathrm{U}|$ & {$[0.001], \mathrm{U}$} & 0.0006 & 0.003 & 0.019 \\
\hline & & & & $\begin{array}{l}.00041 \\
0.0006\end{array}$ & \begin{tabular}{|l|l|}
0.15 \\
0.18
\end{tabular} & 62 & & & & & & & & & & & & & & 0.00 & & & & & & & & & & $\begin{array}{ll}15 \\
357\end{array}$ \\
\hline \\
\hline (Interlab & $\begin{array}{l}5 / 1912005 \\
5 / 1 / 2012005 \\
9 / 12 / 2005\end{array}$ & {$\left[\begin{array}{l}0.0 .0011], \mathrm{U} \\
{[0.001]} \\
{[0.001], \mathrm{U}}\end{array}\right.$} & 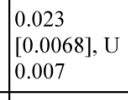 & $\mid \begin{array}{l}0.00099 \\
0.00061, \mathrm{U} \\
0.0010\end{array}$ & $\begin{array}{l}0.012 \\
0.0139 \\
0.012\end{array}$ & & {$\left[\begin{array}{l}{[0.001], \mathrm{U}} \\
{[[0.001]], \mathrm{U}} \\
{[0.001], \mathrm{U}}\end{array}\right.$} & & $\begin{array}{l}001], \mathrm{U} \\
0.011, \mathrm{U} \\
0001], \mathrm{U}\end{array}$ & {$\left[\begin{array}{l}0.0042 \\
{[0.0045], \mathrm{U}} \\
0.0050\end{array}\right.$} & $\mid \begin{array}{l}{\left[\begin{array}{l}{[0.001], \mathrm{U}} \\
\mathrm{N} \\
{[0.001], \mathrm{U}}\end{array}\right.} \\
\end{array}$ & $\left\{\begin{array}{l}0.0048 \\
{[0.0031, \mathrm{U}} \\
0.0016\end{array}\right.$ & $\mid \begin{array}{l}0.06 \\
0.0788 \\
0.02\end{array}$ & & & & & & & & $\begin{array}{l}{[0.0101], \mathrm{U}} \\
{[0.00001] \mathrm{U}} \\
{[0.001], \mathrm{U}}\end{array}$ & & {$\left[\begin{array}{l}{[0.0001], \mathrm{U}} \\
\mathrm{NA} \\
{[0.001], \mathrm{U}}\end{array}\right.$} & & 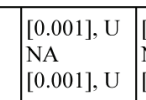 & 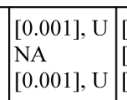 & & $\begin{array}{l}{\left[\begin{array}{l}0.0007 \\
0.00078 \\
0.0007\end{array}\right.} \\
0\end{array}$ & & $\begin{array}{l}0.008 \\
0.0076 \\
0.001\end{array}$ \\
\hline & 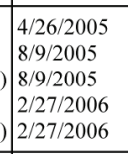 & 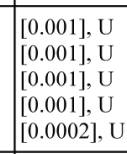 & \begin{tabular}{|l}
0.0075 \\
0.0028 \\
{$\left[\begin{array}{l}0.0028], U \\
0.068 \\
0.278\end{array}\right.$} \\
0.278
\end{tabular} & $\begin{array}{l}0.0012 \\
0.0012 \\
{\left[\begin{array}{l}0.006], \mathrm{U} \\
{[0.00612} \\
0.0012 \\
{[0.006], \mathrm{U}}\end{array}\right.}\end{array}$ & $\begin{array}{l}\mid \begin{array}{l}0.018 \\
0.015 \\
0.017 \\
0.017 \\
0.0021, U \\
0.0254\end{array} \\
0.025\end{array}$ & $\begin{array}{l}0.012 \\
0.011 \\
0.0137 \\
0.014 \\
0.0324 \\
\end{array}$ & 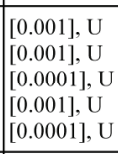 & 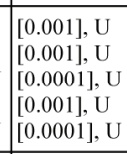 & 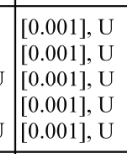 & $\begin{array}{l}0.0016 \\
0.0011 \\
0.0037 \\
0.0035 \\
0.0052 \\
0.0045\end{array}$ & 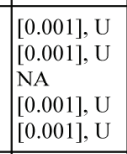 & $\begin{array}{l}0.0027 \\
0.0013 \\
{[0.0031, \mathrm{U}} \\
0.00044 \\
{[0.0031, \mathrm{U}}\end{array}$ & \begin{tabular}{|l|}
0.02 \\
{$\left[\begin{array}{ll}0.01], \mathrm{U} \\
{[0.018, \mathrm{U}} \\
0.028 \\
0.0205\end{array}\right.$} \\
0.020
\end{tabular} & 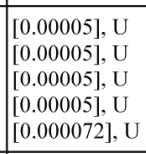 & $\begin{array}{l}0.024 \\
0.025 \\
\text { No2 } \\
0.023 \\
0.023 \\
0.023\end{array}$ & 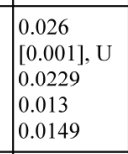 & \begin{tabular}{|l}
0.0048 \\
0.0029 \\
0.0027 \\
0.00222 \\
{$[0.0025], \mathrm{U}$}
\end{tabular} & $\begin{array}{l}0.031 \\
0.0014 \\
0.0027 \\
0.0017 \\
0.0014 \\
\end{array}$ & 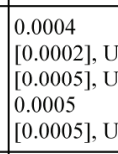 & $\begin{array}{l}0.0014 \\
0.0015 \\
0.015 \\
0.015 \\
0.0015 \\
0.015\end{array}$ & 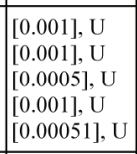 & 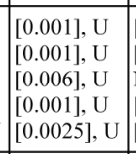 & \begin{tabular}{|l|}
{$[0.001], \mathrm{U}$} \\
{$[0.001], \mathrm{U}$} \\
{$[\mathrm{N}, 0.1], \mathrm{U}$} \\
{$[0.0025], \mathrm{U}$}
\end{tabular} & & 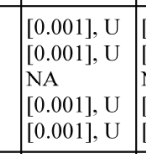 & 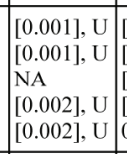 & 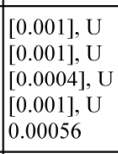 & \begin{tabular}{|l|}
0.00006 \\
0.0004 \\
0.0045 \\
0.00045 \\
0.00054 \\
0.00043
\end{tabular} \mid & $\begin{array}{l}0.007 \\
0.008 \\
0.008 \\
0.008 \\
0.0091 \\
\end{array}$ & \begin{tabular}{|l}
0.022 \\
0.0204 \\
{$\left[\begin{array}{l}0.0074], U \\
0.0005 \\
{[0.0073], U}\end{array}\right.$}
\end{tabular} \\
\hline & 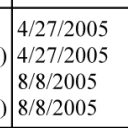 & 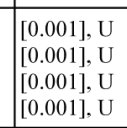 & 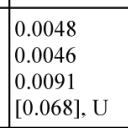 & $\begin{array}{l}0.0014 \\
0.00115 \\
0.00113 \\
{[0.0061, \mathrm{U}}\end{array}$ & \begin{tabular}{|l|}
0.026 \\
0.026 \\
0.026 \\
0.025
\end{tabular} & $\begin{array}{l}0.033 \\
0.035 \\
0.036 \\
0.0342\end{array}$ & $\begin{array}{l}{[0.0011, \mathrm{U}} \\
{\left[\begin{array}{l}{[0.0011], \mathrm{U}} \\
{[0.001], \mathrm{U}} \\
{[0.00001], \mathrm{U}}\end{array}\right.}\end{array}$ & 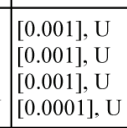 & & $\begin{array}{l}0.0043 \\
0.00043 \\
\text { o.0073 } \\
0.0045\end{array}$ & 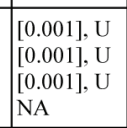 & $\mid$\begin{tabular}{|l|}
0.0017 \\
0.00011 \\
0.0011 \\
$0.00031, \mathrm{U}$
\end{tabular} & $\left.\begin{array}{l}{[0.01], \mathrm{U}} \\
0.01 \\
0.01 \\
{[0.0181], \mathrm{U}}\end{array}\right]$ & $\begin{array}{l}0.00005 \\
0.00005 \\
{[0.00005], U} \\
{[0.000055], U}\end{array}$ & $\begin{array}{l}0.027 \\
0.027 \\
0.026 \\
\mathrm{NA}\end{array}$ & & & & & $\begin{array}{l}0.0047 \\
0.0049 \\
0.0023 \\
\mathrm{NA}\end{array}$ & 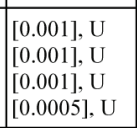 & & & & 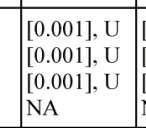 & 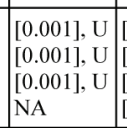 & & & & \begin{tabular}{|l}
0.026 \\
0.027 \\
0.027 \\
{$[0.00411, \mathrm{U}$}
\end{tabular} \\
\hline (Interababratory Field Duplici & \begin{tabular}{|l|l|}
823232005 \\
882320005
\end{tabular} & $\begin{array}{l}.001, \mathrm{U} \\
0.11, \mathrm{U}\end{array}$ & 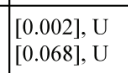 & $\begin{array}{l}\begin{array}{l}0.0015 \\
{[0.006], \mathrm{U}}\end{array} \\
\end{array}$ & $\begin{array}{l}0.022 \\
0.0235\end{array}$ & \begin{tabular}{|l|}
0.026 \\
0.0271
\end{tabular} & $\begin{array}{l}0.11, \mathrm{U} \\
0001], \mathrm{U}\end{array}$ & $\begin{array}{l}0.11, \\
0001,\end{array}$ & {$\left[\begin{array}{l}{[0.001], \mathrm{U}} \\
{[10.001], \mathrm{U}}\end{array}\right.$} & $\begin{array}{l}\begin{array}{l}0.0035 \\
0.004\end{array} \\
\end{array}$ & $\begin{array}{l}{\left[\begin{array}{l}{[0.001], \mathrm{U}} \\
\mathrm{NA}\end{array}\right.} \\
\end{array}$ & $\begin{array}{l}0.0012 \\
{[0.003], \mathrm{U}}\end{array}$ & $\begin{array}{l}{[0.01], \mathrm{U}} \\
{[0.0181] \mathrm{U}}\end{array}$ & $\begin{array}{l}{[0.00005], U} \\
{[0.000055], U}\end{array}$ & $\begin{array}{l}\begin{array}{l}0.028 \\
\mathrm{NA}\end{array} \\
\end{array}$ & $\begin{array}{l}.0 .056 \\
.0598\end{array}$ & $\begin{array}{l}0.0021 \\
0.0023\end{array}$ & \begin{tabular}{|l|}
$0.0001], \mathrm{U}$ \\
0.0013
\end{tabular} & \begin{tabular}{|l}
{$\left[\begin{array}{l}{[0.00022], \mathrm{U}} \\
{[0.0005], \mathrm{U}}\end{array}\right.$} \\
\end{tabular} & $\begin{array}{l}0.0024 \\
\mathrm{NA}\end{array}$ & $\begin{array}{l}{[0.001], \mathrm{U}} \\
{[0.0005], \mathrm{U}}\end{array}$ & {$\left[\begin{array}{l}{[0.0001], \mathrm{U}} \\
{[0.006] \mathrm{U}}\end{array}\right]$} & $\begin{array}{l}{[0.001],} \\
\mathrm{NA}\end{array}$ & $\begin{array}{l}0.056 \\
0.059\end{array}$ & \begin{tabular}{|l|}
{$\left[\begin{array}{l}{[0.001], U} \\
\mathrm{NA}\end{array}\right.$} \\
\end{tabular} & \begin{tabular}{|l|}
{$\left[\begin{array}{l}{[0.001], \mathrm{U}} \\
\mathrm{NA}\end{array}\right.$} \\
$\mid$
\end{tabular} & \begin{tabular}{|l}
{$[0.001], U$} \\
0.0004
\end{tabular} & $\begin{array}{l}0.0006 \\
0.00065\end{array}$ & 89 & \begin{tabular}{|l|}
0.005 \\
{$[0.00877, \mathrm{C}$}
\end{tabular} \\
\hline & 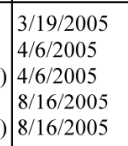 & 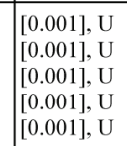 & 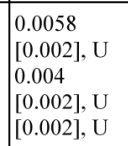 & $\begin{array}{l}0.0018 \\
0.0019 \\
0.0018 \\
0.001818 \\
0.0018\end{array}$ & $\begin{array}{l}0.047 \\
0.047 \\
0.047 \\
0.047 \\
0.047\end{array}$ & $\begin{array}{l}0.18 \\
0.15 \\
0.15 \\
0.118 \\
0.18\end{array}$ & {$\left[\begin{array}{l}{[0.001], \mathrm{U}} \\
{[[0.0011], \mathrm{U}} \\
{[[0.001], \mathrm{U}} \\
{[0.001], \mathrm{U}} \\
{[0.001], \mathrm{U}}\end{array}\right.$} & 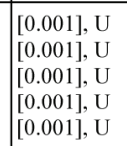 & 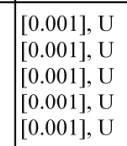 & $\begin{array}{l}0.0031 \\
0.00330 \\
0.0028 \\
0.00228 \\
0.0026\end{array}$ & {$\left[\begin{array}{l}{[0.001], \mathrm{U}} \\
{[[0.001], \mathrm{U}} \\
{[[0.001], \mathrm{U}} \\
{[0.001], \mathrm{U}} \\
{[0.001], \mathrm{U}}\end{array}\right.$} & $\left\{\begin{array}{l}0.0012 \\
0.0023 \\
0.0019 \\
{[0.0019, \mathrm{U}} \\
{[0.001], \mathrm{U}}\end{array}\right.$ & 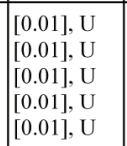 & {$\left[\begin{array}{l}{[0.00005], U} \\
{[0.00005], U} \\
{[0.000505], U} \\
{[0.0 .00505], U} \\
{[0.000055], U}\end{array}\right.$} & $\begin{array}{l}0.033 \\
0.033 \\
0.034 \\
0.034 \\
0.034 \\
0.033\end{array}$ & & & & & $\left\{\begin{array}{l}0.0047 \\
0.0050 \\
0.0049 \\
0.0050 \\
0.0049\end{array}\right.$ & & & & $\begin{array}{l}0.16 \\
0.15 \\
0.15 \\
0.15 \\
0.15\end{array}$ & 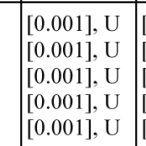 & 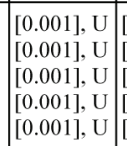 & & & & $\mid \begin{array}{l}0.011 \\
0.005 \\
0.009 \\
0.008 \\
0.0012\end{array}$ \\
\hline (Interlaboratory Field Du & 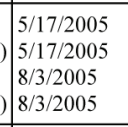 & 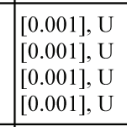 & $\begin{array}{l}0.011 \\
{\left[\begin{array}{ll}0.06087, \mathrm{U} \\
0.027 \\
{[0.0688, \mathrm{U}}\end{array}\right.}\end{array}$ & 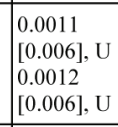 & $\begin{array}{l}0.030 \\
0.0312 \\
0.0363 \\
0.02899\end{array}$ & \begin{tabular}{|l|l|}
0.034 \\
0.037 \\
0.33 \\
0.0361 \\
\end{tabular} & 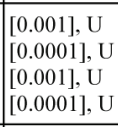 & $\begin{array}{l}.0011], \mathrm{U} \\
.00011, \mathrm{U}\end{array}$ & & $\begin{array}{l}0.017 \\
0.018 .4 \\
0.022 \\
0.0205\end{array}$ & 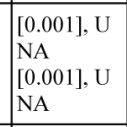 & \begin{tabular}{|l|}
0.0048 \\
0.0031 \\
0.0014 \\
0.0031
\end{tabular} & $\left.\begin{array}{|l|}0.04 \\
0.0289 \\
0.01 \\
{[0.01818], \mathrm{U}}\end{array}\right]$ & & $\begin{array}{l}0.032 \\
\mathrm{~N} A \\
0.02 \\
\mathrm{NA} \\
\mathrm{NA}\end{array}$ & & & & & & {$\left[\begin{array}{l}{[0.001], \mathrm{U}} \\
{[0.00005], \mathrm{U}} \\
{[0.001], \mathrm{U}} \\
{[0.00055], \mathrm{U}}\end{array}\right]$} & & 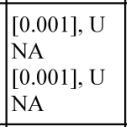 & & 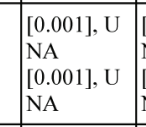 & 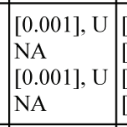 & & & & \\
\hline & $\begin{array}{l}339 / 2005 \\
8 / 31212005 \\
8 / 31 / 2005\end{array}$ & 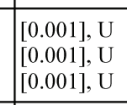 & \begin{tabular}{|l}
{$\left[\begin{array}{l}0.002], U \\
0.0015 \\
0.0016\end{array}\right.$} \\
0.01
\end{tabular} & $\begin{array}{l}0.0008 \\
0.00008 \\
0.0008\end{array}$ & $\begin{array}{l}0.012 \\
0.011 \\
0.011\end{array}$ & $\begin{array}{l}0.034 \\
0.031 \\
0.031\end{array}$ & $\begin{array}{l}{[0.0011, \mathrm{U}} \\
{[0.000011] \mathrm{U}} \\
{[0.001], \mathrm{U}}\end{array}$ & 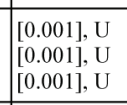 & {$\left[\begin{array}{l}{[0.001, \mathrm{U}} \\
{[0.001), \mathrm{U}} \\
{[0.001], \mathrm{U}}\end{array}\right.$} & \begin{tabular}{|l|}
0.0071 \\
0.00072 \\
0.0073
\end{tabular} & 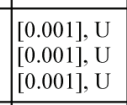 & 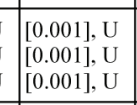 & \begin{tabular}{|l|}
{$[0.01], \mathrm{U}$} \\
{$\left[\begin{array}{l}0.011), \mathrm{U} \\
{[0.01], \mathrm{U}}\end{array}\right.$}
\end{tabular} & 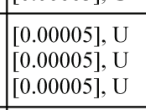 & $\begin{array}{l}0.023 \\
0.025 \\
0.026 \\
0.026\end{array}$ & 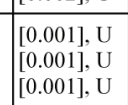 & 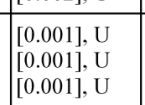 & {$\left[\begin{array}{l}0.0011 \\
{[0.0011], \mathrm{U}} \\
{[0.001], \mathrm{U}}\end{array}\right.$} & 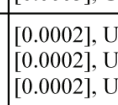 & $\mid \begin{array}{l}0.0048 \\
0.00045 \\
0.0045\end{array}$ & {$\left[\begin{array}{l}{[0.0011], U} \\
{[0.011], U} \\
{[0.001], U}\end{array}\right.$} & $\begin{array}{l}0.001 \\
0.0010 \\
{[0.0011, \mathrm{U}} \\
{[0.010}\end{array}$ & 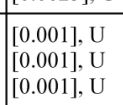 & $\begin{array}{l}0.063 \\
0.058 \\
0.058\end{array}$ & $\left|\begin{array}{l}{[0.001], \mathrm{U}} \\
{[[0.001], \mathrm{U}} \\
{[0.01], \mathrm{U}}\end{array}\right|$ & 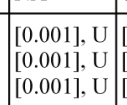 & $\mid\left[\begin{array}{l}{[0.0011, \mathrm{U}} \\
{[0.00011], \mathrm{U}} \\
{[0.001], \mathrm{U}}\end{array}\right.$ & \begin{tabular}{|l}
0.0004 \\
0.0004 \\
0.0004
\end{tabular} & $\begin{array}{l}0.007 \\
0.007 \\
0.007\end{array}$ & \\
\hline & \begin{tabular}{|l|l|}
$825 / 22005$ \\
$121 / 2005$ \\
$122 / 12005$ \\
1005
\end{tabular} & $\begin{array}{l}{[0.001], \mathrm{U}} \\
{\left[\begin{array}{l}[0.0001]], \mathrm{U} \\
{[0.001], \mathrm{U}}\end{array}\right.}\end{array}$ & $\begin{array}{l}0.0044 \\
0.0091 \\
{[0.0688], U}\end{array}$ & 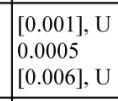 & $\begin{array}{l}0.006 \\
0.025 \\
{[0.0101], \mathrm{U}}\end{array}$ & \begin{tabular}{|l|}
0.020 \\
0.11 \\
0.0195 \\
\end{tabular} & $\begin{array}{l}{[0.001], \mathrm{U}} \\
{\left[\begin{array}{l}{[0.0001], \mathrm{U}} \\
{[0.0001], \mathrm{U}}\end{array}\right.}\end{array}$ & 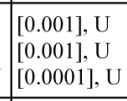 & $\begin{array}{l}{[0.0101, \mathrm{U}} \\
{\left[\begin{array}{ll}0.001], \mathrm{U} \\
{[10.001], \mathrm{U}}\end{array}\right.}\end{array}$ & 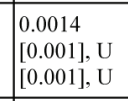 & 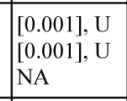 & \begin{tabular}{|l}
0.0013 \\
{$[0.001, \mathrm{U}$} \\
{$[0.003], \mathrm{U}$}
\end{tabular} & 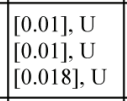 & 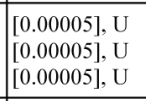 & $\begin{array}{l}0.014 \\
\text { o.015 } \\
\text { NA }\end{array}$ & \begin{tabular}{|l}
{$[0.001], \mathrm{U}$} \\
{$\left[\begin{array}{l}0.0001] \mathrm{U} \\
{[0.0001], \mathrm{U}}\end{array}\right.$}
\end{tabular} & $\begin{array}{l}{[0.001], \mathrm{U}} \\
{[10.0101] \mathrm{U}} \\
{[0.00049], \mathrm{U}}\end{array}$ & 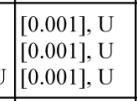 & 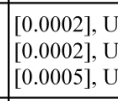 & & 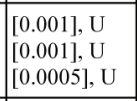 & {$\left[\begin{array}{l}{[0.001], \mathrm{U}} \\
{[0.001], \mathrm{U}} \\
{[0.006], \mathrm{U}}\end{array}\right.$} & & \begin{tabular}{|l}
0.043 \\
0.044 \\
0.047 \\
\end{tabular} & $\begin{array}{l}{[0.001], \mathrm{U}} \\
{[\mathrm{i} .001], \mathrm{U}} \\
\mathrm{NA}\end{array}$ & 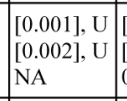 & $\begin{array}{l}{[0.001], U} \\
{[0.0001], \mathrm{U}} \\
0.00054\end{array}$ & \begin{tabular}{|l|l|}
0.0003 \\
0.0003 \\
0.00038
\end{tabular} & $\begin{array}{l}.003 \\
.00027 \\
.0023\end{array}$ & \\
\hline & \begin{tabular}{|l|}
7 \\
$8 / 14 / 1 / 2005$ \\
$8 / 1 / 2005$
\end{tabular} & $\begin{array}{l}{[0.0022], \mathrm{U}} \\
{[0.001], \mathrm{U}}\end{array}$ & \begin{tabular}{|l|}
$0.0 .068], \mathrm{U}$ \\
0.0042
\end{tabular} & 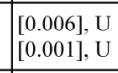 & $\begin{array}{l}0.0152 \\
0.013\end{array}$ & $\begin{array}{l}0.0268 \\
0.028\end{array}$ & {$\left[\begin{array}{l}{[0.011, \mathrm{U}} \\
{[0.001], \mathrm{U}}\end{array}\right.$} & 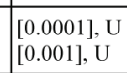 & 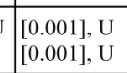 & $\begin{array}{l}0.0018 \\
0.0023\end{array}$ & \begin{tabular}{|l|l|}
$\mathrm{NA}$ \\
{$[0.001], \mathrm{U}$}
\end{tabular} & $\begin{array}{l}{\left[\begin{array}{l}{[0.033], \mathrm{U}} \\
{[0.001], \mathrm{U}}\end{array}\right.} \\
\end{array}$ & 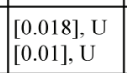 & \begin{tabular}{|l}
{$[0.000055], \mathrm{U}$} \\
{$[0.00005], \mathrm{U}$}
\end{tabular} & \begin{tabular}{|l}
$\mathrm{NA}$ \\
0.023
\end{tabular} & $\begin{array}{l}.0033 \\
.0028 \\
\end{array}$ & \begin{tabular}{|l|}
{$\left[\begin{array}{l}{[0.002], \mathrm{U}} \\
0.0017\end{array}\right.$} \\
\end{tabular} & $\begin{array}{l}0.0014 \\
{[0.001], \mathrm{U}}\end{array}$ & \begin{tabular}{|l}
{$[0.0005], \mathrm{U}$} \\
0.0007
\end{tabular} & $\begin{array}{l}\mathrm{NA} \\
0.0027\end{array}$ & {$\left[\begin{array}{l}{[0.0005], \mathrm{U}} \\
{[0.0011], \mathrm{U}}\end{array}\right.$} & 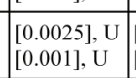 & $\mid \begin{array}{l}{[0.0025], \mathrm{U}} \\
{[[0.001], \mathrm{U}}\end{array}$ & $\begin{array}{l}0.082 \\
0.075\end{array}$ & A & \begin{tabular}{|l|}
$\mathrm{NA}$ \\
{$[0.001], \mathrm{U}$}
\end{tabular} & {$\left[\begin{array}{l}{[0.0004], \mathrm{U}} \\
{[0.001], \mathrm{U}}\end{array}\right.$} & $\begin{array}{l}0.00049 \\
0.0004\end{array}$ & $\begin{array}{l}0.0064 \\
0.007\end{array}$ & $\begin{array}{l}0.0184 \\
0.005\end{array}$ \\
\hline e) & 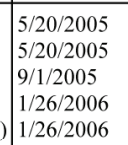 & 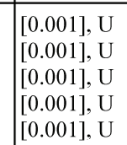 & \begin{tabular}{|l}
0.010 \\
{$\left[\begin{array}{ll}0.010 \\
0.068], U \\
0.003 \\
0.007 \\
0.007\end{array}\right.$}
\end{tabular} & 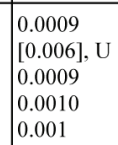 & $\begin{array}{l}0.024 \\
0.023 \\
0.025 \\
0.058 \\
0.058\end{array}$ & $\begin{array}{l}0.048 \\
0.029 \\
0.029 \\
0.054 \\
0.050 \\
0.05\end{array}$ & 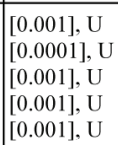 & 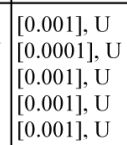 & 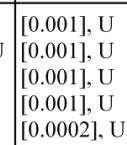 & $\begin{array}{l}\mid \begin{array}{l}0.36 \\
0.375 \\
0.37 \\
0.37 \\
0.40 \\
0.4\end{array} \\
0.4\end{array}$ & 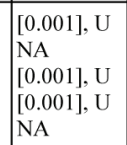 & $\left\{\begin{array}{l}0.0043 \\
{[0.0031, \mathrm{U}} \\
0.0022 \\
0.00017 \\
0.0017\end{array}\right.$ & 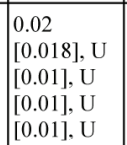 & 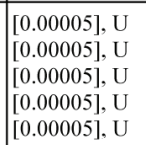 & $\begin{array}{l}0.035 \\
\mathrm{NA} \\
0.034 \\
0.034 \\
\mathrm{NA}\end{array}$ & $\begin{array}{l}0.0015 \\
0.0035 \\
0.031 \\
0.0018 \\
0.0018 \\
0.0018\end{array}$ & 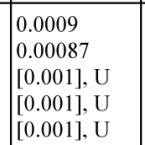 & \begin{tabular}{|l|}
0.0050 \\
{$[0.0063], \mathrm{U}$} \\
0.0068 \\
0.0089 \\
0.0089 \\
\end{tabular} & 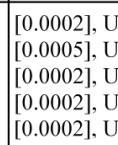 & & $\mid \begin{array}{l}{[0.001], \mathrm{U}} \\
{[0.0005], \mathrm{U}} \\
{[0.001], \mathrm{U}} \\
{[0.0101], \mathrm{U}} \\
{[0.0011] \mathrm{U}}\end{array}$ & \begin{tabular}{|l|}
{$[0.0011, \mathrm{U}$} \\
0.0068 \\
0.0011 \\
0.0015 \\
0.0015
\end{tabular} & 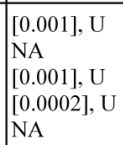 & $\begin{array}{l}0.13 \\
0.13 \\
0.14 \\
0.14 \\
0.14\end{array}$ & \begin{tabular}{|l|}
{$[0.001], \mathrm{U}$} \\
$\mathrm{NA}$ \\
{$[0.001], \mathrm{U}$} \\
{$[\mathrm{IDO} 001], \mathrm{U}$} \\
$\mathrm{NA}$
\end{tabular} & 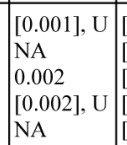 & & $\begin{array}{l}0.0008 \\
0.0011 \\
0.0008 \\
0.00099 \\
0.0009\end{array}$ & $\begin{array}{l}0.007 \\
0.007 \\
0.0054 \\
{[0.001], U} \\
{[0.001], U} \\
{[0.001], U}\end{array}$ & {$\left[\begin{array}{l}0.010 \\
0.011 \\
0.012 \\
0.0102], \mathrm{U} \\
{[0.00202], \mathrm{U}}\end{array}\right.$} \\
\hline & $\begin{array}{l}3323 / 2005 \\
5 / 42005 \\
8 / 172005\end{array}$ & $\begin{array}{l}{[0.001], \mathrm{U}} \\
{\left[\begin{array}{l}0.0001], \mathrm{U} \\
{[0.001], \mathrm{U}}\end{array}\right.}\end{array}$ & \begin{tabular}{|l}
0.012 \\
0.0118 \\
{$[0.002], \mathrm{U}$}
\end{tabular} & \begin{tabular}{|l}
0.0010 \\
0.0009 \\
0.0009
\end{tabular} & $\begin{array}{l}0.085 \\
0.096 \\
0.089 \\
\end{array}$ & $\mid \begin{array}{l}0.076 \\
0.0771 \\
0.10\end{array}$ & 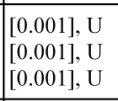 & 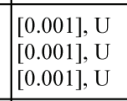 & {$\left[\begin{array}{l}{[0.001, \mathrm{U}} \\
{[0.001], \mathrm{U}} \\
{[0.001], \mathrm{U}}\end{array}\right.$} & \begin{tabular}{|l|l}
0.0024 \\
0.0015 \\
{$[0.001], \mathrm{U}$}
\end{tabular} & 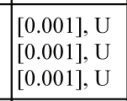 & $\begin{array}{l}0.0051 \\
0.0023 \\
0.0012\end{array}$ & $\left|\begin{array}{l}0.01 \\
0.01 \\
{[0.01], \text { U }}\end{array}\right|$ & {$\left[\begin{array}{l}{[0.00005], \mathrm{U}} \\
{[0.00055], \mathrm{U}} \\
{[0.000055, \mathrm{U}}\end{array}\right.$} & $\begin{array}{l}0.032 \\
0.034 \\
0.034\end{array}$ & $\begin{array}{l}0.045 \\
0.028 \\
0.029\end{array}$ & & & {$\left[\begin{array}{l}0.0147 \\
0.0003 \\
{[0.0002], \mathrm{U}}\end{array}\right.$} & $\begin{array}{l}0.0045 \\
0.0048 \\
0.0046\end{array}$ & 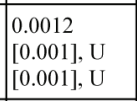 & & & $\begin{array}{l}0.27 \\
0.28 \\
0.28\end{array}$ & & & & & & \\
\hline & 3/22/2005 & , & 0.0037 & 0.000 & 0.017 & 0.024 & {$[0.001, \mathrm{U}$} & & {$[0.001], \mathrm{U}$} & 0.0014 & {$[0.00$} & 22 & 0.04 & D005], U & 0.0. & 07. & 0.00 & 0.00 & 0.0. & 0.0 & & & & 0.028 & & & & & $.0011, \mathrm{U}$ & .54 \\
\hline & 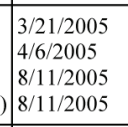 & 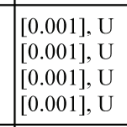 & $\begin{array}{l}0.00041 \\
0.0014 \\
{\left[\begin{array}{ll}0.1002], U \\
[0.02]], U\end{array}\right.}\end{array}$ & \begin{tabular}{|l|l|}
0.0003 \\
0.0004 \\
0.0005 \\
0.0005
\end{tabular} & $\begin{array}{l}0.032 \\
0.037 \\
0.0747 \\
0.048\end{array}$ & $\begin{array}{l}0.018 \\
0.027 \\
0.23 \\
0.20 \\
\end{array}$ & 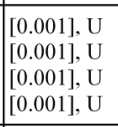 & 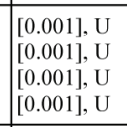 & {$\left[\begin{array}{l}{[0.001, \mathrm{U}} \\
{[0.001], \mathrm{U}} \\
{[0.0 .011, \mathrm{U}} \\
{[0.001], \mathrm{U}}\end{array}\right.$} & $\begin{array}{l}0.00036 \\
{\left[\begin{array}{l}0.001] \\
{[10.01], \mathrm{U}} \\
{[10.001], \mathrm{U}}\end{array}\right.}\end{array}$ & 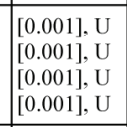 & $\left\{\begin{array}{l}0.0067 \\
0.0037 \\
0.0026 \\
0.027\end{array}\right.$ & \begin{tabular}{|l}
0.06 \\
0.83 \\
1.78 \\
1.80 \\
\end{tabular} & 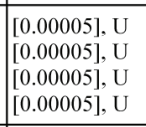 & $\begin{array}{l}0.024 \\
0.027 \\
0.025 \\
0.025 \\
0.025\end{array}$ & $\begin{array}{l}0.000 \\
0.009 \\
0.14 \\
0.14\end{array}$ & $\begin{array}{l}0.0021 \\
0.00017 \\
0.0016 \\
0.0016\end{array}$ & 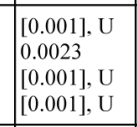 & {$\left[\begin{array}{l}0.0066 \\
0.0024 \\
0.0069 \\
0.0067\end{array}\right.$} & $\begin{array}{l}0.0035 \\
0.0038 \\
0.0021 \\
0.0023 \\
\end{array}$ & 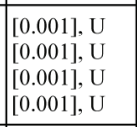 & {$\left[\begin{array}{l}{[0.001], \mathrm{U}} \\
[0.001]], \mathrm{U} \\
{[0.001], \mathrm{U}} \\
{[0.0011], \mathrm{U}}\end{array}\right]$} & 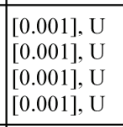 & $\begin{array}{l}0.060 \\
0.068 \\
0.065 \\
0.065 \\
\end{array}$ & 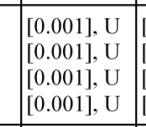 & 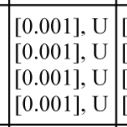 & & 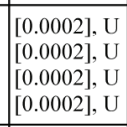 & & \\
\hline & $\begin{array}{l}3 / 2822005 \\
10 / 2005 \\
10205\end{array}$ & 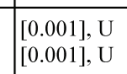 & 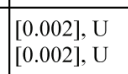 & \begin{tabular}{|l|}
0.0004 \\
0.0004
\end{tabular} & \begin{tabular}{|l|l|}
0.012 \\
0.021
\end{tabular} & $\begin{array}{l}0.0051 \\
0.0056\end{array}$ & $\begin{array}{l}{[0.0001], \mathrm{U}} \\
{[0.001], \mathrm{U}}\end{array}$ & {$\left[\begin{array}{l}{[0.0 .01] 1, \mathrm{U}} \\
{[0.001], \mathrm{U}}\end{array}\right.$} & {$\left[\begin{array}{l}0.0 .011, \mathrm{U} \\
{[0.001], \mathrm{U}}\end{array}\right.$} & $\begin{array}{l}0.0029 \\
0.0018\end{array}$ & $\begin{array}{l}{\left[\begin{array}{l}{[0.001], \mathrm{U}} \\
[0.001]], \mathrm{U}\end{array}\right.} \\
\end{array}$ & {$\left[\begin{array}{l}0.000017], U \\
{[0.001]}\end{array}\right.$} & \begin{tabular}{|l|}
0.03 \\
0.04
\end{tabular} & $\begin{array}{l}{[0.0000055], U} \\
{[0.00005, U}\end{array}$ & {$\left[\begin{array}{l}0.021 \\
0.021\end{array}\right.$} & \begin{tabular}{|l|l|}
0.0046 \\
0.0023
\end{tabular} & $\mid\left[\begin{array}{l}{[0.001], U} \\
{[0.0011], U}\end{array} \mid\right.$ & 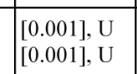 & {$\left[\begin{array}{l}0.00057 \\
0.0006\end{array}\right.$} & $\begin{array}{l}0.0046 \\
0.0049\end{array}$ & $\begin{array}{l}{[0.001], U} \\
{[0.001], U}\end{array}$ & {$[0.001], \mathrm{U}$} & [0.001], U & $\begin{array}{l}0.048 \\
0.550\end{array}$ & $\mid \begin{array}{l}{[0.001], \mathrm{U}} \\
{[0.001], \mathrm{U}}\end{array}$ & 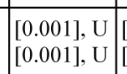 & {$\left[\begin{array}{l}{[0.001], \mathrm{U}} \\
{[0.00}\end{array}\right.$} & \begin{tabular}{|l|l|}
0.0004 \\
0.0004
\end{tabular} & $\begin{array}{l}0.005 \\
0.004\end{array}$ & {$\left[\begin{array}{ll}0.01 \\
0.16\end{array}\right.$} \\
\hline
\end{tabular}


Table 6.2

Summary Results of Trace Elements (Cont.)

Station ID

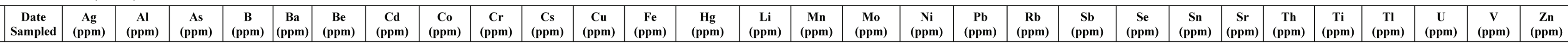
Regional Aquifer Production Well

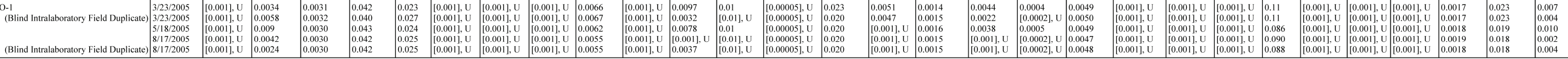
(Blind Intralaboratory Fied Dite Rock Canyon Springs

Spring $2 \mathrm{~B}$

Spring 3

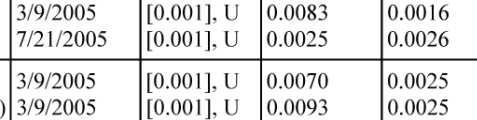

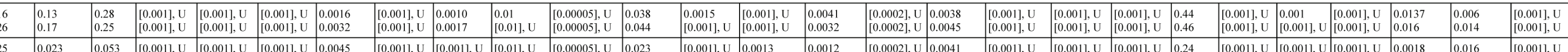

\begin{tabular}{|c|c|c|c|c|c|c|c|c|c|c|c|c|c|c|c|c|c|c|c|c|c|c|c|c|c|c|c|c|c|c|}
\hline $\begin{array}{l}\text { Springl } 3 \\
\text { (Blind Intra }\end{array}$ & 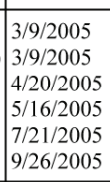 & 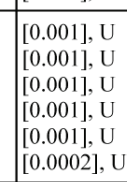 & 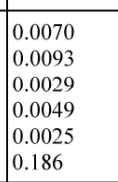 & 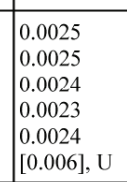 & {$\left[\begin{array}{l}0.023 \\
0.023 \\
0.023 \\
0.025 \\
0.022 \\
0.0216\end{array}\right.$} & $\begin{array}{l}0.053 \\
0.0533 \\
0.015 \\
0.041 \\
0.043 \\
0.0443\end{array}$ & 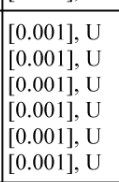 & 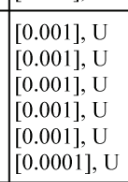 & 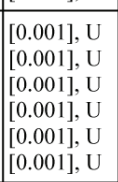 & $\mid \begin{array}{l}0.00045 \\
0.0042 \\
0.0040 \\
0.0040 \\
0.0043 \\
0.0043\end{array}$ & 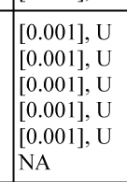 & 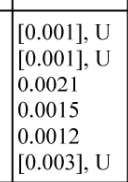 & 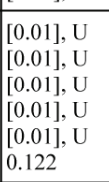 & 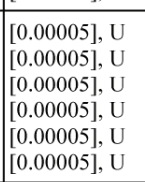 & $\begin{array}{l}{\left[\begin{array}{l}0.023 \\
0.023 \\
0.0224 \\
0.024 \\
0.024 \\
N A\end{array}\right.} \\
N A\end{array}$ & 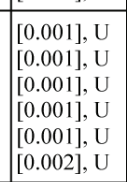 & {$\left[\begin{array}{l}0.0013 \\
0.0012 \\
0.0011 \\
0.0013 \\
0.0012 \\
{[0.0022], \mathrm{U}}\end{array}\right.$} & 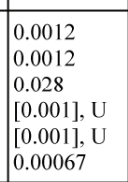 & 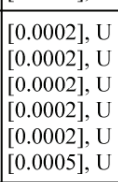 & 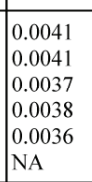 & 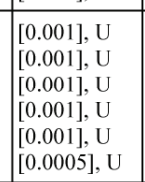 & 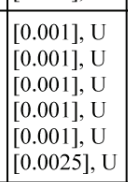 & 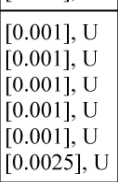 & $\begin{array}{l}0.24 \\
0.23 \\
0.22 \\
0.23 \\
0.22 \\
0.24\end{array}$ & 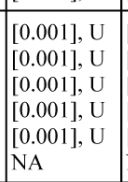 & 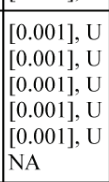 & 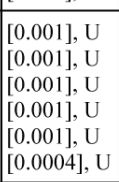 & $\mid \begin{array}{l}0.0018 \\
0.0020 \\
0.00020 \\
0.0023 \\
0.00202 \\
0.0021\end{array}$ & $\begin{array}{l}0.016 \\
0.015 \\
0.014 \\
0.014 \\
0.115 \\
0.0143\end{array}$ & 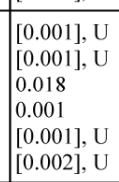 \\
\hline Spring 3A & 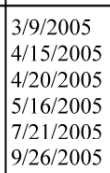 & 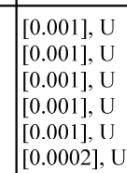 & 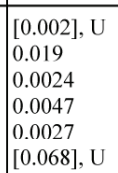 & 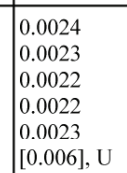 & $\begin{array}{l}0.022 \\
0.021 \\
0.022 \\
0.023 \\
0.022 \\
0.0206\end{array}$ & $\begin{array}{l}0.037 \\
0.037 \\
0.0332 \\
0.030 \\
0.033 \\
0.033 \\
0.304\end{array}$ & 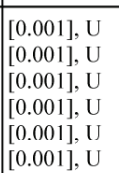 & 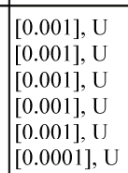 & 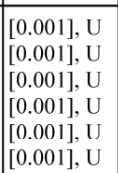 & 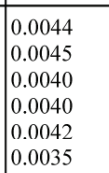 & 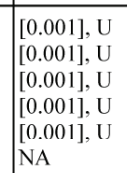 & 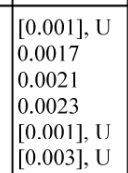 & 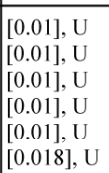 & 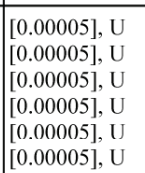 & $\begin{array}{l}0.022 \\
0.025 \\
0.023 \\
0.024 \\
0.023 \\
\text { ing } \\
\text { NA }\end{array}$ & 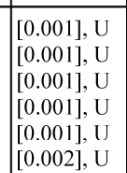 & 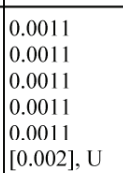 & 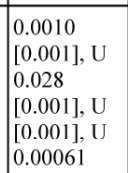 & 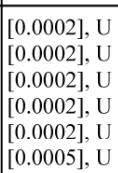 & $\begin{array}{l}0.0042 \\
0.0039 \\
0.0038 \\
0.0040 \\
0.04038 \\
\text { NA }\end{array}$ & 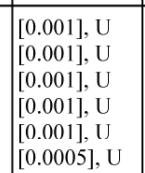 & 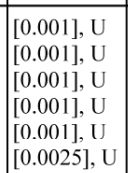 & 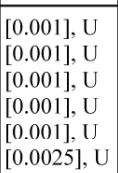 & $\begin{array}{l}0.23 \\
0.21 \\
0.21 \\
0.22 \\
0.22 \\
0.22\end{array}$ & 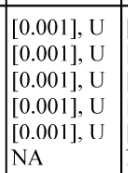 & 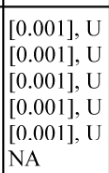 & 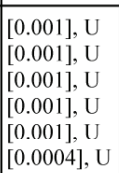 & $\begin{array}{l}0.012 \\
0.0013 \\
0.0013 \\
0.0013 \\
0.0114 \\
0.0114 \\
0.0016\end{array}$ & $\begin{array}{l}0.014 \\
0.013 \\
0.013 \\
0.013 \\
0114 \\
0.1132\end{array}$ & 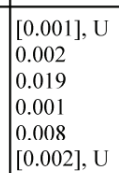 \\
\hline ring 3C & 3/1/1/2005 & {$[0.001], \mathrm{U}$} & 0.0053 & 0.0025 & 0.022 & 0.020 & {$[0.001], \mathrm{U}$} & {$[0.001], \mathrm{U}$} & {$[0.001], \mathrm{U}$} & 0.0050 & {$[0.001], \mathrm{U}$} & {$[0.001], \mathrm{U}$} & 0.02 & {$[0.00005], \mathrm{U}$} & 0.020 & $0.001, \mathrm{U}$ & 0.0011 & {$[0.001], \mathrm{U}$} & {$[0.0002], \mathrm{U}$} & 0.0036 & {$[0.001], \mathrm{U}$} & {$[0.001], \mathrm{U}$} & {$[0.001], \mathrm{U}$} & 0.13 & {$[0.001], \mathrm{U}$} & {$[0.001], \mathrm{U}$} & {$[0.001], \mathrm{U}$} & 0.0014 & 0.013 & {$[0.001], \mathrm{U}$} \\
\hline ring 4 & 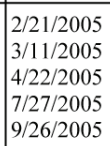 & 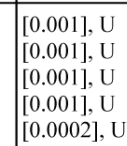 & 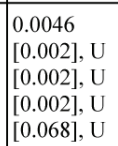 & 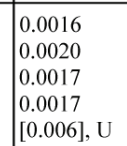 & \begin{tabular}{|l|l}
0.019 \\
0.020 \\
0.019 \\
0.017 \\
0.0179 \\
0.0179
\end{tabular} & $\begin{array}{l}0.039 \\
0.037 \\
0.079 \\
0.039 \\
0.044 \\
0.0402\end{array}$ & 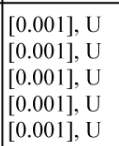 & 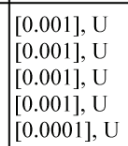 & 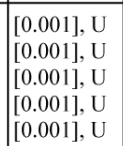 & \begin{tabular}{|l|}
0.0037 \\
0.0039 \\
0.032 \\
0.0032 \\
0.035 \\
0.0033
\end{tabular} & 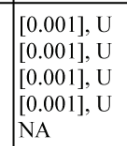 & 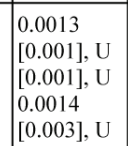 & $\begin{array}{l}0.01 \\
{[0.01], U} \\
{[0.01], U} \\
{[0.01], \mathrm{U}} \\
{[0.018], \mathrm{U}}\end{array}$ & 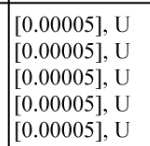 & $\begin{array}{l}0.024 \\
0.022 \\
0.023 \\
0.023 \\
0.022 \\
\mathrm{NA}\end{array}$ & 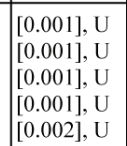 & \begin{tabular}{|l}
0.0011 \\
0.0013 \\
0.0011 \\
0.0011 \\
$0.0002], \mathrm{U}$
\end{tabular} & 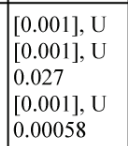 & 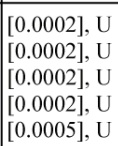 & \begin{tabular}{|l}
0.0032 \\
0.036 \\
0.031 \\
0.0031 \\
0.03030 \\
NA
\end{tabular} & 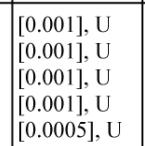 & \begin{tabular}{|l|}
0.0015 \\
0.001 \\
0.0013 \\
0.0013 \\
0.0012 \\
{$[0.0025], \mathrm{U}$}
\end{tabular} & 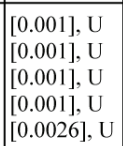 & $\begin{array}{l}0.12 \\
0.13 \\
0.12 \\
0.12 \\
0.13 \\
0.13\end{array}$ & 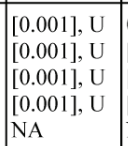 & 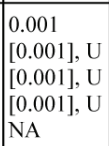 & {$\left[\begin{array}{l}{[0.001], \mathrm{U}} \\
{[[0.001], \mathrm{U}} \\
{[[0.001], \mathrm{U}} \\
{[0.001], \mathrm{U}} \\
{[0.0004], \mathrm{U}}\end{array}\right.$} & \begin{tabular}{|l}
0.0012 \\
0.0009 \\
0.0011 \\
0.00011 \\
0.000096 \\
0.00096
\end{tabular} & $\begin{array}{l}0.010 \\
0.1010 \\
0.009 \\
0.010 \\
0.0087\end{array}$ & 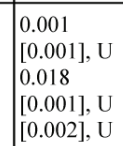 \\
\hline Spring 4A & 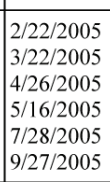 & 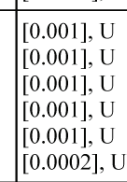 & {$\left[\begin{array}{l}0.0084 \\
0.0085 \\
0.007 \\
0.0065 \\
{\left[\begin{array}{l}0.002], \mathrm{U} \\
{[0.068], \mathrm{U}}\end{array}\right.}\end{array}\right.$} & 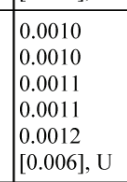 & $\begin{array}{l}0.024 \\
0.024 \\
0.029 \\
0.024 \\
0.020 \\
0.0206\end{array}$ & $\mid \begin{array}{l}0.041 \\
0.0435 \\
0.0222 \\
0.040 \\
0.043 \\
0.0386\end{array}$ & $\begin{array}{l}{[0.001], U} \\
{[[0.001], U} \\
{[[0.001], U} \\
{[[0.001], U} \\
{[[0.001], U} \\
{[0.001], U}\end{array}$ & 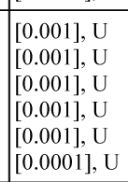 & 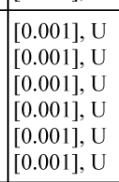 & $\begin{array}{l}0.0042 \\
0.042 \\
0.0040 \\
0.039 \\
0.0039 \\
0.0041 \\
0.0033\end{array}$ & 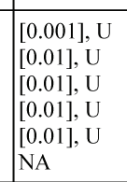 & 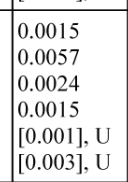 & 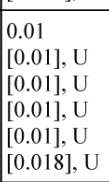 & 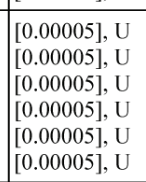 & $\mid \begin{array}{l}0.001 \\
0.030 \\
0.038 \\
0.029 \\
0.023 \\
\text { NA }\end{array}$ & {$\left[\begin{array}{l}{[0.001], U} \\
{[[0.001], U} \\
{[[0.001], U} \\
{[[0.001], U} \\
{[0.001], U} \\
{[0.002], U}\end{array}\right.$} & $\mid \begin{array}{l}0.0011 \\
0.0011 \\
0.00011 \\
0.0011 \\
0.0011 \\
0.0011 \\
{[0.002], \mathrm{U}}\end{array}$ & 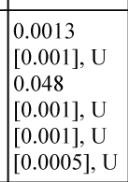 & {$\left[\begin{array}{l}{[0.002], \mathrm{U}} \\
{[0.00022, \mathrm{U}} \\
{[0.0020, \mathrm{U}} \\
{[0.00202], \mathrm{U}} \\
{[0.0002, \mathrm{U}} \\
{[0.0005], \mathrm{U}}\end{array}\right.$} & $\begin{array}{l}0.0029 \\
0.0030 \\
0.03030 \\
0.030 \\
0.030 \\
\text { NA }\end{array}$ & $\left|\begin{array}{l}{[0.001], \mathrm{U}} \\
{[0.001], \mathrm{U}} \\
{[0.001], \mathrm{U}} \\
{[0.001], \mathrm{U}} \\
{[0.001, \mathrm{U}} \\
{[0.0005], \mathrm{U}}\end{array}\right|$ & 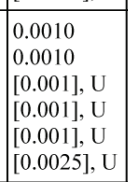 & 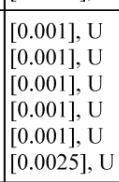 & $\begin{array}{l}0.096 \\
0.12 \\
0.096 \\
0.096 \\
0.095 \\
0.096\end{array}$ & 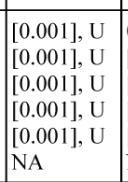 & 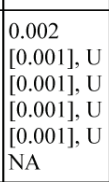 & {$\left[\begin{array}{l}{[0.001], \mathrm{U}} \\
{[[0.001], \mathrm{U}} \\
{[[0.001], \mathrm{U}} \\
{[[0.001], \mathrm{U}} \\
{[[0.001], \mathrm{U}} \\
{[0.0004], \mathrm{U}}\end{array}\right.$} & $\begin{array}{l}0.0012 \\
0.0012 \\
0.0011 \\
0.0011 \\
0.0010 \\
0.0011\end{array}$ & $\begin{array}{l}0.006 \\
0.007 \\
0.006 \\
0.006 \\
0.007 \\
0.007\end{array}$ & $\begin{array}{l}0.003 \\
0.0011, \mathrm{U} \\
0.031,0.011, \mathrm{U} \\
0.001 \\
0.002 \mathrm{l}, \mathrm{U}\end{array}$ \\
\hline $\begin{array}{l}\text { Spring } 4 \text { AA } \\
\text { Blinin ntrt }\end{array}$ & 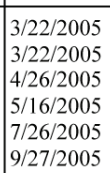 & 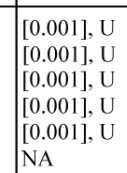 & $\begin{array}{l}0.017 \\
0.0090 \\
0.017 \\
0.011 \\
0.0023 \\
\text { NA }\end{array}$ & $\begin{array}{l}0.0011 \\
0.0011 \\
0.00101 \\
0.0011 \\
0.0012 \\
\text { NA }\end{array}$ & $\begin{array}{l}0.024 \\
0.026 \\
0.028 \\
0.024 \\
0.023 \\
\mathrm{NA}\end{array}$ & $\begin{array}{l}0.038 \\
0.033 \\
0.022 \\
0.035 \\
0.340 \\
0.040\end{array}$ & 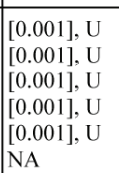 & 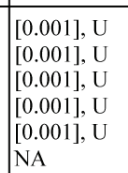 & 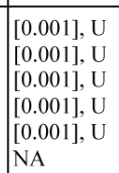 & $\begin{array}{l}0.0043 \\
0.00046 \\
0.0041 \\
0.0038 \\
0.038 \\
0.04040 \\
\mathrm{NA}\end{array}$ & 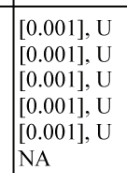 & 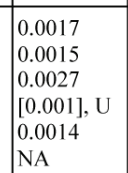 & 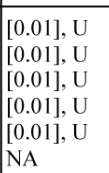 & 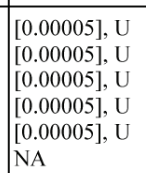 & $\begin{array}{l}0.028 \\
0.0230 \\
0.028 \\
0.028 \\
0.026 \\
0.026 \\
\text { NA }\end{array}$ & 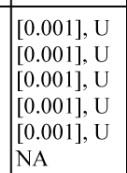 & $\begin{array}{l}0.0012 \\
0.00011 \\
0.0012 \\
0.0011 \\
0.0011 \\
0.0011\end{array}$ & 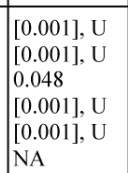 & 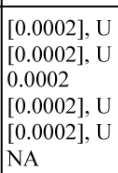 & $\begin{array}{l}0.0032 \\
0.0030 \\
0.0030 \\
0.0029 \\
0.025 \\
\text { NA }\end{array}$ & 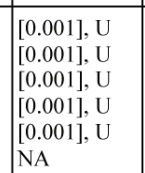 & 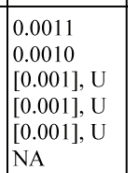 & 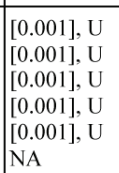 & $\begin{array}{l}0.10 \\
0.12 \\
0.098 \\
0.095 \\
0.098 \\
0.098\end{array}$ & 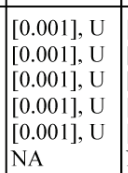 & 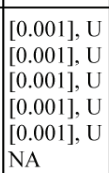 & 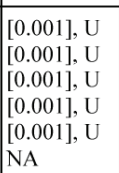 & $\begin{array}{l}0.0014 \\
0.0014 \\
0.00101 \\
0.0012 \\
0.0002 \\
\text { NA } \\
\mathrm{NA}\end{array}$ & $\mid \begin{array}{l}0.007 \\
0.007 \\
0.006 \\
0.006 \\
0.006 \\
0.006\end{array}$ & 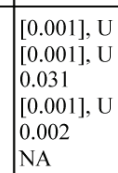 \\
\hline ring $4 B$ & 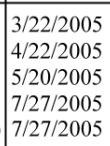 & 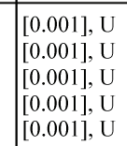 & 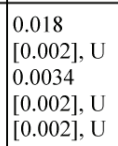 & $\mid \begin{array}{l}0.0013 \\
0.0013 \\
0.0013 \\
0.0013 \\
0.0014 \\
0.0014\end{array}$ & \begin{tabular}{|l}
$\mid \begin{array}{l}0.2020 \\
0.020 \\
0.020 \\
0.0202 \\
0.018 \\
0.017\end{array}$ \\
0.17
\end{tabular} & $\begin{array}{l}0.039 \\
0.044 \\
0.043 \\
0.0438 \\
0.048 \\
0.048\end{array}$ & 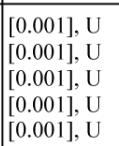 & 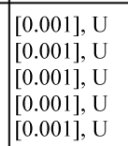 & 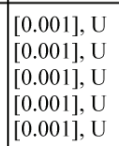 & $\begin{array}{l}0.0035 \\
0.0027 \\
0.0026 \\
00.0029 \\
0.0029\end{array}$ & 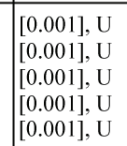 & 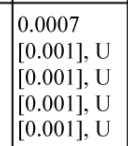 & {$\left[\begin{array}{l}{[0.01], \mathrm{U}} \\
{[0.01], \mathrm{U}} \\
{[0.01], \mathrm{U}} \\
{[0.01], \mathrm{U}} \\
{[0.01], \mathrm{U}}\end{array}\right.$} & 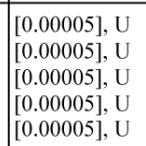 & $\begin{array}{l}0.023 \\
0.022 \\
0.022 \\
0.0219 \\
0.019\end{array}$ & 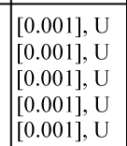 & \begin{tabular}{|l}
0.0011 \\
0.0012 \\
0.0011 \\
0.00111 \\
0.0011
\end{tabular} & 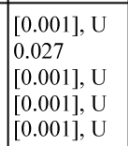 & 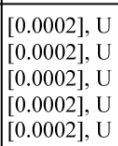 & $\begin{array}{l}0.0035 \\
0.032 \\
0.0033 \\
0.0033 \\
0.0031 \\
0.0031\end{array}$ & \begin{tabular}{|l}
{$[0.001], U$} \\
{$[0.001], U$} \\
{$[0.001], U$} \\
{$[0.0 .01], U$} \\
{$[0.0011], U$}
\end{tabular} & \begin{tabular}{|l}
0.0012 \\
0.0012 \\
{$\left[\begin{array}{l}0.001, U \\
{[0.001,} \\
0.0010 \\
0.0010\end{array}\right.$}
\end{tabular} & 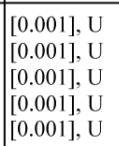 & $\begin{array}{l}0.14 \\
0.14 \\
0.14 \\
0.15 \\
0.14\end{array}$ & 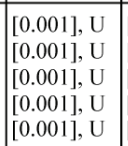 & 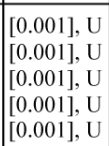 & $\begin{array}{l}{[0.001], U} \\
{[[0.001], U} \\
{[[0.001], U} \\
{[0.001], U} \\
{[0.001], U}\end{array}$ & \begin{tabular}{|l}
0.0015 \\
0.0014 \\
0.0014 \\
0.0014 \\
0.0014
\end{tabular} & \begin{tabular}{|l}
0.009 \\
0.007 \\
0.007 \\
0.007 \\
0.008 \\
0.008
\end{tabular} & $\begin{array}{l}0.001 \\
0.018 \\
0.002 \\
0.0011, \mathrm{U}\end{array}$ \\
\hline pring $4 \mathrm{C}$ & 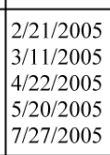 & 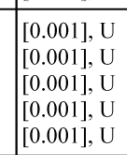 & $\begin{array}{l}0.0090 \\
{\left[\begin{array}{l}0.002], U \\
0.0029 \\
0.0060 \\
{[0.002], U}\end{array}\right.}\end{array}$ & $\mid \begin{array}{l}0.0016 \\
0.0020 \\
0.00017 \\
0.0016 \\
0.0017\end{array}$ & $\begin{array}{l}\mid \begin{array}{l}0.19 \\
0.020 \\
0.021 \\
0.0219 \\
0.019\end{array} \\
0.017\end{array}$ & $\begin{array}{l}0.040 \\
0.048 \\
0.041 \\
0.041 \\
0.038 \\
0.046\end{array}$ & 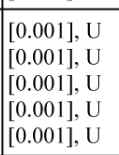 & 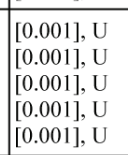 & 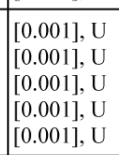 & $\begin{array}{l}0.0039 \\
0.0040 \\
0.0030 \\
0.0035 \\
0.0036 \\
0.038\end{array}$ & 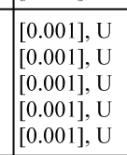 & 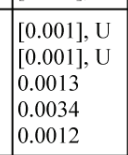 & {$\left[\begin{array}{l}{[0.01], \mathrm{U}} \\
{[0.01], \mathrm{U}} \\
{[0.01], \mathrm{U}} \\
{[0.01], \mathrm{U}} \\
{[0.01], \mathrm{U}}\end{array}\right.$} & 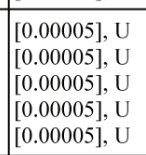 & $\begin{array}{l}0.025 \\
0.022 \\
0.026\end{array}$ & & $\begin{array}{l}0.0011 \\
0.0012 \\
0.0011 \\
0.0011 \\
0.0012 \\
0.0012\end{array}$ & \begin{tabular}{|l}
{$\left[\begin{array}{l}0.001], \mathrm{U} \\
{[0.001], \mathrm{U}} \\
0.027 \\
0.0018 \\
{[0.0011, \mathrm{U}}\end{array}\right.$} \\
0.0
\end{tabular} & & & 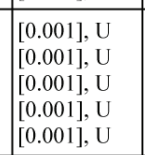 & & 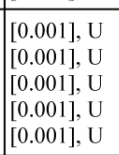 & & 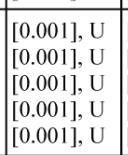 & 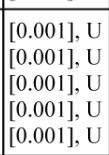 & {$\left[\begin{array}{l}{[0.001], U} \\
{[[0.001], U} \\
{[0.001], U} \\
{[0.001], U} \\
{[0.001], U}\end{array}\right.$} & $\begin{array}{l}0.0011 \\
0.0009 \\
0.00011 \\
0.0013 \\
0.0012\end{array}$ & \begin{tabular}{|l}
0.009 \\
0.010 \\
0.0109 \\
0.0099 \\
0.009 \\
0.010
\end{tabular} & 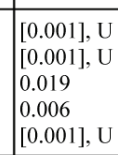 \\
\hline pring 5 & 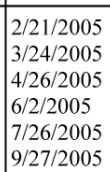 & 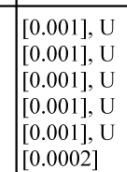 & 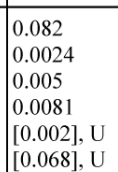 & $\begin{array}{l}0.0013 \\
0.0013 \\
0.0012 \\
0.00112 \\
0.0014 \\
0.0014 \\
10.0061, U\end{array}$ & $\begin{array}{l}0.020 \\
0.019 \\
0.023 \\
0.017 \\
0.019 \\
0.0198\end{array}$ & $\begin{array}{l}0.027 \\
0.022 \\
0.018 \\
0.024 \\
0.030 \\
0.0301 \\
0.0261\end{array}$ & 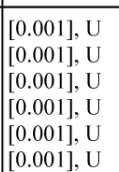 & 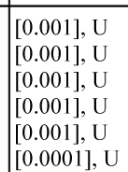 & 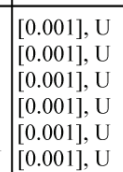 & $\mid \begin{array}{l}0.0057 \\
0.0051 \\
0.00034 \\
0.0044 \\
0.0046 \\
0.0036 \\
0.038\end{array}$ & 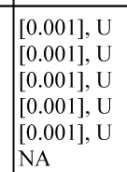 & 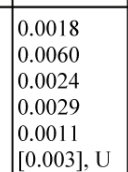 & 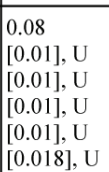 & 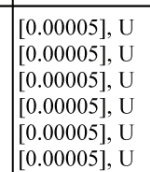 & $\begin{array}{l}0.024 \\
0.024 \\
0.024 \\
0.022 \\
0.023 \\
\text { NA } \\
\text { NA }\end{array}$ & 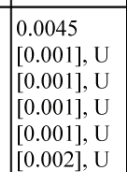 & 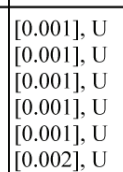 & 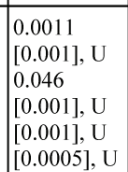 & 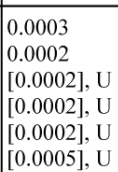 & 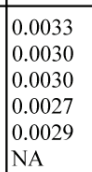 & 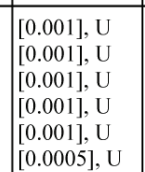 & 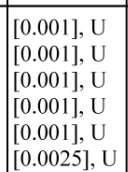 & 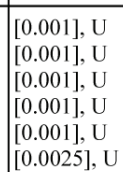 & \begin{tabular}{|l}
0.084 \\
0.0883 \\
0.084 \\
0.092 \\
0.092 \\
0.088 \\
0.086
\end{tabular} & 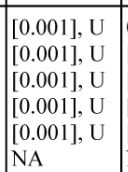 & 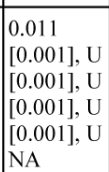 & 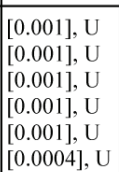 & $\begin{array}{l}0.0009 \\
0.0006 \\
0.0006 \\
0.0005 \\
0.0006 \\
0.0006 \\
0.0055\end{array}$ & $\begin{array}{l}0.011 \\
0.012 \\
0.010 \\
0.1010 \\
0.011 \\
0.01095\end{array}$ & 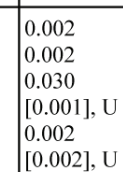 \\
\hline pring 6 & 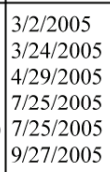 & 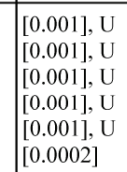 & 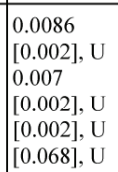 & 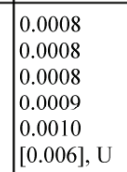 & $\mid \begin{array}{l}0.014 \\
0.015 \\
0.034 \\
0.0313 \\
0.013 \\
0.01414 \\
0.0142\end{array}$ & $\begin{array}{l}0.023 \\
0.0224 \\
0.018 \\
0.023 \\
0.024 \\
0.0246\end{array}$ & 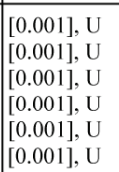 & 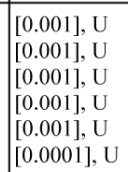 & 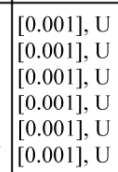 & $\mid \begin{array}{l}0.0042 \\
0.0047 \\
0.00040 \\
0.0035 \\
0.036 \\
0.036 \\
0.0341\end{array}$ & 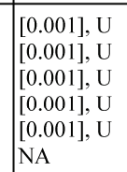 & 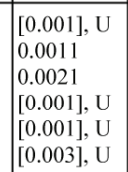 & 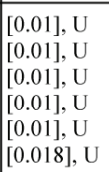 & 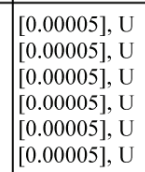 & $\mid \begin{array}{l}0.024 \\
0.024 \\
0.023 \\
0.023 \\
0.023 \\
\text { NA }\end{array}$ & 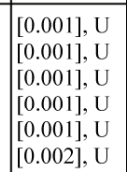 & 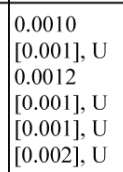 & 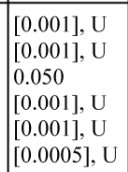 & 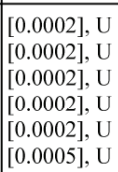 & $\begin{array}{l}0.0030 \\
0.0030 \\
0.03031 \\
0.03029 \\
0.0202\end{array}$ & 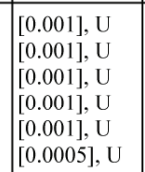 & 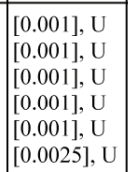 & 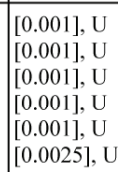 & & 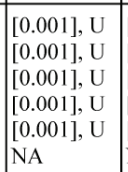 & 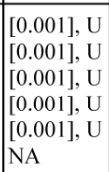 & 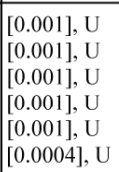 & $\begin{array}{l}0.0003 \\
0.00004 \\
0.0004 \\
0.0004 \\
0.0004 \\
0.00003 \\
0.0003\end{array}$ & \begin{tabular}{|l}
0.008 \\
0.009 \\
0.008 \\
0.007 \\
0.007 \\
0.0073
\end{tabular} & 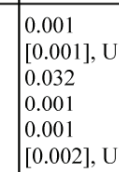 \\
\hline og 9 A & 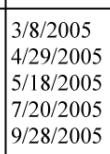 & 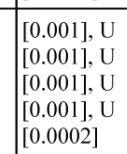 & 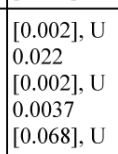 & $\mid \begin{array}{l}0.00101 \\
0.0009 \\
0.0009 \\
0.00010 \\
{[0.006], \text { U }}\end{array}$ & $\begin{array}{l}0.013 \\
0.025 \\
0.012 \\
0.012 \\
0.0114\end{array}$ & $\begin{array}{l}0.014 \\
0.017 \\
0.017 \\
0.0090 \\
0.011 \\
0.01\end{array}$ & 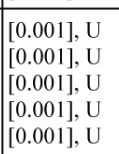 & 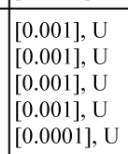 & 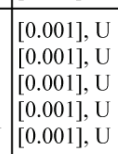 & $\begin{array}{l}0.0029 \\
0.0029 \\
0.0025 \\
00.025 \\
0.0003], 1\end{array}$ & 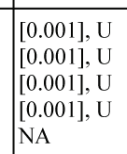 & 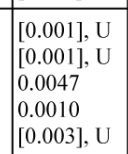 & {$\left[\begin{array}{l}{[0.011], \mathrm{U}} \\
{[0.0 .01], \mathrm{U}}\end{array}\right.$} & 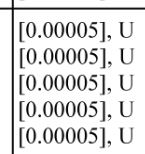 & & 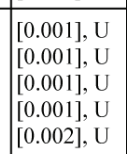 & $\mid \begin{array}{l}0.0013 \\
0.0012 \\
0.0012 \\
0.0012 \\
0.0023\end{array}$ & 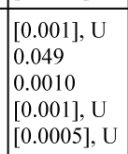 & 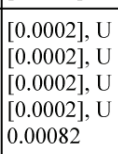 & & 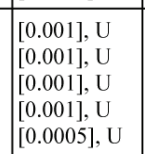 & $\mid[0.0025$ & & & 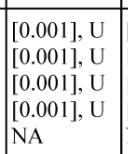 & 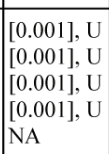 & 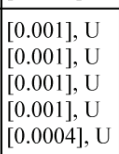 & \begin{tabular}{|l}
0.0003 \\
0.0003 \\
0.0003 \\
0.0003 \\
10.00021. \\
0.00027
\end{tabular} \mid & $\mid \begin{array}{l}0.009 \\
0.008 \\
0.008 \\
0.008 \\
0.0078\end{array}$ & 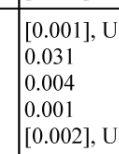 \\
\hline
\end{tabular}


Table 6.2

Summary Results of Trace Elements (Cont.)

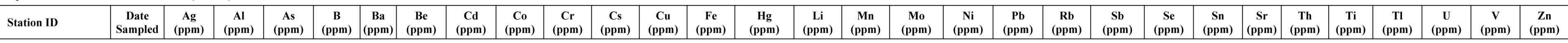

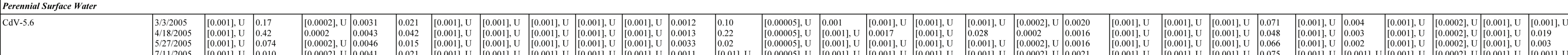

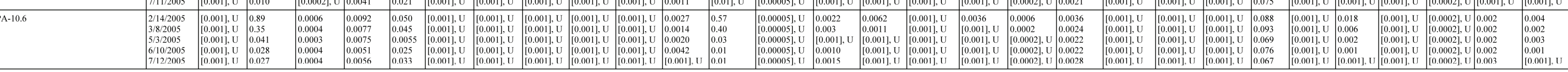
Offitit Reference Perched Volcanics, South Valles Caldera

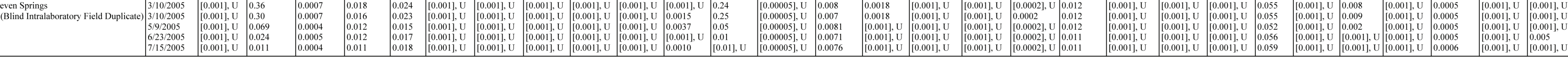

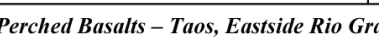

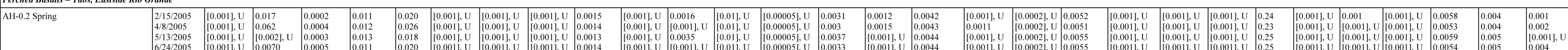

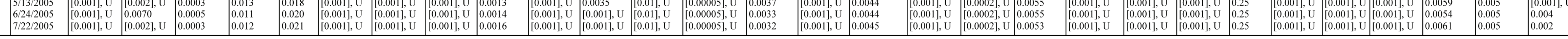
Notes:
NA - Not analyzed.
U - Not detected 
Table 6.3

Summary Results of Stable Isotopes

\begin{tabular}{|c|c|c|c|c|c|}
\hline Station ID & $\begin{array}{c}\text { Date } \\
\text { Sampled }\end{array}$ & $\begin{array}{c}\operatorname{delta}^{2} \mathbf{H} \\
(\%)\end{array}$ & $\begin{array}{l}{ }^{1} \text { Estimated } \\
\text { Recharge } \\
\text { Elevation } \\
\text { d }^{2} \mathbf{H} \\
\text { (ft) }\end{array}$ & $\begin{array}{c}\text { delta }{ }^{18} \mathrm{O} \\
(\% \circ)\end{array}$ & $\begin{array}{l}{ }^{1} \text { Estimated } \\
\text { Recharge } \\
\text { Elevation } \\
\text { d }^{18} \mathrm{O} \\
\text { (ft) }\end{array}$ \\
\hline \multicolumn{6}{|l|}{ Sierra de los Valles } \\
\hline \multicolumn{6}{|l|}{ Perched Volcanics } \\
\hline AL-10.6 Spring & $\begin{array}{l}5 / 12 / 2005 \\
6 / 15 / 2005 \\
7 / 13 / 2005\end{array}$ & $\begin{array}{l}-85.18 \\
-83.80 \\
-83.61\end{array}$ & $\begin{array}{l}8760 \\
8556 \\
8528\end{array}$ & $\begin{array}{l}-12.00 \\
-11.93 \\
-11.83\end{array}$ & $\begin{array}{l}8551 \\
8479 \\
8376\end{array}$ \\
\hline Barbara Spring & $\begin{array}{l}3 / 29 / 2005 \\
5 / 12 / 2005 \\
6 / 15 / 2005 \\
7 / 13 / 2005\end{array}$ & $\begin{array}{l}-81.76 \\
-83.69 \\
-83.58 \\
-83.02\end{array}$ & $\begin{array}{l}8256 \\
8540 \\
8524 \\
8441\end{array}$ & $\begin{array}{l}-11.77 \\
-11.94 \\
-11.90 \\
-11.70\end{array}$ & $\begin{array}{l}8318 \\
8489 \\
8448 \\
8242\end{array}$ \\
\hline Campsite Springs & $\begin{array}{l}5 / 17 / 2005 \\
6 / 8 / 2005 \\
7 / 14 / 2005\end{array}$ & $\begin{array}{l}-84.40 \\
-82.69 \\
-83.23\end{array}$ & $\begin{array}{l}8645 \\
8393 \\
8472\end{array}$ & $\begin{array}{l}-11.84 \\
-11.94 \\
-11.88\end{array}$ & $\begin{array}{l}8386 \\
8489 \\
8427 \\
\end{array}$ \\
\hline CdV-5.0 Spring & $\begin{array}{l}3 / 3 / 2005 \\
4 / 18 / 2005 \\
5 / 27 / 2005 \\
7 / 11 / 2005\end{array}$ & $\begin{array}{l}-83.76 \\
-85.78 \\
-85.14 \\
-83.73\end{array}$ & $\begin{array}{l}8550 \\
8848 \\
8754 \\
8546\end{array}$ & $\begin{array}{l}-11.79 \\
-12.29 \\
-12.23 \\
-12.05\end{array}$ & $\begin{array}{l}8337 \\
8850 \\
8788 \\
8602\end{array}$ \\
\hline PC Spring & $\begin{array}{l}3 / 30 / 2005 \\
5 / 3 / 2005 \\
6 / 10 / 2005 \\
7 / 12 / 2005\end{array}$ & $\begin{array}{l}-86.29 \\
-84.53 \\
-88.42 \\
-88.56\end{array}$ & $\begin{array}{l}8923 \\
8664 \\
9237 \\
9257\end{array}$ & $\begin{array}{l}-12.24 \\
-11.78 \\
-12.68 \\
-12.42\end{array}$ & $\begin{array}{l}8800 \\
8324 \\
9251 \\
8984\end{array}$ \\
\hline $\begin{array}{l}\text { Water Canyon Gallery Spring } \\
\text { (Blind Intralaboratory Field Duplicate) }\end{array}$ & $\begin{array}{l}3 / 4 / 2005 \\
4 / 18 / 2005 \\
5 / 27 / 2005 \\
7 / 11 / 2005 \\
7 / 11 / 2005 \\
9 / 23 / 2005\end{array}$ & $\begin{array}{l}-87.31 \\
-86.21 \\
-85.34 \\
-84.49 \\
-84.40 \\
-83.72\end{array}$ & $\begin{array}{l}9073 \\
8911 \\
8783 \\
8658 \\
8645 \\
8544\end{array}$ & $\begin{array}{l}-12.17 \\
-11.99 \\
-12.11 \\
-12.00 \\
-12.17 \\
-12.47\end{array}$ & $\begin{array}{l}8728 \\
8541 \\
8664 \\
8551 \\
8726 \\
9035\end{array}$ \\
\hline Young Spring & $\begin{array}{l}3 / 23 / 2005 \\
5 / 5 / 2005 \\
6 / 16 / 2005 \\
7 / 12 / 2005\end{array}$ & $\begin{array}{l}-82.81 \\
-86.25 \\
-85.14 \\
-85.25\end{array}$ & $\begin{array}{l}8410 \\
8917 \\
8754 \\
8770\end{array}$ & $\begin{array}{l}-11.93 \\
-11.72 \\
-12.25 \\
-12.07\end{array}$ & $\begin{array}{l}8483 \\
8263 \\
8808 \\
8623\end{array}$ \\
\hline Pajarito Ski Well \#2 & $\begin{array}{l}3 / 2 / 2005 \\
8 / 31 / 2005 \\
1 / 12 / 2006\end{array}$ & $\begin{array}{l}-87.49 \\
-87.73 \\
-87.81\end{array}$ & $\begin{array}{l}9100 \\
9135 \\
9147\end{array}$ & $\begin{array}{l}-12.18 \\
-13.07 \\
-12.48\end{array}$ & $\begin{array}{l}8736 \\
9653 \\
9045\end{array}$ \\
\hline \multicolumn{6}{|l|}{ Pajarito Plateau } \\
\hline \multicolumn{6}{|l|}{ Perched Alluvial } \\
\hline LAO-B & $\begin{array}{l}3 / 3 / 2005 \\
5 / 10 / 2005 \\
8 / 17 / 2005\end{array}$ & $\begin{array}{l}-86.65 \\
-85.74 \\
-80.08\end{array}$ & $\begin{array}{l}8976 \\
8842 \\
8008\end{array}$ & $\begin{array}{l}-11.97 \\
-11.89 \\
-11.84\end{array}$ & $\begin{array}{l}8519 \\
8438 \\
8386\end{array}$ \\
\hline \multicolumn{6}{|l|}{ Perched Volcanics at Surface } \\
\hline Homestead Spring & $\begin{array}{l}3 / 31 / 2005 \\
5 / 9 / 2005 \\
7 / 18 / 2005\end{array}$ & $\begin{array}{l}-91.84 \\
-86.91 \\
-84.45\end{array}$ & $\begin{array}{l}9740 \\
9014 \\
8652\end{array}$ & $\begin{array}{l}-12.44 \\
-11.49 \\
-12.14\end{array}$ & $\begin{array}{l}9004 \\
8026 \\
8695\end{array}$ \\
\hline $\begin{array}{l}\text { Starmer Spring } \\
\text { (Blind Intralaboratory Field Duplicate) }\end{array}$ & $\begin{array}{l}3 / 31 / 2005 \\
5 / 9 / 2005 \\
7 / 18 / 2005 \\
7 / 18 / 2005\end{array}$ & $\begin{array}{l}-89.91 \\
-86.02 \\
-83.87 \\
-84.29\end{array}$ & $\begin{array}{l}9456 \\
8883 \\
8567 \\
8628\end{array}$ & $\begin{array}{l}-12.37 \\
-11.28 \\
-12.16 \\
-12.20\end{array}$ & $\begin{array}{l}8937 \\
7809 \\
8716 \\
8757\end{array}$ \\
\hline
\end{tabular}


Table 6.3

Summary Results of Stable Isotopes (Cont.)

\begin{tabular}{|c|c|c|c|c|c|}
\hline Station ID & $\begin{array}{c}\text { Date } \\
\text { Sampled }\end{array}$ & $\begin{array}{c}\text { delta }^{2} H \\
(\% 0)\end{array}$ & $\begin{array}{l}{ }^{1} \text { Estimated } \\
\text { Recharge } \\
\text { Elevation } \\
\mathbf{d}^{2} \mathbf{H} \\
\text { (ft) }\end{array}$ & $\begin{array}{c}\text { delta }^{18} \mathrm{O} \\
(\%)\end{array}$ & $\begin{array}{l}{ }^{1} \text { Estimated } \\
\text { Recharge } \\
\text { Elevation } \\
\text { d }^{18} \mathrm{O} \\
\text { (ft) }\end{array}$ \\
\hline $\begin{array}{l}\text { Bulldog Spring } \\
\qquad \text { (Blind IntralaboratoryField Duplicate) }\end{array}$ & $\begin{array}{l}3 / 31 / 2005 \\
3 / 31 / 2005 \\
5 / 9 / 2005 \\
6 / 22 / 2005 \\
7 / 18 / 2005\end{array}$ & $\begin{array}{l}-88.72 \\
-89.22 \\
-84.10 \\
-84.29 \\
-83.00\end{array}$ & $\begin{array}{l}9281 \\
9354 \\
8600 \\
8628 \\
8438\end{array}$ & $\begin{array}{l}-12.25 \\
-12.27 \\
-11.15 \\
-12.00 \\
-11.52\end{array}$ & $\begin{array}{l}8807 \\
8828 \\
7676 \\
8551 \\
8057\end{array}$ \\
\hline $\begin{array}{l}\text { Burning Ground Spring } \\
\quad \text { (Blind Intralaboratory Field Duplicate) }\end{array}$ & $\begin{array}{l}4 / 1 / 2005 \\
4 / 1 / 2005 \\
5 / 13 / 2005 \\
7 / 19 / 2005\end{array}$ & $\begin{array}{l}-90.00 \\
-90.61 \\
-83.49 \\
-83.56\end{array}$ & $\begin{array}{l}9470 \\
9560 \\
8511 \\
8521\end{array}$ & $\begin{array}{l}-12.44 \\
-12.38 \\
-11.47 \\
-11.86\end{array}$ & $\begin{array}{l}9004 \\
8941 \\
8005 \\
8407\end{array}$ \\
\hline Martin Spring & $\begin{array}{l}4 / 6 / 2005 \\
5 / 9 / 2005\end{array}$ & $\begin{array}{l}-95.17 \\
-86.69\end{array}$ & $\begin{array}{r}10231 \\
8982\end{array}$ & $\begin{array}{l}-12.86 \\
-11.09\end{array}$ & $\begin{array}{l}9437 \\
7614\end{array}$ \\
\hline $\begin{array}{l}\text { TA-18 Spring } \\
\text { (Blind Intralaboratory Field Duplicate) }\end{array}$ & $\begin{array}{l}3 / 18 / 2005 \\
5 / 9 / 2005 \\
6 / 22 / 2005 \\
8 / 1 / 2005 \\
8 / 1 / 2005\end{array}$ & $\begin{array}{l}-93.82 \\
-91.95 \\
-90.80 \\
-88.44 \\
-88.65\end{array}$ & $\begin{array}{r}10032 \\
9757 \\
9587 \\
9240 \\
9271\end{array}$ & $\begin{array}{l}-12.97 \\
-12.30 \\
-12.74 \\
-12.25 \\
-13.44\end{array}$ & $\begin{array}{r}9554 \\
8860 \\
9313 \\
8808 \\
10034\end{array}$ \\
\hline \multicolumn{6}{|c|}{ Intermediate at Depth, Volcanics and Sediments } \\
\hline LAOI(A)-1.1 & $3 / 4 / 2005$ & -80.63 & 8089 & -11.14 & 7665 \\
\hline MCOBT-4.4 & $3 / 29 / 2005$ & -75.82 & 7381 & -10.66 & 7176 \\
\hline MCOI-6 & $9 / 1 / 2005$ & -74.92 & 7248 & -10.89 & 7408 \\
\hline POI-4 & $\begin{array}{l}3 / 8 / 2005 \\
8 / 3 / 2005\end{array}$ & $\begin{array}{r}-76.28 \\
-74.65\end{array}$ & $\begin{array}{l}7448 \\
7209\end{array}$ & $\begin{array}{l}-10.41 \\
-10.81\end{array}$ & $\begin{array}{l}6914 \\
7325\end{array}$ \\
\hline R-6i & $\begin{array}{l}8 / 24 / 2005 \\
8 / 24 / 2005\end{array}$ & $\begin{array}{r}-79.27 \\
-79.32 \\
\end{array}$ & $\begin{array}{l}7889 \\
7896\end{array}$ & $\begin{array}{l}-11.62 \\
-11.41 \\
\end{array}$ & $\begin{array}{l}8160 \\
7943\end{array}$ \\
\hline TW-1A & $\begin{array}{l}3 / 24 / 2005 \\
8 / 18 / 2005\end{array}$ & $\begin{array}{l}-75.74 \\
-75.39 \\
\end{array}$ & $\begin{array}{l}7369 \\
7318\end{array}$ & $\begin{array}{l}-10.59 \\
-10.82 \\
\end{array}$ & $\begin{array}{l}7103 \\
7336\end{array}$ \\
\hline \multicolumn{6}{|l|}{ Regional Aquifer Wells } \\
\hline R-1 & $\begin{array}{l}5 / 19 / 2005 \\
9 / 12 / 2005\end{array}$ & $\begin{array}{l}-76.37 \\
-75.86 \\
\end{array}$ & $\begin{array}{l}7462 \\
7387 \\
\end{array}$ & $\begin{array}{l}-10.71 \\
-10.51 \\
\end{array}$ & $\begin{array}{l}7222 \\
7016\end{array}$ \\
\hline $\mathrm{R}-2$ & $\begin{array}{l}4 / 26 / 2005 \\
4 / 26 / 2005 \\
8 / 9 / 2005 \\
8 / 9 / 2005 \\
2 / 27 / 2006\end{array}$ & $\begin{array}{l}-75.06 \\
-76.09 \\
-74.76 \\
-74.87 \\
-75.58\end{array}$ & $\begin{array}{l}7269 \\
7421 \\
7225 \\
7241 \\
7346\end{array}$ & $\begin{array}{l}-10.91 \\
-10.95 \\
-10.84 \\
-10.71 \\
-10.64\end{array}$ & $\begin{array}{l}7428 \\
7470 \\
7356 \\
7222 \\
7150\end{array}$ \\
\hline R-4 (Blind Intralaboratory Field Duplicate) & $\begin{array}{l}4 / 27 / 2005 \\
4 / 27 / 2005 \\
8 / 8 / 2005 \\
8 / 8 / 2005\end{array}$ & $\begin{array}{l}-72.85 \\
-72.19 \\
-72.31 \\
-72.22\end{array}$ & $\begin{array}{l}6944 \\
6846 \\
6864 \\
6851 \\
\end{array}$ & $\begin{array}{l}-10.34 \\
-10.38 \\
-10.54 \\
-10.52 \\
\end{array}$ & $\begin{array}{l}6841 \\
6882 \\
7047 \\
7027 \\
\end{array}$ \\
\hline R-6 & $8 / 23 / 2005$ & -72.46 & 6886 & -10.42 & 6924 \\
\hline $\begin{array}{l}\text { R-9 } \\
\text { (Blind Intralaboratory Field Duplicate) } \\
\text { (Blind Intralaboratory Field Duplicate) }\end{array}$ & $\begin{array}{l}3 / 19 / 2005 \\
4 / 6 / 2005 \\
4 / 6 / 2005 \\
8 / 16 / 2005 \\
8 / 16 / 2005\end{array}$ & $\begin{array}{l}-74.41 \\
-75.91 \\
-76.10 \\
-74.25 \\
-73.35 \\
\end{array}$ & $\begin{array}{l}7173 \\
7394 \\
7422 \\
7150 \\
7017 \\
\end{array}$ & $\begin{array}{l}-10.34 \\
-10.28 \\
-10.36 \\
-10.72 \\
-10.95 \\
\end{array}$ & $\begin{array}{l}6843 \\
6779 \\
6862 \\
7233 \\
7470 \\
\end{array}$ \\
\hline $\mathrm{R}-11$ & $\begin{array}{l}5 / 17 / 2005 \\
8 / 3 / 2005 \\
8 / 3 / 2005 \\
8 / 3 / 2005\end{array}$ & $\begin{array}{l}-74.72 \\
-73.55 \\
-73.44 \\
-73.26\end{array}$ & $\begin{array}{l}7119 \\
7047 \\
7031 \\
7004\end{array}$ & $\begin{array}{r}-9.33 \\
-10.49 \\
-10.37 \\
-10.42\end{array}$ & $\begin{array}{l}5801 \\
6996 \\
6872 \\
6924\end{array}$ \\
\hline
\end{tabular}


Table 6.3

Summary Results of Stable Isotopes (Cont.)

\begin{tabular}{|c|c|c|c|c|c|}
\hline Station ID & $\begin{array}{c}\text { Date } \\
\text { Sampled }\end{array}$ & $\begin{array}{c}\operatorname{delta}^{2} H \\
(\% 0)\end{array}$ & $\begin{array}{l}{ }^{1} \text { Estimated } \\
\text { Recharge } \\
\text { Elevation } \\
\text { d }^{\mathbf{2}} \mathbf{H} \\
\text { (ft) }\end{array}$ & $\underset{(\%)}{\text { delta }}{ }^{18} \mathrm{O}$ & $\begin{array}{l}{ }^{1} \text { Estimated } \\
\text { Recharge } \\
\text { Elevation } \\
\text { d }^{18} \mathrm{O} \\
\text { (ft) }\end{array}$ \\
\hline R-13 (Blind Intralaboratory Field Duplicate) & $\begin{array}{l}3 / 10 / 2005 \\
3 / 10 / 2005 \\
9 / 1 / 2005 \\
2 / 2 / 2006\end{array}$ & $\begin{array}{l}-77.65 \\
-78.85 \\
-78.16 \\
-77.68\end{array}$ & $\begin{array}{l}7651 \\
7828 \\
7726 \\
7655\end{array}$ & $\begin{array}{l}-11.06 \\
-10.88 \\
-11.41 \\
-11.10\end{array}$ & $\begin{array}{l}7586 \\
7396 \\
7943 \\
7624\end{array}$ \\
\hline $\begin{array}{l}\text { R-15 } \\
\text { (Blind Intralaboratory Field Duplicate) }\end{array}$ & $\begin{array}{l}3 / 9 / 2005 \\
5 / 25 / 2005 \\
8 / 31 / 2005 \\
8 / 31 / 2005\end{array}$ & $\begin{array}{l}-79.39 \\
-80.71 \\
-78.70 \\
-79.56\end{array}$ & $\begin{array}{l}7907 \\
8101 \\
7805 \\
7932\end{array}$ & $\begin{array}{l}-10.98 \\
-11.11 \\
-11.36 \\
-11.61\end{array}$ & $\begin{array}{l}7498 \\
7634 \\
7892 \\
8149\end{array}$ \\
\hline $\mathrm{R}-18$ & $\begin{array}{l}8 / 25 / 2005 \\
12 / 1 / 2005\end{array}$ & $\begin{array}{l}-84.39 \\
-85.13\end{array}$ & $\begin{array}{l}8643 \\
8752\end{array}$ & $\begin{array}{l}-11.95 \\
-11.93\end{array}$ & $\begin{array}{l}8499 \\
8479\end{array}$ \\
\hline $\mathrm{R}-23$ & $\begin{array}{l}7 / 14 / 2005 \\
8 / 15 / 2005\end{array}$ & $\begin{array}{l}-76.86 \\
-77.05\end{array}$ & $\begin{array}{l}7534 \\
7562\end{array}$ & $\begin{array}{l}-10.89 \\
-10.71\end{array}$ & $\begin{array}{l}7408 \\
7222\end{array}$ \\
\hline $\mathrm{R}-28$ & $\begin{array}{l}5 / 20 / 2005 \\
9 / 1 / 2005 \\
11 / 10 / 2005 \\
1 / 26 / 2006\end{array}$ & $\begin{array}{l}-72.32 \\
-72.29 \\
-71.70 \\
-71.86 \\
\end{array}$ & $\begin{array}{l}6866 \\
6861 \\
6774 \\
6798 \\
\end{array}$ & $\begin{array}{l}-10.26 \\
-10.11 \\
-10.16 \\
-10.12 \\
\end{array}$ & $\begin{array}{l}6759 \\
6604 \\
6656 \\
6615 \\
\end{array}$ \\
\hline TW-1 & $\begin{array}{l}3 / 23 / 2005 \\
5 / 4 / 2005 \\
8 / 17 / 2005\end{array}$ & $\begin{array}{l}-76.59 \\
-74.55 \\
-76.74 \\
\end{array}$ & $\begin{array}{l}7494 \\
7194 \\
7517\end{array}$ & $\begin{array}{r}-10.69 \\
-9.87 \\
-10.83 \\
\end{array}$ & $\begin{array}{l}7201 \\
6357 \\
7346\end{array}$ \\
\hline TW-2 & $3 / 22 / 2005$ & -74.47 & 7182 & -10.80 & 7318 \\
\hline $\begin{array}{l}\text { TW }-3 \\
\text { (Blind Intralaboratory Field Duplicate) }\end{array}$ & $\begin{array}{l}3 / 21 / 2005 \\
4 / 6 / 2005 \\
8 / 11 / 2005 \\
8 / 11 / 2005\end{array}$ & $\begin{array}{l}-74.51 \\
-76.33 \\
-74.02 \\
-74.15\end{array}$ & $\begin{array}{l}7188 \\
7456 \\
7116 \\
7135\end{array}$ & $\begin{array}{l}-10.32 \\
-10.38 \\
-11.93 \\
-11.00\end{array}$ & $\begin{array}{l}6819 \\
6882 \\
8479 \\
7521\end{array}$ \\
\hline TW-8 & $\begin{array}{l}3 / 28 / 2005 \\
10 / 3 / 2005\end{array}$ & $\begin{array}{l}-71.16 \\
-75.32\end{array}$ & $\begin{array}{l}6695 \\
7307\end{array}$ & $\begin{array}{l}-10.38 \\
-10.49\end{array}$ & $\begin{array}{l}6882 \\
6996\end{array}$ \\
\hline \multicolumn{6}{|l|}{ Regional Aquifer Production Well } \\
\hline $\begin{array}{l}\text { O-1 } \\
\text { (Blind Intralaboratory Field Duplicate) } \\
\text { (Blind Intralaboratory Field Duplicate) }\end{array}$ & $\begin{array}{l}3 / 23 / 2005 \\
3 / 23 / 2005 \\
5 / 18 / 2005 \\
8 / 17 / 2005 \\
8 / 17 / 2005\end{array}$ & $\begin{array}{l}-76.55 \\
-77.83 \\
-80.20 \\
-77.82 \\
-77.04\end{array}$ & $\begin{array}{l}7489 \\
7677 \\
8026 \\
7676 \\
7561\end{array}$ & $\begin{array}{l}-11.18 \\
-11.27 \\
-10.13 \\
-11.37 \\
-11.32\end{array}$ & $\begin{array}{l}7707 \\
7799 \\
6625 \\
7902 \\
7851\end{array}$ \\
\hline \multicolumn{6}{|l|}{ White Rock Canyon Springs } \\
\hline Spring 2B & $\begin{array}{l}3 / 9 / 2005 \\
7 / 21 / 2005\end{array}$ & $\begin{array}{l}-73.58 \\
-73.32 \\
\end{array}$ & $\begin{array}{l}7051 \\
7013 \\
\end{array}$ & $\begin{array}{r}-9.97 \\
-10.46 \\
\end{array}$ & $\begin{array}{l}6463 \\
6965 \\
\end{array}$ \\
\hline $\begin{array}{l}\text { Spring } 3 \\
\quad \text { (Blind Intralaboratory Field Duplicate) }\end{array}$ & $\begin{array}{l}3 / 9 / 2005 \\
3 / 9 / 2005 \\
4 / 20 / 2005 \\
5 / 16 / 2005 \\
7 / 21 / 2005 \\
9 / 26 / 2005\end{array}$ & $\begin{array}{l}-77.09 \\
-77.34 \\
-76.28 \\
-76.53 \\
-75.92 \\
-76.64\end{array}$ & $\begin{array}{l}7568 \\
7605 \\
7449 \\
7486 \\
7396 \\
7502\end{array}$ & $\begin{array}{l}-10.37 \\
-10.63 \\
-10.81 \\
-10.70 \\
-10.87 \\
-11.32\end{array}$ & $\begin{array}{l}6874 \\
7139 \\
7325 \\
7212 \\
7387 \\
7851\end{array}$ \\
\hline Spring $3 \mathrm{~A}$ & $\begin{array}{l}3 / 9 / 2005 \\
4 / 15 / 2005 \\
4 / 20 / 2005 \\
5 / 16 / 2005 \\
7 / 21 / 2005 \\
9 / 26 / 2005\end{array}$ & $\begin{array}{l}-76.09 \\
-77.24 \\
-76.20 \\
-77.88 \\
-75.98 \\
-76.74 \\
\end{array}$ & $\begin{array}{l}7421 \\
7590 \\
7437 \\
7684 \\
7405 \\
7517 \\
\end{array}$ & $\begin{array}{l}-10.45 \\
-10.66 \\
-10.62 \\
-10.72 \\
-10.57 \\
-10.88\end{array}$ & $\begin{array}{l}6959 \\
7171 \\
7130 \\
7233 \\
7078 \\
7397 \\
\end{array}$ \\
\hline Spring $3 \mathrm{C}$ & $3 / 11 / 2005$ & -77.27 & 7594 & -10.49 & 6992 \\
\hline
\end{tabular}


Table 6.3

Summary Results of Stable Isotopes (Cont.)

\begin{tabular}{|c|c|c|c|c|c|}
\hline Station ID & $\begin{array}{c}\text { Date } \\
\text { Sampled }\end{array}$ & $\begin{array}{c}\operatorname{delta}^{2} \mathbf{H} \\
(\% 0)\end{array}$ & $\begin{array}{l}{ }^{1} \text { Estimated } \\
\text { Recharge } \\
\text { Elevation } \\
\text { d }^{2} \mathbf{H} \\
\text { (ft) }\end{array}$ & $\begin{array}{l}\text { delta } \\
(\%)\end{array}$ & $\begin{array}{l}{ }^{1} \text { Estimated } \\
\text { Recharge } \\
\text { Elevation } \\
\text { d }^{18} \mathbf{O} \\
\quad \text { (ft) }\end{array}$ \\
\hline Spring 4 & $\begin{array}{l}2 / 21 / 2005 \\
3 / 11 / 2005 \\
4 / 22 / 2005 \\
7 / 27 / 2005 \\
9 / 26 / 2005\end{array}$ & $\begin{array}{l}-77.50 \\
-77.59 \\
-77.23 \\
-76.46 \\
-77.11\end{array}$ & $\begin{array}{l}7628 \\
7642 \\
7589 \\
7475 \\
7571\end{array}$ & $\begin{array}{l}-10.66 \\
-10.82 \\
-10.87 \\
-10.66 \\
-11.11\end{array}$ & $\begin{array}{l}7171 \\
7337 \\
7387 \\
7171 \\
7634\end{array}$ \\
\hline Spring $4 \mathrm{~A}$ & $\begin{array}{l}2 / 22 / 2005 \\
3 / 22 / 2005 \\
4 / 26 / 2005 \\
5 / 16 / 2005 \\
7 / 28 / 2005 \\
9 / 27 / 2005\end{array}$ & $\begin{array}{l}-75.20 \\
-73.98 \\
-74.92 \\
-76.16 \\
-74.13 \\
-75.21\end{array}$ & $\begin{array}{l}7290 \\
7110 \\
7248 \\
7431 \\
7132 \\
7291\end{array}$ & $\begin{array}{l}-10.38 \\
-10.53 \\
-10.72 \\
-10.67 \\
-10.72 \\
-10.77\end{array}$ & $\begin{array}{l}6882 \\
7040 \\
7233 \\
7181 \\
7233 \\
7284\end{array}$ \\
\hline $\begin{array}{l}\text { Spring 4AA } \\
\quad \text { (Blind Intralaboratory Field Duplicate) }\end{array}$ & $\begin{array}{l}3 / 22 / 2005 \\
3 / 22 / 2005 \\
4 / 26 / 2005 \\
5 / 16 / 2005 \\
7 / 26 / 2005 \\
9 / 27 / 2005\end{array}$ & $\begin{array}{l}-74.16 \\
-74.54 \\
-74.72 \\
-74.46 \\
-74.99 \\
-75.24\end{array}$ & $\begin{array}{l}7137 \\
7193 \\
7219 \\
7181 \\
7259 \\
7296\end{array}$ & $\begin{array}{l}-10.58 \\
-10.66 \\
-10.55 \\
-10.62 \\
-10.77 \\
-10.69\end{array}$ & $\begin{array}{l}7088 \\
7167 \\
7058 \\
7130 \\
7284 \\
7202\end{array}$ \\
\hline $\begin{array}{l}\text { Spring } 4 \mathrm{~B} \\
\text { (Blind Intralaboratory Field Duplicate) }\end{array}$ & $\begin{array}{l}3 / 22 / 2005 \\
4 / 22 / 2005 \\
5 / 20 / 2005 \\
7 / 27 / 2005 \\
7 / 27 / 2005\end{array}$ & $\begin{array}{l}-76.40 \\
-76.99 \\
-76.88 \\
-77.63 \\
-76.30\end{array}$ & $\begin{array}{l}7466 \\
7553 \\
7537 \\
7648 \\
7452\end{array}$ & $\begin{array}{l}-10.84 \\
-10.69 \\
-10.70 \\
-10.65 \\
-10.82\end{array}$ & $\begin{array}{l}7361 \\
7202 \\
7212 \\
7161 \\
7336\end{array}$ \\
\hline Spring $4 \mathrm{C}$ & $\begin{array}{l}2 / 21 / 2005 \\
3 / 11 / 2005 \\
4 / 22 / 2005 \\
5 / 20 / 2005 \\
7 / 27 / 2005\end{array}$ & $\begin{array}{l}-76.70 \\
-76.80 \\
-77.94 \\
-79.54 \\
-77.09\end{array}$ & $\begin{array}{l}7511 \\
7525 \\
7693 \\
7929 \\
7568\end{array}$ & $\begin{array}{l}-10.62 \\
-10.69 \\
-10.94 \\
-10.73 \\
-10.91\end{array}$ & $\begin{array}{l}7130 \\
7206 \\
7459 \\
7243 \\
7428\end{array}$ \\
\hline Spring 5 & $\begin{array}{l}2 / 21 / 2005 \\
3 / 24 / 2005 \\
4 / 26 / 2005 \\
6 / 2 / 2005 \\
7 / 26 / 2005 \\
9 / 27 / 2005\end{array}$ & $\begin{array}{l}-76.32 \\
-75.64 \\
-76.22 \\
-76.03 \\
-75.73 \\
-75.85\end{array}$ & $\begin{array}{l}7455 \\
7355 \\
7440 \\
7412 \\
7368 \\
7385\end{array}$ & $\begin{array}{l}-10.65 \\
-10.69 \\
-10.69 \\
-10.72 \\
-10.70 \\
-10.69\end{array}$ & $\begin{array}{l}7161 \\
7199 \\
7202 \\
7233 \\
7212 \\
7202\end{array}$ \\
\hline $\begin{array}{l}\text { Spring } 6 \\
\text { (Blind Intralaboratory Field Duplicate) }\end{array}$ & $\begin{array}{l}3 / 2 / 2005 \\
3 / 24 / 2005 \\
4 / 29 / 2005 \\
7 / 25 / 2005 \\
7 / 25 / 2005 \\
9 / 27 / 2005\end{array}$ & $\begin{array}{l}-76.89 \\
-75.57 \\
-75.93 \\
-74.45 \\
-75.89 \\
-76.36\end{array}$ & $\begin{array}{l}7539 \\
7344 \\
7397 \\
7179 \\
7391 \\
7461\end{array}$ & $\begin{array}{l}-10.84 \\
-11.01 \\
-11.07 \\
-11.20 \\
-11.54 \\
-10.91\end{array}$ & $\begin{array}{l}7356 \\
7533 \\
7593 \\
7727 \\
8077 \\
7428\end{array}$ \\
\hline Spring 9A & $\begin{array}{l}3 / 8 / 2005 \\
4 / 29 / 2005 \\
5 / 18 / 2005 \\
7 / 20 / 2005 \\
9 / 28 / 2005\end{array}$ & $\begin{array}{l}-79.76 \\
-79.66 \\
-78.61 \\
-78.04 \\
-79.07\end{array}$ & $\begin{array}{l}7962 \\
7947 \\
7792 \\
7708 \\
7860\end{array}$ & $\begin{array}{l}-10.92 \\
-11.11 \\
-11.39 \\
-11.24 \\
-11.24\end{array}$ & $\begin{array}{l}7438 \\
7634 \\
7923 \\
7768 \\
7768\end{array}$ \\
\hline \multicolumn{6}{|c|}{ Perennial Surface Water West of Pajarito Fault Zone } \\
\hline $\mathrm{CdV}-5.6$ & $\begin{array}{l}3 / 3 / 2005 \\
4 / 18 / 2005 \\
5 / 27 / 2005 \\
7 / 11 / 2005\end{array}$ & $\begin{array}{l}-82.59 \\
-86.33 \\
-84.43 \\
-84.91\end{array}$ & $\begin{array}{l}8378 \\
8929 \\
8649 \\
8720\end{array}$ & $\begin{array}{l}-11.77 \\
-12.48 \\
-12.36 \\
-12.23\end{array}$ & $\begin{array}{l}8314 \\
9045 \\
8922 \\
8788\end{array}$ \\
\hline
\end{tabular}


Table 6.3

Summary Results of Stable Isotopes (Cont.)

\begin{tabular}{|c|c|c|c|c|c|}
\hline Station ID & $\begin{array}{c}\text { Date } \\
\text { Sampled }\end{array}$ & $\begin{array}{c}\text { delta }^{2} H \\
(\% 0)\end{array}$ & $\begin{array}{c}{ }^{1} \text { Estimated } \\
\text { Recharge } \\
\text { Elevation } \\
\text { d }^{2} \mathbf{H} \\
\text { (ft) }\end{array}$ & $\begin{array}{c}\text { delta } \\
(\% 0)\end{array}$ & $\begin{array}{c}{ }^{1} \text { Estimated } \\
\text { Recharge } \\
\text { Elevation } \\
\text { d }^{18} \mathrm{O} \\
\text { (ft) }\end{array}$ \\
\hline PA-10.6 & $\begin{array}{l}2 / 14 / 2005 \\
3 / 8 / 2005 \\
5 / 3 / 2005 \\
6 / 10 / 2005 \\
7 / 12 / 2005\end{array}$ & $\begin{array}{l}-88.90 \\
-87.38 \\
-86.66 \\
-87.43 \\
-86.79\end{array}$ & $\begin{array}{l}9307 \\
9084 \\
8977 \\
9091 \\
8997\end{array}$ & $\begin{array}{l}-12.44 \\
-11.95 \\
-12.22 \\
-12.50 \\
-12.30\end{array}$ & $\begin{array}{l}9004 \\
8499 \\
8778 \\
9066 \\
8860\end{array}$ \\
\hline \multicolumn{6}{|l|}{ Offsite Reference } \\
\hline \multicolumn{6}{|l|}{ Perched Volcanics, South Valles Caldera } \\
\hline $\begin{array}{l}\text { Seven Springs } \\
\quad \text { (Blind Intralaboratory Field Duplicate) }\end{array}$ & $\begin{array}{l}3 / 10 / 2005 \\
3 / 10 / 2005 \\
5 / 9 / 2005 \\
6 / 23 / 2005 \\
7 / 15 / 2005\end{array}$ & $\begin{array}{l}-98.62 \\
-99.74 \\
-99.88 \\
-97.94 \\
-97.89\end{array}$ & $\begin{array}{l}10739 \\
10904 \\
10924 \\
10639 \\
10631\end{array}$ & $\begin{array}{l}-13.69 \\
-13.69 \\
-13.63 \\
-13.62 \\
-13.33\end{array}$ & $\begin{array}{r}10288 \\
10296 \\
10230 \\
10219 \\
9921\end{array}$ \\
\hline \multicolumn{6}{|l|}{ Perched Basalts - Taos, Eastside Rio Grande } \\
\hline AH-0.2 Spring & $\begin{array}{l}2 / 15 / 2005 \\
4 / 8 / 2005 \\
5 / 13 / 2005 \\
6 / 24 / 2005 \\
7 / 22 / 2005\end{array}$ & $\begin{array}{l}-99.20 \\
-99.67 \\
-99.31 \\
-97.86 \\
-97.64\end{array}$ & $\begin{array}{l}10824 \\
10893 \\
10840 \\
10627 \\
10595\end{array}$ & $\begin{array}{l}-13.52 \\
-13.48 \\
-13.45 \\
-13.53 \\
-13.73\end{array}$ & $\begin{array}{l}10116 \\
10075 \\
10044 \\
10127 \\
10333\end{array}$ \\
\hline
\end{tabular}


T-24 
Table 6.4

Summary Results of Tritium and the Noble Gases Helium-3, Helium-4, and Neon

\begin{tabular}{|c|c|c|c|c|c|c|c|c|c|c|c|c|c|c|}
\hline Station ID & $\begin{array}{c}\text { Date } \\
\text { Sampled }\end{array}$ & $\begin{array}{l}\text { Analytical } \\
\text { Laboratory }\end{array}$ & $\begin{array}{c}\text { Helium } \\
(1 \mathrm{E}-8 \mathrm{cc} / \mathrm{g})\end{array}$ & $\begin{array}{c}\text { Neon } \\
(1 \mathrm{E}-8 \mathrm{8c} / \mathrm{g})\end{array}$ & $\begin{array}{c}\text { Helium } \\
\text { Corrected } \\
(1 \mathrm{E}-8 \mathrm{8cc} / \mathrm{g})\end{array}$ & $\begin{array}{c}\mathrm{DEL}^{4} \mathrm{He} \\
(\%)\end{array}$ & $\begin{array}{l}\text { DEL }^{3} \mathrm{He} \\
(\%)\end{array}$ & $\begin{array}{l}\mathrm{R}(3 / 4) \\
\text { in } \mathrm{Ra}\end{array}$ & $\begin{array}{l}\text { Tritium } \\
\text { (TU) }\end{array}$ & $\begin{array}{c}\text { Uncertainty } \\
( \pm \mathbf{T U})\end{array}$ & $\begin{array}{c}\text { Apparent } \\
{ }^{3} \mathbf{H} /{ }^{3} \mathbf{H e ~ A g e ~} \\
\text { (year) }\end{array}$ & $\begin{array}{c}\text { Uncertainty } \\
\text { (year) }\end{array}$ & $\mid \begin{array}{l}\text { Initial } \\
{ }^{3} \mathrm{H} \text { (TU) }\end{array}$ & QUALITY OF DATA/COMMENTS \\
\hline \multicolumn{15}{|l|}{ Sierra de los Valles } \\
\hline \multicolumn{15}{|l|}{ Perched Volcanics } \\
\hline AL-10.6 Spring & $\begin{array}{l}5 / 12 / 2005 \\
7 / 13 / 2005\end{array}$ & \begin{tabular}{|l} 
Univ. Miami \\
Univ. Miami
\end{tabular} & $\begin{array}{l}5.20 \\
6.54\end{array}$ & $\begin{array}{l}20.82 \\
21.48\end{array}$ & $\begin{array}{l}5.13 \\
6.22\end{array}$ & $\begin{array}{r}8.01 \\
31.56\end{array}$ & $\begin{array}{r}9.76 \\
16.60\end{array}$ & $\begin{array}{l}1.00 \\
0.87\end{array}$ & $\begin{array}{l}3.12 \\
2.10\end{array}$ & $\begin{array}{l}0.13 \\
0.03\end{array}$ & $\begin{array}{l}10.68 \\
19.99\end{array}$ & $\begin{array}{l}1.16 \\
0.87\end{array}$ & $\begin{array}{l}5.70 \\
6.47\end{array}$ & \begin{tabular}{|l|}
$\begin{array}{l}\text { Acceptable } \\
\text { Acceptable }\end{array}$ \\
\end{tabular} \\
\hline Barbara Spring & $\begin{array}{l}\text { 3/29/2005 } \\
7 / 13 / 2005\end{array}$ & $\begin{array}{l}\text { Univ. Miami } \\
\text { Univ. Miami }\end{array}$ & $\begin{array}{l}5.99 \\
5.43\end{array}$ & $\begin{array}{l}19.37 \\
19.22\end{array}$ & $\begin{array}{l}5.94 \\
5.40\end{array}$ & $\begin{array}{l}29.24 \\
17.73\end{array}$ & $\begin{array}{l}7.20 \\
0.33\end{array}$ & $\begin{array}{l}0.82 \\
0.84\end{array}$ & $\begin{array}{l}0.39 \\
0.58\end{array}$ & $\begin{array}{l}0.12 \\
0.01\end{array}$ & $\begin{array}{r}31.05 \\
2.41\end{array}$ & $\begin{array}{l}6.59 \\
6.85\end{array}$ & $\begin{array}{l}2.24 \\
0.66\end{array}$ & \begin{tabular}{|l|} 
Acceptable \\
Acceptable
\end{tabular} \\
\hline Campsite Springs & $\begin{array}{l}5 / 17 / 2005 \\
7 / 14 / 2005\end{array}$ & \begin{tabular}{|l|} 
Univ. Miami \\
Univ. Miami
\end{tabular} & $\begin{array}{l}6.91 \\
7.05\end{array}$ & $\begin{array}{l}21.65 \\
19.39\end{array}$ & $\begin{array}{l}6.23 \\
7.00\end{array}$ & $\begin{array}{l}35.22 \\
52.17\end{array}$ & $\begin{array}{l}21.61 \\
35.02 \\
\end{array}$ & $\begin{array}{l}0.89 \\
0.88\end{array}$ & $\begin{array}{l}1.03 \\
0.56\end{array}$ & $\begin{array}{l}0.15 \\
0.01\end{array}$ & $\begin{array}{l}33.01 \\
50.47\end{array}$ & $\begin{array}{l}2.90 \\
0.81\end{array}$ & $\begin{array}{l}6.61 \\
9.65 \\
\end{array}$ & $\begin{array}{l}\text { Acceptable } \\
\text { Acceptable }\end{array}$ \\
\hline CdV-5.0 Spring & $\begin{array}{l}\text { 3/3/2005 } \\
7 / 11 / 2005\end{array}$ & $\begin{array}{l}\text { Univ. Miami } \\
\text { Univ. Miami }\end{array}$ & $\begin{array}{r}9.58 \\
37.32\end{array}$ & $\begin{array}{l}27.81 \\
69.85\end{array}$ & $\begin{array}{r}7.44 \\
23.05\end{array}$ & $\begin{array}{r}57.36 \\
387.94 \\
\end{array}$ & $\begin{array}{r}65.76 \\
241.22\end{array}$ & $\begin{array}{l}1.04 \\
0.70\end{array}$ & $\begin{array}{l}18.64 \\
27.37\end{array}$ & $\begin{array}{l}0.28 \\
0.16\end{array}$ & $\begin{array}{l}11.65 \\
<62\end{array}$ & $\begin{array}{c}0.26 \\
-\end{array}$ & $\begin{array}{r}35.91 \\
\text { NC }\end{array}$ & $\begin{array}{l}\text { Suspect. Sample may have been contaminated with air bubble(s). } \\
\text { Noble-gas data not acceptable; assumed sample contaminated with/ air bubble(s). }\end{array}$ \\
\hline PC Spring & $\begin{array}{l}3 / 30 / 2005 \\
6 / 29 / 2005 \\
7 / 12 / 2005\end{array}$ & $\begin{array}{l}\text { Univ. Miami } \\
\text { USGS - Denver } \\
\text { Univ. Miami }\end{array}$ & $\begin{array}{l}4.92 \\
3.61 \\
4.83\end{array}$ & $\begin{array}{l}21.23 \\
16.00 \\
20.89\end{array}$ & $\begin{array}{r}4.88 \\
\mathrm{NR} \\
4.82\end{array}$ & $\begin{array}{l}1.57 \\
1.01 \\
0.75\end{array}$ & $\begin{array}{l}3.41 \\
0.00 \\
1.78\end{array}$ & $\begin{array}{l}1.00 \\
1.00 \\
0.99\end{array}$ & $\begin{array}{l}12.45 \\
11.13 \\
21.58 \\
\end{array}$ & $\begin{array}{l}0.19 \\
0.13 \\
0.13\end{array}$ & $\begin{array}{l}1.25 \\
0.71 \\
0.38 \\
\end{array}$ & $\begin{array}{c}0.37 \\
\text { NR } \\
0.22 \\
0\end{array}$ & $\begin{array}{l}13.36 \\
11.58 \\
22.05\end{array}$ & \begin{tabular}{|l} 
Acceptable \\
Acceptable \\
Acceptable
\end{tabular} \\
\hline $\begin{array}{l}\text { Water Canyon Gallery Spring } \\
\text { (Blind Intralaboratory Field Duplicate) }\end{array}$ & $\begin{array}{l}10 / 7 / 2004 \\
3 / 4 / 2005 \\
7 / 11 / 2005 \\
7 / 11 / 2005\end{array}$ & \begin{tabular}{|l|} 
USGS - Denver \\
Univ. Miami \\
Univ. Miami \\
Univ. Miami \\
\end{tabular} & $\begin{array}{r}3.48 \\
5.48 \\
11.23 \\
53.02\end{array}$ & $\begin{array}{l}15.10 \\
20.95 \\
20.51 \\
80.88\end{array}$ & $\begin{array}{r}\mathrm{NR} \\
5.24 \\
11.00 \\
35.39 \\
\end{array}$ & $\begin{array}{r}0.06 \\
11.52 \\
136.25 \\
660.30\end{array}$ & $\begin{array}{r}0.00 \\
8.22 \\
93.63 \\
432.98 \\
\end{array}$ & $\begin{array}{l}1.00 \\
0.96 \\
0.81 \\
0.70\end{array}$ & $\begin{array}{l}2.15 \\
8.03 \\
6.56 \\
6.76\end{array}$ & $\begin{array}{l}0.00 \\
0.21 \\
0.06 \\
0.06\end{array}$ & $\begin{aligned} & 2.28 \\
& 4.20 \\
&<62 \\
&<62\end{aligned}$ & $\begin{array}{l}0.003 \\
0.55 \\
- \\
-\end{array}$ & $\begin{array}{r}2.45 \\
10.17 \\
\mathrm{NC} \\
\mathrm{NC}\end{array}$ & $\begin{array}{l}\text { Acceptable } \\
\text { Acceptable } \\
\text { Acceptable; however, initial }{ }^{3} \mathrm{H} \text { not calculated due to excess }{ }^{4} \mathrm{He} \text {. } \\
\text { Noble-gas data not acceptable; assumed sample contaminated with air bubble(s). }\end{array}$ \\
\hline Young Spring & $\begin{array}{l}3 / 23 / 2005 \\
7 / 1 / 2005 \\
7 / 12 / 2005\end{array}$ & \begin{tabular}{|l|} 
Univ. Miami \\
USGS - Denver \\
Univ. Miami
\end{tabular} & $\begin{array}{l}4.85 \\
\mathrm{NR} \\
5.49\end{array}$ & $\begin{array}{l}19.66 \\
\mathrm{NR} \\
19.59\end{array}$ & $\begin{array}{l}4.82 \\
\mathrm{NR} \\
5.38\end{array}$ & $\begin{array}{c}3.91 \\
\mathrm{NR} \\
17.01\end{array}$ & $\begin{array}{c}1.87 \\
\mathrm{NR} \\
15.03\end{array}$ & $\begin{array}{l}0.96 \\
\text { NR } \\
0.97\end{array}$ & $\begin{array}{l}8.10 \\
7.70 \\
7.72\end{array}$ & $\begin{array}{l}0.22 \\
0.00 \\
0.05\end{array}$ & $\begin{array}{l}1.02 \\
\text { NR } \\
7.16\end{array}$ & $\frac{0.56}{0.43}$ & $\begin{array}{r}8.57 \\
\text { NR } \\
11.55\end{array}$ & $\begin{array}{l}\text { Acceptable } \\
\text { Noble-gas data not acceptable; assumed sample contaminated with air bubble(s). } \\
\text { Acceptable }\end{array}$ \\
\hline Pajarito Ski Well \# 2 & $\begin{array}{l}10 / 6 / 2004 \\
3 / 2 / 2005 \\
8 / 31 / 2005\end{array}$ & \begin{tabular}{|l|} 
USGS - Denver \\
Univ. Miami \\
Univ. Miami \\
\end{tabular} & $\begin{array}{r}4.42 \\
14.05 \\
5.00\end{array}$ & $\begin{array}{l}19.90 \\
28.06 \\
20.82\end{array}$ & $\begin{array}{c}\mathrm{NR} \\
11.99 \\
4.98 \\
\end{array}$ & $\begin{array}{r}-0.60 \\
150.51 \\
4.44 \\
\end{array}$ & $\begin{array}{r}0.00 \\
154.41\end{array}$ & $\begin{array}{l}0.98 \\
1.01\end{array}$ & $\begin{array}{l}11.34 \\
10.44 \\
12.04\end{array}$ & $\begin{array}{l}0.28 \\
0.17 \\
0.07\end{array}$ & $\begin{array}{c}-0.73 \\
<62 \\
1.07\end{array}$ & $\begin{array}{l}\mathrm{NR} \\
- \\
0.37\end{array}$ & $\begin{array}{c}10.88 \\
\text { NC } \\
12.78\end{array}$ & $\begin{array}{l}\text { Acceptable } \\
\text { Noble-gas data are suspect; assumed sample contaminated with air bubble(s). Initial } 3 \mathrm{H} \\
\text { not calculated due to excess } 4 \mathrm{He} \text {. } \\
\text { Acceptable }\end{array}$ \\
\hline \multicolumn{15}{|l|}{ Pajarito Plateau } \\
\hline \multicolumn{15}{|l|}{ Perched Alluvial } \\
\hline $\begin{array}{l}\text { LAO-B } \\
\qquad \text { (Interlaboratory Field Duplicate Split) }\end{array}$ & $\begin{array}{l}5 / 10 / 2005 \\
8 / 17 / 2005 \\
8 / 17 / 2005\end{array}$ & \begin{tabular}{|l|} 
Univ. Miami \\
Univ. Miami \\
USGS - Denver
\end{tabular} & $\begin{array}{r}5.75 \\
38.97 \\
4.21\end{array}$ & $\begin{array}{l}20.98 \\
40.09 \\
17.80\end{array}$ & $\begin{array}{r}5.70 \\
33.40 \\
\mathrm{NR}\end{array}$ & $\begin{array}{r}19.43 \\
600.24 \\
2.87\end{array}$ & $\begin{array}{r}18.23 \\
526.62 \\
0.10\end{array}$ & $\begin{array}{l}0.98 \\
0.89 \\
0.97\end{array}$ & $\begin{array}{l}19.99 \\
17.47 \\
17.37\end{array}$ & $\begin{array}{l}0.30 \\
0.11 \\
0.03\end{array}$ & $\begin{array}{r}3.84 \\
<62 \\
-0.02\end{array}$ & $\frac{0.24}{\mathrm{NR}}$ & $\begin{aligned} 24.81 \\
\text { NC } \\
17.35\end{aligned}$ & $\begin{array}{l}\text { Acceptable } \\
\text { Noble-gas data not acceptable; assumed sample contaminated with/ air bubble(s). } \\
\text { Acceptable }\end{array}$ \\
\hline \multicolumn{15}{|c|}{ Perched Volcanics at Surface } \\
\hline Homestead Spring & $\begin{array}{l}3 / 31 / 2005 \\
7 / 18 / 2005\end{array}$ & $\begin{array}{l}\text { Univ. Miami } \\
\text { Univ. Miami }\end{array}$ & $\begin{array}{l}5.86 \\
5.45\end{array}$ & $\begin{array}{l}23.53 \\
20.35\end{array}$ & $\begin{array}{l}4.95 \\
5.18\end{array}$ & $\begin{array}{r}4.74 \\
12.04\end{array}$ & $\begin{array}{r}7.12 \\
11.72\end{array}$ & $\begin{array}{l}1.01 \\
0.98\end{array}$ & $\begin{array}{l}23.75 \\
21.54\end{array}$ & $\begin{array}{l}0.36 \\
0.13\end{array}$ & $\begin{array}{l}1.34 \\
2.32\end{array}$ & $\begin{array}{l}0.20 \\
0.20\end{array}$ & $\begin{array}{l}25.62 \\
24.54\end{array}$ & \begin{tabular}{|l|} 
Acceptable \\
Acceptable
\end{tabular} \\
\hline $\begin{array}{l}\text { Starmer Spring } \\
\quad \text { (Blind Intralaboratory Field Duplicate) }\end{array}$ & $\begin{array}{l}3 / 31 / 2005 \\
7 / 18 / 2005 \\
7 / 18 / 2005\end{array}$ & $\begin{array}{l}\text { Univ. Miami } \\
\text { Univ. Miami } \\
\text { Univ. Miami }\end{array}$ & $\begin{array}{r}10.85 \\
6.37 \\
5.32\end{array}$ & $\begin{array}{l}33.94 \\
24.93 \\
20.45\end{array}$ & $\begin{array}{l}6.91 \\
5.05 \\
5.29\end{array}$ & $\begin{array}{r}46.55 \\
6.83 \\
11.91\end{array}$ & $\begin{array}{l}35.51 \\
18.58 \\
14.88\end{array}$ & $\begin{array}{l}0.91 \\
1.09 \\
1.01\end{array}$ & $\begin{array}{l}24.81 \\
17.08 \\
16.08\end{array}$ & $\begin{array}{l}0.37 \\
0.10 \\
0.10\end{array}$ & $\begin{array}{l}5.65 \\
4.45 \\
3.85\end{array}$ & $\begin{array}{l}0.21 \\
0.24 \\
0.25\end{array}$ & $\begin{array}{l}34.09 \\
21.95 \\
19.98\end{array}$ & $\begin{array}{l}\text { Noble-gas data are suspect; sample may have been contaminated with air bubble(s). } \\
\text { Acceptable } \\
\text { Acceptable }\end{array}$ \\
\hline $\begin{array}{l}\text { Bulldog Spring } \\
\text { (Blind Intralaboratory Field Duplicate) }\end{array}$ & $\begin{array}{l}3 / 31 / 2005 \\
3 / 31 / 2005 \\
7 / 18 / 2005\end{array}$ & $\begin{array}{l}\text { Univ. Miami } \\
\text { Univ. Miami } \\
\text { Univ. Miami }\end{array}$ & $\begin{array}{l}5.29 \\
5.21 \\
5.54\end{array}$ & $\begin{array}{l}20.13 \\
20.27 \\
21.25\end{array}$ & $\begin{array}{l}5.29 \\
5.17 \\
5.23\end{array}$ & $\begin{array}{r}12.50 \\
9.90 \\
11.09\end{array}$ & $\begin{array}{l}14.13 \\
12.59 \\
11.98\end{array}$ & $\begin{array}{l}1.00 \\
1.01 \\
0.99\end{array}$ & $\begin{array}{l}37.56 \\
39.47 \\
35.18\end{array}$ & $\begin{array}{l}0.47 \\
0.49 \\
0.21\end{array}$ & $\begin{array}{l}1.66 \\
1.42 \\
1.51\end{array}$ & $\begin{array}{l}0.13 \\
0.13 \\
0.13\end{array}$ & $\begin{array}{l}41.24 \\
42.74 \\
38.30\end{array}$ & $\begin{array}{l}\text { Acceptable } \\
\text { Acceptable } \\
\text { Acceptable }\end{array}$ \\
\hline $\begin{array}{l}\text { Burning Ground Spring } \\
\text { (Blind Intralaboratory Field Duplicate) }\end{array}$ & $\begin{array}{l}4 / 1 / 2005 \\
4 / 1 / 2005 \\
7 / 19 / 2005\end{array}$ & $\begin{array}{l}\text { Univ. Miami } \\
\text { Univ. Miami } \\
\text { Univ. Miami }\end{array}$ & $\begin{array}{l}5.37 \\
7.02 \\
5.36\end{array}$ & $\begin{array}{l}20.19 \\
23.60 \\
21.72\end{array}$ & $\begin{array}{l}5.35 \\
6.02 \\
4.91\end{array}$ & $\begin{array}{r}13.79 \\
27.97 \\
4.32\end{array}$ & $\begin{array}{r}20.86 \\
28.85 \\
9.03\end{array}$ & $\begin{array}{l}1.05 \\
0.99 \\
1.03\end{array}$ & $\begin{array}{l}44.90 \\
45.92 \\
21.24\end{array}$ & $\begin{array}{l}0.56 \\
0.57 \\
0.13\end{array}$ & $\begin{array}{l}2.03 \\
2.69 \\
1.86\end{array}$ & $\begin{array}{l}0.12 \\
0.12 \\
0.21\end{array}$ & $\begin{array}{l}50.33 \\
53.44 \\
23.59\end{array}$ & $\begin{array}{l}\text { Acceptable } \\
\text { Acceptable } \\
\text { Acceptable }\end{array}$ \\
\hline Martin Spring & 4/6/2005 & Univ. Miami & 5.94 & 19.94 & 5.94 & 26.98 & 20.00 & 0.93 & 39.10 & 0.59 & 2.21 & 0.14 & 44.28 & Acceptable \\
\hline $\begin{array}{l}\text { TA-18 Spring } \\
\text { (Blind Intralaboratory Field Duplicate) }\end{array}$ & $\begin{array}{l}3 / 18 / 2005 \\
8 / 1 / 2005 \\
8 / 1 / 2005\end{array}$ & $\begin{array}{l}\text { Univ. Miami } \\
\text { Univ. Miami } \\
\text { Univ. Miami }\end{array}$ & $\begin{array}{l}6.02 \\
6.91 \\
7.11\end{array}$ & $\begin{array}{l}22.06 \\
23.63 \\
22.50\end{array}$ & $\begin{array}{l}5.80 \\
6.23 \\
6.77\end{array}$ & $\begin{array}{l}20.16 \\
29.16 \\
40.17\end{array}$ & $\begin{array}{l}22.21 \\
35.72 \\
44.64\end{array}$ & $\begin{array}{l}1.00 \\
1.04 \\
1.02\end{array}$ & $\begin{array}{l}31.74 \\
29.25 \\
30.91\end{array}$ & $\begin{array}{l}0.48 \\
0.18 \\
0.19\end{array}$ & $\begin{array}{l}3.05 \\
5.02 \\
5.80\end{array}$ & $\begin{array}{l}0.17 \\
0.15 \\
0.14\end{array}$ & $\begin{array}{l}37.68 \\
38.80 \\
42.85\end{array}$ & $\begin{array}{l}\text { Acceptable } \\
\text { Acceptable } \\
\text { Acceptable }\end{array}$ \\
\hline
\end{tabular}


Table 6.4

Summary Results of Tritium and the Noble Gases Helium-3, Helium-4, and Neon (Cont.)

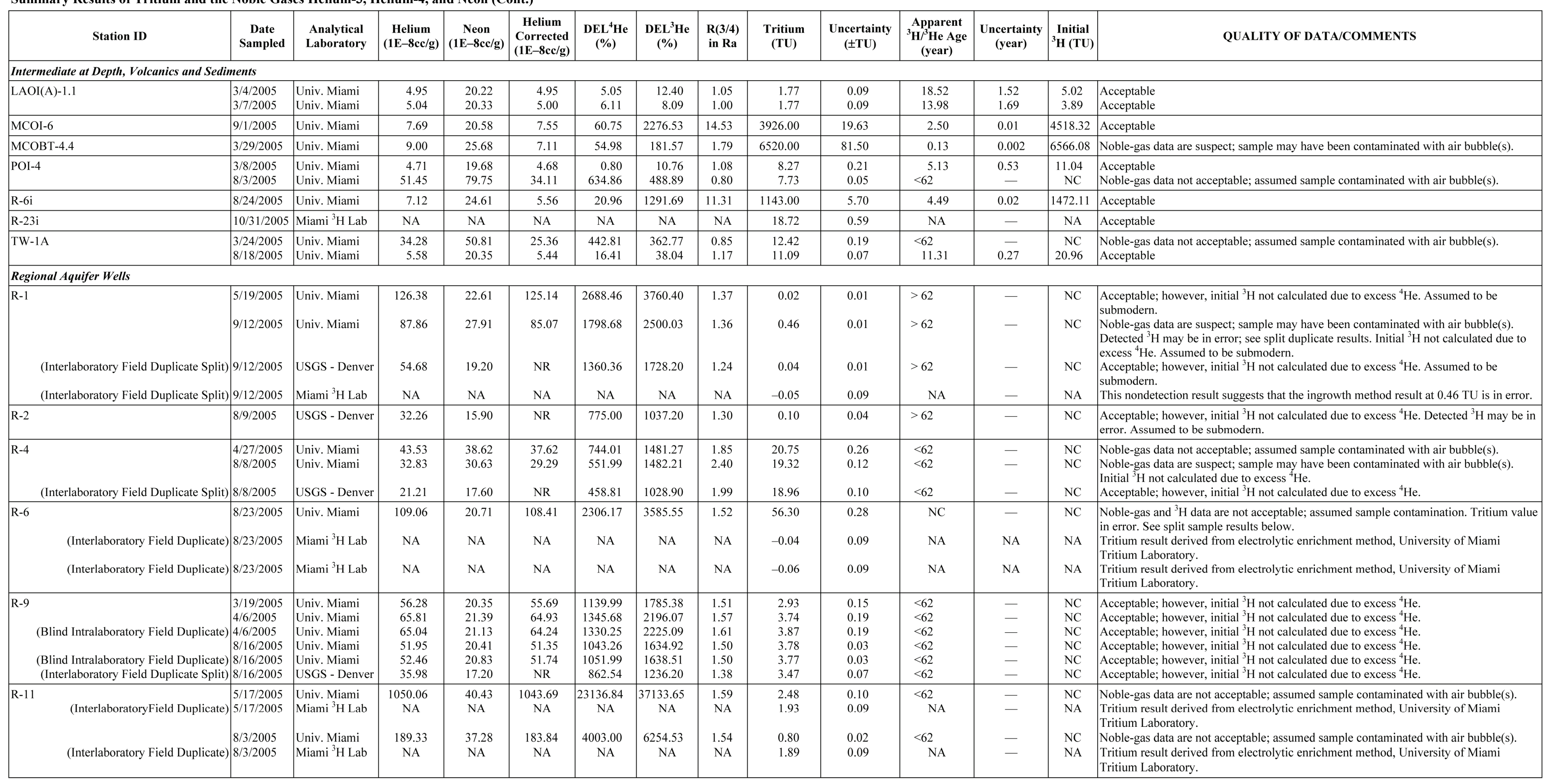


Table 6.4

Summary Results of Tritium and the Noble Gases Helium-3, Helium-4, and Neon (Cont.)

\begin{tabular}{|c|c|c|c|c|c|c|c|c|c|c|c|c|c|c|}
\hline Station ID & $\begin{array}{c}\text { Date } \\
\text { Sampled }\end{array}$ & $\begin{array}{l}\text { Analytical } \\
\text { Laboratory }\end{array}$ & \begin{tabular}{|c} 
Helium \\
$(1 \mathrm{E}-8 \mathrm{cc} / \mathrm{g})$
\end{tabular} & $\begin{array}{l}\text { Neon } \\
(1 \mathrm{E}-8 \mathrm{cc} / \mathrm{g})\end{array}$ & \begin{tabular}{|c} 
Helium \\
Corrected \\
$(1 \mathrm{E}-8 \mathrm{scc} / \mathrm{g})$
\end{tabular} & $\begin{array}{c}\text { DELL } \mathrm{He} \\
(\%)\end{array}$ & $\begin{array}{l}\text { DEL }^{3} \mathrm{He} \\
(\%)\end{array}$ & $\begin{array}{l}\mathrm{R}(3 / 4) \\
\text { in Ra }\end{array}$ & $\begin{array}{c}\text { Tritium } \\
\text { (TU) }\end{array}$ & $\begin{array}{l}\text { Uncertainty } \\
\quad( \pm \mathbf{T U})\end{array}$ & $\begin{array}{c}\text { Apparent } \\
{ }^{3} \mathbf{H}^{3} \mathbf{H e ~ A g e ~} \\
\text { (year) }\end{array}$ & $\begin{array}{c}\text { Uncertainty } \\
\text { (year) }\end{array}$ & $\begin{array}{l}\text { Innitial } \\
{ }^{3} \mathbf{H} \text { (TU) }\end{array}$ & QUALITY OF DATA/COMMENTS \\
\hline${ }^{\mathrm{R}-13}$ (Blind Intralaboratory Field Duplicate) & $\begin{array}{l}3 / 10 / 2005 \\
3 / 10 / 2005 \\
9 / 1 / 2005\end{array}$ & $\begin{array}{l}\text { Univ. Miami } \\
\text { Univ. Miami } \\
\text { Univ. Miami } \\
\text { Miami }{ }^{3} \mathrm{H} \text { Lab }\end{array}$ & $\begin{array}{l}8.11 \\
8.61 \\
9.19\end{array}$ & $\begin{array}{l}20.82 \\
21.45 \\
20.30\end{array}$ & $\begin{array}{l}7.42 \\
7.75 \\
8.65\end{array}$ & $\begin{array}{l}64.72 \\
71.96 \\
92.14\end{array}$ & $\begin{array}{r}79.29 \\
84.61 \\
114.61\end{array}$ & $\begin{array}{l}1.08 \\
1.06 \\
1.10\end{array}$ & $\begin{array}{l}0.01 \\
0.01 \\
0.14\end{array}$ & $\begin{array}{l}0.01 \\
0.01 \\
0.01\end{array}$ & $\begin{array}{l}>62 \\
>62 \\
>62\end{array}$ & $\begin{array}{l}\overline{-} \\
\overline{-}\end{array}$ & $\begin{array}{l}\mathrm{NC} \\
\mathrm{NC} \\
\mathrm{NC}\end{array}$ & 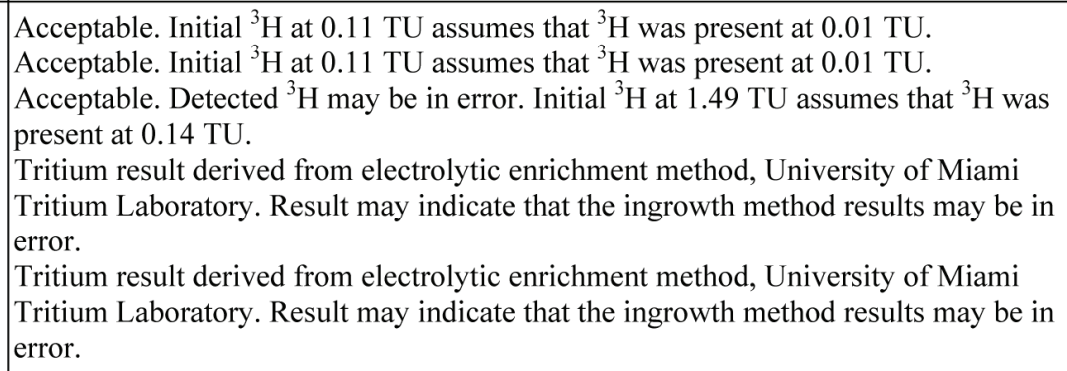 \\
\hline $\begin{array}{r}\text { (Blind Intralaboratory Field Duplicate) } \\
\text { (Interlaboratory Field Duplicate) }\end{array}$ & $\begin{array}{l}3 / 9 / 2005 \\
3 / 9 / 2005 \\
8 / 31 / 2005 \\
8 / 31 / 2005 \\
8 / 31 / 2005\end{array}$ & $\begin{array}{l}\text { Univ. Miami } \\
\text { Univ. Miami } \\
\text { Univ. Miami } \\
\text { Univ. Miami } \\
\text { Miami }{ }^{3} \mathrm{H} \text { Lab }\end{array}$ & $\begin{array}{c}6.46 \\
7.28 \\
7.08 \\
7.23 \\
\mathrm{NA}\end{array}$ & $\begin{array}{l}19.27 \\
24.13 \\
21.33 \\
21.36 \\
\text { NA }\end{array}$ & $\begin{array}{l}6.26 \\
5.68 \\
6.29 \\
6.42 \\
\text { NA }\end{array}$ & $\begin{array}{l}38.40 \\
25.67 \\
38.95 \\
42.13 \\
\mathrm{NA}\end{array}$ & $\begin{array}{l}44.91 \\
39.26 \\
51.52 \\
53.41 \\
\mathrm{NA}\end{array}$ & $\begin{array}{l}1.03 \\
1.09 \\
1.08 \\
1.06 \\
\text { NA }\end{array}$ & $\begin{array}{l}6.91 \\
6.91 \\
9.87 \\
9.52 \\
9.62\end{array}$ & $\begin{array}{l}0.17 \\
0.17 \\
0.07 \\
0.06 \\
0.30\end{array}$ & $\begin{array}{c}17.21 \\
15.76 \\
14.90 \\
15.62 \\
\text { NA }\end{array}$ & $\begin{array}{c}0.52 \\
0.53 \\
0.27 \\
0.26 \\
-\end{array}$ & $\begin{array}{r}18.21 \\
16.78 \\
22.82 \\
22.94 \\
\text { NA }\end{array}$ & $\begin{array}{l}\text { Acceptable } \\
\text { Acceptable } \\
\text { Acceptable } \\
\text { Acceptable } \\
\text { Tritium result derived from electrolytic enrichment method, University of Miami } \\
\text { Tritium Laboratory. } \\
\end{array}$ \\
\hline (Interlaboratory Field Duplicate) & $\begin{array}{l}8 / 25 / 2005 \\
8 / 25 / 2005\end{array}$ & $\begin{array}{l}\text { USGS - Denver } \\
\text { Miami }{ }^{3} \mathrm{H} \text { Lab }\end{array}$ & $\begin{array}{l}4.13 \\
\mathrm{NA}\end{array}$ & $\begin{array}{l}17.80 \\
\text { NA }\end{array}$ & $\begin{array}{l}\mathrm{NR} \\
\mathrm{NA}\end{array}$ & $\begin{array}{l}-0.22 \\
\mathrm{NA}\end{array}$ & $\begin{array}{l}0.00 \\
\mathrm{NA}\end{array}$ & $\begin{array}{l}1.01 \\
\text { NA }\end{array}$ & $\begin{array}{r}<0.02 \\
0.13\end{array}$ & $\begin{array}{l}0.01 \\
0.09\end{array}$ & $\begin{array}{l}>62 \\
\mathrm{NA}\end{array}$ & $=$ & $\begin{array}{l}\text { NC } \\
\text { NA }\end{array}$ & $\begin{array}{l}\text { Acceptable. No }{ }^{3} \mathrm{H} \text { detected; assumed submodern. } \\
\text { Tritium result derived from electrolytic enrichment method, University of Miami } \\
\text { Tritium Laboratory. }\end{array}$ \\
\hline $\mathrm{R}-23$ & $8 / 15 / 2005$ & USGS - Denver & 10.02 & 19.80 & NR & 135.95 & 161.00 & 1.16 & $<0.02$ & 0.03 & $>62$ & - & $\mathrm{NC}$ & Acceptable; however, initial ${ }^{3} \mathrm{H}$ not calculated due to excess ${ }^{4} \mathrm{He}$. \\
\hline (InterlaboratoryField Duplicate) & $\begin{array}{l}5 / 20 / 2005 \\
5 / 20 / 2005 \\
9 / 1 / 2005 \\
9 / 1 / 2005\end{array}$ & $\begin{array}{l}\text { Univ. Miami } \\
\text { Miami }{ }^{3} \mathrm{H} \mathrm{Lab}\end{array}$ & $\begin{array}{c}348.50 \\
\text { NA } \\
424.48 \\
\text { NA }\end{array}$ & $\begin{array}{l}19.48 \\
\mathrm{NA}\end{array}$ & $\begin{array}{c}348.18 \\
\text { NA }\end{array}$ & $\begin{array}{l}7643.26 \\
\mathrm{NA}\end{array}$ & $\begin{array}{c}12602.35 \\
\mathrm{NA}\end{array}$ & $\begin{array}{l}1.63 \\
\mathrm{NA}\end{array}$ & $\begin{array}{l}57.57 \\
46.87\end{array}$ & $\begin{array}{l}0.72 \\
1.59 \\
0.25 \\
1.78\end{array}$ & $\begin{array}{l}42-62 \\
\mathrm{NA}\end{array}$ & $\begin{array}{l}- \\
- \\
-\end{array}$ & $\begin{array}{l}\text { NC } \\
\text { NA } \\
\text { NC } \\
\text { NA }\end{array}$ & $\begin{array}{l}\text { Acceptable; however, initial }{ }^{3} \mathrm{H} \text { not calculated due to excess }{ }^{4} \mathrm{He} \text {. } \\
\text { Tritium result derived from electrolytic enrichment method, University of Miami } \\
\text { Tritium Laboratory. } \\
\text { AAcceptable; however, initialal }{ }^{3} \mathrm{H} \text { not calculalted due to excess }{ }^{4} \mathrm{He} \text {. } \\
\text { Tritium result derived from electrolytic enrichment method, University of Miami } \\
\text { Tritium Laboratory. }\end{array}$ \\
\hline TW-1 & $\begin{array}{l}3 / 23 / 2005 \\
8 / 17 / 2005 \\
\end{array}$ & $\begin{array}{l}\text { Univ. Miami } \\
\text { Univ. Miami }\end{array}$ & $\begin{array}{l}5.42 \\
5.56 \\
\end{array}$ & $\begin{array}{l}19.57 \\
20.81\end{array}$ & $\begin{array}{l}5.39 \\
5.18 \\
\end{array}$ & $\begin{array}{l}16.51 \\
11.83 \\
\end{array}$ & $\begin{array}{l}34.75 \\
16.95 \\
\end{array}$ & $\begin{array}{l}1.14 \\
1.03 \\
\end{array}$ & $\begin{array}{l}35.34 \\
34.84 \\
\end{array}$ & $\begin{array}{l}0.53 \\
0.17 \\
\end{array}$ & $\begin{array}{l}3.99 \\
2.09 \\
\end{array}$ & $\begin{array}{l}0.16 \\
0.13\end{array}$ & $\begin{array}{l}44.25 \\
39.18 \\
\end{array}$ & $\begin{array}{l}\text { Acceptable } \\
\text { Acceptable }\end{array}$ \\
\hline TW-2 & $3 / 22 / 2005$ & Univ. Miami & 5.38 & 20.24 & 5.21 & 12.10 & 14.41 & 1.00 & 2.32 & 0.11 & 17.02 & 1.28 & 6.05 & Acceptable \\
\hline (Blind Intralaboratory Field Duplicate) & $\begin{array}{l}\text { 3/21/2005 } \\
4 / 6 / 2005 \\
8 / 11 / 2005 \\
8 / 11 / 2005 \\
\end{array}$ & \begin{tabular}{|l} 
Univ. Miami \\
Univ. Miami \\
Univ. Miami \\
Univ. Miami \\
\end{tabular} & $\begin{array}{r}93.91 \\
55.15 \\
128.31 \\
141.44 \\
\end{array}$ & $\begin{array}{l}20.17 \\
19.59 \\
19.18 \\
19.33 \\
\end{array}$ & $\begin{array}{r}93.41 \\
55.11 \\
128.27 \\
141.37 \\
\end{array}$ & $\begin{array}{l}1973.29 \\
1091.17 \\
2699.95 \\
2985.83 \\
\end{array}$ & $\begin{array}{l}3027.47 \\
1546.21 \\
43966.67 \\
4748.79 \\
\end{array}$ & $\begin{array}{l}1.50 \\
1.37 \\
1.59 \\
1.56 \\
\end{array}$ & $\begin{array}{l}4.64 \\
4.64 \\
1.21 \\
1.34 \\
\end{array}$ & $\begin{array}{l}0.12 \\
0.12 \\
0.02 \\
0.01\end{array}$ & $\begin{array}{l}<62 \\
<62 \\
<62 \\
<62 \\
\end{array}$ & $\begin{array}{l}- \\
- \\
- \\
-\end{array}$ & $\begin{array}{l}\mathrm{NC} \\
\mathrm{NC} \\
\mathrm{NC} \\
\mathrm{NC}\end{array}$ & $\begin{array}{l}\text { Acceptable; however, initial }{ }^{3} \mathrm{H} \text { not calculated due to excess }{ }^{4} \mathrm{He} . \\
\text { Acceptable; however, initial }{ }^{3} \mathrm{H} \text { not calculated due to exceess }{ }^{4} \mathrm{He} \text {. } \\
\text { Acceptable; however, initial }{ }^{3} \mathrm{H} \text { not calculated due to excess }{ }^{4} \mathrm{He} \text {. } \\
\text { Acceptable; however, initial }{ }^{3} \mathrm{H} \text { not calculated due to excess }{ }^{4} \mathrm{He} \text {. }\end{array}$ \\
\hline TW- 8 & $\begin{array}{l}3 / 28 / 2005 \\
10 / 3 / 2005 \\
\end{array}$ & $\begin{array}{l}\text { Univ. Miami } \\
\text { Univ. Miami } \\
\end{array}$ & $\begin{array}{l}12.58 \\
12.14 \\
\end{array}$ & $\begin{array}{l}19.29 \\
19.51\end{array}$ & $\begin{array}{l}12.41 \\
11.86 \\
\end{array}$ & $\begin{array}{l}173.59 \\
162.54 \\
\end{array}$ & $\begin{array}{l}223.54 \\
194.37 \\
\end{array}$ & $\begin{array}{l}1.17 \\
1.11\end{array}$ & $\begin{array}{r}10.67 \\
2.89 \\
\end{array}$ & $\begin{array}{l}0.16 \\
0.04\end{array}$ & $\begin{array}{l}<62 \\
<62\end{array}$ & - & $\begin{array}{l}\mathrm{NC} \\
\mathrm{NC}\end{array}$ & $\begin{array}{l}\text { Acceptable; however, initial }{ }^{3} \mathrm{H} \text { not calculated due to excess }{ }^{4} \mathrm{He} \\
\text { Acceptable; however, initial }{ }^{3} \mathrm{H} \text { not calculated due to excess }{ }^{4} \mathrm{He} \text {. }\end{array}$ \\
\hline \multicolumn{15}{|l|}{ Regional Aquifer Production Well } \\
\hline \begin{tabular}{|r} 
O-1 \\
(Blind Intralaboratory Field Duplicate) \\
(Interlaboratory Field Duplicate)
\end{tabular} & $\begin{array}{l}3 / 23 / 2005 \\
3 / 23 / 2005 \\
5 / 18 / 2005 \\
5 / 18 / 2005 \\
8 / 17 / 2005\end{array}$ & $\begin{array}{l}\text { Univ. Miami } \\
\text { Univ. Miami } \\
\text { Univ. Miami } \\
\text { Miami }{ }^{3} \mathrm{H} \text { Lab } \\
\text { Univ. Miami }\end{array}$ & $\begin{array}{c}1818.18 \\
1037.52 \\
1471.52 \\
\text { NA } \\
739.26\end{array}$ & $\begin{array}{l}19.37 \\
23.44 \\
19.57 \\
\mathrm{NA} \\
33.35\end{array}$ & $\begin{array}{l}1817.83 \\
1036.00 \\
1471.05 \\
\text { NA } \\
734.82\end{array}$ & $\begin{array}{l}40602.62 \\
23096.78 \\
33046.57 \\
\text { NA } \\
16457.46\end{array}$ & $\begin{array}{l}69296.97 \\
35147.52 \\
56389.70 \\
\text { NA }\end{array}$ & $\begin{array}{l}1.69 \\
1.51 \\
1.69 \\
\text { NA }\end{array}$ & $\begin{array}{r}10.12 \\
8.93 \\
12.87 \\
10.31 \\
10.56\end{array}$ & $\begin{array}{l}0.15 \\
0.22 \\
0.17 \\
0.30 \\
0.06 \\
0.07\end{array}$ & $\begin{array}{l}<62 \\
<62 \\
<62 \\
\text { NA } \\
<62 \\
<62\end{array}$ & $\begin{array}{l}- \\
- \\
- \\
- \\
-\end{array}$ & $\begin{array}{l}\mathrm{NC} \\
\mathrm{NC} \\
\mathrm{NC} \\
\mathrm{NA} \\
\mathrm{NC}\end{array}$ & 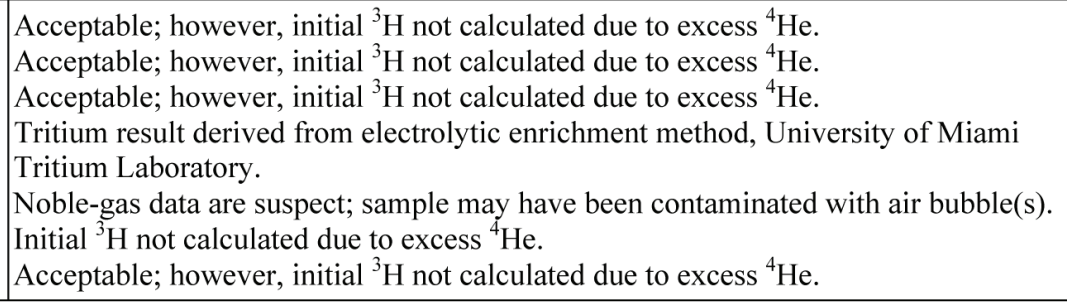 \\
\hline \multicolumn{15}{|c|}{ White Rock Canyon Springs } \\
\hline Spring 2B & 7/21/2005 & Univ. Miami & 5.50 & 19.69 & 5.14 & 14.12 & 22.75 & 1.06 & 3.41 & 0.03 & 17.48 & 0.59 & 9.11 & Acceptable \\
\hline $\begin{array}{l}\text { Spring } 3 \\
\text { (Blind Intralaboratory Field Duplicate) }\end{array}$ & $\begin{array}{l}3 / 9 / 2005 \\
3 / 9 / 2005 \\
7 / 21 / 2005\end{array}$ & $\begin{array}{l}\text { Univ. Miami } \\
\text { Univ. Miami } \\
\text { Univ. Miami }\end{array}$ & $\begin{array}{l}8.06 \\
7.33 \\
6.10\end{array}$ & $\begin{array}{l}18.82 \\
18.74 \\
20.29\end{array}$ & $\begin{array}{l}8.02 \\
7.31 \\
5.62\end{array}$ & $\begin{array}{l}76.84 \\
61.18 \\
24.10\end{array}$ & $\begin{array}{l}76.59 \\
67.94 \\
25.80\end{array}$ & $\begin{array}{l}0.99 \\
1.03 \\
1.00\end{array}$ & $\begin{array}{l}0.28 \\
0.35 \\
0.49\end{array}$ & $\begin{array}{l}0.08 \\
0.11 \\
0.01\end{array}$ & $\begin{array}{l}<62 \\
<62 \\
47.45\end{array}$ & $\overline{\bar{z}} \overline{\bar{c}}$ & \begin{tabular}{l|l}
$\mathrm{NC}$ \\
$\mathrm{NC}$ \\
7.07
\end{tabular} & $\begin{array}{l}\text { Acceptable } \\
\text { Acceptable } \\
\text { Acceptable }\end{array}$ \\
\hline Spring 3A & $\begin{array}{l}\text { 3/9/2005 } \\
4 / 15 / 2005 \\
7 / 21 / 2005\end{array}$ & $\begin{array}{l}\text { Univ. Miami } \\
\text { Univ. Miami } \\
\text { Univ. Miami }\end{array}$ & $\begin{array}{r}67.20 \\
10.03 \\
9.34\end{array}$ & $\begin{array}{l}83.52 \\
19.53 \\
21.68\end{array}$ & $\begin{array}{r}48.48 \\
9.75 \\
8.44\end{array}$ & $\begin{array}{r}972.49 \\
115.70 \\
86.81\end{array}$ & $\begin{array}{r}948.01 \\
117.35 \\
96.86\end{array}$ & $\begin{array}{l}0.97 \\
1.00 \\
1.04\end{array}$ & $\begin{array}{l}1.58 \\
2.35 \\
0.47\end{array}$ & $\begin{array}{l}0.12 \\
0.12 \\
0.01\end{array}$ & $\begin{array}{l}<62 \\
<62 \\
<62\end{array}$ & $\begin{array}{l}- \\
- \\
-\end{array}$ & $\begin{array}{l}\mathrm{NC} \\
\mathrm{NC} \\
\mathrm{NC}\end{array}$ & $\begin{array}{l}\text { Noble-gas data are not acceptable; assumed sample contaminated with air bubble(s). } \\
\text { Acceptable; however, initial }{ }^{3} \mathrm{H} \text { not calculated due to excess }{ }^{4} \mathrm{He} \text {. } \\
\text { Acceptable }\end{array}$ \\
\hline
\end{tabular}


Table 6.4

Summary Results of Tritium and the Noble Gases Helium-3, Helium-4, and Neon (Cont)

\begin{tabular}{|c|c|c|c|c|c|c|c|c|c|c|c|c|c|c|}
\hline Station ID & $\begin{array}{c}\text { Date } \\
\text { Sampled }\end{array}$ & $\begin{array}{l}\text { Analytical } \\
\text { Laboratory }\end{array}$ & $\begin{array}{c}\text { Helium } \\
(\mathbf{1 E - 8 c c / g})\end{array}$ & $\begin{array}{c}\text { Neon } \\
(1 \mathrm{E}-8 \mathrm{cc} / \mathrm{g})\end{array}$ & $\begin{array}{c}\text { Helium } \\
\text { Corrected } \\
(1 \mathbf{1 E - 8 c e / g})\end{array}$ & $\begin{array}{l}\text { DEL }{ }^{4} \mathrm{He} \\
(\%)\end{array}$ & $\begin{array}{l}\text { DEL }^{3} \mathrm{He} \\
(\%)\end{array}$ & $\begin{array}{l}\mathrm{R}(3 / 4) \\
\text { in Ra }\end{array}$ & $\begin{array}{l}\text { Tritium } \\
\text { (TU) }\end{array}$ & $\begin{array}{c}\text { Uncertainty } \\
( \pm \mathbf{T U})\end{array}$ & $\begin{array}{c}\text { Apparent } \\
{ }^{3} \mathbf{H} /{ }^{/} \mathbf{H e} \text { Age } \\
\text { (year) }\end{array}$ & $\begin{array}{l}\text { Uncertainty } \\
\text { (year) }\end{array}$ & \begin{tabular}{|l|} 
Initial \\
${ }^{3} \mathbf{H}(\mathbf{T U})$
\end{tabular} & QUALITY OF DATA/COMMENTS \\
\hline Spring $3 \mathrm{C}$ & $3 / 11 / 2005$ & Univ. Miami & 4.59 & 19.15 & 4.59 & 0.03 & 0.17 & 0.98 & 1.61 & 0.08 & 0.46 & 2.75 & 1.65 & Acceptable. Sample may have been impacted by river water. \\
\hline Spring 4 & $\begin{array}{l}2 / 21 / 2005 \\
3 / 11 / 2005 \\
7 / 27 / 2005\end{array}$ & $\begin{array}{l}\text { Univ. Miami } \\
\text { Univ. Miami } \\
\text { Univ. Miami }\end{array}$ & $\begin{array}{l}5.06 \\
5.75 \\
5.61\end{array}$ & $\begin{array}{l}19.19 \\
19.84 \\
19.85\end{array}$ & $\begin{array}{l}5.04 \\
5.55 \\
5.34\end{array}$ & $\begin{array}{r}9.91 \\
20.92 \\
17.07\end{array}$ & $\begin{array}{l}13.22 \\
21.38 \\
20.12\end{array}$ & $\begin{array}{l}1.01 \\
0.99 \\
1.01\end{array}$ & $\begin{array}{l}2.78 \\
3.27 \\
6.15\end{array}$ & $\begin{array}{l}0.04 \\
0.08 \\
0.06\end{array}$ & $\begin{array}{l}14.11 \\
17.44 \\
10.72 \\
\end{array}$ & $\begin{array}{l}0.88 \\
0.79 \\
0.47 \\
\end{array}$ & $\begin{array}{r}6.15 \\
8.73 \\
11.25 \\
\end{array}$ & \begin{tabular}{|l} 
Acceptable \\
Acceptable \\
Acceptable
\end{tabular} \\
\hline Spring 4A & $\begin{array}{l}2 / 22 / 2005 \\
3 / 22 / 2005 \\
7 / 28 / 2005\end{array}$ & $\begin{array}{l}\text { Univ. Miami } \\
\text { Univ. Miami } \\
\text { Univ. Miami }\end{array}$ & $\begin{array}{l}4.66 \\
5.36 \\
7.33 \\
\end{array}$ & $\begin{array}{l}18.54 \\
18.54 \\
20.40\end{array}$ & $\begin{array}{l}4.65 \\
5.36 \\
6.81\end{array}$ & $\begin{array}{r}3.04 \\
18.61 \\
50.59 \\
\end{array}$ & $\begin{array}{r}7.00 \\
20.89 \\
65.02 \\
6\end{array}$ & $\begin{array}{l}1.02 \\
1.00 \\
1.08 \\
\end{array}$ & $\begin{array}{l}0.14 \\
0.18 \\
0.25 \\
\end{array}$ & $\begin{array}{l}0.01 \\
0.06 \\
0.02\end{array}$ & $\begin{array}{l}46.40 \\
61.03 \\
<62 \\
\end{array}$ & $\begin{array}{l}3.54 \\
6.67 \\
-\end{array}$ & $\begin{array}{l}1.92 \\
5.89 \\
\mathrm{NC}\end{array}$ & \begin{tabular}{|l} 
Acceptable \\
Acceptable \\
Acceptable
\end{tabular} \\
\hline $\begin{array}{l}\text { Spring 4AA } \\
\text { (Blind Intralaboratory Field Duplicate) } \\
\text { (Blind Intralaboratory Field Duplicate) } \\
3\end{array}$ & \begin{tabular}{|l|}
$2 / 22 / 2005$ \\
$2 / 22 / 2005$ \\
$3 / 22 / 2005$ \\
$3 / 22 / 2005$ \\
$7 / 26 / 2005$ \\
\end{tabular} & $\begin{array}{l}\text { Univ. Miami } \\
\text { Univ. Miami } \\
\text { Univ. Miami } \\
\text { Univ. Miami } \\
\text { Univ. Miami }\end{array}$ & $\begin{array}{l}4.59 \\
5.22 \\
5.02 \\
5.00 \\
5.37 \\
\end{array}$ & $\begin{array}{l}18.81 \\
20.52 \\
18.83 \\
19.30 \\
18.78 \\
\end{array}$ & $\begin{array}{l}4.56 \\
4.69 \\
4.98 \\
4.83 \\
5.36\end{array}$ & $\begin{array}{r}0.54 \\
3.39 \\
9.84 \\
6.44 \\
17.94 \\
\end{array}$ & $\begin{array}{r}4.37 \\
5.03 \\
9.40 \\
4.86 \\
23.50 \\
\end{array}$ & $\begin{array}{l}1.02 \\
1.00 \\
0.98 \\
0.97 \\
1.03\end{array}$ & $\begin{array}{l}0.65 \\
0.56 \\
0.60 \\
0.62 \\
0.69\end{array}$ & $\begin{array}{l}0.02 \\
0.02 \\
0.18 \\
0.19 \\
0.01\end{array}$ & $\begin{array}{l}17.63 \\
21.00 \\
28.49 \\
19.39 \\
40.34 \\
\end{array}$ & $\begin{array}{l}2.91 \\
2.90 \\
5.80 \\
6.07 \\
1.01\end{array}$ & $\begin{array}{l}1.75 \\
1.84 \\
2.98 \\
1.85 \\
6.69 \\
\end{array}$ & $\begin{array}{l}\text { Acceptable } \\
\text { Acceptable } \\
\text { Acceptable } \\
\text { Acceptable } \\
\text { Acceptable } \\
\end{array}$ \\
\hline (Bling 4B Intralaboratory Field Duplicate) & $\begin{array}{l}2 / 21 / 2005 \\
3 / 22 / 2005 \\
7 / 27 / 2005 \\
7 / 27 / 2005 \\
\end{array}$ & \begin{tabular}{|l} 
Univ. Miami \\
Univ. Miami \\
Univ. Miami \\
Univ. Miami \\
\end{tabular} & $\begin{array}{l}4.73 \\
4.64 \\
5.54 \\
6.58 \\
\end{array}$ & $\begin{array}{l}19.07 \\
19.15 \\
19.12 \\
20.13 \\
\end{array}$ & $\begin{array}{l}4.73 \\
4.63 \\
5.52 \\
6.26 \\
\end{array}$ & $\begin{array}{r}3.12 \\
0.92 \\
20.52 \\
36.73 \\
\end{array}$ & $\begin{array}{r}3.76 \\
3.93 \\
10.74 \\
41.10 \\
\end{array}$ & $\begin{array}{l}0.99 \\
1.01 \\
0.91 \\
1.02 \\
\end{array}$ & $\begin{array}{l}10.10 \\
12.94 \\
11.95 \\
12.18 \\
\end{array}$ & $\begin{array}{l}0.15 \\
0.16 \\
0.07 \\
0.07\end{array}$ & $\begin{array}{r}1.61 \\
1.32 \\
3.65 \\
11.00 \\
\end{array}$ & $\begin{array}{l}0.43 \\
0.34 \\
0.33 \\
0.25 \\
\end{array}$ & $\begin{array}{l}11.05 \\
13.94 \\
14.67 \\
22.63 \\
\end{array}$ & \begin{tabular}{|l} 
Acceptable \\
Acceptable \\
Acceptable \\
Acceptable
\end{tabular} \\
\hline Spring $4 \mathrm{C}$ & $\begin{array}{l}10 / 8 / 2004 \\
2 / 21 / 2005 \\
3 / 1 / 12005 \\
7 / 27 / 2005\end{array}$ & \begin{tabular}{|l|} 
USGS - Denver \\
Univ. Miami \\
Univ. Miami \\
Univ. Miami \\
\end{tabular} & $\begin{array}{l}4.20 \\
4.58 \\
6.17 \\
5.80 \\
\end{array}$ & $\begin{array}{l}17.50 \\
18.94 \\
19.31 \\
22.80\end{array}$ & $\begin{array}{l}\mathrm{NR} \\
4.58 \\
6.06 \\
4.70 \\
\end{array}$ & $\begin{array}{r}4.51 \\
0.20 \\
32.75 \\
2.80 \\
\end{array}$ & $\begin{array}{r}\mathrm{NR} \\
3.42 \\
30.60 \\
1.91 \\
\end{array}$ & $\begin{array}{l}0.99 \\
1.01 \\
0.97 \\
0.97 \\
\end{array}$ & $\begin{array}{l}2.61 \\
3.14 \\
3.23 \\
3.15 \\
\end{array}$ & $\begin{array}{l}0.00 \\
0.03 \\
0.08 \\
0.03 \\
\end{array}$ & $\begin{array}{r}5.89 \\
4.33 \\
21.79 \\
2.53 \\
\end{array}$ & $\begin{array}{l}\text { NR } \\
1.16 \\
0.72 \\
1.26 \\
\end{array}$ & $\begin{array}{r}3.63 \\
4.00 \\
11.01 \\
3.64 \\
\end{array}$ & \begin{tabular}{|l} 
Acceptable \\
Acceptable \\
Acceptable \\
Acceptable
\end{tabular} \\
\hline Spring 5 & $\begin{array}{l}2 / 21 / 2005 \\
3 / 24 / 2005 \\
7 / 26 / 2005\end{array}$ & \begin{tabular}{|l|} 
Univ. Miami \\
Univ. Miami \\
Univ. Miami
\end{tabular} & $\begin{array}{r}5.80 \\
6.42 \\
45.85 \\
\end{array}$ & $\begin{array}{l}18.52 \\
18.86 \\
50.61\end{array}$ & $\begin{array}{r}5.79 \\
6.31 \\
36.60 \\
\end{array}$ & $\begin{array}{r}28.42 \\
40.00 \\
710.84 \\
\end{array}$ & $\begin{array}{r}32.73 \\
39.67 \\
592.39 \\
\end{array}$ & $\begin{array}{l}1.02 \\
0.98 \\
0.85\end{array}$ & $\begin{array}{l}0.005 \\
0.001 \\
0.003\end{array}$ & $\begin{array}{l}0.01 \\
0.01 \\
0.001\end{array}$ & $\begin{array}{l}>62 \\
>62 \\
>62 \\
\end{array}$ & $\begin{array}{l}- \\
- \\
-\end{array}$ & $\begin{array}{l}\mathrm{NC} \\
\mathrm{NC} \\
\mathrm{NC}\end{array}$ & $\begin{array}{l}\text { Acceptable. } \\
\text { Acceptable. } \\
\text { Noble-gas data are not acceptable; assumed sample contaminated with air bubble(s). }\end{array}$ \\
\hline (Blind Intralaboratory Field Duplicate) & $\begin{array}{l}3 / 2 / 2005 \\
3 / 24 / 2005 \\
7 / 25 / 2005 \\
7 / 25 / 2005 \\
\end{array}$ & \begin{tabular}{|l} 
Univ. Miami \\
Univ. Miami \\
Univ. Miami \\
Univ. Miami \\
\end{tabular} & $\begin{array}{l}5.32 \\
5.46 \\
5.75 \\
5.76 \\
\end{array}$ & $\begin{array}{l}18.67 \\
19.40 \\
21.70 \\
21.88\end{array}$ & $\begin{array}{l}5.26 \\
5.20 \\
4.83 \\
4.78 \\
\end{array}$ & $\begin{array}{r}16.70 \\
15.24 \\
6.94 \\
6.04 \\
\end{array}$ & $\begin{array}{r}16.62 \\
20.81 \\
6.67 \\
3.85 \\
\end{array}$ & $\begin{array}{l}0.98 \\
1.03 \\
0.98 \\
0.96 \\
\end{array}$ & $\begin{array}{l}0.01 \\
0.01 \\
0.22 \\
0.23\end{array}$ & $\begin{array}{l}0.01 \\
0.01 \\
0.01 \\
0.01\end{array}$ & $\begin{array}{l}>62 \\
>62 \\
38.66 \\
29.35 \\
\end{array}$ & $\begin{array}{r}- \\
\overline{3} .33 \\
4.63 \\
\end{array}$ & $\begin{array}{l}\mathrm{NC} \\
\mathrm{NC} \\
1.90 \\
1.20\end{array}$ & $\begin{array}{l}\text { Acceptable. Initial }{ }^{3} \mathrm{H} \text { at } 0.33 \mathrm{TU} \text { assumes that }{ }^{3} \mathrm{H} \text { was present at } 0.01 \mathrm{TU} \text {. } \\
\text { Acceptable. Initial }{ }^{3} \mathrm{H} \text { at } 0.33 \mathrm{TU} \text { assumes that }{ }^{3} \mathrm{H} \text { was present at } 0.01 \mathrm{TU} \text {. } \\
\text { Acceptable; mixing with Rio Grande water may have occurred. } \\
\text { Acceptable; mixing with Rio Grande water may have occurred. }\end{array}$ \\
\hline Spring 9A & $\begin{array}{l}3 / 8 / 2005 \\
7 / 20 / 2005\end{array}$ & \begin{tabular}{|l} 
Univ. Miami \\
Univ. Miami
\end{tabular} & $\begin{array}{l}5.47 \\
8.10\end{array}$ & $\begin{array}{l}18.96 \\
19.94\end{array}$ & $\begin{array}{l}5.35 \\
7.72\end{array}$ & $\begin{array}{l}18.47 \\
70.43\end{array}$ & $\begin{array}{l}22.97 \\
55.79\end{array}$ & $\begin{array}{l}1.02 \\
0.90\end{array}$ & $\begin{array}{l}0.001 \\
0.022\end{array}$ & $\begin{array}{l}0.01 \\
0.004\end{array}$ & $\begin{array}{l}>62 \\
>62\end{array}$ & - & $\begin{array}{l}\mathrm{NC} \\
\mathrm{NC}\end{array}$ & $\begin{array}{l}\text { Acceptable. } \text { No }{ }^{3} \mathrm{H} \text { detected; assumed submodern. } \\
\text { Acceptable. Detected }{ }^{3} \mathrm{H} \text { may be in error. Initial }{ }^{3} \mathrm{H} \text { at } 0.33 \text { TU assumes that }{ }^{3} \mathrm{H} \text { was } \\
\text { present at } 0.02 \mathrm{TU} \text {. }\end{array}$ \\
\hline \multicolumn{15}{|c|}{ Perennial Surface Water West of Pajarito Fault Zone } \\
\hline \begin{tabular}{l|l}
$\mathrm{CdV}-5.6$ & 3 \\
\end{tabular} & $\begin{array}{l}3 / 3 / 2005 \\
7 / 11 / 2005\end{array}$ & \begin{tabular}{|l} 
Univ. Miami \\
Univ. Miami
\end{tabular} & $\begin{array}{l}5.44 \\
4.90\end{array}$ & $\begin{array}{l}22.75 \\
20.07\end{array}$ & $\begin{array}{l}5.38 \\
4.82 \\
\end{array}$ & $\begin{array}{l}8.64 \\
3.40\end{array}$ & $\begin{array}{l}8.19 \\
2.68\end{array}$ & $\begin{array}{l}0.98 \\
0.98\end{array}$ & $\begin{array}{l}15.63 \\
16.69\end{array}$ & $\begin{array}{l}0.09 \\
0.10\end{array}$ & $\begin{array}{l}2.38 \\
0.72 \\
\end{array}$ & $\begin{array}{l}0.29 \\
0.27\end{array}$ & $\begin{array}{l}17.87 \\
17.38\end{array}$ & \begin{tabular}{|l} 
Acceptable \\
Acceptable
\end{tabular} \\
\hline PA-10.6 & $\begin{array}{l}2 / 14 / 2005 \\
3 / 8 / 2005 \\
7 / 12 / 2005\end{array}$ & $\begin{array}{l}\text { Univ. Miami } \\
\text { Univ. Miami } \\
\text { Univ. Miami }\end{array}$ & $\begin{array}{r}18.05 \\
6.46 \\
5.00 \\
\end{array}$ & $\begin{array}{l}25.90 \\
22.29 \\
19.22 \\
\end{array}$ & $\begin{array}{r}16.77 \\
6.16 \\
4.89 \\
\end{array}$ & $\begin{array}{r}246.27 \\
27.73 \\
7.36 \\
\end{array}$ & $\begin{array}{r}239.90 \\
31.84 \\
6.93 \\
\end{array}$ & $\begin{array}{l}0.97 \\
1.02 \\
0.98\end{array}$ & $\begin{array}{l}19.79 \\
17.42 \\
21.34\end{array}$ & $\begin{array}{l}0.30 \\
0.26 \\
0.13\end{array}$ & $\begin{array}{r}25.81 \\
7.07 \\
1.40 \\
\end{array}$ & $\begin{array}{l}0.26 \\
0.27 \\
0.20\end{array}$ & $\begin{array}{l}84.64 \\
25.93 \\
23.09\end{array}$ & $\begin{array}{l}\text { Noble-gas data are suspect; sample may have been contaminated with air bubble(s). } \\
\text { Acceptable } \\
\text { Acceptable }\end{array}$ \\
\hline \multicolumn{15}{|l|}{ Offsite Reference } \\
\hline \multicolumn{15}{|l|}{ Perched Volcanics, South Valles Caldera } \\
\hline Seven Springs & $\begin{array}{l}3 / 10 / 2005 \\
7 / 15 / 2005 \\
\end{array}$ & $\begin{array}{l}\text { Univ. Miami } \\
\text { Univ. Miami } \\
\end{array}$ & $\begin{array}{l}5.07 \\
5.35\end{array}$ & $\begin{array}{l}19.97 \\
21.11\end{array}$ & $\begin{array}{l}5.06 \\
5.00\end{array}$ & $\begin{array}{l}8.08 \\
6.92 \\
\end{array}$ & $\begin{array}{r}10.28 \\
2.15 \\
\end{array}$ & $\begin{array}{l}1.00 \\
0.94\end{array}$ & $\begin{array}{r}9.13 \\
4.38 \\
\end{array}$ & $\begin{array}{l}0.24 \\
0.04 \\
\end{array}$ & $\begin{array}{l}4.55 \\
2.12 \\
\end{array}$ & $\begin{array}{l}0.50 \\
0.95 \\
\end{array}$ & $\begin{array}{r}11.79 \\
4.93 \\
\end{array}$ & $\begin{array}{l}\text { Acceptable } \\
\text { Acceptable }\end{array}$ \\
\hline \multicolumn{15}{|c|}{ Perched Basalts - Taos, Eastside Rio Grande } \\
\hline (Blind Intralaboratory Field Duplicate) & $\begin{array}{l}2 / 15 / 2005 \\
4 / 8 / 2005 \\
7 / 22 / 2005 \\
7 / 22 / 2005\end{array}$ & $\begin{array}{l}\text { Univ. Miami } \\
\text { Univ. Miami } \\
\text { Univ. Miami } \\
\text { Univ. Miami }\end{array}$ & $\begin{array}{l}6.34 \\
6.27 \\
9.38 \\
9.21\end{array}$ & $\begin{array}{l}22.39 \\
19.65 \\
27.79 \\
27.20\end{array}$ & $\begin{array}{l}5.47 \\
6.19 \\
6.96 \\
6.96\end{array}$ & $\begin{array}{l}18.39 \\
33.98 \\
50.69 \\
50.60\end{array}$ & $\begin{array}{l}57.97 \\
74.55 \\
62.88 \\
68.35\end{array}$ & $\begin{array}{l}1.31 \\
1.28 \\
1.07 \\
1.10\end{array}$ & $\begin{array}{l}6.46 \\
6.11 \\
6.49 \\
6.51\end{array}$ & $\begin{array}{l}0.10 \\
0.15 \\
0.06 \\
0.06\end{array}$ & $\begin{array}{l}21.26 \\
25.26 \\
22.23 \\
23.27\end{array}$ & $\begin{array}{l}0.41 \\
0.51 \\
0.32 \\
0.31\end{array}$ & $\begin{array}{l}21.37 \\
25.33 \\
22.68 \\
24.12\end{array}$ & $\begin{array}{l}\text { Acceptable } \\
\text { Acceptable } \\
\text { Noble-gas data are suspect; sample may have been contaminated with air bubble(s). } \\
\text { Noble-gas data are suspect; sample may have been contaminated with air bubble(s). }\end{array}$ \\
\hline
\end{tabular}


Table 6.4

Summary Results of Tritium and the Noble Gases Helium-3, Helium-4, and Neon (Cont.)

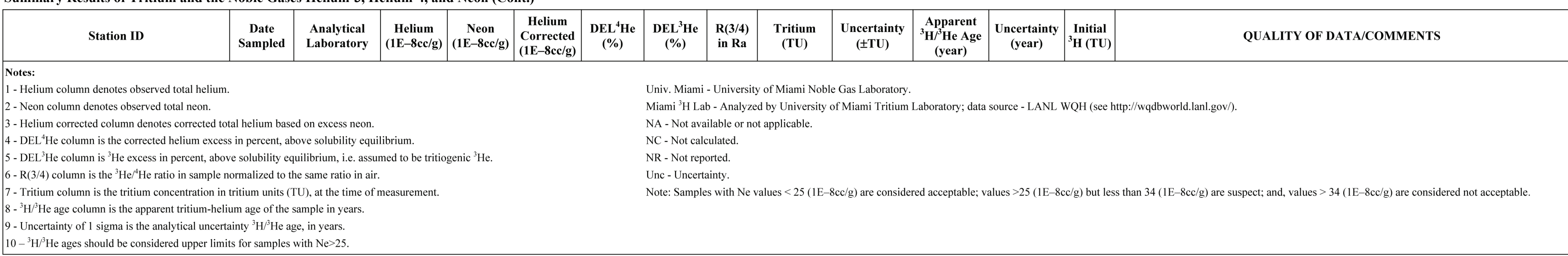



Table 6.5

Summary Results of Delta ${ }^{13} \mathrm{C}$, Fraction Modern Carbon $\left({ }^{14} \mathrm{C}\right)$, and Unadjusted Groundwater Ages

\begin{tabular}{|c|c|c|c|c|c|c|c|c|c|}
\hline Station ID & $\begin{array}{l}\text { Date } \\
\text { Sampled }\end{array}$ & $\begin{array}{c}\text { Analytical } \\
\text { Laboratory/Org }\end{array}$ & $\begin{array}{l}{ }_{(\%)} \\
\mathrm{CHCO}_{3}\end{array}$ & $\begin{array}{c}\text { Fraction of Modern Carbon } \\
\text { (normalized) }\end{array}$ & 1 Sigma $+/-$ & $\begin{array}{c}\text { Fraction of Modern Carbon } \\
\text { (non-normalized) }\end{array}$ & 1 Sigma +/- & $\begin{array}{c}\text { Unadjusted }{ }^{14} \mathrm{C} \text { Ages } \\
\text { (years) }\end{array}$ & 2 Sigma $+/-$ \\
\hline \multicolumn{10}{|l|}{ Sierra de los Valles } \\
\hline \multicolumn{10}{|l|}{ Perched Volcanics } \\
\hline Barbara Spring & 7/13/2005 & Univ of Az/NMED & -15.0 & 0.7190 & 0.0028 & 0.7290 & 0.0028 & 2486 & 63 \\
\hline Campsite Springs & $7 / 14 / 2005$ & Univ of Az/NMED & -14.2 & 0.7023 & 0.0041 & 0.7132 & 0.0042 & 2662 & 94 \\
\hline (Intralaboratory Blind Field Duplicate) & $\begin{array}{l}12 / 23 / 2005 \\
12 / 23 / 2005\end{array}$ & $\begin{array}{l}\text { Univ of Az/NMED } \\
\text { Univ of Az/NMED }\end{array}$ & $\begin{array}{l}-9.2 \\
-8.2\end{array}$ & $\begin{array}{l}1.1107 \\
1.0980\end{array}$ & $\begin{array}{l}0.0041 \\
0.0081\end{array}$ & $\begin{array}{l}1.1394 \\
1.1288 \\
\end{array}$ & $\begin{array}{l}0.0042 \\
0.0083\end{array}$ & $\begin{array}{l}-1102 \\
-1026 \\
\end{array}$ & $\begin{array}{r}59 \\
119 \\
\end{array}$ \\
\hline PC Spring & $6 / 29 / 2005$ & Univ of Az/USGS & -14.7 & 1.1053 & 0.0047 & 1.1213 & 0.0048 & -973 & 68 \\
\hline Water Canyon Gallery Spring & 9/23/2005 & Univ of Az/NMED & -15.7 & 0.9933 & 0.0036 & 1.0057 & 0.0036 & -99 & 58 \\
\hline Pajarito Ski Well \#2 & $1 / 12 / 2006$ & Univ of Az/NMED & -12.4 & 1.0591 & 0.0041 & 1.0795 & 0.0042 & -668 & 62 \\
\hline \multicolumn{10}{|l|}{ Regional Aquifer Wells } \\
\hline R-1 & $9 / 12 / 2005$ & Univ of Az/NMED & -14.9 & 0.6309 & 0.0035 & 0.6398 & 0.0035 & 3534 & 89 \\
\hline (Intralaboratory Blind Field Duplicate) & $\begin{array}{l}8 / 9 / 2005 \\
8 / 9 / 2005 \\
2 / 27 / 2006\end{array}$ & $\begin{array}{l}\text { Univ of Az/NMED } \\
\text { Univ of Az/USGS } \\
\text { Univ of Az/NMED }\end{array}$ & $\begin{array}{l}-14.9 \\
-14.3 \\
-14.9\end{array}$ & $\begin{array}{l}0.5812 \\
0.5817 \\
0.5990\end{array}$ & $\begin{array}{l}0.0029 \\
0.0031 \\
0.0034\end{array}$ & $\begin{array}{l}0.5894 \\
0.5906 \\
0.6074\end{array}$ & $\begin{array}{l}0.0029 \\
0.0031 \\
0.0034\end{array}$ & $\begin{array}{l}4193 \\
4177 \\
3951\end{array}$ & $\begin{array}{l}80 \\
86 \\
91 \\
\end{array}$ \\
\hline (Intralaboratory Blind Field Duplicate) & $\begin{array}{l}8 / 8 / 2005 \\
8 / 8 / 2005\end{array}$ & $\begin{array}{l}\text { Univ of Az/NMED } \\
\text { Univ of Az/USGS }\end{array}$ & $\begin{array}{l}-11.8 \\
-11.1\end{array}$ & $\begin{array}{l}0.3775 \\
0.3775\end{array}$ & $\begin{array}{l}0.0020 \\
0.0021\end{array}$ & $\begin{array}{l}0.3852 \\
0.3858\end{array}$ & $\begin{array}{l}0.0020 \\
0.0021\end{array}$ & $\begin{array}{l}7609 \\
7598\end{array}$ & $\begin{array}{l}85 \\
89\end{array}$ \\
\hline R-6 & $8 / 23 / 2005$ & Univ of Az/NMED & -12.3 & 0.4457 & 0.0022 & 0.4544 & 0.0022 & 6283 & 79 \\
\hline R-9 & $8 / 16 / 2005$ & Univ of Az/NMED & -9.0 & 0.2518 & 0.0031 & 0.2584 & 0.0032 & 10817 & 198 \\
\hline $\mathrm{R}-11$ & $8 / 3 / 2005$ & Univ of Az/NMED & -10.7 & 0.4509 & 0.0027 & 0.4612 & 0.0028 & 6164 & 96 \\
\hline $\mathrm{R}-13$ & $\begin{array}{l}9 / 1 / 2005 \\
2 / 2 / 2006\end{array}$ & $\begin{array}{l}\text { Univ of Az/NMED } \\
\text { Univ of Az/NMED }\end{array}$ & $\begin{array}{l}-14.1 \\
-14.1\end{array}$ & $\begin{array}{l}0.6260 \\
0.6205\end{array}$ & $\begin{array}{l}0.0026 \\
0.0032\end{array}$ & $\begin{array}{l}0.6359 \\
0.6303\end{array}$ & $\begin{array}{l}0.0026 \\
0.0033\end{array}$ & $\begin{array}{l}3584 \\
3655 \\
\end{array}$ & $\begin{array}{l}67 \\
83\end{array}$ \\
\hline $\mathrm{R}-15$ & $8 / 31 / 2005$ & Univ of Az/NMED & -13.4 & 0.6448 & 0.0028 & 0.6559 & 0.0028 & 3335 & 70 \\
\hline (Intralaboratory Blind Field Duplicate) & $\begin{array}{l}8 / 25 / 2005 \\
8 / 25 / 2005 \\
12 / 1 / 2005\end{array}$ & $\begin{array}{l}\text { Univ of Az/NMED } \\
\text { Univ of Az/USGS } \\
\text { Univ of Az/NMED }\end{array}$ & $\begin{array}{l}-14.9 \\
-14.2 \\
-14.8\end{array}$ & $\begin{array}{l}0.9086 \\
0.9127 \\
0.9161\end{array}$ & $\begin{array}{l}0.0040 \\
0.0041 \\
0.0041\end{array}$ & $\begin{array}{l}0.9214 \\
0.9269 \\
0.9292\end{array}$ & $\begin{array}{l}0.0041 \\
0.0042 \\
0.0042\end{array}$ & $\begin{array}{l}604 \\
557 \\
536\end{array}$ & $\begin{array}{l}71 \\
72 \\
72\end{array}$ \\
\hline (IntralaboratoryBlind Field Duplicate) & $\begin{array}{l}7 / 14 / 2005 \\
8 / 15 / 2005 \\
8 / 15 / 2005\end{array}$ & $\begin{array}{l}\text { Univ of Az/NMED } \\
\text { Univ of AzNMED } \\
\text { Univ of Az/USGS }\end{array}$ & $\begin{array}{l}-10.4 \\
-10.6 \\
-9.9\end{array}$ & $\begin{array}{l}0.5582 \\
0.6132 \\
0.6086\end{array}$ & $\begin{array}{l}0.0030 \\
0.0032 \\
0.0033\end{array}$ & $\begin{array}{l}0.5712 \\
0.6273 \\
0.6235\end{array}$ & $\begin{array}{l}0.0031 \\
0.0033 \\
0.0034\end{array}$ & $\begin{array}{l}4444 \\
3693 \\
3742\end{array}$ & $\begin{array}{l}86 \\
84 \\
87\end{array}$ \\
\hline R-28 & $\begin{array}{l}9 / 1 / 2005 \\
1 / 26 / 2006\end{array}$ & $\begin{array}{l}\text { Univ of Az/NMED } \\
\text { Univ of Az/NMED }\end{array}$ & $\begin{array}{l}-11.4 \\
-11.8 \\
\end{array}$ & $\begin{array}{l}0.4772 \\
0.4913 \\
\end{array}$ & $\begin{array}{l}0.0022 \\
0.0022\end{array}$ & $\begin{array}{l}0.4874 \\
0.5014\end{array}$ & $\begin{array}{l}0.0022 \\
0.0022\end{array}$ & $\begin{array}{l}5720 \\
5493 \\
\end{array}$ & $\begin{array}{l}74 \\
72 \\
\end{array}$ \\
\hline TW-1 & $8 / 17 / 2005$ & Univ of Az/NMED & -12.7 & 1.8992 & 0.0075 & 1.9346 & 0.0076 & -5354 & 63 \\
\hline TW-3 & $8 / 11 / 2005$ & Univ of Az/NMED & -10.1 & 0.4211 & 0.0030 & 0.4312 & 0.0031 & 6704 & 114 \\
\hline \multicolumn{10}{|l|}{ Regional Aquifer Production Well } \\
\hline O-1 & $8 / 17 / 2005$ & Univ of Az/NMED & -9.5 & 0.2851 & 0.0024 & 0.2923 & 0.0025 & 9827 & 135 \\
\hline \multicolumn{10}{|l|}{ White Rock Canyon Springs } \\
\hline Spring 3 & $\begin{array}{l}7 / 21 / 2005 \\
9 / 26 / 2005\end{array}$ & $\begin{array}{l}\text { Univ of Az/NMED } \\
\text { Univ of Az/NMED }\end{array}$ & $\begin{array}{l}-11.8 \\
-13.1\end{array}$ & $\begin{array}{l}0.4353 \\
0.4669\end{array}$ & $\begin{array}{l}0.0023 \\
0.0023\end{array}$ & $\begin{array}{l}0.4442 \\
0.4752\end{array}$ & $\begin{array}{l}0.0023 \\
0.0023\end{array}$ & $\begin{array}{l}6465 \\
5923\end{array}$ & $\begin{array}{l}85 \\
79\end{array}$ \\
\hline (Intralaboratory Blind Field Duplicate) & $\begin{array}{l}7 / 21 / 2005 \\
9 / 26 / 2005 \\
9 / 26 / 2005\end{array}$ & $\begin{array}{l}\text { Univ of Az/NMED } \\
\text { Univ of AzNMED } \\
\text { Univ of Az/NMED }\end{array}$ & $\begin{array}{l}-12.3 \\
-13.2 \\
-12.8\end{array}$ & $\begin{array}{l}0.3809 \\
0.3982 \\
0.3982\end{array}$ & $\begin{array}{l}0.0022 \\
0.0026 \\
0.0021\end{array}$ & $\begin{array}{l}0.3883 \\
0.04052 \\
0.4055\end{array}$ & $\begin{array}{l}0.0022 \\
0.0026 \\
0.0021\end{array}$ & $\begin{array}{l}7545 \\
7203 \\
7197\end{array}$ & $\begin{array}{r}93 \\
105 \\
85\end{array}$ \\
\hline Spring 4 & $\begin{array}{l}7 / 27 / 2005 \\
9 / 26 / 2005\end{array}$ & $\begin{array}{l}\text { Univ of Az/NMED } \\
\text { Univ of Az/NMED }\end{array}$ & $\begin{array}{l}-12.7 \\
-12.9\end{array}$ & $\begin{array}{l}0.6819 \\
0.6771\end{array}$ & $\begin{array}{l}0.0040 \\
0.0030\end{array}$ & $\begin{array}{l}0.6946 \\
0.6894\end{array}$ & $\begin{array}{l}0.0041 \\
0.0031\end{array}$ & $\begin{array}{l}2874 \\
2934\end{array}$ & $\begin{array}{l}94 \\
71\end{array}$ \\
\hline 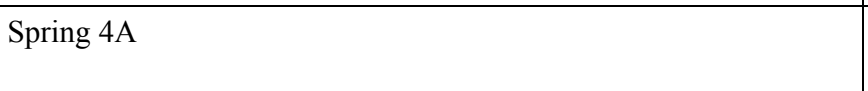 & $\begin{array}{l}7 / 28 / 2005 \\
9 / 27 / 2005\end{array}$ & $\begin{array}{l}\text { Univ of Az/NMED } \\
\text { Univ of Az/NMED }\end{array}$ & $\begin{array}{l}-11.4 \\
-11.4\end{array}$ & $\begin{array}{l}0.4406 \\
0.4281\end{array}$ & $\begin{array}{l}0.0031 \\
0.0021\end{array}$ & $\begin{array}{l}0.4500 \\
0.4372\end{array}$ & $\begin{array}{l}0.0032 \\
0.0021\end{array}$ & $\begin{array}{l}6361 \\
6592\end{array}$ & $\begin{array}{r}113 \\
79\end{array}$ \\
\hline
\end{tabular}


Table 6.5

Summary Results of Delta ${ }^{13} \mathrm{C}$, Fraction Modern Carbon ( ${ }^{4} \mathrm{C}$ ), and Unadjusted Groundwater Ages (Cont.)

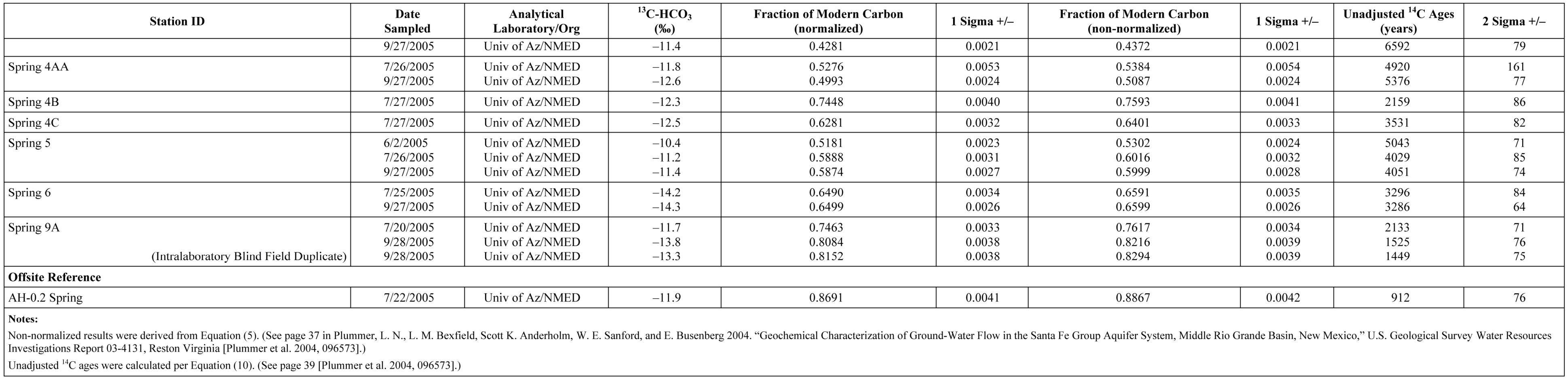


Table 7.1

Summary of Age Data and Age Interpretations Using Multiple Parameters

\begin{tabular}{|c|c|c|c|c|c|c|c|c|c|}
\hline Station ID & $\begin{array}{c}\text { Date } \\
\text { Sampled } \\
(\mathbf{m o} / \text { day/yr) }\end{array}$ & $\begin{array}{c}{ }^{3} \mathrm{H} \\
(\mathrm{TU})\end{array}$ & $\begin{array}{c}\text { Apparent } \\
{ }^{3} \mathbf{H}^{\beta} \mathrm{He} \text { Age } \\
\text { (year) }\end{array}$ & $\begin{array}{l}\text { Initial } \\
{ }^{3} \mathbf{H} \text { (TU) }\end{array}$ & $\begin{array}{c}\text { Initial }{ }^{3} \mathrm{H} \text { Plots } \\
\text { Above, Near, or Below } \\
{ }^{3} \mathrm{H} \text { Input Curve }\end{array}$ & $\begin{array}{l}{ }^{14} \mathrm{C} \text { age } \\
>1000 \text { years } \\
\text { (yes or no) }\end{array}$ & $\begin{array}{c}\text { Presence of } \\
\text { Anthropogenic Contaminants } \\
\text { (yes or no) }\end{array}$ & $\begin{array}{l}\text { Interpreted } \\
\text { Age Category }\end{array}$ & Comments \\
\hline \multicolumn{10}{|l|}{ Sierra de los Valles } \\
\hline \multicolumn{10}{|l|}{ Perched Volcanics } \\
\hline AL-10.6 Spring & $\begin{array}{l}5 / 12 / 2005 \\
7 / 13 / 2005\end{array}$ & $\begin{array}{l}3.12 \\
2.10\end{array}$ & $\begin{array}{l}10.68 \\
19.99\end{array}$ & $\begin{array}{l}5.70 \\
6.47\end{array}$ & $\begin{array}{l}\text { Below } \\
\text { Below }\end{array}$ & $\begin{array}{l}\text { Unknown } \\
\text { Unknown }\end{array}$ & $\begin{array}{l}\text { No } \\
\text { No }\end{array}$ & $\begin{array}{l}\text { Modern or Mixed? } \\
\text { Modern or Mixed? }\end{array}$ & \\
\hline Barbara Spring & $\begin{array}{l}3 / 29 / 2005 \\
7 / 13 / 2005 \\
\end{array}$ & $\begin{array}{l}0.39 \\
0.58\end{array}$ & $\begin{array}{r}31.05 \\
2.41 \\
\end{array}$ & $\begin{array}{l}2.24 \\
0.66\end{array}$ & $\begin{array}{l}\text { Below } \\
\text { Below }\end{array}$ & $\begin{array}{l}\text { Yes } \\
\text { Yes } \\
\end{array}$ & $\begin{array}{l}\text { No } \\
\text { No }\end{array}$ & \begin{tabular}{l|l|} 
Mixed \\
Mixed \\
\end{tabular} & \\
\hline Campsite Springs & $\begin{array}{l}5 / 17 / 2005 \\
7 / 14 / 2005\end{array}$ & $\begin{array}{l}1.03 \\
0.56\end{array}$ & $\begin{array}{l}33.01 \\
50.47\end{array}$ & $\begin{array}{l}6.61 \\
9.65\end{array}$ & $\begin{array}{l}\text { Below } \\
\text { Below }\end{array}$ & $\begin{array}{l}\text { Yes } \\
\text { Yes }\end{array}$ & $\begin{array}{l}\text { No } \\
\text { No }\end{array}$ & $\begin{array}{l}\text { Mixed } \\
\text { Mixed }\end{array}$ & \\
\hline CdV-5.0 Spring & $3 / 3 / 2005$ & 18.64 & 11.65 & 35.91 & Above & No & Yes $\left({ }^{3} \mathrm{H}\right)$ & Modern & $\begin{array}{l}{ }^{3} \mathrm{H}{ }^{\beta} \mathrm{He} \text { age is suspect because sample may have been contaminated } \\
\text { with air bubble(s). }\end{array}$ \\
\hline PC Spring & $\begin{array}{l}3 / 30 / 2005 \\
6 / 29 / 2005 \\
7 / 12 / 2005\end{array}$ & $\begin{array}{l}12.45 \\
11.13 \\
21.58\end{array}$ & $\begin{array}{l}1.25 \\
0.71 \\
0.38 \\
\end{array}$ & $\begin{array}{l}13.36 \\
11.58 \\
22.05\end{array}$ & $\begin{array}{l}\text { Above } \\
\text { Above } \\
\text { Above }\end{array}$ & $\begin{array}{l}\text { No } \\
\text { No } \\
\text { No }\end{array}$ & $\begin{array}{l}\left.\text { Yes }{ }^{3} \mathrm{H}\right) \\
\text { Yes }\left({ }^{3} \mathrm{H}\right) \\
\text { Yes }\left({ }^{3} \mathrm{H}\right) \\
\end{array}$ & $\begin{array}{l}\text { Modern } \\
\text { Modern } \\
\text { Modern } \\
\end{array}$ & $\begin{array}{l}\text { Tritium from local atmospheric sources? } \\
\text { Tritium from local atmospheric sources? } \\
\text { Tritium from local atmospheric sources? } \\
\end{array}$ \\
\hline Water Canyon Gallery & $\begin{array}{l}10 / 7 / 2004 \\
3 / 4 / 2005\end{array}$ & $\begin{array}{l}2.15 \\
8.03 \\
\end{array}$ & $\begin{array}{l}2.28 \\
4.20\end{array}$ & $\begin{array}{r}2.45 \\
10.17\end{array}$ & $\begin{array}{l}\text { Below } \\
\text { Above }\end{array}$ & $\begin{array}{l}\text { No } \\
\text { No }\end{array}$ & $\begin{array}{l}\text { No } \\
\text { Yes }\left({ }^{3} \mathrm{H}\right)\end{array}$ & $\begin{array}{l}\text { Modern } \\
\text { Modern }\end{array}$ & Tritium from local atmospheric sources? \\
\hline Young Spring & $\begin{array}{l}3 / 23 / 2005 \\
7 / 12 / 2005\end{array}$ & $\begin{array}{l}8.10 \\
7.72\end{array}$ & $\begin{array}{l}1.02 \\
7.16\end{array}$ & $\begin{array}{r}8.57 \\
11.55\end{array}$ & $\begin{array}{l}\text { Above } \\
\text { Near }\end{array}$ & $\begin{array}{l}\text { Unknown } \\
\text { Unknown }\end{array}$ & $\begin{array}{l}\text { Yes }\left({ }^{3} \mathrm{H}\right) \\
\text { Yes }\left({ }^{3} \mathrm{H}\right) ?\end{array}$ & $\begin{array}{l}\text { Modern } \\
\text { Modern }\end{array}$ & $\begin{array}{l}\text { Tritium from local atmospheric sources? } \\
\text { Tritium from local atmospheric sources? }\end{array}$ \\
\hline Pajarito Ski Well \#2 & $\begin{array}{l}10 / 6 / 2004 \\
8 / 31 / 2005\end{array}$ & $\begin{array}{l}11.34 \\
12.04 \\
\end{array}$ & $\begin{array}{r}-0.73 \\
1.07 \\
\end{array}$ & $\begin{array}{l}10.88 \\
12.78\end{array}$ & $\begin{array}{l}\text { Above } \\
\text { Above }\end{array}$ & $\begin{array}{l}\text { No } \\
\text { No }\end{array}$ & $\begin{array}{l}\text { Yes }\left({ }^{3} \mathrm{H}\right) \\
\text { Yes }\left({ }^{3} \mathrm{H}\right)\end{array}$ & $\begin{array}{l}\text { Modern } \\
\text { Modern }\end{array}$ & $\begin{array}{l}\text { Tritium from local atmospheric sources? } \\
\text { Tritium from local atmospheric sources? }\end{array}$ \\
\hline \multicolumn{10}{|l|}{ Pajarito Plateau } \\
\hline \multicolumn{10}{|l|}{ Perched Alluvial } \\
\hline \multicolumn{10}{|l|}{ Perched Volcanics at Surface } \\
\hline Homestead Spring & $\begin{array}{l}3 / 31 / 2005 \\
7 / 18 / 2005\end{array}$ & $\begin{array}{l}23.75 \\
21.54\end{array}$ & 2.32 & $\begin{array}{l}25.62 \\
24.54\end{array}$ & $\begin{array}{l}\text { Above } \\
\text { Above }\end{array}$ & $\begin{array}{l}\text { Unknown } \\
\text { Unknown }\end{array}$ & $\begin{array}{l}\text { Yes }\left({ }^{3} \mathrm{H}, \operatorname{var} \mathrm{Cl}\right) \\
\text { Yes }\left({ }^{3} \mathrm{H}, \operatorname{var} \mathrm{Cl}\right)\end{array}$ & $\begin{array}{l}\text { Modern } \\
\text { Modern }\end{array}$ & $\begin{array}{l}\text { Tritium from local atmospheric sources? } \\
\text { Cl from road salt? } \\
\text { Tritium from local atmospheric sources? } \\
\text { Cl from road salt? }\end{array}$ \\
\hline (Blind Intralaboratory Field Duplicate) & $\begin{array}{l}7 / 31 / 2005 \\
7 / 18 / 2005 \\
7 / 18 / 2005\end{array}$ & 17.08 & $\begin{array}{l}5.65 \\
4.45 \\
3.85\end{array}$ & $\begin{array}{l}34.09 \\
21.95 \\
19.98\end{array}$ & $\begin{array}{l}\text { Above } \\
\text { Above } \\
\text { Above }\end{array}$ & $\begin{array}{l}\text { Unknown } \\
\text { Unknown }\end{array}$ & $\begin{array}{l}\text { Yes }\left({ }^{3} \mathrm{H}, \operatorname{var} \mathrm{Cl}\right) \\
\text { Yes }\left({ }^{3} \mathrm{H}, \operatorname{var} \mathrm{Cl}\right) \\
\text { Yes }\left({ }^{3} \mathrm{H}, \operatorname{var} \mathrm{Cl}\right)\end{array}$ & $\begin{array}{l}\text { Modern } \\
\text { Modern } \\
\text { Modern }\end{array}$ & $\begin{array}{l}{ }^{3} \mathrm{H}^{\beta} \mathrm{He} \text { age is suspect because sample may have been contaminated } \\
\text { with air bubble(s). } \\
\text { Tritium from local atmospheric sources? } \\
\text { Cl from road salt? } \\
\text { Tritium from local atmospheric sources? } \\
\mathrm{Cl} \text { from road salt? }\end{array}$ \\
\hline $\begin{array}{l}\text { Bulldog Spring } \\
\text { (Blind Intralaboratory Field Duplicate) }\end{array}$ & $\begin{array}{l}3 / 31 / 2005 \\
3 / 31 / 2005 \\
7 / 18 / 2005\end{array}$ & $\begin{array}{l}37.56 \\
39.47 \\
35.18\end{array}$ & $\begin{array}{l}1.66 \\
1.42 \\
1.51\end{array}$ & $\begin{array}{l}41.24 \\
42.74 \\
38.30\end{array}$ & $\begin{array}{l}\text { Above } \\
\text { Above } \\
\text { Above }\end{array}$ & $\begin{array}{l}\text { Unknown } \\
\text { Unknown } \\
\text { Unknown }\end{array}$ & $\begin{array}{l}\text { Yes }\left({ }^{3} \mathrm{H}, \mathrm{Cl}, \mathrm{SO}_{4}, \mathrm{ClO}_{4}, \mathrm{HE}, \mathrm{VOC}\right) \\
\text { Yes }\left({ }^{3} \mathrm{H}, \mathrm{Cl}, \mathrm{SO}_{4}, \mathrm{ClO}_{4}, \mathrm{HE}, \mathrm{VOC}\right) \\
\text { Yes }\left({ }^{3} \mathrm{H}, \mathrm{Cl}, \mathrm{SO}_{4}, \mathrm{ClO}_{4}, \mathrm{HE}, \mathrm{VOC}\right)\end{array}$ & $\begin{array}{l}\text { Modern } \\
\text { Modern } \\
\text { Modern }\end{array}$ & \\
\hline $\begin{array}{l}\text { Burning Ground Spring } \\
\text { (Blind Intralaboratory Field Duplicate) }\end{array}$ & $\begin{array}{l}4 / 1 / 2005 \\
4 / 1 / 2005 \\
7 / 19 / 2005\end{array}$ & $\begin{array}{l}44.90 \\
45.92 \\
21.24 \\
\end{array}$ & $\begin{array}{l}2.03 \\
2.69 \\
1.86 \\
\end{array}$ & $\begin{array}{l}50.33 \\
53.44 \\
23.59\end{array}$ & $\begin{array}{l}\text { Above } \\
\text { Above } \\
\text { Above }\end{array}$ & $\begin{array}{l}\text { Unknown } \\
\text { Unknown } \\
\text { Unknown } \\
\end{array}$ & $\begin{array}{l}\left.\text { Yes ( }{ }^{3} \mathrm{H}, \mathrm{Ba}, \mathrm{Cl}_{1} \mathrm{SO}_{4}, \mathrm{ClO}_{4}, \mathrm{HE}, \mathrm{VOC}\right) \\
\text { Yes }\left({ }^{\mathrm{H}}, \mathrm{Ba}, \mathrm{Cl}_{4}, \mathrm{Sl}_{4}, \mathrm{HE}, \mathrm{VOC}\right) \\
\text { Yes }\left({ }^{3} \mathrm{H}, \mathrm{Ba}, \mathrm{Cl}, \mathrm{SO}_{4}, \mathrm{ClO}_{4}, \mathrm{HE}, \mathrm{VOC}\right)\end{array}$ & $\begin{array}{l}\text { Modern } \\
\text { Modern } \\
\text { Modern }\end{array}$ & \\
\hline Martin Spring & $4 / 6 / 2005$ & 39.10 & 2.21 & 44.28 & Above & Unknown & Yes ( $\left.{ }^{3} \mathrm{H}, \mathrm{Ba}, \mathrm{Cl}, \mathrm{SO}_{4}, \mathrm{ClO}_{4}, \mathrm{HE}, \mathrm{VOC}\right)$ & Modern & \\
\hline $\begin{array}{l}\text { TA-18 Spring } \\
\quad \text { (Blind Intralaboratory Field Duplicate) }\end{array}$ & $\begin{array}{l}3 / 18 / 2005 \\
8 / 1 / 2005 \\
8 / 1 / 2005\end{array}$ & $\begin{array}{l}31.74 \\
29.25 \\
30.91\end{array}$ & $\begin{array}{l}3.05 \\
5.02 \\
5.80\end{array}$ & $\begin{array}{l}37.68 \\
38.80 \\
42.85\end{array}$ & $\begin{array}{l}\text { Above } \\
\text { Above } \\
\text { Above }\end{array}$ & $\begin{array}{l}\text { Unknown } \\
\text { Unknown } \\
\text { Unknown }\end{array}$ & $\begin{array}{l}\text { Yes }\left({ }^{3} \mathrm{H}, \mathrm{Ba}, \mathrm{Cl}, \mathrm{SO}_{4}, \mathrm{HE}\right) \\
\text { Yes }\left({ }^{3} \mathrm{H}, \mathrm{Ba}, \mathrm{Cl}, \mathrm{SO}_{4}, \mathrm{HE}\right) \\
\text { Yes }\left({ }^{\mathrm{H}} \mathrm{H}, \mathrm{Ba}, \mathrm{Cl}, \mathrm{SO}_{4}, \mathrm{HE}\right)\end{array}$ & $\begin{array}{l}\text { Modern } \\
\text { Modern } \\
\text { Modern }\end{array}$ & \\
\hline
\end{tabular}


Table 7.1

Summary of Age Data and Age Interpretations Using Multiple Parameters (Cont.)

\begin{tabular}{|c|c|c|c|c|c|c|c|c|c|}
\hline Station ID & $\begin{array}{c}\text { Date } \\
\text { Sampled } \\
(\text { mo/day/yr) }\end{array}$ & $\begin{array}{c}{ }^{3} \mathbf{H} \\
(\mathbf{T U})\end{array}$ & $\begin{array}{c}\text { Apparent } \\
{ }^{3} \mathrm{H} /{ }^{3} \mathrm{He} \mathrm{Age} \\
\text { (year) }\end{array}$ & $\begin{array}{l}\text { Initial } \\
{ }^{3} \mathbf{H} \text { (TU) }\end{array}$ & $\begin{array}{c}\text { Initial }{ }^{3} \mathrm{H} \text { Plots } \\
\text { Above, Near, or Below } \\
{ }^{3} \mathrm{H} \text { Input Curve }\end{array}$ & $\begin{array}{l}{ }^{14} \mathrm{C} \text { age } \\
>1000 \text { years } \\
\text { (yes or no) }\end{array}$ & $\begin{array}{l}\text { Presence of } \\
\text { Anthropogenic Contaminants } \\
\text { (yes or no) }\end{array}$ & $\begin{array}{l}\text { Interpreted } \\
\text { Age Category }\end{array}$ & Comments \\
\hline \multicolumn{10}{|c|}{ Intermediate at Depth, Volcanics and Sediments } \\
\hline POI-4 & $3 / 8 / 2005$ & 8.27 & 5.13 & 11.04 & Near & Unknown & Yes $\left({ }^{3} \mathrm{H}, \mathrm{NO}_{3}, \mathrm{Cl}, \mathrm{SO}_{4}\right)$ & Mixed? & \\
\hline R-6i & $8 / 24 / 2005$ & 1143.00 & 4.49 & 1472.11 & Above & Unknown & Yes $\left({ }^{3} \mathrm{H}, \mathrm{NO}_{3}, \mathrm{Cl}, \mathrm{ClO}_{4}, \mathrm{SO}_{4}\right)$ & Mixed? & \\
\hline $\mathrm{R}-23 \mathrm{i}$ & $10 / 31 / 2005$ & 18.72 & $\mathrm{NC}$ & $\mathrm{NC}$ & $\mathrm{NC}$ & Unknown & Yes $\left({ }^{3} \mathrm{H}, \mathrm{NO}_{3}, \mathrm{Cl}, \mathrm{SO}_{4}\right)$ & Mixed? & \\
\hline TW-1A & $8 / 18 / 2005$ & 11.09 & 11.31 & 20.96 & Near & Unknown & Yes $\left({ }^{3} \mathrm{H}, \mathrm{NO}_{3}, \mathrm{Cl}, \mathrm{SO}_{4}\right)$ & Mixed? & \\
\hline LAOI(A)-1.1 & $\begin{array}{l}\text { 3/4/2005 } \\
3 / 7 / 2005\end{array}$ & $\begin{array}{l}1.77 \\
1.77\end{array}$ & $\begin{array}{l}18.52 \\
13.98\end{array}$ & $\begin{array}{l}5.02 \\
3.89\end{array}$ & $\begin{array}{l}\text { Below } \\
\text { Below }\end{array}$ & $\begin{array}{l}\text { Unknown } \\
\text { Unknown }\end{array}$ & $\begin{array}{l}\text { No } \\
\text { No }\end{array}$ & $\begin{array}{l}\text { Mixed? } \\
\text { Mixed? }\end{array}$ & \\
\hline MCOI-6 & 9/1/2005 & 3926.00 & 2.50 & 4518.32 & Above & Unknown & Yes $\left({ }^{3} \mathrm{H}, \mathrm{NO}_{3}, \mathrm{Cl}, \mathrm{ClO}_{4}, \mathrm{SO}_{4}, \mathrm{Cr}\right)$ & Mixed? & \\
\hline MCOBT-4.4 & 3/29/2005 & 6520.00 & 0.125 & 6566.080 & Above & Unknown & Yes $\left({ }^{3} \mathrm{H}, \mathrm{NO}_{3}, \mathrm{Cl}, \mathrm{ClO}_{4}, \mathrm{SO}_{4}, \mathrm{Cr}\right)$ & Mixed? & $\begin{array}{l}{ }^{3} \mathrm{H} /{ }^{3} \mathrm{He} \text { age is suspect because sample may have been contaminated } \\
\text { with air bubble(s). }\end{array}$ \\
\hline \multicolumn{10}{|l|}{ Regional Aquifer Wells } \\
\hline R-1 & $\begin{array}{l}5 / 19 / 2005 \\
9 / 12 / 2005\end{array}$ & $\begin{array}{l}0.02 \\
0.04\end{array}$ & $\begin{array}{l}>62 \\
>62\end{array}$ & $\begin{array}{l}\mathrm{NC} \\
\mathrm{NC}\end{array}$ & $\begin{array}{l}\text { NA } \\
\text { NA }\end{array}$ & $\begin{array}{l}\text { Yes } \\
\text { Yes }\end{array}$ & $\begin{array}{l}\text { No } \\
\text { No }\end{array}$ & $\begin{array}{l}\text { Submodern } \\
\text { Submodern }\end{array}$ & $\begin{array}{l}\text { Initial } l^{3} \mathrm{H} \text { and }{ }^{3} \mathrm{H}^{\beta} \mathrm{He} \text { age not calculated due to excess }{ }^{4} \mathrm{He} \text {. } \\
\text { Innitial }^{3} \mathrm{H} \text { and }{ }^{3} \mathrm{H} /{ }^{\beta} \mathrm{He} \text { age not calculated due to excess }{ }^{4} \mathrm{He} \text {. }\end{array}$ \\
\hline $\mathrm{R}-2$ & $8 / 9 / 2005$ & 0.10 & $>62$ & $\mathrm{NC}$ & NA & Yes & No & Submodern & Initial ${ }^{3} \mathrm{H}$ and ${ }^{3} \mathrm{H} / 3 \mathrm{He}$ age not calculated due to excess ${ }^{4} \mathrm{He}$. \\
\hline (Blind Field Duplicate Split with USGS) & $\begin{array}{l}8 / 8 / 2005 \\
8 / 8 / 2005\end{array}$ & $\begin{array}{l}19.32 \\
18.96\end{array}$ & $\begin{array}{l}<62 \\
<62\end{array}$ & $\begin{array}{l}\mathrm{NC} \\
\mathrm{NC}\end{array}$ & $\begin{array}{l}\mathrm{NA} \\
\mathrm{NA}\end{array}$ & $\begin{array}{l}\text { Yes } \\
\text { Yes }\end{array}$ & $\begin{array}{l}\text { Yes }\left({ }^{3} \mathrm{H}, \mathrm{NO}_{3}, \mathrm{Cl}, \mathrm{ClO}_{4}, \mathrm{SO}_{4}\right) \\
\left.\text { Yes ( }{ }^{3} \mathrm{H}, \mathrm{NO}_{3}, \mathrm{Cl}, \mathrm{ClO}_{4}, \mathrm{SO}_{4}\right)\end{array}$ & $\begin{array}{l}\text { Mixed } \\
\text { Mixed }\end{array}$ & $\begin{array}{l}{ }^{3} \mathrm{H}^{3} \mathrm{He} \text { age is suspect because sample may have been contaminated } \\
\text { with air bubble(s). Initial }{ }^{3} \mathrm{H} \text { not calculated due to excess }{ }^{4} \mathrm{He} \text {. } \\
\text { Initial }{ }^{3} \mathrm{H} \text { not calculated due to excess }{ }^{4} \mathrm{He} \text {. }\end{array}$ \\
\hline (Blind Interlaboratory Field Duplicate) & $\begin{array}{l}8 / 23 / 2005 \\
8 / 23 / 2005 \\
8 / 23 / 2005\end{array}$ & $\begin{array}{l}56.30 \\
<0.09 \\
<0.09\end{array}$ & $\begin{array}{l}\mathrm{NC} \\
\mathrm{NA} \\
\mathrm{NA}\end{array}$ & $\begin{array}{l}\text { NC } \\
\text { NA } \\
\text { NA }\end{array}$ & $\begin{array}{l}\text { NA } \\
\text { NA } \\
\text { NA }\end{array}$ & $\begin{array}{l}\text { Yes } \\
\text { Yes } \\
\text { Yes }\end{array}$ & $\begin{array}{l}\text { No } \\
\text { No } \\
\text { No }\end{array}$ & $\begin{array}{l}\text { Submodern } \\
\text { Submodern } \\
\text { Submodern }\end{array}$ & $\begin{array}{l}{ }^{3} \mathrm{H} \text { result in error due to sample contamination. See duplicate results } \\
\text { below. Assumed to be submodern. }\end{array}$ \\
\hline $\begin{array}{r}\text { (Blind Intralaboratory Field Duplicate) } \\
\text { (Blind Intralaboratory Field Duplicate) } \\
\text { (Blind Field Duplicate Split with USGS) }\end{array}$ & $\begin{array}{l}3 / 19 / 2005 \\
446 / 2005 \\
4 / 6 / 2005 \\
8 / 16 / 2005 \\
8 / 166005 \\
8 / 16 / 2005 \\
\end{array}$ & $\begin{array}{l}2.93 \\
3.74 \\
3.87 \\
3.78 \\
3.77 \\
3.47 \\
\end{array}$ & $\begin{array}{l}<62 \\
<62 \\
<62 \\
<62 \\
<62 \\
<62 \\
<62\end{array}$ & $\begin{array}{l}\mathrm{NC} \\
\mathrm{NC} \\
\mathrm{NC} \\
\mathrm{NC} \\
\mathrm{NC} \\
\mathrm{NC}\end{array}$ & $\begin{array}{l}\text { NA } \\
\text { NA } \\
\text { NA } \\
\text { NA } \\
\text { NA } \\
\text { NA }\end{array}$ & $\begin{array}{l}\text { Yes } \\
\text { Yes } \\
\text { Yes } \\
\text { Yes } \\
\text { Yes } \\
\text { Yes }\end{array}$ & 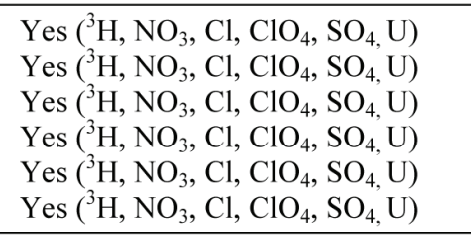 & $\begin{array}{l}\text { Mixed } \\
\text { Mixed } \\
\text { Mixed } \\
\text { Mixed } \\
\text { Mixed } \\
\text { Mixed } \\
\end{array}$ & 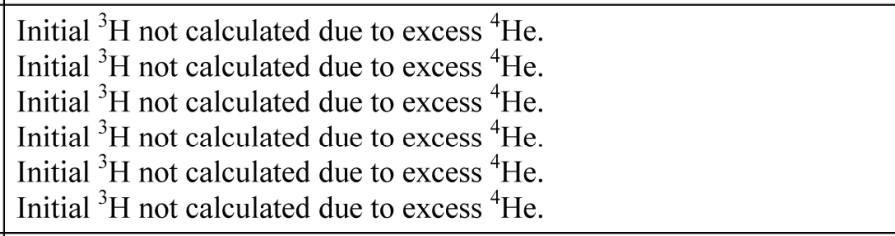 \\
\hline R-11 & $\begin{array}{l}5 / 17 / 2005 \\
8 / 3 / 2005\end{array}$ & $\begin{array}{l}2.48 \\
0.80\end{array}$ & $\begin{array}{l}<62 \\
<62 \\
662\end{array}$ & $\begin{array}{ll}\mathrm{NC} \\
\mathrm{NC}\end{array}$ & $\begin{array}{l}\mathrm{NA} \\
\mathrm{NA}\end{array}$ & $\begin{array}{l}\text { Yes } \\
\text { Yes }\end{array}$ & $\begin{array}{l}\text { Yes }\left({ }^{3} \mathrm{H}, \mathrm{NO}_{3}, \mathrm{Cl}_{1} \mathrm{ClO}_{4}, \mathrm{SO}_{4}, \mathrm{Cr}\right) \\
\text { Yes }\left({ }^{3} \mathrm{H}, \mathrm{NO}_{3}, \mathrm{Cl}, \mathrm{ClO}_{4}, \mathrm{SO}_{4}, \mathrm{Cr}\right)\end{array}$ & $\begin{array}{l}\text { Mixed } \\
\text { Mixed } \\
\end{array}$ & $\begin{array}{l}\text { Sample contaminated with air bubble(s). Assumed mixed. } \\
\text { Sample contaminated with air bubble(s). Assumed mixed. }\end{array}$ \\
\hline (Blind Intralaboratory Field Duplicate) & $\begin{array}{l}3 / 10 / 2005 \\
3 / 1 / 12005 \\
9 / 1 / 2005\end{array}$ & $\begin{array}{l}0.01 \\
0.01 \\
0.14\end{array}$ & $\begin{array}{l}<62 \\
<62 \\
<62\end{array}$ & $\begin{array}{l}\mathrm{NC} \\
\mathrm{NC} \\
\mathrm{NC}\end{array}$ & $\begin{array}{l}\mathrm{NA} \\
\mathrm{NA} \\
\mathrm{NA}\end{array}$ & $\begin{array}{l}\text { Yes } \\
\text { Yes } \\
\text { Yes }\end{array}$ & $\begin{array}{l}\mathrm{Yes}\left(\mathrm{NO}_{3}\right) \\
\text { Yes }\left(\mathrm{NO}_{3}\right) \\
\text { Yes }\left(\mathrm{NO}_{3}\right)\end{array}$ & $\begin{array}{l}\text { Mixed } \\
\text { Mixed } \\
\text { Mixed }\end{array}$ & $\begin{array}{l}\text { Initial }{ }^{3} \mathrm{H} \text { at } 0.11 \text { TU assumes that }{ }^{3} \mathrm{H} \text { was present at } 0.01 \mathrm{TU} \text {. } \\
\text { Initial }{ }^{3} \mathrm{H} \text { at } 0.11 \text { TU assumes that }{ }^{3} \mathrm{H} \text { was present at } 0.01 \mathrm{TU} \\
\text { Detected } \\
\text { present at } 0.14 \text { may be in error. Initial }\end{array}$ \\
\hline (Blind Intralaboratory Field Duplicate) & $\begin{array}{l}3 / 9 / 2005 \\
3 / 9 / 2005 \\
8 / 31 / 2005 \\
8 / 31 / 2005\end{array}$ & $\begin{array}{l}6.91 \\
6.91 \\
9.87 \\
9.52\end{array}$ & $\begin{array}{l}17.21 \\
15.76 \\
14.90 \\
15.62\end{array}$ & $\begin{array}{l}18.21 \\
16.78 \\
22.82 \\
22.94\end{array}$ & $\begin{array}{l}\text { Near } \\
\text { Near } \\
\text { Near } \\
\text { Near }\end{array}$ & $\begin{array}{l}\text { Yes } \\
\text { Yes } \\
\text { Yes } \\
\text { Yes }\end{array}$ & 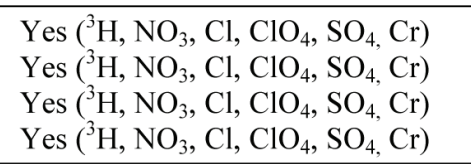 & $\begin{array}{l}\text { Mixed } \\
\text { Mixed } \\
\text { Mixed } \\
\text { Mixed }\end{array}$ & \\
\hline R-18 & $8 / 25 / 2005$ & $<0.02$ & $>62$ & $\mathrm{NC}$ & $\mathrm{NA}$ & No & No & Submodern & $\begin{array}{l}\text { Carbon-14 ages for samples collected on 8/25/05 and 12/1/05 were } 580 \\
\text { and 536 years, respectively. }\end{array}$ \\
\hline $\mathrm{R}-23$ & $8 / 15 / 2005$ & $<0.02$ & $>62$ & $\mathrm{NC}$ & NA & Yes & Yes $\left(\mathrm{NO}_{3}, \mathrm{Cl}, \mathrm{ClO}_{4}\right.$ ?, $\left.\mathrm{SO}_{4}\right)$ & Mixed & Initial ${ }^{3} \mathrm{H}$ not calculated due to excess ${ }^{4} \mathrm{He}$. \\
\hline $\mathrm{R}-28$ & $\begin{array}{l}5 / 20 / 2005 \\
9 / 1 / 2005\end{array}$ & $\begin{array}{l}57.57 \\
50.78\end{array}$ & $\begin{array}{l}42-62 \\
42-62 \\
\end{array}$ & $\begin{array}{l}\mathrm{NC} \\
\mathrm{NC}\end{array}$ & $\begin{array}{l}\mathrm{NA} \\
\mathrm{NA}\end{array}$ & $\begin{array}{l}\text { Yes } \\
\text { Yes }\end{array}$ & $\begin{array}{l}\text { Yes ( }\left({ }^{3} \mathrm{H}_{1} \mathrm{NO}_{3}, \mathrm{Cl}_{1}, \mathrm{ClO}_{4}, \mathrm{SO}_{4}, \mathrm{Cr}\right) \\
\text { Yes }\left({ }^{3} \mathrm{H}, \mathrm{NO}_{3}, \mathrm{Cl}, \mathrm{ClO}_{4}, \mathrm{SO}_{4}, \mathrm{Cr}\right)\end{array}$ & $\begin{array}{l}\text { Mixed } \\
\text { Mixed }\end{array}$ & $\begin{array}{l}\text { Initial }{ }^{3} \mathrm{H} \text { not calculated due to excess }{ }^{4} \mathrm{He} \\
\text { Intitial }{ }^{3} \mathrm{H} \text { not calculated due to excess }{ }^{4} \mathrm{He} \text {. }\end{array}$ \\
\hline TW-1 & $\begin{array}{l}3 / 23 / 2005 \\
8 / 17 / 2005\end{array}$ & $\begin{array}{l}35.34 \\
34.84\end{array}$ & $\begin{array}{l}3.99 \\
2.09\end{array}$ & $\begin{array}{l}44.25 \\
39.18\end{array}$ & $\begin{array}{l}\text { Above } \\
\text { Above }\end{array}$ & $\begin{array}{l}\text { No } \\
\text { No }\end{array}$ & $\begin{array}{l}\text { Yes }\left({ }^{3} \mathrm{H}, \mathrm{NO}_{3}, \mathrm{Cl}, \mathrm{ClO}_{4}, \mathrm{SO}_{4}, \mathrm{U}\right) \\
\text { Yes }\left({ }^{3} \mathrm{H}, \mathrm{NO}_{3}, \mathrm{Cl}, \mathrm{ClO}_{4}, \mathrm{SO}_{4}, \mathrm{Cr}\right)\end{array}$ & $\begin{array}{l}\text { Mixed } \\
\text { Mixed }\end{array}$ & \\
\hline TW-2 & 3/22/2005 & 2.32 & 17.02 & 6.05 & Below & Unknown & No & Mixed & \\
\hline
\end{tabular}


Table 7.1

Summary of Age Data and Age Interpretations Using Multiple Parameters (Cont.)

\begin{tabular}{|c|c|c|c|c|c|c|c|c|c|}
\hline Station ID & $\begin{array}{c}\text { Date } \\
\text { Sampled } \\
(\text { mo/day/yr) }\end{array}$ & $\begin{array}{c}{ }^{3} \mathrm{H} \\
(\mathrm{TU})\end{array}$ & $\begin{array}{c}\text { Apparent } \\
{ }^{3} \mathbf{H}^{\beta} \mathrm{He} \text { Age } \\
\text { (year) }\end{array}$ & $\begin{array}{l}{ }^{\text {Initial }} \\
{ }^{3} \mathrm{H} \text { (TU) }\end{array}$ & $\begin{array}{c}\text { Initial }{ }^{3} \mathrm{H} \text { Plots } \\
\text { Above, Near, or Below } \\
{ }^{3} \mathrm{H} \text { Input Curve }\end{array}$ & $\begin{array}{l}{ }^{14} \mathrm{C} \text { age } \\
>1000 \text { years } \\
\text { (yes or no) }\end{array}$ & $\begin{array}{c}\text { Presence of } \\
\text { Anthropogenic Contaminants } \\
\text { (yes or no) }\end{array}$ & $\begin{array}{l}\text { Interpreted } \\
\text { Age Category }\end{array}$ & Comments \\
\hline (Blind Intralaboratory Field Duplicate) & $\begin{array}{l}3 / 21 / 2005 \\
4 / 6 / 2005 \\
8 / 11 / 2005 \\
8 / 11 / 2005\end{array}$ & $\begin{array}{l}4.64 \\
4.64 \\
1.21 \\
1.34\end{array}$ & $\begin{array}{l}<62 \\
<62 \\
<<2 \\
<62\end{array}$ & $\begin{array}{l}\mathrm{NC} \\
\mathrm{NC} \\
\mathrm{NC} \\
\mathrm{NC}\end{array}$ & $\begin{array}{l}\text { NA } \\
\text { NA } \\
\text { NA } \\
\text { NA }\end{array}$ & $\begin{array}{l}\text { Yes } \\
\text { Yes } \\
\text { Yes } \\
\text { Yes }\end{array}$ & $\begin{array}{l}\text { Yes }\left({ }^{3} \mathrm{H}\right) \\
\text { Yes }\left({ }^{3} \mathrm{H}\right) \\
\text { Yes }\left({ }^{3} \mathrm{H}\right) \\
\text { Yes }\left({ }^{3} \mathrm{H}\right)\end{array}$ & $\begin{array}{l}\text { Mixed } \\
\text { Mixed } \\
\text { Mixed } \\
\text { Mixed }\end{array}$ & 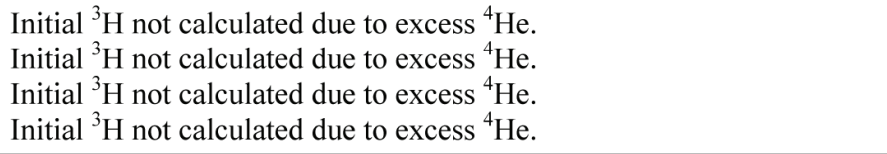 \\
\hline TW-8 & $\begin{array}{l}3 / 28 / 2005 \\
10 / 3 / 2005\end{array}$ & $\begin{aligned} 10.67 \\
2.89\end{aligned}$ & $\begin{array}{l}<62 \\
<62\end{array}$ & $\begin{array}{l}\mathrm{NC} \\
\mathrm{NC}\end{array}$ & $\begin{array}{l}\mathrm{NA} \\
\mathrm{NA}\end{array}$ & $\begin{array}{l}\text { Yes } \\
\text { Yes }\end{array}$ & $\begin{array}{l}\text { Yes }\left({ }^{3} \mathrm{H}\right) \\
\text { Yes }\left({ }^{3} \mathrm{H}\right)\end{array}$ & $\begin{array}{l}\text { Mixed } \\
\text { Mixed }\end{array}$ & $\begin{array}{l}\text { Initial }{ }^{3} \mathrm{H} \text { not calculated due to excess }{ }^{4} \mathrm{He} \text {. } \\
\text { Initial }{ }^{3} \mathrm{H} \text { not calculated due to excess }{ }^{4} \mathrm{He} \text {. }\end{array}$ \\
\hline \multicolumn{10}{|l|}{ Regional Aquifer Production Well } \\
\hline (Blind Intralaboratory Field Duplicate) & $\begin{array}{l}3 / 23 / 2005 \\
3 / 23 / 2005 \\
5 / 18 / 2005 \\
8 / 17 / 2005 \\
8 / 17 / 2005 \\
\end{array}$ & $\begin{array}{r}10.12 \\
8.93 \\
12.87 \\
10.56 \\
12.38 \\
\end{array}$ & $\begin{array}{l}<62 \\
<62 \\
<62 \\
<62 \\
<62 \\
<62 \\
\end{array}$ & $\begin{array}{l}\mathrm{NC} \\
\mathrm{NC} \\
\mathrm{NC} \\
\mathrm{NC} \\
\mathrm{NC}\end{array}$ & $\begin{array}{l}\text { NA } \\
\text { NA } \\
\text { NA } \\
\text { NA } \\
\text { NA }\end{array}$ & $\begin{array}{l}\text { Yes } \\
\text { Yes } \\
\text { Yes } \\
\text { Yes } \\
\text { Yes }\end{array}$ & 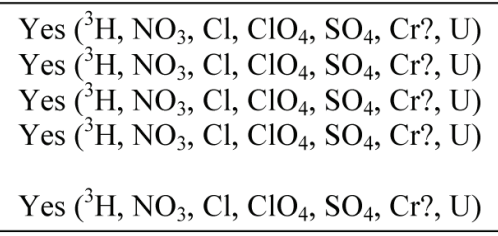 & $\begin{array}{l}\text { Mixed } \\
\text { Mixed } \\
\text { Mixed } \\
\text { Mixed } \\
\text { Mixed }\end{array}$ & 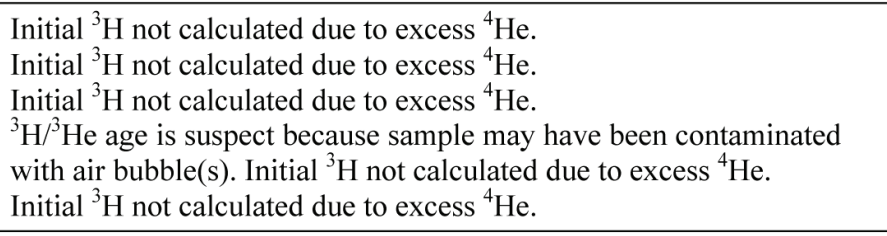 \\
\hline \multicolumn{10}{|l|}{ White Rock Canyon Springs } \\
\hline Spring 2B & $7 / 21 / 2005$ & 3.41 & 17.48 & 9.11 & Near & Unknown & Yes $\left({ }^{3} \mathrm{H}, \mathrm{NO}_{3}, \mathrm{Cl}, \mathrm{SO}_{4}, \mathrm{~B}, \mathrm{Ba}, \mathrm{U}\right)$ & Mixed? & \\
\hline $\begin{array}{l}\text { Spring } 3 \text { (Blind Intralaboratory Field Duplicate) } \\
\end{array}$ & $\begin{array}{l}3 / 9 / 2005 \\
3 / 9 / 2005 \\
7 / 21 / 2005\end{array}$ & $\begin{array}{l}0.28 \\
0.35 \\
0.49\end{array}$ & $\begin{array}{l}<62 \\
<62 \\
47.45\end{array}$ & $\begin{array}{l}\mathrm{NC} \\
\mathrm{NC} \\
7.07\end{array}$ & $\begin{array}{l}\text { NA } \\
\text { NA } \\
\text { Below }\end{array}$ & $\begin{array}{l}\text { Yes } \\
\text { Yes } \\
\text { Yes } \\
\end{array}$ & 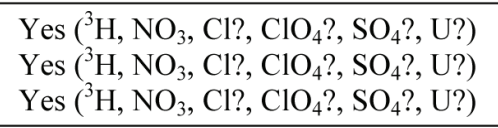 & $\begin{array}{l}\text { Mixed } \\
\text { Mixed } \\
\text { Mixed }\end{array}$ & \\
\hline Spring 3A & $\begin{array}{l}3 / 9 / 2005 \\
7 / 21 / 2005\end{array}$ & $\begin{array}{l}2.35 \\
0.47\end{array}$ & $\begin{array}{l}<62 \\
<62 \\
<62\end{array}$ & $\begin{array}{l}\mathrm{NC} \\
\mathrm{NC}\end{array}$ & $\begin{array}{l}\mathrm{NA} \\
\mathrm{NA}\end{array}$ & $\begin{array}{l}\text { Yes } \\
\text { Yes }\end{array}$ & $\begin{array}{l}\text { Yes ( }{ }^{3} \mathrm{H}_{1} \mathrm{NO}_{3}, \mathrm{Cl}_{2}, \mathrm{ClO}_{4} \text { ?, } \mathrm{SO}_{4} \text { ? }, \mathrm{U} \text { ?) } \\
\text { Yes ( }{ }^{3} \mathrm{H}, \mathrm{NO}_{3}, \mathrm{Cl}^{2}, \mathrm{ClO}_{4} \text { ?, } \mathrm{SO}_{4} \text { ?, U?) }\end{array}$ & $\begin{array}{l}\text { Mixed } \\
\text { Mixed }\end{array}$ & Initial ${ }^{3} \mathrm{H}$ not calculated due to excess ${ }^{4} \mathrm{He}$. \\
\hline Spring $3 \mathrm{C}$ & $3 / 11 / 2005$ & 1.61 & 0.46 & 1.65 & Below & Unknown & Yes ( ${ }^{3} \mathrm{H}, \mathrm{NO}_{3}, \mathrm{Cl}$ ?, $\mathrm{ClO}_{4}$ ?, $\mathrm{SO}_{4}$ ?, $\mathrm{U}$ ?) & Mixed & Sample may have been impacted by river water. \\
\hline Spring 4 & $\begin{array}{l}2 / 21 / 2005 \\
3 / 11 / 2005 \\
7 / 27 / 2005\end{array}$ & $\begin{array}{l}2.78 \\
3.27 \\
6.15\end{array}$ & $\begin{array}{l}14.11 \\
17.44 \\
10.72\end{array}$ & $\begin{array}{r}6.15 \\
8.73 \\
11.25\end{array}$ & $\begin{array}{l}\text { Near } \\
\text { Near } \\
\text { Near }\end{array}$ & $\begin{array}{l}\text { Yes } \\
\text { Yes } \\
\text { Yes }\end{array}$ & $\begin{array}{l}\left.\text { Yes ( }{ }^{(} \mathrm{H}, \mathrm{NO}_{3}, \mathrm{Cl}_{1} \mathrm{ClO}_{4}, \mathrm{SO}_{4}, \mathrm{U} ?\right) \\
\text { Yes }\left({ }^{3} \mathrm{H}, \mathrm{NO}_{3}, \mathrm{Cl}^{2}, \mathrm{ClO}_{4}, \mathrm{SO}_{4}, \mathrm{U} ?\right) \\
\left.\text { Yes ( }{ }^{3} \mathrm{H}, \mathrm{NO}_{3}, \mathrm{Cl}, \mathrm{ClO}_{4}, \mathrm{SO}_{4}, \mathrm{U} \text { ? }\right)\end{array}$ & $\begin{array}{l}\text { Mixed } \\
\text { Mixed } \\
\text { Mixed }\end{array}$ & \\
\hline Spring 4A & $\begin{array}{l}2 / 22 / 2005 \\
3 / 22 / 2005 \\
7 / 28 / 2005\end{array}$ & $\begin{array}{l}0.14 \\
0.18 \\
0.25\end{array}$ & $\begin{array}{l}46.40 \\
61.03 \\
<62\end{array}$ & $\begin{array}{l}1.92 \\
5.89 \\
\mathrm{NC}\end{array}$ & $\begin{array}{l}\text { Near } \\
\text { Near } \\
\text { NA }\end{array}$ & $\begin{array}{l}\text { Yes } \\
\text { Yes } \\
\text { Yes }\end{array}$ & 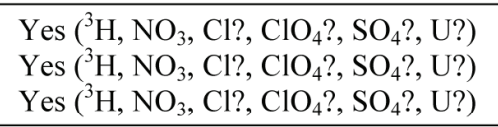 & $\begin{array}{l}\text { Mixed } \\
\text { Mixed } \\
\text { Mixed } \\
\end{array}$ & \\
\hline $\begin{array}{l}\text { Spring 4AA } \\
\text { (Blind Intralaboratory Field Duplicate) } \\
\text { (Blind Intralaboratory Field Duplicate) }\end{array}$ & $\begin{array}{l}2 / 22 / 2005 \\
2 / 22 / 2005 \\
3 / 22 / 2005 \\
3 / 22 / 2005 \\
7 / 26 / 2005 \\
\end{array}$ & $\begin{array}{l}0.65 \\
0.56 \\
0.60 \\
0.62 \\
0.69 \\
\end{array}$ & $\begin{array}{l}17.63 \\
21.00 \\
28.49 \\
19.39 \\
40.34 \\
\end{array}$ & $\begin{array}{l}1.75 \\
1.84 \\
2.98 \\
1.85 \\
6.69 \\
\end{array}$ & $\begin{array}{l}\text { Below } \\
\text { Below } \\
\text { Below } \\
\text { Below } \\
\text { Below }\end{array}$ & $\begin{array}{l}\text { Yes } \\
\text { Yes } \\
\text { Yes } \\
\text { Yes } \\
\text { Yes } \\
\end{array}$ & 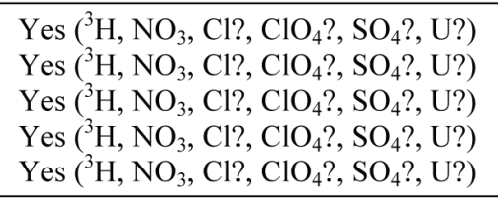 & $\begin{array}{l}\text { Mixed } \\
\text { Mixed } \\
\text { Mixed } \\
\text { Mixed } \\
\text { Mixed }\end{array}$ & \\
\hline (Blind Intralaboratory Field Duplicate) & $\begin{array}{l}2 / 21 / 2005 \\
3 / 22 / 2005 \\
7 / 27 / 2005 \\
7 / 27 / 2005\end{array}$ & $\begin{array}{l}10.10 \\
12.94 \\
11.95 \\
12.18\end{array}$ & $\begin{array}{r}1.61 \\
1.32 \\
3.65 \\
11.00\end{array}$ & $\begin{array}{l}11.05 \\
13.94 \\
14.67 \\
22.63\end{array}$ & $\begin{array}{l}\text { Above } \\
\text { Above } \\
\text { Above } \\
\text { Above }\end{array}$ & $\begin{array}{l}\text { Yes } \\
\text { Yes } \\
\text { Yes } \\
\text { Yes }\end{array}$ & 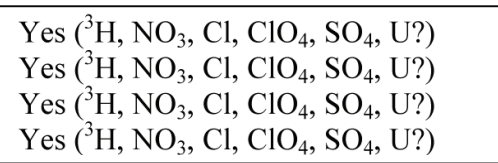 & $\begin{array}{l}\text { Mixed } \\
\text { Mixed } \\
\text { Mixed } \\
\text { Mixed }\end{array}$ & \\
\hline Spring 4C & $\begin{array}{l}10 / 8 / 2004 \\
2 / 21 / 2005 \\
3 / 11 / 2005 \\
7 / 27 / 2005\end{array}$ & $\begin{array}{l}2.61 \\
3.14 \\
3.23 \\
3.15\end{array}$ & $\begin{array}{r}5.89 \\
4.33 \\
21.79 \\
2.53\end{array}$ & $\begin{array}{r}3.63 \\
4.00 \\
11.01 \\
3.64\end{array}$ & $\begin{array}{l}\text { Below } \\
\text { Below } \\
\text { Below } \\
\text { Below }\end{array}$ & $\begin{array}{l}\text { Yes } \\
\text { Yes } \\
\text { Yes } \\
\text { Yes }\end{array}$ & 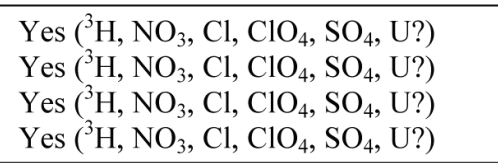 & $\begin{array}{l}\text { Mixed } \\
\text { Mixed } \\
\text { Mixed } \\
\text { Mixed }\end{array}$ & \\
\hline Spring 5 & $\begin{array}{l}2 / 21 / 2005 \\
3 / 24 / 2005 \\
7 / 26 / 2005\end{array}$ & $\begin{array}{l}0.005 \\
0.001 \\
0.003\end{array}$ & $\begin{array}{l}>62 \\
>62 \\
>62\end{array}$ & $\begin{array}{l}\mathrm{NC} \\
\mathrm{NC} \\
\mathrm{NC}\end{array}$ & $\begin{array}{l}\text { NA } \\
\text { NA } \\
\text { NA }\end{array}$ & $\begin{array}{l}\text { Yes } \\
\text { Yes } \\
\text { Yes }\end{array}$ & 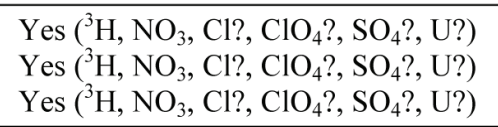 & $\begin{array}{l}\text { Mixed } \\
\text { Mixed } \\
\text { Mixed }\end{array}$ & Sample contaminated with air bubble(s). Assumed mixed. \\
\hline (Blind Intralaboratory Field Duplicate) & $\begin{array}{l}3 / 2 / 2005 \\
3 / 22 / 2005 \\
7 / 25 / 2005\end{array}$ & $\begin{array}{l}0.01 \\
0.01 \\
0.22\end{array}$ & $\begin{array}{l}>62 \\
>62 \\
38.66\end{array}$ & $\begin{array}{l}\mathrm{NC} \\
\mathrm{NC} \\
1.90\end{array}$ & $\begin{array}{l}\mathrm{NA} \\
\mathrm{NA} \\
\mathrm{NA}\end{array}$ & $\begin{array}{l}\text { Yes } \\
\text { Yes } \\
\text { Yes }\end{array}$ & $\begin{array}{l}\text { No } \\
\text { No } \\
\text { Yes }\left({ }^{3} \mathrm{H} ?\right)\end{array}$ & $\begin{array}{l}\text { Submodern } \\
\text { Submodern } \\
\text { Submodern } \\
\text { Submodern }\end{array}$ & 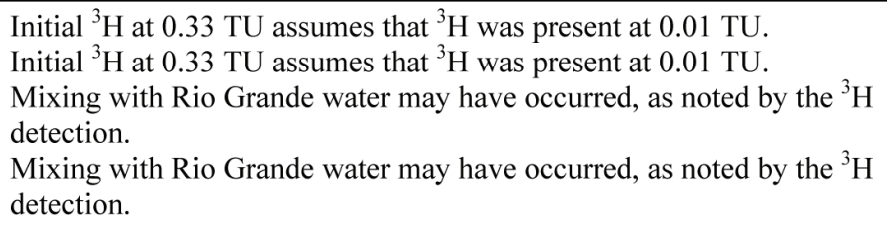 \\
\hline
\end{tabular}


Table 7.1

Summary of Age Data and Age Interpretations Using Multiple Parameters (Cont.)

\begin{tabular}{|c|c|c|c|c|c|c|c|c|c|}
\hline Station ID & $\begin{array}{c}\text { Date } \\
\text { Sampled } \\
\text { (mo/day/yr) }\end{array}$ & $\begin{array}{c}{ }^{3} \mathrm{H} \\
(\mathrm{TU})\end{array}$ & $\begin{array}{c}\text { Apparent } \\
{ }^{3} \mathbf{H}^{\beta} \mathrm{He} \text { Age } \\
\text { (year) }\end{array}$ & $\begin{array}{l}\text { Initial } \\
{ }^{3} \mathbf{H} \text { (TU) }\end{array}$ & $\begin{array}{c}\text { Initial }{ }^{3} \text { H Plots } \\
\text { Above, Near, or Below } \\
{ }^{3} \text { Input Curve }\end{array}$ & $\begin{array}{l}{ }^{14} \mathrm{C} \text { age } \\
>1000 \text { years } \\
\text { (yes or no) }\end{array}$ & $\begin{array}{c}\text { Presence of } \\
\text { Anthropogenic Contaminants } \\
\text { (yes or no) }\end{array}$ & $\begin{array}{l}\text { Interpreted } \\
\text { Age Category }\end{array}$ & Comments \\
\hline Spring 9A & $\begin{array}{l}3 / 8 / 2005 \\
7 / 20 / 2005\end{array}$ & $\begin{array}{l}0.001 \\
0.022\end{array}$ & $\begin{array}{l}>62 \\
>62\end{array}$ & $\begin{array}{l}\mathrm{NC} \\
\mathrm{NC}\end{array}$ & $\begin{array}{l}\text { NA } \\
\text { NA }\end{array}$ & $\begin{array}{l}\text { Yes } \\
\text { Yes }\end{array}$ & $\begin{array}{l}\text { No } \\
\text { No }\end{array}$ & $\begin{array}{l}\text { Submodern } \\
\text { Submodern }\end{array}$ & $\begin{array}{l}\text { Detected }{ }^{3} \mathrm{H} \text { may be in error. Initial }{ }^{3} \mathrm{H} \text { at } 0.33 \mathrm{TU} \text { assumes that }{ }^{3} \mathrm{H} \text { was } \\
\text { present at } 0.02 \mathrm{TU} \text {. }\end{array}$ \\
\hline \multicolumn{10}{|c|}{ Perennial Surface Water West of Pajarito Fault Zone } \\
\hline CdV-5.6 & $\begin{array}{l}3 / 3 / 2005 \\
7 / 11 / 2005 \\
\end{array}$ & $\begin{array}{l}15.63 \\
16.69 \\
\end{array}$ & $\begin{array}{l}2.38 \\
0.72 \\
\end{array}$ & $\begin{array}{l}17.87 \\
17.38 \\
\end{array}$ & $\begin{array}{l}\text { Above } \\
\text { Above }\end{array}$ & $\begin{array}{l}\text { No } \\
\text { No }\end{array}$ & $\begin{array}{l}\text { Yes }\left({ }^{3} \mathrm{H}\right) \\
\text { Yes }\left({ }^{3} \mathrm{H}\right) \\
\end{array}$ & $\begin{array}{l}\text { Modern } \\
\text { Modern }\end{array}$ & \begin{tabular}{|l|} 
Tritium from local atmospheric sources? \\
Tritium from local atmospheric sources?
\end{tabular} \\
\hline PA-10.6 & $\begin{array}{l}2 / 14 / 2005 \\
3 / 8 / 2005 \\
7 / 12 / 2005\end{array}$ & $\begin{array}{l}19.79 \\
17.42 \\
21.34\end{array}$ & $\begin{array}{r}25.81 \\
7.07 \\
1.40\end{array}$ & $\begin{array}{l}84.64 \\
25.93 \\
23.09\end{array}$ & $\begin{array}{l}\text { Above } \\
\text { Above } \\
\text { Above }\end{array}$ & $\begin{array}{l}\text { No } \\
\text { No } \\
\text { No }\end{array}$ & $\begin{array}{l}\text { Yes }\left({ }^{3} \mathrm{H}\right) \\
\text { Yes }\left({ }^{3} \mathrm{H}\right) \\
\text { Yes }\left({ }^{(} \mathrm{H}\right)\end{array}$ & $\begin{array}{l}\text { Modern } \\
\text { Modern } \\
\text { Modern }\end{array}$ & $\begin{array}{l}{ }^{3} \mathrm{H} /{ }^{3} \mathrm{He} \text { age is suspect because sample may have been contaminated } \\
\text { with air bubble(s). } \\
\text { Tritium from local atmospheric sources? } \\
\text { Tritium from local atmospheric sources? }\end{array}$ \\
\hline \multicolumn{10}{|l|}{ Offsite Stations } \\
\hline \multicolumn{10}{|l|}{ Perched Volcanics, South Valles Caldera } \\
\hline Seven Springs & $\begin{array}{l}3 / 10 / 2005 \\
7 / 15 / 2005\end{array}$ & $\begin{array}{l}9.13 \\
4.38\end{array}$ & $\begin{array}{l}4.55 \\
2.12\end{array}$ & $\begin{array}{r}11.79 \\
4.93\end{array}$ & $\begin{array}{l}\mathrm{NA} \\
\mathrm{NA}\end{array}$ & $\begin{array}{l}\text { No } \\
\text { No }\end{array}$ & $\begin{array}{l}\text { No } \\
\text { No }\end{array}$ & $\begin{array}{l}\text { Modern } \\
\text { Modern }\end{array}$ & \\
\hline \multicolumn{10}{|c|}{ Perched Basalts - Taos, Eastside Rio Grande } \\
\hline (Blind Intralaboratory Field Duplicate) & $\begin{array}{l}2 / 15 / 2005 \\
4 / 8 / 2005 \\
7 / 22 / 2005 \\
\\
7 / 22 / 2005\end{array}$ & $\begin{array}{l}6.46 \\
6.11 \\
6.49 \\
\\
6.51\end{array}$ & $\begin{array}{l}21.26 \\
25.26 \\
22.23 \\
23.27\end{array}$ & $\begin{array}{l}21.37 \\
25.33 \\
22.68 \\
24.12\end{array}$ & $\begin{array}{l}\text { NA } \\
\text { NA } \\
\text { NA } \\
\text { NA }\end{array}$ & $\begin{array}{l}\text { No } \\
\text { No } \\
\text { No } \\
\text { No }\end{array}$ & $\begin{array}{l}\text { Unknown } \\
\text { Unknown } \\
\text { Unknown } \\
\\
\text { Unknown }\end{array}$ & $\begin{array}{l}\text { Mixed } \\
\text { Mixed } \\
\text { Mixed } \\
\text { Mixed }\end{array}$ & $\begin{array}{l}{ }^{3} \mathrm{H} /{ }^{3} \mathrm{He} \text { age is suspect because sample may have been contaminated } \\
\text { with air bubble(s). } \\
{ }^{3} \mathrm{H} /{ }^{/} \mathrm{He} \text { age is suspect because sample may have been contaminated } \\
\text { with air bubble(s). }\end{array}$ \\
\hline \multicolumn{10}{|l|}{$\begin{array}{l}\text { Notes: } \\
\text { TU - tri } \\
\text { NA - nc } \\
\text { NC - no } \\
\text { ? - Can }\end{array}$} \\
\hline
\end{tabular}


This report has been reproduced directly from the best available copy. It is available electronically on the Web (http://www.doe.gov/bridge).

Copies are available for sale to U.S. Department of Energy employees and contractors from:

Office of Scientific and Technical Information

P.O. Box 62

Oak Ridge, TN 37831

(865) 576-8401

Copies are available for sale to the public from: National Technical Information Service

U.S. Department of Commerce

5285 Port Royal Road

Springfield, VA 22161

(800) 553-6847 
- Los Alamos NATIONAL LABORATORY

EST.1943 